Citizenship Policies in the

New Europe

Expanded and Updated Edition

RAINER BAUBÖCK, BERNHARD PERCHINIG \& WIEBKE SIEVERS (EDS.)
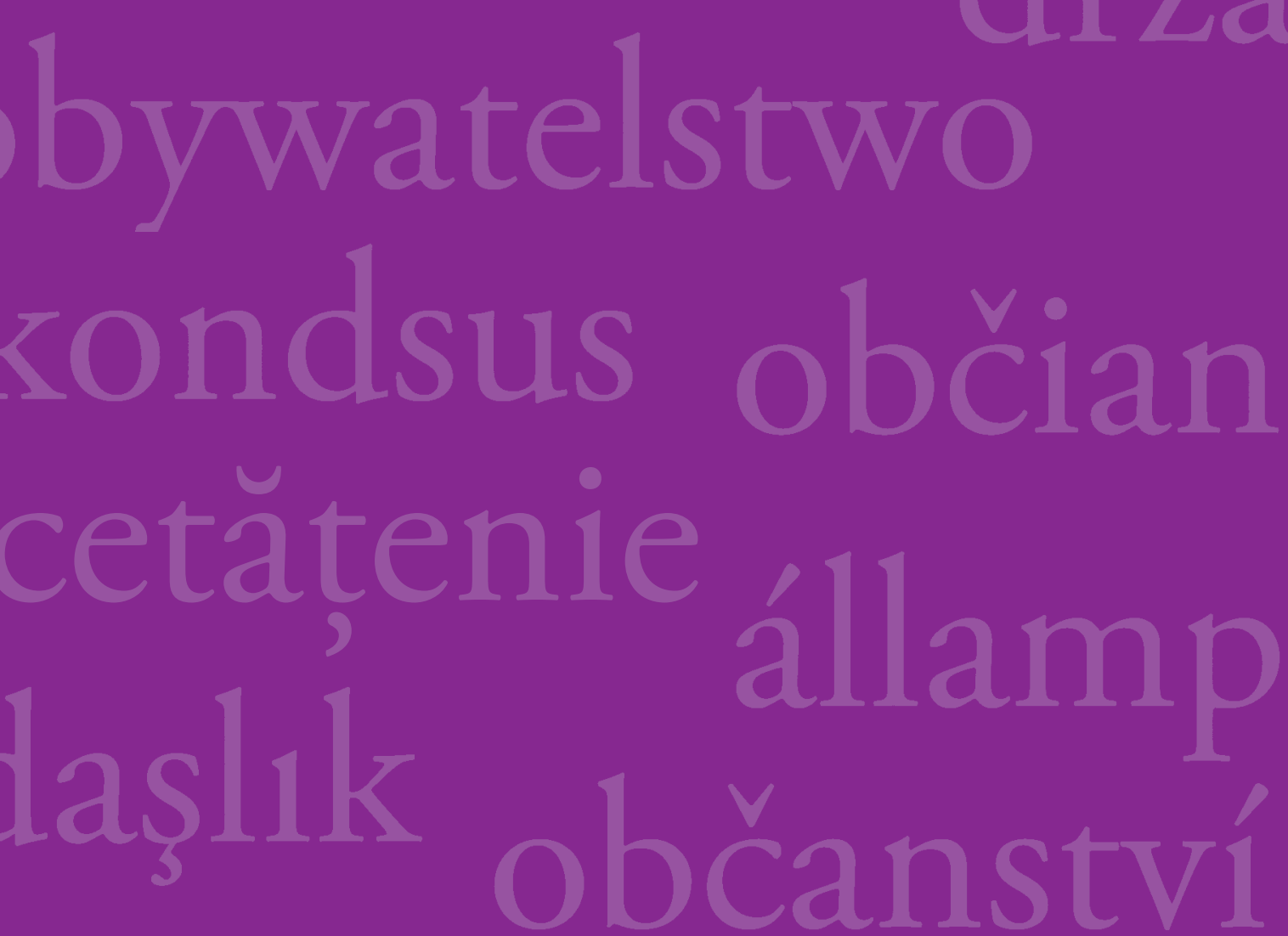

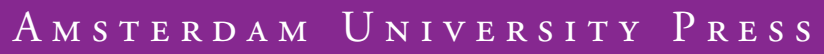


Citizenship Policies in the New Europe 


\section{IMISCOE}

International Migration, Integration and Social Cohesion in Europe

The IMISCOE Network of Excellence unites over 500 researchers from European institutes specialising in studies of international migration, integration and social cohesion. The Network is funded by the Sixth Framework Programme of the European Commission on Research, Citizens and Governance in a Knowledge-Based Society. Since its foundation in 2004, IMISCOE has developed an integrated, multidisciplinary and globally comparative research project led by scholars from all branches of the economic and social sciences, the humanities and law. The Network both furthers existing studies and pioneers new research in migration as a discipline. Priority is also given to promoting innovative lines of inquiry key to European policymaking and governance.

The IMISCOE-Amsterdam University Press Series was created to make the Network's findings and results available to researchers, policymakers and practitioners, the media and other interested stakeholders. High-quality manuscripts authored by IMISCOE members and cooperating partners are published in one of four distinct series.

IMISCOE Research advances sound empirical and theoretical scholarship addressing themes within IMISCOE's mandated fields of study.

IMISCOE Reports disseminates Network papers and presentations of a time-sensitive nature in book form.

IMISCOE Dissertations presents select PhD monographs written by IMISCOE doctoral candidates.

IMISCOE Textbooks produces manuals, handbooks and other didactic tools for instructors and students of migration studies.

IMISCOE Policy Briefs and more information on the Network can be found at www.imiscoe.org. 


\title{
Citizenship Policies in the New Europe
}

\author{
Expanded and Updated Edition
}

\author{
edited by \\ Rainer Bauböck \\ Bernhard Perchinig \\ Wiebke Sievers
}

IMISCOE Research 
Cover design: Studio Jan de Boer BNO, Amsterdam Layout: The DocWorkers, Almere

$\begin{array}{ll}\text { ISBN } & 9789089641083 \\ \text { e-ISBN } & 9789048502257 \\ \text { NUR } & 74 \mathrm{I} / 763\end{array}$

(c) IMISCOE / Amsterdam University Press, Amsterdam 2009

All rights reserved. Without limiting the rights under copyright reserved above, no part of this book may be reproduced, stored in or introduced into a retrieval system, or transmitted, in any form or by any means (electronic, mechanical, photocopying, recording or otherwise) without the written permission of both the copyright owners and the authors of the book. 


\section{Contents}

List of figures and tables II

Preface I5

Andre Liebich

Introduction: Altneuländer or the vicissitudes of citizenship in the new EU states 2I

I New states and old concerns, or why there is not much plural citizenship in the Altneuländer 2I

2 Old categories and new principles, or how ethnicity has trumped other grounds of citizenship 24

3 Old wrongs and new rights, or how to use citizenship to correct history 3I

4 Conclusion: The historical past, the ethnic present and the immigrant future 37

Annex: Constitutional preambles (extracts) 38

\section{Part I Restored states}

Priit Järve

I Estonian citizenship: Between ethnic preferences and democratic obligations 45

I.I History of Estonian nationality 45

I.2 Basic principles of the most important current modes of acquisition and loss of nationality 50

I.3 Current debates on nationality 53

I.4 Statistics on acquisition of nationality since I992 58

I.5 Conclusions 60

Kristine Krūma

2 Checks and balances in Latvian nationality policies: National agendas and international frameworks 67

2.I History of nationality policy 67

2.2 Basic principles for the acquisition and loss of nationality 74

2.3 Current political debates 80

2.4 Statistics 83

2.5 Conclusions 88 
Kristīne Krūma

3 Lithuanian nationality: Trump card to independence and its current challenges 97

3.I History of nationality policy 97

3.2 Basic principles of the most important current modes of acquisition and loss of nationality I06

3.3 Current political debates II2

3.4 Statistics II4

3.5 Conclusions II6

\section{PART II STATES WITH HISTORIES OF SHIFTING BORDERS}

Agata Górny and Dorota Pudzianowska

4 Same letter, new spirit: Nationality regulations and their implementation in Poland 123

4.I Polish nationality in historical perspective I24

4.2 Basic principles of current regulations on Polish nationality I28

4.3 The unresolved debate (I999-200I) I34

4.4 Acquisitions of Polish nationality in figures 136

4.5 Conclusions I4I

Mária M. Kovács and Judit Tóth

5 Kin-state responsibility and ethnic citizenship: The Hungarian case I5I

5.I History of Hungarian policies on nationality since I945 I52

5.2 Current nationality legislation $\quad$ I54

5.3 Current political debates on (dual) citizenship $\quad$ I58

5.4 Trends in statistics ${ }^{6} 6_{5}$

$5 \cdot 5$ Conclusions 169

Constantin Iordachi

6 Politics of citizenship in post-communist Romania:

Legal traditions, restitution of nationality and multiple memberships $\quad$ I77

6.I History of Romanian nationality ${ }_{17} 8$

6.2 Democratic transformation: Current regulations on ascription, acquisition and loss of nationality $\mathrm{I} 84$

6.3 Current political debates I9I

6.4 Statistics on the restitution of nationality I98

6.5 (Re)constructing nationality in post-communist Romania:

Comparative perspectives 200 
Daniel Smilov and Elena Jileva

7 The politics of Bulgarian citizenship: National identity, democracy and other uses 2 II

7.I History 2I2

7.2 Current citizenship rules and practices 220

$7 \cdot 3$ Current political debates 226

7.4 Current statistical trends 235

7.5 Conclusions 238

\section{Part III Post-Partition STATES}

\section{Andrea Baršová}

8 Czech citizenship legislation between past and future 249

8.I History of Czechoslovak citizenship policies 249

8.2 Basic principles of acquisition and loss of Czech citizenship 254

8.3 Current political debates 258

8.4 Statistics $26 \mathrm{I}$

8.5 Conclusions 263

Dagmar Kusá

9 The Slovak question and the Slovak answer: Citizenship during the quest for national self-determination and after 275

9.I History of Slovak citizenship 276

9.2 Current regulations of acquisition and loss of Slovak citizenship 284

9.3 Current political debates and reform plans 289

9.4 Statistical trends (acquisition of Slovak citizenship since I993) 294

$9 \cdot 5$ Conclusions 296

Felicita Medved

Io From civic to ethnic community? The evolution of Slovenian citizenship 305

IO.I History of citizenship policies 305

I0.2 Basic principles of acquisition and loss of Slovenian citizenship 3I3

I0.3 Current political debates 320

I0.4 Statistics 323

I0.5 Conclusions 325

ıo.6 Epilogue 327 
Francesco Ragazzi and Igor Štiks

II Croatian citizenship: From ethnic engineering to inclusiveness 339

II.I The history of citizenship policy in Croatia since I945 340

II.2 Acquisition and loss of Croatian citizenship: Current legal provisions 347

II.3 Current political debates and planned changes 352

II.4 Statistical developments 353

II.5 Conclusions 355

\section{Part IV MediterraneAn POST-IMPERIAL StATES}

Eugene Buttigieg

I2 Malta's citizenship law: Evolution and current regime 367

I2.I Historical background 367

I2.2 Current modes of acquisition and loss of citizenship 373

I2.3 Statistical developments 379

I2.4 Recent reforms 38I

I2.5 Conclusions 383

Nicos Trimikliniotis

I3 Nationality and citizenship in Cyprus since I945:

Communal citizenship, gendered nationality and the adventures of a post-colonial subject in a divided country 389

I3.I History of nationality policy since I945 390

I3.2 Modes of acquisition and loss of citizenship 397

I3.3 Current debates: The challenges of gender equality, migration, Europeanisation and reunification 405

I3.4 Statistical developments since I985: The 'politics of numbers' and the 'numbers game' 408

I3.5 Conclusions 409

Zeynep Kadirbeyoglu

I4 Changing conceptions of citizenship in Turkey 4I9

I4.I History of Turkish citizenship law 4I9

I4.2 Modes of acquisition and loss of Turkish citizenship 426

I4.3 Statistics 428

I4.4 Conclusions 43I

I4.5 Epilogue 432 
Wiebke Sievers

'A call to kinship'? Citizenship and migration in the new Member States and the accession countries of the EU 439

I Excluding long-term residents and their descendants: Initial determination of citizenship in Estonia, Latvia, Slovenia and Croatia 440

2 Reaching out to emigrants and expatriates: Restitution laws, dual nationality and status laws 446

3 Excluding recent immigrants: Naturalisation requirements 452

4 Conclusions 455

List of contributors 459 



\section{List of figures and tables}

Figure I.I Estonian citizens and stateless persons in Estonia, I992-I January 2008, per cent of total population 48

Figure I.2 Naturalisation in Estonia, 1992-2007, persons naturalised per year in thousands 59

Table 2.I Changes in ethnic composition of Latvia's population 83

Table 2.2 Citizens and non-citizens of Latvia 83

Table 2.3 Residents of Latvia on I July 2008 (by ethnic origin) 83

Table 2.4 Children of non-citizens and stateless persons born after 2I August I99I who were granted Latvian nationality (3I May 2008) 84

Table 2.5 Numbers of naturalisations in Latvia per year 85

Table 2.6 Numbers of persons passing history and language exams for naturalisation 86

Table 2.7 Ethnic origin of applicants for naturalisation in Latvia (3I May 2008) 87

Table 2.8 Age of applicants for naturalisation in Latvia (3I May 2008) 87

Table 3.I Ethnic composition in Lithuania II4

Table 3.2 Number of naturalised persons, 2003-2007 II5

Table 3.3 Number of persons who have lost Lithuanian citizenship, by reasons II5

Table 3.4 Retention of the right to Lithuanian citizenship II5

Table 4.I Foreigners granted Polish nationality by conferment in I992-200I and by conferment, acknowledgement and spousal acquisition in 2002-2006, by (former) nationality I37

Figure 4.I Acquisitions of Polish nationality by conferment (I992-2006) I39

Table 4.2 Repatriation visas to Poland in I997-2006, by repatriates' previous country of residence I4I

Table 5.I Number of naturalisations and re-naturalisations as well as terminations of nationality in Hungary, I985-I994 I66

Table 5.2 Distribution of nationality law cases in Hungary, I998-2008 $\quad$ I67 
Table 5.3 Ratio of naturalisation decisions in Hungary in 2002, 2007 and 2008 I68

Table 6.I Naturalisations in Romania, I6 June 2000-29

October 2008 I98

Figure 6.I Duration in months of the process of naturalisation in Romania, by original nationality of applicants accepted in 2005, 2006 and 2007 I99

Table 7.I Number of decrees issued by the Vice-President of the Republic of Bulgaria for change of citizenship for the period I January 200I-3I December 2006236

Table 7.2 Number of applications for a change of citizenship for the period I January 2000-3I December 2006237

Table 8.I Conceptual scheme of Act No. 40/1993 Coll. on the Acquisition and Loss of Citizenship of the Czech Republic 252

Table 8.2 Naturalisations (excluding Slovak nationals) in the Czech Republic, I993-2007 262

Table 8.3 Number of Slovak and other nationals acquiring Czech citizenship from 200I-2007 262

Table 8.4 Slovak nationals who acquired Czech citizenship by declaration (Section I8a of Act No. 40/1993 Coll.) 262

Table 8.5 Former Czechoslovak nationals who (re-)acquired Czech citizenship by declaration under Act No. 193/1999 Coll. 263

Table 9.I Number of persons who acquired citizenship of the Slovak Republic, I993-2008 294

Figure 9.I Czechs and other foreign nationals who acquired citizenship of the Slovak Republic, I995-2008 296

Table 9.2 Refugees and asylum seekers in the Slovak Republic, I995-2008 296

Table Io.I Admission to Slovenian citizenship based on supplementary and corrective initial determination rules (art. 40, I991, art. I9, 2002) and on standard provisions for naturalisation by country of origin, 25 June I99I-3I December 2008324

Table I0.2 Regular and facilitated naturalisations by groups of persons in Slovenia, I99I-2008 324

Table I0.3 Regular and facilitated naturalisations in Slovenia per year, I991-2008 324

Table I0.4 Reasons for granting exceptional naturalisations in Slovenia 324

Table I0.5 Exceptional naturalisations in Slovenia per year, I99I-2008 325 
Table io.6 Release from Slovenian citizenship per year, I99I-2008 325

Table I2.I Acquisition of Maltese nationality by registration for I998-2008 according to the grounds for registration 380

Figure I2.I Number of naturalisations and registrations in Malta, I990-2008 380

Table i3.I Acquisitions of Cypriot citizenship by modes, I985-3 March 2009408

Table I4.I Automatic acquisition of Turkish citizenship, I990-2008 429

Table I4.2 Acquisition of Turkish citizenship through a decision of the authorities, I990-2008 429

Table I4.3 Loss of Turkish citizenship by a decision of the authorities, 2000-2008 430

Table I4.4 Previous loss of citizenship by those who have reacquired Turkish citizenship according to three main categories, 2000-2004 43I 



\section{Preface}

It is not often that academic books are published in a second edition within less than two years from the date of first publication. Sometimes the reason is that a book turns out to be a bestseller and reaches beyond a specific audience. Unfortunately, we cannot pretend that this applies to the present volume. Why, then, did we still think that it was worth putting out an expanded and thoroughly revised second edition?

Firstly, the European Union was enlarged again in 2007. We now include the newest Member States, Bulgaria and Romania, in our comparison. The analyses of these two countries further confirm the complexity of citizenship arrangements in the post-communist countries of Central and Eastern Europe, which use their citizenship legislations to build and maintain external relations with ethnic kin populations and diaspora groups in neighbouring states.

Secondly, we had already included Turkey in the first edition; the new edition also contains a chapter on Croatia and thus fully covers the official candidates for membership, which are currently negotiating

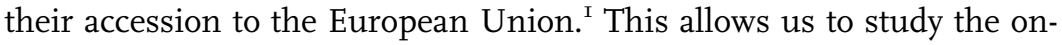
going impact of enlargement on concepts and policies of citizenship. Moreover, both Turkey and Croatia are major source countries of immigration for the fifteen pre-2004 EU countries. These traditions as sending countries are reflected in the Turkish and Croatian citizenship legislations, which interact with the citizenship policies of countries where the Turkish and Croatian emigrants have settled. Finally, the two accession states both share several important features or historical connections with the newer Member States. The conceptions of citizenship in Turkey and Cyprus still show traces of the Ottoman legacy and Turkey also shares some Mediterranean commonalities with Malta, while Croatia has had to cope with challenges of state formation in the postYugoslavian context that are similar to those of Slovenia.

Thirdly, one of the main results of our comparative studies on the acquisition and loss of nationality in the European Union is that citizenship policies have become thoroughly politicised and are therefore also subject to frequent changes. This increased volatility of reforms means that published results can be quickly superseded by new events. We have therefore offered all of the authors the opportunity to update 
and revise their chapters so that they cover significant new developments.

Nevertheless, one of the basic rationales of this publication has remained the same. While there has been a growing interest in comparative research on citizenship policies in major countries of immigration, both overseas and in Europe, most comparative studies are limited in geographic scope to a small number of already well-researched countries. The present volume looks at countries that are rarely included in these studies. ${ }^{2}$

Why concentrate only on the twelve new Member States plus Croatia and Turkey. There are various reasons for this choice. The initial idea for analysing the nationality regulations in this particular group of countries originated in another EU-funded project called The Acquisition of Nationality in EU Member States: Rules, Practises and Quantitive Developments, or 'NATAC' for short. NATAC provided the first strictly comparative analysis of the rules and practices regulating the acquisition and loss of nationality in the fifteen 'old' EU Member States. Unlike earlier, similar studies, it was not limited to country reports but used a new methodology that facilitates the comparison of the regulations across countries. The results of this project are published in two volumes (Bauböck, Ersbøll, Groenendijk \& Waldrauch 2006). Volume I contains comparative reports with chapters on the modes of acquiring and losing nationality, the statistics on nationality, the trends in nationality laws and the statuses of denizenship and quasi-citizenship in the fifteen states. Volume 2 supplies specific background information on the historical and political evolution of the nationality legislation in each individual country, structured according to a common grid in order to facilitate comparative analyses.

This book represents a first attempt at adapting the methodology developed in the NATAC project to the new Member States and the accession countries of the EU. The country reports included in this volume are structured according to a common grid that is similar to the one used for Volume 2 of the above mentioned publication. Each chapter contains a historical outline of nationality policy since 1945 that provides a broad overview of developments with special emphasis on important reforms, breaks from basic principles of nationality acquisition and loss and regulations for special groups of people (e.g. an ethnic diaspora). Subsequently, the authors summarise the basic principles of the most important current modes of acquisition and loss of nationality in their respective countries. A third section looks at current political debates and any changes planned for the future. Finally, the reports present the statistical developments since 1985, describe which modes of acquisition and loss of nationality are dealt with by the available statistics and explain important breaks in the numbers of acquisitions 
and loss of nationality in their country. Like the country reports gathered for the NATAC project, the reports included in this volume do not primarily aim at a legal comparison but concentrate on the historical and political background of current regulations for the acquisition and loss of nationality. A further question guiding our research was the impact of the EU and other international bodies on the evolution of these regulations.

Nevertheless, this book on citizenship in the new Europe is a publication in its own right with a very specific focus. The concepts of nationality and citizenship in the fourteen countries under discussion in this volume generally differ quite strongly from those prevalent in Western Europe. By and large, citizenship in these countries is still closely linked to an ethnic interpretation of nationality, transmission to subsequent generations is exclusively based on descent, there is greater hostility towards multiple nationality, and greater emphasis is laid on citizenship links with ethnic kin-minorities in neighbouring countries and expatriates. Indeed, emigration has played a more important role for recent citizenship reforms in these countries than immigration. Yet, a few among them are already experiencing another transition, from a sending country to a transit country and finally to a receiving country of new immigration. Moreover, eleven of these countries have also undergone a transition from communist to democratic rule. A final fundamental contrast with the old fifteen EU Member States is that none of these countries has enjoyed continuous independence within the present state borders for more than 60 years. In addition to dealing with individual acquisition and loss of citizenship, these countries therefore had to resolve the puzzling problems of initial collective citizenship determination for large populations in the context of state restoration, of new establishment after partitioning or secession or of geographic relocations of borders. Again, this has sometimes implied a return to ethnic roots and the exclusion of long term residents and their children for political reasons, such as the restrictive access to Estonian and Latvian citizenship for Russian immigrants who settled there after i940.

This book does not include a detailed comparison of specific provisions in nationality law, as provided by Harald Waldrauch in volume I of the NATAC project on the fifteen 'old' Member States. However, we have added two comparative chapters to the fourteen case studies: a revised and updated version of Andre Liebich's introduction to the first edition, which traces the historical trajectories of citizenship in the post-communist states, and a new comparative overview of the main features of current citizenship legislation by Wiebke Sievers that concludes the present volume. Both chapters emphasise the specific challenge of new state formation and initial determination of citizenship. 
What we provide in this book is not a definitive account of comparative citizenship studies in this European region, but a starting point for further inquiries. There are four main areas where we see a need for future research.

Firstly, in order to fully understand how citizenship policies affect specific groups of migrants or minorities, we need to break down the laws into their components and study then how they are implemented and how the legislation of different countries interacts in generating legal statuses or bundles of rights and obligations. The research line initiated by the NATAC project should therefore eventually also be fully applied to the new Member States and accession countries. ${ }^{3}$

Secondly, we need to go beyond comparing legislative output to promote studies of the policy formation process that leads to citizenship reform. Political parties, associations lobbying for specific interests, international organisations and public discourses in the mass media are all important factors that need to be researched in order to better understand how and why citizenship issues enter the political agenda.

Thirdly, building on these solid empirical foundations, one can try to condense the comparison into quantitative indices that measure how open or closed a citizenship regime is for newcomers or for external affiliations of emigrants and kin minorities. In the past, such standardised comparisons were often based on a few selected indicators, such as provisions on ius soli, residence requirements for naturalisation and toleration of dual citizenship. By studying the citizenship laws of the new EU Member States we can see why this approach is often misleading. Formal residence requirements do not always tell us how easy access to naturalisation is. Some countries only start counting residence periods from the day the applicant has acquired a residence permit, which may take several years depending on the status of the applicant and the country of residence. In other countries, discretion regarding naturalisation is fairly unlimited. Moreover, toleration of dual citizenship often applies only to emigrants, not immigrants. We are happy to report that recent attempts to standardise the comparison between citizenship policies have improved, partly as a result of the findings of the NATAC project. We want to mention here specifically the revised version of Marc M. Howard's Citizenship Policy Index (Howard 2010), Sara Wallace Goodman's CIVIX index that measures language, country knowledge and value commitment requirements (Wallace Goodman 20I0), as well as the new version of the Migrant Integration Policy Index MIPEX (British Council 2008).

Fourthly, the point of standardised comparison is often to encourage policy changes oriented towards best practices in other countries. From a social science perspective, the main goal, however, is to explain why countries adopt or change the policies they have. The NATAC volumes 
and the present book provide much material for contextual policy explanation, but have not attempted a systematic comparative explanation. Much of the older literature in this field is based on extrapolating trends from a few case studies. Using NATAC results, recent studies have revised some earlier hypotheses about a general trend towards liberal convergence and have suggested some new ideas on how to explain variations between countries (see e.g. Joppke 2007, 2008; de Groot \& Vink 2010). Comparative analyses of larger numbers of cases using quantitative indicators in order to identify causal variables for policy change are still rare. The aforementioned recent studies by Howard and Wallace Goodman illustrate that citizenship policies are now examined by the whole range of disciplinary and methodological approaches available in the social sciences.

We hope that the present volume will encourage many more researchers to overcome the Western bias that has shaped the field of citizenship studies for such a long time by including the new Member States and accession countries in their comparative studies. We also hope that this book will alert policymakers to the fact that the common citizenship of the European Union connects the citizenship regimes of Member States. In Europe, distinct historic legacies and sovereign powers of self-determination in matters of citizenship are increasingly challenged through growing interdependence between states connected through migration and supranational integration.

\section{Rainer Bauböck, Bernhard Perchinig and Wiebke Sievers \\ Vienna and Florence, August 2008}

\section{Notes}

I The Former Yugoslav Republic of Macedonia has also been a candidate since 9 November 2005, but accession negotiations have not commenced due to its conflict with Greece over the name 'Macedonia'.

2 The first edition of this book was based on papers presented at a conference held in Vienna from 30 June to 2 July 2005. This conference was organised within the framework of the EU-funded Network of Excellence IMISCOE (International Migration, Integration and Social Cohesion in Europe) by a thematic research cluster that focuses on migration and citizenship. We would like to thank the European Committee for funding this meeting, the IMISCOE Editorial Committee and Amsterdam University Press for providing a platform for the dissemination of our work, all reviewers for their helpful comments and, last but not least, Karina Hof for her meticulous work on the proofs.

3 This is one of the major aims of the project Access to Citizenship in Europe (EUCITAC), which is financed by The European Fund for the Integration of Third Country Nationals and coordinated by Rainer Bauböck together with Jo Shaw from the University of Edinburgh. EUCITAC aims to install a web-based observatory on 
citizenship in Europe within the European Union Democracy Observatory (EUDO), which is currently being built by the Robert Schuman Centre of the European University Institute.

\section{Bibliography}

Bauböck, R., E. Ersbøll, K. Groenendijk \& H. Waldrauch (eds.) (2006), Acquisition and Loss of Nationality. Policies and Trends in 15 European Countries. Vol. 1: Comparative Analyses, Vol. 2: Country Analyses. Amsterdam: Amsterdam University Press.

British Council (2008), Migrant Integration Policy Index. www.integrationindex.eu.

Groot, R. de \& M. Vink (2010), 'Citizenship Attribution in Western Europe: International Framework and Domestic Trends', Journal of Ethnic and Migration Studies 36 (4) (forthcoming).

Howard, M.M. (2010), 'Liberalizing Change or Continued Restrictiveness? Explaining Variation in Citizenship Laws in II EU Countries', Journal of Ethnic and Migration Studies 36 (4) (forthcoming).

Joppke, C. (2007), 'Transformation of Citizenship: Status, Rights, Identity', Citizenship Studies II (I): 37-48.

Joppke, C. (2008), 'Comparative Citizenship: A Restrictive Turn in Europe?’, Law Q Ethics of Human Rights 2 (I): I-4I.

Wallace Goodman, S. (20I0), 'Integration Requirements for Integration's Sake? Identifying, Categorizing, and Comparing Civic Integration Policies', Journal of Ethnic and Migration Studies 36 (4) (forthcoming). 


\title{
Introduction: Altneuländer or the vicissitudes of citizenship in the new EU states
}

\author{
Andre Liebich
}

\begin{abstract}
Altneuland is the title of a novel written over a century ago by the Zionist leader Theodor Herzl. The old-new land Herzl had in mind was Palestine but the term is apposite for the lands with which this volume is concerned, in particular, the former communist states that have recently joined the European Union. From the point of view of the issue of citizenship, these countries display a peculiar blend of antiquity and novelty that deserves careful consideration. In this introduction, I therefore propose to make a survey of the preconditions and conditions of citizenship in the new EU Member States through the prism of 'old' and 'new.' Applying these terms, I shall first consider the specificities of statehood in this group of countries; I shall then look at the evolution of principles of political membership, and, finally, I shall consider the efforts to incorporate the past into the present citizenship provisions.
\end{abstract}

\section{$1 \quad$ New states and old concerns, or why there is not much plural citizenship in the Altneuländer}

When the First World War broke out, less than a century ago, only two of the twelve new members of the EU enjoyed statehood. Bulgaria had acquired sovereignty barely six years earlier and Romania, though a fully sovereign state for a generation, was to change boundaries so substantially as an outcome of the First World War that it was practically recreated. Of the remaining countries, five (Poland, Hungary, Lithuania, Latvia, Estonia) arose as a result of the Paris Peace Treaties (I9I9). Only one (Hungary) has enjoyed uninterrupted statehood since I9I8 and, in the case of the Baltic states, their statelessness in this period has lasted longer than their statehood. ${ }^{\mathrm{I}}$ Two European states (Cyprus and Malta) acquired independence in the course of Cold War decolonialisation. ${ }^{2}$ Three other countries (Slovenia, the Czech Republic, Slovakia as well as potential EU Member State Croatia) have only become states in the last fifteen years (though Slovakia and Croatia had a brief and not very happy experience as states during the Second World War). 
To be sure, at least two countries, Poland and Hungary, have long been acknowledged, even when absent from the map and even by such sceptics as Marx and Engels, as one-time historic states (Rosdolsky I986; Connor I984). Other countries, notably Bulgaria, Lithuania and the Czech Republic, might make weaker claims to a distant statehood in a more or less misty past. The contrast with the situation of the 'old' fifteen EU Member States could not be more striking. Although the 'old' EU also numbers three countries that only arose after the First World War (Finland, Austria, Ireland) and one whose existence was interrupted (Austria), twelve of the fifteen old EU countries have known uninterrupted statehood for periods running from well over a century (Germany, Luxemburg, Italy, Belgium, Greece) to many hundreds of years (United Kingdom, the Netherlands, Spain, Portugal, Sweden, Denmark, France).

The recent and discontinuous statehood that characterises the new EU states has broad implications for political attitudes and identity. The Hungarian public intellectual Istvan Bibó has spoken of the 'distress of the small states of Eastern Europe', by which he means 'anguish at the perspective of the disappearance of one's own people and country' (Bibó I99I [1946]: I3-69). This anxiety is based on the historical realities noted above but it is reinforced by demography. Though there are smaller states in the old EU, some of the new Member States are very small indeed (Slovenia, Estonia, Latvia and Lithuania together are smaller in population than Belgium or Portugal) and all of them combined, excepting Poland, have the population of one of the larger EU Member States, such as France or Italy. Even Poland, whose population is larger than all the other new EU adherents put together, is itself only about the size of Spain. And, as though to underline that in East Central Europe even a population of 38 million nationals does not spare one from brooding on the survival of the state, Poland's hymn still begins, somewhat ominously, 'Poland has not yet perished while we are alive' (further on these arguments, Liebich 2008).

The fragility of statehood in East Central Europe drives all these countries in the direction of a state-reinforcing overcompensation. The preambles to most constitutions or other foundational documents (see annex) evoke ancient genealogies and historical continuities. Moreover, the Baltic states' insistence on the legal fiction of uninterrupted statehood, despite a half century of statelessness, leads them to adopt constitutional and legislative dispositions that transform a fixed date into a marker of timelessness. Legitimacy apparently reposes, at least in part, upon antiquity and continuity and the search for these is a serious task (Liebich 1995).

One would imagine that this kind of tenacious attachment to a recent and therefore tenuous type of statehood would be reflected in the 
philosophy and provisions regarding plural citizenship (Liebich 2000). This is indeed the case, though the variations are many and are themselves significant. Generally speaking, one sees a spectrum running from qualified or court-imposed interdiction (Czech Republic and Lithuania) to unqualified (Hungary) or almost unqualified (Slovakia) acceptance of plural citizenship. ${ }^{3}$ In between, we find the countries that tend strongly towards acceptance (Poland and Slovenia) and a growing number of countries that do not allow plural citizenship for naturalised citizens but authorise it for members of their own ethnic group who repatriate in their country of origin, for citizens by birth who naturalise abroad or even for co-ethnic kin groups residing abroad.

The situation in many of these countries appears to be in flux. Three countries (Latvia, Poland and Slovenia) stipulate either that nationals will only be 'considered' citizens of the respective country or that nationals will 'not be recognised' as citizens of another country. In the cases of Poland and Slovenia, administrative authorities may require a candidate for naturalisation to relinquish previous citizenships but they apparently rarely do so. In Latvia, the courts have ruled that plural citizenship can be prohibited, but this applies only for naturalised citizens. Lithuania, where the Constitution states that no one may be a citizen of both Lithuania and another state (art. I2, para. 2), moved towards the acceptance of plural citizenship for its pre-I940 nationals and their descendants, even those who did not repatriate. These innovations have since been struck down by the national courts as unconstitutional and discriminatory, leaving Lithuania with no provision for plural citizenship. Estonia, somewhat casuistically, does not accept plural citizenship on the basis of the I995 citizenship law but does accept it on the basis of its 1938 law. This effectively means that only naturalised citizens are required to relinquish their previous nationalities.

Whether a country edges towards the position of accepting or limiting plural citizenship, it generally looks out for its own ethnic kin, waiving most requirements, sometimes including language or residency requirements, on behalf of expatriates and even their descendants or on behalf of minorities abroad. In addition to the cases mentioned above, this policy of ethnic preference is particularly blatant in the cases of Bulgaria and Croatia, where the purpose is to establish the symbolic borders of the nation, beyond those of the state. This is also the thrust of the Romanian policy of extending citizenship to those persons and their descendants who were Romanian citizens before Romania's territorial losses in I940. In contrast to other cases, however, this extension also includes non-Romanian ethnics living in these areas. All three countries, but particularly Romania, which has thus offered its citizenship to many if not most of the inhabitants of Moldova and some 
inhabitants of Ukraine, have pulled back from this policy - a policy that could be considered generous or imperialistic, as one would have it - since these countries have found themselves swamped with 'opportunistic' applications that defeat the original ethnic in-gathering intention of the policy.

All in all, one may identify a tendency, however weak, towards the relaxation of the injunctions against plural citizenship. ${ }^{4}$ States have abrogated the communist-era bilateral conventions on elimination of cases of dual nationality. This relaxation does not, however, bring these states closer to the spirit of the most recent European Convention on Nationality (1997), which accepts plural citizenship as much as earlier conventions discouraged it. Most of these states reserve plural citizenship for their own ethnic kin. They are therefore not reacting to pressures for euro-compatibility but rather to pressures from their own émigré communities and from nationalist politicians. As a consequence of the fall of communism, these countries have reconciled themselves with their historical émigré communities, just as these communities abroad have reconciled themselves with their countries of origin. A recent development is that these countries are producing a significant new wave of emigration. Part brain drain, part cheap labour, stimulated by globalisation as well as by EU enlargement, these new emigrants are even more interested in maintaining ties with their home countries than their predecessors.

The meanderings of policies regarding plural citizenship, which have provoked intense public debate in many of these countries, bring to the fore two characteristics of citizenship in the post-communist states. First, the triumph of ethnic conceptions of citizenship over others; second, the use of citizenship policy as a means to right historical wrongs. These are the themes of the following two sections of this introduction.

\section{Old categories and new principles, or how ethnicity has trumped other grounds of citizenship}

The classic distinction between civic and ethnic conceptions of citizenship, as well as that between citizenship founded upon ius soli and ius sanguinis, apply to the countries under discussion here too. ${ }^{5}$ Significantly, what might be considered the more enlightened variant of citizenship, civic citizenship (or at least a prototype of civic citizenship), as well as the more progressive principle of membership, ius soli, belong to these countries' past rather than to their present.

In the two countries of the area under discussion that have the strongest state tradition, Poland and Hungary, a medieval conception 
of political citizenship prevailed well after it had disappeared elsewhere. In both countries, as in some other parts of Europe, the gentry or equestrian estate was seen as constituting the nation, that is, the politically enabled and active part of the population. If, from the perspective of global justice, 'citizenship in Western liberal democracies is the modern equivalent of feudal privilege' (Carens I987: 252), then feudal privilege may well be the medieval equivalent of citizenship. The originality of the Polish and Hungarian cases was that this estate, largely made up of the landowning squirearchy or even the landless petty gentry, though still only a small minority, comprised a far broader section of the overall population than it did, for example, in Western Europe. ${ }^{6}$ Here, as in pre-modern Western Europe, estate identity overrode linguistic or ethnic criteria. In the vast multiethnic entities that were the Polish and Hungarian kingdoms, referred to as the Polish-Lithuanian Commonwealth and the Lands of the Crown of Saint Stephen, social status thus trumped the multitude of potentially competing blood connections. The Polish szlachcic (noble or gentleman) was proud to declare himself natione polonus, gente ruthenus (or lituanus), thus affirming that Polish political identity was compatible with Ruthenian (that is, Ukrainian, in modern terms) or Lithuanian primordial ties. As these terms may recall, a neutral dead language, Latin, was the political lingua franca of this class well into the eighteenth century in the case of Poland and into the middle of the nineteenth century in Hungary (Walicki I994; Bárány I990: 20I).

Political citizenship was thus a function of estate membership. In Hungary, the crown was theoretically elective; in Poland, it was effectively elective until the disappearance of the Polish state in I795, with the electorate consisting of the gentry estate. In spite of huge disparities of wealth and power, members of this estate cultivated a formal equality to such an extent that in Poland all titles of nobility were outlawed (Davies I982: 239ff). In both countries as well as in Bohemia, Diets made up of members of the nation met regularly, deliberated vociferously and exercised power to various degrees (Schramm I996).

In Bohemia, the estate system proved weaker and decayed earlier than in Hungary and Poland. As in these two countries, the estate system here did not originally differentiate among ethnic or linguistic identities, in this case, between Germans and Slavs. It cultivated a Bohemian 'land patriotism [...] the patriotism of our aristocracy' (Sayer I998: $57 \mathrm{ff}$ ). Only in the wake of the seismic events of $\mathrm{i} 848$, did Bohemian and local identities change into ethnic ones. Bohemians and Budweisers became Czechs or Germans, to quote the title of a recent study which emphasises that 'ethnicity was only one form of nationhood among several in Habsburg Central Europe, yet one that came to dominate the others' (King 2002: IO). However, in Bohemia, territorial- 
based identity remained strong. During the First World War, Thomas Masaryk originally founded his case for Bohemian independence on the state rights of the historic Kingdom of Bohemia. He put aside this argument only when he saw that it did not impress British decision makers, who were indifferent to antiquarian constitutional niceties in countries other than their own. He also downplayed it as he realised that it did not further the project of uniting Slovakia with the Czech lands in a future Czechoslovak state (Agnew 2000; Galandauer I993).

The territorial demarcation of political membership, intimately connected to citizenship based on ius soli, was firmly anchored elsewhere in East Central Europe as well.7 From the early Middle Ages, the Hungarian comitat gave local territorial content to the principle of gentry self-government (Bak I990: 66; Holub I958). After I848 the comitat remained a fundamental and prestigious administrative unit. The Polish Dietines, assemblies of local gentry, were the effective units of government in pre-partition Poland from the fifteenth century to the late eighteenth century (Davies I982: 323). Polish exiles after 1830, having abandoned the now obsolete idea of a Polish gentry nation, defined the Polish nation in territorial terms, as consisting of all those who lived in the territory of Poland before the first partition of 1772 (Kukiel I955; Liebich 2004). Restoration of the Polish state within these borders was still the demand of Polish activists at the time of the First World War. ${ }^{8}$ Finally, until I9I8, throughout the whole territory of the Austro-Hungarian empire (with the partial exception of Bosnia-Herzegovina), Heimatrecht (indigénat, pertinenza), an original form of communal citizenship, was the basic building block of state citizenship (Redlich I907). ${ }^{9}$ This institution, which deserves the attention of historians of citizenship, appears to have survived unto the present day only in Switzerland. ${ }^{\text {IO }}$

The Allied and Associated Powers, victors in the First World War, had fought, purportedly, for the rights of small nations and for the principle of national self-determination. Their objective was the creation of national states, that is, states that were, if not ethnically homogeneous, at least responsive to the aspirations of ethnic nations in East Central Europe. In setting down the rules for acquisition of citizenship in the successor states, however, the victorious powers resorted to territorial criteria. Anyone habitually resident (in the case of former German or Russian territory) or possessing communal Heimatrecht (in the case of former Austria-Hungary) within the new frontiers of a state was entitled to that citizenship. The solution did not preclude citizenship conundra for individuals who were not of the majority 'race and language' and who did not possess - or could not prove - present or past Heimatrecht in their state of residence - for example, some Hungarians in Slovakia (Napier 1932). This was perhaps the last time that a 
territorial principle predominated over ethnic criteria in determining citizenship in the countries with which we are concerned. Henceforth, territoriality, like social status in an earlier period, became a criterion of the past and ethnicity took the lead in regards to citizenship.

In the post-First World War peace treaties the victors were thus obliged to make concessions to the principle of ethnicity, at least as an alternative criterion for the determination of citizenship. The treaties allowed for a right of citizenship option. In the case of the Treaty of Versailles with Germany, individuals could determine their citizenship not only on the basis of habitual residence but also by virtue of their place of birth, on condition that their parents were domiciled in that place at the time of their birth. As one commentator stated, 'it [was] impossible that there be any question of race or language [italics in original]' in setting criteria for optants 'since Poland counts masses of Jews among its nationals [ressortissants] speaking a special jargon, and more than one third of the citizens of Czechoslovakia are of the German language' (Brustlein I922: 35). In fact, race and language were precisely the criteria applied for the successor states of the Habsburg empire. Individuals having Heimatrecht anywhere in the former Austria-Hungary could choose, instead of the citizenship of the state in which their commune now lay, the citizenship of the state where the majority of the population was made up of people speaking their language and was of their 'race'. In a sort of counterpart to the Treaty of Versailles provision that citizenship could also be based on one's place of birth in addition to one's current place of residence, the Treaty of Saint Germain and the Treaty of Trianon allowed citizenship to be claimed on the basis of an earlier Heimatrecht just previous to one's current Heimatrecht (Subbotitch 1926; Brustlein 1922).

One is tempted to see in the differential dispositions with regard to Germany and Austria-Hungary an expression of the different perceptions of these two countries, Germany being seen as governed by more civic and Austria-Hungary by more ethnic considerations. Confirmation of such an approach might be sought in the fact that the Treaty of Versailles speaks of Czechoslovaks (art. 85) and Poles (art. 9I) who are German nationals, yet does not define a Czechoslovak or a Pole, unlike Trianon and Saint Germain, which specifically evoke 'race and language'. It may be simply the logic of Heimatrecht that leads in this direction. As Heimatrecht replaces birth place and encourages the cult of a petite patrie or a spirit of subjective belonging, it may be expected that Heimatrecht-based citizenship on a state scale would edge away from a strictly impersonal basis of citizenship, such as birthplace, and seek out other criteria for belonging.

Since I9I8, the prevailing conceptions of identity in all of the countries in question have led them to look towards ethnic criteria in defin- 
ing those entitled to citizenship, as we have already seen in the discussion about the selective authorisation of plural citizenship. On a formal level, the governing principle of the citizenship laws presented in this volume is descent without reference to ethnicity, albeit, in the case of the Baltic states, with a strict time reference. Bulgaria even proclaims an apparent ius soli principle that is, in fact, negated in the same breath because, according to the Constitution, any child born on Bulgarian territory is a citizen, unless it acquires another citizenship by origin (art. 25, para. I; my italics). Ius soli is, in fact, so marginalised that in some countries (i.e. Latvia, Romania, Hungary), restrictions are made on the naturalisation of foundlings, who, one might assume, would be automatically granted citizenship. ${ }^{\mathrm{II}}$ In addition to explicit ethnic criteria with regard to naturalisation, the underlying ethnic concept of citizenship can be found explicitly in schemes that attempt to establish a quasi-citizenship or a special connection with co-nationals abroad.

The most famous recent case of such an attempt at quasi-citizenship - 'fuzzy' citizenship as one scholar has called it - is that of the Hungarian Status Law of 200I (Fowler 2002). This measure provoked an enormous storm in the states concerned, the countries of the Hungarian diaspora. The question was examined by international bodies, notably the Venice Commission ${ }^{\mathrm{I2}}$ and the Council of Europe. The Hungarian Status Law was finally adopted in significantly modified form, having served as a reminder of the passions that issues of citizenship can arouse (see Kántor, Majtenyi, Ieda, Vizi \& Halász 2004).

The Hungarian Status Law provides a certain number of advantages to its beneficiaries. When in Hungary status holders enjoy the same cultural and educational benefits as Hungarian citizens, as well as subsidised travel, and some social security and health service benefits. They can work for up to three months a year in Hungary without restriction. The Law provides additional advantages to Hungarian teachers living abroad (not just teachers of Hungarian but those teaching in Hungarian) and subsidies to families abroad who send their children to local Hungarian schools. State subsidies are guaranteed for Hungarian-language institutions and for Hungarian community organisations abroad.

The Hungarian Status Law is not unique. Overcoming lengthy bureaucratic and political obstacles, Poland finally introduced a Polish Card in 2007. Slovenia has adopted the Republic of Slovenia and Slovenians Abroad Act (2006), which serves a similar purpose. Slovakia has adopted a full-fledged Law on Expatriate Slovaks (I997). The beneficiaries can reside in Slovakia 'for a long period' of time and can be employed - apparently, for an unlimited period - without a work permit and without permanent residence status. They receive assistance 'to maintain their Slovak identity,' wherever they may be. There is some 
alleviation of provisions governing social security contributions while elderly expatriates receive travel subsidies within Slovakia. Lithuania's citizenship law (2002) provides for a certificate of indefinite 'retention of the right to citizenship' for pre-June I940 Lithuanian citizens as well as 'persons of Lithuanian descent' - the term is unspecified - residing abroad.

Why did the Hungarian status law provoke a storm abroad whereas there does not appear to have been any such adverse reaction to, say, the corresponding Slovak law? The answer seems to lie in the respective definitions of prospective beneficiaries. Significantly, and perhaps paradoxically, the Slovak law has not caused international concern because it defines its beneficiaries in ethnic terms whereas the Hungarian law is vague on ethnic requirements and precise on territorial conditions.

Slovak expatriate status may be granted to an individual without Slovak citizenship who has 'Slovak nationality or Slovak ethnic origin and Slovak cultural and language awareness.' Slovak ethnic origin is obtained if at least one ancestor 'up to the third generation had Slovak nationality.' 'Cultural and language awareness' depends on 'at least passive knowledge of the Slovak language and basic knowledge of Slovak culture or declaring himself/herself actively for the Slovak ethnic [sic].' I do not propose to ponder the ambiguities of the expression 'declaring [oneself] actively for the Slovak ethnic.' Rather, let me cite, for purposes of comparison, the definition contained in the Hungarian Status law:

This Act shall apply to persons declaring themselves to be of Hungarian nationality, who are not Hungarian citizens and who have their residence in the Republic of Croatia, the Federal Republic of Yugoslavia, Romania, the Republic of Slovenia, the Slovak Republic or the Ukraine and who have lost their Hungarian citizenship for reasons other than voluntary renunciation. (art. I, para. I)

Simply declaring oneself to be 'of Hungarian nationality,' as certified by a recognised Hungarian community organisation abroad, is sufficient to obtain the 'Certificate of Hungarian Nationality' provided for in the Status Law. Note also that by referring only to persons of Hungarian nationality rather than Hungarian ancestry or descent, the Status Law might be seen as thinking in terms of a state of affairs that disappeared in 1920 .

Underlying the difference in reactions provoked by the Hungarian Status Law and the (non) reaction to the Slovak Expatriate Law, is historical experience. For almost a millennium, Hungary, even when its 
own sovereignty was impaired, dominated the Danubian basin and outlying areas. All or parts of the countries mentioned in the Status Law belonged to the Crown of Saint Stephen. For centuries, the Hungarian nobility - the Hungarian nation in the feudal sense, as we have seen above - owned and governed these territories. After having long magyarised local elites, in the nineteenth century the Hungarian state also launched a sweeping campaign of general magyarisation. The Slovaks have been, in contrast, a dominated nation par excellence (dominated, in fact, by Hungarians). The subjects of the Slovak Expatriate Law are, above all, Slovak emigrants in America and elsewhere. The law also concerns Slovaks in the Czech Republic - the largest minority in that state since the dissolution of Czechoslovakia - as well as the small, and much assimilated, Slovak minority in Hungary, sometimes invoked by Bratislava to counter Budapest's complaints about the treatment of the Hungarian minority in Slovakia.

The overwhelming importance of history in determining reactions to the respective status and expatriate laws is confirmed by the Polish example. While the project of a Polish Card was stalling, Poland promulgated a law on Repatriation (2000) that formalised a procedure previously adumbrated in the Nationality Act. I shall deal with other aspects of this law in the following section, but here let me point out that although this Polish law does dwell on ethnicity, like the Slovak law, it also has a determining territorial component, like the Hungarian statute. Crucially, however, the territorial scope of the Polish law is defined in such a way to exclude any former Polish territories. It concerns Poles 'in the Asian part of the former Union of Soviet Socialist Republics' - that is the three Caucasian Republics, the Asian part of the Russian Federation and the Central Asian Republics (art. 9, para. I). The Polish Sejm (Lower House of Parliament) specifically rejected the senate's proposed amendment that repatriation provisions be extended to Poles in all states of the former socialist bloc. ${ }^{\mathrm{I} 3}$ The Repatriation Law thus excludes Ukraine, Byelorussia and Lithuania, all of which were integrated in the pre-I795 Polish Commonwealth (Rzeczpospolita) and parts of which were still included in the Polish 'Second Republic,' i.e. the interwar Polish state. Although there are considerable numbers of Poles in these countries and, at least in the case of Byelorussia, they may have not only economic but serious political reasons for seeking repatriation, Poland seems to be bending over backwards to avoid the suspicion that it is thinking in terms of its imperial past or historical boundaries. In the case of Hungary, there is a strong suspicion that this is precisely the thinking behind the Status Law. ${ }^{\text {I4 }}$

In summary, the new EU states go to considerable lengths to include those whom they consider their own. This is usually understood as facilitating naturalisation - sometimes to the extent of dropping virtually 
all standard requirements in exchange for a declaration of national consciousness (as in the case of Bulgaria or EU candidate Croatia). Whether 'one's own' are co-ethnics, as is usually the case, or inhabitants of lost territories, as in Romania, the twofold purpose is the same. First, as we have argued, the purpose is to define the boundaries of one's imaginary community; and, second, the purpose is to rectify the wrongs of the past. It is to the latter objective that we shall now turn.

\section{Old wrongs and new rights, or how to use citizenship to correct history}

A peculiarity of the new EU states is that citizenship laws and related provisions are formulated with the intention of redressing past wrongs. The compensatory or restitutional function - Wiedergutmachung, in the literal sense of the term - is particularly strong with respect to the recent communist past, though it extends to earlier periods as well.

The Polish Repatriation Act mentioned above is a prime example of an attempt at such historical redress. The preamble to the Act begins by 'recognising that the duty of the Polish state is to allow the repatriation of Poles who had remained in the East [...] due to deportations, exile and other ethnically motivated forms of persecution.' Repatriates enjoy significant benefits. They acquire Polish citizenship on the day they cross the Polish border (art. 4). Their costs of resettlement are underwritten by the Polish state.

Repatriates are of 'Polish extraction [and] declaring Polish nationality.' Polish extraction is defined as having at least one parent or grandparent or two great grandparents who held Polish citizenship or who cultivated 'Polish traditions and customs' (art. 5). Polish nationality is ascertained by demonstrating 'links with Polish provenance, in particular by cultivating Polish language, traditions, and customs.' Knowledge of Polish is, obviously, an advantage but it is not a requirement to the same degree as 'traditions and customs', since the latter suffice to confirm the Polish nationality of one's forbearers. These traditions and customs remain undefined, allowing wide latitude for consular officials who, according to the law, decide whether an individual meets criteria for repatriation. One supposes that some of the most evocative traditions for the vast majority of today's Polish population would be religious; for example, celebration of Christmas in the Polish style. This might encompass non-Catholic Christian Poles and even non-believers but it would exclude members of other faiths, such as observant Jews.

In spite of what one might expect from the preamble and spirit of the law, proof of deportation, forced exile or persecution are not condi- 
tions for obtaining repatriate status. The law also covers, perhaps inadvertently, those individuals (and their descendants) who emigrated willingly to some of the peripheries of the Russian Empire or of the USSR; for example, as employees in Siberian development projects or in the military or civil service of the Russian or Soviet state. ${ }^{15}$ The primary target of the law, however, are those families who were deported in I939I940 from Soviet-occupied Eastern Poland (even though these areas are no longer part of Poland) as well as earlier exiles and deportees; members of the Polish minority in the USSR transferred in the Stalinist era to areas far from the Polish border; and Polish nationalists and revolutionaries exiled under the tsar, especially after the 1905 Revolution in the Russian Empire and the 1863 Insurrection in the Polish and Lithuanian lands, but perhaps even earlier and under other circumstances. The number of persons affected by the Repatriation Act is insignificant. Between 1997 and 2006, the total number of the repatriated, including non-Polish spouses, was some five thousand, the largest number of whom came from Kazakhstan (see Górny \& Pudzianowska in this volume). However, the symbolic significance of the act as an affirmation that the act of conferring citizenship may be used to right the wrongs of history, far back into the past, is enormous.

Although attempts to replace the communist-era Polish citizenship law (I962) bogged down in legislative paralysis, the bill proposed by the Sejm to the senate in 2000 gives further insight into the hypothesis formulated above regarding the objective of righting historical wrongs through citizenship law. ${ }^{\mathrm{I}}$

According to the proposed bill, the President may confer Polish citizenship, upon his or her own decision, on foreigners who did military service during the I939-I945 war in the Polish army or in Polish military formations attached to Allied forces on all fronts, or who served in Polish underground formations and organisations, including those in partisan units attached to such organisations. These individuals do not need to have possessed Polish citizenship in the past (art. I7, paras. I.I, I.2, 2). The bill also provides for restitution of citizenship, without presidential intervention and simply on the basis of a declaration before a consular official within a specified time period, for some individuals who left Poland between I September 1939 and 4 June I989 - the latter date being identified as the beginning of the end of communist rule. Those reinstated include individuals who, in order to leave Poland, were forced to renounce their citizenship under threat of 'repressions and chicaneries', including arrest, loss of work or dwelling, or expulsion from schools, including universities (art. 28, para. I.I.b). The specific victims of communist persecution covered in this provision would seem to be, above all, those students, intellectuals and others purged as 'Zionists' in 1968. Reinstatement is not granted to those 
who left Poland voluntarily on the basis of a declaration that they belonged to a non-Polish ethnic group and who 'obtained the citizenship of the native country of their nationality' (art. 28, para. 2.4.). This provision is aimed at preventing ethnic Germans or others from benefiting from the reinstatement granted to the victims of the ig 68 purges. Finally, the bill offers restitution of citizenship to those who had lost it by enlisting in the armed forces of Great Britain, the US or France after (!) 9 May I945. In a sense, the bill appears to be saying that Poland - the real Poland which is now able to express itself - had never taken a stand against its wartime allies during the Cold War.

The Czech Republic, also keen to underline and correct the injustices of the communist era, adopted restitution laws. The Law on the Citizenship of Some Former Czechoslovak Citizens (I999) opens with the following, somewhat grandiose declaration:

Parliament, in order to assuage the legacy of certain wrongs that occurred in the period I948 to I989, and realising that Czechs and compatriots living abroad contribute to maintaining and cultivating the national cultural heritage as well as to deepening ties of common belonging with the Czech Republic and realising that Czech emigrants developed, in exile, notable spiritual, political and cultural activity in favour of renewal of freedom and democracy in its homeland and that this activity deserves extraordinary recognition.

In fact, however, the law benefits all individuals and their descendants who lost their Czechoslovak citizenship during this period for whatever reason, including by virtue of the prohibition on plural citizenship in Czechoslovakia or by virtue of naturalisation in a state that prohibited dual citizenship but, presumably, no longer does so now. Restitution of citizenship here may thus be seen as a favour or as a sort of citizenship amnesty offered to all Czechs, whatever the circumstances of their loss of citizenship. The law did have a cut-off period that expired in 2004; however, the deadline was abolished (Seitlová 2005: II; Baršová in this volume). With regard to the numerically significant and politically vocal Czech-American lobby, the bilateral convention dating back to I928 between the US and Czechoslovakia prohibiting dual citizenship had already been invalidated by a government decree in 1997, without reference to the 1993 Czech Citizenship Law article (art. I7) prohibiting dual citizenship in general. In practical terms, the I999 law on former Czechslovak citizens would therefore be superfluous for this important group. This law, as well as other legal dispositions, takes care to include some categories of Slovaks among its beneficiaries and dual Czech and Slovak citizenship is authorised, again as an exception to a 
general prohibition. One could argue, however, that the latter provisions are no longer prompted by considerations of historical justice but, rather, amount to housecleaning operations dealing with some of the messy aspects of the Czech-Slovak divorce.

In the case of the Baltic states, the very reemergence of these countries is itself seen as a redress for historical injustice. Naturally, citizenship laws also serve the purpose here of correcting past iniquities and they do so largely by legally abolishing the time period during which injustice was perpetrated. The Estonian Nationality Law (1995) does not mention specific dates, yet this does not mean that it is neutral with regard to them. At the time of registration for Estonian citizenship in I989, those who had an a priori legal claim to citizenship were only those who were themselves, or one of those whose forbearers was, an Estonian citizen on I6 June I940, the date of the Soviet ultimatum leading to occupation. In accordance with the thesis on state continuity, in 1992 the Estonian Parliament voted to reapply the Citizenship Act of 1938 , as amended up to I6 June I940 (Thiele 2002). The latter qualification deprived a number of resident non-Estonian nationals of eligibility for facilitated naturalisation. Like certain other countries, Estonia specifically states that it will not grant or restore citizenship to those who have acted against the interests of the state (art. 2I, para. 3). Independent of this provision, the Estonian law, until 2005, also denied citizenship (by denying permanent residence status, which is a precondition for citizenship) to individuals and spouses of individuals who entered Estonia 'in conjunction with the assignment of military personnel into active service, the reserve forces or retirement' (art. 2I, para. 6). An exception was made in the law for individuals who had retired from the armed forces of a foreign state and had been married for at least five years (and were still married) to a natural-born Estonian citizen. (One wonders how many such cases there may be.) Apparently, historical injustices may be righted not only by conferring citizenship but also by denying it.

Latvia's Citizenship Law (1994) also identifies citizens, in the first instance, as those who were citizens on I7 June I940 and their descendants, unless they had become citizens of another state after 4 May I990 (art. 2, para. I). Naturalisation by Latvians abroad during the period of occupation is thus distinguished from naturalisation since the reacquisition of independence. This is in accordance with the idea that, since the occupation was illegal, no change of a citizen's legal status could occur in that period and thus those who were citizens in 1940 continued to be citizens in 1990, whatever they had done in the meantime. The law also considers as citizens women and their descendants who lost Latvian citizenship by virtue of a law of I9I9 concerning women who married foreigners. This provision too - variants of which 
may be found in other citizenship laws - represents the correction of a historical injustice, though one related to gender rather than communist rule. Restrictions on who can obtain Latvian citizenship are more severe in some respects than those in Estonia. Citizenship will not be granted to those whom courts have identified as propagating, after 4 May I990, racist or totalitarian ideas (the latter comprising communist ideas) as well as those who, after I3 January I99I, acted against the Republic of Latvia through participation in the Communist Party (CPSU [LCP]) or front organisations, including the Organisation of War and Labour Veterans. In Latvia, neither retired Soviet military and police personnel, albeit only those who came to Latvia directly after demobilisation, nor former employees or even informants for the Soviet security services are eligible for citizenship. This also holds true for military personnel who came to Latvia on active service. Brief mention is made of persons who entered Latvia in accordance with the Mutual Assistance Pact between Latvia and the USSR of 5 October I939, the followup to the Molotov-Ribbentrop Pact, but this only seems to exclude the possibility of exceptional rather than regular naturalisation (art. I3, para. I.3).

Lithuania adopted the earliest and most liberal policies of naturalisation among the Baltic states. It did, however, distinguish between citizens by right and 'potential citizens', the latter being Soviet-era immigrants with no criminal record and with a legal income, who were entitled to opt for Lithuanian citizenship within two years upon adoption of the law. Citizens by right, even according to the most recent Lithuanian Citizenship Law (2002), were considered to be those who held citizenship prior to I5 June I940, and their descendants. The aim of historical redress is revealed in an article (art. I4, para. 2) that makes it easier for deportees or political prisoners who married Lithuanian citizens, as well as for their children born in exile, to become naturalised. In these cases, naturalisation is facilitated even further (compared to other spouses of Lithuanian citizens) by shortening the residency period from seven to five years. Here legislators could also not resist introducing historical memory into citizenship law.

In most countries, redressing historical wrongs and favouring co-ethnics are intimately connected matters and the issue of plural citizenship is grafted onto this connection. In some cases, however, redressing wrongs may inflect the ethnic connection while creating a breach with regards to the issue of plural citizenship. The Bulgarian and the Romanian cases illustrate this inter-relationship.

Bulgaria opened the door to plural citizenship when it naturalised or renaturalised Bulgarian ethnic Turks who had been expelled in I989, in the last gasp of an increasingly chauvinistic but dying communist regime. A newly de-communised Bulgaria thus sought to make 
amends for this brutal treatment of its citizens. In the meantime, however, these Turks had been granted Turkish citizenship, making them ineligible for Bulgarian citizenship according to the provisions of the communist-era Citizenship Law (I968) that was still in force and even according to the new democratic Constitution (I99I). Bulgaria's new Citizenship Law (1998), however, made provisions for allowing Turks to reclaim their Bulgarian citizenship. Considerations of restitutive justice thus overrode the reluctance to tolerate plural citizenship for anyone other than ethnic Bulgarians and, indeed, nudged Bulgaria towards a more liberal naturalisation policy for ethnic Bulgarians. Even after historical justice had been done, however, the question of the ethnic Turks who had been driven out remained a burning political issue. The dispute within the Bulgarian political spectrum became one that had to do with the voting rights of ethnic Turks who had reacquired Bulgarian citizenship but were not residing permanently within Bulgaria. Therefore, it cannot be said, even after redress was achieved, that the matter has been successfully closed with no further chance of sequels (see Smilov \& Jileva in this volume).

Romania, as we have seen, chose to redress the wrongs committed by its dismemberment in I940 by extending an offer of citizenship to all individuals who had been or were descended from Romanian citizens, as defined by the extended border that emerged in the wake of the First World War. This was an offer that could be taken up via a simplified procedure, without any obligation of repatriation or renunciation of other citizenships. There was, however, something paradoxical about this initiative. Romania had been quick to recognise the sovereignty of the Republic of Moldova, whose borders correspond to a large part of Romania's lost Bessarabia. Romania did not, however, make territorial claims against Moldova, nor against Ukraine, which, during the time it was a Soviet republic, acquired part of Bessarabia and part of the province of Bukovina that had been Austrian before it became Romanian in I9I9. This curiously subdued form of irredentism mirrors, to some extent, the Bulgarian position regarding the naturalisation of Macedonians. Bulgaria instantly recognised the sovereignty of the new post-Yugoslav Macedonian state but refused to recognise the Macedonian language (creating difficulties for the authentication of bilateral agreements) and thus, given the importance of language in defining nationality in this part of Europe, took an ambiguous stance with regard to the existence of a Macedonian nation. Romania explained its extension of citizenship not as a negation of Moldovan or Ukrainian sovereignty but as a protest against - and redress of - the iniquity of the Molotov-Ribbentrop Pact of 1939, which made the dismemberment of Romania possible. 
The Romanian effort to redress historical wrongs also provoked undesired consequences, as did the corresponding Bulgarian policy described here. Perhaps the Romanian government believed that its offer of citizenship would not be taken up, inasmuch as both Moldova (at the time) and Ukraine did not authorise dual citizenship? Somewhat cynically, the expected result would be that the inhabitants of these two 'lost lands' would regret the change of borders and would yearn for their former homeland! In fact, the Romanian offer was taken up so enthusiastically that somewhere between I00,000 and 300,000 individuals, mostly Moldovans, became Romanian citizens. Apparently, Romanian naturalisation became something of a business, involving dubious third-party brokers. In the face of an avalanche of applications, Romania at first suspended the process (200I) and then tightened its requirements (2003). A further cause of this change must have been the realisation that the policy of naturalisation was not doing anything to promote Romanian consciousness or any other Romanian interests in Moldova. The modifications transformed the restitution of citizenship to former citizens (irrespective of their ethnicity) into a policy that involves the repatriation of ethnic Romanians into Romania. Thus, even when there is the initial desire to right wrongs in territorial terms, without regard to ethnicity, the issue is eventually still defined in ethnic terms.

\section{Conclusion: The historical past, the ethnic present and the immigrant future}

All of the countries surveyed in this introduction, with the exception of Poland, have adopted new citizenship laws in the post-communist era. All citizenship laws and related instruments, including Poland's, have been subject to substantial tinkering or, indeed, fundamental revisions.

From the studies collected in this volume we may tentatively suggest that the issue of redressing historical wrongs, especially those dating from the communist period, is now losing its saliency. This concern with the historical past has now blended with a powerfully asserted emphasis on ethnic identity. It is this emphasis that has cleared away the earlier barriers to plural citizenship, thus confirming the tenet that one's kin will always remain one's own, wherever they may be and whatever other allegiances they may have.

The new Europe has not, however, turned its attention to any of the future issues regarding citizenship, notably those raised by what will undoubtedly be a rising wave of immigration in the years to come. A number of countries, perhaps most acutely among the Baltic states, are already experiencing a labour shortage caused by widespread emigra- 
tion, whether it is temporary or permanent. All of the countries, without exception, are undergoing a demographic decline of more or less drastic proportions. This vacuum is most likely to be filled by immigrants from further East or even from the former colonial world. This will be a completely unprecedented situation for countries that have always been exporters of labour and have never possessed colonial empires.

The countries of the new Europe are barely completing the process of updating their understandings of citizenship from those that existed in the pre-communist and communist periods to ones that correspond to their present self-image. One wonders how they will undertake the transition to yet another conception of citizenship encompassing a new reality that is only now emerging.

\section{Annex: Constitutional preambles (extracts)}

Croatia (I990) The millennial national identity of the Croatian nation and the continuity of its statehood, confirmed by the course of its entire historical experience in various political forms and by the perpetuation and growth of state-building ideas based on the historical right to full sovereignty of the Croatian nation, manifested itself:

- in the formation of Croatian principalities in the 7 th century;

- [twelve other historical dates follow to confirm Croatian statehood].

Czech Republic (I993) We, the citizens of the Czech Republic in Bohemia, Moravia, and Silesia, at the time of the renewal of an independent Czech state, being loyal to all good traditions of the ancient statehood of Czech Crown's Lands and the Czechoslovak State.

Estonia (1992) Unwavering in their faith and with an unswerving will to safeguard and develop a state which is established on the inextinguishable right of the Estonian persons to national self-determination and which was proclaimed on February 24, I9I8 [...] which shall guarantee the preservation of the Estonian nation and its culture throughout the ages, the Estonian people adopted, on the basis of art. I of the Constitution which entered into force in 1938 , by Referendum held on June 28, 1992 the following Constitution.

Hungary (1989) In order to facilitate a peaceful political transition to a constitutional state, establish a multi-party system, parliamentary democracy and a social market economy, the Parliament of the Republic of Hungary hereby establishes the following text as the Constitution of 
the Republic of Hungary, until the country's new Constitution is adopted.

Latvia (I990) ${ }^{\mathrm{I7}}$ The independent state of Latvia, founded on I8 November I9I8, was granted international recognition in I920 and became a member of the League of Nations in I92I. The Latvian Nation's right to self-determination was implemented in April I920, when the people of Latvia gave their mandate to the Constituent Assembly chosen by universal, equal, direct and proportional elections. In February I922, the Assembly adopted the Constitution of the Republic of Latvia, which is still in effect de iure.

Lithuania (I992) The Lithuanian Nation having established the State of Lithuania many centuries ago [...] having for centuries defended its freedom and independence [...] having preserved its spirit, native language, writing, and customs.

Poland (I997) Recalling the best traditions of the First and the Second Republic [...] Obliged to bequeath to future generations all that is valuable from our over one thousand years' heritage, bound in community with our compatriots dispersed throughout the world.

Slovakia (I992) mindful of the political and cultural heritage of our forebears, and of the centuries of experience from the struggle for national existence and our own statehood, in the sense of the spiritual heritage of Cyril and Methodius and the historical legacy of the Great Moravian Empire.

Slovenia (I99I) [Proceeding ...] from the historical fact that in a centuries-long struggle for national liberation we Slovenes have established our national identity and asserted our statehood.

\section{Notes}

I One might group Poland along with Hungary as being a state with uninterrupted continuity since I9I8. Poland was partitioned in I939 and its demise was decreed by the partitioning (and occupying) powers, Germany and the USSR. Its disappearance was not acknowledged by the other Great Powers who recognised its government in exile until the restoration of the country in I945.

2 This chapter focuses on comparing the histories of post-communist countries of East Central Europe. The post-colonial states Cyprus and Malta as well as Turkey require separate treatment. They are, however, included in the comparative overview of migration and citizenship (see Sievers in this volume).

3 In the Czech Republic, the fundamental principle of exclusive citizenship has been breached by a number of exceptions, notably the acceptance of dual citizenship for ex-Czechoslovaks who have become Slovaks as well as for repatriates (see below). In 
Slovakia, the provision that renouncement of former citizenship is 'in favour' of naturalisation is so weak as to be self-negating.

4 As we see from the chapter by Eugene Buttiegieg, this tendency, conceived in ethnic terms and directed at a diaspora, encompasses Malta as well.

5 I take the point that the civic-West/ethnic-East stereotype 'when true is only weakly true, and according to several measures is false' (Shulman 2002: 554). With respect to conceptions of citizenship, however, the civic/ethnic distinction seems to me a useful heuristic device in tracing a historical evolution.

6 In Poland, II-I3 per cent of the population belonged to the equestrian estate in the sixteenth century, 9-Io per cent in the eighteenth century. In France, under the July Monarchy (1830-1848), I.5 per cent of the population was enfranchised. In Britain, the corresponding figure at that time $(\mathrm{I} 828)$ was 3.2 per cent (figures cited by Walicki I982: I6). In Hungary, the gentry numbered 3-5 per cent of the population by the fifteenth century (Engel I990: 43).

7 The two new Balkan states of the EU present contrasting situations. As soon as Bulgaria acquired autonomy in 1878 it conferred citizenship on all of its inhabitants. At approximately the same time, Romania instituted a citizenship policy based on ethnicity that also applied for naturalisation (see Smilov \& Jileva as well as Iordachi in this volume).

8 According to Soubbotitch (1926: 55), many (unnamed) Polish jurists argued that Poland had never ceased to exist because the partitions were in fact occupations. The analogy with present-day Baltic positions is striking (see section 3 of this chapter). I have not found examples of such Polish arguments but their existence is confirmed, a contrario, through a vehement attack on such arguments by Schätzel (I92I).

9 It might be noted, too, that there was no Austro-Hungarian citizenship. Austrian and Hungarian citizenship laws (the legal regimes were entirely separate) did not require candidates for naturalisation to prove that they had lost their previous nationality but, as of 1870 , they did require such proof of Hungarians seeking to become Austrians and vice versa (Soubbotitch I926: I5).

Io A recent reference source refers to indigénat as 'a second-degree nationality preserved by nationals of a federal entity' - which neither Hungary nor Austria ever was - and describes it as 'vieilli' or archaic (Salmon 200I). Even today, however, to 'be a Swiss citizen implies a cantonal indigénat and a communal citizenship. The three levels are inseparable. No one can be a national (ressortissant) of a canton without communal citizenship or Swiss without a cantonal indigénat' (http://etat.geneve.ch). The same document refers to 'nationalité (indigénat) genevoise'. In addition to a droit de cité communal there is also a concept in some localities of bourgeoisie communale that implies a co-proprietorship of communal assets.

II Latvia restricts citizenship to foundlings born on Latvian territory after 2I August I99I, the date of the Moscow coup that might be seen as the last gasp of the USSR (see Krūma in this volume). Romania grants foundlings citizenship not on the basis of birth on Romanian territory but under the assumption that their parents (or at least one of them) held Romanian citizenship (see Iordachi in this volume). Hungary grants foundlings nationality on a conditional basis; the presumption of statelessness or Hungarian parentage may be rebutted without any time limit (Kovács \& Toth in this volume).

I2 The European Commission for Democracy through Law, an advisory commission of the Council of Europe.

I3 Radio Free Europe/Radio Liberty, 'Polish Repatriation to Focus "Mainly" on Compatriots from Kazakhstan', Daily Report, 9 November 2000.

I4 Countering the claim that Hungary defines the scope of its Status Law in terms of its historic boundaries, one might note that the Status Law does not extend to Austria, though part of historic Hungary today lies within Austria. This exception is 
not sufficient to alleviate suspicions. In fact, it nourishes other grounds for resentment: the Status Law does not cover Austria because one of the tacit intentions of the Law is to minimise the effects for expatriate Hungarians of Hungary's entry into the EU. The resulting inequality of status for citizens of Romania (until 2007), Serbia, Ukraine, etc. was one of the principal grounds for international reservations vis-à-vis the law.

I5 Some such individuals would be covered by the provision that repatriation cannot be offered to anyone who 'during their stay outside the Republic of Poland acted against the vital interests of the Republic of Poland or participated in human rights violations' (arts. 8.3 a and b). The law also excludes those who repatriated from Poland between I944 and I957 to some Soviet Republics. Presumably, however, descendants of all these individuals are still eligible for repatriation if they meet other requirements.

I6 Ustawa z dnia 29 czerwca 2000 r. o obywatelstwie polskim, Tekst ustawy przekazany do Senatu zgodnie z art. 48 regulaminu Sejmu (nie zakończony proces legislacyjny) [Statute of 29 June 2000 regarding Polish citizenship, text of statute transmitteed to Senate according to article 48 of the Senate Regulation (uncompleted legislative process)]. http://orka.sejm.gov.pl.

I7 Declaration on the Renewal of Independence.

\section{Bibliography}

Agnew, H. L. (2000), 'New States, Old Identities? The Czech Republic, Slovakia and Historical Understandings of Statehood', Nationalities Papers 28 (4): 6I9-650.

Bak, J. (I990), 'The Late Medieval Period, I382-I526', in P. F. Sugar, P. Hanák \& T. Frank (eds.), A History of Hungary, 54-82. London: I. B. Tauris.

Bárány, G. (I990), 'The Age of Royal Absolutism, I790-I848', in P. F. Sugar, P. Hanák \& T. Frank (eds.), History of Hungary, I74-208. London: I. B. Tauris.

Bibó, I. (ed.) (I99I), 'The Distress of the East European Small States [I946]', in his Democracy, Revolution, Self-Determination, ed. by K. Nagy, I3-69. Boulder: Atlantic Research and Publications.

Brustlein, A. (I922), 'La Notion de l'indigénat dans les traités de paix de Versailles, de Saint Germain et de Trianon', Journal du droit international 49: 34-53.

Carens, J. (I987), 'Aliens and Citizens: The Case for Open Borders', Review of Politics 49 (2): $25 \mathrm{I}-273$.

Connor, W. (1984), The National Question in Marxist-Leninist Theory and Strategy. Princeton: Princeton University Press.

Davies, N. (I982), God's Playground: A History of Poland, vol. I: The Origins to 1795. New York: Columbia University Press.

Engel, P. (I990), 'The Age of the Angevines, I30I-I382', in P.F. Sugar, P. Hanák \& T. Frank (eds.), A History of Hungary, 34-53. London: I. B. Tauris.

Fowler, B. (2002), 'Fuzzing Citizenship, Nationalising Political Space. A Framework for Interpreting the Hungarian "Status Law" as a New Form of Kin-State Policy in Central and Eastern Europe', Working Paper 40. ESRC (Economic and Social Research Council), One Europe or Several? ESRC European Research Programme. www.one-europe.ac.uk.

Galandauer, J. (I993), '30 kvĕtna I9I7: Slovensko poprvé v programu legitimní ceské politické representace (jak česi překročili řeku litavu)' [Slovakia for the the first time in a programme of legitimate Czech political representation (how the Czechs crossed the Leitha river)], Sbornik Vojenské Akademie V Brnĕ Si (348): I35-I42. 
Holub, J. (1958), 'La Représentation politique en Hongrie au Moyen Age,' in Studies presented to the International Commission for the History of Representatives and Parliamentary Institutions, Tenth International Congress of Historical Sciences (Rome, I955), 79-I2I. Louvain: Edition Nauwelaerts.

Kántor, Z., B. Majtenyi, O. Ieda, B. Vizi \& I. Halász (2004), The Hungarian Status Law: Nation building and/or Minority Protection. Hokkaido: Slavic Research Centre. http://src-h.slav.hokudai.ac.jp.

King, J. (2002), Budweisers into Czechs and Germans: A Local History of Bohemian Politics 1848-1948. Princeton: Princeton University Press.

Kukiel, M. (I955), Czartoryski and European Unity 1770-1861. Princeton: Princeton University Press.

Liebich, A. (I995), 'Nations, States, Minorities: Why is Eastern Europe Different?', Dissent $42(3): 313-318$.

Liebich, A. (2000), 'Plural Citizenship in Post-Communist States', International Journal of Refugee Law I2 (I): 97-I07.

Liebich, A. (2004), 'Czartoryski and the Quest for Polish Statehood', ASN and Studjum Europy Wschodniej Conference Paper, Warsaw, July 2004.

Liebich, A. (2008), 'How Different is the New Europe? Perspectives on the New Europe', CEU Political Science Journal 3 (3): 269-292

Napier, W. (I932), 'Nationality in the Succession States of Austria-Hungary', Transactions of the Grotius Society I8: I-I6.

Redlich, J. (I907), 'The Municipality. I. Austria. The Commune System', Journal of the Society of Comparative Legislation 8 (I): $\mathrm{12}-40$.

Rosdolsky, R. (I986) [1934], Engels and the 'Non-Historic' Peoples: The National Question in the Revolution of 1848. Translated, edited and with an introduction by J.-P. Himka. Glasgow: Critique Books.

Salmon, J. (ed.) (200I), Dictionnaire de droit international public. Bruxelles: Bruylant.

Sayer, D. (1998), The Coasts of Bohemia: A Czech History. Translated from the Czech by A. Sayer. Princeton: Princeton University Press.

Schätzel, W. (I92I), 'Polens Untergang und Wiedererrichtung vom völkerrechtlichen Standpunkt', Archiv des öffentlichen Rechts 40 (I): 73-86.

Schramm, G. (1996), 'Polen-Böhmen-Ungarn: Übernationale Gemeinsamkeiten in der politischen Kultur des späten Mittelalters und der frühen Neuzeit', in J. Bahlcke, H.J. Bömelburg \& N. Kersken (eds.), Ständefreiheit und Staatsgestaltung in Ostmitteleuropa: Übernationale Gemeinsamkeiten in der politischen Kultur vom 16.-18. Jahrhundert, I338. Leipzig: Universitätsverlag.

Seitlová, J. (2005), 'Senàt navrhuje lhůtu pro navráčení občanstvi' [Senate proposes to open a timeline for restoring citizenship], Veřejna správa I6 (6): II.

Shulman, S. (2002), 'Challenging the Civic/Ethnic and West/East Dichotomies in the Study of Nationalism', Comparative Political Studies 35 (5): $554-585$.

Soubbotitch, I. V. (1926), Effets de la dissolution de l'Autriche-Hongrie sur la nationalité de ses ressortissants. Paris: Rousseau \& Cie.

Thiele, C. (2002), 'Staatsangehörigkeit in den baltischen Staaten: Das Beispiel Estland', Osteuropa 52 (6): 729-742.

Walicki, A. (1982), Philosophy and Romantic Nationalism: The Case of Poland. Oxford: Clarendon Press.

Walicki, A. (1994), Poland between East and West: The Controversies over Self-Definition and Modernization in Partitioned Poland. Harvard University: Ukrainian Research Institute. 
Part I

Restored states 



\title{
1 Estonian citizenship: Between ethnic preferences and democratic obligations
}

\author{
Priit Järve
}

The most important reform in the nationality policy of Estonia after I945 was the restoration of the pre-I940 nationality in 1992 by reintroducing the 1938 Citizenship Act with slight changes. In I995, Estonia adopted a new Citizenship Act which did not change the basic principles of the acquisition and loss of Estonian nationality but established more demanding requirements for the acquisition of nationality by naturalisation.

\subsection{History of Estonian nationality}

\subsubsection{Nationality policy since 1945}

The Republic of Estonia was established in I9I8. In I940, it was annexed to the Soviet Union as the Estonian Soviet Socialist Republic under threat of military force. As a result, the citizens of the Republic of Estonia were incorporated into the Soviet citizenry. Estonian nationality was replaced by Soviet nationality. Between 194I and 1944, Estonia was occupied by Nazi Germany. In I944, Estonia was re-conquered by the Red Army, and Soviet nationality was once again imposed upon the people on its territory. Estonian nationality ceased to exist de facto. ${ }^{\mathrm{I}}$ Instead, the Soviet passports, which were issued in Estonia after the Second World War, included a mandatory line with ethnic identification of the carrier. 'Estonian' became one of such identifications to be used in Soviet internal passports (Soviet passports for travel abroad did not mention ethnicity). In Estonia, as opposed to many internal regions of the USSR, everyone was issued Soviet internal passports upon reaching the age of sixteen. These passports, not valid for travel abroad, gave the holders relative freedom to travel within the Soviet Union. The authorities stamped the carrier's domicile registration (propiska) and marital status into the passport.

The Soviet Union sought to merge the different ethnic nations and groups living in the country into a new civic identity - the Soviet people. While the Soviet authorities claimed that such an identity was emerging, and some citizens reported that they already regarded themselves as 'Soviets', the official registration of different ethnic identities 
was not discarded. Thus, Estonians had the inscription 'Estonian' in their passports until the dissolution of the Soviet Union, ${ }^{2}$ though, this inscription could not be automatically converted into Estonian nationality after independence. Since I992, only pre-I940 nationals and their descendants, regardless of their ethnic identification, were entitled to acquire Estonian nationality by registration. Those Estonians who settled in Estonia after I940 and their descendants (with 'Estonian' in their Soviet passports) could not acquire Estonian nationality by simple registration but had to take the path of naturalisation. At the same time, pre-I940 nationals and their descendants of non-Estonian ethnic origin (with 'Jew', 'Russian', 'Latvian', 'Pole', etc. in their Soviet passports) could acquire Estonian nationality by registration. In new Estonian passports the registration of ethnic identity was dropped.

The debate on nationality between liberal and conservative camps started in Estonia at the end of the I980s when the national independence movement was gathering momentum. In I989, the campaign of registering the citizens of the pre-war Republic of Estonia and their descendants was carried out by the Estonian Citizens' Committees, voluntary associations established during the perestroika era to sustain the idea of the legal continuity of the pre-war Estonian state. On the positive side, this campaign helped restore the awareness of the link between the individual and the state. At the same time, being led by national conservatives, it firmly introduced the exclusive approach towards Estonian nationality. The conservatives pointed at drastic changes in the ethnic composition of the population of Estonia due to a considerable influx of Russian-speaking immigrants under the Soviet regime. These settlers had pushed the share of non-Estonians in the population up from around io per cent in I940 to unprecedented 38.5 per cent in 1989 .

In I992, the conservatives emerged as winners in the debate on nationality. As a result, the Citizenship Act of 1992 was based on the principle of the restitution of the pre-I940 nationality. Only those who were citizens in I940 and their descendants (regardless of ethnicity) were granted Estonian nationality by registration, those who settled in Estonia after I940 were offered the possibility of becoming Estonian nationals through naturalisation. As an immediate consequence of this Act the majority of non-Estonians as well as a small number of Estonians were not granted the right to participate in the national referendum on the country's new Constitution in I992 and in the first parliamentary elections after independence later the same year. Estonia's new political leadership considered the great number of non-Estonian settlers as a threat to the nation. Under these conditions, nationality became an instrument for the attainment of national homogeneity and for the political containment of Soviet era settlers. The interests of the 
Estonian ethnic nation, as then understood, were given priority over full democratic participation.

In Estonia these exclusionary policies enjoyed relatively wide support as a reaction to the changes in the ethnic composition of the population. A survey of public opinion, carried out in the Baltic states in I993, showed that the principle of limiting nationality to descendants of the pre-I940 citizens was supported by 44 per cent of Estonian, 52 per cent of Latvian and 12 per cent of Lithuanian respondents (Rose \& Maley I994: 3I-34). These differences among the Baltic respondents correlated very clearly with the demographics of the respective countries: the bigger the share of non-titular groups in a given state, the stronger the reluctance to let them participate in political life.

The restoration of pre-I940 nationality had profound political consequences. The exclusion of the majority of non-Estonians from the formation of state institutions and from the process of adoption of crucial legal documents, including the Constitution, enabled Estonians to entrench themselves firmly in all the major posts of the state avoiding power-sharing with minorities. During the referendum on independence in Estonia in March I99I there were I,I44,309 persons with the right to vote. During the referendum on the Estonian Constitution in the summer 1992, after the adoption of the first Citizenship Act, the reported number of eligible voters was 689,319, or only about 60 per cent of the I99I figure. Consequently, 454,990 adults had been disenfranchised (Semjonov 2000: I5). It was therefore not surprising that the Parliament elected in I992 was Ioo per cent Estonian.

The restoration of pre-I940 nationality caused mass statelessness of non-Estonians, which harmed the relations between different ethnic communities inside Estonia, caused tension in the relations with Russia (the absolute majority of non-citizens were Russians), and evoked criticism, usually disguised as 'recommendations', from prominent international and regional organisations such as the United Nations, the OSCE, the Council of Europe and the European Union.

Between 1992 and I January 2008, the share of stateless residents in Estonia declined from 32 to 9 per cent (see Figure I.I). However, the inability and/or the lack of motivation of older cohorts of non-citizens to master the Estonian language at the necessary level raises doubts of whether the problem of statelessness will be easily overcome in the near future if the conditions of naturalisation remain the same.

\subsubsection{Restoration of Estonian nationality ${ }^{3}$}

On 26 February I992, the Supreme Council of the Republic of Estonia put the version of 16 June I940 of the Citizenship Act of I938 into force. The main features of this nationality regulation were the ius san- 
Figure 1.1 Estonian citizens and stateless persons in Estonia, 1992-1 January 2008, per cent of total population

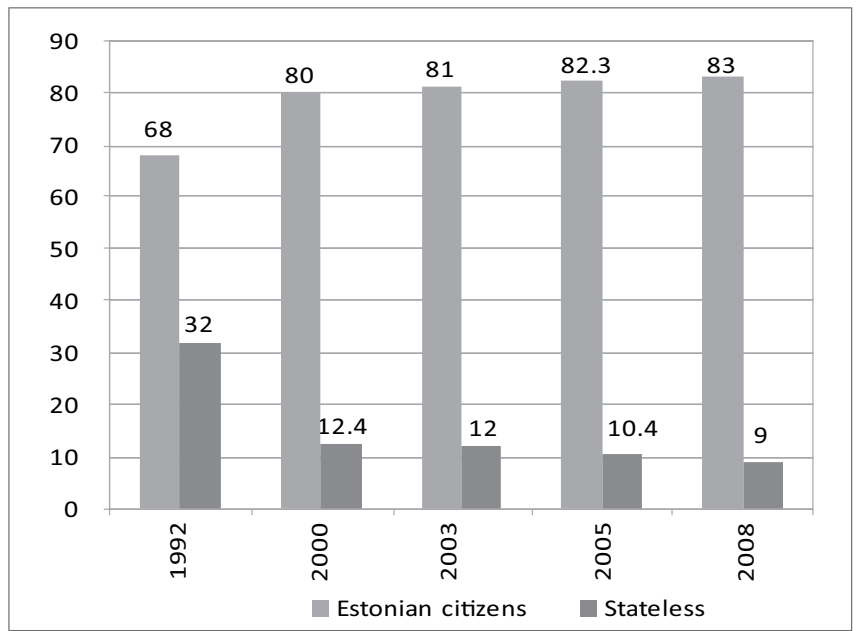

Source: Estonian Ministry of the Interior and Statistical Office of Estonia

guinis principle and the avoidance of dual nationality. Pursuant to art. 3 of this Law, every person who possessed or whose parents possessed Estonian nationality before I6 June I940 - the day of the Soviet ultimatum followed by the annexation of Estonia - had a legal claim to Estonian nationality. About 80,000 non-Estonians thereby acquired Estonian nationality.

Russians and others who came to Estonia after I6 June 1940, all in all almost one third of the entire population in 1992, were automatically excluded from Estonian nationality. In essence, they were mostly immigrant workers but perceived by many as colonial settlers with no right to automatic acquisition of Estonian nationality. The only way for them to acquire Estonian nationality was through naturalisation. As a precondition for naturalisation, the applicant had to have his or her permanent place of residence in the Estonian territory (as proved by propiska) for at least two years before and one year after the application date (residence census 'two plus one') and had to prove their knowledge of the Estonian language. The earliest date for establishing the permanent place of residence was set at 30 March I990. The required time period was counted only from that day onwards, so that 30 March I993 was the earliest date when one could acquire Estonian nationality by naturalisation. Thus, a large part of the population, especially Russians, did not have the right to vote or the right to run for office in the parliamentary election of 20 September 1992 and were therefore excluded from political participation, giving rise to further tensions in a 
situation that was already strained. These tensions were somewhat eased by the right of non-citizens to vote at the local elections after I996.

After some changes in the 1992 Citizenship Act, a new Citizenship Act was passed on I9 January I995 and entered into force on I April I995. ${ }^{4}$ The new Act integrated all regulations on nationality and introduced some new conditions for naturalisation (residence in Estonia on the basis of a permanent residence permit issued at least five years prior to the date of written application for Estonian nationality and at least one year after the registration of the written application; and a test on the knowledge of the Estonian Constitution and the Citizenship Act).

According to the initial version of the I995 Citizenship Act, children of stateless parents born in Estonia could not acquire Estonian nationality after birth. This was in violation of the International Covenant of Civil and Political Rights (art. 24(3)) and the Convention on the Rights of the Child (art. 7(I)), both of which Estonia had ratified. These provisions proclaim the right of the child to acquire a nationality. This controversy triggered a heated discussion. Some politicians and lawmakers saw the danger of compromising the governing principle of nationality acquisition (ius sanguinis) by adding the ius soli principle to it.

After political and academic debates, in which the role of recommendations issued by international actors should not be underestimated, an amendment to the Citizenship Act was finally adopted in December I998, which entered into force on I2 July 1999. Pursuant to this amendment, children under the age of fifteen born on Estonian territory after 26 February I 992 can acquire the Estonian nationality on the basis of a declaration if their parents are stateless and have been legal residents of Estonia during the previous five years. This new regulation did not include children between the ages of fifteen and eighteen who are under the protection of art. I of the Convention on the Rights of the Child and children born before 26 February i992. Thiele (I999) argues that this domestic regulation was not fully in line with Estonia's international obligations.

Some changes in the legislation on nationality have made the naturalisation process easier for certain groups of applicants. For example, in June 2002, the Estonian Parliament adopted amendments to the Citizenship Act, which created special conditions for acquisition of Estonian nationality through naturalisation by persons with severe or moderate disabilities (such as a visual, hearing or speech impairment). Disabled persons who have appropriate medical certificates are not obliged to pass exams on knowledge of the language or of the Estonian Constitution and the Citizenship Act. There are also other measures being taken to facilitate naturalisation such as free-of-charge language 
courses since the beginning of 2009 (financed by the European Commission) and recognition of Estonian language and civics exams taken by students of Russian-language schools as valid for naturalisation.

\subsection{Basic principles of the most important current modes of acquisition and loss of nationality}

The basic principles of Estonian nationality are stipulated in art. 8 of the Constitution as follows: every child with at least one parent who is an Estonian national shall have the right, by birth, to Estonian nationality; any person who as a minor lost his or her Estonian nationality shall have the right to have his or her nationality restored; no person may be deprived of Estonian nationality acquired by birth; no person may be deprived of Estonian nationality because of his or her beliefs. As further specified by art. 8, the conditions and procedures for the acquisition, loss and restoration of Estonian nationality shall be established by the Citizenship Act. The basic constitutional principles of nationality are reiterated in arts. 5(I), I6(I), 28(3) and 28(2) of the 1995 Citizenship Act respectively.

\subsubsection{Acquisition of nationality}

Acquisition of Estonian nationality is stipulated by Chapters 2 and 3 (arts. 5 through 15) of the 1995 Citizenship Act. This includes acquisition of nationality by birth, by naturalisation and for achievements of special merit. Nationality by naturalisation and for achievements of special merit shall be granted by a decision of the Estonian government.

According to art. 5, nationality is acquired by birth if at least one of the child's parents holds Estonian nationality at the time of the child's birth. Nationality is also acquired by birth if the child is born after the death of his or her father and if the father held Estonian nationality at the time of his death. If a child of unknown parents is found in Estonia, a court can declare that the child has acquired Estonian nationality by birth upon application by the guardian of the child or a guardianship authority, unless the child is proven to be a citizen of another state. According to art. 5, nobody shall be deprived of Estonian nationality acquired by birth.

Arts. 6 through I5 establish conditions for acquisition of Estonian nationality by naturalisation and for achievements of special merit. The conditions for acquisition of nationality by naturalisation differ depending on whether a person is at least fifteen years of age or under that age. 
An alien ${ }^{5}$ who is at least fifteen years of age and wishes to acquire Estonian nationality by naturalisation shall have stayed in Estonia on the basis of a permanent residence permit for at least five years prior to the date on which he or she submits an application for Estonian nationality and for one year from the day following the date of registration of the application. Additionally, he or she must have knowledge of the Estonian language and of the Constitution of the Republic of Estonia and the Citizenship Act. In accordance with the requirements provided for in this Act, he or she must also have a permanent legal income which ensures his or her own subsistence and that of his or her dependants, be loyal to the Estonian state, and take the following oath: 'In applying for Estonian citizenship, I swear to be loyal to the constitutional order of Estonia.'

For a minor to acquire Estonian nationality by naturalisation, an application by his or her parents, or by a single or adoptive parent of Estonian nationality, accompanied by specific documents, is required. After the amendments to the Citizenship Act, which entered into force on I2 July I999, a minor's stateless parents and stateless single or adoptive parent(s) also have the right to apply for nationality by naturalisation for a minor.

Estonian nationality can be acquired for achievements of special merit to the Estonian state, which are defined as 'achievements which contribute to the international reputation of Estonia in the areas of culture or sports or in other areas' (art. Io). Proposals for the granting of nationality for achievements of special merit may be submitted by members of the Estonian government. The government is required to approve the granting of citizenship for achievements of special merit. According to the amendment which entered into force in November I995 (seven months after the Citizenship Act entered into force), Estonian nationality for achievements of special merit may be granted to not more than ten persons per year.

However, in some cases, naturalisation is ruled out. According to art. 2I of the I995 Citizenship Act, Estonian nationality shall not be granted to or resumed by a person who:

I. submits false information upon application for Estonian nationality;

2. does not observe the constitutional order and laws of Estonia;

3. has acted against the Estonian state and its security;

4. has committed a criminal offence for which a punishment of imprisonment of more than one year was imposed and whose criminal record has not expired or who has been repeatedly punished under criminal procedure for intentionally committed criminal offences;

5. has been employed or is currently employed by foreign intelligence or security services; 
6. has served as a professional member of the armed forces of a foreign state or who has been assigned to the reserve forces thereof or has retired there from, nor shall Estonian nationality be granted to or resumed by the spouse of such a person.

Thus, art. 2I(6) clearly targets those non-Estonians (together with their spouses) who are not Estonian nationals by birth and who remained in Estonia after they retired from the Soviet Army. ${ }^{6}$ However, the same art. 2I also offers them one possibility of acquiring Estonian nationality. It stipulates that Estonian nationality may be resumed by, or granted to, a person who has retired from the armed forces of a foreign state if the person has been married for at least five years to a person who acquired Estonian nationality by birth and if the marriage has not been terminated by divorce.

\subsubsection{Loss of nationality}

Conditions and procedures for loss of Estonian nationality are stipulated in Chapter 6 of the 1995 Citizenship Act (arts. 22 through 30). According to these stipulations, a person shall cease to be an Estonian national I) through release from Estonian nationality; 2) through deprivation of Estonian nationality, and 3) upon acceptance of the citizenship of another state.

A person who wishes to be released from Estonian nationality shall submit an application, identification documents, a certificate which proves that he or she has acquired the citizenship of another state or will acquire the citizenship of another state in connection with his or her release from Estonian nationality, and pay the state fee. ${ }^{7}$ According to art. 26, release from Estonian nationality may be refused to a person if: I) the person would become stateless as a result; 2) he or she has unfulfilled obligations towards the Estonian state; 3 ) he or she is in active service in the Estonian Defence Forces. Decisions on release from Estonian nationality shall be taken by the government.

According to art. 28, a person shall be deprived of Estonian nationality by an order of the Estonian Government if he or she I) as an Estonian national, enters state public service or military service of a foreign state without permission from the Estonian Government; 2) joins the intelligence or security service of a foreign state or foreign organisation which is armed or militarily organised or which engages in military exercises; 3 ) forcibly attempts to change the constitutional order of Estonia; 4) upon the acquisition of Estonian nationality by naturalisation or upon resumption of Estonian nationality submits false information and thereby conceals facts which would have precluded the granting of Estonian nationality to him or her or which 
would have precluded him or her from resuming Estonian nationality; 5) is a citizen of another state but has not been released from Estonian nationality. This latter provision makes it possible to deprive naturalised dual citizens of their Estonian nationality if they have acquired another nationality. Since Estonian law is in principle opposed to dual nationality, such persons are obliged to apply for release from their Estonian nationality.

Art. 28(3) establishes an important difference between nationals by birth and by naturalisation. It stipulates that the reasons for deprivation of nationality listed in art. 28 do not apply to persons who acquire Estonian nationality by birth. It means that those who have acquired nationality by naturalisation are vulnerable - they can be deprived of their newly obtained nationality.

Art. 29 addresses the loss of Estonian nationality upon acceptance of citizenship of another state or renunciation of Estonian nationality. It stipulates that a person is deemed by the government agency authorised by the Estonian Government to have ceased being an Estonian citizen upon acceptance of the citizenship of another state or upon renunciation of Estonian nationality in favour of the citizenship of another state. Nevertheless, in light of these stipulations, it remains unclear what happens if an Estonian national by birth does not declare his or her wish to be released from Estonian nationality after he or she has acquired, or is going to acquire another nationality. While the I995 Citizenship Act rules out multiple nationality (arts. 2 and 3) the state has been quite tolerant in cases of the resumption of Estonian nationality by emigrants under art. I6(I) which grants everyone who loses Estonian nationality as a minor the right to resume Estonian nationality. Several such Estonians holding multiple nationalities have been members of the Estonian Government and elected to Parliament.

\subsection{Current debates on nationality}

\subsubsection{The focus of the debate}

From the very outset of Estonian nationality policy in I992, the approaches of Estonians and Russian-speakers to the issue of nationality have been almost diametrically opposed to each other. The approach characteristic of the Estonians draws heavily on history and underlines that the changes in the ethnic composition during the Soviet years, when the share of Estonians fell from 90 per cent to almost 60 per cent between I940 and 1989, were dangerous for the survival of the Estonian nation. Therefore, refusal to grant nationality to Soviet-era settlers by registration was regarded by many Estonians as an adequate re- 
action to these changes in the population. The Estonian side also argues that in comparison with the citizenship laws of other countries the Estonian requirements for nationality are quite liberal by current international standards.

The opposite approach, taken by the Russian-speaking minorities and by several international actors, maintains that history and nation do not matter as much as the Estonians think they do. Rather, one should start with the present multi-ethnic situation and think about individuals. As a characteristic example of this view, Helsinki Watch pointed out that it 'rejects the argument that all those who came to Estonia after I940 did so illegally and therefore were never citizens. Their residency was legally established under the applicable law at the time they entered the territory of Estonia. Those who settled in Estonia after I940 must be treated as individuals, not as instruments of state policy, however reprehensive that policy may have been' (Helsinki Watch I993: I4).

According to the proponents of this view, stateless people are a security risk, since the interests of these individuals are not properly represented at the state level, and their behaviour can be unpredictable. The underlying implication of this argument is usually that Estonia should grant nationality more generously by further simplifying its conditions for naturalisation, especially the language requirements. Most of the ensuing debate has been about the political acceptability of such simplifications, and in most cases the Estonian legislators have rejected the proposals to that end. After more than fifteen years of debates, the opposition between the two approaches has somewhat softened but is still far from having disappeared. As long as there remain many tens of thousands of stateless persons, the debate will probably continue.

\subsubsection{International debate}

Estonia was regularly encouraged by international actors to speed up naturalisation to reduce the proportion of non-citizens in the population, especially during the country's accession to the European Union. Estonia had to discuss its nationality issues with international partners and to even make changes in its Citizenship Act to bring it into alignment with the country's international obligations and to promote naturalisation. Several international and regional organisations, foreign embassies in Estonia, and international NGOs not only participated in the debate but also provided necessary know-how and financial assistance to their Estonian interlocutors. However, under the conditions set by the 1995 Citizenship Act naturalisation slowed down for several years. In 1997, international partners persuaded the Estonian authori- 
ties to launch a policy of integration for non-Estonians. A special government agency (Bureau of the Minister of Population Affairs ${ }^{8}$ ) and a special foundation for the integration of non-Estonians ${ }^{9}$ were established, which started to work out and to implement integration programmes and action plans to resolve the problem of statelessness. ${ }^{\text {IO }}$

After several years of modest yields, the numbers of naturalised citizens briefly surged after Estonia joined the EU in 2004. Estonia interpreted the admission to the EU as the ultimate international approval of its nationality policies. The EU and other international actors virtually stopped issuing recommendations on how Estonia should develop its nationality policy. Only Russia has not dropped the problem of statelessness in Estonia from its political agenda. It remains to be seen to what degree Russia can internationalise this issue in its contacts with the EU, in the framework of the OSCE and in the Council of Europe.

In the wake of Estonia's admission to the EU, inputs from international actors have ceased to inform the domestic debate on nationality issues. Since then, this debate has been shaped more than ever before by internal incentives.

\subsubsection{Domestic debate}

Estonian policy on nationality has remained conservative ever since independence, without major 'home-made' debates after the Citizenship Act of I992 was adopted. Instead, the mainstream political parties have regularly declared prior to national elections that, regardless of the election results, the Citizenship Act and the corresponding policies will not be changed.

The Estonian political elite deemed that the initial non-inclusion of Soviet-era settlers into the citizenry served the interests of the survival of the Estonian ethnic nation and its culture. According to a statement by a former Estonian minister, the ultimate hope for the future of the non-Estonians was 'that a third or so will become Estonian citizens, a third may remain here with Russian citizenship, and at least a third will leave' (Lieven I993: 377). By 2000, these hopes had only partially materialised, mainly because the formation of a persistent contingent of stateless residents had not been anticipated. The results of the population censuses of 1989 and 2000 showed that 29 per cent of non-Estonians from I989 had become Estonian citizens by 2000 and I4 per cent had obtained Russian citizenship, while the total number of nonEstonians had decreased from 602,38I to 439,833, or by 27 per cent between the two censuses. ${ }^{\text {II }}$ In 2000, I73,539 non-Estonians, or 39 per cent of their number in 2000, were Estonian citizens, 86,067 non-Estonians, or 20 per cent, were Russian citizens and I70,349 non-Esto- 
nians, or 39 per cent, were stateless residents (Statistical Office of Estonia 200I: I3-I4). By the end of 2007, the number of stateless residents had fallen to II6,248, which was i9 per cent of the number of non-Estonians in 1989 and 26 per cent of their number in $2000 .^{\mathrm{I} 2}$

In I995, minority members won six seats of the IOI in the Estonian Parliament, for the first time since independence, as representatives of the so-called Russian parties (minority parties). They organised a separate faction which tried to initiate changes in the Citizenship Act in order to make the acquisition of nationality easier for stateless Russianspeakers. However, all those attempts were systematically aborted by firm resistance from the Estonian majority in the Parliament. As a result, the minority parties were compromised in the eyes of Russianspeaking voters and during the 2002 national elections these parties were unable to surpass the 5 per cent threshold to get into the Parliament. In 2002, nine and in 2007 eight candidates of minority origin were elected to the Estonian Parliament on the lists of the so-called Estonian parties, which have started to compete among themselves for the votes of naturalised non-Estonians. As members of mainstream parties, minority MPs hope to be more successful than before in defending the interests of non-Estonians, by promoting naturalisation, minority education and the public use of minority languages.

\subsubsection{Changes in public opinion}

Many Estonians, influenced by history, came to perceive Russia and Russians as threats. Surveys of public opinion and sociological research of the early I990s showed that Estonians tended to support the official nationality policies which sought to control the participation of Russians in Estonian politics with the help of the Citizenship Act. Approximately one fifth of Estonians thought that the official policies, including the language requirements for obtaining nationality were not harsh enough. In 2000, 46 per cent of Estonians believed that Estonia would benefit if non-Estonians left the country (Kruusvall 200I).

The majority of Russian-speakers in Estonia have considered the official policies on nationality, let alone the more radical views reflected in various media outlets, internet chat-rooms and elsewhere, as unfair and discriminatory. Nevertheless, the data from integration monitoring in 2000 showed that non-Estonians were predominantly oriented towards acquiring Estonian nationality: it was desired by 80 per cent of the family members of Estonian citizens who were without nationality, by 62 per cent of the family members of non-citizens, and by 6 I per cent of the family members of Russian citizens. Estonian nationality was desired in the first place for children, but also for spouses and parents. At the same time, I2 per cent of the family members of non-citi- 
zens did not want citizenship, and 16 per cent had not made up their minds. It might well be that a certain number of non-citizens had resigned themselves to their status and did not see any particular reason (or possibility) to change it (Hallik 200I).

While the official Estonian view on nationality has remained basically the same since I992, the public opinion of Estonians has changed due to an increase in overall tolerance and the proliferation of related values. Most remarkably, the integration monitoring of 2005 showed that already as much as 54 per cent of Estonians have agreed to grant nationality to Russians born in Estonia on simplified terms. Only about one third of Estonians held this view in 2000 (37 per cent in 2002). ${ }^{\mathrm{I}}$ Thus, by 2005, the majority of Estonians no longer perceived the Russians as a grave threat. Moreover, ordinary Estonians were more tolerant with regard to nationality issues than official policies. These changes in public opinion might have facilitated new policy initiatives to overcome the problem of statelessness. However, in 2007, the situation took a different turn.

On 27 April 2007, just two weeks before the Russians traditionally celebrate the anniversary of the defeat of Nazi Germany, the Estonian government clumsily relocated a Soviet-era war memorial from the centre of Tallinn, provoking street riots by mostly Russian-speaking youths who felt insulted. Approximately I,200 people were arrested, while many were injured and one Russian citizen was stabbed to death. Attitudes of the Estonians and the Russian speakers towards each other hardened and various integration efforts seemed to be severely compromised. The riots and their aftermath, such as the siege of the Estonian Embassy in Moscow by a youth organisation, drew broad international attention.

In March 2008, the Russian Embassy in Tallinn reported a doubling in the number of applicants for Russian citizenship between August 2007 and March 2008 compared with the same periods in 2006 and 2007. According to embassy officials, many applicants noted that they had 'lost confidence in Estonian democracy'. The applicants were also motivated by the opportunities of visa-free travel and of finding jobs in both the Schengen area and Russia. ${ }^{\mathrm{I}}$ This change in non-Estonians' attitudes had already been detected by a July 2007 Estonian survey, which showed that after the relocation of the war memorial, the trust that non-Estonians had in Estonian state institutions had fallen to 24 per cent (among non-Estonian youths to II per cent; while among Estonians it remained as high as 62 per cent). This is in sharp contrast with figures from 2005, when trust in Estonian institutions among non-Estonians was similar to that of Estonians (Heidmets 2008: 59). Given these changes, the numbers of stateless residents in Estonia may continue to decline, as it is predicted, but it is hard to see how in- 
creasing numbers opting for Russian nationality can be perceived as in Estonia's best interests, particularly in light of the August 2008 armed conflict in Georgia.

\subsection{Statistics on acquisition of nationality since 1992}

Estonian statistics on acquisition of nationality date from after the 1992 Citizenship Act was adopted. The introduction of this Act granted Estonian nationality by registration to 68 per cent of the population who, or whose predecessors, were Estonian nationals before I7 June I940. The rest of the population ( 32 per cent) who, or whose predecessors, were not Estonian nationals before that date, were given the status of aliens. Over 95 per cent of those aliens were not of Estonian descent.

In I993, after several reorganisations at governmental level, the Estonian Citizenship and Migration Board (CMB) was established. ${ }^{\mathrm{I}}{ }^{\text {The }}$ $\mathrm{CMB}$ is a government agency acting within the administrative area of the Ministry of Internal Affairs and its main tasks include: determining the status of persons living in Estonia either as Estonian citizens or as aliens and issuing identity documents to the residents of Estonia, as well as receiving and processing applications for acquiring and restoring Estonian nationality, as well as for exemptions from Estonian nationality, and preparing the respective material for the government of the Republic to decide on these applications (CMB 2003: 4).

Currently, the CMB provides the most reliable statistics on nationality and naturalisation in Estonia. According to these data, between I992 and 2005 as many as I38,246 persons acquired Estonian nationality via naturalisation (CMB 2006: I9). ${ }^{\mathrm{I}}$ Two special categories of applicants account for more than one-third of that number. Between I992 and I995, a simplified fast-track procedure for naturalisation without a language exam was available for those aliens (Soviet-era settlers) who had participated in the elections of the Estonian Citizens' Congress in I990 and had registered as applicants for nationality prior to March I990 (of those, 24,IO2 were naturalised), as well as for Estonians living outside Estonia, of whom 25,293 used this simplified procedure (CMB 2006: 20).

Besides those two special categories, the CMB has provided statistics on the following categories of persons naturalised between I992 and 2005:

I. those who acquired Estonian nationality based on general conditions, i.e. who passed all of the exams (58, о 6 persons);

2. minors under fifteen years of age $(29,46 \mathrm{I})$;

3. those without active legal capacity and the disabled (648);

4. those granted nationality for achievements of special merit (726). 
Moreover, 2,679 persons lost their Estonian nationality, while the government also refused to grant nationality to 605 applicants during this same period (CMB 2006: 20).

The process of naturalisation has not been a homogeneous flow of applications and their approval. After the Citizenship Act of 1992, the tempo of naturalisation was much higher than in the wake of the I995 Citizenship Act, which changed the conditions of naturalisation by making the language exam more rigorous and by adding an exam on the Constitution and the Citizenship Act which also had to be taken in the Estonian language. Thus, between 1992 and I996, as many as 87,7 I2 persons naturalised under the conditions set by the first Citizenship Act, or 60 per cent of all persons who have naturalised between I992 and 2007 (see Figure I.2). In I996, I6,740 persons passed the citizenship language exam, which followed the old rules and requirements. In I997, only 2,099 persons passed an upgraded language exam (UNDP I999: 42).

However, in spite of the complications related to naturalisation, such as language exams which are considered difficult by the applicants, and the growing share of non-Estonians among the citizens, who are eyed with suspicion by ethnic conservatives, no political force in Estonia has proposed stopping the process. As a result, in November 2005, the overall number of naturalised persons $(\mathrm{I} 37, \mathrm{I} 99)$ finally surpassed the number of stateless persons $(\mathrm{I} 36,533) .{ }^{\mathrm{I}}$

Figure 1.2 Naturalisation in Estonia, 1992-2007, persons naturalised per year in thousands

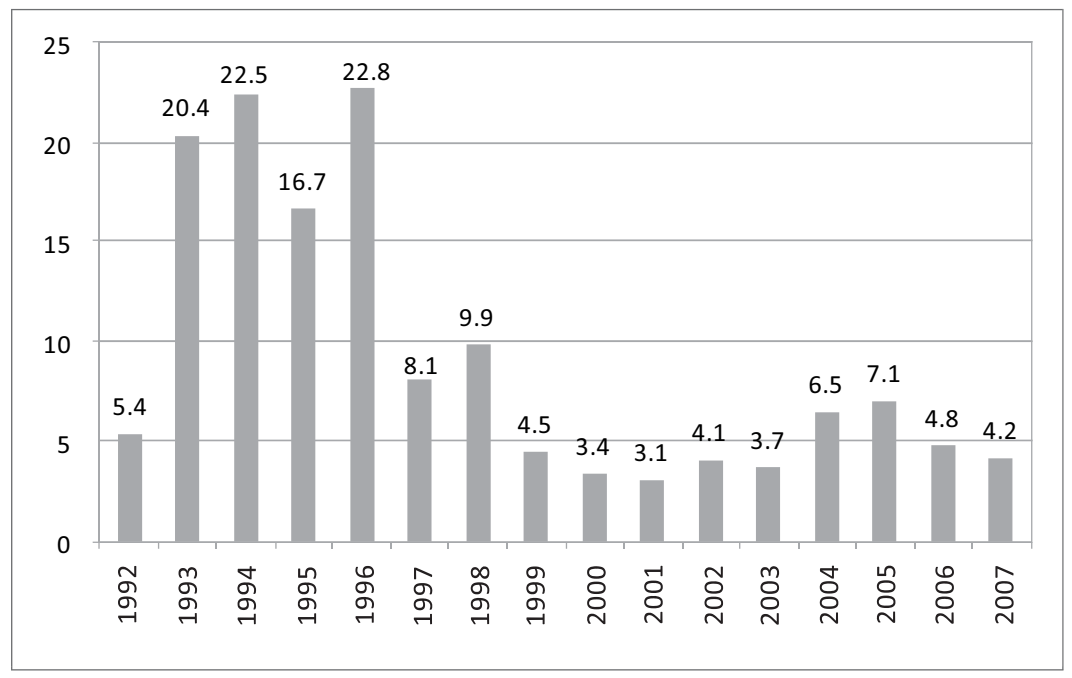

Source: Estonian Citizenship and Migration Board 


\subsection{Conclusions}

The current naturalisation process in Estonia is a politically sensitive and cautious inclusion of non-citizens in which international 'supportive pressure' has played an important role. Naturalisation has brought new members to Estonian citizenry, made it ethnically more diverse and moved the country closer to full democratic participation. It is estimated that about 20 per cent of all Estonian nationals are non-Estonians. More than half of them acquired nationality after I992 through naturalisation. However, II6,000 permanent residents of Estonia still had no nationality by the end of 2007. This means that sustained practical efforts to promote integration and naturalisation are still needed in Estonian society for years to come. Both non-Estonians and Estonians should be targeted in order to promote better mutual understanding and cultural accommodation. Further attempts at prudent statesmanship are required to reduce the negative effects of the events of April 2007 and to restore the image of Estonian nationality in the Russian-speaking community.

Steps should also be taken in developing legal instruments and standards concerning nationality and statelessness. While Estonia has signed and ratified the majority of international instruments aimed at combating racial and ethnic discrimination, ${ }^{18}$ it has so far failed to sign and ratify a number of international treaties dealing with issues of nationality and statelessness such as the UN Convention of the Status of Stateless Persons (1954); the UN Convention on the Nationality of Married Women (1957); the UN Convention on the Reduction of Statelessness (I96I); the Convention of the International Commission of Civil Status to Reduce the Number of Cases of Statelessness (I973); and the European Convention on Nationality (1997).

One is inclined to hope that membership in the EU and the proliferation of democratic values will motivate Estonia to sign and ratify more international treaties in the near future to help overcome statelessness and promote the political participation of minorities through citizenship.

Chronological list of citizenship-related legislation in Estonia

\begin{tabular}{|c|c|c|}
\hline Date & Document & Source \\
\hline 1992 & Constitution of Estonia & $\begin{array}{l}\text { www.legislationline.org; } \\
\text { www.legaltext.ee } \\
\text { (in Estonian) }\end{array}$ \\
\hline 1992 & Citizenship Act & $\begin{array}{l}\text { www.legaltext.ee } \\
\text { (in Estonian) }\end{array}$ \\
\hline
\end{tabular}




\begin{tabular}{|c|c|c|c|}
\hline Date & Document & Content & Source \\
\hline 1993 & $\begin{array}{l}\text { Aliens Act (consolidated in } \\
\text { 2003) }\end{array}$ & $\begin{array}{l}\text { Regulates the entry of } \\
\text { aliens into Estonia, their } \\
\text { stay, residence and } \\
\text { employment in Estonia } \\
\text { and the bases for legal } \\
\text { liability of aliens }\end{array}$ & $\begin{array}{l}\text { www.legislationline.org; } \\
\text { www.legaltext.ee } \\
\text { (in Estonian) }\end{array}$ \\
\hline 1995 & $\begin{array}{l}\text { Citizenship Act (adopted } \\
19 \text { January 1995, entered } \\
\text { into force } 1 \text { April 1995) }\end{array}$ & $\begin{array}{l}\text { Replaces the Citizenship } \\
\text { Act of 1992; does not } \\
\text { change the basic principles } \\
\text { of acquisition and loss of } \\
\text { nationality but establishes } \\
\text { more demanding } \\
\text { requirements for the } \\
\text { acquisition of nationality } \\
\text { by naturalisation }\end{array}$ & $\begin{array}{l}\text { www.legislationline.org; } \\
\text { www.legaltext.ee } \\
\text { (in Estonian) }\end{array}$ \\
\hline 1995 & $\begin{array}{l}\text { Citizenship Act } \\
\text { Amendment Act of } 18 \\
\text { October } 1995 \text { (entered into } \\
\text { force } 20 \text { November 1995) }\end{array}$ & $\begin{array}{l}\text { Establishes that } \\
\text { citizenship for } \\
\text { achievements of special } \\
\text { merit may be granted to no } \\
\text { more than ten persons per } \\
\text { year }\end{array}$ & $\begin{array}{l}\text { www.legislationline.org; } \\
\text { www.legaltext.ee } \\
\text { (in Estonian) }\end{array}$ \\
\hline 1995 & Language Act & $\begin{array}{l}\text { Establishes the Estonian } \\
\text { language as the only } \\
\text { official language of } \\
\text { Estonia; regulates the } \\
\text { requirements for } \\
\text { proficiency in the Estonian } \\
\text { language and the use of } \\
\text { Estonian and foreign } \\
\text { languages in Estonia }\end{array}$ & $\begin{array}{l}\text { www.coe.int; } \\
\text { www.legaltext.ee } \\
\text { (in Estonian) }\end{array}$ \\
\hline 1997 & Aliens Act Amendment Act & $\begin{array}{l}\text { Establishes new conditions } \\
\text { for issuing permanent } \\
\text { residence permits (at least } \\
\text { three years residence } \\
\text { within the last five years on } \\
\text { the basis of a temporary } \\
\text { residence permit) }\end{array}$ & $\begin{array}{l}\text { www.legislationline.org; } \\
\text { www.legaltext.ee } \\
\text { (in Estonian) }\end{array}$ \\
\hline 1998 & $\begin{array}{l}\text { Citizenship Act } \\
\text { Amendment Act of } 8 \\
\text { December } 1998 \text { (entered } \\
\text { into force } 12 \text { July 1999) }\end{array}$ & $\begin{array}{l}\text { Provides for acquisition of } \\
\text { citizenship for children of } \\
\text { stateless single or adoptive } \\
\text { parents; introduces } \\
\text { deprivation of citizenship } \\
\text { in case of submission of } \\
\text { false information in the } \\
\text { process of application and } \\
\text { loss of citizenship upon } \\
\text { acceptance of the } \\
\text { citizenship of another state }\end{array}$ & $\begin{array}{l}\text { ww.legislationline.org; } \\
\text { www.legaltext.ee } \\
\text { (in Estonian) }\end{array}$ \\
\hline 1999 & Identity Documents Act & $\begin{array}{l}\text { Establishes an identity } \\
\text { document requirement } \\
\text { and regulates the issue of }\end{array}$ & $\begin{array}{l}\text { www.legislationline.org; } \\
\text { www.legaltext.ee } \\
\text { (in Estonian) }\end{array}$ \\
\hline
\end{tabular}




\begin{tabular}{|c|c|c|c|}
\hline Date & Document & Content & Source \\
\hline & & $\begin{array}{l}\text { identity documents to } \\
\text { Estonian citizens and } \\
\text { aliens by the Republic of } \\
\text { Estonia }\end{array}$ & \\
\hline 2000 & $\begin{array}{l}\text { Citizenship Act } \\
\text { Amendment Act of } 14 \text { June } \\
2000 \text { (entered into force } \\
10 \text { July 2000) }\end{array}$ & $\begin{array}{l}\text { Amends the requirements } \\
\text { for naturalisation for a } \\
\text { person with a severe, } \\
\text { profound or moderate } \\
\text { disability }\end{array}$ & $\begin{array}{l}\text { www.legislationline.org; } \\
\text { www.legaltext.ee } \\
\text { (in Estonian) }\end{array}$ \\
\hline 2001 & Penal Code Article 174 & $\begin{array}{l}\text { Establishes penalties for } \\
\text { the alteration of a child's } \\
\text { descent by substituting a } \\
\text { child with a child of } \\
\text { another person for } \\
\text { personal gain, or if causing } \\
\text { alteration of the child's } \\
\text { citizenship }\end{array}$ & $\begin{array}{l}\text { www.legislationline.org; } \\
\text { www.legaltext.ee } \\
\text { (in Estonian) }\end{array}$ \\
\hline 2001 & $\begin{array}{l}\text { Citizenship Act } \\
\text { Amendment Act of } 14 \\
\text { November } 2001 \text { (entered } \\
\text { into force } 1 \text { February 2002) }\end{array}$ & $\begin{array}{l}\text { Revises the wording of } \\
\text { some articles as a result of } \\
\text { changes in other civil laws }\end{array}$ & $\begin{array}{l}\text { www.legislationline.org; } \\
\text { www.legaltext.ee } \\
\text { (in Estonian) }\end{array}$ \\
\hline 2002 & $\begin{array}{l}\text { Citizenship Act } \\
\text { Amendment Act of } 5 \text { June } \\
2002 \text { (entered into force } 1 \\
\text { July 2002) }\end{array}$ & $\begin{array}{l}\text { Specifies rules for the } \\
\text { naturalisation of children } \\
\text { whose parents are dead, } \\
\text { missing or have restricted } \\
\text { active legal capacity or } \\
\text { whose parents are } \\
\text { deprived of their parental } \\
\text { rights }\end{array}$ & $\begin{array}{l}\text { www.legislationline.org; } \\
\text { www.legaltext.ee } \\
\text { (in Estonian) }\end{array}$ \\
\hline 2002 & $\begin{array}{l}\text { Citizenship Act } \\
\text { Amendment Act of } 19 \text { June } \\
2002 \text { (entered into force } 1 \\
\text { August 2002) }\end{array}$ & $\begin{array}{l}\text { Rules that the government } \\
\text { of the Republic shall } \\
\text { substantiate the granting } \\
\text { of citizenship for } \\
\text { achievements of special } \\
\text { merit (but not the refusal } \\
\text { to grant citizenship on } \\
\text { these grounds); regulates } \\
\text { the fees for the acquisition } \\
\text { of citizenship by } \\
\text { naturalisation, for } \\
\text { resumption of and for } \\
\text { release from citizenship }\end{array}$ & $\begin{array}{l}\text { www.legislationline.org; } \\
\text { www.legaltext.ee } \\
\text { (in Estonian) }\end{array}$ \\
\hline 2002 & $\begin{array}{l}\text { Citizenship Act } \\
\text { Amendment Act of } 15 \\
\text { October } 2002 \text { (entered } \\
\text { into force } 10 \text { November } \\
\text { 2002) }\end{array}$ & $\begin{array}{l}\text { Regulates the } \\
\text { naturalisation of persons } \\
\text { with a severe, profound or } \\
\text { moderate disability }\end{array}$ & $\begin{array}{l}\text { www.legislationline.org; } \\
\text { www.legaltext.ee } \\
\text { (in Estonian) }\end{array}$ \\
\hline 2003 & $\begin{array}{l}\text { Citizenship Act } \\
\text { Amendment Act of } 29 \\
\text { January } 2003 \text { (entered into } \\
\text { force } 1 \text { March 2003) }\end{array}$ & $\begin{array}{l}\text { Regulates the procedures } \\
\text { for acquisition of } \\
\text { citizenship for adopted } \\
\text { children }\end{array}$ & $\begin{array}{l}\text { www.legislationline.org; } \\
\text { www.legaltext.ee } \\
\text { (in Estonian) }\end{array}$ \\
\hline
\end{tabular}




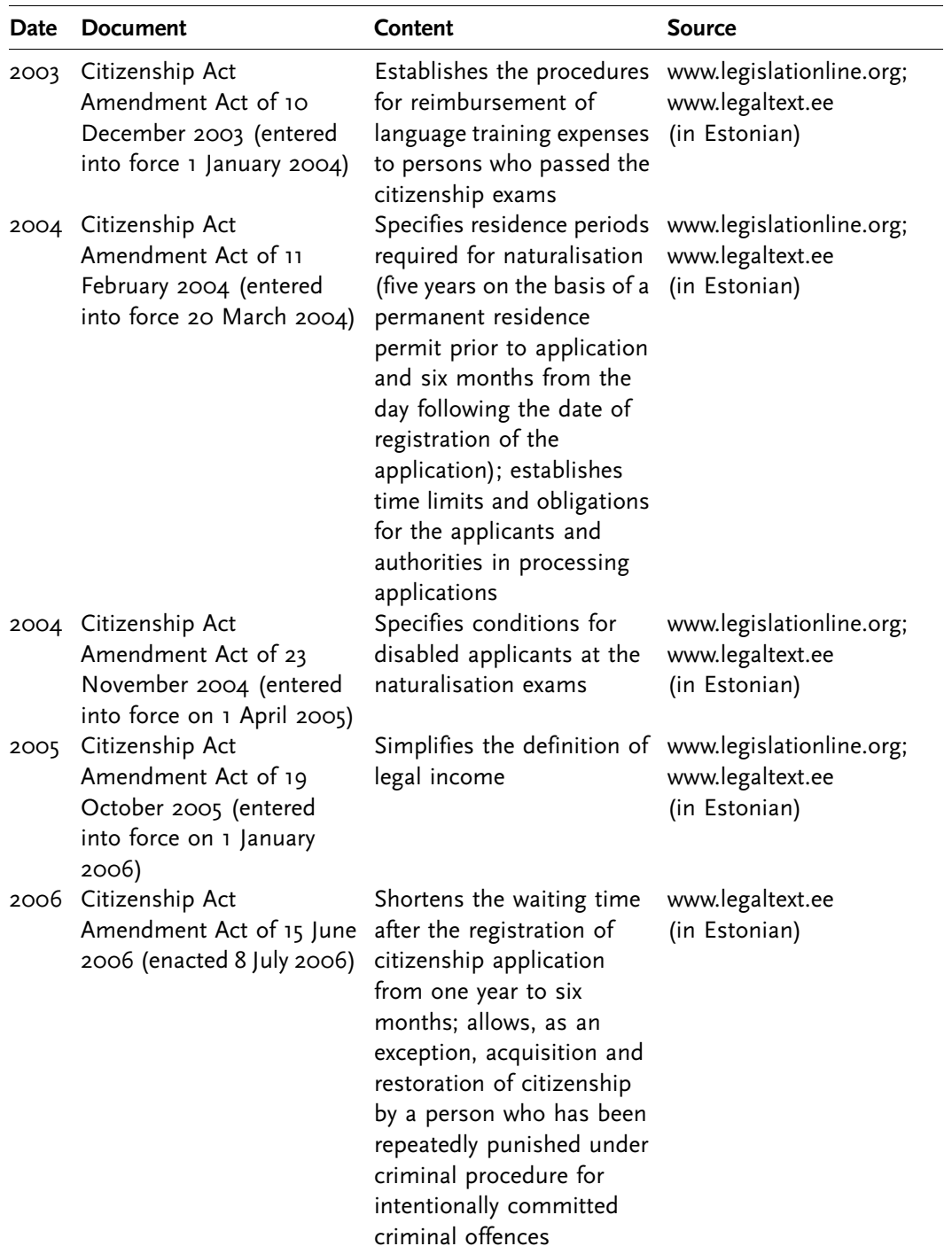

\section{Notes}

I Although the I977 Constitution of the Estonian SSR used the term 'citizens of the Estonian SSR', it was merely a synonym for the mandatory Soviet registration of domicile (in Russian: propiska).

2 In this chapter the terms 'Estonian', 'Russian', etc. designate ethnicity. The term 'non-Estonians' refers to all individuals whose ethnic origin is different from that of 
Estonians. The term 'Russian-speakers' stands for those non-Estonians whose mother tongue, or predominantly used language, is Russian.

This subsection draws on Thiele (1999: 14-16).

4 An English translation is available at www.legislationline.org.

5 Estonian law uses the term 'alien' rather than 'foreign national' to categorise a person who is not an Estonian citizen (Aliens Act of 1993, art. 8). The category of 'aliens' also applies to stateless persons who form a large group among Estonia's noncitizens. The Estonian identification document issued to a stateless person is called an 'Alien's passport' which many stateless persons who were born in the country consider as inappropriate, if not insulting. In Estonian political discourse the stateless persons are characterised differently from the legal jargon as individuals 'who have undetermined citizenship' which gives the whole issue a slightly more positive twist.

6 According to some estimates, this group, which the authorities consider to be a threat to state security, is comprised of approximately 30,000 persons (including family members). Their pensions and health insurances are paid by the Russian Federation. Many of them are also citizens of the Russian Federation. Until 2006, before the new EU regulations were enacted, Estonia provided Soviet Army retirees with temporary residence permits. Now, they enjoy the right to permanent residence permits as nationals of third states who have legally resided in an EU Member State for five years or more. Paradoxically, after Estonia was fully integrated into the Schengen area in 2008 , those permanent residents who hold a Russian passport can travel without a visa from the Pacific Ocean to the Atlantic Ocean, while Estonian citizens still need a visa to travel to Russia.

7 In May 2008, the state fee for naturalisation as well as for release from Estonian nationality was 200 Estonian kroons (I3 euros), while the minimum monthly salary was 3,600 Estonian kroons (230 euros). Applicants do not usually consider this fee to be a significant obstacle.

8 See www.rahvastikuminister.ee.

9 See www.meis.ee (Non-Estonians' Integration Foundation).

IO In 2000 , the government of Estonia adopted the state programme 'Integration in Estonian Society 2000-2007'; in April 2008, the government adopted the second state programme of integration for 2008-2013 (see www.rahvastikuminister.ee).

II After 199I, depopulation became a firm trend in Estonia. The censuses of 1989 and 2000 show that while all minority groups diminished in size, only the Ukrainians, Byelorussians, Tatars, Jews and Germans lost more than one third of their population. At the same time, the most numerous group - the Russians in Estonia had decreased from 475 to $35 \mathrm{I}$ thousand, or only by one fourth. All in all, the absolute number of non-Estonians went down 27 per cent between the two censuses while the absolute number of Estonians decreased by only i2 per cent. As a result, the share of Estonians in the total population went up 6.4 percentage points from 6I.5 to 67.9. According to the census of 2000 , the total population of Estonia was I,370,052 (in 1989: 1,565,622) (Statistical Office of Estonia 200I: I4).

I2 See www.rahvastikuminister.ee.

I3 See the results of Integration Monitoring 2000, 2002, and 2005 at www.meis.ee.

I4 See 'Huvi vene kodakondsuse vastu on kasvanud [Interest in Russian citizenship has grown]', www.delfi.ee, 23 March 2008; Madis Taras, 'Vene kodakondsust taotletakse varasemast aktiivsemalt [People apply for Russian citizenship more actively than before]', Eesti Päevaleht [Estonian Daily], 24 March 2008. www.epl.ee.

I5 Estonians, worried by growing immigration, had already started introducing measures during the pre-Gorbachev era to bring this process under control. Thus, in the early I980s, the municipality of Tallinn, the capital of Estonia, started to limit the 
number of workers that industries and other enterprises were allowed to bring into Estonia, charging them considerable fees for every worker who eventually settled in Tallinn. It is interesting that the legality of these improvised methods was not challenged by Moscow, possibly because the growing inter-ethnic tensions had already sparked public unrest among the youth in Tallinn in the autumn of I980. However, a more systemic foundation for the immigration policy was laid in I990, when the Supreme Council of the Estonian Soviet Socialist Republic (Estonian SSR) established the National Migration Board of the Estonian SSR, the predecessor of the CMB. This agency's task was to carry out state control of migration and issue residence and work permits. For that purpose the Supreme Council adopted the 'Immigration Law of the Estonian SSR', which entered into force on I July I990. This law established the requirement that any alien who wanted to settle in Estonia must apply for a residence permit. The first permits were issued in January I99I.

I6 Between I992 and 3I.I2.2007, I47,228 persons were naturalised in Estonia according to updates available at www.rahvastikuminister.ee.

I7 Source: www.rahvastikuminister.ee.

I8 These documents include the Convention on the Prevention and Punishment of the Crime of Genocide (entry into force in Estonia I9 January 1992), the International Convention on the Elimination of All Forms of Racial Discrimination (20 November I99I), the International Covenant on Economic, Social and Cultural Rights (2I January 1992), the International Covenant on Civil and Political Rights (2I January 1992), the Optional Protocol to the Covenant on Civil and Political Rights (2I January 1992), the Convention on the Elimination of All Forms of Discrimination against Women (20 November I99I), the Convention on the Rights of the Child (20 November I99I), the Framework Convention for the Protection of National Minorities (I February 1998).

\section{Bibliography}

CMB (Estonian Citizenship and Migration Board) (2006), Yearbook 2006. Tallinn. www.mig.ee.

Hallik K. (200I), 'Citizenship - Precondition To or Result of Integration?', in Integration Monitoring 2000, CD-ROM Integrating Estonia, Minister Katrin Saksa Büroo.

Heidmets M. (ed.) (2008), Eesti Inimarengu Aruanne 2007 [Estonian Human Development Report 2007]. Tallinn: Eesti Koostöö Kogu.

Helsinki Watch (1993), Integrating Estonia's Non-Citizen Minority. www.hrw.org.

Kruusvall, J. (200I), 'Understanding Integration in Estonian Society', in Integration Monitoring 2000, CD-ROM Integrating Estonia, Minister Katrin Saksa Büroo.

Lieven, A. (1993), The Baltic Revolution. New Haven and London: Yale University Press.

Rose, R. \& W. Maley (1994), 'Conflict or Compromise in the Baltic States?', RFE/RL Research Report 3 (28).

Semjonov, A. (2000), 'Estonia: Nation Building and Integration. Political and Legal Aspects', COPRI Working Paper 8.

Statistical Office of Estonia (200I), 2000 Population and Housing Census, 2. Tallinn: Statistical Office of Estonia.

Thiele, C. (I999), 'The Criterion of Citizenship for Minorities: The Example of Estonia', ECMI Working Paper 5.

UNDP (United Nations Development Programme) (1999), Estonian Human Development Report 1999. Tallinn. www.gi.ee. 



\title{
2 Checks and balances in Latvian nationality policies: National agendas and international frameworks ${ }^{\mathrm{I}}$
}

\author{
Kristīne Krūma
}

\begin{abstract}
Latvia, upon the restoration of its independence in I99I, strictly followed the principle of state continuity. This has also been reflected in nationality policies which followed the ex iniuria ius non oritur principle. However, Latvia had to take the framework of international law that existed when independence was restored into account and had to deal with a large number of Soviet-era settlers. This led to the creation of a specific category of persons in international law, namely so-called non-citizens, which has become the main issue of international debates on Latvian nationality policies.
\end{abstract}

\subsection{History of nationality policy}

\subsubsection{Nationality policy prior to regaining independence}

An important step in the process of consolidating the new statehood proclaimed on I8 November I9I8 was the adoption of the Law on Citizenship in I9I9. This Law was not repealed after the occupation of Latvia by the Soviet Union in I940. At the same time, Latvian nationals became nationals of the USSR by way of automatic imposition of the latter's nationality.

There were different views regarding the status of Baltic nationals after the Second World War. In some of the lawsuits initiated by Baltic nationals concerning their nationality they were still considered Baltic nationals by the courts of other states. The varying treatment of Baltic nationals by other states prevailed until I99I when the Baltic states regained their independence.

Upon the restoration of independence in 1990 the decision-makers were faced with the dilemma of the two main options available regarding nationality. Under the first option it was argued that the original state had disintegrated or disappeared and that a new state had been founded. The newly-founded state could therefore determine its nationals on the basis of its territory - a 'zero option'. As far as this option is concerned, one may add, however, that the codification efforts of the International Law Commission at the United Nations concern- 
ing the nationality of persons in situations of state succession showed that awarding nationality to all residents by successor states that emerged from the dissolution of a predecessor state is by no means an automatic or established rule of international law. ${ }^{2}$ It would have been a preferred solution, especially in view of the existing obligation not to create statelessness, but state practices continue to vary.

The second option emanated from the concept of state continuity, which implies the continuity of the nationality of the state in question (Thiele I999: I2). ${ }^{3}$ When adopting nationality legislation Latvia was guided by the principle of the continuity of the state and the humanitarian principles prohibiting the imposition of the nationality of the occupying country upon nationals of the occupied country. It was argued that automatic conferral of USSR nationality on the population of the Baltic states as a consequence of their occupation in I940 was unlawful under international law as long as the Baltic states were presumed to exist (Kalvaitis I998: 23I; Ziemele 200I: 233). ${ }^{4}$ Therefore, Latvian nationals recovered de facto rights and obligations deriving from their Latvian nationality but those USSR nationals who arrived in Latvia as a result of its foreign occupation were made subject to the naturalisation procedure according to relevant legal provisions.

\subsubsection{Restoration of nationality}

During this period, the political institutions of the Soviet era were still in place. However, their freedom to act was significantly restricted. Since Latvia was guided by the principle of state continuity it had to restore not only nationality but also its pre-I940 institutions, including its parliament. The post-Soviet institutions acting during this period had a limited capacity. Their authority was only to preserve continuity until the fifth legitimately elected Parliament started functioning.

According to the state continuity thesis, the aggregate body of Latvian nationals was re-established in accordance with the I9I9 Law on Citizenship, as amended in I927. It was again considered applicable with the adoption of the I5 October I991 Resolution on the Renewal of the Republic of Latvia's Citizens' Rights and Fundamental Principles of Naturalisation by the Supreme Council. The presumption was that Latvian nationality had continued to exist, irrespective of the loss of independence in I940. The Decree on the Order in which the Citizens of the Soviet Socialist Republics Lithuania, Latvia and Estonia are Granted USSR Citizenship (I940) on the basis of which Soviet nationality was imposed on Latvian nationals was declared null and void ab initio.

According to the Resolution, the following groups of individuals were recognised as nationals: (I) those who were Latvian nationals on I7 June I940 and their descendants, if they had lived in the country and had re- 
gistered by I July I992; (2) persons who were Latvian nationals on I7 June 1940 and their descendants if they did not reside in Latvia or were nationals of another state and had submitted an expatriation permit; (3) persons born and residing in Latvia if their parents were unknown.

The process of naturalisation was also made easy for those living in Latvia on I7 June I940 without Latvian nationality. This approach was based on the premise that if Latvia had not been occupied, these persons could have acquired nationality (Ziemele i998: 208).

It was considered that only the nationals proper, as defined by the I9I9 Law, could legitimately restore the political system of Latvia and thus take part in the elections for the Fifth Parliament in I993. Others who did not qualify for nationality could apply for naturalisation under the I9I9 Law and the Resolution. Since the requirements for naturalisation were high, including inter alia sixteen years of residence, naturalisation based on the Resolution never occurred (Ziemele I998: 208; Kalvaitis I998: 255).

\subsubsection{Basis for current nationality policy}

During the parliamentary election campaign in I993, nationality was the most important issue. Proposals ranged from repatriation of all Soviet-era settlers to a zero option. The elected Parliament in a way represented the opinion of Latvian nationals as to how the state should proceed in this matter. Initial proposals were very strict. According to the first model adopted by Parliament, the first applications for naturalisation would have been accepted in 2000 and then only at a rate of o.I per cent of the previous year's total number of nationals. This would have resulted in approximately a thousand new nationals annually. This draft was heavily criticised by Western democracies and by international organisations. As a result, the President of Latvia refused to sign the adopted law. Complex nationality issues became even the reason for postponing Latvian membership of the Council of Europe.

The new Law on Citizenship was adopted only on 22 July I994. According to art. 2, as amended in $1995,{ }^{5}$ nationals of Latvia are: (I) those who were nationals on the date of occupation and their descendants, unless they had acquired the nationality of another state after Latvia proclaimed its independence on 4 May I990; (2) Latvians and Livs ${ }^{6}$ who reside permanently in Latvia, do not hold the nationality of another state or have received an expatriation permit; (3) women who reside permanently in Latvia and had lost their nationality according to the Law on Citizenship of I9I9 as well as their descendants unless they had acquired the nationality of another state after 4 May I990; (4) naturalised persons; (5) children who are found in the territory of Latvia 
whose parents are unknown; (6) orphans living in an orphanage or a boarding school in Latvia; (7) children born of parents both of whom were nationals of Latvia at the time of such birth, irrespective of the place of birth of the children; (8) those who permanently reside in Latvia and are duly registered and who have completed a full educational course in general education schools in which Latvian was the language of instruction, or in mixed language schools, if they are not nationals of another state or have received an expatriation permit. As argued by Ineta Ziemele, the latter category broadens the scope of Latvian nationals in that it includes those former USSR nationals who may have integrated into Latvian society, irrespective of their place of birth (Ziemele 200I: 235). The right of a child to acquire Latvian nationality was ensured by providing that, if at least one parent is a Latvian citizen, the child will acquire Latvian nationality, subject to mutual agreement by the parents.

Those who did not belong to the abovementioned groups had to naturalise according to the procedures established by law and the regulations of the Cabinet of Ministers. ${ }^{7}$ Although naturalisation requirements were made easier, they were still exclusionary. The law provided for gradual naturalisation, the so-called 'window-system', thus limiting the rights of individuals to freely choose the timing for naturalisation. It provided that persons will be naturalised in stages starting in 1996 and ending in 2003 (Kalvaitis 1998: 23I). After 2003, anyone would have the right to apply. ${ }^{8}$ This approach was adopted because it was expected that considerable numbers of non-citizens would apply for Latvian nationality and civil servants would therefore be unable to ensure proper application of the law. However, the number of applications turned out to be much lower than expected. The reasons for the low interest were only analysed after the law was adopted. The main reasons identified were (I) lack of knowledge of the Latvian language; (2) unwillingness to enter into obligatory military service; (3) the easier requirements for obtaining a Russian visa for non-citizens; (4) the number of rights already granted; (5) political mistrust and disappointment at not having been granted nationality automatically and (6) an identity crisis after the collapse of the USSR.

\subsubsection{Recent developments of nationality policy}

There were many assessments on the compliance of Latvia's laws with applicable international standards in the area of nationality. These were accompanied by numerous recommendations, in particular concerning facilitation of access to nationality for Soviet-era settlers. In view of the constant pressure of the UN Commission on Human Rights, the Council of Europe, the OSCE High Commissioner on National Minori- 
ties and most notably the European Union, ${ }^{9}$ Latvia amended its Citizenship Law in I998 (Tomaševski 2000: 340). The amendments were confirmed in a referendum and became effective in November i998. ${ }^{\text {IO }}$ These amendments abolished the 'window-system' and provided nationality for children born in Latvia after 2I August I99I to stateless persons or non-citizens. In accordance with art. 3 of the Citizenship Law, the parents of the child were required to submit an application for the acquisition of nationality before the child reached the age of fifteen. ${ }^{\text {II }}$ In addition to these amendments, the naturalisation procedure was simplified, i.e. several groups of individuals were identified for exemption from the naturalisation process or who did not have to pass the naturalisation exams. Thus, for instance, applicants over the age of 65 were exempted from the history test. ${ }^{\text {I2 }}$

Western countries and international organisations provided considerable assistance to Latvia with the objective of overcoming the main barriers which kept the numbers of applications for nationality low. Special attention was paid to language training. About 50 different sets of learning and informational material were published and 45 projects to facilitate naturalisation were initiated, an information centre was established and a number of campaigns were organised.

Notwithstanding the amendments and campaigning, the numbers of non-citizens are still quite high. By July 2008, there were about 365,I64 non-citizens in Latvia (in 1995, the number was 735,000). However, in the period between the start of the naturalisation process in I995 and 30 April 2008, only I28,825 persons were granted Latvian citizenship, including I3,639 minors (the rest were either repatriated or acquired Russian nationality while remaining residents of Latvia). Various attempts to speed up the naturalisation of non-citizens have had limited success. Within the last ten years the number of non-citizens has not decreased very much. ${ }^{\mathrm{I} 3}$ The reasons for the lack of interest are changing however. For instance knowledge of the language and military service are no longer mentioned in public opinion polls as important barriers to naturalisation. The Naturalisation Board expects that naturalisation could be completed in five years but there will still be about I30,000 persons who will choose to remain non-citizens for the rest of their lives. However, this projection seems to be overly optimistic, as the naturalisation process has almost come to a halt.

\subsubsection{The status of non-citizens}

When Latvia regained its independence in I99I it inherited large Russian-speaking communities who had arrived there from the ex-USSR. The Soviet central authorities had encouraged large-scale immigration of the labour force, to meet the local demands of Soviet industrialisa- 
tion and ethnic politics. Consequently, the collapse of the Soviet Union affected mostly the Russian people and other Eastern Slav groups such as Byelorussians and Ukrainians (Berg \& van Meurs 200I: 139). The historical minorities of Slav origin living in the Baltic states before the Soviet invasion were treated differently.

The collapse of the Soviet Union and the ensuing independence of Latvia created problems for persons living in Latvia who suddenly realised that they were nationals of a state that no longer existed. Various international organisations were criticising Latvia for having too many inhabitants without nationality. This was due to the fact that former USSR nationals were not automatically granted Latvian nationality, nor did they apply for Russian nationality or the nationality of another state. Western European countries and international organisations considered that a large number of persons without any factual nationality could constitute a risk for internal stability and could provoke ethnic conflicts. They could not be extradited as settlers from an occupying state because this would be contrary to human rights law which prohibits the expulsion of aliens en masse. Nor could these persons be classified as stateless because that would be against the principle on the reduction of statelessness.

Under the circumstances, a special status of non-citizen was introduced. Non-citizens are those who were USSR nationals but who, after I99I, did not qualify for Latvian nationality and did not acquire Russian or any other nationality. The Former USSR Citizens Act in art. I states:

The persons governed by this Act - 'non-citizens' - shall be those nationals of the former USSR, and their children, who are resident in Latvia [...] and who satisfy all of the following criteria:

I. on I July I992 they were registered as being resident within the territory of Latvia, regardless of the status of their residence; or their last registered place of residence by I July I992 was in the Republic of Latvia; or a court has established that before the abovementioned date they had been resident within the territory of Latvia for not less than ten years;

2. they do not hold Latvian nationality;

3. they are not and have not been nationals of any other state.

This provision recognises non-citizens as a special category whose legal status in some areas provides them with more rights and guarantees than, for example, proper permanent residents, however non-citizens are not yet nationals of Latvia. 
Special rights given to non-citizens of Latvia can be summarised as follows. Non-citizens are given a special passport. The passport not only grants them the special status of belonging to the state, thus giving them the constitutional right to return, but it has also been recognised by the EU as valid for visa-free travel (Regulation I932/2006/ EC). Moreover, Russia has decided to provide holders of the non-citizen passport with visa-free travel to Russia (see sect. 2.3 below). In accordance with art. 2 of the Former USSR Citizens Act, non-citizens of Latvia cannot be deported, which is not the case with third-country nationals. When ratifying international conventions, Latvia as a rule submits a declaration requesting the equal treatment of citizens and noncitizens. For instance, upon ratification of the European Convention on Extradition and its Protocols in I997, Latvia stated that it shall apply to both citizens and non-citizens. Non-citizens enjoy human rights granted to nationals and this has been submitted by Latvia and accepted by a number of international treaty monitoring bodies. Moreover, in accordance with art. 2 of the Law on Diplomatic and Consular Service, they enjoy diplomatic protection of Latvia.

Latvia does not allow non-citizens the right to be elected at national and municipal levels or to hold public office. Moreover, non-citizens in Latvia are restricted from practising certain professions like those of: judge, court bailiff, notary, prosecutor, policeman, state security officer, land surveyor, fireman, national guard, captain of a crew, private detective, attorney, or employee in diplomatic and consular service. There are also restrictions on possessing land and repatriation. Although, unlike immigrants in the EU, non-citizens are not nationals of any other state, they are treated as long-term resident third-country nationals in the EU framework in accordance with the provisions of Directive 2003/I09/EC. ${ }^{\text {I4 }}$ This approach has been criticised by experts ${ }^{\mathrm{I5}}$ and raises questions about the extent that Latvia can live up to its international human rights obligations, i.e. especially those that fall under the International Covenant on Civil and Political Rights.

Up to now there have been several attempts to classify non-citizens under a heading recognised by international law. ${ }^{16}$ Since Latvia's accession to the European Union there has been little or no pressure from international organisations regarding Latvia's citizenship policy and the issue of its non-citizens. Moreover, Latvian courts have recently given an authoritative interpretation of the status of non-citizens, the most important of which is the ruling of the Constitutional Court. ${ }^{\text {I7 }}$

The Constitutional Court had to review the amendments made to the Former USSR Citizens Act which provided for the revocation of the status of non-citizen for persons who acquired the status of permanent residence in another country after I June 2004. Before these amendments were instituted, the status could only be renounced on 
condition that a nationality had been acquired. The Court regarded the amendments as unconstitutional. It started analysing the adoption of the Former USSR Citizens Act in historical and political context and concluded that the opinion that Latvia had a duty to grant nationality automatically to those individuals and their descendants who have never been Latvian nationals and arrived during occupation is unfounded (para. I3). The Court acknowledged that the introduction of the status of non-citizen was a complicated political compromise as a result of which a category unknown in international law was created. The Court has noted that Latvia has consistently defended its position that non-citizens cannot be qualified as stateless persons and this view has been accepted by the international monitoring bodies (Ziemele \& Kruma 2003) ${ }^{18}$ In its judgment (para. I7) the Court defined the status of non-citizen in the following way:

The status of non-citizens is not and cannot be considered as a mode of Latvian nationality. However, the rights given to non-citizens and the international obligations which Latvia has undertaken in relation to these persons, signify that the legal link of non-citizens to Latvia is recognised to a certain extent and based on it mutual obligations and rights have emerged. This is derived from art. 98 of the Constitution which inter alia states that anyone who possesses a Latvian passport has a right to protection by the state and the right to freely return to Latvia.

The court therefore confirmed that non-citizens have a special link to Latvia which entails mutual rights and obligations. Those are, however, different from the ones that nationals have. It can be argued that noncitizens possess 'functional Latvian nationality', i.e. they have many of the same rights as nationals except for political rights and the right to hold certain positions but they cannot be defined as nationals.

Latvia has adopted a so called 'carrot-stick' policy towards non-citizens, i.e. if they want to enjoy the rights of EU nationals, then they have to become nationals of a Member State. The current problem lies in the fact that the number of non-citizens is considerable and it is not decreasing fast enough.

\subsection{Basic principles for the acquisition and loss of nationality}

\subsubsection{Acquisition of nationality}

\section{General principles}

According to the Citizenship Law of 1994 Latvian nationality is acquired on the basis of the ius sanguinis principle. Moreover, Latvian 
nationality legislation maintains the continuity of Latvian nationality, as identified in I9I9. This is evident in the I991 Resolution which refers to the restoration of the rights of Latvian nationals and not to a restoration of the institution of 'nationality', which is presumed to exist.

In addition to the ius sanguinis principle, there are groups of individuals who are granted nationality almost automatically. ${ }^{\text {I9 }}$ Firstly, certain ethnic groups: Latvians and Livs are nationals if they live permanently in Latvia and hold no other nationality. However, if they immigrate from other countries they will be subject to a simplified naturalisation procedure. Secondly, persons who completed education in schools with Latvian as a language of instruction. Thirdly, women who lost their nationality in accordance with the archaic rule on revocation of nationality upon marriage with a person of another nationality. Fourthly, children, whose parents are unknown, and orphans.

Lastly, children born after 2I August I99I to persons who are stateless or non-citizens. In order to apply for nationality in the case of statelessness a child should be: (I) a permanent resident; (2) stateless or a non-citizen 'for the entire time' of its life prior to application; (3) fluent in Latvian which is verified by a document from an educational establishment or by the Commission of the Naturalisation Board; (4) over the age of fifteen. The applicant also should not have a criminal record of more than five years of imprisonment. Until the child reaches the age of fifteen, the application can be submitted by both parents jointly or separately, or by the adoptive parents of a child, if they are stateless or non-citizens and have resided in Latvia for at least five years. It shall be noted that a certificate of language proficiency shall be submitted only by those minors who have not been registered by their parents until the age of fifteen. Moreover, after they have reached the age of eighteen general naturalisation requirements apply.

Art. I3 provides for the admission to nationality for special meritorious service beneficial to Latvia. A decision must be made by parliament on each individual case. A person cannot acquire dual nationality by the application of art. I3, and the restrictions of art. II are applicable (see below).

\section{Dual nationality}

Dual nationality is, in principle, not permitted in Latvia. The I994 Citizenship Law does not, however, exclude this possibility if the person has registered his or her Latvian nationality. This means that Latvia will not create dual nationality, while acknowledging that other states may do so.

The Citizenship Law is indeed ambiguous in relation to dual nationality. Art. 9 provides that a person who acquires Latvian nationality cannot be a dual national. Para. 2 of the same article states that in the 
case where a person is considered to be a national of another state, in his or her relations with Latvia the person is only considered to be a citizen of Latvia. Art. 24 provides the possibility to revoke nationality by court decision if a person has acquired the nationality of another state without renunciation of his or her Latvian nationality. The possibility to hold dual Latvian nationality and that of another state is set out in the Transition Regulations of the Citizenship Law. They provided that those Latvian nationals who, during the period from I7 June I940 until 4 May I990, left Latvia as refugees or were deported and their descendants could register as Latvian nationals until I July I995. This provision is gender neutral meaning that descendants of either parent could register. However, it does not mention that they have to renounce their current nationality.

The Latvian Constitutional Court has ruled that dual nationality can arise at birth and is prohibited only in cases of naturalisation. Moreover, a child cannot be refused dual citizenship on the basis of formal requirements. ${ }^{20}$ However, the question as to whether children must renounce their other citizenships when they come of age remains unclear.

\section{Naturalisation}

Individuals who have registered with the Residents' Register are considered to reside lawfully in Latvia and are entitled to acquire nationality through naturalisation if they have received a permanent residence permit. The naturalisation requirements are the following: (I) permanent residence in Latvia for five years counting from 4 May I990; ${ }^{2 \mathrm{I}}$ (2) knowledge of the Latvian language, the Constitution, ${ }^{22}$ the anthem and the history of Latvia; (3) a loyalty oath to the Republic of Latvia; and (4) legal source of income (art. I2).

The Law provides for a special naturalisation procedure in cases where applicants have been nationals of Lithuania, Estonia or Poland before the USSR intervention and have lived in Latvia for at least five years. These rules also include their descendants (art. I4). ${ }^{23}$ The special procedure also applies to persons married to Latvian citizens for not less than ten years, who have been residing in Latvia for at least five years, even if the spouse has passed away (art. I4). A special procedure provides that these applications are considered expediently.

Upon application, a person shall declare that he or she does not hold any other nationality and that none of the restrictions apply as specified in art. II of the Citizenship Law.

Article II establishes restrictions for naturalisation, if a person:

- has acted against the independence of Latvia and its powers, which has been established by the courts;

- propagated totalitarian ideals or ethnic or racial hatred, which has been established by the courts; 
- served in the institutions of another state, including the armed forces;

- served in the USSR army and was called-up from outside Latvia;

- has been employed by the KGB, the security or the intelligence or similar service of another state;

- has been sentenced in Latvia or another state for a crime that is also a crime in Latvia;

- has, after I3 January I99I, worked in any organisations against Latvia. $^{24}$

This Article seems to follow a rather exclusionary approach. For instance, if a person has been convicted for any crime (even if imprisonment was only for a year) he or she can never apply for Latvian nationality. Also, the restrictions in relation to the affiliation with the KGB could be challenged as to their legitimacy and proportionality since there are nationals who have had the affiliation but who were nationals or acquired nationality by registration.

Children up to the age of sixteen acquire nationality together with the naturalised parent without undergoing the naturalisation process as established in art. I2. This is also the case if the parents have not reached an agreement but the child permanently resides in Latvia or in cases of adoption. Nationality is granted to a minor from fourteen to eighteen years of age only with his or her written consent (art. I6). If a minor's nationality has changed and his or her consent has not been obtained, he or she can, within a year of coming of age, renew Latvian nationality irrespective of the period of residence in Latvia (art. I6, para. 2). If the nationality of a child has changed as a result of the marriage of (one of) its parents, the naturalisation procedure will not be applicable if the child wishes to renew his or her Latvian nationality.

In accordance with art. 4 of the Citizenship Law, all Latvian nationals are equal irrespective of the way nationality has been acquired. This is a constitutional principle confirmed by the Constitution in art. 9I stating that all are equal before the law and human rights shall be respected without any discrimination.

The Naturalisation Board, working under the auspices of the Ministry of Justice, is responsible for the examination of applications for naturalisation. During the naturalisation procedure the Board co-operates with other institutions with the aim of verifying the information submitted by the applicants. Its decisions are subject to appeal in court. ${ }^{25}$ During court proceedings the naturalisation process is suspended until the decision of a final instance or until the case is dropped. The procedure of naturalisation is set out in detail in a number of regulations of the Cabinet of Ministers. The Regulations on the Procedure of Acceptance and Review of Naturalisation Applications include application 
forms and specify the procedure for submission of applications and the documents to be submitted. ${ }^{26}$ Naturalisation takes place in regional units of the Naturalisation Board. In 2004, the procedure for submitting documents was liberalised and the requirement that documents must be submitted in the regional unit of the registered place of residence of the applicant was lifted. The naturalisation procedure is relatively easy and takes no more than six months from the date of application. The fee for naturalisation has also been lowered several times. Since 2003 , it has been set at 20 Lats (approximately 30 euros) and at 3 Lats (4 euros) for certain groups of applicants. ${ }^{27}$ Persons may withdraw their applications at any stage of the naturalisation procedure.

The requirements for the examinations are set out in the Regulations on the Examination of Proficiency in the Latvian Language and the Examination of Knowledge of the Basic Principles of the Constitution, the Text of the National Anthem and the History of Latvia for Persons Who Wish to Acquire the Citizenship of Latvia through Naturalisation. The regulations provide that knowledge of the language, of the Constitution, the anthem and history shall be tested by an examination commission established by the Naturalisation Board. ${ }^{28}$ Persons exempt from the tests are those who: (I) have acquired primary, secondary or higher education in educational institutions with Latvian as the language of instruction, (2) have disabilities. Persons over the age of $6_{5}$ shall be subject to the Latvian language test only. ${ }^{29}$

According to sect. 4, the employees of the Naturalisation Board, the members of the Standing Committee on the Implementation of the Citizenship Law of the Parliament as well as representatives from other organisations and institutions shall be allowed to be present in the examinations as observers if they have received permission from the head of the Naturalisation Board. The examination of language proficiency takes place within two months from the day when all the necessary documents have been submitted, and the examination of the other topics two months after passing of the language exam (sect. 6). If the applicant does not attend or fails the exam he or she can retake the exam after three months in the case of the language exam and after one month in the case of the so-called knowledge exam (sect. 9).

The language proficiency exam has a written and an oral part (sect. II). According to sect. 22, the examination commission shall assess the applicant's ability to read, write, listen and understand talks on topics of everyday life. Applicants above the age of 65 only take the oral language test (sect. 2I).

Language proficiency has often been mentioned as the main obstacle to naturalisation. Therefore, in 1996 , the State Programme for Latvian Language Learning was initiated. In the framework of the programme a number of language courses and information campaigns on naturali- 
sation were conducted by the Naturalisation Board with financial assistance from various international organisations and Western countries. Overall figures for the success rate remain high; between 1996 and May 2008 only I2 per cent of the applicants failed the exam. However, over the past four years, the passing rate has shown a steady decline. In 2007, for instance, 2I per cent of the applicants failed the language test.

The applicant can choose whether to take the knowledge exam orally or in writing (sect. 23). The success rate is similar to the language exam. The overall failure rate is about 4 per cent. However, in 2007, Io per cent of those who took the exam failed.

The decreasing success rates can no longer be explained in terms of numbers of applicants, which skyrocketed in 2004 (when Latvia acceded to the EU), but fell back to I998 levels thereafter.

\subsubsection{Loss of nationality}

Latvian nationality is lost in cases of renunciation or revocation. According to art. 23, renunciation can take place if a person has been guaranteed the nationality of another state except if he or she has unfulfilled obligations towards the state or has not fulfilled mandatory military service. The clause on the fulfilment of obligations towards the state is unclear, i.e. whether it involves fiscal or other obligations. Such a broad formulation may make it possible to arbitrarily deny the right to change nationality (Ziemele I998: 248). Moreover, since 2004 Latvia has a professional army and mandatory military service has been abolished.

Art. 24 provides for three cases when nationality can be revoked by a decision of a regional court, namely, if a person (I) has acquired the nationality of another state without renouncing Latvian nationality; (2) continues to serve in foreign armed forces or similar institutions without permission from the Cabinet of Ministers; or (3) has acquired nationality by fraud. The provision applies equally to all nationals, except for those who hold dual nationality and are thus exempted from the application of art. 24 (Ziemele I998: 247). Family members are also not affected by such proceedings. These grounds comply with those identified in the Convention on the Reduction of Statelessness. If a person continues to reside permanently in Latvia for five years then this revocation does not affect future naturalisation (art. 25, para. 2). 


\subsection{Current political debates}

The nationality issue still appears in public debates and is referred to by both left-wing and right-wing parties, although in different contexts. Recent studies by Latvian scholars conclude that the so-called Compatriots Policy, which was established by the Russian Federation, seeks to minimise non-citizen interest in naturalising and integrating into Latvian society. The Compatriots Policy supports Russian-speakers residing abroad, which is a concept that has been successfully 'sold' to the West. Other common designations used by the state authorities of the Russian Federation include 'Russian compatriots' or 'Russian diasporas'. Since 1992, Russia has continuously tried to introduce 'issues involving Russian Compatriots' onto the agendas of all the major regional and international organisations (Muižnieks 2006: I2I-I22). The Russian Compatriots Policy was first outlined by the so-called Karaganov Doctrine, conceived by Sergey Karaganov, an adviser to the President of the Russian Federation, on 6 October 1992. The doctrine perceives the territory of the former USSR as a region of special interest and mandates for Russia. ${ }^{30}$ Recently it has been reconfirmed officially by the Russian Foreign Policy Concept (adopted by the Russian President on I2 July 2008). The Concept distinguishes a separate foreign policy dimension called the 'humanitarian trend' of Russian foreign policy, which inter alia includes the protection of the interests of ethnic Russians living abroad. The approach was even further sharpened after the conflict in Georgia. Thus, the so-called Medvedev Doctrine refers to protection of lives and dignity of Russian citizens, wherever they may be. ${ }^{3 \mathrm{I}}$ The Presidential Administration, the Russian Foreign Affairs Ministry and the Russian State Duma (the parliament) are the key institutions that provide support for non-citizen organisations in Latvia (Lerhis \& Kudors 2008: 72).

Another factor that increases divisions within Latvian society is the growing importance of the Russian media, which have become largely self-sufficient and in terms of their size have (for some time now) eclipsed the Latvian-language media. The most popular and influential media for non-citizens in Latvia is television, which broadcasts programmes produced and transmitted in Russia. The main Russian TV channels, censored by the Kremlin, are available in every cable TV package. Print media and the internet, however, play a less significant role in the Russian socialisation of non-citizens (Zepa 2005: 5). Due to the popularity of Russian TV channels in Latvia, the local editions of Russian-language newspapers and magazines have to follow general information protocol from Russia. Announcements and proclamations made by the Ministry of Foreign Affairs of the Russian Federation and other Russian institutions are published via the official news agencies 
'ITAR-TASS' and 'Interfax', and routinely reprinted in Latvia by the Russian-language newspapers Chas and Vesti Segodnya. Four attempts to produce bilingual newspapers have thus far failed because they were unable to meet the needs of their various audiences.

Russia has also decided to simplify the entry procedure for former USSR citizens currently living in Latvia and Estonia who have not obtained the citizenship of any country. The decree, signed by President Dmitry Medvedev on I8 June 2008 , grants these persons visa-free travel to Russia provided they have a valid travel document - a non-citizen passport in the case of Latvia and an aliens passport in the case of Estonia. Minors must present either a valid travel document or a birth certificate if they are listed in the passport of an accompanying guardian. The decree became effective upon signing and the government has adopted all the necessary measures for its implementation. ${ }^{32}$ The Latvian Ministry of Foreign Affairs has protested this decision as it may bring the naturalisation of non-citizens to a halt. ${ }^{33}$

Latvian right-wing parties are discussing the need to amend the Citizenship Law for two main reasons. Firstly, it has been acknowledged that certain technical amendments are necessary. This holds true for the so-called 'forgotten children', i.e. children whose parents have naturalised but have forgotten to naturalise their children. Other proposals concern state security considerations with regard to terrorists and those working in the security services of other states. However, these proposals have not been specific enough and the debate remains general.

Secondly, the proponents of amendments identify a need to liberalise Latvia's dual citizenship policy. ${ }^{34}$ This debate was provoked by numerous studies by Latvian researchers and claims made by Latvian citizens who have made use of their free-movement rights after Latvia joined the EU (Krūma 2006; Strategic Analysis Commission 2006). The strict policy regarding dual citizenship has been criticised by Latvian citizens living abroad, especially those in other EU Member States. According to recent estimates, about 86,000 Latvian citizens have left Latvia since 2004 and the numbers continue to steadily increase (Indans \& Krūma 2007: 165). The depopulation problem is further aggravated by the fact that Latvia has Europe's lowest birth rate. The Latvian government has responded to these demographic changes by establishing a working group to draft proposals for a new regulation regarding dual citizenship. The debate initially concerned only children. ${ }^{35}$ However, the Minister of Integration has suggested that those who were forced to leave or were deported during the occupation period and those who acquired another citizenship while residing in another state should also be granted the right to hold dual nationality. ${ }^{36} \mathrm{He}$ thus proposed extending the initial deadline envisaged in the Transitional Regulations of the Citizenship Law, which required that the for- 
mer group register by I July I995. In the course of the debate, the possibility of holding dual citizenship was also suggested, mentioning in particular those former Latvian citizens who hold the citizenship of another EU Member State. Yet another discussion concerns a method to establish whether a person has acquired another nationality without informing Latvian authorities. One of the main problems is that verification requires the cooperation of other states. The Office of Citizenship and Migration Affairs estimates that currently 30,793 Latvian citizens also hold another citizenship. This number includes persons who have been granted dual citizenship according to the Citizenship Law, i.e. those who registered until I July 1995 irrespective of place of residence. ${ }^{37}$

Finally, further debates can be expected concerning two cases at the European Court of Human Rights (ECHR). The recent ruling of the Grand Chamber in the Andrejeva case established that Latvia has discriminated against non-citizens concerning the calculation of their pensions. The ECHR considered it disproportionate to disregard employment periods of non-citizens in Russian or Ukrainian enterprises before I99I in pension calculations. It dismissed the Latvian government's argument that such pension claims shall be subject to international agreements on social security. The Latvian judge present at the hearing disagreed with this ruling, arguing that the ECHR disregarded the historical context of the case. So far, only the Russian media have extensively reported on this case but further debates are to be expected. ${ }^{38}$ The second case concerns Jurijs Petropavlovskis, who is a non-citizen and a member of the radical group Headquarters for the Protection of Russian Schools, which organised various protests against an education reform requiring more subjects to be taught in Latvian. He has declared that he would run as a candidate in local government elections after being naturalised. According to various media sources, he publicly advocated the use of violence, bloodshed and terrorism and threatened to act on these after his naturalisation. ${ }^{39}$ The Cabinet of Ministers refused his application for nationality based on the argument that he is not loyal to the state. This was a precedent confirmed by the Administrative Court Senate, which stated that the Cabinet of Ministers has wide discretion in granting citizenship and that the decision is predominantly political. 


\subsection{Statistics}

\subsubsection{Status and ethnic composition of Latvian inhabitants}

The following tables on status and ethnic composition of Latvian inhabitants illustrates both Latvian national sentiments from the I930s when they were a considerable majority and the current situation where Latvia is still hosting large numbers of non-citizens. ${ }^{40}$

As is evident from Table 2.I, the ethnic composition of Latvia's residents changed considerably during the occupation.

Table 2.2 shows that, notwithstanding various efforts to liberalise naturalisation requirements, the numbers of non-citizens have not decreased significantly since the beginning of the I990s.

Table 2.3 illustrates that it was mainly residents of Russian or Eastern Slav origin who became stateless or non-citizens after the restoration of independence in I990. The situation has not changed since then and the naturalisation process is generally slow.

Table 2.1 Changes in ethnic composition of Latvia's population

\begin{tabular}{llll}
\hline & 1935 & 1995 & 2008 \\
\hline Latvians & $75.5 \%$ & $55.1 \%$ & $59.0 \%$ \\
Non-Latvians & $24.5 \%$ & $44.8 \%$ & $41.0 \%$
\end{tabular}

Sources: Ziemele 2001: 236; Naturalisation Board, www.np.gov.lv

Table 2.2 Citizens and non-citizens of Latvia

\begin{tabular}{lcc}
\hline & 1993 & \multicolumn{1}{c}{2008} \\
\hline Nationals & $1,715,930(71.8 \%)$ & $1,858,718(81.8 \%)$ \\
Non-citizens and foreign nationals & $673,398(28.2 \%)$ & $412,889(18.2 \%)$ \\
Total & $2,389,328$ & $2,271,617$ \\
\hline
\end{tabular}

Sources: Ziemele 2005: 156, 365; Naturalisation Board, www.np.gov.lv; Register of Residents of the Department of Citizenship and Migration, www.pmlp.gov.lv

Table 2.3 Residents of Latvia on 1 July 2008 (by ethnic origin) ${ }^{41}$

\begin{tabular}{lrrrrr}
\hline & Citizens & Non-citizens & $\begin{array}{c}\text { Foreigners or stateless } \\
\text { individuals }\end{array}$ & Total & $\%$ \\
\hline Latvians & $1,340,824$ & 1,667 & 1,162 & $1,343,653$ & 59.1 \\
Russians & 367,181 & 240,784 & 26,194 & 634,159 & 27.9 \\
Byelorussians & 31,207 & 49,085 & 2,734 & 83,036 & 3.7 \\
Ukrainians & 17,670 & 34,635 & 4,687 & 56,992 & 2.5 \\
Poles & 40,428 & 12,432 & 859 & 53,719 & 2.4 \\
Lithuanians & 18,388 & 9,943 & 2,272 & 30,603 & 1.4 \\
Estonians & 1,492 & 558 & 448 & 2,498 & 0.1 \\
Other (including & 41,528 & 16,060 & 9,369 & 66,957 & 2.9 \\
undeclared or unkown) & & & & & \\
Total & $1,858,718$ & 365,164 & 47,725 & $2,271,617$ & 100.0 \\
\hline
\end{tabular}

Source: Naturalisation Board, www.np.gov.lv. 


\subsubsection{Acquisition of nationality by children}

The discussions before the 1998 referendum on the possibility of granting nationality to children of non-citizens and stateless persons were heated and there were arguments that large numbers of children would acquire nationality without being sufficiently integrated. Currently available statistics tell the opposite.

Table 2.4 Children of non-citizens and stateless persons born after 21 August 1991 who were granted Latvian nationality (31 May 2008)

\begin{tabular}{lc}
\hline Ethnic origin & Number \\
\hline Latvians, Livs & 2 \\
Lithuanian & 168 \\
Estonian & 33 \\
Russian & 5,386 \\
Polish & 293 \\
Byelorussians & 500 \\
Ukrainian & 549 \\
Not indicated & 235 \\
Other & 369 \\
Recognised as citizens & 7,394 \\
\hline
\end{tabular}

Source: Naturalisation Board, www.np.gov.lv

In total 7,394 children, of whom 5,386 are of Russian origin, have benefited from the amendments to the Citizenship Law in I998. This figure is unsatisfactory considering that there are altogether about 20,000 children who have the right to acquire nationality according to the provisions of the Citizenship Law. In 2004, the Minister for Integration, together with the Minister for Children and Family Affairs, conducted an information campaign sending information to the parents of these children. As a result there was an increase in the number of applications (Brands-Kehre \& Puce 2005: 24). ${ }^{4 \mathrm{I}}$ Experts have suggested replacing the current system with the automatic registration of children born to parents who are stateless or non-citizens as nationals.

\subsubsection{Naturalisation}

\section{Naturalised persons per year}

As argued above, naturalisation rates remain low but with positive tendencies. The respective statistics allow some general conclusions to be drawn regarding the motivation of the potential applicants for nationality to start on the naturalisation process. 
Table 2.5 Numbers of naturalisations in Latvia per year

\begin{tabular}{lcc}
\hline Year & $\begin{array}{c}\text { Persons applying } \\
\text { for naturalisation }\end{array}$ & $\begin{array}{l}\text { Naturalised } \\
\text { persons }\end{array}$ \\
\hline 1995 & 4,543 & 984 \\
1996 & 2,627 & 3,016 \\
1997 & 3,075 & 2,992 \\
1998 & 5,608 & 4,439 \\
1999 & 15,183 & 12,427 \\
2000 & 10,692 & 14,900 \\
2001 & 8,672 & 10,637 \\
2002 & 8,370 & 9,844 \\
2003 & 11,268 & 10,049 \\
2004 & 21,297 & 16,064 \\
2005 & 19,807 & 19,736 \\
2006 & 10,581 & 16,439 \\
2007 & 3,308 & 6,826 \\
2008 & 2,601 & 3,004 \\
Total & 127,632 & 131,357 \\
\hline
\end{tabular}

Source: Naturalisation Board, www.np.gov.lv

The biggest wave of naturalisation started after the window system was abolished. In I998, only 4,439 persons were naturalised; the number rose to 12,427 persons in I999. This increase might also be due to a number of campaigns for naturalisation taking place at the time.

The second wave of naturalisations started after it became clear that Latvia would become a member of the European Union. From 2003 to 2004 , the number of naturalisations rose from 10,049 to 16,064 . In 2005 , I9,736 persons were naturalised. However, since 2005, the numbers of applications have decreased. Moreover, a growing number of applicants have failed the naturalisation exams (see Table 2.6). The authors of the report 'Democracy Audit' (Brands-Kehre \& Pūce 2005) believe that the decrease in applications is due to a lack of motivation to naturalise on the part of non-citizens. Firstly, non-citizens consider that they automatically deserve nationality. Secondly, there are certain benefits in retaining the status of non-citizen, mainly less travel restrictions to the CIS countries. Thirdly, there is the fear of the naturalisation exams. The last reason is the fee which, although it has been lowered, is still relatively high for many people in Latvia.

\section{Ethnic origin of applicants for naturalisation}

The ethnic origin of applicants for naturalisation is indicative of the fact that Latvia is still dealing with its post-occupation legacies. The migration rates are insignificant and applicants for naturalisation are Soviet-era settlers. 


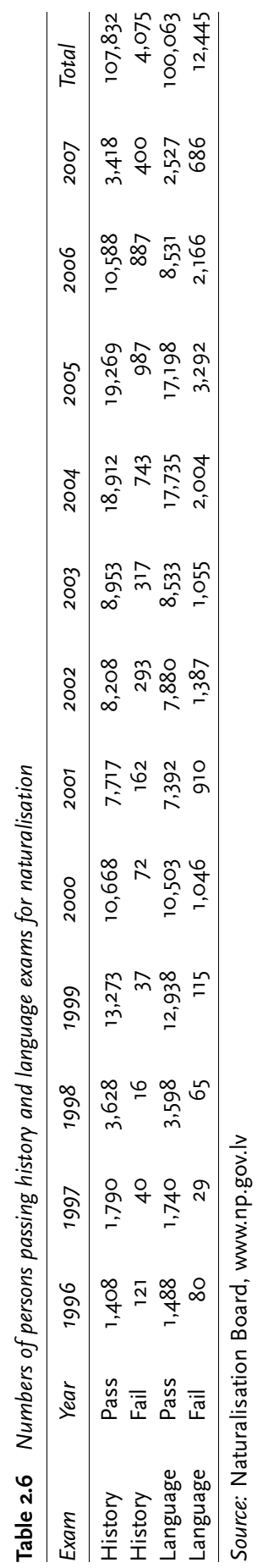


Table 2.7 Ethnic origin of applicants for naturalisation in Latvia (31 May 2008)

\begin{tabular}{lr}
\hline Ethnic origin & Total \\
\hline Latvians, Livs & 71 \\
Lithuanians, Estonians & 4,536 \\
Russian & 82,820 \\
Polish & 5,056 \\
Byelorussian & 12,542 \\
Ukrainian & 11,247 \\
Not indicated & 61 \\
Other & 5,154 \\
\hline
\end{tabular}

Source: Naturalisation Board, www.np.gov.lv

During the Soviet-era, large numbers of 'blue-collar socio-economic' profile immigrants were sent to Latvia. At that time the Soviet central government put emphasis on the promotion of economic industrialisation. Latvia has suffered under this policy because (I) Latvia hosted the headquarters of the Soviet army for the Baltic region and (2) the Latvian political elite was most sympathetic compared to other Baltic states.

\section{Age of applicants for naturalisation}

Most applicants are found in the age groups of eighteen to 30 and 3I40. These statistics exemplify that if the 'window system' had been maintained the numbers would be different because the age groups starting at 4I represent a considerable proportion of those who applied for naturalisation.

Table 2.8 Age of applicants for naturalisation in Latvia (31 May 2008)

\begin{tabular}{lrr}
\hline Age of applicants & Number & $\%$ \\
\hline $15-17$ & 10,625 & 8.7 \\
$18-30$ & 38,428 & 31.6 \\
$31-40$ & 24,082 & 19.8 \\
$41-50$ & 25,006 & 20.6 \\
$51-60$ & 15,136 & 12.4 \\
61 and older & 8,310 & 6.9 \\
\hline
\end{tabular}

Source: Naturalisation Board, www.np.gov.lv

Nationality granted for special meritorious service for the benefit of Latvia With regard to granting of nationality for special meritorious service two periods can be distinguished. From 1995 to 1998 there were 199 cases of naturalisation due to special services, whereas the number has dropped to only twelve since I999.

This decline is explained by changes in the Citizenship Law in 1998 when the so-called 'window system' was dropped. Therefore, those who 
want to become nationals can apply for naturalisation and they do not have to rely on the special procedure for the extension of nationality by parliament. This procedure most often is used for sportsmen.

\subsection{Conclusions}

Latvian nationality policy is based on the concept of state continuity. The rights attached to nationality were therefore restored to those who were nationals at the time of the occupation of Latvia in I940 and their descendants. This policy led to the situation that a large group of people who settled in Latvia during occupation remained stateless. Due to international pressure to comply with the international legal framework, especially regarding the reduction of statelessness, Latvia introduced the status of non-citizen. A so-called carrot-and-stick policy has been adopted with regards to this group. Non-citizens are denied political rights and the right to hold certain posts or to be employed in certain professions. In order to enjoy these rights they have to naturalise.

Taking into account that nationality is a politically sensitive topic in Latvia, it is doubtful that radical changes will occur in the near future. The difficult compromise made in 1998 is satisfactory for the ruling centre-right parties. However, the question of the fate of non-citizens in the framework of EU law remains unresolved.

Chronological list of citizenship-related legislation in Latvia

\begin{tabular}{|c|c|c|c|}
\hline Date & Document & Content & Source \\
\hline 1919 & $\begin{array}{l}\text { Law on Citizenship } \\
\text { (amended in 1927) }\end{array}$ & $\begin{array}{l}\text { Defines the basic } \\
\text { principles of acquisition } \\
\text { and loss of nationality } \\
\text { during the interwar period }\end{array}$ & \\
\hline 1922 & $\begin{array}{l}\text { Constitution of the } \\
\text { Republic of Latvia } \\
\text { (adopted } 15 \text { February } 1922 \\
\text { with latest amendments } \\
\text { on } 15 \text { December 2005) }\end{array}$ & $\begin{array}{l}\text { Is restored after } \\
\text { restoration of } \\
\text { independence }\end{array}$ & www.ttc.lv (in Latvian) \\
\hline 1940 & $\begin{array}{l}\text { Decree on the Order in } \\
\text { which the Citizens of the } \\
\text { Soviet Socialist Republics } \\
\text { Lithuania, Latvia and } \\
\text { Estonia are Granted USSR } \\
\text { Citizenship }\end{array}$ & $\begin{array}{l}\text { Imposes Soviet nationality } \\
\text { on nationals of the three } \\
\text { Baltic states automatically }\end{array}$ & \\
\hline 1990 & $\begin{array}{l}\text { Declaration on the } \\
\text { Renewal of Independence } \\
\text { of the Republic of Latvia ( } 4\end{array}$ & $\begin{array}{l}\text { Restores the authority of } \\
\text { the } 1922 \text { Constitution and } \\
\text { suspends it immediately }\end{array}$ & \\
\hline
\end{tabular}




\begin{tabular}{|c|c|c|c|}
\hline Date & Document & Content & Source \\
\hline & May 1990) & $\begin{array}{l}\text { except for a few provisions } \\
\text { that could only be } \\
\text { suspended by a } \\
\text { referendum }\end{array}$ & \\
\hline 1991 & $\begin{array}{l}\text { Resolution on the Renewal } \\
\text { of the Republic of Latvia's } \\
\text { Citizens' Rights and } \\
\text { Fundamental Principles of } \\
\text { Naturalisation }\end{array}$ & $\begin{array}{l}\text { Aims at reconstituting the } \\
\text { body of nationals who } \\
\text { could elect a legitimate } \\
\text { parliament; based on the } \\
1919 \text { Law }\end{array}$ & \\
\hline 1994 & Law on Citizenship & $\begin{array}{l}\text { Provides a 'window } \\
\text { system' limiting the right } \\
\text { to naturalise on the basis } \\
\text { of age }\end{array}$ & $\begin{array}{l}\text { www.coe.int; } \\
\text { www.ttc.lv (in Latvian) }\end{array}$ \\
\hline 1995 & $\begin{array}{l}\text { Amendments of } \\
\text { Citizenship Law }\end{array}$ & $\begin{array}{l}\text { Provides for the right to } \\
\text { citizenship for Latvians } \\
\text { and Livs who have } \\
\text { registered domicile in } \\
\text { Latvia, persons who have } \\
\text { acquired education in } \\
\text { Latvian as well as women } \\
\text { who lost their citizenship } \\
\text { by marriage in accordance } \\
\text { with the } 1919 \text { Law }\end{array}$ & \\
\hline 1995 & $\begin{array}{l}\text { Law on the Status of } \\
\text { Former USSR Citizens } \\
\text { Who Are Not Citizens of } \\
\text { Latvia or Any Other State } \\
\text { (amended in 1997, 1998, } \\
\text { and 2000) }\end{array}$ & $\begin{array}{l}\text { Introduces the status of } \\
\text { non-citizen }\end{array}$ & $\begin{array}{l}\text { www.humanrights.lv } \\
\text { (in Latvian) }\end{array}$ \\
\hline 1997 & $\begin{array}{l}\text { Amendments of } \\
\text { Citizenship Law }\end{array}$ & $\begin{array}{l}\text { Makes technical } \\
\text { amendments }\end{array}$ & \\
\hline 1998 & $\begin{array}{l}\text { Amendments of } \\
\text { Citizenship Law }\end{array}$ & $\begin{array}{l}\text { Repeals 'window system'; } \\
\text { liberalises access to } \\
\text { Latvian nationality for } \\
\text { children of non-citizens } \\
\text { and the stateless }\end{array}$ & \\
\hline 1999 & $\begin{array}{l}\text { Regulation No. } 32 \text { on the } \\
\text { Procedure for the } \\
\text { Acceptance and Review of } \\
\text { the Application on the } \\
\text { Recognition of a Child as a } \\
\text { Citizen of Latvia }\end{array}$ & $\begin{array}{l}\text { Specifies the procedure } \\
\text { and documents to be } \\
\text { submitted to the } \\
\text { Naturalisation Board with } \\
\text { an application for the } \\
\text { recognition of a child as a } \\
\text { citizen }\end{array}$ & www.legislationline.org \\
\hline 1999 & $\begin{array}{l}\text { Regulation No. } 33 \text { on the } \\
\text { Examination of Proficiency } \\
\text { in the Latvian Language } \\
\text { and the Examination of } \\
\text { Knowledge of the Basic } \\
\text { Principles of the } \\
\text { Constitution, the Text of } \\
\text { the National Anthem and }\end{array}$ & $\begin{array}{l}\text { Provides for the procedure } \\
\text { to be followed during } \\
\text { examinations; identifies } \\
\text { the persons to be } \\
\text { exempted from tests; } \\
\text { specifies the competences } \\
\text { and obligations of the } \\
\text { examination commissions }\end{array}$ & www.np.gov.lv (in Latvian) \\
\hline
\end{tabular}




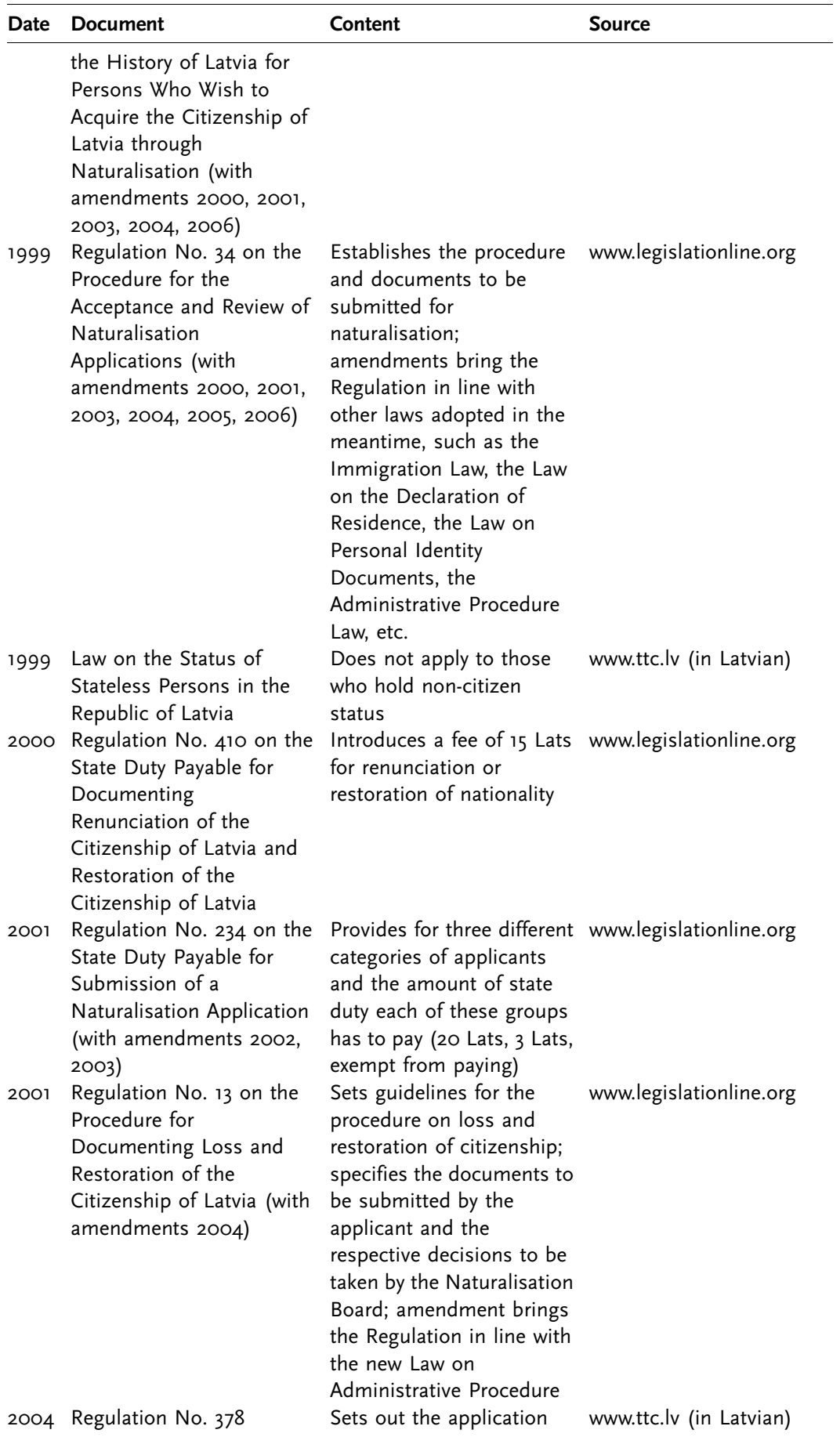




\begin{tabular}{|c|c|c|c|}
\hline Date & Document & Content & Source \\
\hline & $\begin{array}{l}\text { Regarding Passports for } \\
\text { Latvian Citizens and Aliens } \\
\text { as well as Travel } \\
\text { Documents for Stateless } \\
\text { Persons }\end{array}$ & $\begin{array}{l}\text { procedures for passports } \\
\text { and the contents of each } \\
\text { document }\end{array}$ & \\
\hline 2004 & $\begin{array}{l}\text { Regulation No. } 1011 \text { on the } \\
\text { Procedure to Determine } \\
\text { the Status of Latvian Non- } \\
\text { citizens }\end{array}$ & $\begin{array}{l}\text { Provides for the procedure } \\
\text { to be followed by } \\
\text { applicants and the Office } \\
\text { of Citizenship and } \\
\text { Migration Affairs regarding } \\
\text { decisions as to whether a } \\
\text { person satisfies all the } \\
\text { conditions to qualify for } \\
\text { the status }\end{array}$ & $\begin{array}{l}\text { www.pmlp.gov.lv } \\
\text { (in Latvian) }\end{array}$ \\
\hline 2007 & $\begin{array}{l}\text { Regulation No. } 353 \text { on the } \\
\text { Examination of Proficiency } \\
\text { in the Latvian Language } \\
\text { and the Examination of } \\
\text { Knowledge of the Basic } \\
\text { Principles of the } \\
\text { Constitution, the Text of } \\
\text { the National Anthem and } \\
\text { the History of Latvia } \\
\text { provided in the Citizenship } \\
\text { Law }\end{array}$ & $\begin{array}{l}\text { Replaces Regulation No. } \\
\text { 33; consolidates the } \\
\text { amendments }\end{array}$ & \\
\hline
\end{tabular}

\section{Notes}

I I would like to thank Prof. Ineta Ziemele for her comments on the draft of this article. The usual disclaimer applies.

2 UN Doc. A/RES/55/I53 (Nationality of Natural Persons in relation to the Succession of States), 30 January 200I.

3 For a detailed treatment of this principle, see Ziemele 2005 .

4 Latvia, like the other Baltic states, was guided by the principle ex iniuria ius non oritur, which has been seen as a rather inflexible approach.

5 In I995, grounds (2), (3) and (8) were included.

6 Livs are a historic indigenous group of Finno-Ugric descent living near the Baltic sea.

7 See the part on naturalisation in section 2 in this chapter.

8 For instance a person who was 45 years of age and born in Latvia could apply for naturalisation in 2000 , while a person who was twenty could apply in 1996 .

9 The European Union 'expressed grave concern at certain aspects of the [...] law on citizenship adopted in Latvia' (European Commission, General Report on the Activities of the European Union 1994 Brussels/Luxembourg I995, para. 759). See also the Opinion No. I83 (I995) on Latvia's application for membership in the Council of Europe; stars.coe.fr. Latvia was also cited three times under the UN 1503 procedure concerning gross and persistent violations of Human Rights (in I995, I997 and 2000). 
Io The amendments were adopted on 22 June 1998. The referendum was held on 3 October 1998 and about 53 per cent of the electorate voted for the adoption of the amendments.

II Only in exceptional cases can such an application be submitted by a single parent, i.e. by a mother if there is no entry regarding the father in the birth record or by the remaining parent if one parent is deceased.

I2 Apart from that, the requirements of exams and the fee for naturalisation have been lowered a number of times.

I3 See the section on statistics at the end of this chapter.

I4 The EU accession negotiations avoided the issues related to the status and rights of non-citizens. The Commission of the European Union, when interpreting the scope of the application of the so called Third-country Nationals' Directive (Council Directive 2003/109/EC of 25 November 2003 Concerning the Status of Thirdcountry Nationals who are Long-term Residents, Official Journal, L oI6, 23 January 2004, pp. 0044-0053) stated that "the expression "third-country national" covers all persons who are not citizens of the Union in the sense of Article I7 paragraph I of the EC Treaty, that is to say those who do not have the nationality of an EU Member State. This indicates that those with undetermined citizenship fall within the scope of the directive. Letter from the Directorate-General of Justice and Home Affairs, European Commission to the Permanent Delegation of Latvia in the EU institutions, 23 June 2003. This places non-citizens at a disadvantage compared to the status they have enjoyed so far.

I5 See the conclusions by an EU Network of Independent Experts on Fundamental Rights, Synthesis report for 2003, p. 88 . The experts regret that the situation of noncitizens has not been resolved during the entry negotiations between Latvia and the EU.

i6 For instance, Kees Groenendijk suggested calling them 'denizens', a term describing residents enjoying a status between alien and citizen (Groenendijk 1993: I5).

I7 See Constitutional Court Case 2004-I5-0I06, Official Gazette No. 40, 9 March 2005. Most of the other rulings (approximately 200 during 2004-2008) were passed by the administrative courts. The numbers of cases concerning access to status are limited. The most illustrative case is that of Galina Bakriseva, who, in the Court's opinion, may have the right to non-citizen status notwithstanding her service in the Russian armed forces. Other cases concern children whose parents - either one or both - are foreign citizens who have agreed to register their child as a non-citizen of Latvia (see, for example, the Zaharov case, No. A42348705 AA 934-06/10, 28 April 2006). Moreover, even if parents have acquired non-citizen status as a result of fraudulent methods, this is not a valid enough reason to deprive their children of their non-citizen status (Case No. A42051204 SKA-24/2008, I4 February 2008). Most cases deal with the revocation of the non-citizen status. The majority of these concern non-citizens who have acquired another citizenship but failed to inform Latvian authorities. However, the courts have been cautious when confirming the authorities' revocation decisions. Thus, the Supreme Court Senate declared the following in the Saakjan case: The link of a non-citizen to the Republic of Latvia is closer than is that of a stateless person or alien. Therefore, the revocation of the status of non-citizen means a significant limitation of the rights of the respective person (Decision of 2004, No. SKA-89, C2726I80I).

I8 See Consideration of Reports Submitted by States Parties under Article 9 of the Convention. Concluding observations of the Committee on the Elimination of Racial Discrimination, 55 ${ }^{\text {th }}$ Session 2-27 August 1999, CERD/C/304/Add.79 I2 April 200I, paras I2-I4, and 63rd Session, 4-22 August, CERD/C/63/CO/7 Io December 2003, paras I2-I3. Consideration of Reports Submitted by States Parties under Article 40 of 
the Covenant, Human Rights Committee, $79^{\text {th }}$ Session, CCPR/CO/79/LVA, I December 2003, paras I6-I8.

I9 Almost automatic acquisition means that a person shall approach the regional office of the Naturalisation Board and submit documents testifying that the person permanently resides in Latvia as well as supporting documents confirming that the person belongs to one of the groups of persons qualifying for almost automatic citizenship (for instance, diploma of secondary education in Latvian).

20 Decision of the Latvian Constitutional Court, Case No. 2007-07-OI, 2I August 2007.

2 I According to para. 4 of art. 24 of the Immigration Law, permanent residence can be acquired after five years of residence in Latvia with a temporary residence permit. This means that a person shall reside five years in Latvia in order to obtain permanent residence and a further five years with permanent residence to acquire the right to apply for citizenship. Exceptional cases provide for a shorter residence requirement as permanent residence permits can be issued in certain cases immediately after arrival (for instance, family reunification, former citizens and noncitizens and alike).

22 The Law states that a person shall know the basic principles of the Constitution of the Republic of Latvia and the Constitutional Law Rights and Obligations of a Citizen and a Person. However, this law became obsolete on 6 November I998 when the Constitution was supplemented with a chapter on human rights.

23 In the cases of Estonia and Lithuania, they had to be citizens of the respective countries on I7 June I940, but in the Polish case on I September 1939.

24 These include the Communist Party of the Soviet Union, the Latvian Communist Party, the Working People's International Front of the Latvian SSR, the United Council of Labour Collectives, the Organisation of War and Labour Veterans, the AllLatvia Salvation of Society Committee or their regional Committees or the Union of Communists of Latvia. Concerning the legality of similar limitations for running for public office, see the case of Ždanoka v. Latvia, application No. 58278/00, Judgment of Grand Chamber of ECHR, I6 March, 2006, especially paras. II9 and I20.

25 The Naturalisation Board is considered as one of the best performing institutions in Latvia. In relation to court cases the statistics show that out of 338 court cases the Naturalisation Board has lost only five.

26 A special procedure is provided by the Regulations on the Procedure for the Acceptance and the Review of the Application on the Recognition of a Child to be a Citizen of Latvia. The documents submitted are subject to verification by the Office of Citizenship and Migration Affairs and the Ministry of the Interior if a child has reached the age of fourteen (minimum age for criminal liability). Any other state and self government institution can be approached by the Board (sect. I9).

27 Regulations on the State Duty Payable for Submission of a Naturalisation Application, Regulations No. 234 (Record No. 26, para. 43), Riga, 5 June 200I. The rate is lowered to 3 Lats for: (I) members of poor families or poor persons; (2) unemployed; (3) members of families with more than three under age children; (4) persons receiving old-age pension; (4) disabled persons with a certain degree of disability; (5) pupils and students; (6) full-time students of tertiary education establishments. Persons exempted are: (I) politically repressed; (2) severely disabled persons; (3) orphans and children who are not under their parents' charge; (4) persons sheltered by social care institutions of the state or self-government. The fees were changed in 1997, 200I and 2002.

28 It was common practice that language proficiency had to be verified even after a person had passed the exam in case he or she wanted to hold public office. This practice was changed after the decision of the Human Rights Committee in the Ignatane case (Communication No. 884/I999, 3I July 200I). Antonina Ignatane was 
deleted from the list of candidates for local government elections after language inspectors conducted an unexpected language examination at her place of work concluding that her level of language proficiency did not correspond to the highest degree necessary to be elected to local government. See also Podkolzina v. Latvia, application No. 46726/99 at the ECHR, 9 July 2002.

29 These exceptions were introduced in 1998.

30 The doctrine seeks to reintegrate this region by increasing Russia's influence in the former USSR Republics and does not rule out the use of force 'within the limits of the law' if necessary. Other measures include: I) promoting not the return of 'Russian-speaking' residents to Russia, but their stay in the former Soviet Republics, since they can then be used to realise Russia's long-term interests in the region; 2) expanding Russian investments as a tool to increase political influence; 3) applying economic sanctions and other means of pressure against 'disobedient' former USSR Republics; 4) using human rights and ethnic minority rights with regard to Russian minorities as a weapon against the former USSR Republics; 5) advocating a 'zero solution' in the citizenship laws of the former Soviet Republics. i.e. an automatic granting of citizenship in the respected states (for more detail, see Lerhis \& Kudors 2008: 36-62).

3I The Foreign Policy Concept of the Russian Federation is available at www.kremlin.ru. See also 'Russia's new foreign policy strategy will continue to defend Russian nationals' interests in the Baltics', LETA [National News Agency], I7 July 2008; and the report on the Russian Federation Foreign Policy (ОБЗОР ВНЕШНЕЙ ПОЛИТИКИ РОССИЙСКОЙ ФЕДЕРАЦИИ) at www.un.int.

32 'Visa waiving for Latvia's “non-citizens"' jeopardizes Russia-EU talks', Ria Novosti [Russian national news agency], I8 June 2008. en.rian.ru.

33 'Ārlietu ministrijas paziņojums par Krievijas Federācijas lēmumu atcelt vīzu režīmu daļai Latvijas iedzīvotāju [Announcement of the Ministry of Foreign Affairs concerning the decision of the Russian Federation to lift visa regime for a group of Latvia's inhabitants]', press release, Latvian Ministry of Foreign Affairs, I8 June 2008. www.am.gov.lv.

34 Z. Stankeviča, 'Latvija zaudē izcilus pilsoņus likuma burta dēļ [Latvia loses outstanding citizens because of the strict law]', Neatkarīgā Rìta Avize [daily newspaper], I5 October 2007.

35 I. Matisane, 'Dubultpilsonību bērniem varētu ieviest jau šogad [Dual citizenship for children could be introduced already this year]', Official Gazette, 25 July 2007. www.lv.lv; G. Laganovskis, 'Tieslietu ministrs: dubultpilsonībai nepieciešams jauns likums [Minister of Justice: dual citizenship requires new law]', Official Gazette, I4 May 2008. www.lv.lv; G. Laganovskis, 'Tieslietu ministrs pię̧auj dubultpilsonību [Minister of Justice allows dual nationality]', Official Gazette, II July 2008. www.lv.lv.

36 A. Eriņa, 'Turpina gatavot priekšlikumus par pilsonības piešķiršanu ārvalstīs dzimušo Latvijas pilsoņu bērniem [Drafting of proposals for granting citizenship to children of Latvian citizens born abroad continues]', LETA, 24 October 2007; A. Eriņa, 'Pilsonības likumā rosina paredzēt dubultpilsonību ārzemēs dzīvojošo Latvijas pilsonsu bērniem [Suggestion to make provisions in the Citizenship Law for dual citizenship of children of Latvian citizens living abroad], LETA, 24 April 2004.

37 This data is available at www.pmlp.gov.lv.

38 Application No. 55707/00, Grand Chamber Judgment I8 February 2009.

39 There are several publications concerning these allegations, such as, 'Štāba brīdinājumus par sadursmēm uzskata par provokāciju [Warnings from Stab about clashes with police considered as provocation]', Diena [daily newspaper], I4 August 2004. This publication refers to an earlier article where Petropavlovskis listed I60 combatants under his command (2I February 2004). See also the interview with Pet- 
ropavlovskis: Mūrniece I., 'Intervija ar Juriju Petropavlovski: “Mums vajadzīgs starptautisks skandāls!" [Interview with J. Petropavlovskis: "We need International Scandal']', Latvijas Avize [daily newspaper], 20 December 2004. Russian sources can be found at: www.2004.novayagazeta.ru.

40 I. Rubule, 'Ārzemēs atbalsta dubultpilsonības ieviešanu' [Outside Latvia there is support for the introduction of dual citizenship], Portal of Latvians living abroad, 2 August 2008. www.latviesi.com.

4I The Table is based on data on ethnic origin as indicated by residents. At the beginning of the I990s, all residents were required to declare their ethnic origin which was mentioned both in their passports and in the Register of Residents. Current practice is that those applying for naturalisation are required to declare their ethnic origin on an application form that they submit to the Naturalisation Board. This requirement is optional as is the reference to ethnic origin in the passport.

42 The number of applications received during 2004 was equal to the numbers received between 1998-2004.

\section{Bibliography}

Berg, E. \& W. van Meurs (200I), 'Legacies of the Past, Ethnic and Territorial Conflict Potentials', in I. Kempe (ed.), Beyond EU Enlargement, vol. 1, The Agenda of Direct Neighbourhood for Eastern Europe. Gütersloh: Bertelsmann Foundation Publishers.

Brands-Kehre, I. \& I. Pūce (2005), 'Politiskā nācija un pilsonība' [Political nation and citizenship], in Demokrātijas audits, SPPI, SAK, LU Apgāds. Also available at www.politika.lv.

Groenendijk K. (I993), 'Nationality, Minority and Statelessness: The Case of the Baltic States', Helsinki Monitor 4 (3): 13-25.

Indāns I. \& K. Krūma (2007), 'Vienoti daudzveidībā: imigrācija un integrācija [United in Diversity: Immigration and Integration]', in Savējie un Svešie. Sabiedrības Radikalizācijas Tendences Latvijā, Eiropā un Pasaulē [Belonging and Remaining Outside. Tendencies of Radicalization of Society: Latvia, Europe and the World], Zinātniski pētnieciskie raksti 6 (I6): I49-176.

Kalvaitis, R. (I998), 'Citizenship and national identity in the Baltic States', Boston University International Law Journal I6: 23I-27I.

Krūma K. (2006), Dubultā pieeja dubultpilsonībai [Dual approach to dual citizenship]. Public policy portal. www.politika.lv.

Lerhis, A. \& A. Kudors (2008), Outside influence on the ethnic integration process in Latvia. Riga: Centre for East European Political Studies.

Muižnieks N. (2006), 'Russian Foreign Policy Towards "Compatriots" in Latvia', in N. Muižnieks (ed.), Latvian-Russian Relations: Domestic and International Dimensions. Rīga: LU Apgāds and Baltijas Sociālo zinātngu institūts, Integrācijas prakse un perspektīvas, II9-I30. www.politika.lv.

Strategic Analysis Commission under auspices of the State President (2006), Latvija un brīva darbaspēka kustība: Irijas piemērs [Latvia and the free movement of workers: The Irish case]. www.president.lv.

Thiele, C. (I999), 'The Criterion of Citizenship for Minorities: The Example of Estonia', ECMI Working Paper 5.

Tomaševski, K. (2000), Responding to Human Rights Violations. The Hague: Martinus Nijhoff Publishers.

Zepa, B. (2005), Ethnopolitical tension in Latvia: In search of a conflict solution. Riga: Baltic Institute of Social Sciences. 
Ziemele, I. (1998), State Continuity and Nationality in the Baltic States: International and Constitutional Law Issues. PhD Dissertation. Wolfson College Cambridge.

Ziemele, I. (200I), 'State Continuity, Human Rights and Nationality in the Baltic States', in T. Jundzis (ed.), The Baltic States at Historical Crossroads, 224-248. Riga: Academy of Sciences of Latvia.

Ziemele, I. (2005), State Continuity and Nationality: The Baltic States and Russia. Past, Present and Future as Defined by International Law. Leiden, Boston: Martinus Nijhoff Publishers.

Ziemele, I. \& K. Krūma (2003), 'Eiropas Savienības pilsonība un Latvijas nepilsonii’ [European Union citizenship and Latvian non-citizens], Latvijas Vēstnesis, pielikums Jurista Vārds 33 . 


\title{
3 Lithuanian nationality: Trump card to independence and its current challenges ${ }^{\mathrm{I}}$
}

\author{
Kristīne Krūma
}

There are slight differences between the Latvian and Lithuanian approaches as far as the transition from the Soviet to democratic institutions is concerned. Lithuania could be said to have used the Soviet legal and institutional basis for the adoption of the decisions necessary at the time more than Latvia did. However, it will be argued that these differences do not challenge the underlying principle of ex iniuria ius non oritur followed also by Latvia and Estonia.

In comparison to other Baltic states, Lithuania escaped close international scrutiny of its nationality policies (see Järve and Krūma in this volume). Therefore, nationality has, until recently, not created any major international controversies. Only after Lithuania encountered hurdles related to the presidential discretion for granting nationality has the issue attracted attention, especially on the national political agenda. Since then there have been heated debates on the need to change the Lithuanian approach to dual citizenship.

\subsection{History of nationality policy}

\subsubsection{General overview of nationality policy}

The same scenario of imposing Soviet nationality upon their nationals was applied in all three Baltic states, including Lithuania. However, Soviet Citizenship Law did allow the Soviet republics much authority regarding nationality matters (Kalvaitis I998: 240). This was seized by Lithuania in 1989 when it enacted its first Citizenship Law.

Guided by the principle of ex iniuria ius non oritur, Lithuania, having declared independence on II March I990, first reinstated the I938 Constitution and simultaneously suspended some of its articles as they were incompatible with democratic principles or the institutions provided for no longer existed. Following the full suspension of the 1938 Constitution, the Provisional Basic Law was enacted, accounting for present-day realities (Kalvaitis I998: 243). The 1992 Constitution was carefully drafted with reference to laws in force before 1940 and with an emphasis on constitutional continuity (Ziemele 2005: 40). However, the enactment of the 1989 Citizenship Law before adoption of the 
Constitution is the main difference to the approaches adopted in the two other Baltic states because Lithuania was guided by the conflicting principle ex factis ius oritur, at least to a certain extent. This means that the new Constitution was adopted by an extended body of nationals in comparison to the citizenship laws prior to I940.

The development of Lithuanian nationality legislation can be divided into three main phases. The first phase started with the Law adopted in I989 providing for liberal conditions upon which Lithuanian nationality could be acquired. This phase ended with the Law of I99I when Lithuania had already restored its independence and stricter criteria for the acquisition of nationality were introduced. This second phase is problematic and confusing because there were various attempts to find a balance between compliance with the principle of continuity of nationality and the avoidance of double nationality. The third phase was initiated by the new 2002 Law on Citizenship. It attempts to streamline provisions of the I99I Law and its numerous amendments and to liberalise the regulation of dual nationality.

\subsubsection{The 1989 Citizenship Law}

The first Lithuanian nationality law was adopted on 3 November I989. The Law identified four categories of persons who were or could become nationals of Lithuania:

- Those who held Lithuanian citizenship prior to I5 July I940 including their children and grandchildren, as well as those who were permanent residents in the territory of the Lithuanian SSR on I5 July I940 and their children and grandchildren provided that they are or have been permanent residents of the Lithuanian SSR.

- Those who had a permanent place of residence in the Lithuanian SSR if they were born in the territory of the Lithuanian SSR or can prove that at least one of their parents or grandparents was born there and if they are not citizens of another state.

- Other persons who at the time of the adoption of the Law were permanent residents for at least two years and had employment or other legal source of support in Lithuania. Thus, the law allowed those who arrived in Lithuania during the Soviet period to acquire Lithuanian nationality (with some exceptions, such as Soviet army officers). They had to declare their intention to become nationals within two years following the entry into force of the law ${ }^{2}$, i.e. until November I99I. Upon registration they had to swear an oath of allegiance to the Lithuanian Constitution and laws (Kalvaitis I998: 244, 26I). This principle applied irrespective of their nationality or language abilities. 
- Those who had acquired the Lithuanian nationality in accordance with the law.

According to the Constitutional Court of Lithuania in Case 7/94, the Law differentiated between existing and potential holders of Lithuanian nationality. ${ }^{3}$ Persons who were nationals prior to occupation, their descendants and permanent residents on I5 June I940 who continued to reside in the country when the Law entered into force, were considered nationals ipso facto. The same applied to persons born in the territory of Lithuania and still residing there, and those whose parents were born or resided in that territory. These persons were considered as having a permanent legal relationship with Lithuania; a principle which was considered particularly important in Lithuania for its nationality policies (Ziemele I998: 223). Finally, those who were deported from the territory of Lithuania or emigrated after the occupation, as well as their children and grandchildren, also retain the right to Lithuanian citizenship.

Soviet-era immigrants were only considered potential nationals as they were guaranteed the right to freely decide on their nationality. After they accepted nationality they all had to take a pledge of loyalty to Lithuania (Kalvaitis I998: 26I). In case 7/94, the Constitutional Court emphasised that there were differences between this category of persons and other nationals. The latter never had permanent legal relations with Lithuania and they were immigrants holding Soviet nationality. After the restoration of an independent Lithuania, they became foreigners if they did not use the option provided for by the ig89 Law. It has to be recalled that this choice was not obvious or easy at the time. In I989 or even I990, it was still difficult to foresee the collapse of the Soviet Union. Taking an oath of allegiance to Lithuania required certain convictions. 90 per cent $(87$ per cent according to other sources) of non-Lithuanian permanent residents registered as nationals under these provisions. Only I per cent of the pre-independence electorate chose not to become nationals of the Republic of Lithuania (Kalvaitis I998: 26I).

The law did not provide for dual nationality. This was confirmed in the Provisional Basic Law in art. I3 which stated that as a rule, a citizen of Lithuania may not at the same time be a citizen of another state. The subsequent amendments on I6 April I991 confirmed that Lithuanian nationality is lost upon the acquisition of the nationality of another state. However, a number of exceptions existed at that time as well. These concerned those who were nationals of Lithuania prior to I5 June I940 and their descendants. 


\subsubsection{The 1991 Citizenship Law}

The second Citizenship Law in Lithuania was adopted on Io December I99I. ${ }^{4}$ It established who are to be considered Lithuanian nationals. The new law ended the liberal period when any resident could apply for nationality after two years of residence and introduced stricter requirements. It was subsequently amended several times: i9 November I992, I6 July I993, 3 October I995 and 6 February i996. The following comments on the I99I Law take these amendments into account.

The law identified groups of individuals eligible for Lithuanian nationality. Initially those included:

- nationals of Lithuania prior to I5 June I940 including their children and grandchildren if they had not acquired nationality of another state;

- permanent residents of Lithuania between 9 January I9I9 and I5 June I940 within the territory of the present Lithuania, their children or grandchildren, if they continue to reside in Lithuania and are not nationals of another country;

- persons of Lithuanian origin who left Lithuania prior to I6 February I9I8, if they have not acquired nationality of another state; ${ }^{5}$

- persons who acquired nationality in accordance with the Law on Citizenship effective prior to I99I;

- other persons who acquired nationality under the Law (naturalised).

The Supreme Council in the Resolution on the Procedure for Implementing the Republic of Lithuania Law on Citizenship of Io December I99I, clarified in sect. 5 that persons serving in the armed forces, internal troops and state security structures, as well as other law enforcement and repressive structures of the Soviet Union must not be considered as permanently residing or employed in Lithuania. This was in line with the Supreme Council Resolution on I939 Treaties between Germany and the USSR and Elimination of their Consequences for Lithuania (7 February I990) and the Supreme Council Declaration on the Status of Soviet Armed Forces in Lithuania (I9 March I990). They stated that servicemen of the occupation army were not entitled to the right to participate in elections organised in Lithuania, with the exception of those who under the I989 Law on Citizenship could be recognised as nationals of Lithuania. A descendant of a Lithuanian citizen, as identified prior to I5 June I940, who had served in the Soviet army, was not excluded from Lithuanian nationality. The USSR nationality was declared null and void with respect to these individuals as it was for all other Lithuanian nationals. The Constitutional Court stated: 
Such a decision meant that the consequences of occupation and annexation with regard to citizens of Lithuania on whom citizenship of the Soviet Union had been forced against their will, were being undone. It goes without saying, that such a decision on the part of the state could only be adopted regarding its citizens, and the state could by no means resolve issues concerning the citizenship of another state.

According to art. I2 of the I99I Lithuanian Constitution, with the exception of cases established by law, no person may be a citizen of the Republic of Lithuania and another state at the same time. The Citizenship Law deals with the issue of dual citizenship in a confusing way which is closely connected with a certain conflict between the principles of continuity of nationality and the principle of effective link that the Law tries to accommodate. Relevant provisions of the Law have been amended several times to clarify who can and who cannot acquire dual citizenship. Concerns were expressed by the Lithuanian nationals who could not obtain Lithuanian passports because they had in the meantime acquired another nationality. They were therefore denied the possibility to restore their nationality because dual nationality was prohibited. The Council of Europe characterised this situation as unsatisfactory (Ziemele 1998: 220).

Explanations were given by the Constitutional Court in Case 7/94 when it dealt with questions pertaining to the right of members of the Soviet armed forces to acquire Lithuanian nationality. The Constitutional Court was approached by a group of MPs who challenged the validity of the Resolution of the Parliament which provided that members of the USSR army, who had terminated their service before I March I992 and 4 November 1994, and had been issued a Citizen Certification Card, could acquire citizenship. The Court declared the provisions of the Resolution unconstitutional. It clarified that the 1989 Citizenship Law 'did not provide an option for a citizen of Lithuania to be at the same time a citizen of another state'. This was supported by another general principle of the 1989 Law, providing that Lithuanian nationality is lost with the acquisition of another nationality (Ziemele I998: 220). The Court noted that there is only one exception to this general rule, i.e. those who were nationals of the Republic of Lithuania prior to I5 June 1940 and their descendants. The latter explanation relates to the application of the principle of continuity of nationality while the prohibition of dual nationality is linked in principle to the understanding of effective link by Lithuania as concerns its decisions on nationality issues.

According to this ruling of the Constitutional Court, the Law was amended in 1995. Art. I provided that nationals of Lithuania prior to I5 
June 1940 and their children are nationals of Lithuania if they have not repatriated to their ethnic homeland (this new requirement was not changed in response to the court decision. In fact, it was declared unconstitutional by the court in 2006). The requirement that they are not permitted to be nationals of another state was lifted. However, this condition was still applicable to their grandchildren until the amendments of 2 July 1997, which permitted these, too, to retain their other nationality.

This amendment also affected arts. I7 and I8 of the I99I Law. Art. I7 stated that the right to nationality of Lithuania shall be retained for an indefinite period for (I) those who were nationals prior to I5 June I940 and their children provided that they have not repatriated i.e. departed to their ethnical homeland and (2) persons of Lithuanian origin residing in other states. ${ }^{6}$ According to the 1995 amendments a person with one Lithuanian parent or grandparent and who is Lithuanian him or herself shall be considered a person of Lithuanian origin. The same amendments provided for differentiation between the above mentioned categories (I) and (2). While the first group could retain another nationality, the second had to renounce the nationality of another state and return to Lithuania for permanent residence in order to be granted Lithuanian nationality. Thus, the Law grouped persons according to their ethnic origin and according to whether they had departed for their ethnic homeland or another country. In both cases, those who were entitled to citizenship but resided abroad were not considered Lithuanian citizens ex lege. They had to express the corresponding intention and meet the requirements established by law. ${ }^{7}$

Art. I8 stated that all persons mentioned in art. I7 should renounce the nationality of another state. Moreover, persons of Lithuanian origin residing in other states shall become permanent residents as well as take the oath to Lithuania in order to acquire nationality. ${ }^{8}$ Such a complicated scheme reflects the problems caused by the prohibition of dual nationality when the independence of a state, which was suppressed for a considerable time, is restored. It was only when amendments were made in 1993 that those who were deported or left Lithuania during occupation and their children who had not acquired nationality of another state by birth and lived in other states could recover Lithuanian nationality by presenting a written notice to the authorities. Before these amendments neither provisions of art. I7 or art. I8 provided possibilities to acquire dual nationality.

Therefore, on the one hand, the Law identifies nationals with respect to whom the prohibition of dual nationality does not apply, i.e. groups of individuals whose right to nationality is retained for an indefinite period without renouncing their present nationality. On the other hand, there are groups of persons who have the right to nationality but 
the right can only be exercised when they renounce their present nationality (Ziemele 200I: 235-236).

Distinctions apply also to different categories of children, i.e. those who are considered nationals by birth and those who have to acquire nationality although they are born in Lithuania. A child born to parents one of whom is a Lithuanian citizen shall be a citizen irrespective of his or her place of birth if at least one parent has permanent residence in Lithuania (art. 9). If, however, both parents reside outside Lithuania they shall reach an agreement on the child's nationality until he or she is eighteen years of age. Foundlings shall be considered nationals while children born to stateless persons who are permanent residents in Lithuania shall acquire Lithuanian nationality (arts. IO and II). The articles do not specify whether these children have to be born in Lithuania, which may imply that the Law means children who have arrived in the country with their parents. Both articles draw a distinction between children who shall be nationals by birth and those who have to acquire nationality (Ziemele I998: 237).

In relation to spouses of Lithuanian nationals art. I4 provided a simplified procedure for the acquisition of nationality, i.e. three years of residence in Lithuania while married, the passing of exams on language and the Constitution as well as the renunciation of their previous nationality. The amendments of 1992 added another category of persons subject to a simplified procedure. It stated that those who are married to Lithuanian nationals who were deportees or political prisoners and their children born in exile shall be granted Lithuanian nationality if they are married for at least three years and have moved for permanent residence to Lithuania together with their spouse. These persons would only have to renounce their previous nationality and to pass an examination on the Constitution of Lithuania.

Lithuania's general approach to the regulation of nationality, especially in the early i990s, can be considered as more liberal compared to the other Baltic states. First, most of the Soviet-era settlers acquired nationality on the basis of the 1989 Law while Latvia and Estonia re-established the body of nationals on the basis of the legislation of the pre-occupation period. Second, Lithuania did not introduce any quota system while Latvia only abolished its quota system in $1998.9^{9}$ Third, Lithuania included residence during the Soviet period as valid for nationality purposes. Latvia and Estonia took into account only the residence after restoration of independence. Therefore, Lithuania managed to avoid criticism which continues to be addressed to Latvia and Estonia. This has often been explained by the different proportion of nonindigenous populations residing in Lithuania when independence was restored. 
The Lithuanian approach cannot be qualified as a 'pure zero option' because there were distinctions made between different groups of persons. The principle of continuity of nationality remained the main point of departure for deciding how to identify nationals. That is the reason why some of the groups were not considered nationals ipso facto and were subject to naturalisation according to the I989 Law. However, the procedure was very simple and a majority of the groups affected by this clause, mainly former USSR nationals, naturalised. As a consequence, the I99I Law did not really have to address the issues concerning the former USSR nationals, except when these did not use the I989 Law option (Ziemele I998: 225). However, concerning nationals, a distinction was made between the execution of the right to nationality and the restoration of nationality. Restoration concerns situations where the original nationality was not retained throughout the occupation or when some actions are needed to re-instate it (Ziemele I998: 224).

\subsubsection{The 2002 Citizenship Law}

The third Law on Citizenship was adopted on I7 September 2002 and entered into force on I January 2003. It repealed the I99I Law and incorporated certain related laws (such as the Law on the Validity of Citizenship Documents). The Law was subsequently amended in 2003 and $2004 .{ }^{\text {IO }}$ One of the main issues which was publicly debated was the question of Lithuanian émigrés holding dual nationality. ${ }^{\text {II }}$ Emigrants voiced their discontent with the fact that they were stripped of their Lithuanian nationality when acquiring the nationality of another state. The new Law accommodated their requests and in addition provided for possibilities to have their nationality status re-instated. However, some national minorities protested against the Law. They argued that permitting dual nationality only to ethnic Lithuanians contravenes the Constitution and international norms.

The new Law on the Implementation of the Republic of Lithuania Law on Citizenship was adopted in 2003 (amended in 2004). One of the main provisions stated that those who applied for nationality under the I989 Law, but did not receive a document confirming their status and were residing abroad, lost their nationality on 3I December 2003. This decision was made by the Minister of the Interior.

The new Citizenship Law slightly amended art. I defining the categories of nationals. It now includes references not only to children and grandchildren of persons who were nationals prior to I5 June I940 or permanent residents from 9 January I9I9 to I5 June I940 but also to their great-grandchildren. Moreover, those who were nationals prior to I5 June I940 and their descendants (including great-grandchildren) do not have an obligation to renounce a nationality held from another 
state. Reference to I6 February I9I8 has been lifted and, thus, any person of Lithuanian descent is a Lithuanian citizen if he or she does not have any other nationality. Hence, the Law expands the category of persons who have an inherent right to nationality of Lithuania up to the fourth generation, and introduces conditions for simplified restoration of nationality for those who lost their Lithuanian nationality but have an inherent right to it. The former art. I7 has been simplified and art. I8 has been deleted altogether.

The conditions upon which a child is considered a citizen if only one parent is a Lithuanian citizen have also been slightly changed. According to the new art. 9, a child shall be a citizen if born in the territory of Lithuania and one of the parents is a national. In the case of a child born outside Lithuania, his or her nationality is to be determined by an agreement between the parents (of whom one must be a Lithuanian national) until he or she reaches eighteen years of age. This shall be done irrespectively of their place of permanent residence. Art. Io provides ius soli acquisition of nationality for children whose parents are stateless persons permanently residing in Lithuania.

The conditions for acquiring Lithuanian nationality were made stricter for spouses (art. I4). Firstly, the 2002 Law provided that only those spouses who had been married for at least five years and had been resident in Lithuania for that period were to be granted nationality. They had to pass exams on language and the Constitution and were not allowed to hold another nationality. Thus, stricter requirements were introduced as previously only three years of residence were required. With the amendments effective from January 2005, the residence requirement for spouses of Lithuanian nationals has been raised even further to seven years. ${ }^{\text {I2 }}$ Secondly, persons married to Lithuanian nationals who were deportees or political prisoners and their children born in exile are no longer exempt from the Lithuanian language exam. They also have to reside in Lithuania for five, not three years as before. Thirdly, the Law has introduced conditions upon which a person can acquire nationality in the case of his or her spouse being deceased, if they were married for more than a year with residence in Lithuania. In these cases a person could acquire Lithuanian nationality after three years of residence provided that he or she passes the exams on language and the Constitution and renounces his or her previous nationality. However, after the amendments effective from January 2005 the residence requirement was raised to five years.

It shall be noted that at least some amendments were introduced because of a ruling of the Constitutional Court of Lithuania in case No. $40 / 03$ of 30 December 2003 regarding the granting of nationality by way of exception. ${ }^{\mathrm{I}}$ A Seimas resolution asked the Court's ruling on the possible violation of the constitutional principle of equality by the Pre- 
sident when he granted nationality by exception to one of his advisors, Jurij Borisov. These events were heatedly debated and subsequently led to an impeachment procedure against the President. In summary, the Constitutional Court ruled that in cases where the President grants nationality by way of exception he or she shall verify the service which was given to Lithuania as a state, establish whether the person has permanent factual links with Lithuania, whether the applicant is not subject to any exceptions mentioned in the Law as well as his or her possibilities to recover nationality on his or her own initiative in accordance with the Law. Moreover, the Court emphasised that the legislator cannot deny the nature and meaning of the institution of citizenship and the relevance of the Constitution, which allows dual nationality only in individual cases provided for by the law. This means that cases of dual citizenship must be extraordinarily rare and exceptional.

Generally the Law streamlines the conditions for the acquisition and retention of nationality of the previous Law which due to its numerous amendments became too cumbersome. A number of provisions are excluded because they do not relate to the acquisition or retention of nationality but rather dealt with the conditions for entry and residence in the territory of Lithuania. The Law is clearer regarding the continuity and restoration of nationality as well as dual nationality. Moreover, it brings the conditions in line with the requirements of human rights law (groups excluded from acquiring nationality, loss of nationality due to invalid passport, etc.) and provides for stricter requirements in certain cases (spouses). Finally, the Law grants more authority to the Minister of the Interior and clarifies a number of provisions in relation to the naturalisation procedure. These latest provisions came into force on I April 2006. ${ }^{\text {I4 }}$

\subsection{Basic principles of the most important current modes of acquisition and loss of nationality}

\subsubsection{General principles of the acquisition of nationality}

Art. I2 of the Constitution proclaims that 'citizenship of the Republic of Lithuania shall be acquired by birth or on other grounds established by law'. However, the Citizenship Law does not mention the principle of reducing statelessness as a possible guideline for the nationality policy of the state (Ziemele I998: 248). There is no support for the argument that Lithuania has adopted the ius soli principle in addition to the ius sanguinis principle as basis for the acquisition of nationality in the Law.

Art. 7 enumerates the grounds on which the nationality of Lithuania can be acquired by: (I) birth; (2) exercising the right to nationality; (3) 
naturalisation; (4) international treaties; (5) reference to other grounds provided in legislation. Reference to international treaties is unclear. It can be argued that in cases where the Citizenship Law contravenes Lithuania's international obligations the norms of the treaties would then be directly applicable.

\subsubsection{Right to nationality}

The Lithuanian Citizenship Law identifies a number of groups who are considered Lithuanian nationals by birth and by exercising the right to nationality. The Law provides for the retaining of the right to citizenship. It was designed to prevent persons residing in foreign states who had held citizenship prior to the occupation from losing their link to Lithuania, irrespective of their ethnic origin. Those who retained the right to citizenship could become citizens in two ways - by claiming the right to citizenship or by restoring their citizenship. ${ }^{15} \mathrm{Na}-$ tionals are, firstly, those individuals who were nationals by right, i.e. they were nationals before I5 June 1940 or are of Lithuanian descent. However, a distinction is made within this category of people between nationals ipso facto who do not have to renounce the nationality of another state and those who have to do so in order to become nationals of Lithuania. In both cases their right is preserved indefinitely. Secondly, nationals are people who were born in the territory and have subsequently resided there (Ziemele 200I: 237). They are given the right to acquire nationality on the basis of application because their links with Lithuania are not considered as obvious (Ziemele 200r: 237). Otherwise, they are regarded as foreigners, albeit with the right to permanent residence. In comparison with the first group, their right to opt for nationality is not preserved indefinitely (Ziemele I998: 222). Thirdly, children born to Lithuanian parents and foundlings shall be Lithuanian nationals while children born to stateless persons have the right to acquire nationality. The provision is neutral regarding the gender of the parents.

Nationals residing outside Lithuania can submit their applications to diplomatic and consular missions. The Minister of the Interior has the authority to submit a recommendation to recognise a person as having lost nationality, and to receive applications for retention of nationality by persons who were nationals prior to 15 May 1940 and those of Lithuanian descent. According to art. 29 if a person fails to obtain the necessary documents attesting Lithuanian nationality held prior to I5 June I940 or his or her Lithuanian descent, the Minister of the Interior or Minister of Foreign Affairs and institutions authorised by them may apply to the Presidential Citizenship Commission for a verification of facts. The Commission presents its recommendatory findings 
to the Minister of the Interior or the institution authorised by him. According to art. 3I, repeated applications shall be accepted no earlier than one year after the adoption of the previous decision.

\subsubsection{Naturalisation}

Art. I2 lays down several requirements to be met in order to acquire Lithuanian nationality.

The requirements are the following:

- passing the Lithuanian language exam (speaking and reading); ${ }^{\mathrm{I} 6}$

- ten years of permanent residence in Lithuania;

- permanent employment contract or a constant legal source of support;

- knowledge of the Constitution;

- lack of any other nationality; and

- agreement to take the oath to Lithuania.

Amendments in I995 lifted the requirements of the language exam and the knowledge of the Constitution exam for persons over 65 years of age, disabled persons of group $\mathrm{I}$ and $\mathrm{II}^{\mathrm{I}}{ }^{7}$ and the sick with grave chronic mental diseases. These exceptions were upheld in the 2002 Law. In addition, this Law has lifted the requirement that refugees have to be stateless or renounce their nationality prior to applying for Lithuanian nationality.

Art. I2 provides that interests of the state have to be taken into consideration when nationality is granted. The application of this provision is unclear and open to discretion.

The terms 'permanent residence in the territory of Lithuania' and 'constant legal source of support' were clarified in sect. 3 of the Supreme Council Resolution on the Procedure for Implementing the Republic of Lithuania Law on Citizenship (adopted on Io December I99I). A person shall be considered as permanently residing in Lithuania if he or she has been registered in the register of permanent residents, has accommodation, and is employed in Lithuania under an employment contract or has another paid occupation in Lithuania and pays taxes there. A person will also be considered as permanently residing if he or she is somebody's dependent or is paid a pension legally due to him or her in Lithuania. Residency is counted including the period I940-I99I (Kalvaitis I998: 264).

Lithuanian practice as confirmed by the Constitutional Court in Case 7/94 has established that neither an occupying army nor repressive structures of a foreign state which resided in Lithuania without consent of Lithuania's authorities could be considered as lawfully residing for the purpose of the permanent residence requirement of the Citizen- 
ship Law (Ziemele 200I: 236). Likewise, service in such foreign forces cannot be considered as legal employment. Moreover, this interpretation is valid also in the context of the I989 Law.

According to art. I6, the President has the right to grant nationality by exception. The requirements for this option are, first, significant contribution to strengthening of Lithuanian statehood by the person in question. Second, the person has to contribute to Lithuania's power and its authority in the international community. Third, the person should be integrated into the Lithuanian society, i.e. he or she must have permanent factual links with Lithuania. Fourth, according to the ruling of the Constitutional Court in Case 40/03, art. I3 is applicable in these cases.

Art. I3 identifies the groups of persons precluded from acquiring nationality. Those include persons who (I) have committed crimes against humanity or acts of genocide; (2) have taken part in criminal activities against Lithuania; (3) before coming to Lithuania have been tried for a deliberate crime for which the criminal liability is imposed in Lithuania or have been sentenced in Lithuania; (4) are chronic alcoholics or drug addicts and (5) have especially dangerous infectious diseases.

The exclusion of alcoholics, drug addicts and criminals applied until the adoption of the 2002 Law. Criminals who were convicted before the adoption of the Law were subject to an ex post facto penalty to their punishment. The exclusion from naturalisation of alcoholics and drug addicts was particularly pernicious because it discouraged them from seeking needed treatment. ${ }^{\mathrm{I}}$

Since I January 2005, groups (I) and (2) have been broadened and now include not only those persons who committed aforementioned crimes but also those who were preparing or attempting to commit those crimes and acts. Moreover, the amendments added that those who do not have the right to reside in Lithuania cannot be granted nationality.

Since then, art. I3 on conditions for withholding nationality has been changed to bring it in line with human rights requirements. Firstly, it no longer states that chronic alcoholics, drug addicts or those ill with especially dangerous infectious diseases cannot become nationals. Secondly, the scope of persons who have had criminal charges against them has been minimised. The Law no longer refers to persons who, before coming to Lithuania, have been tried for a deliberate crime but only to persons who, before coming to Lithuania, have had a custodial sentence imposed on them for a premeditated crime. Also, in relation to those convicted in Lithuania, reference is made to premeditated crimes, not deliberate ones.

The procedures for resolving issues related to nationality are set out in chapter V of the Law. The chapter includes detailed information as 
to what documents shall be submitted in each case when a person applies for nationality. According to para. Io of art. 28 all applications for the acquisition, renunciation and restoration of nationality shall be submitted to the President through the executive institution of the municipality. Applications for nationality are reviewed by the Citizenship Commission which is established by the President. It submits proposals for a decision to the President. Decrees by the President should be co-signed by the Minister of the Interior. According to the Constitutional Court, the responsibility for these decrees lies with the ministers. The reason for this is that the President can be removed from office only for grave violations of the Constitution. In the case of a denial, an applicant is provided with a reasoned decision in writing. According to art. 30, decrees by the President concerning the granting, retention, restoration or loss of nationality as well as declaring an act on the granting of nationality invalid are published in the Official Gazette.

\subsubsection{Loss of nationality}

The grounds for loss of Lithuanian nationality are outlined in art. I8. It provides that nationality is lost (I) upon renunciation; (2) upon acquisition of nationality of another state; (3) on grounds provided for by international agreements to which Lithuania is a party. ${ }^{\text {I9 }}$ Paragraph 2 of the same article states that nationality should not be lost in cases when a person acquires the citizenship of another state with which Lithuania has concluded a contract on dual citizenship. A person may be recognised as having lost nationality if he or she is in the military service of another state or is employed in the public service of a non-EU Member State without permission of the Lithuanian authorities. According to the amendments in 2004 (effective of I April 2006), a Lithuanian citizen working in another state under the permission of the Lithuanian authorities would lose Lithuanian nationality if he or she were to injure the interests of Lithuania. The formulation is wide and it is unclear what is meant by damaging Lithuanian interests. Acquiring the nationality of another state does not result in loss of nationality for two groups of persons, i.e. those who were nationals prior to I5 June I940 and their descendants as well as persons of Lithuanian descent. ${ }^{20} \mathrm{~A}$ person may be recognised as having lost nationality if he or she is in the military service of another state or is employed in the public service of another state without permission of the Lithuanian authorities.

Moreover, there are a number of grounds on which naturalisation can be invalidated. Art. 2I provides that, firstly, naturalisation will be deemed invalid if nationality has been acquired by fraud or if a person has committed international crimes provided for by the international treaties or customary law (aggression, genocide, crimes against human- 
ity, war crimes or crimes against Lithuania). Secondly, the act of naturalisation will be declared invalid if the court establishes that after I5 June I940 a person has 'organised or carried out deportation or extermination of the residents, suppressed the resistance movement in Lithuania' (official translation). The same result would be reached if a court establishes that a person took part in the actions against independence and territorial integrity of Lithuania after II March I990.

The act of invalidation applies to naturalised nationals and Lithuanian descendants, if they have opted for Lithuanian nationality (Ziemele I998: 22I). A declaration of invalidity may be used as an additional penalty in relation to other criminal charges, e.g. if a person has committed crimes against humanity, acts of genocide or crimes against the Republic of Lithuania, prior to or after acquisition of nationality, as determined by the court decree. Original nationals cannot be subjected to such an additional penalty in similar circumstances (Ziemele i998: 250). The article does not set any precise time limit within which charges brought against a person for crimes against Lithuania could affect naturalisation. This again opens the possibility of arbitrary decisions which could result in statelessness and would run contrary to the rule prohibiting arbitrary deprivation of nationality (Ziemele i998: 250).

Art. 30 provides that invalidation of nationality is enacted by the President of Lithuania who issues a decree to that effect. The decree is not subject to judicial scrutiny. As the Lithuanian Citizenship Law is both complex and cumbersome on a number of issues the right to appeal decisions would be more than desirable (Ziemele i998: 222).

According to art. I9, everyone has a right to renounce their nationality. However, the same article provides for exceptions. Thus application for renunciation may not be considered if the person has been charged with a criminal act or if a court judgement passed on the person has become effective and enforceable. Setting the absence of criminal charges as a condition for the renunciation of nationality may also raise human rights considerations. The person may still be entitled to renounce nationality, which would not affect procedures employed by the state as long as the person remains within its jurisdiction (Ziemele I998: 249).

The Law on Citizenship places additional safeguards in order not to allow cases of statelessness to arise. Art. 20 provides that a person who has lost nationality as a result of renunciation or on grounds provided in an international treaty may be reinstated with Lithuanian nationality if he or she submits an application while having permanently resided in Lithuania for at least ten years, has a legal source of support and is stateless. Special conditions are provided for those who were nationals or permanent residents before I5 June I940 and their descendants as well as persons of Lithuanian descent. If they have lost nationality as a result of renunciation or on the basis of an 
international treaty, Lithuanian nationality is restored automatically on the basis of application.

\subsection{Current political debates}

The most recent proposals in the field of nationality policies aim to resolve issues concerning dual nationality. Over the years, the group entitled to dual citizenship has been considerably expanded.

According to the Citizenship Law, the right to nationality is retained by, and dual nationality allowed for, those who were nationals prior to I5 June I940, their children, grandchildren and great-grandchildren who have not repatriated, as well as persons of Lithuanian descent. Thus, several categories can be distinguished. Firstly, persons of Lithuanian origin are considered to be Lithuanian citizens and retain the right to citizenship irrespective of where they reside abroad. Secondly, persons of other ethnic origin are divided into two groups depending on where they reside. If their place of residence is their ethnic homeland, they are not considered citizens of Lithuania. For instance, if Poles holding Lithuanian citizenship moved to Poland during the period of Soviet annexation they no longer qualify for Lithuanian citizenship.

According to art. I2, para. 2 of the Lithuanian Constitution, no one may be a citizen of both the Republic of Lithuania and another state at the same time except in individual cases provided for by law. This article forms part of Chapter One of the Constitution, which, according to art. I47, can only be altered by referendum, meaning that more than half of the electorate must vote in favour of a change. However, recent amendments to the Citizenship Laws have provided large groups of persons with the right to dual nationality. In response to a petition presented by an Israeli citizen who also claimed to be a Lithuanian citizen this reform was challenged in the Constitutional Court by a group of parliamentarians and by the Vilnius Regional Administrative Court.

The Court emphasised that art. I2 of the Constitution should be interpreted narrowly, i.e. that cases of dual citizenship must be extraordinarily rare and exceptional, and that the Constitution does not permit the widespread granting of dual citizenship. In cases involving the granting of citizenship based on special merits, the Court has stressed that candidates must prove permanent factual links to the state and must be integrated into society before being granted citizenship. The Court considers the provisions for dual citizenship in the Citizenship Law to be highly controversial, inconsistent and confusing. Some provisions are barely compatible with each other while others are phrased ambiguously. As a consequence, the Court declared those provisions of the Citizenship Law that could lead to dual nationality as unconstitu- 
tional. While the Court noted that it is not against the Constitution to grant a right to Lithuanian citizenship, the relevant articles providing for the right to retain another nationality when acquiring or regaining Lithuanian nationality were found to be in violation of art. I2 of the Constitution. This conclusion is confusing because in its earlier ruling in case 7/94, the Court accepted the practice of dual citizenship in relation to pre-I940 nationals and their descendants. Moreover, the Court declared that categorising people according to their ethnic origins to establish whether their right to citizenship has been retained or not (in the case of repatriation) violates art. 29 of the Constitution, which provides for equality before the law. ${ }^{2 \mathrm{I}}$

During the spring and summer of 2007, several proposals for amendments were tabled. For instance, it was suggested that dual citizenship should be allowed for children born abroad if at least one parent is a Lithuanian citizen. The draft amendments were criticised by experts as being too general and ambiguous and became bogged down in various parliamentary committees. Meanwhile, the Lithuanian parliamentary Social Liberals successfully collected the 40 signatures of members of parliament necessary to initiate a referendum on the legalisation of dual citizenship. ${ }^{22}$ This referendum was planned to coincide with parliamentary elections in the fall of 2008 but did not take place. $^{23}$

However, the amendments were reconsidered in 2008 and adopted by the Human Rights Committee on 4 June and subsequently by parliament on 30 June 2008. The amendments concerned seven groups. Most notably among these amendments was the one that prevented persons who had acquired citizenship of EU and NATO Member States or of a country with which Lithuania has signed a mutual agreement on dual citizenship from losing their Lithuanian citizenship. ${ }^{24}$ Seventyeight MPs voted in favour of the amendments, four against them and nine abstained. Nevertheless, the Lithuanian legal scholar Dainius Zalimas has argued that these amendments violate the Constitution and devalue the significance of Lithuanian citizenship. He has suggested solving the problems that emigrants encounter by regulating the right to citizenship rather than citizenship itself. He has also advocated for the adoption of regulations similar to the Polish card system (see Górny \& Pudzianowska in this volume), which would allow for the preservation of certain benefits for former Lithuanian citizens who have acquired citizenship in another country. ${ }^{25}$

President Valdas Adamkus vetoed certain provisions in the amendments, including the provisions on dual citizenship for those who hold a passport of an EU or a NATO Member State. According to the President, the amendments broaden too widely the possibilities for granting (retaining) dual citizenship and 'create legal prerequisites for dual citi- 
zenship that allow a rare exemption to become a widespread phenomenon'. The parliament agreed with the President and amended the law again on I5 July 2008. The vote was 66 parliamentarians approving the President's amendments, while ten voted against them and seven abstained. The adopted amendments expanded the possibilities for dual citizenship, e.g. for children who acquire Irish or Lithuanian citizenship by birth. However, this is not the end of the story. With the presidential veto, the current law became the provisional law, valid only until I January 20I0. Since neither the government nor interest groups have come up with a new law, the president entrusted a group of lawyers with the task of presenting solutions. The group concluded that it is highly unlikely that a referendum on the amendment of art. I2 of the Constitution would succeed (the law can only be changed if a majority of at least 50 per cent of all eligible voters agree). The group of lawyers therefore drafted a new Law on Citizenship, presented to the president on 9 February 2009.

\subsection{Statistics}

Taking into account that nationality and statelessness issues were not high on the political agenda due to the liberal approach adopted in the I989 Law, no exact statistics were maintained. Lithuanian statistical information is therefore rather poor.

Table 3.I shows that the share of the titular ethnic group has been rather high in Lithuania compared to Estonia and Latvia.

Table 3.1 Ethnic composition in Lithuania

\begin{tabular}{lllll}
\hline & 1979 & 1989 & 2001 & 2007 \\
\hline Lithuanians & $80 \%$ & $79.6 \%$ & $83.5 \%$ & $84.7 \%$ \\
Non-Lithuanians & $20 \%$ & $20.4 \%$ & $16.5 \%$ & $15.4 \%$ \\
\hline
\end{tabular}

Sources: Statistikos Departmentas, 1979, 1989, 2001: population censuses, 2007: estimation carried out based on the data of the Residents' Register central database, www.stat. gov.lt

Data for the period from I993 onwards are not available because no exact statistics were maintained during that period. Data on naturalisation has only become available since 2002. The statistics show that the number of persons acquiring Lithuanian citizenship was insignificant between 2003 and 2007. Most of the new Lithuanian citizens were former Russian citizens or stateless persons. For instance, out of the 370 persons granted Lithuanian citizenship in 2007 , II3 were former Russian citizens and $\mathrm{i} 84$ were former stateless persons. 
Table 3.2 Number of naturalised persons, 2003-2007

\begin{tabular}{llllll}
\hline Year & 2003 & 2004 & 2005 & 2006 & 2007 \\
\hline Number & 389 & 610 & 435 & 467 & 370 \\
\hline
\end{tabular}

Source: Migration Department 2008: 56

A relatively large number of persons lost nationality between 2003 and 2007. Moreover, the number increased over the years, especially due to acquisition of nationality of another state (see Table 3.3).

Table 3.3 Number of persons who have lost Lithuanian citizenship, by reasons

\begin{tabular}{|c|c|c|c|c|c|}
\hline \multirow{2}{*}{ Grounds for loss of citizenship } & \multicolumn{5}{|c|}{ Number of persons } \\
\hline & 2003 & 2004 & 2005 & 2006 & 2007 \\
\hline Withdrawal of Lithuanian citizenship & 235 & 315 & 207 & 216 & 280 \\
\hline Acquiring citizenship of another state & 372 & 386 & 265 & 485 & 610 \\
\hline $\begin{array}{l}\text { The person lawfully decided on Lithuanian citi- } \\
\text { zenship by } 4 \text { November } 1991 \text { in accordance } \\
\text { with the Law on Citizenship of } 3 \text { November } \\
1989 \text {, resides in a foreign state and has not, } \\
\text { before } 31 \text { December } 2003 \text {, approached institu- } \\
\text { tions authorised by the Minister of the Interior } \\
\text { or Lithuanian consular offices in foreign coun- } \\
\text { tries for issue of a document evidencing } \\
\text { Lithuanian citizenship }\end{array}$ & - & 96 & 283 & 197 & 123 \\
\hline Severance of actual ties with Lithuania & 1 & 1 & - & - & - \\
\hline $\begin{array}{l}\text { Children under fourteen, if both parents lose } \\
\text { citizenship }\end{array}$ & - & - & - & - & 2 \\
\hline Total & 608 & 798 & 755 & 898 & 1,015 \\
\hline
\end{tabular}

Source: Migration Department 2008: 58

The retention of the right to citizenship did not play a significant role between 2003 and 2007. However, the numbers increased in 2007. Most applicants are Russian and Byelorussian citizens.

Table 3.4 Retention of the right to Lithuanian citizenship

\begin{tabular}{llllll}
\hline & 2003 & 2004 & 2005 & 2006 & 2007 \\
\hline $\begin{array}{l}\text { Decisions on retention of the right of aliens to } \\
\text { citizenship }\end{array}$ & 145 & 90 & 20 & 47 & 163 \\
$\begin{array}{l}\text { Number of certificates issued for retention of the } \\
\text { right to citizenship }\end{array}$ & 99 & 67 & 35 & 49 & 201 \\
\hline
\end{tabular}

Source: Migration Department 2008: 61 


\subsection{Conclusions}

The Lithuanian approach to nationality issues has been considered as more liberal than the regulations in other Baltic states because it did not apply pre-1940 citizenship laws in order to reconstitute its body of nationals. The Citizenship Law of 1989 provided easy criteria for acquisition of nationality. As a result of these liberal laws, most of its residents acquired Lithuanian nationality. However, the Citizenship Law of I99I, enacted immediately after restoration of independence, introduced much stricter requirements for the acquisition of Lithuanian nationality. These are still in existence and in certain cases are more stringent than the regulations in other Baltic states, such as the conditions on residence before applying for citizenship.

One of the major areas currently debated is the regulation of dual nationality in Lithuania. Dual nationality became restricted ever since the adoption of the 1991 Citizenship Law and Constitution. Although it was extended over the years, Lithuania was still criticised for the exclusionary nature and unclear application of dual citizenship. The situation has become even more acute since the Constitutional Court of Lithuania delegitimised nearly 30 statutory and sub-statutory provisions and omissions in the nationality legislation on dual citizenship. The possible solutions remain unclear, but they will have to be found by January zоло when the now provisional Citizenship Law will become invalid.

Another problem of Lithuanian nationality policy is the wide discretion given to the president concerning the granting of nationality. Notwithstanding the amendments introduced after the decision of the Constitutional Court in the Paksas case, the judicial review of all decisions related to nationality would be a welcome development. This would also facilitate Lithuania's ratification of the European Convention on Nationality which has not yet been signed.

Chronological list of citizenship-related legislation in Lithuania

\begin{tabular}{|c|c|c|c|}
\hline Date & Document & Content & Source \\
\hline 1989 & $\begin{array}{l}\text { Supreme Soviet of the } \\
\text { Lithuanian Soviet Socialist } \\
\text { Republic Law on } \\
\text { Citizenship ( } 3 \text { November } \\
\text { 1989, No. XI-3329) }\end{array}$ & $\begin{array}{l}\text { Reconstitutes the body of } \\
\text { nationals by restoring } \\
\text { nationality to those who } \\
\text { were nationals before the } \\
1940 \text { occupation and their } \\
\text { descendants; provides for } \\
\text { liberal naturalisation of } \\
\text { residents }\end{array}$ & www.uta.edu \\
\hline 1991 & $\begin{array}{l}\text { Republic of Lithuania Law } \\
\text { on Citizenship }\end{array}$ & $\begin{array}{l}\text { Introduces stricter } \\
\text { naturalisation }\end{array}$ & www.uta.edu \\
\hline
\end{tabular}




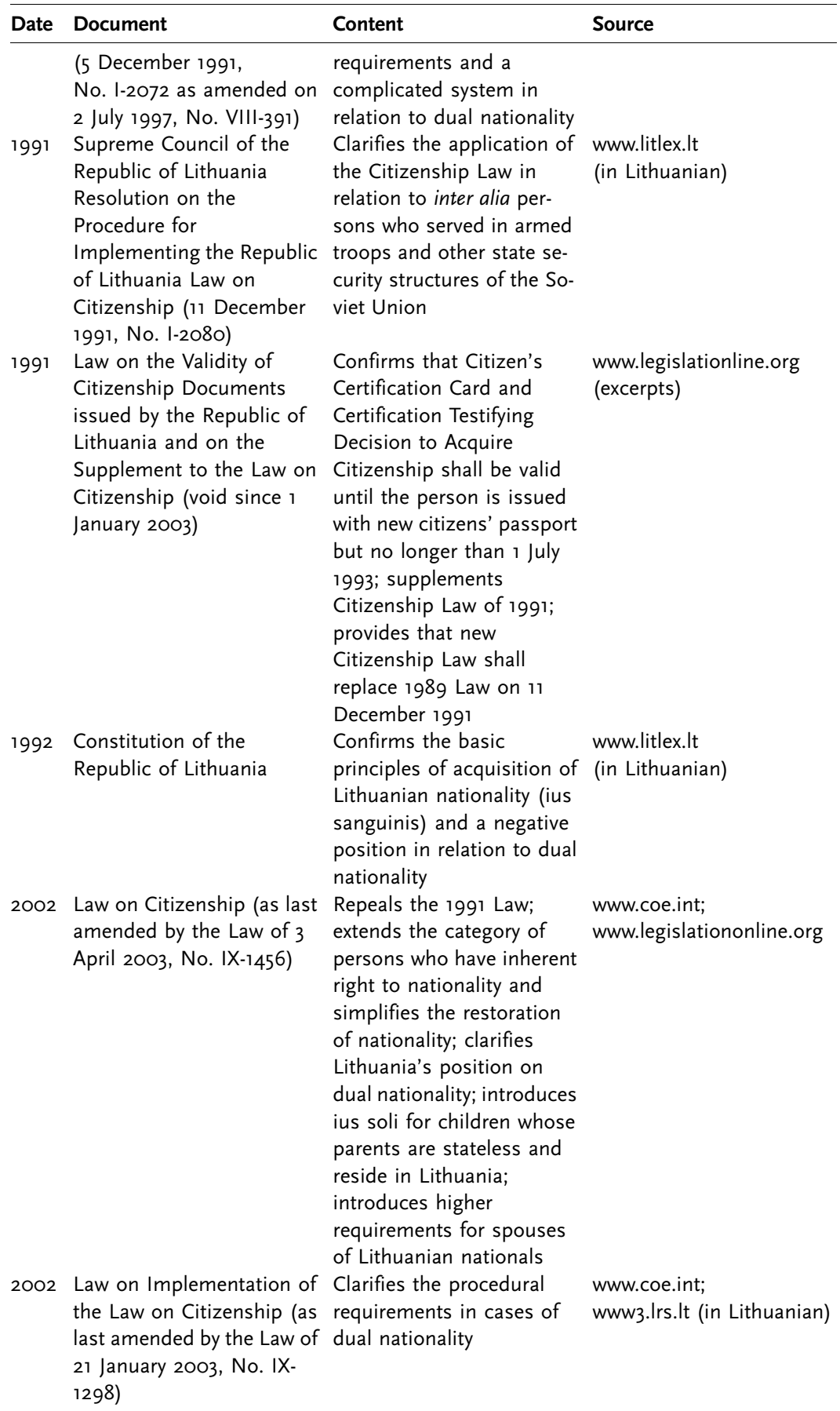




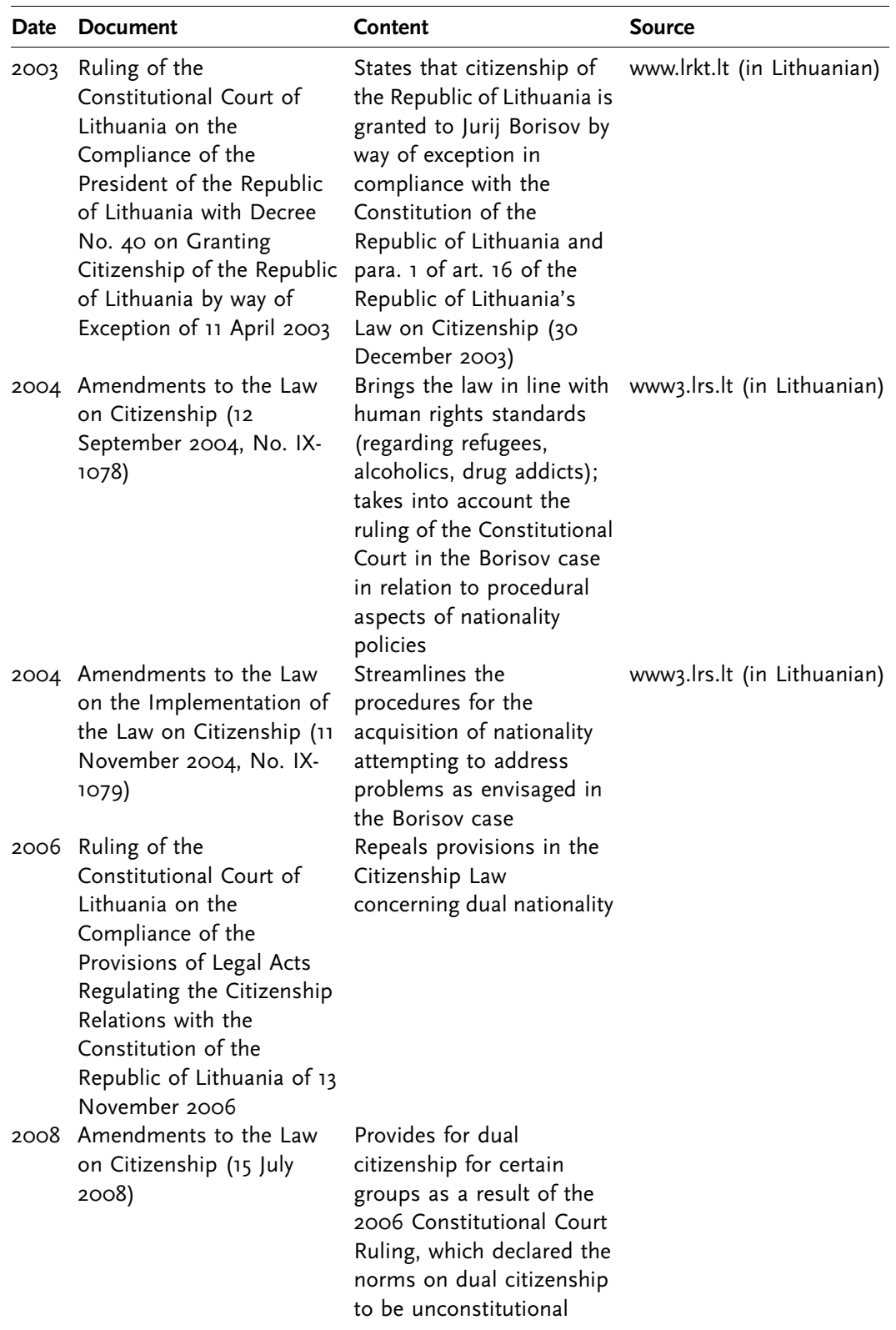




\section{Notes}

I I would like to thank Prof. Ineta Ziemele and Prof. Egidijus Kuris for their comments on the draft of this article. The usual disclaimer applies.

2 Permanent residence was determined by so-called propiska which is similar to a residence permit nowadays. It had to be obtained before individuals could move to another place. This was applicable not only in between republics but also within republics. Report on Lithuania, European Commission against Racism and Intolerance. Strasbourg, September I997, ECRI (97) 56 para. 6.

3 Case No. 7/94 of 13 April I994 (I994) I E.E.C.R.C.L.255. Available at www.lrkt.lt.

4 The texts used here are available at www.litlex.lt and www.minelres.lv.

5 This option was inserted with amendments of 3 October 1995.

6 This article was slightly amended on 6 February 1996. Prior to these amendments, the law provided that citizenship shall be retained by children who had Lithuanian citizenship until I5 June 1940 and who were born in Lithuania or in refugee camps but are at present residing in other states.

7 Constitutional Court case No. 45/03-36/04

8 Before amendments of 7 December 1993, this condition was also applicable to children of those who held Lithuanian citizenship until I5 June I940.

9 See chapter 2 on Latvia in this volume.

IO Certain provisions of amendments have been effective since I April 2006, but some since I January 2005 .

II For details on these debates, see the articles 'Lithuanian émigrés unhappy with citizenship loss', ELTA [National News Agency], 6 June 200I, 'New Law will entitle Lithuanian emigrants to keep citizenship', ELTA, I7 September 2002, and 'Adamkus signed controversial citizenship law', ELTA 30 September 2002.

I2 The proposed amendments were even stricter and debate was reopened after the President of Lithuania intervened with proposals to liberalise the procedure for naturalisation of spouses in Lithuania. The compromise reached was that the required term of residency would be increased from five to seven years, but not to ten years as foreseen in the draft law (86 in favour, five against, seven abstentions). The President also opposed the additional requirement that the couple should have minor children who are Lithuanian citizens. In his view, this would contradict the principle of equality contained in the Constitution. The proposals made by the President were harshly criticised by conservative members of parliament. They saw the proposals as a threat to the survival of the Lithuanian nation and national identity. Moreover, they were afraid that liberal citizenship procedures might stimulate marriages of convenience, often referring to Denmark to illustrate this point. See 'Seimas approves more liberal procedures for admission to citizenship via marriage', ELTA, 9 December 2004.

I3 Concerning this case, see also 'Lithuanian Practice in International Law 2004', as reported in the Baltic Yearbook of International Law 5, 2005: 329-332.

I4 In addition, on I April 2006 the authority on questions of citizenship, formerly attributed to municipal institutions, was transferred to the Department of Migration of the Ministry of the Interior.

I5 Constitutional Court case No. 45/03-36/04.

I6 On II February 2004, the Ministers of Education and Science and Justice confirmed the programme of exams on the basics of the Lithuanian Constitution and language. The procedure for the organisation and implementation of the exams was confirmed by both ministers on I March 2004 . 
I7 There are three disability groups of which group I is the most serious. The group is assigned by a special commission on the basis of a diagnosis. Assignments can be for a defined period or for life. Group I is as a rule assigned for life.

I8 Provisions at issue were closely monitored, at least, by Human Rights Watch, which on a number of occasions condemned their application and advocated their abolition. See the reports on human rights developments in Latvia, Lithuania and Estonia available at www.hrw.org.

I9 Before the 2002 Law was adopted, it was possible to lose one's citizenship on the basis of severance of actual links with Lithuania. A person who has lived abroad with an invalid passport for more than three years or who has entered foreign military or public service without the permission of the competent authorities was considered to have severed links with Lithuania.

20 However, it is not entirely clear because according to art. I, para. 3, persons of Lithuanian descent can acquire Lithuanian citizenship if they are not citizens of any other state. The only plausible explanation can be that according to art. I8 they do not lose their right to acquire Lithuanian citizenship because they possess the citizenship of another state.

2I Lithuanian Constitutional Court Ruling in Case No. 45/03-36/04, I3 November 2006.

22 'Lithuanian parliament collects signatures to initiate referendum on dual citizenship', $B N S$ [National News Agency], I5 September 2007.

23 Radzevičūte A., 'Lietuvā iespējams referendums par dubultpilsonību [The referendum on dual nationality in Lithuania is possible]', Diena [Latvian daily newspaper], 7 September 2007 .

24 The other six groups are: (i) political deportees and prisoners and three generations of their descendants; (ii) those who left Lithuania during the Soviet era as well as three generations of their descendants; (iii) persons of Lithuanian descent living in countries sharing a common border with Lithuania; (iv) persons already in possession of passports from two other countries, granted by special decree of the President; (v) offspring born to Lithuanian citizens anywhere in the world; (vi) Lithuanians living in any nation that has signed an international agreement with Lithuania on dual citizenship ('Dual citizenship now allowed in Lithuania', The Baltic Times, I July 2008, www.baltictimes.com).

25 'Seimas' Decision on multiple citizenship is unconstitutional and illogical', ELTA, 30 June 2008.

\section{Bibliography}

Kalvaitis, R. (1998), 'Citizenship and national identity in the Baltic States', Boston University International Law Journal I6: 23I-27I.

Migration Department (2008), Migration Yearbook 2007. Vilnius: Migration Department.

Ziemele, I. (1998), State Continuity and Nationality in the Baltic States: International and Constitutional Law Issues. PhD Dissertation. Wolfson College Cambridge.

Ziemele, I. (200I), 'State Continuity, Human Rights and Nationality in the Baltic States', in T. Jundzis (ed.), The Baltic States at Historical Crossroads, 224-248. Riga: Academy of Sciences of Latvia.

Ziemele, I. (2005), State Continuity and Nationality: The Baltic States and Russia. Past, Present and Future as Defined by International Law. Leiden, Boston: Martinus Nijhoff Publishers. 


\section{Part II}

States with histories of shifting borders 



\title{
4 Same letter, new spirit: Nationality regulations and their implementation in Poland
}

\author{
Agata Górny and Dorota Pudzianowska
}

The development of the legal notion of Polish citizenship has gone through twists and turns, shaped by the history of the country. Belonging to the Polish nation has not always meant belonging to the Polish state. Radical reconfigurations of Poland's borders in the last century explain this conceptual inconsistency as much as substantial political and economic emigration from Poland does. Moreover, the Polish People's Republic promoted the communist idea of a single socialist community comprised of inhabitants of Soviet Bloc countries. Thus, geopolitics defined a concept of the nation that was far removed from how many Polish people construed their own identity.

In the Polish case, it is, therefore, justified to differentiate between the distinct concepts of ethnicity and nationality/citizenship. The latter concept refers to the affiliation to the state and thus denotes the legal bond between a citizen and the state. Ethnicity constitutes more of a subjective feeling of belonging to an ethnic group or to a given nation, along with concurrent objective criteria relating to a person's ancestry. ${ }^{\mathrm{I}}$ Such a distinction is necessary in an examination of Polish nationality regulations and practice. In our opinion, ethnicity was very important in the formulation of the law on nationality in the Polish People's Republic and still plays a role in current Polish legislation.

The goal of this chapter is to demonstrate evolutions in the field of Polish nationality, particularly focusing on its acquisition and loss. We present changes not only in written law, but also in administrative practice regarding Polish nationality. This is necessary because of the high level of discretion that the Polish public authorities have in this field. Analyses of regulations are further enriched with selected statistics on the acquisition of Polish nationality in order to better represent the nature of the phenomenon in Poland.

Apart from analysing legal acts and statistics, we also devote some space to recently proposed bills on Polish nationality in order to indicate the direction in which the approach towards Polish nationality has been evolving since the I990s. We argue that contemporary Polish nationality policy (if we can talk about one) still puts the emphasis on emigrants and the diaspora rather than on immigrants. Our argument is supported by the debate and the work on new legislation relating to 
matters of Polish nationality in the Polish Parliament during I999200I. The focus on the diaspora is also evident when we consider the two most recent acts adopted in the field related to nationality, namely the Repatriation Act $(2000)^{2}$ and the Act on the Polish Ethnicity Card $(2007)^{3}$ (Ustawa o Karcie Polaka).

The chapter opens with a historical overview of developments in nationality legislation from the post-war era to the present. It then discusses basic rules governing the acquisition and loss of Polish nationality in contemporary Poland. The third section analyses debates regarding new regulations and their underlying orientations as well as trends in Polish nationality policy. Finally, selected statistics on the acquisition of Polish nationality are provided and discussed.

\subsection{Polish nationality in historical perspective}

\subsubsection{Introductory remarks}

There have been three acts on Polish nationality - enacted in 1920, ${ }^{4}$ $195 \mathrm{I}^{5}$ and $1962^{6}$ - that share important elements. First of all, the acquisition of Polish nationality by birth has always been driven by the principle of descent (ius sanguinis), with the territorial principle (ius soli) merely playing an auxiliary role. Secondly, due to radical changes in Poland's international borders and long periods of emigration from Poland, establishing whether a given individual holds Polish nationality has always been crucial to Polish legislation on this matter. Finally, rules concerning foreigners' naturalisation in Poland have been of secondary importance in the debates and legislation on Polish nationality, despite considerable growth in immigration to Poland since the early iggos.

\subsubsection{Post-war arrangements (1945-1962)}

The end of the Second World War and agreements signed between Stalin and other allied leaders radically altered Polish territory. This involved two major changes - loss of (formerly) eastern Polish lands inhabited by Polish citizens and the acquisition of eastern German lands populated largely by German citizens (the 'Regained Territories'). The loss of the eastern Polish territories brought with it the problem of repatriating Polish citizens from the new Soviet territory. This act was based on several Polish-Soviet mutual repatriation agreements signed in the I940s and in I957. On the basis of these agreements, people of Polish and Jewish ethnicity, who had been Polish citizens as of I7 September I939, were entitled to move and resettle within Poland's new borders (Łodziński I998). All repatriates were treated as Polish citi- 
zens, and automatically lost their foreign nationality upon repatriation in Poland. The repatriation agreements signed with the Soviet Union also concerned the resettlement of Polish citizens of non-Polish (Ukrainian, Belarusian, Russian, etc.) ethnicity to the USSR. Thus, in both repatriation actions ethnicity constituted a decisive criterion.

Nevertheless, the biggest national group expatriated from Poland in the post-war period, on the basis of the Potsdam agreements, were Germans. They were officially excluded by the Act on the Exclusion of Persons of German Ethnicity from Polish Society (1946). ${ }^{7}$ This applied to Germans not verified as Polish nationals or those manifesting their German origins. ${ }^{8}$ Ethnic Poles, even those who had been German citizens before the Second World War, were entitled to stay in Poland. Special public bodies were established and appropriate legal rules introduced to verify the Polish ethnicity of those who wished to stay in Poland. ${ }^{9}$ Two pivotal legal acts announced at that time were the Act on Polish Nationality of Persons of Polish Ethnicity Inhabiting the Regained Territories (1946) ${ }^{\mathrm{IO}}$ and a similar decree for inhabitants of the former Free City of Gdańsk (Danzig) (I947). ${ }^{\text {II }}$ These acts directly linked a person's nationality to his or her ethnicity.

Verification of ethnicity and objective ethnicity criteria were also included in the 195I Act on Polish Nationality. The Act obliged the inhabitants of the Regained Territories and the former Free City of Gdańsk to obtain adequate documents certifying their Polish ethnicity. It also gave the right to Polish nationality to all Polish repatriates. Again, Polish citizenship was based primarily on ethnic criteria. This link was also reflected in two subsequent legal acts concerning the permission for the renunciation of Polish nationality for people of German $(1956)^{12}$ and Jewish (1958) ${ }^{\mathrm{I3}}$ ethnicities who left for their ethnic homelands (Albiniak \& Czajkowska I996: 324-325). Such acts were designed to simplify the renunciation of Polish nationality. Behind these acts, however, lay the idea of expelling those with non-Polish ethnicity from the country. The fact that this pressure was directed towards selected ethnic groups is symptomatic of this trend.

\subsubsection{Stabilisation (1962-1989)}

Another Act on Polish Nationality was passed in 1962. This Act remained in effect, without any major amendments, until the end of the communist era in Poland. It did not challenge the rules of acquisition and loss of Polish nationality included in the 1951 Act. The 1962 Act did not directly address the issue of Polish ethnicity, although it still accorded special rights to repatriates returning to Poland. ${ }^{\mathrm{I}}$

The link between the ethnicity of a person and his or her right to Polish nationality was made an issue in the late Ig6os. Polish authori- 
ties officially challenged the loyalty of Polish citizens of Jewish origin. These people, who were perceived as having 'dual loyalties' and had often been active in some way in political life, were forced to leave Poland after signing a document expressing their intention to renounce their Polish nationality upon acquisition of Israeli nationality (Stola 2000). The legal basis for this 'action of mass renunciation of Polish nationality' was the aforementioned Decree of 1958. It is not within the scope of this analysis to present the comprehensive political background behind this move asking Jews to repudiate their Polish nationality. ${ }^{15}$ This episode demonstrates, however, how the concept of Polish ethnicity and its tight connection with the right to Polish nationality was exploited in Poland under the communist regime.

Furthermore, the communist authorities often required Polish emigrants to relinquish their Polish nationality whenever they came to visit Poland. If they refused to do so, they risked being imprisoned in Poland for illegally overstaying abroad. Here 'a need to renounce' Polish nationality was justified not in terms of the ethnicity criterion, but in terms of a lack of loyalty towards the Polish People's Republic and its ideology.

In general, the analysis of legal acts on Polish nationality, alone, does not allow for a thorough understanding of the issues of nationality in communist Poland. This is due to the authorities' high level of discretionary powers regarding Polish nationality at that time, which was particularly evident in how ethnicity was used in administrative decisions. Although absent from the 1962 Act on Polish Nationality, ethnicity was a factor in decisions regarding Polish nationality and played a particular role in relation to German and Jewish minorities. Special decrees designed for these two groups in 1956 and 1958 were in force until I984 (Albiniak \& Czajkowska I996: 326).

\subsubsection{Political and economic transition (the post-1989 era)}

The end of the Polish People's Republic and the establishment of the Third Republic of Poland necessitated deep economic and political reforms in the country. Likewise, policymakers claimed as early as 1989 that there was need for a new nationality law. However, the 1962 Act on Polish Nationality, with some amendments in the late I990s and at

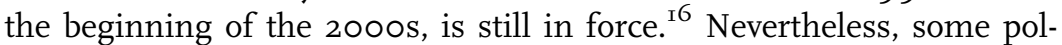
icy changes regarding Polish nationality have been introduced. These changes in policy take advantage of the way provisions of the 1962 Act on Polish Nationality were formulated. Therefore, an approach based on a high level of discretion of public officials in conferring Polish nationality has been continued in the Third Republic of Poland. 
The most significant amendments to the 1962 Act were introduced in I997-I998. Rules regarding the loss of Polish nationality were changed since one of the clauses of the Act - namely that 'acquisition of a foreign nationality results in the loss of Polish nationality' - violated the 1997 Polish Constitution ${ }^{\text {I7 }}$ (Jagielski 2000). An amendment was passed to make it impossible to deprive anybody of Polish nationality unless he or she expressed the desire to renounce it. A definition of the type of stay (permanent residence permit) was added to the fiveyear residence requirement for naturalisation. Although the exact period of total legal residence in Poland varies for different groups of foreigners, in practice, this change amounts to at least ten years of residency before a foreigner can apply for naturalisation, because it takes at least five years to obtain a permanent residence permit. Changes were also introduced to the procedure of acquiring nationality by marriage. Whereas this path to Polish nationality was previously open only to foreign women married to Poles, foreign men can now also acquire Polish nationality by marrying a Polish woman. In 200I, provisions concerning repatriation were removed from the Act on Polish Nationality. A separate legal act known as the Repatriation Act that dealt with this issue was implemented in 2000.

The Ordinance of the President of the Republic of Poland put into force in $2000^{18}$ was a step towards reducing discretion in decisions regarding the acquisition and loss of Polish nationality, although it did not change the procedures significantly. However, while these procedures previously had no legally binding basis, the 2000 Ordinance lists all of the documents and forms required by the Presidential Chancellery to process appropriate applications. The President initiated another significant change to Polish nationality policy. In I999, he expressed his will (in the form of a legal act) to terminate all of the remaining conventions with other former communist countries concerning prevention of dual nationality. ${ }^{\text {I9 }}$ These conventions had affected foreigners' naturalisation processes by creating inequality among applicants for Polish nationality. Most former Soviet Bloc citizens were not allowed to retain their previous nationalities upon naturalisation in Poland, whereas other foreigners were subject to the discretionary decision by the Polish President. Since 2002, as a consequence of the President's initiative, Poland has ceased to be a party to those conventions. $^{20}$ 


\subsection{Basic principles of current regulations on Polish nationality}

\subsubsection{Principles concerning Polish nationality}

The legal regulations concerning Polish nationality can be found in the amended ig62 Act on Polish Nationality as well as in the Repatriation Act of 2000. The I997 Polish Constitution formulated two principles concerning nationality (art. 34). One states that the basic mode of acquisition of Polish nationality is by birth to parents who are Polish citizens (the ius sanguinis principle). ${ }^{2 \mathrm{I}}$ The other principle stipulates an absolute guarantee that no one can be deprived arbitrarily of his or her Polish nationality.

Other principles are stated in the Act on Polish Nationality itself. The principle of the continuity of Polish nationality (art. I) translates the idea of the persistence of Polish nationality in time (from the moment of its acquisition until the moment of its loss) into law. Under this principle, the nationality status acquired under a given statute survives all subsequent changes in the statute, i.e. it is always considered under the law in force at the moment of acquisition. The principle of exclusivity of Polish nationality (art. 2) means that a person with dual or multiple nationality is treated (domestically but also abroad) as a Polish national by the Polish public authorities; it cannot be interpreted as forbidding dual nationality. The principle of equal citizenship rights for both husband and wife (art. 3) means that a conclusion of marriage by a Polish national with a person who is not a Polish national does not produce an automatic change in nationality for either husband or wife and a change of nationality of one spouse does not induce the change of nationality of the other. ${ }^{22}$

\subsubsection{Acquisition of Polish nationality}

Polish law provides for several modes of acquiring Polish nationality, which can be divided into three basic groups according to their legal form. The first group comprises modes of acquiring nationality ex lege (acquisition at birth and acquisition through the repatriation procedure). The second group comprises modes of acquisition through application (acquisition by conferment and acknowledgement). The third group unites modes of acquisition through declaration (by marriage, option and reacquisition).

Acquisition of nationality at birth is mainly based on the ius sanguinis principle. A child acquires Polish nationality irrespective of the place of birth when at least one parent is a Polish national (art. 4.2 and art. 6). If the child has only one parent who is a Polish national and acquires another nationality at birth, the parents can renounce the child's Polish nationality within three months after birth. Children born in Po- 
land to foreign parents do not acquire Polish nationality unless they would otherwise be stateless. This means that ius soli is treated as an auxiliary principle to determine the nationality of a child found or born in the Polish territory if the child's parents are unknown, stateless or their nationality cannot be established (art. 5). All changes in the determination of a parent of a child or with regard to the nationality of one or both parents will be considered in determining the nationality of a child only if they occur within one year from the birth of the child (art. 7.I) Hence, acquisition of nationality by legitimisation, for instance, is possible until the child's first birthday. Afterwards, legitimisation would have no effect on the child's nationality.

Automatic acquisition of nationality is also possible through repatriation. This is the only mode of acquiring Polish nationality not defined in the Act on Polish Nationality but in a separate statute, namely the Repatriation Act of 2000. According to this act, those holding a repatriation visa automatically acquire Polish nationality on the day they cross the Polish border (art. 4). Repatriation visas are granted to those of Polish descent, which is further defined to include those who once had Polish nationality or who have at least one parent or grandparent or two great-grandparents who were ethnic Poles or held Polish nationality. Other conditions include a declaration by the person concerned that he or she is of Polish ethnicity and proof of attachment to Polish culture by nurturing Polish language, traditions and customs (art. 5). Thus, this law uses both an ethnic criterion (Polish descent) and a cultural criterion to determine a person's belonging to the Polish nation. ${ }^{23}$

A foreigner may be granted Polish nationality by conferment (regular naturalisation) if he or she has resided in Poland for at least five years on the basis of one of three types of permanent residence permit (art. 8). ${ }^{24}$ Since such a permit may only be acquired after at least five years of legal residence, ${ }^{25}$ it follows that the period after which a person is eligible for naturalisation is at least ten years. Applications are submitted via voivods (provincial governors) or consuls (for those living abroad) and these public authorities as well as the Minister of Internal Affairs (prior to 2007 the Head of the Foreigners' Office) normally give their opinion on the application. Apart from information on the required period of residence, applications have to include information on the parents' nationality, sources of income, past employment, knowledge of the Polish language and services rendered to Poland (or Polish diaspora organisations, etc.). ${ }^{26}$ The power to grant nationality is a constitutional prerogative of the President of the Republic of Poland. The decision of the President is entirely discretionary since the criteria are unclear, especially with regard to the assessment of the additional information. ${ }^{27}$ The President also does not have to grant nationality even if all of the conditions have been fulfilled. The President's decision 
may even be called arbitrary in the sense that the decisions do not have to be justified and there is no judicial review available, ${ }^{28}$ which may be considered contrary to the provisions of art. II and art. I2 of the European Convention on Nationality (ECN) of I997. ${ }^{29}$ In 'particularly justified cases' the President can disregard the residence requirement (art. 8.2), but this only applies to achievement-based acquisition of nationality. The conferment may be conditional upon providing proof of loss of the former nationality through withdrawal or renunciation (art. 8.3). From all of these provisions it is evident that the conferment procedure cannot be regarded as a legal entitlement and is instead based on the exercise of sovereign power by the head of state.

A stateless person or a person whose nationality cannot be established can be acknowledged as a Polish citizen if he or she has resided in Poland for at least five years on the basis of one of three types of permanent residence permit (art. 9; also see note 24). As with the naturalisation of foreign nationals, this is a discretionary procedure. However, in contrast to the regular naturalisation procedure, in this case the decisions are not made by the President but by voivods and constitute administrative case decisions that have to be justified. In these cases, administrative and judicial reviews are available.

Under Polish law (art. 8.4-8.7) Polish nationality acquired by parents through conferment can be extended to their minor children. When both parents acquire Polish nationality by conferment, it is automatically extended to children under sixteen years of age, whereas the child's consent is necessary if the child is sixteen or older. If only one parent acquires nationality, it may be extended to a child if other conditions are fulfilled - either the child is under this parent's exclusive parental authority or the other parent is a Polish citizen or the other parent gives his or her consent for the child's acquisition of nationality in front of a relevant public authority. The same rules apply to the filial extension of acquisition of Polish nationality through the acknowledgement procedure, provided that these children reside in Poland (art. 9.4).

Finally, there are three modes of acquiring nationality by declaration. The first is spousal acquisition of nationality (art. Io). The spouse of a Polish national acquires Polish nationality upon making a declaration (which has to be accepted by the relevant public authority, i.e. voivods or consuls) when he or she has lived in Poland on the basis of a permanent residence permit and has been married to the Polish national for at least three years. Compared to regular naturalisation, the minimum period of stay required is thus shortened by half (five instead of ten years). The voivod or consul can exercise full discretion whether to make the acceptance of the declaration conditional upon the proof of loss of the former nationality. 
Another mode of acquiring nationality by declaration is acquisition of nationality by option (art. 6.3). This mode addresses those who (having one parent who is a Polish national) lost their Polish nationality in childhood by parental declaration (loss of nationality by option). They can reacquire this nationality in the period between the time they turn sixteen and six months after coming of age upon making a declaration in front of the relevant public authorities, i.e. voivods or consuls.

The third and last mode of acquiring nationality by declaration is reacquisition of nationality (art. II), also called reintegration. A Polish citizen who lost Polish nationality by marrying a foreign citizen can regain his or her nationality if the aforementioned marriage ceases to exist. In these cases a declaration made in front of the relevant public authorities, i.e. voivods or consuls, must also be accepted. As in the case of acquisition of nationality by marriage, the public authorities can make the acceptance of the declaration dependent upon the proof of loss of the former nationality.

\subsubsection{Loss of Polish nationality}

As we have already mentioned, Polish nationality cannot be withdrawn against the will of the person concerned. A Polish citizen can lose his or her nationality if he or she renounces it; the loss is conditional upon the consent of the President of Poland (art. I3). The decision concerning the issuing of this consent is the President's constitutional prerogative and is thus not subject to administrative or judicial review. A permit to renounce one's Polish nationality issued by the President extends to children who are under parental authority if both parents stand to lose their nationality. It is automatic unless the children are sixteen years of age or older (in which case their agreement is necessary). A permit given to only one parent extends to children under parental authority if the second parent has no parental authority, if he or she is not a Polish citizen or if he or she is a Polish citizen but consents to the child losing the Polish nationality in front of relevant public authorities.

Polish nationality may also be lost shortly after birth due to parental decision (loss by option). For a child who has acquired Polish nationality at birth, parents may choose the nationality of a foreign country of which one of the parents is a national. This must be done within three months of the child's birth (art. 6.I), regardless of whether the child is born in Poland or abroad. However, as already explained, a child can reacquire his or her Polish nationality lost in this way (acquiring Polish nationality by option, art. 6.3). The optional renunciation of Polish nationality acquired by ius sanguinis, however, does not apply if, for ex- 
ample, both parents are Polish nationals abroad and the child has acquired the nationality of his or her country of birth through ius soli.

During the communist period, the rules governing the loss of Polish nationality were quite different. Many emigrants lost their nationality contrary to their wills and would now like to have their Polish nationality restored. Unfortunately, there is no procedure to this end. Some emigrants use the procedure in front of the voivod, who is authorised to establish whether a given individual has acquired and currently holds Polish citizenship, has forfeited it or has never held it. Through an administrative decision, this authority can certify that someone holds Polish nationality following proceedings that take into account the principle of continuity of Polish nationality.

\subsubsection{Dual nationality}

Dual and multiple nationality is allowed under Polish law. There are, however, certain nuances concerning the possibility of acquiring this status. Dual nationals by birth are never required to choose one nationality over the other (neither upon reaching the age of majority nor at any other time). Naturalisation procedures, by contrast, distinguish between, on the one hand, individuals seeking to become naturalised Polish citizens and, on the other hand, Polish citizens seeking to naturalise in another state. The law in force favours the latter and Polish citizens can freely obtain other nationalities while retaining their Polish citizenship. Foreigners seeking to access Polish citizenship, however, may be required - at the discretion of relevant public authorities - to relinquish other nationality ties. One is thus tempted to use Sanford Levinson's formulation to say that Polish law 'tolerates political bigamy so long as the second political marriage follows, rather than precedes, acquiring [Polish] citizenship' (cited in Schuck 2002: 72).

Although nowadays multiple nationality as a legal status is tolerated in Poland, this has not always been the case in the past. A ban on dual nationality was a guiding principle of the 1920 and I95I Acts on Polish Nationality. This historical fact, as well as the wording of art. 2 of the I962 Act on Polish Nationality, seems responsible for some confusion. The article states that 'according to the law, a Polish national cannot be recognised as a national of another country'. The Highest Administrative Court interpreted this provision as a prohibition of dual or multiple nationality in one of its judgments. ${ }^{30}$ Such an interpretation seems, however, inconsistent with the wording of the very article as it uses the term 'recognised' (uznawany). This is obviously not the same as stating a prohibition of having multiple nationalities, and the 1962 Act refrains from restating an explicit prohibition of multiple citizenship in earlier regulations. Therefore, the view that Polish law generally prohi- 
bits dual nationality does not prevail and is - correctly - not shared by most legal scholars (Jagielski I998; Ramus I968; Mincer-Jaśkowska I998). Art. 2 should be interpreted as a rule resolving a very particular problem, which arises in domestic law when a Polish national holds several nationalities. Accordingly, a dual or multiple national will always be treated as a Polish national by Polish public authorities inside the Polish territory as well as abroad. A multiple citizenship holder cannot claim rights that stem from an additional nationality status or avoid obligations stemming from Polish nationality or ask to be treated as a foreigner (Ramus I968). In other words, foreign citizenship ties are considered irrelevant in front of Polish public authorities and he or she is treated as if he or she was Polish only. This reading of art. 2 also coincides with the specific rules governing acquisition of Polish nationality as thus far described.

\subsubsection{Act on the Polish Ethnicity Card}

As with other countries in the Central and Eastern European region, Poland has recently passed a law giving certain benefits to members of its kin minorities living abroad. The Act on the Polish Ethnicity Card ${ }^{3 \mathrm{I}}$ was passed in September 2007. The first bill of this law was discussed in parliament almost ten years earlier. The scope of the card is restricted to ethnic Poles who are not Polish nationals, but are nationals of one of the fifteen successor states of Soviet Union republics (art. 2.2). The Polish Ethnicity Card confirms a person's belonging to the Polish nation and the right to benefits provided for by the Act (art. 3). It may be issued to a person who declares himself or herself to be a member of the Polish nation and who fulfils the conditions specified in the statute. These conditions are of mixed ethnic and cultural character and it should be noted that the ethnic criterion (descent) is not obligatory. Instead of proving Polish descent a certificate issued by one of the non-governmental organisations operating in these countries (specified in the Prime Minister's decree, obwieszczenie) may be presented, confirming active engagement in activities concerning Polish language and culture or other involvement in Polish national minority communities for at least three years prior to the application. In any event, it is necessary to prove attachment to 'Polishness' through having at least basic knowledge of the Polish language, which must be considered by the applicant to be his or her native language, as well as knowledge and practice of Polish traditions and customs (art. 2.I).

The law provides for different benefits, which include easier access to the labour market (holders of the card do not need a work permit and they can undertake economic activity in Poland on the same basis as Polish nationals), and some educational, cultural and health bene- 
fits. In order to enter Polish territory, the holder of a Polish ethnicity card still has to apply for a visa, but may be exempted from the fee for a national visa (or this fee may be refunded) (arts. 5-8). The actual meaning of these benefits is different depending on whether a holder of the card is a citizen of a European Union country (in this case Latvia, Lithuania, Estonia) or not. Third country nationals holding the Polish ethnicity card enjoy free access to the labour market, free immediate medical assistance and access to education at tertiary level, free entry to state-run museums and 37 per cent travel reduction for train transport. For EU citizens, only the last two benefits are of any significance (Jagielski \& Pudzianowska 2008).

The Act on the Polish Ethnicity Card was not easy to draft. It took over ten years of discussions as there was a range of controversies regarding the shape of the successive bills (see Jagielski \& Pudzianowska 2008). Many commentators claimed that it was discriminatory, and that it was dangerous to create a privileged group of people having special rights in Poland who are residents of foreign countries. This argument was not specific to Poland and was present in all countries that adopted a kin minority legislation (see Kovács \& Tóth, Kusá, Medved and Smilov \& Jileva in this volume). Moreover, a number of practical arguments against the card were discussed during the parliamentary debates (see Górny, Grzymała-Kazłowska, Koryś \& Weinar 2003). These concerned high costs, the danger of abuse of the card by economic migrants, etc. Even though domestic controversies were extensive, it can be argued that the Polish Ethnicity Card did not produce many reactions on the international arena (unlike, for example, the Hungarian Status Law of 200I). The Belarusian government's negative reaction is the exception to the rule that can be easily explained. On the one hand, apart from Ukrainians, Belarusian citizens are expected to be the main recipients of the Polish ethnicity cards. On the other hand, the negative reaction of Belarus is in line with the more general Belarusian policy towards the Polish minority in Belarus, marked as it is by a variety of more or less openly demonstrated conflicts and repressions from the Belarusian authorities. Interestingly enough, preparations for a Belarusian Ethnicity Card have recently been announced.

\subsection{The unresolved debate (1999-2001)}

Changes in the Polish nationality law have been planned since i989, but only selected goals have been achieved to date. The most important act - the Act on Polish Nationality - remains unchanged, although several bills on Polish nationality have already been proposed and discussed in the Polish Parliament. Work on nationality legislation was 
particularly intensive during the third parliamentary term (I997-200I), when post-Solidarity parties held a majority in the Polish Parliament. In the fourth parliamentary term (200I-2005), when post-communist parties held the majority, work on nationality legislation was postponed (see Górny, Grzymała-Kazłowska, Koryśs \& Weinar 2003) only to reappear on the agenda during the fifth and sixth legislative terms under a majority of post-Solidarity parties (2005-2007 and 2007-present). Nevertheless, works on the Act on Polish Nationality did not enter the phase of parliamentary readings and discussions.

Apart from the ideological rationale for introducing new legislation on nationality with democratic transition in all CEE countries, new social currents require new solutions for the law on Polish nationality. For example, it is necessary to establish clear rules concerning reinstatement of Polish nationality for people who were deprived of it in various 'historical contexts'. Moreover, issues relating to the repatriation of people of Polish descent from the territory of the ex-USSR again became prominent in the I990s. Last but not least, increasing immigration to Poland requires that rules on naturalisation be reevaluated and made less discretionary.

The repatriation problem was solved legislatively with the introduction of the Repatriation Act in 2000. Seven years later, the Act on the Polish Ethnicity Card introduced some privileges for members of Polish kin minorities. The enactment of this latter statute can also be regarded as a partial solution to the problem of the reinstatement of Polish nationality, as part of the diaspora considers it as a symbolic confirmation of their belonging to the Polish nation. However, a new Act on Polish nationality is still missing. Its preparation started in the late I990s and three bills on Polish nationality have been proposed. The most recent one, which was submitted by a working group comprising representatives of various parties in 2000 , combined the two earlier proposals. Certain issues included in the latest bill demonstrate the political background and aims behind the formulation of a new Act on Polish Nationality and are worth noting.

In the bill - as in all acts on Polish nationality - the basic principle for being recognised as a Polish citizen was the ius sanguinis principle. This newest bill foresaw special procedures for people who intended to reacquire their Polish nationality. In fact, as stated in the introduction to the bill, the problem of 'reinstating Polish nationality to all those who have the right to it' was considered very important by the bill's authors. The proposed reinstatement procedure would have applied to those who had lost Polish nationality on the basis of previous Acts on Polish Nationality (1920, I95I, I962) and whose relinquishing of Polish nationality had not been 'fully voluntary'. ${ }^{32}$ Applicants' entitlement to this procedure would not have been conditional on living perma- 
nently in Poland. The bill also proposed a procedure for granting nationality to a particular group of people of Polish origin: Polish veterans of the Second World War. As far as the naturalisation procedure is concerned, the Bill on Polish Nationality added to the requirement regarding length of stay contained in the I962 Act, criteria referring to the applicants' level of social, economic and cultural integration into Polish society. They included adequate knowledge of the Polish language, evidence of the applicants' ability to sustain themselves in Poland and absence of a criminal record and of behaviour that does not violate loyalty towards the Polish state. These criteria were intended to set more precise and thereby less discretionary criteria for naturalisation in Poland.

The focus of discussions and political and legislative action regarding Polish nationality and related matters has been undoubtedly on the Polish diaspora and Polish emigrants, with immigration and naturalisation being of secondary importance. The parliamentary debates in I999-200I on such proposals were fairly uncontroversial (Górny, Grzymała-Kazłowska, Koryś \& Weinar 2003) and can thus be considered indicative of a consensual approach to nationality matters observed in the contemporary Polish political scene. The reasons for the lack of consensus on the bill, which led to its withdrawal from the parliamentary agenda, are not clear. It seems, however, that the issue dividing the Polish Parliament was the problem of explicit acceptance of dual nationality (Górny, Grzymała-Kazłowska, Koryś \& Weinar 2007), which was more a problem of a symbolic nature, rather than a legal one.

\subsection{Acquisitions of Polish nationality in figures}

\subsubsection{Comment on data}

Data on acquisitions of Polish nationality have just recently been integrated into the main statistical system and database on foreigners. For the years I992-200I we will therefore focus on acquisitions through only one procedure, namely the conferment of Polish nationality, for which nationwide data are available for the I990s. To make our description for that period more precise and informative, we have enriched it with fragmented data regarding other procedures. These data include information on foreigners who were naturalised through acknowledgement and marriage procedures in $1997^{33}$ and results of research carried out in the Warsaw voivodeship in I999, when data on applicants for Polish nationality in I989-1998 based on the three most important procedures - acquisition through conferment, acknowledgement and marriage - were collected. ${ }^{34}$ When describing later years (2002-2006) we refer to acquisitions of Polish nationality through all 
three procedures: conferment, acknowledgement and spousal acquisition. Finally, we also provide data on repatriation to Poland for the period i997-2006.

\subsubsection{Naturalisations: Conferment and two other procedures}

In I992-200I, two consecutive Polish presidents granted Polish nationality to 8,979 people under the conferment procedure. In this period, the biggest national group of newly admitted Polish citizens were Germans (I6 per cent). Other important groups were Israelis ( 8 per cent), Canadians ( 8 per cent), Bulgarians (5 per cent) and Americans (4 per cent) (see Table 4.I). However, as much as 20 percent of the applicants originated from the former Soviet Union.

Table 4.1 Foreigners granted Polish nationality by conferment in 1992-2001 and by conferment, acknowledgement and spousal acquisition in 2002-2006, by (former) nationality

\begin{tabular}{|c|c|c|c|c|}
\hline \multirow[t]{2}{*}{ Nationality } & \multicolumn{2}{|c|}{$\begin{array}{l}\text { Acquisitions by conferment } \\
\text { procedure in 1992-2001 }\end{array}$} & \multicolumn{2}{|c|}{ All ${ }^{b}$ acquisitions in 2002-2006 } \\
\hline & Number of persons & $\%$ & Number of persons & $\%$ \\
\hline German & 1,416 & 16 & 328 & 4 \\
\hline Israeli & 726 & 8 & 469 & 5 \\
\hline Canadian & 676 & 8 & 184 & 2 \\
\hline Bulgarian & 490 & 5 & 165 & 2 \\
\hline American & 381 & 4 & 149 & 2 \\
\hline $\begin{array}{l}\text { The former Soviet Union, } \\
\text { including the Baltic states }\end{array}$ & 1,778 & 20 & 4,392 & 51 \\
\hline Other & 3,512 & 39 & 2,925 & 34 \\
\hline Total & 8,979 & 100 & 8,612 & 100 \\
\hline
\end{tabular}

a We include the general category ex-USSR, since for as many as 804 persons the statistics do not indicate from which former Soviet Union republic they originate.

${ }^{b}$ Does not include acquisitions by repatriation, which are demonstrated in Table 4.2. Sources: Kępińska 2007; data provided by the Polish President's Chancellery

In the I990s, most applicants for Polish nationality originated from countries constituting traditional areas of destination for Polish emigrants: Germany, the US, Canada and various countries in Western Europe (e.g. France). The intensive Polish-Bulgarian student exchanges during the communist era resulted in many Polish-Bulgarian marriages and complicated nationality matters for their families. It is evident that the conferment procedure has been used by successive Presidents to restore Polish nationality to Polish emigrants who had lost it. This also explains the high number of Israelis 'naturalising' in Poland. 
The number of ex-USSR citizens naturalising via the conferment procedure in Poland in the I990s and 2000s is also quite high. It does not fully reflect, however, the predominance of ex-Soviet citizens in contemporary migration to Poland, since they were particularly likely to use the acknowledgement procedure in the I990s. This was due to the requirement to relinquish their original nationality in accordance with bilateral conventions on the prevention of dual nationality, which were still in effect between Poland and countries of the former Soviet Bloc in the I990s. As these persons were generally stateless, they qualified for the acknowledgement procedure. In I989-I998, in the Warsaw voivodeship, 76 per cent of ex-USSR citizens (stateless persons at the moment of applying) used the acknowledgement procedure and citizens of this region constituted 94 per cent of all those applying for naturalisation under this procedure.

The importance of applicants for Polish nationality originating from the ex-USSR is more visible in the data on acquisitions for 2002-2006, where all three procedures are included. Newly naturalised Polish citizens from this area constitute as much as $5^{\mathrm{I}}$ per cent of the total, with the Ukrainians being the leading group (27 per cent of the total number of acquisitions and 54 per cent of the acquisitions by nationals of the former Soviet Union). Immigrants from the former Soviet Union have constituted the main segment of the 'new wave' of immigration to Poland, which began in the late rg8os, and these migrants began qualifying for naturalisation in the second half of the I990s. The subsequent termination of bilateral conventions on the prevention of dual nationality with some Soviet Bloc countries allowed more and more exUSSR citizens to use the conferment procedure.

The chart showing the number of acquisitions of nationality by conferment in the whole period analysed here shows a roughly u-shaped curve (see Figure 4.I), so long as we exclude the latest figures for 2006. The highest annual numbers registered were I,522 (in I992), I,79I (2004) and 2,625 (2005), whereas two among the three smallest annual figures (679 and 555) occurred in the mid-I990s (in I996 and I997), and the third (662) in 2006. The 'boom' of naturalisations registered at the beginning of the I990s was caused mainly by 'early reconferments' of Polish nationality. For example, in the I992-I995 period, over one quarter of the people granted Polish nationality were German citizens, probably many or most of whom had lost their Polish nationality in the past.

The dramatic increase ( 56 per cent) in the number of acquisitions in I998 can be partly explained by factors described above. Among them, the increase in the number of applications by Israelis (and other Polish emigrants) seems to be important. The number of 'naturalising' Israelis rose in I998 after President Kwaśniewski’s aforementioned promise 
Figure 4.1 Acquisitions of Polish nationality by conferment (1992-2006)

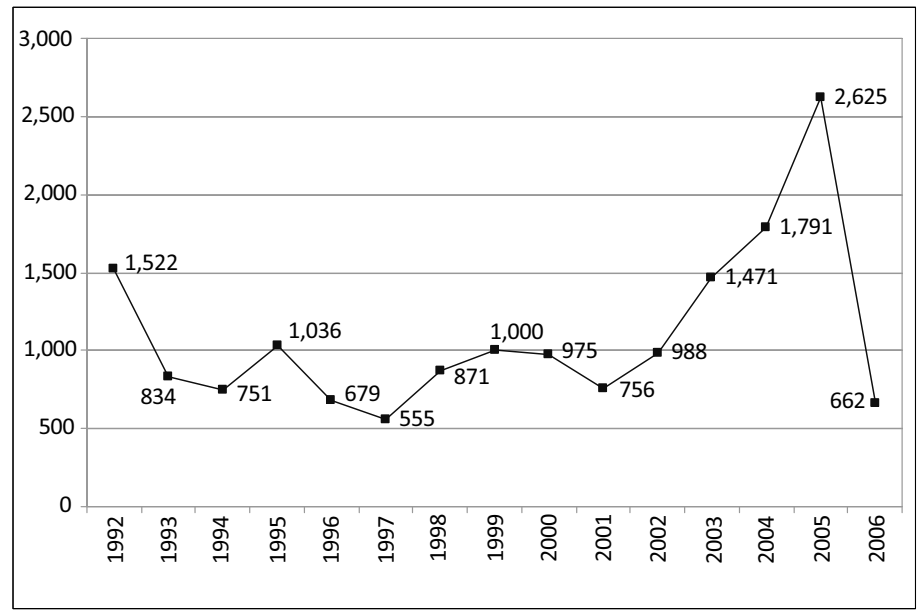

Sources: Kępińska 2007; data provided by the Polish President's Chancellery

of a 'broad and uncomplicated restoration'. In I997, the President granted Polish nationality to only nineteen Israelis, whereas in I998, the respective number was six times higher (II4 persons). Then, as mentioned above, a gradual increase in the numbers of ex-USSR citizens using the conferment procedure also contributed to the increase in acquisitions.

The sharp decrease in the number of acquisitions of Polish nationality by conferment in 2006 deserves some explanation. Its main cause is the change of the Head of State: Lech Kaczyński, who is close to the right-wing parties, replaced Aleksander Kwaśniewski, who came from the main post-communist party. In 2005 - the last year of the Kwaśniewski presidency - many cases were processed faster than usual in order to be completed before his term came to an end. Thereafter, President Kaczyński appeared to be reluctant to grant Polish nationality, at least at the beginning of his term.

Data on the conferment procedure certainly only describe part of the phenomenon of naturalisations in Poland though, in our opinion, they provide an accurate snapshot of national groups interested in Polish nationality, especially in the 2000 s. In the I990s, the number of applicants for the acknowledgement procedure was slightly higher than for the conferment procedure. In the 2000s, the first of these procedures almost totally lost its importance due to the abrogation of conventions on the prevention of dual nationality. In fact, between 2002 and 2004, 
fewer than 200 people were naturalised through any procedure other than conferment.

The remaining procedure, i.e. spousal acquisition, played a secondary role in the I990s and is still of only marginal importance. In I997, for example, only 52 foreign women used this mode of acquisition. In the Warsaw voivodeship during the period I992-I998, the number was 73 women. At the same time, the annual numbers of mixed marriages in Poland were much higher - between 3,000 and 3,500 were concluded in the I990s and 2000s, respectively. Spousal acquisition gained more importance after 1999 when it started applying not only to women, but also to men, and when conditions regarding applications became more 'reasonable'. It is likely to increase in importance, since ex-USSR citizens no longer have to relinquish their foreign nationality upon naturalisation in Poland. In 2002, for example, from among 3,552 mixed marriages concluded in Poland, over 40 per cent involved citizens of post-Soviet countries.

\subsubsection{Repatriation}

The repatriation procedure was introduced amidst much discussion. On the one hand, speculation about thousands of people of Polish descent (not always genuine) who would take advantage of the repatriation procedure was aired in the media and in parliament. On the other hand, virtually nobody dared to question Poland's obligation to take care of its exiles in faraway Asiatic republics of the former Soviet Union. The controversies surrounding repatriation influenced the final shape of the Repatriation Act of 2000 by limiting repatriation to a very small group of people. As a rule the repatriation procedure only applies to persons who have lived permanently in certain Asiatic republics prior to 2000 . Thus, it is designed for those who did not manage to repatriate themselves in the I940s and I950s. The requirement that a would-be repatriate has to be invited by an official institution or a private person further limits the accessibility of this procedure.

In all, during the I997-2006 period, only 4,0I5 repatriation visas were issued and 5,293 repatriates arrived via the repatriation program (Kępińska 2004, 2007). The actual number of people who acquired Polish nationality through the repatriation procedure is somewhere between these two figures, since new arrivals include non-Polish members of repatriate families. From 200I to 2006, 2,935 people acquired Polish nationality as repatriates. As demonstrated in Table 4.2, people from Kazakhstan represent the majority among repatriates (based on a count of visas issued). Residents of other former republics of the Soviet Union are in the minority and this relationship will persist due to the structure of the Repatriation Act. 
Table 4.2 Repatriation visas to Poland in 1997-2006, by repatriates' previous country of residence

\begin{tabular}{lrrrrrrrrrr}
\hline $\begin{array}{l}\text { Country of previous } \\
\text { residence }\end{array}$ & 1997 & 1998 & 1999 & 2000 & 2001 & 2002 & 2003 & 2004 & 2005 & 2006 \\
\hline Total & 316 & 281 & 278 & 662 & 804 & 613 & 301 & 269 & 252 & 239 \\
Azerbaijan & - & - & - & - & - & - & - & - & - & 1 \\
Belarus & - & 10 & 15 & 45 & 140 & 127 & 43 & 39 & 30 & 25 \\
Czech Republic & - & - & - & - & 2 & 4 & 1 & 1 & 1 & 1 \\
Georgia & - & - & - & - & - & 1 & 3 & - & 3 & 3 \\
Kazakhstan & 316 & 245 & 172 & 361 & 216 & 194 & 156 & 122 & 155 & 125 \\
Lithuania & - & - & 11 & 16 & 20 & 3 & - & 1 & 1 & 1 \\
Latvia & - & 1 & 1 & 10 & - & - & - & - & - & - \\
Moldova & - & 1 & 2 & 10 & 9 & 5 & 2 & - & 2 & 1 \\
Russian Federation & - & 7 & 8 & 10 & 36 & 31 & 11 & 35 & 32 & 40 \\
Ukraine & - & 15 & 69 & 210 & 381 & 245 & 77 & 56 & 23 & 27 \\
Uzbekistan & - & 2 & - & - & - & 2 & 8 & 15 & 5 & 14 \\
\hline
\end{tabular}

Source: Central Statistical Office, from Kępińska (2007: 95)

According to the available fragmented data on acquisitions of Polish nationality, naturalisation remains a limited phenomenon in Poland. In the I990s and 2000s, the annual numbers of persons granted Polish nationality did not exceed 3,000, although the beginning of the I990s produced a visible increase in naturalisations. For example, in the Warsaw voivodeship, 26 and 80 applicants had been granted Polish nationality in $1990^{35}$ and I99I, respectively, whereas in I992, the number rose to 203, with no decrease evident in subsequent years.

\subsection{Conclusions}

There have been surprisingly few changes in Polish legislation on nationality since 1962. The post-communist Third Republic of Poland did not pass a new law on nationality despite expectations. All this does not mean, however, that nothing changed at the level of practice regarding Polish nationality. Political attitudes also changed, a fact that is exemplified by President Kwaśniewski's declaration in 1998 to return Polish nationality to those who had lost it during the communist era.

In general, the characteristic feature of legislation on Polish nationality is discretionary power given to public officials in making decisions. Consequently, changing policy in nationality matters does not necessarily require changes in the written law. At the same time, uncovering the mechanisms of this policy in practice requires looking beyond the written law. Even though the 1962 Act on Polish Nationality makes acquisition of Polish nationality conditional only on the duration and 
type of an applicant's stay in Poland, civil servants also take into account other factors referring to a foreigner's social and cultural integration as well as his or her family and financial situation.

Poles living abroad and/or returning to Poland and their right to Polish nationality were the focus of the debate on reforms to Polish nationality law in the 2000 s. It is important to remember that only some of the applicants for Polish nationality are immigrants. A visible proportion of new citizens - around half in the I990s - are people who had lost Polish nationality under communism and repatriates. This is undoubtedly a temporary phenomenon. The proportion has already started to decline and will continue to do so as the pool of individuals interested in reacquiring their Polish nationality wanes and as the number of 'typical immigrants' who qualify for acquisition of Polish nationality, which is already relatively high today, gradually grows.

Polish accession to the European Union boosted discussions on immigration to Poland in the context of the shift of the EU border to Poland's eastern border. However, it did not affect the discourse on Polish nationality, which was absent from the political and public agenda in pre- and post-accession periods. This absence was probably due to the post-communist majority in the Polish Parliament between 200I and late 2005, which was not eager to tackle nationality (and other) issues pertaining to how to 'deal with the communist past'. Works on legislation relating to nationality issues were resumed in the fifth (20052007) and sixth (2007-20II) legislative periods when the post-Solidarity parties had a majority in Parliament. It is, however, too early to analyse the proceedings relating to the most recent Bill on Polish Nationality since it has not been yet discussed in Parliament.

It can be also argued that another consequence of Polish accession to the EU is the visible increase in the interest in Polish nationality among diaspora members. The number of applications for certification/recognition of Polish nationality submitted to Polish consulates abroad, especially outside Europe, grew in the 2000s. In 2000, only 765 such applications were registered, whereas in 2004 their number reached 3,807. In 2000-2002, the largest number of applications came from Germany. In 2003, Argentina was first with 505 applications (Centre of Migration Research 2005). ${ }^{36}$ We are certainly not talking about acquisitions of Polish nationality, but about situations whereby people, usually descendants of Polish emigrants, who are entitled to citizenship but are not registered citizens (not having a national registry number and passport, possibly due to a lack of interest on their part), take advantage of this right. ${ }^{37}$

All in all, it seems that interest in Polish nationality, which was rather weak in the I990s and at the beginning of the 2000s, has been growing recently. Moreover, it is likely to further increase in light of on- 
going immigration to Poland and the fact that Polish nationality has entailed European Union citizenship since 2004.

\section{Chronological list of citizenship-related legislation in Poland}

\begin{tabular}{|c|c|c|c|}
\hline Date & Legislative act & Content & Source \\
\hline 1920 & $\begin{array}{l}\text { Act on Nationality of } \\
\text { Poland }\end{array}$ & $\begin{array}{l}\text { Regulates modes of } \\
\text { acquisition and loss of } \\
\text { Polish nationality }\end{array}$ & $\begin{array}{l}\text { www.dziennik-ustaw.pl } \\
\text { (in Polish) }\end{array}$ \\
\hline 1938 & $\begin{array}{l}\text { Act on Deprivation of } \\
\text { Polish Nationality }\end{array}$ & $\begin{array}{l}\text { Regulates modes of loss } \\
\text { of Polish nationality }\end{array}$ & $\begin{array}{l}\text { www.dziennik-ustaw.pl } \\
\text { (in Polish) }\end{array}$ \\
\hline 1946 & $\begin{array}{l}\text { Decree Concerning } \\
\text { Exclusion of Persons of } \\
\text { German Ethnicity from } \\
\text { Polish Society }\end{array}$ & $\begin{array}{l}\text { Defines the framework } \\
\text { for the exclusion and } \\
\text { eventual deportation of } \\
\text { persons of German } \\
\text { ethnicity living on the } \\
\text { Polish territory after the } \\
\text { Second World War }\end{array}$ & $\begin{array}{l}\text { www.dziennik-ustaw.pl } \\
\text { (in Polish) }\end{array}$ \\
\hline 1946 & $\begin{array}{l}\text { Act on Polish Nationality } \\
\text { of Persons of Polish } \\
\text { Ethnicity Inhabiting the } \\
\text { Regained Territories }\end{array}$ & $\begin{array}{l}\text { Defines the conditions } \\
\text { for entitlement to Polish } \\
\text { nationality for persons } \\
\text { living in North-Western } \\
\text { Poland (territories } \\
\text { belonging to Germany } \\
\text { before the Second World } \\
\text { War) }\end{array}$ & $\begin{array}{l}\text { www.dziennik-ustaw.pl } \\
\text { (in Polish) }\end{array}$ \\
\hline 1947 & $\begin{array}{l}\text { Act on Polish Nationality } \\
\text { of Persons of Polish } \\
\text { Ethnicity Inhabiting the } \\
\text { Former City of Gdańsk }\end{array}$ & $\begin{array}{l}\text { Defines the conditions } \\
\text { for entitlement to Polish } \\
\text { nationality for persons } \\
\text { living in the former city } \\
\text { of Gdańsk (Danzig) }\end{array}$ & $\begin{array}{l}\text { www.dziennik-ustaw.pl } \\
\text { (in Polish) }\end{array}$ \\
\hline 1951 & Act on Polish Nationality & $\begin{array}{l}\text { Regulates modes of } \\
\text { acquisition and loss of } \\
\text { Polish nationality }\end{array}$ & $\begin{array}{l}\text { www.dziennik-ustaw.pl } \\
\text { (in Polish) }\end{array}$ \\
\hline 1956 & $\begin{array}{l}\text { Decree of the Council of } \\
\text { the State No. } 37 / 56 \\
\text { Concerning the } \\
\text { Permission for German } \\
\text { Repatriates to Renounce } \\
\text { Polish Nationality } \\
\text { (unpublished) }\end{array}$ & $\begin{array}{l}\text { Provides a fast track for } \\
\text { the renunciation of } \\
\text { Polish nationality for } \\
\text { people leaving for } \\
\text { Germany }\end{array}$ & \\
\hline 1958 & $\begin{array}{l}\text { Decree of the Council of } \\
\text { the State No. } 5 / 58 \\
\text { Concerning the } \\
\text { Permission for People } \\
\text { Leaving for Israel to } \\
\text { Renounce Polish } \\
\text { Nationality } \\
\text { (unpublished) }\end{array}$ & $\begin{array}{l}\text { Provides a fast track for } \\
\text { the renunciation of } \\
\text { Polish nationality for } \\
\text { people leaving for Israel }\end{array}$ & \\
\hline 1962 & Act on Polish Nationality & $\begin{array}{l}\text { Regulates modes of } \\
\text { acquisition and loss of }\end{array}$ & $\begin{array}{l}\text { www.coe.int; } \\
\text { www.uric.gov.pl }\end{array}$ \\
\hline
\end{tabular}




\begin{tabular}{|c|c|c|c|}
\hline Date & Legislative act & Content & Source \\
\hline & & Polish nationality & $\begin{array}{l}\text { (in Polish); } \\
\text { www.dziennik-ustaw.pl } \\
\text { (in Polish); } \\
\text { www.abc.com.pl } \\
\text { (in Polish) }\end{array}$ \\
\hline 1997 & $\begin{array}{l}\text { Amendment of the Act } \\
\text { on Polish Nationality }\end{array}$ & $\begin{array}{l}\text { Extends required time of } \\
\text { residence in Poland (by } \\
\text { five years) by introducing } \\
\text { the clause that only stay } \\
\text { on the basis of } \\
\text { permanent residence } \\
\text { permit be counted }\end{array}$ & \\
\hline 1997 & $\begin{array}{l}\text { Constitution of the } \\
\text { Republic of Poland } \\
\text { (excerpts) }\end{array}$ & $\begin{array}{l}\text { Protects citizenship } \\
\text { status: 'A Polish citizen } \\
\text { shall not lose Polish } \\
\text { citizenship except by } \\
\text { renouncing it' (art. 34.2) }\end{array}$ & www.legislationline.org \\
\hline 1998 & $\begin{array}{l}\text { Amendment of the Act } \\
\text { on Polish Nationality }\end{array}$ & $\begin{array}{l}\text { Introduces equality in } \\
\text { treatment of husbands } \\
\text { and wives of Polish } \\
\text { citizens with regard to } \\
\text { acquisition of Polish } \\
\text { nationality; removes all } \\
\text { possibilities of losing } \\
\text { Polish nationality against } \\
\text { person's will; makes } \\
\text { resignation from Polish } \\
\text { citizenship fully } \\
\text { dependent on the will of } \\
\text { its holder }\end{array}$ & \\
\hline 1999 & $\begin{array}{l}\text { Act on Terminating the } \\
\text { Convention, Being } \\
\text { Effective in Polish- } \\
\text { Belarusian Relations, } \\
\text { between the Polish } \\
\text { People's Republic } \\
\text { Government and the } \\
\text { USSR Government } \\
\text { Concerning the } \\
\text { Prevention of Cases of } \\
\text { Dual Nationality, signed } \\
\text { in Warsaw on } 31 \text { March } \\
1965\end{array}$ & $\begin{array}{l}\text { Expresses Poland's will } \\
\text { to terminate the } \\
\text { Convention on } \\
\text { Prevention of Dual } \\
\text { Citizenship in force } \\
\text { between Poland and } \\
\text { Belarus }\end{array}$ & $\begin{array}{l}\text { www.dziennik-ustaw.pl } \\
\text { (in Polish); } \\
\text { www.abc.com.pl } \\
\text { (in Polish) }\end{array}$ \\
\hline 1999 & $\begin{array}{l}\text { Act on Terminating the } \\
\text { Convention, Being } \\
\text { Effective in Polish-Czech } \\
\text { Relations between the } \\
\text { Polish People's Republic } \\
\text { and the Czechoslovak } \\
\text { Socialistic Republic } \\
\text { Concerning Regulations }\end{array}$ & $\begin{array}{l}\text { Expresses Poland's will } \\
\text { to terminate the } \\
\text { Convention on } \\
\text { Prevention of Dual } \\
\text { Citizenship in force } \\
\text { between Poland and the } \\
\text { Czech Republic }\end{array}$ & $\begin{array}{l}\text { www.dziennik-ustaw.pl } \\
\text { (in Polish); } \\
\text { www.abc.com.pl } \\
\text { (in Polish) }\end{array}$ \\
\hline
\end{tabular}




\begin{tabular}{|c|c|c|c|}
\hline Date & Legislative act & Content & Source \\
\hline & $\begin{array}{l}\text { on Dual Nationality, } \\
\text { signed in Warsaw on } 17 \\
\text { May } 1965\end{array}$ & & \\
\hline 1999 & $\begin{array}{l}\text { Act on Terminating the } \\
\text { Convention between the } \\
\text { Polish People's Republic } \\
\text { and the Mongolian } \\
\text { People's Republic } \\
\text { Concerning Regulations } \\
\text { on Dual Nationality, } \\
\text { signed in Ulan Bator on } \\
23 \text { May } 1975\end{array}$ & $\begin{array}{l}\text { Expresses Poland's will } \\
\text { to terminate the } \\
\text { Convention on } \\
\text { Prevention of Dual } \\
\text { Citizenship in force } \\
\text { between Poland and } \\
\text { Mongolia }\end{array}$ & $\begin{array}{l}\text { www.dziennik-ustaw.pl } \\
\text { (in Polish); } \\
\text { www.abc.com.pl } \\
\text { (in Polish) }\end{array}$ \\
\hline 1999 & $\begin{array}{l}\text { Act on Terminating the } \\
\text { Convention, Being } \\
\text { Effective in Polish-Slovak } \\
\text { Relations between the } \\
\text { Polish People's Republic } \\
\text { and the Czechoslovak } \\
\text { Socialistic Republic } \\
\text { Concerning Regulations } \\
\text { on Dual Nationality, } \\
\text { signed in Warsaw on } 17 \\
\text { May } 1965\end{array}$ & $\begin{array}{l}\text { Expresses Poland's will } \\
\text { to terminate the } \\
\text { Convention on } \\
\text { Prevention of Dual } \\
\text { Citizenship in force } \\
\text { between Poland and } \\
\text { Slovakia }\end{array}$ & $\begin{array}{l}\text { www.dziennik-ustaw.pl } \\
\text { (in Polish); } \\
\text { www.abc.com.pl } \\
\text { (in Polish) }\end{array}$ \\
\hline 1999 & $\begin{array}{l}\text { Act on Terminating the } \\
\text { Convention, Being } \\
\text { Effective in Polish- } \\
\text { Ukrainian Relations, } \\
\text { between the Polish } \\
\text { People's Republic } \\
\text { Government and the } \\
\text { USSR Government } \\
\text { Concerning Prevention of } \\
\text { Cases of Dual } \\
\text { Nationality, signed in } \\
\text { Warsaw on } 31 \text { March } \\
1965\end{array}$ & $\begin{array}{l}\text { Expresses Poland's will } \\
\text { to terminate the } \\
\text { Convention on } \\
\text { Prevention of Dual } \\
\text { Citizenship in force } \\
\text { between Poland and } \\
\text { Ukraine }\end{array}$ & $\begin{array}{l}\text { www.dziennik-ustaw.pl } \\
\text { (in Polish); } \\
\text { www.abc.com.pl } \\
\text { (in Polish) }\end{array}$ \\
\hline 2000 & Repatriation Act & $\begin{array}{l}\text { Defines the framework } \\
\text { for the repatriation of } \\
\text { people of Polish descent } \\
\text { from the Asiatic } \\
\text { republics of the ex-USSR }\end{array}$ & $\begin{array}{l}\text { www.legislation.org; } \\
\text { www.uric.gov.pl } \\
\text { (in Polish); } \\
\text { www.dziennik-ustaw.pl } \\
\text { (in Polish); } \\
\text { www.abc.com.pl } \\
\text { (in Polish) }\end{array}$ \\
\hline 2000 & $\begin{array}{l}\text { Ordinance of the } \\
\text { President of the Republic } \\
\text { of Poland concerning the } \\
\text { procedure in cases of } \\
\text { conferment or giving } \\
\text { permission to renounce } \\
\text { one's Polish nationality, } \\
\text { as well as specimen }\end{array}$ & $\begin{array}{l}\text { Defines the documents } \\
\text { to be submitted and the } \\
\text { exact procedures for the } \\
\text { acquisition of nationality } \\
\text { by conferment }\end{array}$ & $\begin{array}{l}\text { www.dziennik-ustaw.pl } \\
\text { (in Polish); } \\
\text { www.abc.com.pl } \\
\text { (in Polish) }\end{array}$ \\
\hline
\end{tabular}




\begin{tabular}{|c|c|c|c|}
\hline Date & Legislative act & Content & Source \\
\hline & $\begin{array}{l}\text { certificates and } \\
\text { applications }\end{array}$ & & \\
\hline 2001 & $\begin{array}{l}\text { Amendment of the Act } \\
\text { on Polish Nationality }\end{array}$ & $\begin{array}{l}\text { Introduces changes } \\
\text { relating to registration of } \\
\text { acquisitions and losses } \\
\text { of Polish nationality; } \\
\text { removes rules applying } \\
\text { to repatriation procedure }\end{array}$ & \\
\hline 2003 & $\begin{array}{l}\text { Amendment of the Act } \\
\text { on Polish Nationality }\end{array}$ & $\begin{array}{l}\text { Introduces procedural } \\
\text { changes }\end{array}$ & \\
\hline $2005-2007$ & $\begin{array}{l}\text { Amendments of the Act } \\
\text { on Polish Nationality }\end{array}$ & $\begin{array}{l}\text { Introduce minor changes } \\
\text { resulting partly from the } \\
\text { accession of Poland to } \\
\text { the EU }\end{array}$ & \\
\hline 2007 & $\begin{array}{l}\text { Act on Polish Ethnicity } \\
\text { Card }\end{array}$ & $\begin{array}{l}\text { Defines the conditions } \\
\text { for entitlement to the } \\
\text { Polish Ethnicity Card; } \\
\text { introduces certain } \\
\text { benefits to members of } \\
\text { Polish kin-minorities in } \\
\text { fifteen post-Soviet states } \\
\text { including easier access } \\
\text { to the labour market and } \\
\text { some educational, } \\
\text { cultural and health } \\
\text { benefits }\end{array}$ & $\begin{array}{l}\text { www.poland.gov.pl } \\
\text { (in Polish, Russian } \\
\text { and other languages) }\end{array}$ \\
\hline
\end{tabular}

\section{Notes}

I It is beyond the scope of this chapter to discuss the complex relation between ethnicity and nationality/citizenship. Though following, for example, Thomas Hylland Eriksen (I999: 35), it is worth mentioning that the distinguishing mark of nationalism (when talking about nationality he refers to nationalism) is by definition its relation to the state. A nationalist holds that political boundaries should be coterminous with cultural boundaries, whereas many ethnic groups do not demand command over the state.

2 Repatriation Act, Journal of Law I60, 2000 , III8.

3 Act on the Polish Ethnicity Card, Journal of Law I80, 2007, I280. In the official English translation, the Polish Ethnicity Card is sometimes called the 'Polish Charter' and there can be nothing more misleading. It is important to note that the Polish Ethnicity Card in the title of the act refers to the document that is issued under the act to certain subjects who are not Polish citizens, but are citizens of certain states entitled to certain privileges within Polish territory. The card thus does not ascertain the identity of the subject and can be compared to a student card inasmuch as it serves as proof of certain entitlements under the act. In its symbolic function, the card is deemed to ascertain that its holder 'belongs to the Polish Nation' defined in ethnic terms in this statute (art. 3).

4 Act on Nationality of Poland, Journal of Law 44, I920, 44. 
5 Act on Polish Nationality, Journal of Law 5, I951, 25.

6 Act on Polish Nationality, Journal of Law IO, I962, 49.

7 Act on the Exclusion of Persons of German Ethnicity from the Polish Society, Journal of Law 66, 1946, 404.

8 The exclusion involved forced resettlement from the Polish territory and the loss of property in Poland.

9 To be positively verified as Polish, a person had to prove his or her coming from a Polish family and express his or her desire to belong to the Polish nation.

Io Act on Polish Nationality of Persons of Polish Ethnicity Inhabiting the Regained Territories, Journal of Law 15, I946, 106.

II Act on Polish Nationality of Persons of Polish Ethnicity Inhabiting the Former Free City of Gdańsk, Journal of Law 65, 1947, 378.

I2 Decree of the Council of the State No. 37/56 of 1956 Concerning the Permission for German Repatriates to Renounce Polish Nationality, (unpublished).

I3 Decree of the Council of the State No. 5/58 of I958 Concerning the Permission for People Leaving for Israel to Renounce Polish Nationality, (unpublished).

I4 In fact, few people took advantage of this procedure, as there were no appropriate guidelines for its implementation.

I5 It would be an oversimplification to look for origins of that action only in the antiSemitic attitudes of the Polish elites and society. Not all Jews were forced to leave Poland. Moreover, some of them remained not only in Poland but also in various Polish political structures.

I6 Act on Polish Nationality, Journal of Law 28, 2000, 353 (version including amendments).

I7 Constitution of the Republic of Poland, Journal of Law 78, 1997, 483.

I8 Ordinance of the President of the Republic of Poland concerning the procedure in cases of conferment or giving permission to renounce one's Polish nationality, as well as specimen certificates and applications, Journal of Law I8, 2000, 23I.

I9 They include conventions signed with the Soviet Union (1965), Czechoslovakia (I965), Bulgaria (I972), Mongolia (I975) and the German Democratic Republic (I975) (Albiniak \& Czajkowska I996).

20 At the time of writing, only the Ukrainian government has not ratified the termination of the convention.

2I This is a guiding principle for the legislature, meaning that the preference in the nationality regime should be given to the ius sanguinis principle and that other principles should only play an auxiliary role.

22 This refers only to automatic change of nationality as a consequence of marriage. Polish nationality law does provide for facilitated naturalisation of foreign spouses of Polish nationals.

23 It should be noted that these conditions are defined differently in the recently adopted Act on the Polish Ethnicity Card.

24 These are: I) a permit to settle (zezwolenie na osiedlenie sie)); 2) a long-term resident's EC residence permit (zezwolenie na pobyt rezydenta dtugoterminowego Wspólnot Europejskich) as defined in the Act on Aliens (arts. 64, 65); and 3) right of permanent residence (prawo statego pobytu) as defined in the Act on the Entry into, Residence in and Exit from the Republic of Poland of Nationals of the European Union Member States and their Family Members (Journal of Law I44, 2006, 1043).

25 In some cases, the period after which a permanent residence permit may be acquired is longer. For example, for people who have been granted subsidiary protection it is seven years, which means that to be eligible for naturalisation such a person has to wait at least twelve years (art. 64 of the Act on Aliens, Journal of Law I28, 2003, II75). 
26 Attachment to the Ordinance of the President of the Republic of Poland concerning the procedure in cases of conferment or giving the permit to resign from Polish nationality and specimen certificates and applications, Journal of Law I8, 2000, 23I.

27 The study on positive and negative decisions on applications for Polish nationality in the Warsaw voivodship in 1989-1998 shows that Polish origins may influence a positive decision on nationality (Górny 200I).

28 Cf. the resolution of the Highest Administrative Court of 9 November I998, OPD 4/ 98, ONSA I999, book I, item 6 .

29 Art. II ECN requires that decisions relating to the acquisition, retention, loss, recovery or certification of nationality contain reasons in writing; while art. I2 demands that these decisions be left open to an administrative or judicial review. Poland has signed, but not yet ratified the ECN.

30 Judgment of 28 December 1994, V SA 1507/94; see Mincer-Jaśkowska I996.

3I Act on the Polish Ethnicity Card, Journal of Law I80, 2007, I280.

32 They had not expressed their will to decline Polish nationality (deprivation on the basis of the Act of 1920) or they were 'forced' to relinquish Polish nationality (deprivation on the basis of the Acts of I95I and 1962).

33 Data from regional departments for 1997 were collected in one ad hoc action. For 2002-2006, we do not have exact data on the acknowledgement and marriage procedures but only on the total for all three procedures. Moreover, we have separate data only for the conferment procedure, but not for the years 2005-2006.

34 The database of $\mathrm{I}, 483$ applicants, among whom I, $3 \mathrm{I} 4$ were granted Polish nationality, was compiled on the basis of personal data files.

35 The number for 1990 may be slightly underestimated, as files were checked according to the year of application. We started from 1989 and it is likely that somebody applying prior to 1989 and who received Polish nationality in 1990 was not registered in our database.

36 By I8 November 2004, 259 applications had been submitted in Argentina.

37 Data collected by Agnieszka Weinar in the research project entitled 'New Poles, new Europeans - dual nationality among descendants of Polish emigrants in Argentina'.

\section{Bibliography}

Albiniak, M. \& A. Czajkowska (I996), Przepisy o obywatelstwie polskim 1919-1995. Toruń: Wydawnictwo 'Dom Organizatora'.

Centre of Migration Research, Warsaw University, Centre for International Relations (2005), 'Wzrost liczby wniosków o potwierdzenie polskiego obywatelstwa', Biuletyn Migracyjny I. www.migration-news.uw.edu.pl.

Eriksen, T.H. (I999), 'Ethnicity, race and nation', in M. Guibernau \& J. Rex (eds.), The Ethnicity Reader: Nationalism, Multiculturalism and Migration, 33-42. Cambridge: Polity Press.

Górny, A. (200I), 'Polish citizenship in relation to concepts of integration and transnationalism', in J.W. Dacyl (ed.), Challenges of cultural diversity in Europe, 217-253. Stockholm: Centre for Research in International Migration and Ethnic Relations.

Górny, A., A. Grzymała-Kazłowska, P. Koryś \& A. Weinar (2003), 'Multiple citizenship in Poland', ISS UW Working Papers, Migration Series 53. www.migracje.uw.edu.pl.

Górny, A., A. Grzymała-Kazłowska, P. Koryś \& A. Weinar (2007), 'Selective tolerance? Regulation, practice and discussion regarding dual nationality in Poland', in T. Faist (ed.), Dual Citizenship in Europe: From Nationhood to Societal Integration, I47-I69. Avebury: Ashgate. 
Jagielski, J. (I998), Obywatelstwo polskie. Zagadnienia podstawowe. Warsaw: Wydawnictwa Prawnicze.

Jagielski, J. (2000), 'Podstawowe instytucje oraz kierunki zmian polskiego prawa o obywatelstwie', Newsletter of the Information Office of the Council of Europe 4-5: 98-108.

Jagielski, J. \& Pudzianowska, D. (2008), Komentarz do Ustawy o Karcie Polaka. Warsaw: Wolters Kluwer.

Kępińska, E. (2004), 'Recent trends in international migration. The 2004 SOPEMI Report for Poland', ISS UW Working Papers, Migration Series 56. www.migracje.uw.edu. pl.

Kępińska, E. (2007), 'Recent trends in international migration. The 2007 SOPEMI Report for Poland', ISS UW Working Papers, Migration Series 29/87. www.migracje.uw.edu.pl.

Łodziński, S. (1998), 'Polish citizenship - ethnic boundaries and the issue of citizenship in Polish society', in B. Balla \& A. Sterbling (eds.), Ethnicity, nation and culture. Central and East European Perspectives, I49-I64. Hamburg: Kramer.

Mincer-Jaśkowska, M. (1996), 'Glosa do wyroku NSA z 28 grudnia I994, V SA 1507/94', Orzecznictwo Sadów Polskich 7-8: item I3I.

Ramus, W. (I968), Prawo o obywatelstwie polskim. Warsaw: Wydawnictwo Prawnicze

Schuck, P. (2002), 'Plural citizenships', in R. Hansen \& P. Weil (eds.), Dual Nationality, Social Rights and Federal Citizenship in the US and Europe, 6I-IOO. New York: Berghan Books.

Stola, D. (2000), Kampania antysyjonistyczna w Polsce 1967-1968. Warsaw: ISP PAN. 



\title{
5 Kin-state responsibility and ethnic citizenship: The Hungarian case
}

\author{
Mária M. Kovács and Judit Tóth
}

The preference for the naturalisation of ethnic Hungarians has been considered a counterbalance to the troubled history of a nation artificially split among various states and as a tool for preserving cultural identity in the twentieth century. The principle of ethnicity has been observed directly in nationality legislation and migration law through regulations for visa, residence and employment permits, and asylum status (Tóth I995). Due to the ideology of a 'threatened Hungarian ethnic identity' the relationship between the social and economic integration of migrants, migration law, naturalisation and citizenship has never been publicly discussed (Fullerton, Sik \& Tóth I997). Hungarian authorities need not give reasons for refusing an application for naturalisation and there is no legal remedy against a negative decision. This is justified by referring to the sovereign power of the state and, in cases of rejection, by a presumption of the applicants' missing ethnic and cultural ties to Hungary. An extension of preference in naturalisation to European Union citizens was smoothly passed in 2003, partly because of the supposed ethnic proximity of applicants in adjacent states. ${ }^{\text {I }}$ Provisions supportive of family unity in nationality law are widely accepted and so are the discretionary powers in naturalisation proceedings that determine who is to be allowed to join this rather homogeneous society (Tóth 2005).

On the other hand, there are some contentious components of the nationality regulations in contemporary Hungary.

- Naturalisation and its precondition, the authorisation of permanent residence, are criticised as being too time-consuming and expensive, and the requirements for documentation as too bureaucratic. In other words, ethnic Hungarians, being the largest group of applicants, do not see themselves as preferential beneficiaries when it comes to the attitude of the authorities or to procedural provisions.

- Moreover, certain privileges of Hungarian citizenship were extended to EU nationals and migrants under the scope of Community law in the accession process (Tóth 2004a).

- The role of naturalisation in the process of migrant integration has been unclear. While the applicant is required to be highly integrated in a cultural, economic and social sense, integration programmes 
do not exist at all, which means that integration can only be achieved by individual effort. The applicant must also not endanger public order and is investigated in this regard in various ways.

- Nationality as a basket of various rights and obligations is basically considered by the general public as a historical, cultural, ethnic and emotional issue without awareness of its existing legal and normative status and its neutral significance in a democratic rule-of-law system. For this reason, public opinion is strongly divided into "normativists' and 'nation builders', representing different standpoints concerning voting rights, principles for the acquisition of nationality, dual citizenship and never-ending citizenship for emigrants in the diaspora.

- As for ethnic Hungarians, the right to have the family and given name and the name of the applicants' prior place of residence and birthplace in their original ethnic language was finally introduced in amendments related to the naturalisation and registry process. $^{2}$ This causes certain confusion in the registration of foreigners and nationals since registration is, in theory, based on the authenticity and unaltered nature of existing identity documents. Moreover, this right is exclusively reserved for ethnic Hungarians; it does not apply to the non-Hungarian version of names of, for instance, naturalised refugees or stateless migrants belonging to a linguistic minority, which would be registered in the dominant language in their countries of origin.

\subsection{History of Hungarian policies on nationality since 1945}

Although the first Act on Hungarian Nationality (1879) became increasingly restrictive through amendments adopted during wars, its ius sanguinis principle has remained dominant up to the present day. This Act was in force until I948. The history of Hungarian policies on nationality since I945 can be divided into the following periods:

I945-I948: The Armistice Agreement concluded in Moscow (I945) ${ }^{3}$ annulled all the modifications of nationality that had come about as a result of the territorial changes of the Hungarian state between I939 and I945. Millions of former Hungarian citizens who ended up under the jurisdiction of neighbouring states lost their Hungarian nationality. The Peace Agreement fixed the borders of the Hungarian state along the frontiers as they had existed on the last day before the war began. ${ }^{4}$ Between I945 and I948 temporary regulations on nationality considered all those residing in Hungary in I945 as nationals except for those holding the nationality of another state. Bilateral agreements on population exchange initiated by Czechoslovakia and the expulsion of Ger- 
mans resulted in the deprivation of nationality for those falling under these measures. ${ }^{5}$ Individuals who had not returned to Hungary following the conclusion of the war were deprived of their citizenship and, between 1946 and I948, their property was confiscated. ${ }^{6}$ Finally, the citizenship status of communists who had fled Hungary during the interwar years was settled. ${ }^{7}$

I948-1956: In I946 a reform of the legal status and civil rights of children born out of wedlock established their full equality, ${ }^{8}$ but only the new Act on Hungarian Nationality of $1948^{9}$ provided a coherent legal framework for the acquisition of nationality through changes in family and personal status. The Act provided for the equal treatment of children born out of wedlock and stipulated that all nationals residing abroad should be registered, without, however, creating techniques for registration in the absence of consular relations. The Act recognised the pending Hungarian nationality of undocumented persons who had been residing in Hungary for a given number of years.

I956-1989: This period witnessed the emancipation of spouses on the basis of the New York Convention of 1957 on married women, ${ }^{\text {IO }}$ the principles of which were inserted into the third Act on Nationality adopted in $1957 .{ }^{\text {II }}$ The executive rules of the Act were not published and were implemented by confidential order, such as the one requiring emigrants to renounce their nationality and social insurance rights. Following the 1956 revolution and the mass emigration it triggered, a broad amnesty was proclaimed for returnees and a registry of nationals permanently abroad was established. ${ }^{\text {I2 }}$

I989-I993: After 1989, Hungary started reforms to establish the rule of law and constitutionalism. In 1989 the prohibition of deprivation of nationality was regulated in the modified Constitution. ${ }^{\mathrm{I3}}$ At the same time the nationality of expatriate nationals who had been deprived of their nationality arbitrarily was restored upon request. ${ }^{\mathrm{I}}$ The Geneva Convention of $195 \mathrm{I}^{\mathrm{IS}}$ inspired the preferential naturalisation of refugees that was inserted into the nationality law. The fourth Act on Nationality passed in 1993 made preconditions for naturalisation more restrictive but preferences based on ethnic and family ties were intended to compensate for this. ${ }^{16}$ Between 1989 and 1993 Hungary terminated bilateral agreements with former socialist states that excluded dual citizenship.

I994-2005: This period is marked by Hungary's accession efforts to the EU and by political debates on the status of ethnic Hungarians living outside Hungary's borders. During this time the Act on Nationality was amended three times, ${ }^{17}$ due to the ratification of the European Convention on Nationality (1997) and the UN Convention on Stateless

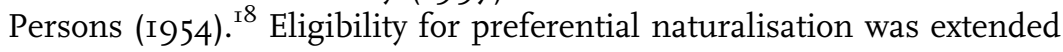
to EU citizens and a super-preference was adopted in favour of ethnic 
Hungarians in the shadow of the upcoming Schengen restrictions (Tóth 2003).

In the period under discussion there were three major breaks in basic principles. Although from 1879 onwards Hungary tolerated multiple nationality, between 1946 and 1989 the main rule was the exclusion of dual citizenship through bilateral agreements with socialist states. Mixed couples had to choose one of their nationalities for their child. After i989, the modified Constitution abolished the arbitrary deprivation of nationality. International principles of human rights relevant to nationality were inserted into the law, while a growing circle of preferences was defined as a core element of domestic legislation.

\subsection{Current nationality legislation}

\subsubsection{Current principles in nationality legislation}

The Constitution contains a guarantee relating to citizenship, i.e. the prohibition of its arbitrary deprivation (art. 69). Other rules are to be settled in legislation to be adopted by a two-thirds voting majority. The two-thirds rule, however, does not apply to the ratification of international agreements on citizenship.

The Nationality Act ensures the equality of rights of citizens. It guarantees that all citizens have identical legal standing irrespective of the legal title of acquisition of citizenship. The 1997 European Convention on Nationality obliges participating states to refrain from discrimination between their citizens, whether they are nationals by birth or have acquired nationality subsequently.

Discrimination is forbidden among Hungarian nationals, irrespective of the legal title under which their citizenship was granted. The Act contains only one exception with regard to withdrawal of citizenship which only applies to citizens by naturalisation.

The right to change citizenship is also included in the Nationality Act. Withdrawal of citizenship is an exception. The more common procedure is renunciation by a person who lives abroad and thus would presumably not become stateless. Measures aimed at the prevention of statelessness restrict the right of the individual to self-determination and the sovereignty of the state in accordance with the conventions of the UN and the European Convention. The only legitimate reason for the withdrawal of citizenship is if it was acquired in a manifestly fraudulent manner. Moreover, in the case of renunciation the person must prove that he or she has obtained another citizenship.

Domestic law ensures the granting of citizenship at birth by descent (ius sanguinis) while ius soli is applied as an auxiliary principle for abandoned or stateless children. The Act on Nationality supports family 
unity (with respect to legal status) by various preferences for the naturalisation of spouses and (adopted) minors. Refugees and stateless persons are also given priority for admission to citizenship. Hungarian regulations are special in granting preferential treatment to persons who are former Hungarian nationals and to ethnic Hungarians in the process of acquiring citizenship.

Hungary tolerates multiple citizenship, and the state strives to create rules and enter into agreements to avoid conflicts between different legal systems. A person acquiring Hungarian nationality by naturalisation need not renounce his or her prior citizenship. The circle of bilateral agreements and the European Convention regulate several legal relationships with respect to persons of multiple citizenship (e.g. with regard to military service or taxation). Furthermore, those having another citizenship are entitled to the same rights and obligations in the territory of Hungary as other nationals, with the exception of employment in the police or security services (Tóth 2004b). On the other hand, the principle of genuine link ${ }^{\mathrm{I} 9}$ requires a factual, effective and close relationship between Hungary and the applicant for naturalisation or other modes of acquiring citizenship, regardless of his or her existing other citizenship. However, for those in possession of Hungarian nationality and living abroad the genuine and effective link to Hungary is irrelevant. Since I929, millions of (lawful) emigrants and their descendants have preserved their Hungarian nationality despite acquiring a second or third nationality, and despite the absence of close relations, or cultural and ethnic affiliation to Hungary.

Hungarian citizenship shall be certified with a valid document (identity card, passport, citizen's certificate). In case of doubt it will need to be either attested by the authorities or a certificate issued. Upon request, the responsible minister issues a certificate on the existence of citizenship or its cessation, or verifies that the person concerned has never been a Hungarian national. The certificate is valid for one year from the date of issuance. The certificate's contents may be contested before the Municipal Court by the person concerned, his or her lawful representative, the public prosecutor as well as the person's guardian. ${ }^{2 \circ}$

The regulatory principles and essence of the citizenship system in Hungary are in harmony with international legal norms. Hungary is a signatory to all important conventions that define the framework of the development of the law. However, some shortfalls in procedural guarantees are still apparent.

\subsubsection{Current modes of acquisition and loss of nationality}

There are seven legal titles of acquisition of Hungarian nationality with different requirements: 
I. The child of a Hungarian national obtains Hungarian citizenship by birth (ius sanguinis) regardless of the place of birth.

2. The child of a stateless immigrant in possession of a permanent residence permit or an abandoned child of unknown parents shall be considered as a Hungarian national unless or until this presumption is rebutted (e.g. when he or she obtains a foreign citizenship due to the clarification of his or her parent's identity and nationality). There is no time limit for rebuttal; presumption of Hungarian nationality on the basis of ius soli is therefore conditional.

3. Hungarian nationality of exiled nationals who were deprived of their nationality between I945 and I990 shall be restored upon request. A declaration addressed to the President of the State reinstates the nationality of the exiled national immediately when it is made. Acquisition of nationality is also possible by declaration in case the applicant was born in Hungary and has not acquired another nationality through his or her parent by birth, provided that at the time of the person's birth he or she resided in Hungary, he or she has lived without interruption in Hungary for a period of at least five years by the time of submission of the declaration and he or she is not older than nineteen years. Another ground for acquisition applies if the applicant was born from a Hungarian national mother and a foreign father before I October 1957 and did not become a Hungarian national by birth.

4. Presumptive paternity ensures nationality by law for a child born out of wedlock if a parent who declares paternity or a judgement recognises paternity/maternity, or if the parents marry subsequently (family law facts).

5. Upon request the restitution of citizenship is ensured if the applicant could not obtain a new citizenship within one year of his or her renunciation of Hungarian citizenship.

6. Naturalisation implies a long procedure and is conditional on various preconditions. Basic, non-preferential cases of naturalisation shall meet all of the following requirements:

- permanent residence in Hungary for eight years in possession of a permanent residence permit or EEA citizens' residence permit,

- clean criminal record and no current criminal proceedings,

- proven means of stable livelihood and residence in Hungary,

- naturalisation must not violate national interest of the state, and

- successful examination taken on basic constitutional issues in the Hungarian language. If the applicant attended a Hungarian language primary or secondary school or university either in Hungary or in another state, he or she is exempt from the exam. The requirements for preferential naturalisation differ from basic ones as follows: 
- The permanent residence requirement is reduced to five years if the applicant was born on Hungarian territory or has established residence in Hungary before reaching legal age or is stateless.

- The permanent residence requirement is reduced to three years, if the applicant has been married to a citizen for three years, or he or she has a minor child who is a Hungarian citizen, or if the applicant has been adopted by a Hungarian citizen or is an officially recognised refugee.

- There is a permanent residence requirement if any of the applicant's ascendants was a Hungarian national and he or she declares himself or herself to be an ethnic Hungarian.

The permanent residence requirement can also be waived

- in the case of the extension of naturalisation to a minor child, i.e. if the applicant is a minor and his or her application was submitted along with that of a parent who qualifies for naturalisation,

- if the applicant is a minor and has been adopted by a Hungarian citizen,

- if the President of the State or the Minister of Foreign Affairs determines that the applicant's naturalisation is of 'overriding interest' to the Republic of Hungary (for instance, if he or she is a top-level artist, athlete, or scientist). The proven means of stable livelihood and residence of the applicant can also be waived by the President of the State.

7. Requirements for re-naturalisation include a permanent residence permit of the applicant whose nationality has ceased, a clean criminal record and no current criminal proceedings, proven means of stable livelihood and residence in Hungary, and the assurance that his or her naturalisation does not violate Hungarian national interests.

Loss of nationality shall be based on

1. Renunciation: A national residing abroad may renounce his or her nationality if he or she possesses another nationality or relies on the probability of its acquisition.

2. Withdrawal: Hungarian nationality may be withdrawn only if a person who has acquired nationality by naturalisation has violated the law on nationality, in particular by misleading the authorities by submitting false data or omitting data or facts. In practice, however, there have not been actual cases in which this provision would have been applied to persons that would have become stateless as a result. Ten years after naturalisation, Hungarian nationality may no longer be withdrawn. 


\subsection{Current political debates on (dual) citizenship}

\subsubsection{The Hungarian Status Law and the referendum on dual citizenship}

Minority protection for ethnic Hungarians and nation building has inspired debate in contemporary Hungary. There are numerous ramifications of the political discussions on legal development but we will describe only two aspects briefly here and give a concrete example in order to highlight the interrelations between nationality law, migration law, external relations, European integration and nation building.

Although the list of states and criteria for visa obligations became part of Community control, bilateral agreements on visa-free travelling were maintained up to Hungary's accession to the EU. Issuing visas, including a national visa (in the terminology of the Schengen regime), has just been reformed in favour of Hungarian minorities living in adjacent third countries. In 2006 a visa allowing its holder to stay in Hungary and a multi-entry visa for ethnic Hungarian visitors has been introduced. This visa may be issued for five years to a foreign applicant who is capable of sustaining himself or herself, and wishes to use his or her stay in Hungary for practising the Hungarian language and cultural activities. Under this visa, employment or study in Hungary is not allowed. The text of the visa agreements is neutral but there are plans to reform them to reflect certain ethno-national priorities towards Romania, Ukraine and Serbia-Montenegro. ${ }^{2 \mathrm{I}}$ In brief, the visa policy intends to secure the possibility for individuals belonging to the Hungarian external kin-minorities to freely visit and enter Hungary in order to compensate for Community law and security requirements (Tóth 2004b).

The Act on Benefits for Ethnic Hungarians living in Neighbouring States of Hungary (usually called the Status Law) was adopted in 200I after stormy political debates. It introduced a specific certificate for ethnic Hungarians living in Slovakia, Romania, Ukraine, Slovenia, SerbiaMontenegro and Croatia. Because of constitutional inconsistency and international protests (Kántor 2004), the law was modified in 2003 ending some of the individual benefits (employment, social insurance and public health) that were available in Hungary to holders of the Ethnic Hungarian Certificate (identity card). ${ }^{22}$ In December 2004, another support system (Homeland Fund) for community building was adopted. ${ }^{23}$ Naturally, this set of direct ethnically-based assistance by diaspora law (Tóth 2000) can legalise and inspire migratory movements toward Hungary.

On 5 December 2004, Hungary held a referendum on whether it should offer Hungarian citizenship to Hungarians living outside the borders of the Hungarian state. ${ }^{24}$ The novel aspect of the proposal was not the introduction of dual citizenship itself, since the option of ob- 
taining a Hungarian second citizenship had long been available for permanent residents within the country. The innovation would have been to remove all residency requirements from the pre-conditions for obtaining a Hungarian second citizenship. Ethnic Hungarians in neighbouring states, and possibly living elsewhere, were to be granted the opportunity of obtaining Hungarian citizenship merely by declaring themselves as of Hungarian linguistic affiliation, at a Hungarian consular office, or if they hold a Hungarian Certificate, confirming their Hungarian nationality. The proposal was thus directed at external coethnic minorities living in neighbouring states and at members of the Hungarian diaspora elsewhere in the world.

The text of the referendum question was as follows: 'Do you think that Parliament should pass a law allowing Hungarian citizenship with preferential naturalization to be granted to those, at their request, who claim to have Hungarian nationality, do not live in Hungary and are not Hungarian citizens, and who prove their Hungarian nationality by means of a "Hungarian Identity Card" issued pursuant to Article I9 of Act LXII of 200I or in another way to be determined by the law which is to be passed?'25

Although the referendum question left the criteria of eligibility open for future lawmaking, an approximation of potentially eligible claimants can be made on the basis of the size of the Hungarian population in the neighbouring states numbering around three million. ${ }^{26}$ Assuming that the majority of those made eligible by the reform would actually claim citizenship, the proportions of the resulting change would exceed the growth of Germany's citizenry after unification, but of course, without the corresponding territorial enlargement. This then points to the second specificity of the Hungarian situation, namely that the dimensions of Hungary's kin-minority problem are unusually large even for Europe. Nearly a quarter of all ethnic Hungarians live outside Hungary's borders in neighbouring states.

Political debates on the referendum within Hungary were tremendously polarised. Indeed, in 2003 , the initiative to call a referendum had not come from within the Hungarian political establishment, but from a radical and somewhat marginal organisation not well integrated into Hungarian politics, the World Federation of Hungarians (Debreczeni 2004). ${ }^{27}$ The Federation had contested the policies of the Hungarian Government on citizenship matters for years and had also set itself on a collision course with the more moderate Hungarian minority parties across the borders, especially when it mounted opposition against the Orbán Government's (1998-2002) efforts, supported by external Hungarian minorities, to provide an alternative solution to dual citizenship through the creation of the Status Law of 200I. ${ }^{28}$ The law established the certificate for ethnic Hungarians living in neighbouring 
states, ${ }^{29}$ entitling its beneficiaries to a set of cultural and economic rights, including seasonal working permits in Hungary. However, the Federation insisted that the benefits provided by the law were no substitute for what the Hungarians really needed, which was full Hungarian citizenship..$^{30}$

The Status Law provoked angry response in neighbouring states (see Kusá and Iordachi in this volume). Hungary was accused of irredentist nationalism, of creating a 'veiled form of dual citizenship', the ultimate effect of which was to call the sovereignty of the neighbouring states into question. Hungary was also criticised by the European Union for the unilateral adoption of the law, for not having consulted the states in question, and for the extraterritorial aspects of the law. But despite this negative response, the World Federation of Hungarians insisted that Hungary must proceed with the unilateral creation of non-resident trans-border citizenship for ethnic Hungarians. ${ }^{3 \mathrm{I}}$ Responding to arguments that such a step would not be compatible with the terms of Hungary's accession to the Union, in the spring of 2003, the federation called on Hungarian voters to say 'no' to Hungary's accession. Hungary should only join the EU if it could take trans-border Hungarians into the Union even if the state in which they live remains outside of it (Csergo \& Goldzeiger 2004). So, in October 2003, the Federation began collecting signatures for a referendum on establishing non-resident citizenship for trans-border Hungarians.

This points then to the third specificity of the Hungarian story, namely that the initiative for citizenship reform came from outside the Hungarian political establishment. Only this feature can explain the puzzle of why any political actor would take the risk of launching an initiative that has only limited support within Hungary itself and therefore carries the prospect of its own defeat.

Initially, mainstream Hungarian parties on all sides reacted very cautiously to the initiative, along with the more moderate groups of transborder minorities. Only after a few months did the mainstream rightwing parties (FIDESZ and MDF) along with the President of the Republic declare their support for the referendum, while the socialists and liberals turned against it. ${ }^{32}$ What followed was an agitated, occasionally hysterical, campaign leading up to the referendum that fulfilled the prophecy of its own failure ending up invalid on account of the low number of participants. Eventually, 63.33 per cent of the eligible voters stayed away from the referendum. Among those who cast their ballots, 51.57 per cent voted in favour of the reform, 48.43 per cent against. ${ }^{33}$

No research is available on the question of what precisely motivated Hungarian voters in their choices. Welfare protectionism could well have played a role, given the fact that, apart from Slovakia, the living 
standards of trans-border Hungarians are way below those of Hungarians, and that the arguments of the Socialist Party against dual citizenship relied primarily on the costs of the reform. An equally important motive may have been the fear of instability at the borders resulting from conflicts with Hungary's neighbours. Voters may also have been influenced by the perception that dual citizenship would eventually lead to voting rights. What is sufficiently clear, however, is that, at least for now, trans-border dual citizenship could only be created in Hungary without the popular mandate of the Hungarian electorate, the mandate that the supporters of the initiative had hoped to obtain in the referendum. To quote one liberal opponent of the initiative (Kis 2004a: 4): 'The offer was made to a nation of ten million to enlarge its homeland beyond the state-borders to the entire Carpathian basin. The nation refused to take the risk and accept the costs.'

But given the enormous disappointment of trans-border Hungarians with the result, the issues raised during the campaign will remain on the agenda of Hungarian politics for quite some time to come.

\subsubsection{Implications of trans-border dual citizenship}

The arguments for the Hungarian trans-border dual citizenship initiative are fundamentally different from those advanced in favour of dual citizenship in the major immigration states of Western Europe. In the immigration states dual citizenship is an instrument used to integrate labour migrants into their country of immigration. Dual citizenship in this case works towards the decoupling of citizenship from ethnicity. In contrast, the Hungarian initiative is part of a counter-trend present in a number of European countries of re-linking citizenship with ethnicity.

The Hungarian suggestion associates eligibility for extraterritorial dual citizenship with membership in an ethnically defined community. Dual citizenship would thus purposefully reaffirm the connection between ethno-cultural nationality and citizenship, which is precisely the connection that most immigration states have been trying to weaken when tolerating dual citizenship (Fowler 2002).

Advocates of the reform wish to overcome this difficulty by presenting their plan as based on a traditional ius sanguinis concept rather than on ethnicity. In this view, trans-border citizenship is not something that would be newly granted to ethnic Hungarians. Trans-border Hungarians would only 'regain' the citizenship of their ancestors who had been citizens of the Hungarian part of the Dual Monarchy before the First World War. ${ }^{34}$ However, there are several difficulties with this approach (Nagy 2004). ${ }^{35}$

The first difficulty is political. After the First World War, those Hungarians who ended up as minorities in neighbouring states were ob- 
liged by the Peace Treaties to opt for the citizenship of their new home state, or, if they declined to do so, to move to Hungary. Therefore, in the eyes of Hungary's neighbours, any unilateral change in the citizenship status of minority Hungarians would amount to a unilateral breach of treaty obligations, to a revision of the terms of the peace treaty that still serves as the basis of international legitimacy for the current borders of these states. It was for a similar reason that the Italian law of 2000 that offered Italian citizenship to the Italian diaspora did not extend this offer to the descendants of Italians in Dalmatia, Istria and Fiume, i.e. those regions that were ceded by Italy to Yugoslavia in the post-war treaties.

Second, trans-border populations whose ancestors bore the citizenship of a larger Hungarian state in the Dual Austro-Hungarian Monarchy before the First World War include millions of non-Hungarians. So, even if the ius sanguinis view was applied, the only way to narrow down eligibility for Hungarian dual citizenship to those with a Hungarian ethno-cultural affiliation would be to apply an ethnic definition.

A third feature of dual citizenship that emerged from the referendum initiative was the potentially weak distinction between active and inactive citizenship for dual citizens. In most immigration states, transnational dual citizenship implies that only the citizenship of the current country of residence is active, so that the rights associated with the external citizenship are dormant (Faist 2005). However, in the case of Hungarian trans-border citizenship such clear-cut distinctions between periods of active and inactive citizenship would be hard to make (Vizi 2003). ${ }^{36}$ Therefore, with regard to the potential content of non-resident trans-border citizenship, the general perception that has emerged in Hungary is that even if dual citizenship would initially be created without voting rights, it would only be a matter of time before large numbers of trans-border voters would begin casting their ballots. In view of these implications, it is hardly surprising that the proposal created passionate debates both within Hungary and among the Hungarian minorities in the neighbouring states. For many participants the question at stake was whether Hungary should experiment with ideas that are pulling it away from, rather than bringing it closer to "mainstream' Europe. As János Kis summarised it, the victory of the 'yes' votes would mean nothing less than putting Hungarian parliamentarianism in danger and transforming the nature of Hungarian democracy. Since elections in Hungary are usually won by a narrow margin, the appearance of trans-border voters would most likely mean that 'the outcome of Hungarian elections would regularly be decided by voters who do not pay taxes in Hungary and who are, in general, not subject to its laws'. A further element of 'organised irresponsibility' inherent in such a solution would be that those casting the swing votes may be 
people who had never even lived in Hungary so that their political choices would be made on a highly selective image of issues and candidates. For all these reasons, he concluded, "the victory of "yes votes" would pull us back to the murky nationalism of past ages, it would lock up Hungarian politics in the prison of revisionist nostalgia, it would poison public life within Hungary as well as our relationship with neighbouring states and with trans-border Hungarians, and it would damage the level of our acceptance within the European Union' ${ }^{37}$

In stark contrast to the liberals, advocates of the initiative argued that their proposal is modelled on concepts and processes that are part and parcel of an integrated Europe of the future, a de-territorialised world in which individuals with multiple identities are entitled to a legal expression of the free choice of their nationality. Advocates argued that all European states accept ethnicity as part of the basis of citizenship, most even making provisions for the acquisition of benefits, including citizenship, for co-ethnics who are citizens of another state. The problem with European norms and practices, they argued, is not that there is no connection between ethnicity and citizenship but that Europe is in a process of denial about this connection, treating ethnicity as though it was a disreputable relative on whom we rely secretly, but whom we hide from others (Schöpflin 2004). They pointed to plans or existing legislation on non-resident citizenship for co-ethnic kin within the European Union in Italy, Greece, Slovakia and the Czech Republic. A particularly relevant example is Silesian Germans who, from the early I990s, were able to obtain German passports in addition to their Polish ones and, by implication, European citizenship, without having to take up residence in Germany. These precedents, they argued, point to the legitimacy, even within the core nations of the European Union, of using dual citizenship for the inclusion of trans-border co-ethnics in the citizenry of the homeland.

Liberal opponents challenged this interpretation of larger European processes and insisted that the EU would regard the ethnicist turn in Hungarian legislation as a breach of common principles laid down in European agreements (Tóth 2004c). ${ }^{38}$ Secondly, they criticised the confrontational attitude towards Hungary's neighbours promoted by this policy. The problem with unilateral action is not so much that it violates international law, but that it is self-defeating. To quote the above mentioned newspaper article by János Kis again: The unilateral creation of Hungarian citizens in the territory of other states is nothing but a 'mirage' that provokes 'phony wars over phony questions and phony answers'.

Thirdly, opponents argued, that the creation of dual citizenship cannot be justified by reference to the approval by trans-border minorities either, because these groups are themselves divided over the issue and 
do not speak with a single voice. ${ }^{39}$ In the end, any unilateral move by Hungary to create dual citizenship would remain 'a game of illusions played between Hungarian nationalists and a minority within the Hungarian minority' in a useless, but 'ritual display of imagined political togetherness' (Kis 2004b).

Fourthly, critics objected that dual citizenship is incompatible with claims of autonomy raised by trans-border minorities. ${ }^{40}$ Concurring with Rainer Bauböck they maintained that parallel 'claims of multiple citizenship and territorial autonomy should be seen as mutually incompatible. They would create fears in the host society about irredentist threats to its territorial integrity that cannot be easily dismissed as unreasonable' (Bauböck 2006: I59-I60).

Therefore, according to the socialists and the liberals, Hungary must take a new look at its homeland policies regarding kin-minorities. The discourse advocated by the two mainstream right-wing parties aims at recreating a 'unitary Hungarian nation' over and above existing stateborders by means of creating legal bonds between parts of the Hungarian nation living in several countries (Stewart 2004). Hungary should step back from this confrontational approach because it relies on outright ignorance about the sensitivities of other states. Instead, it should clearly articulate its policies in the conceptual framework of minority protection. Hungary must accept that trans-border Hungarians are the citizens of other states and should promote the protection of Hungarian minorities in their efforts to secure equal individual and collective rights in their home states.

Finally, there are obvious ambiguities in the arguments of both sides in the debate. The idea of dual citizenship emerged in Hungary with reference to a larger international trend of increasing toleration of dual citizenship, partly within the European Union and partly within the East-Central European region. However, while in the immigration states of Europe the idea of dual citizenship is not associated with nationalist policies, in Hungary, as in many other states of the region, the demand for dual citizenship has mostly migrated to the nationalist right. In the Hungarian referendum debate, the battle over dual citizenship has been cast as a debate between the nationalist right as supporters, on the one hand, and the Europe-oriented liberals, as opponents, on the other. However, this representation of the debate is, to some extent, self-made and arbitrary. In fact, in their support of dual citizenship the nationalists have mainly been drawing on the arguments of European liberals. At the same time, liberals relied on counter-arguments they claimed to have extrapolated from relevant European norms and practices, but these practices are much too diverse to form the basis of a coherent interpretation. Unsurprisingly, by the end, both sides failed to present a fully convincing, coherent interpretation of 
those international norms and practices that would support their respective positions. In the final analysis it is quite possible that the conflicting stances of the two sides in the debate may stem from concerns that are only remotely connected to the problems of trans-border Hungarians, namely from conflicting opinions, and concerns about the long-term stability of Hungary's transitional democracy. After all, parliamentary practices have not been firmly established in Hungary for much more than a decade. Yet, in the Hungarian context, the creation of trans-border non-resident dual citizenship would most likely amount to a mass enfranchisement of a new electorate that, similar to all episodes of mass enfranchisement in the past, would introduce new uncertainties into the system and could lead to an internal destabilisation of Hungarian democracy itself. In this respect, both sides share the same intuition, namely that if instituted, trans-border citizenship would most likely have the effect of freezing the regular rotation of parliamentary forces for some time to come in favour of the nationalist right: a prospect that is as welcome on one side as it is feared on the other.

\subsection{Trends in statistics}

Data on trends of acquisition and termination of citizenship is information of public interest. ${ }^{4 \mathrm{I}}$ Nevertheless relevant data is only partially available and in more detail only since 200I. Available data contain numbers on naturalisation, re-naturalisation and on the termination of nationality. Between I958 and I984 there were more cases of emigration than immigration (Tóth I997), and the total number of naturalised and re-naturalised persons was 16,156 while at least 24,082 left the country. The yearly average of naturalisations and re-naturalisations was 622 while the average terminations of nationality was 926. During this time there was no change in citizenship law, so it is only by examining legal and political practices that we can find an explanation for the growth in the rate of nationality loss after i967. A substantial proportion of removal-upon-request came from female Hungarian spouses marrying husbands from European states that prohibited dual citizenship.

Between 1985 and 1989 , the number of terminations was even higher than the number of naturalisations and re-naturalisations, but the difference between them decreased. The major groups of applicants for naturalisation were from the adjacent and socialist states (Romania, Czechoslovakia, Soviet Union and East Germany) while the direction of emigration/marriage migration was towards Austria and Yugoslavia. 
Table 5.1 Number of naturalisations and re-naturalisations as well as terminations of nationality in Hungary, 1985-1994

\begin{tabular}{|c|c|c|c|c|}
\hline \multirow{2}{*}{$\frac{\text { Year }}{1990}$} & \multicolumn{2}{|c|}{ Naturalisation/Re-naturalisation } & \multicolumn{2}{|c|}{ Removal/Renunciation } \\
\hline & & 3,170 & & 1,184 \\
\hline & Czech/Slovak & 63 & Czech/Slovak & 2 \\
\hline & Yugoslav & 21 & Yugoslav & 18 \\
\hline & Austrian & 11 & Austrian & 169 \\
\hline & Romanian & 2,661 & Romanian & 1 \\
\hline & Soviet & 156 & Soviet & 1 \\
\hline & East German & 35 & East German & 70 \\
\hline & Non-European & 96 & Non-European & 1 \\
\hline \multirow[t]{8}{*}{1991} & & 5,893 & & 441 \\
\hline & Czech/Slovak & 25 & Czech/Slovak & 2 \\
\hline & Yugoslav & 22 & Yugoslav & 3 \\
\hline & Austrian & 18 & Austrian & 80 \\
\hline & Romanian & 5,114 & Romanian & - \\
\hline & Soviet & 306 & Soviet & - \\
\hline & Stateless & 13 & & \\
\hline & Non-European & 186 & Non-European & 1 \\
\hline \multirow[t]{8}{*}{1992} & & 21,880 & & 1,149 \\
\hline & Czech/Slovak & 249 & Czech/Slovak & 7 \\
\hline & Yugoslav & 1 & Yugoslav & 3 \\
\hline & Austrian & 7 & Austrian & 211 \\
\hline & Romanian & 20,624 & Romanian & - \\
\hline & Ex-Soviet & 569 & Ex-Soviet & - \\
\hline & Stateless & 7 & & \\
\hline & Non-European & 60 & Non-European & 3 \\
\hline \multirow[t]{8}{*}{1993} & & 11,521 & & 2,084 \\
\hline & Czech/Slovak & 55 & Czech/Slovak & 5 \\
\hline & Yugoslav & 309 & Yugoslav & - \\
\hline & Austrian & 20 & Austrian & 314 \\
\hline & Romanian & 9,956 & Romanian & - \\
\hline & Ex-Soviet & 843 & Ex-Soviet & - \\
\hline & Stateless & 7 & & \\
\hline & Non-European & 75 & Non-European & 3 \\
\hline \multirow[t]{8}{*}{1994} & & 9,238 & & 1,688 \\
\hline & Czech/Slovak & 40 & Czech/Slovak & 7 \\
\hline & Yugoslav & 888 & Yugoslav & - \\
\hline & Austrian & 1 & Austrian & 346 \\
\hline & Romanian & 6,254 & Romanian & 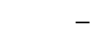 \\
\hline & Ex-Soviet & 1,730 & Ex-Soviet & - \\
\hline & Stateless & 1 & & \\
\hline & Non-European & 120 & Non-European & 2 \\
\hline Total 1985-1994 & & 55,409 & & 11,492 \\
\hline Yearly average 1985-1994 & & 5,541 & & 1,149 \\
\hline
\end{tabular}

Source: www.bmbah.hu

Since 1990, the number of naturalisations has increased. This is not only due to the larger number of ethnic Hungarian applicants but also to the changing interpretation of the legal rules in force. The constitu- 
tional reform, aimed at establishing rule of law, influenced the practice of the Ministry of the Interior. If an applicant met the legal requirements the discretionary power of naturalisation had to be interpreted such that a positive decision on naturalisation was to be granted by the President. However, this practice of 'self-limitation' could not compensate for the more restrictive preconditions of naturalisation adopted by the Act on Hungarian Nationality in I993. The number of non-European applicants is growing, but has still remained marginal since the I990s.

Table 5.2 Distribution of nationality law cases in Hungary, 1998-2008

\begin{tabular}{|c|c|c|c|c|c|c|c|c|c|c|c|}
\hline & 1998 & 1999 & 2000 & 2001 & 2002 & 2003 & 2004 & 2005 & 2006 & 2007 & 2008 \\
\hline $\begin{array}{l}\text { Applications for } \\
\text { naturalisation/ } \\
\text { re-naturalisation }\end{array}$ & 3,593 & 3,160 & 3,963 & 4,282 & 4,282 & 4,453 & 4,916 & 5,761 & 9,127 & 5,437 & 4,143 \\
\hline \multicolumn{12}{|c|}{ Applicants with citizenship (\%): } \\
\hline Romania & & & & & 61 & 60 & 63 & 69.8 & 69.8 & 73.2 & 60 \\
\hline Yugoslavia/Serbia & & & & & 17 & 15 & 13 & 9.5 & 5.8 & 8.9 & 12 \\
\hline Ukraine & & & & & 11 & 15 & 13 & 8.5 & 8.8 & 9.2 & 15 \\
\hline Other European & & & & & 6 & 14 & 14 & 9.2 & 11.8 & 5 & 3 \\
\hline Non-European & & & & & 5 & 5 & 3 & 2.5 & 3.3 & 3.2 & 7 \\
\hline Stateless & & & & & 1 & 1 & 1 & 0.5 & 0.5 & 0.5 & 0.5 \\
\hline $\begin{array}{l}\text { Naturalised and } \\
\text { re-naturalised persons }\end{array}$ & 6,203 & 6,203 & 7,538 & 5,934 & 3,890 & 5,579 & 5,667 & 9,981 & 6,564 & 9,398 & 8,132 \\
\hline $\begin{array}{l}\text { Applications for } \\
\text { re-obtaining nationality } \\
\text { upon declaration of } \\
\text { expatriation, prior } \\
\text { nationals (persons) }\end{array}$ & 232 & 200 & 208 & 194 & 212 & 151 & 144 & 136 & 104 & 85 & 68 \\
\hline $\begin{array}{l}\text { Applications for } \\
\text { certificate of existing } \\
\text { nationality (persons) }\end{array}$ & 3,934 & 4,264 & 3,935 & 3,924 & 4,401 & 4,803 & 5,984 & 5,482 & 4,121 & 4,276 & 4,958 \\
\hline $\begin{array}{l}\text { Reinstatement of } \\
\text { nationality (persons) }\end{array}$ & - & - & - & 1 & 1 & 2 & 1 & o & o & o & o \\
\hline $\begin{array}{l}\text { Applications for } \\
\text { renunciation of } \\
\text { nationality (cases) }\end{array}$ & 893 & 728 & 748 & 684 & 609 & 463 & 189 & 135 & 126 & 82 & 69 \\
\hline $\begin{array}{l}\text { Accepted renunciations of } \\
\text { nationality (persons) }\end{array}$ & 1,070 & 995 & 955 & 791 & 857 & $n / a$ & 236 & 164 & 137 & 98 & 107 \\
\hline
\end{tabular}

Note: $\mathrm{n} / \mathrm{a}=$ not available

Source: www.bmbah.hu

Over the past number of years Hungary has become an immigration country for large numbers of ethnic Hungarians and, increasingly for others coming from more distant regions. There are three major channels for immigrants to become nationals: (I) naturalisation, (2) prior nationals, mainly expatriates re-obtaining Hungarian nationality by de- 
claration or re-naturalisation, (3) expatriates or their descendants living abroad who can prove Hungarian citizenship through a verification procedure of existing citizenship (Certificate of Nationality). This restoration of legal ties with Hungary was made possible by political changes and new rules on rehabilitation and compensation for damages or harm committed against nationals by the socialist regime. Between I998 and 2008, the number of naturalised and re-naturalised persons was below the number of applicants for a citizenship card, which serves to certify the holder's Hungarian nationality. The ratio of naturalisation according to legal titles for the years 2002, 2007 and 2008 proves that preferential cases vastly outweigh non-preferential ones, which represented between 3 and 6 per cent of all cases (Table 5.3).

Table 5.3 Ratio of naturalisation decisions in Hungary in 2002, 2007 and 2008

\begin{tabular}{|c|c|c|c|c|c|c|c|}
\hline \multirow[t]{2}{*}{ Type of legal titles } & \multirow[t]{2}{*}{ Art. } & \multicolumn{2}{|c|}{2002} & \multicolumn{2}{|c|}{2007} & \multicolumn{2}{|c|}{2008} \\
\hline & & Total & $\%$ & Total & $\%$ & Total & $\%$ \\
\hline $\begin{array}{l}\text { No preference (basic } \\
\text { decision) }\end{array}$ & $4 \int(1)$ & 244 & 6.27 & 186 & 2.71 & 206 & 3.39 \\
\hline $\begin{array}{l}\text { Weak preference (applicant } \\
\text { was born in Hungary) }\end{array}$ & $4 \int(4) a$. & 3 & 0.0 & 90 & 1.31 & 70 & 1.15 \\
\hline $\begin{array}{l}\text { Weak preference (applicant } \\
\text { immigrated as minor to } \\
\text { Hungary) }\end{array}$ & $4 \int(4) b$. & 2 & 0.0 & 136 & 1.98 & 136 & 2.24 \\
\hline $\begin{array}{l}\text { Medium preference } \\
\text { (applicant's spouse is } \\
\text { Hungarian national) }\end{array}$ & $4 \int(2) a$. & 325 & 8.35 & 402 & 5.87 & 380 & 6.26 \\
\hline $\begin{array}{l}\text { Medium preference } \\
\text { (applicant's minor child is } \\
\text { Hungarian national) }\end{array}$ & $4 \int(2) b$. & 49 & 1.25 & 123 & 1.79 & 118 & 1.94 \\
\hline $\begin{array}{l}\text { Medium preference } \\
\text { (applicant is a recognised } \\
\text { refugee) }\end{array}$ & $4 \int(2) d$ & 17 & 0.4 & 43 & 0.62 & 22 & 0.36 \\
\hline $\begin{array}{l}\text { Strong preference (applicant } \\
\text { is a minor) }\end{array}$ & $4 \int(5)$ & 9 & 0.2 & 27 & 0.39 & 11 & 0.18 \\
\hline $\begin{array}{l}\text { Strong preference (applicant } \\
\text { is a minor adopted by a } \\
\text { national) }\end{array}$ & $4 \int(6)$ & 30 & 0.7 & 4 & 0.05 & 7 & 0.11 \\
\hline $\begin{array}{l}\text { Strong preference (applicant } \\
\text { is an ethnic Hungarian) }\end{array}$ & $4 \int(3)$ & 2,447 & 62.9 & 5,158 & 75.33 & 4,713 & 77.66 \\
\hline Re-naturalisation & $5 \pi$ & 764 & 19.6 & 676 & 9.87 & 403 & 6.64 \\
\hline Total & & 3,890 & 100.0 & 6,845 & 100.0 & 6,066 & 100.0 \\
\hline
\end{tabular}

Source: www.bmbah.hu

Table 5.3 indicates that, beyond the ethnic immigration from the Carpathian basin, family reunification and repatriation of prior nationals have added the largest numbers of new nationals. 


\subsection{Conclusions}

In Hungary, the term 'nation' is interpreted and used in law as a concept referring to membership in the cultural, ethnic and linguistic community. But the substance of the term remains indefinable by law. This reveals contradictions between existing laws and the Constitution. On the one hand, art. 6 of the Constitution refers to the kin-state's responsibility for kin-minorities living across the borders. However, the definition of membership in the minority or ethnic community is vague, and various preferential provisions legally discriminate against certain categories of people despite the fact that the state is party to dozens of international treaties aimed at avoiding such discrimination. Furthermore, minorities living in Hungary are distinct participants in the state, in possession of subjective and collective constitutional rights, although, in their case as well, membership of a specific ethnic or national entity cannot be defined. Due to this problem neither statistics on membership of minorities living in Hungary, nor hard data on immigrants entering Hungary and enjoying legal preferences in the country are available. According to Rainer Bauböck, "[h]istoric traditions and the distinction between ethnic and civic nationhood are increasingly irrelevant for explaining legislative changes'.$^{42}$ Despite a standard level of immigration, in the case of Hungary Bauböck's suggestion is less evident than among the old EU Member States (Tóth \& Sik 2003). The recently failed referendum of 5 December 2004 on ex lege citizenship being granted to ethnic Hungarian minorities living in adjacent states is a case in point as it would have used ethnic preferences for granting non-resident citizenship to trans-border Hungarians. The role of nationality law in the integration process of migrants has not been discussed publicly and the need to harmonise Hungarian citizenship with that of other Member States of the European Union has not been put on the agenda.

Chronological list of citizenship-related legislation in Hungary

\begin{tabular}{|c|c|c|c|}
\hline Date & Document & Content & Source \\
\hline 1946 & $\begin{array}{l}\text { Act XV on Czech-Slovak- } \\
\text { Hungarian Agreement }\end{array}$ & $\begin{array}{l}\text { Deprives those who fall } \\
\text { under the bilateral } \\
\text { agreements on population } \\
\text { exchange of Hungarian } \\
\text { nationality }\end{array}$ & \\
\hline 1947 & $\begin{array}{l}\text { Government Decree } \\
12.200\end{array}$ & $\begin{array}{l}\text { Deprives expelled } \\
\text { Germans of Hungarian } \\
\text { nationality }\end{array}$ & \\
\hline 1947 & Act $X$ & $\begin{array}{l}\text { Deprives those who have } \\
\text { not returned to Hungary }\end{array}$ & \\
\hline
\end{tabular}




\begin{tabular}{|c|c|c|c|}
\hline Date & Document & Content & Source \\
\hline 1948 & $\begin{array}{l}\text { Act LX on Hungarian } \\
\text { Nationality }\end{array}$ & $\begin{array}{l}\text { following the conclusion of } \\
\text { the war of Hungarian } \\
\text { nationality } \\
\text { Like the previous Act of } \\
1879 \text {, is based on ius } \\
\text { sanguinis; provides for the } \\
\text { equal treatment of children } \\
\text { born out of wedlock; } \\
\text { stipulates that all nationals } \\
\text { residing abroad should be } \\
\text { registered; recognises the } \\
\text { pending Hungarian } \\
\text { nationality of } \\
\text { undocumented persons }\end{array}$ & \\
\hline 1949 & Constitution (excerpts) & & www.legislationline.org \\
\hline 1957 & $\begin{array}{l}\text { Act } \mathrm{V} \text { on Hungarian } \\
\text { Nationality }\end{array}$ & $\begin{array}{l}\text { Introduces the } \\
\text { emancipation of spouses; } \\
\text { includes executive rules, } \\
\text { such as the one requiring } \\
\text { emigrants to renounce } \\
\text { their nationality and social } \\
\text { insurance rights }\end{array}$ & \\
\hline 1989 & $\begin{array}{l}\text { Act XXXI amending the } \\
\text { Constitution of } 1949 \\
\text { (excerpts) }\end{array}$ & $\begin{array}{l}\text { Prohibits arbitrary } \\
\text { deprivation of nationality }\end{array}$ & \\
\hline 1993 & $\begin{array}{l}\text { Citizenship Act (Act LV of } \\
1993 \text { on Hungarian } \\
\text { Nationality) }\end{array}$ & $\begin{array}{l}\text { Provides that the } \\
\text { nationality of expatriate } \\
\text { nationals who have been } \\
\text { arbitrarily deprived of their } \\
\text { nationality is restored } \\
\text { upon request; includes } \\
\text { preferential naturalisation } \\
\text { of refugees and stricter } \\
\text { conditions for } \\
\text { naturalisation, but also } \\
\text { preferences based on } \\
\text { ethnic and family ties }\end{array}$ & $\begin{array}{l}\text { www.coe.int; } \\
\text { www.huembwas.org; } \\
\text { www.bmbah.hu/ } \\
\text { jogszabalyok.php } \\
\text { (in Hungarian) }\end{array}$ \\
\hline 1993 & $\begin{array}{l}\text { Government Decree 125/ } \\
1993 \text { on the Execution of } \\
\text { Act No. LV of } 1993 \text { on } \\
\text { Hungarian Nationality }\end{array}$ & $\begin{array}{l}\text { Defines formats and } \\
\text { procedural rules }\end{array}$ & $\begin{array}{l}\text { www.coe.int; } \\
\text { www.bmbah.hu/ } \\
\text { jogszabalyok.php } \\
\text { (in Hungarian) }\end{array}$ \\
\hline 2001 & $\begin{array}{l}\text { Legislation on Kin- } \\
\text { minorities (Act LXII of } \\
2001 \text { on Ethnic } \\
\text { Hungarians Living in } \\
\text { Neighbouring Countries) }\end{array}$ & $\begin{array}{l}\text { Introduces an identity card } \\
\text { for ethnic Hungarians; lists } \\
\text { allowances and benefits } \\
\text { granted to holders of such } \\
\text { cards (mainly in Hungary) }\end{array}$ & \\
\hline 2001 & $\begin{array}{l}\text { Act XXXII amending Act LV } \\
\text { of } 1993 \text { on Hungarian } \\
\text { Nationality }\end{array}$ & $\begin{array}{l}\text { Allows ethnic Hungarians } \\
\text { to have the family and } \\
\text { given name in their } \\
\text { original ethnic language; } \\
\text { introduces facilitated }\end{array}$ & \\
\hline
\end{tabular}




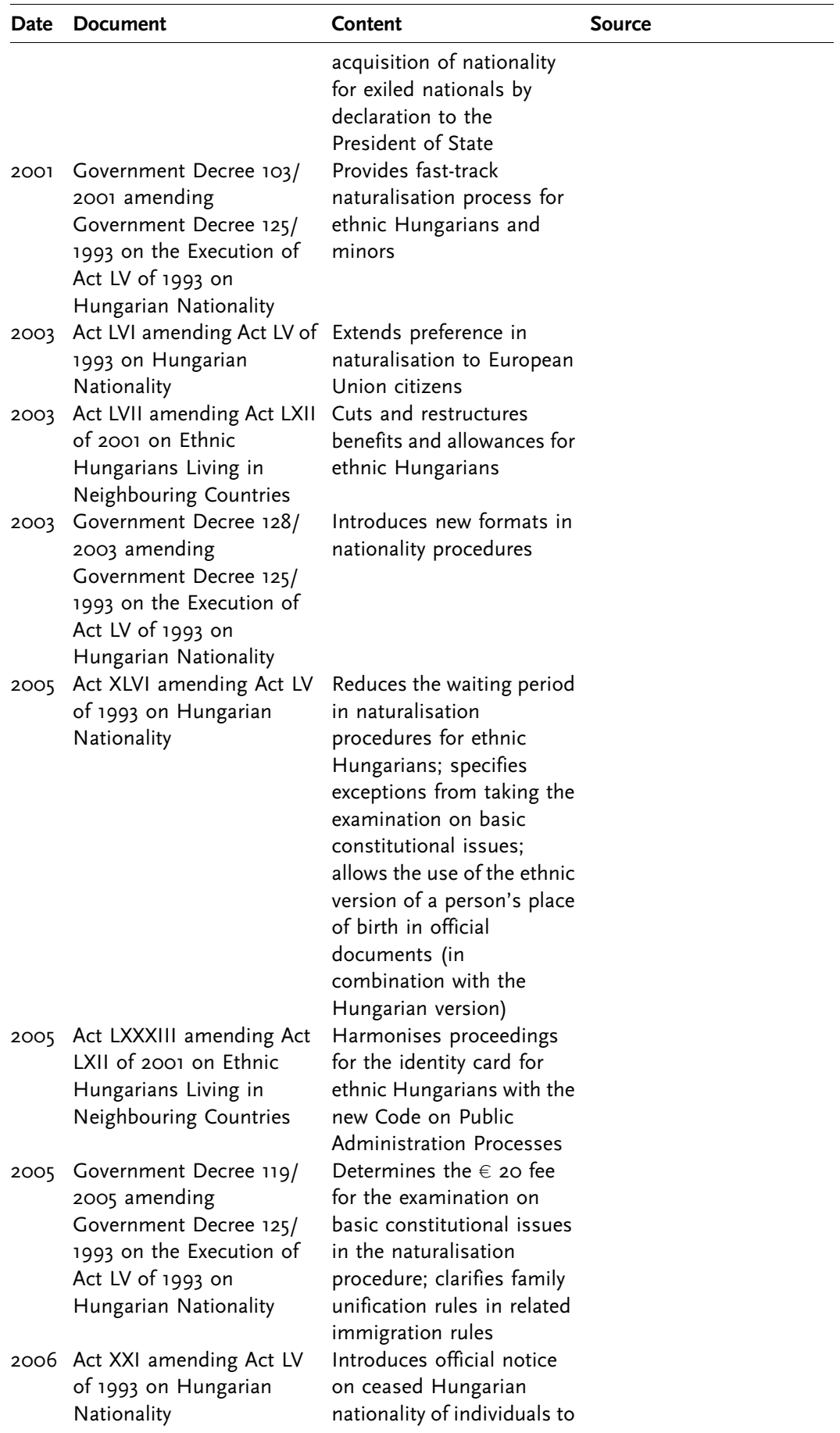




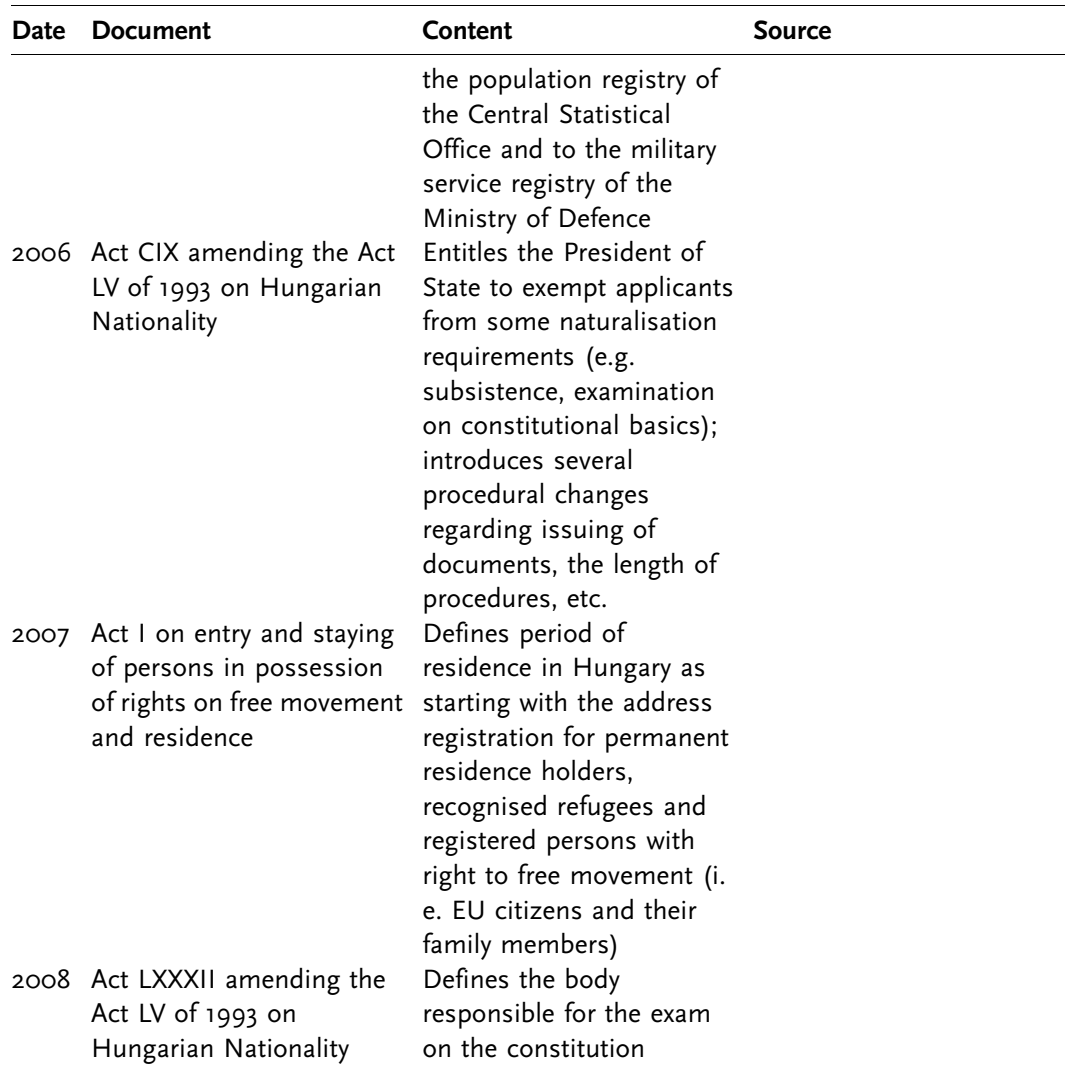

\section{Notes}

I Act LVI of 2003 amending Act LV of 1993 on Hungarian Nationality. It entered into force with the accession of Hungary to the European Union on I May 2004.

2 Act XXXII of 200I amending Act LV of I993 on Hungarian Nationality, Government Decree No. I25 of 22 September 1993, Decree of the Minister of the Interior No. 6 of 7 March 2003.

3 Concluded in Moscow on 20 January 1945 and published in Act V of I945.

4 The Peace Agreement was concluded in Paris and published in Act XVIII of I947. It entered into force by Government Decree II.80o of I947.

5 See details in Czech-Slovak-Hungarian Agreement published in Act XV of 1946 and Government Decree I2.200 of 1947 .

6 In particular, Act X of 1947 and Act XXVI of I948.

7 For instance, Prime Minister Decree 9.590 of 1945.

8 Act XXIX of 1946.

9 Act LX of 1948. 
Io Published in Law-Decree No. 2 of 1960.

II Act $\mathrm{V}$ of 1957 .

I2 Law-Decree No. II of 1955, No. 7 of 1956 , No. II of 1956; Ministerial Decree of the Interior 2 of II January 1956.

I3 Act XXXI of 1989 introduced a substantially new Constitution but formally it was only an amendment.

I4 Provisions of Act XXVII of 1990 and Act XXXII of 1990 were inserted into the third Act on Nationality in 1993.

I5 Published in Law-Decree No. I5 of 1989.

I6 Act VL of 1993.

I7 Acts XXXII of 200I, LVI of 2003 and XLVI of 2005.

I8 Published in Acts II and III of 2003.

I9 This principle is a legal expression of the fact that the individual who obtains this citizenship - directly through the law or as a result of the action of the authorities is in actual fact more closely related to the state whose citizen he or she is than to any other state (Lichtenstein v. Guatemala, I995 WL I (International Court of Justice) generally known as the Nottebohm case).

20 Act on Hungarian Nationality, arts. IO-I2.

2I Before accession, Hungary had agreements on visa-free travel with six neighbours, and a voucher system was defined with the Ukraine. For the sake of legal harmonisation these agreements were modified. Visa requirements were introduced for Ukrainian and Serbian citizens, while the agreement with Romania introduced a maximum length of stay.

22 Act LXII of $200 \mathrm{I}$ on Ethnic Hungarians Living in Neighbouring Countries. It was amended by Act LVII of 2003. Its administrative rules on financial, technical and procedural issues are laid down in ten government and ministerial Decrees.

23 Act II of 2005 on the Homeland Fund covers various community-building projects for kin-minorities living in adjacent states.

24 In Hungary, a referendum is valid if at least 25 per cent of the electorate returns identical votes, or if participation is higher than 50 per cent of the total number of eligible voters. In this case neither criterion was fulfilled.

25 Official translation provided by the Government's Election Office (Országos Választási Bizottság), www.election.hu, last accessed 5 May 2005.

26 According to the statistics published in 2004 by the Hungarian Government Office for Trans-Border Hungarians (Határon Túli Magyarok Hivatala), the number of Hungarians living in Romania, Ukraine, Serbia and Montenegro, Slovakia, Croatia and Slovenia as provided by the official censuses in these countries between 2000 and 2002 amounted to $2,429,000$, among these in Romania I,435,000; Ukraine I56,000; Serbia and Montenegro 293,000; Slovakia 516,000; Croatia 16,000 and Slovenia 8,500 (see www.htmh.hu, last accessed 5 May 2005). The estimate for the number of trans-border Hungarians potentially eligible for Hungarian citizenship based on ethnic identification is higher than these numbers, which is explained by the assumption that more people would be able to fulfil the criteria of Hungarian affiliation than those who actually declare themselves Hungarian in government censuses. The number of potential claimants on such grounds globally was estimated at around five million by the Under Secretary for Foreign Affairs, András Bársony ('Határok nélkül', Kossuth Rádió, I6 January 2003. www.hhrf.org, last accessed 5 May 2005). Also see note 34 .

27 J. Debreczeni, 'Hazárdjáték' [Gambling], Népszabadság [daily newspaper], 27 November 2004 .

28 The Hungarian name of the federation is Magyarok Világszövetsége. 
29 Since its adoption, approximately a quarter of all trans-border Hungarians applied for the Hungarian ID. There are about 850,000 card-holders today.

30 As a result of the conflict surrounding the Status Law, the Orbán Government withdrew public funding from the Federation.

3I Soon after the announcement of the plan for the referendum it became clear that any legislation on dual citizenship would have to happen unilaterally, as the Romanian president promptly announced his country's opposition.

32 On I2 November 2004, President Ferenc Mádl, in a speech addressed to the Hungarian Permanent Assembly (MÁÉRT), spoke of the perception of the referendum initiative by external minorities as an act of 'historical justice' and added: 'I call upon Hungarians to use their votes to assume a sense of community with Hungarians outside of our borders' (www.martonaron.hu, last accessed I7 February 2005).

33 'A kettős állampolgárságról, Adatok, állásfoglalások, elemzések' [On dual citizenship, data, opinions and analyses]. www.martonaron.hu, last accessed i7 February 2005.

34 Hungarian citizens who had emigrated from Hungary retained their Hungarian citizenship. This, however, did not apply to former citizens of Hungary in the neighbouring states who had lost their Hungarian citizenship as a result of the peace treaties that redrew the borders of the Hungarian state. The possibility of inheriting Hungarian citizenship applies only to people whose right to Hungarian citizenship is derived from their connection to the territory of the state of Hungary as delineated in the Paris Peace Treaty of 1947.

35 The dimension of the population potentially affected by the ius sanguinis transmission of citizenship is difficult to assess. Given the fact that in I920, Hungary's population had been reduced to half of what it had been before the war (with a corresponding reduction of two-thirds of its territory), the idea that ius sanguinis transmission could automatically create dual citizens after any number of generations would amount to the obligation to re-activate the 'dormant' citizenship of people whose numbers may surpass half of Hungary's current population. The peace treaty of 1920 reduced Hungary's population from I8.2 million to 7.9 million and its territory from $282,000 \mathrm{~km}^{2}$ to $93,000 \mathrm{~km}^{2}$. Trans-border Hungarians are estimated to number about 3.5 million, while people (with their offspring) who retain a ius sanguinis right to Hungarian citizenship (e.g. those who emigrated after 1939) are estimated to be about I.5 million.

36 Hungarian trans-border citizenship, if ever instituted, is more likely to be in line with that of Croatia where trans-border dual citizens retain some of their rights associated with Croatian citizenship, including voting rights in Croatian elections, even at times when their alternate citizenship is active (see Ragazzi \& Štiks in this volume). But while trans-border Croats vote for a quota of expatriate seats, transborder Hungarians would find it easy to vote for regular seats without putting their alternate citizenship to rest. This is because Hungarian regulations on the declaration of residence are extremely lax, requiring only three months of residence for a citizen to activate his or her right to vote. Moreover, in order to avoid the disenfranchisement of the homeless, voters can be admitted to the voters' registry without actually possessing an address or residence permit by simply making a declaration of residence at a given locality at the municipal office. According to recent changes in Italian law, Italian non-resident citizens may also vote in referenda and national elections for a fixed number of seats. However, the numerical dimensions of the Italian case are radically different from that of Hungary. There are altogether 2.7 million non-resident Italian citizens, which is equivalent to about 3 per cent of the resident citizenry of Italy, as opposed to the size of the trans-border Hungarian population that represents 30-35 per cent of Hungary's current citizenry. 
37 J. Kis, 'Miért megyek el szavazni?' [Why am I taking part in the voting?], Népszabadság, 20 November 2004.

38 Especially in the European Convention on Nationality (1997) ratified by Hungary in 2002 which stipulates in art. 2/a that "'nationality" means the legal bond between a person and a State and does not indicate the person's ethnic origin', and restricts the 'recovery of former nationality' of a given state to those residing on its territory.

39 For example, the biggest Hungarian party of the large Hungarian minority of Romania, which has substantial representation in the Romanian parliament and government, has traditionally been, at best, lukewarm about dual citizenship. However, the most vocal advocates of trans-border Hungarian citizenship also come from Romania and they also rely on a substantial constituency. Minorities themselves do not speak with a single voice because the attitudes of the different groups of which they are composed are derivative of the long-term view each of these groups takes on the possibilities of negotiating a better status for themselves in their host states. Even if the idea of dual citizenship enjoyed the support of the majority of trans-border Hungarians, this support would be based on a demagogic-populist misrepresentation of what is actually possible.

40 T. Bauer, 'Kettős Kapituláció' [Dual Capitulation], Népszabadság, 8 January 2004.

4I Art. 6I of the Constitution provides a fundamental right to free expression and obtaining as well as freely disseminating information of interest to the general public. A separate law regulates its implementation (Act LXIII of 1992).

42 See 'Western European Countries Tend to Follow a Liberalizing Trend towards Citizenship Policies. Interview with Rainer Bauböck'. www.migrationonline.cz.

\section{Bibliography}

Bauböck, R. (2006), 'Citizenship: International, State, Migrant and Democratic Perspectives', in J. Palme \& K. Tamas (eds.), Globalizing Migration Regimes, I44-I66. Avebury: Ashgate.

Csergō, Z. \& J. Goldgeier (2004), 'Nationalist Strategies and European Integration', in Z. Kántor, B. Majtényi, O. Ieda, B. Vizi \& I. Halász (eds.), The Hungarian Status Law: Nation Building and/or Minority Protection, 270-302. Hokkaido: Slavic Research Centre. http://src-h.slav.hokudai.ac.jp/coe2i/publish/no4_ses/contents.html.

Faist, T. (2005), 'Transnationalization in International Migration: Implications for the Study of Citizenship and Culture', Transnational Communities Programme: Working Paper Series 8. www.transcomm.ox.ac.uk.

Fowler, B. (2002), 'Fuzzing citizenship, nationalising political space: A framework for interpreting the Hungarian "status law" as a new form of kin-state policy in East-Central Europe', Centre for Russian and East European Studies, European Research Institute, University of Birmingham, Working Paper 40. www.one-europe.ac.uk.

Fullerton, M., E. Sik \& J. Tóth (eds.) (1997), From Improvisation toward Awareness? Contemporary Migration Politics in Hungary. Yearbook of the Research Group on International Migration. Budapest: Institute for Political Science, Hungarian Academy of Sciences.

Kántor, Z. (2004), 'Re-institutionalizing the Nation - Status Law and Dual Citizenship', Regio I: 40-49.

Kis, J. (2004a), 'Nemzetegyesítés vagy kisebbségvédelem' [Unification of the Nation or Minority Protection], Elet és Irodalom 51: 3-4.

Kis, J. (2004b), 'The Status Law: Hungary at the Crossroads', in Z. Kántor, B. Majtényi, O. Ieda, B. Vizi \& I. Halász (eds.), The Hungarian Status Law: Nation Building and/or 
Minority Protection, I52-I76. Hokkaido: Slavic Research Centre. http://src-h.slav.hokudai.ac.jp/coe2I/publish/no4_ses/contents.html.

Nagy, B. (2004), Kettôs Állampolgárság: Nemzet, állam, polgár: kisérlet a fogalmi rendteremtésre [Dual Citizenship: Nation, State and Citizen: An Attempt at Conceptual Clarification]. www.martonaron.hu.

Schöpflin, G. (2004), 'Citizenship and Ethnicity: The Hungarian Status Law', in Z. Kántor, B. Majtényi, O. Ieda, B. Vizi \& I. Halász (eds.), The Hungarian Status Law: Nation Building and/or Minority Protection, 87-I04. Hokkaido: Slavic Research Centre. http://src-h.slav.hokudai.ac.jp/coe2I/publish/no4_ses/contents.html.

Stewart, M. (2004), 'The Hungarian Status Law: A New European Form of Transnational Politics?’, in Z. Kántor, B. Majtényi, O. Ieda, B. Vizi \& I. Halász (eds.), The Hungarian Status Law: Nation Building and/or Minority Protection, I20-I5I. Hokkaido: Slavic Research Centre. http://src-h.slav.hokudai.ac.jp/coe2I/publish/no4_ses/contents.html.

Tóth, J. (I995), "Who are the Desirable Immigrants in Hungary under the Newly Adopted Laws?', in M. Fullerton, E. Sik \& J. Tóth (eds.), Refugees and Migrants: Hungary at a Crossroads. Yearbook of the Research Group on International Migration, 57-68. Budapest: Institute for Political Science, Hungarian Academy of Sciences.

Tóth, J. (2000), 'Diaspora in Legal Regulations: 1989-I999', in I. Kiss \& C. McGovern (eds.), New Diasporas in Hungary, Russia and Ukraine: Legal Regulations and Current Politics. Budapest: Open Society Institute/COLPI.

Tóth, J. (2003), 'Connections of Kin-minorities to the Kin-state in the Extended Schengen Zone', European Journal of Migration and Law 5: 20I-227.

Tóth, J. (2004a), Státusjogok. Kisebbségkutatás Könyvek. Budapest: Lucidus Kiadó.

Tóth, J. (2004b), 'Aspects of Analysing the Minority Problem', in L. Szarka (ed.), Hungary and the Hungarian Minorities: Trends in the Past and Our Time. Atlantic Studies on Society in Change I22, 223-244. New York: Columbia University Press.

Tóth, J. (2004c), 'Kettős állampolgárságot Népszavazással?' [Dual Citizenship by Referendum?], Fundamentum 2: 80-87.

Tóth, J. (2005), 'Principles and Practice of Nationality Law in Hungary', Regio 8: 2I-39.

Tóth, J. \& E. Sik (2003), 'Joining an EU identity. Integration of Hungary or the Hungarians?’, in W. Spohn \& A. Triandafyllidou (eds.), Europeanisation, National Identities and Migration. Changes in Boundary Constructions between Western and Eastern Europe. London: Routledge.

Tóth, P. P. (1997), Haza csak egy van? Menekülők, bevándorlók, új állampolgárok 1988-1994 [Is there only one homeland? Refugees, immigrants, new citizens]. Budapest: Püski.

Vizi, B. (2003), 'A határon túli olaszoktól a külföldön élő olasz állampolgárokig - az olasz állampolgárság kiterjesztése az ezredfordulón' [From trans-border Italians to Italian citizens living abroad], Kisebbségkutatás 4: 685-694. 


\title{
6 Politics of citizenship in post-communist Romania: Legal traditions, restitution of nationality and multiple memberships
}

\author{
Constantin Iordachi
}

A member of the European Union since January 2007, Romania has brought a rich historical experience into the union that goes all the way back to long-lasting Byzantine and Ottoman imperial legacies and to the more recent successive waves of Western- and Soviet-style modernisation. Given Romania's multiple historical legacies, which combine pan-European trends with Central and Southeast European regional features, the history of Romanian citizenship legislation challenges the clear-cut and neatly defined analytical dichotomies, such as 'old' versus 'new' states and 'civic' versus 'ethnic' or 'inclusive' vs. 'exclusive' citizenship doctrines, which are erroneously regarded as corresponding to 'Western' vs. 'Eastern' historical experiences (for a critique of such views, see Iordachi 2006).

This chapter focuses on the interplay of historical legacies in the evolution of Romanian citizenship, underlining continuities and ruptures in the transition from communist to post-communist policies of national membership. Methodologically, I distinguish between two institutional dimensions of citizenship: the legal category of nationality that defines membership in a state understood as a territorial and national organisation; and citizenship as rights and duties stemming from membership and participation in a political community. The first dimension encompasses the construction of legal and political borders between state citizens and aliens. The second dimension refers to the civil, political and social entitlements of citizenship (Marshall I950). ${ }^{\text {I }}$

Like the other contributions in this book, this chapter focuses on the first legal dimension of nationality, which is regulated mainly by constitutions and citizenship laws. Particular attention is devoted to the most contested component of post-communist Romania's nationality policy: the right to reacquisition of nationality by former citizens and their descendants living outside the state's (post-I945) borders. This policy resulted in the massive (re-)naturalisation of Moldovan and Ukrainian citizens stripped of their Romanian nationality following the I940-I94I/I944 Soviet occupation of Bessarabia and Northern Bukovina. I argue that Romania's policy regarding the restoration of national- 
ity should be placed in the political and analytical context of post-communist restitution. Restitution in its various forms has been an important component of legal systems since ancient times, referring to the return of a person to his or her original status and of restoration of his or her rights or property, prior to a loss, injury or abuse. In post-communist Central and Eastern Europe, the concept took on a peculiar legal meaning because it denoted the process of undoing communist legal and political abuses and dispossessions. Restitution was central to post-communist legal and political transformation, which was aimed at the restoration of the status-quo ante (before the communist takeover). From this perspective, the legal 'revolutions' initiated in I989, which led to the dismantling of the communist regimes, should be understood more in the original meaning of the term 'revolution', that is, as a movement of rotation, which returns to an original position.

In post-communist East Central Europe, practices of restitution have been applied to a wide range of societal domains. Yet, to date, research has focused almost exclusively on the reconstruction of individual and communal property rights. An important but largely understudied aspect is the restitution of nationality to former de-naturalised citizens. In the context of post-communist nationalist upsurge, this practice was not simply a necessary legal reparation for past injustices; it was also seen as a means of recreating the pre-communist citizenry and national community and as a means for the restoration of national identity, allegedly lost under communist rule, which was defined as a regime of Soviet occupation. The gap between political visions of recreating the inter-war national 'imagined community' and the far-reaching practical complications this project generated led to a multitude of political, legal-procedural and diplomatic crises, with wide domestic and international implications. These complications and the debates surrounding them account for the numerous shifts and turns of Romania's policy regarding the restitution of nationality, which culminated in the temporary suspensions of the process of restitution during the period from 2001 to 2007 .

\subsection{History of Romanian nationality}

\subsubsection{The making of Romanian nationality: Pre-communist legacies}

Modern Romania was established in I859 through the state union of the principalities of Moldova and Wallachia. After their establishment in the fourteenth century, the two principalities were part of the Byzantine political tradition and Eastern Orthodox religious commonwealth. They fell under Ottoman domination in the fifteenth century and were subject to Ottoman suzerainty until I878; and thereafter experienced 
major stages of nation- and state-building during the "long nineteenth century', with such landmarks as the Congress of Paris (1856), the Congress of Berlin (1879), and the Versailles Peace Treaties (I9I9I920), all part of successive geo-political reorganisations of Southeast Europe by the great European powers. One can identify several historical periods in the development of Romanian citizenship, corresponding to major stages in the process of nation-building and state-building: I859-I9I8, I9I8-I937, I937-I944, I944-I989 and I989 to the present.

The legal bases of the modern Romanian nationality were set by the I865 Civil Code, which emulated the French legal system put forward in the 1804 Code Civil, based on the ius sanguinis principle in ascribing nationality at birth, and a selective policy of naturalisation of aliens, favouring those born and raised in the country. The French model was nevertheless amended in several respects: the Romanian Civil Code, soon supplemented but also partially (and restrictively) modified by a modern Constitution adopted in I866, introduced Christian religion and Romanian ethnicity as criteria for naturalisation, both absent in the Code Civil. Firstly, until I879, Jews were excluded from Romanian nationality, on the basis of their religion, even if born and raised in the country for generations; on this basis, they were deprived of substantial civil, social and political rights. In I879, under pressure from the international community, Jews were granted access to naturalisation; however, instead of a fast and collective citizenship emancipation, Jews were only allowed to apply for individual naturalisation that could be granted by parliament by means of a special law adopted for each individual case. This lengthy and highly bureaucratic practice explains the small number of naturalisations before the First World War, the great majority of Jews remaining non-citizen permanent residents. Secondly, the Romanian state pursued an active national policy: ethnic Romanians from neighbouring countries immigrating to the "mother country' were granted privileged access to nationality, without a naturalisation stage, i.e. without the necessity of having lived in the country for a period of ten years. (They could prove their ethnic origin by means of witness accounts or certificates of ethnicity issued by Romanian communities abroad and further corroborated by their knowledge of the Romanian language.) This practice, euphemistically called 'recognition' of citizenship, was justified by the incomplete ethnic boundaries of the Romanian nation-state and legitimised an irredentist policy of incorporating Romanians from Austria-Hungary, Russia and the Balkans. This legal model functioned until the First World War, with only minor modifications necessitated by the annexation of Northern and Southern Dobrogea/Dobrudja from the Ottoman Empire and from Bulgaria in I878 and in I9I3, respectively (Iordachi 2002). 
The socio-political upheaval of the Great War brought significant changes to the Romanian citizenry. Firstly, interwar 'Greater Romania' almost doubled in size and population compared to the pre-war 'Old Kingdom' by incorporating the province of Bessarabia (situated between the rivers Prut and Dniestr and annexed by Russia in I8I2) and territories that had been previously part of Austria-Hungary - namely Bukovina, Transylvania, the Banat, Maramuress and the Partium. For the first time in their modern history, ethnic Romanians thus lived in a single 'national and unitary state', as Greater Romania was defined by the I923 Constitution. Although dominated by Romanians, the new state also included a high ratio of ethnic and religious minorities: 28.I per cent of the total population in I930, including Hungarians (7.9 per cent), Germans (4.I per cent), Jews (4.0 per cent), Ruthenians (3.2 per cent), Russians (2.3 per cent), Bulgarians (2.0 per cent), Gypsies (I.5 per cent), Turks (0.9 per cent) and Tartars (O.I per cent) (Institutul Central de Statistică I940: 44-45). Secondly, the events of the war generated an unprecedented liberalisation of access to citizenship. Under international pressure, Romania took final steps towards the full civil and political emancipation of Jews. Adopted in February I924, the new law on nationality granted citizenship to all legal inhabitants of the Old Kingdom and the annexed territories. It also preserved the main features of Romanian citizenship doctrine by stipulating three main ways of acquiring nationality: (I) by descent, according to the principle of ius sanguinis; (2) by marrying a Romanian man; and (3) by naturalisation, after having fulfilled a residence requirement of ten years following the declaration of intent to naturalise. Foreigners born and raised in Romania were exempt from the mandatory residential stage, provided they requested naturalisation upon reaching maturity. Thirdly, the liberalisation of access to citizenship was accompanied by major socio-political reorganisations of the country. Comprehensive reforms such as universal male suffrage (I9I8), massive land redistribution (I92I) and the new liberal Constitution (I923) remodelled the country into a multiparty parliamentary monarchy.

While the new liberal regime remained largely unconsolidated and marred by major regional and socio-political cleavages, it is important to note that political pluralism was preserved almost throughout the entire interwar period, free parliamentary elections being held as late as I937, at a time when the European continent was mostly dominated by authoritarian political regimes. Ironically, the I937 parliamentary elections turned out to be Romania's last free elections before I990.

The Romanian citizenship doctrine suffered significant changes just prior to and during the Second World War, with long-term legal consequences. Firstly, under the joint pressure of right-wing organisations from below and the authoritarian tendencies of King Carol II (I930- 
I940) from above, in I938, the multiparty parliamentary regime collapsed, being replaced by a (short-lived) regime of royal dictatorship (1938-1940). The new political changes were also reflected in a new law on citizenship, adopted in I939 at King Carol's initiative. The law did not alter the main principles of ascribing citizenship, but introduced numerous changes in the procedure of naturalisation, placed under the control of the Ministry of Justice. The most important change was that naturalised citizens were granted full political rights only six years after the act of naturalisation. The law served as a basis of Romania's nationality policy until I947/1952, when it was amended and then fully abolished by the new communist regime; however, in the post-communist period, many of its provisions have been reinstated. Secondly, the political accession of the extreme right led to the massive de-naturalisation of Romanian Jews, their deprivation of substantive political and civil rights during the royal dictatorship of King Carol II and their partial deportation and extermination during the dictatorial regime of Ion Antonescu (I940-I944). Thirdly, during the Second World War, Greater Romania suffered major territorial losses. In I940 - under the new political conditions created by Nazi Germany's military domination in Europe - Romania was forced to cede NorthWestern Transylvania to Hungary and Southern Dobrogea to Bulgaria. Following the 1939 'Ribbentrop-Molotov' Non-Aggression Pact, which divided the spheres of influence between Nazi Germany and the USSR, on 28 June I940 the Soviet army occupied the provinces of Bessarabia and Northern Bukovina. Romania ceded these provinces without resistance, but in June 194I, it joined Nazi Germany's anti-Soviet war and managed to temporarily liberate the occupied territories (I94II944).

In I944, a coalition of communists and democratic parties ousted Antonescu from power, reinstated the 1923 Constitution, abolished all anti-Semitic discriminatory laws and restored citizenship to all denaturalised inhabitants. The new democratic Romania also joined the antifascist military coalition and restored its control over Northwestern Transylvania. The return to the legal and territorial order of interwar Greater Romania was nevertheless hampered by several factors: firstly, in 1944, the Soviets reoccupied Bessarabia, which became the Moldavian Soviet Socialist Republic (MSSR) and included also the Transnistria region (a long conundrum situated across the river Dniestr) and Northern Bukovina, which was granted to the Ukraine (together with the southern part of Bessarabia, detached from the MSSR). Secondly, the Soviets intervened in the political process by installing the tiny Communist Party in power and initiating the forceful Sovietisation of Romania. The understanding of the communist legacy is essential to 
our effort to grasp the main features of citizenship policies in the postcommunist period.

\subsubsection{A new legal beginning: Nationality under the communist regime}

The communist regime implemented radical changes to Romania's legal and political system (I945-1989). Through three consecutive constitutions (1948, I952, I965), major changes to the civil code and an allencompassing set of laws regulating every sphere of activity, the new political regime broke with the past and redefined the nature of the state by emulating the Soviet model of development. As a legal boundary defining membership in the national and social-political community, citizenship legislation was an essential dimension of the communist political transformation and was therefore subject to many revisions in 1947, 1948, 1952, I954, 1956 and 1971, reflecting the shifts and turns of the political regime.

The communist regime redefined the conditions of acquisition and loss of nationality. With the stroke of a pen, Decree No. 33/1952 abolished all existing laws on citizenship (art. Io); instead, in two pages and ten articles, it set new rules for the acquisition of Romanian nationality, defining the legal boundaries of the socialist nation. Romanian nationality was ascribed at birth iure sanguinis to children of at least one Romanian parent. In a major departure from the legal tradition of the country, the decree thus allowed the transmission of nationality on the paternal as well as on the maternal line in mixed families, provided that at least one parent lived in Romania. This transmission could not result in dual citizenship: upon adulthood, children born into mixed marriages had to choose between the nationality of the mother or the father, by parental accord. Combined with Decree No. 130/1949 (which allowed official investigations of the paternity of children, thus eliminating 'illegitimacy' as an accepted legal category), these stipulations contributed to the formal legal equality of women, since they were legally enabled to transmit their own nationality to their children.

The decree discontinued the traditional ius soli policy of naturalisation of aliens born in the country and the privileged naturalisation of ethnic Romanians living abroad. Decisions on the naturalisations of aliens, as well as on the renunciations or withdrawals of nationality were taken by the Presidium of the Grand National Assembly, established in 1947 after the abolition of the monarchy and the proclamation of the republic.

After 1958, political divergences with Moscow and the move of the Romanian leaders towards political autonomy and a 'national' path to building socialism led to significant changes in the official socialist ideology. With the retreat of the Red Army (I958), Romanian leaders 
renounced external sources of legitimisation and recuperated traditional themes of nationalist ideology in an attempt to gain broader domestic support (Shafir 1985). Initiated under the last years of Gheorghe Gheorghiu-Dej's rule, the nationalist turn of the regime, which was intensified during the rule of Nicolae Ceauşescu (1965-1989), resulted in a syncretism between nationalism and a 'decayed Marxism,' best described by the concept of 'national-communism' (Verdery I99I).

The new nationalist orientation of the regime was also reflected in the definition given to the legal principle governing the ascription of nationality at birth. Adopted in I97I, the new Law on Romanian citizenship reconfirmed the principle of ius sanguinis as the very foundation of a homogeneous national community and imbued it with nationalist connotations. Art. 5 of the law read:

As an expression of the relationship between parents and children, of the uninterrupted continuity of the fatherland of previous generations that fought for social and national freedom, children born of Romanian parents on the territory of the Socialist Republic of Romania are Romanian citizens. (emphasis added) ${ }^{2}$

This definition linked the application of the ius sanguinis principle to birth on the territory and uninterrupted continuity of the nation in its 'fatherland'. It made reference not only to parents and children in the transmission of nationality, but also to generations. Other articles of the law made evident that this link operated only at symbolic-ideological level, the principle of ius sanguinis being in fact also applied to children of citizens born outside the country. The argument was nevertheless meant to emphasise the 'autochthonous' roots of the Romanian people and the historical 'symbiosis' between the nation, its territory and the new socialist citizenry, thus alluding to the idea of organic nationalism elaborated by Romantic nationalist thinkers in the first half of the nineteenth century and brought to political prominence by rightwing organisations in the interwar period.

In addition to ascription through ius sanguinis at birth, Romanian nationality could also be acquired by naturalisation, by adoption and by repatriation. Naturalisation was granted at adulthood by the Council of State (a leading organ of the republic created in I96I) to persons who: a) were born in Romania and lived there at the time of their request; b) were born abroad but had lived uninterruptedly in Romania for at least five years; c) were married to a Romanian citizen and had lived in the country for at least three years. In addition to the residence condition, aliens were required to:

I. prove, through their behaviour and attitude, attachment to the Romanian state and the Romanian people; 
2. be eighteen years of age or above;

3. undertake socially useful work or prove sufficient material means of subsistence;

4. renounce their foreign nationality or any commitment of loyalty to a foreign power and swear allegiance to Socialist Romania.

The Romanian state reserved its right to unilaterally withdraw the nationality of those individuals who 'broke with the fatherland by crossing the border clandestinely or, after relocating their domicile abroad, assumed a foreign nationality, worked against the interests of the country or enrolled in a foreign army' (art. I9). Access to nationality was firmly controlled by the executive power; Ceauşescu alone, as the president of the Council of State (from December i967 to December I989), could grant or withdraw Romanian nationality.

\subsection{Democratic transformation: Current regulations on ascription, acquisition and loss of nationality}

The I989 collapse of the communist regime and the gradual democratisation of the political system had a powerful impact on Romanian citizenship legislation, resulting in the redefinition of the legal criteria of membership in the national community. Without significant dissident or reformist movements during the communist period on which to build the process of democratisation, post-communist Romania modelled its legal and political systems on the interwar political regime: the restitution of urban and land property, the recreation of political parties and parliament's structure and organisation were all shaped by its precommunist tradition. Yet, in many ways, the communist legacy deeply affected the society and could not be written off as a simple "parenthesis' in the country's development.

Citizenship legislation is a relevant example in this respect. Adopted in March I99I, the new Law on Romanian Citizenship was modelled on the I939 Law, abrogated by the communist regime in 1952; yet it also preserved many provisions of the I97I Law, resulting in a novel synthesis. The I99I Law specified four main ways of acquiring nationality by different categories of inhabitants:

I. ascription at birth, through transmission iure sanguinis to descendants of citizens, provided at least one of the child's parents holds Romanian nationality at the time of the child's birth;

2. adoption of an alien child by a Romanian citizen;

3. by the act of repatriation of former citizens; and

4. upon request, by naturalisation of aliens born in Romania or who have lived there for a certain period of time. 


\subsubsection{Acquisition at birth}

The ascription of Romanian nationality at birth is governed solely by the principle of ius sanguinis, being granted to children who are: I) born within the territory of the country to two Romanian citizen parents; 2) born within the territory of the country in mixed marriages with only one Romanian citizen; and 3) born abroad to at least one Romanian parent. That the principle of ius soli is of no relevance in the ascription of nationality at birth is made evident by the provisions concerning the nationality of newly-born children of unknown parents; they are granted citizenship not on the basis of their birth on Romania's territory, but under the assumption that their parents held Romanian nationality (art. 5). Evidence to the contrary results in loss of nationality, followed by the obligation of naturalisation (art. 30). In order to make it clear that this procedure does not constitute an ius soli ascription of nationality, a 2003 amendment to the citizenship law rephrased art. 5 to read that the child found on Romanian territory is considered to be [instead of 'is...'] a Romanian citizen' (art. 5, 3/I; emphasis added).

\subsubsection{Naturalisation}

The I99I Law granted naturalisation, upon request, to adult aliens and their minor children, who were: a) born in Romania and lived there at the time of their request; b) born abroad but had lived uninterruptedly in Romania for at least five years; c) married to a Romanian citizen and had lived in the country for at least three years. In addition to the residence requirement, applicants also had to:

I. prove, through their behaviour and attitude, their attachment to the Romanian state and people;

2. be eighteen years of age or above;

3. prove they possess sufficient material means of existence;

4. have a clean criminal record; and

5. have 'sufficient knowledge of the Romanian language' in order to be able to integrate into society.

Although the naturalisation requirements have been amended several times since I99I (see next section), the procedure of naturalisation, which is patterned on the I939 Law, has remained the same. Applications have to be filed personally or through authorised attorneys to a Commission of Citizenship set up by the Ministry of Justice and made up of five judges of the Bucharest Court, appointed for four years by the president of the court. Upon their registration, requests for naturalisation are published in the Official Monitory of Romania, Part III, and 
are subsequently examined by the Commission. Decisions on naturalisation are taken by the Romanian government upon the recommendation of the commission and are published in the Official Monitory of Romania, Part I. Naturalisation becomes effective upon the would-be citizens taking the oath of loyalty in front of the Ministry of Justice, a sub-secretary of state, or the chief of diplomatic missions abroad.

Romanian citizenship legislation underwent substantial amendments, additions and modifications in 1999, 2002, 2003 and 2008 which were necessitated by the process of European integration and the intensification of immigration and emigration. As a reaction to growing migration tides, coupled with EU pressure to strictly control external acquisitions of Romanian citizenship, requirements for naturalisation have been tightened. The mandatory residence period for the naturalisation of foreigners was increased from five to seven years in I999, and to eight years in 2003 (albeit reduced to five years for foreigners married to Romanian citizens). In order to eliminate cases of fraud, a I999 amendment demands a 'continuous, stable and legal' residence, while a 2003 amendment requires foreigners applying for naturalisation to effectively relocate to Romania, spend at least six months per year in the country and pay taxes there. ${ }^{3}$ In 1999, the residency requirement was reduced to half for persons of international reputation, a privilege granted since 2003 also to those who have invested more than 500,000 euros in Romania. In 2008, this sum was increased to 5 million euros and the shorter residency requirement was extended also to refugees and to citizens of EU Member States.

Moreover, besides the longer residency requirement, a I999 amendment to art. 9 of the law introduced additional conditions for naturalisation, such as sufficient knowledge of the Romanian language, of 'elementary notions of Romanian culture and civilisation,' of the Constitution and, since 2003, of the national anthem. Applicants for naturalisation also need to sign a declaration of loyalty to the Romanian state. Persons suspected of terrorism and those who present potential threats to national security are ineligible for naturalisation.

\subsubsection{Loss of nationality}

According to the I99I Law, Romanian nationality can be forfeited: I) as a result of the unilateral withdrawal by the state; 2) through voluntary individual renunciation by citizens; 3 ) or in other special cases, such as the adoption of children by foreign citizens (art. 24). Firstly, the Romanian state could terminate the nationality of those individuals who had obtained their naturalisation by fraud, who worked abroad against the interests of the country or who enrolled in an enemy army (art. 25). Secondly, the Law allowed Romanian citizens to renounce their nation- 
ality 'for solid reasons' according to a special procedure and pending official approval, provided they are not under trial and have no debts to private or public parties (art. 27).

Since 200I, in particular, Romania has become a major source country of labour migration, especially to Italy and Spain; taking advantage of the freedom of movement, an estimated two to two and a half million Romanian citizens currently live and work abroad either temporarily or permanently. The most recent stipulations on the loss of Romanian nationality express the Romanian state's concern to preserve legal ties with its citizens living abroad and to reduce the number of external renunciations of nationality. To this end, in 2003 , the Romanian state waived its right to unilaterally terminate the nationality of 'natural citizens' who had obtained it at birth (art. 24.d). In addition, in 2007, the procedure for the individual renunciation of citizenship became even more complex, costly and bureaucratic. These stipulations, combined with the fact that the principle of ius sanguinis operates externally without generational limits (so that Romanian nationality can be passed on indefinitely to subsequent generations born abroad even in cases of acquisition of a new nationality as long as parents do not renounce their nationality of origin), account for the fact that the number of individual renunciations or losses of Romanian nationality has been rather small - varying from $\mathrm{I} 2,594$ persons in 1999 to 10,938 persons in 2005 (National Institute of Statistics 2006: 8I-83) - especially when compared to the massive number of Romanian citizens living abroad on a temporary or even permanent basis.

\subsubsection{Restitution of nationality and multiple memberships}

The most debated provision of the post-communist citizenship legislation was the right to restitution of nationality to former citizens. A traditional feature of the Romanian modern legal system, the right to renaturalisation survived in various forms under the communist regime as well. Although the Socialist Republic conceived of itself as a new state and granted citizenship to all inhabitants living in the country, it also (partially) employed the principle of restitution in order to reconstruct Romania's interwar citizenry on new political bases. Thus, a law passed in I947 restored Romanian nationality to all those denaturalised during the Second World War under discriminatory legislation or foreign occupation. The 1952 decree granted Romanian nationality to all inhabitants who had settled in the country by I920 (the ratification of the Peace Treaty with Austria) but who had failed to qualify for citizenship under previous laws. Another decree passed in I954 reconfirmed Romanian nationality for all those who had held this legal status as of 28 June 1940 and had resided in Romania ever since. Under Soviet 
pressure, the deadline for restitution was chosen specifically to exclude from this right the inhabitants of Soviet-occupied Bessarabia and Northern Bukovina, a clear indication of the limits of the communists' policy on nationality restitution.

The communist regime also permitted the re-naturalisation of former citizens, but granted this right according to strict political criteria. Art. I.c of the 1952 Decree and art. 7 of the I97I Law allowed former citizens to reacquire their nationality upon request on the basis of a special authorisation issued by the Presidium of the National Assembly or, after 1969, by the Council of State. Re-naturalisation was conditional on the renunciation of the claimant's foreign nationality, repatriation and 'integration into the socialist society' (i.e. integration into the workforce) as well as an attachment to the communist political regime, to be affirmed by an oath of loyalty. In exceptional cases, the Council of State authorised former citizens applying for re-naturalisation to maintain their domicile abroad, but they were expressly required to renounce 'in an authentic form' their foreign nationality or - in case they did not hold a foreign nationality - 'any commitment, obligation of fidelity or oath of loyalty to a foreign state' (I97I Law, art. IO and art. II). Due to massive violations of human rights and the deterioration of the standard of living, few former citizens applied for repatriation; on the contrary, in the late I980s, numerous Romanian citizens fled abroad in order to escape political persecution and material hardship.

Upon the collapse of the communist regime, the repatriation of previously persecuted persons and the restitution of nationality to former citizens were the major concerns of the new revolutionary power, which was eager to resume ties with the Romanian Diaspora and kinminorities abroad. On 3I December 1989, the National Salvation Front guaranteed the right of repatriation to all Romanian citizens residing abroad (Decree No. 7). In addition to the repatriation of Romanian citizens in exile, the decree also facilitated the reacquisition of nationality by former Romanian citizens living abroad (art. 2), by request, through the act of repatriation. Unlike the I97I Law, the new decree did not require former citizens re-naturalised in Romania to renounce their foreign nationality, thus implicitly opening a gate to dual nationality.

In May I990, a new decree passed by the provisional government enlarged the rights to reacquisition of nationality by former citizens. While the 1989 Decree made re-naturalisation conditional on repatriation, the 1990 Decree granted former citizens the right to retrieve their Romanian nationality, upon request, 'even if they hold another nationality and they do not establish their domicile in Romania.' ${ }^{4}$ In doing so, the decree explicitly allowed certain categories of citizens to hold dual nationality for the first time in Romania's legal history. 
The provisions on repatriation and reacquisition of nationality were reconfirmed and enlarged by the I99I Law on Citizenship. The law stipulated three modalities for the reacquisition of Romanian nationality: (I) by repatriation (art. 8); (2) re-naturalisation by request without repatriation (art. II); and (3) 'restoration' of nationality to former Romanian citizens (art. 35) living in the lost territories of the interwar Greater Romania. Firstly, the law guaranteed former citizens the right to re-naturalisation through repatriation: 'The person who has lost Romanian citizenship can re-acquire it through repatriation, if he or she expresses a manifest desire to do so' (art. 8). Secondly, in line with the I990 Decree, the I99I Law allowed reacquisition of nationality by former Romanian citizens even without repatriation: '[f]ormer Romanian citizens who, before 22 December i989, have lost their Romanian citizenship for different reasons,' can reacquire Romanian citizenship by request even if they retain their foreign citizenship and their domicile abroad (art. 37; emphasis added). Thirdly, and most importantly, the I99I Law introduced a new form of access to Romanian nationality that can be generically called 'restoration' or 'restitution.' An additional paragraph to art. 37 stipulated that the right to reacquisition of nationality is also granted to all those who 'were stripped of Romanian citizenship against their will or for reasons beyond their control, and their descendants' (emphasis added).

Due to the imprecise and ambiguous wording of the law, at first glance, the difference between the second and third forms of re-naturalisation is not evident: the second referred to those who had lost Romanian citizenship 'for various reasons', while the third referred to those who had lost citizenship 'against their will or for reasons beyond their control'. The official interpretation of the law, however, made it evident that the first paragraph referred to those who had lost nationality as a result of individual actions that unilaterally breached their citizenship contract with the Romanian state, while the second concerned those citizens denaturalised en masse as a result of territorial changes. In so doing, the additional paragraph to art. 37 introduced several major innovations into Romanian citizenship legislation:

Firstly, the right to reacquisition of nationality was not restricted only to those persons who had emigrated due to political persecution or were stripped of citizenship by the communist regime; it was also granted to 'all former citizens and their descendants' regardless of when or under what conditions they had lost Romanian nationality. Although not specifically mentioned in the text of the law, the main beneficiaries of the policy of restoration of nationality have been the inhabitants of the former Soviet Socialist Republic of Moldova, and those of the provinces of Northern Bukovina and Southern Bessarabia in the Ukraine. Following the Soviet wartime occupation, the inhabitants of these pro- 
vinces were forcefully stripped of their Romanian nationality; the I99I Law has enabled them to retrieve that legal status. (Equally eligible were the inhabitants of Southern Dobrudja ceded by Romania to Bulgaria in I940, yet no claims to Romanian citizenship were reported from this province).

Secondly, in a departure from the established legal tradition of the country that had prohibited dual nationality, the law allowed re-naturalised former Romanian citizens to retain their foreign nationality as well as their domicile abroad. In doing so, the law generated a novel category of non-resident dual citizens living in neighbouring countries.

Thirdly, compared to regular naturalisations, the restitution of nationality was subject to a simpler procedure: re-naturalisation requests could be sent by post or by third-party intermediaries to the Romanian embassies or consulates abroad. Applicants were exempt from consular taxes and the major conditions of naturalisation required of 'regular' aliens. Moreover, the process of re-naturalisation did not necessitate an official interview and the personal presence of the claimant in Bucharest, as the oath of loyalty could be taken at Romania's diplomatic representations abroad. It was thus technically possible for a descendant of a former citizen living abroad to 'reacquire' Romanian citizenship without ever travelling to the country.

Overall, the legislation on the reacquisition of Romanian nationality was highly expansive, albeit legally ambiguous. It combined the right to re-naturalisation of expatriates and their repatriation with the principle of restoration of nationality to former citizens and their descendants living in former historical provinces of interwar Greater Romania, including their right to hold dual nationality. How can one account for these multiple forms of nationality restitution? According to the legislators, the motivations behind these provisions were democratic, as they were meant to redress communist injustice by allowing anticommunist political dissidents or expatriates to reacquire, upon request, their lost rights. Adopted in anticipation of the imminent dismemberment of the USSR, the March I99I Law was also animated by implicit nationalist motivations, which aimed to symbolically undo the effects of the Soviet occupation of Bessarabia and Northern Bukovina and to reconstruct the interwar national community. Seen in a historical retrospective, the law thus completed the process of restoration of the citizenship body of interwar Greater Romania. Initiated in the postI944 period (see above the laws adopted in 1947, I952 and 1954), this process had, under Soviet pressure, left out the inhabitants of Bessarabia and Northern Bukovina. 


\subsection{Current political debates}

The new policy on the restitution of nationality has triggered numerous domestic and international political debates. Far from concentrating on legal technicalities, these debates were linked to major political issues such as the communist legacy, the ethnic-cultural boundaries of the nation, issues of state sovereignty and territoriality, diplomatic relations with neighbouring countries and the compatibility of this policy with the European standard on nationality laws and minority protection.

\subsubsection{Dual nationality}

A first set of political debates concerned the right to dual nationality. Was dual nationality permitted only for former citizens reacquiring Romanian nationality or was it open to all Romanian citizens? Although the I99I Law on Romanian Citizenship allowed re-naturalised Romanian citizens to hold dual nationality, this provision did not imply a generalised acceptance of dual nationality, but only a tolerance of dual membership of re-naturalised citizens. For other modes of naturalisation, the I99I Law explicitly eliminated the tolerance of dual nationality. For example, children adopted by aliens lost their Romanian nationality upon acquiring the nationality of their adoptive parents (art. 29). Yet, as noted above, the law did not contain provisions referring to the legal status of Romanian citizens residing abroad who acquired another nationality, and did not expressly oblige them to renounce their Romanian nationality if the receiving state tolerated dual nationality in naturalisations, thus de facto allowing for dual membership.

The most debated issue was the right of Romania's ethnic Hungarians to hold dual nationality, mostly in connection with campaigns by political forces in Hungary for their access to Hungarian nationality (for details on these campaigns, see Kovács \& Tóth in this volume). The Romanian-Hungarian post-communist debate over dual nationality was linked to a wider ideological controversy between the two countries over contrasting but also overlapping definitions of the nation (Iordachi 2004: 257-260). These debates originated in the separation of the citizenries of the two countries following the collapse of Austro-Hungary after the First World War, and led to numerous diplomatic and territorial conflicts. During the communist period, Hungary abandoned the idea of recovering lost territories but focused instead on the issue of kin-minority protection, legitimised by an ethno-cultural definition of the nation. To Hungary's policy of treating its kin minorities abroad as an integral part of the Hungarian nation and its pretence of monitoring their treatment in neighbouring countries, Romania answered with 
a statist definition of the nation according to which all inhabitants of the country - irrespective of their ethnicity - were Romanian citizens and full members of the socialist nation, ethnic Hungarians included. The Romanian-Hungarian political-diplomatic conflict over the status of ethnic Hungarians in Romania reached a peak in the late I980s, as became manifest, for example, during the meetings of the Conference for Security and Cooperation in Europe that took place in Vienna (1986-1989); it also continued in the post-communist period, even if at a lower intensity. Leading Romanian politicians criticised the stipulations of the 200I Hungarian Status Law pertaining to Romanian citizens of Hungarian origin, agreeing to its implementation only after Hungary granted access to its labour market to all Romanian citizens, irrespective of their ethnicity; they also declared their opposition to the granting of dual nationality to Romania's ethnic Hungarians. With the liberalisation of the status of dual citizens in Romania in 2003 (see next paragraph), on the one hand, and the failure of the 2004 national referendum in Hungary over granting dual nationality to ethnic Hungarians living abroad, on the other hand, the debates over the issue faded away from the public agenda, with dual citizenship ceasing to be a matter of political contestation. In retrospect, it is important to note that, while rejecting the right to dual nationality for Romania's ethnic Hungarians, Romanian policymakers defended this right in the case of Moldovan citizens opting for Romanian nationality. This contradiction can be explained by the fact that Romania acted simultaneously in a double role: as a 'nationalising state' in regard to the Hungarian minority in Transylvania and as an 'external homeland' in relation to ethnic Romanians in Bessarabia and Bukovina (Iordachi 2004: 32; for a conceptualisation of these roles, see Brubaker 1996).

A second set of debates concerned the legal status of dual citizens. The 199I Constitution restricted the political rights of dual citizens, granting access to 'public office or dignity, civil or military,' only to persons 'whose citizenship is only and exclusively Romanian, and whose domicile is in Romania' (art. I6.3; emphasis added). Gradually, the great increase in the number of dual citizens led to a 'normalisation' of their status. In 2003, as part of numerous amendments to the Constitution, the restrictions on the political participation of dual citizens were lifted. Currently, the only condition of eligibility to public office, including the parliament and the presidency, is 'Romanian citizenship and domicile in the country.'

The restoration of Romanian nationality to Moldovan and Ukrainian citizens has generated a new category of non-resident dual citizens. What is the legal status of these absentee citizens? According to the Romanian legislation, non-resident dual citizens acquired automatic access to full social and political rights, except for the rights and obligations 
that are temporarily discontinued for citizens residing abroad, such as the obligation to pay taxes and perform one's military service (also discontinued for resident citizens since 2006), and - until 2003 - eligibility for public offices and awards (restricted for dual citizens; see above paragraph). It is intriguing to note, however, that the public debates over the restoration of Romanian nationality and the right to dual nationality focused on the national and geo-political effects of this policy, mostly in connection to Romania's relation to the Republic of Moldova and, to a lesser extent, the Ukraine. The debates did not address the question of the new citizens' potential socio-political integration into Romanian society or the devaluation of citizenship implied by the policy of granting nationality to persons who have not proven their knowledge of the country's legislation and might not have even visited Romania.

The massive numbers of restitutions of Romanian citizenship to Moldovan and Ukrainian citizens also generated international debates regarding issues of overlapping citizenries and the loyalty of dual citizens. Firstly, Romania's policy on the restitution of nationality contradicted the internal legislation of two neighbouring states, since neither Moldova (until 2000) nor the Ukraine allowed their citizens to hold dual nationality. Secondly, Moldovan and Ukrainian policymakers accused Romania of using dual nationality as a strategy of increasing its political influence in the region, with the final aim of reacquiring its lost territories. Romania's citizenship policy was thus perceived as adding to regional instability rather than to retroactive justice and integration.

Diplomatic debates concentrated mainly on Romania's relationship to the Republic of Moldova. With the establishment of the new state in I99I, Romania was trapped in 'the dilemma of the Romanian-Romanian relations' (Cojocaru 200I). In the early I990s, the diplomatic relations between the two countries seemed to proceed in tune with the strategy of the 'two Romanian states', put forward by the Moldovan Popular Front and shared by numerous politicians in Romania, according to which Moldova's independence represented the first step toward a gradual and negotiated process of political unification between the two countries. To this end, Romania inaugurated a policy of special partnership with Moldova, introduced visa-free and passport-free travel between the two countries, set up special educational programmes for Moldovan students and built a comprehensive network of inter-ministerial consultations. However, at the political-diplomatic level, the two countries soon drifted further apart. That was mostly because the Republic of Moldavia was tormented by internal inter-ethnic conflicts and secessionist movements, tacitly or openly supported by Moscow, which degenerated into a civil war in 1992 in the multiethnic province of 
Transnistria (also known as the Trans-Dniestr region). Fearing that ethnic strife would lead to disintegration, Moldovan leaders decided to consolidate the statehood of the new republic by relying on the Soviet version of local identity, i.e. on Moldovenism rather than on the pan-Romanian national identity. This change in Moldova's internal policy affected its relations to Romania. At the official level, the formula of the 'two Romanian states' was gradually abandoned, with Romania and Moldova defining themselves as 'two brotherly states' and then more neutrally as 'two neighbouring states'. After the electoral victory of the Communist Party in 200I, the diplomatic relations between Romania and the Republic of Moldova worsened considerably. The new Moldovan President Vladimir Voronin launched aggressive cultural polices meant to strengthen the Moldovan identity, to marginalise Greater Romanian unionist forces and to forcefully reduce Romania's political influence in the republic. Moreover, blaming Romania's irredenta policies, Voronin put forward his own plans for a Greater Moldova, raising territorial claims to Romania's province of Moldova. ${ }^{5}$ This obstructionist policy led to an almost complete deadlock in the diplomatic relations between the two countries.

\subsubsection{The restoration of nationality in practice: Domestic and international constraints}

From I99I to 200I, the policy of restoration of Romanian nationality was applied without major convulsions, resulting in massive (re-)naturalisations of Moldovan citizens. Since 200I, however, Romania has considerably slowed down the process of restitution for two main reasons. Firstly, the number of applications from Moldova has increased dramatically since January 200I, when Romanian citizens were granted visa-free travel in the Schengen space, effectively clogging the bureaucratic process of restoration of nationality. Secondly, although the European Commission repeatedly stated that the policy of restitution of citizenship is an internal matter for Romania, several EU agencies voiced concerns that, upon Romania's accession in January 2007, the country's policy on restitution of nationality could become an uncontrollable gate of access to the Schengen space of non-EU citizens, bypassing restrictive immigration policies. These combined challenges generated a series of crises in the process of restitution, leading to its intermittent suspension from December 200I to September 2007.

According to official figures, between August and December 200I alone the Commission for Citizenship received approximately 300 demands for nationality per day, or an aggregate of I9,000 in six months. ${ }^{6}$ Confronted with this massive influx of requests, the government temporarily suspended the provisions on the restoration of na- 
tionality by emergency ordinances valid for two periods of six months each, from December 200I to June 2002, and then again from November 2002 to May 2003, subsequently approved by parliament. In justifying the approval of the second ordinance, a parliamentary report in April 2003 pointed out that the 'explosive increase in the number of demands' blocked the work of the commission, which was composed of only five magistrates. It also blamed the fact that, according to official statistics, most of the re-naturalisation demands were opportunistic, being made 'in the new context created by the elimination of visa requirements for Romanian citizens who travel in the Schengen space, as well as in view of Romania's prospective integration into the North Atlantic structures.' Pointing out that 'the reparatory character taken into account at the time of elaboration of the Law on Citizenship is present in fewer and fewer cases,' the parliament asked the government to identify a legal solution 'to eliminate re-acquisitions of nationality for a purpose alien to the original intention of the law."

At the end of each period of suspension of the restoration of nationality, the government implemented major alterations of the citizenship law by two emergency ordinances passed in June 2002 and April 2003. The first ordinance unified the provisions on the reacquisition of nationality with those on the restoration of nationality in a single article (art. Io) placed in the section dealing with naturalisation, thus implying that the restoration of nationality to former citizens was a privileged naturalisation granted by the Romanian state and not an automatic entitlement to nationality. The restoration of nationality continued to be exempted from consular taxes (art. 36, para. 2); in addition, claimants were given the right to contest the decision of the Commission of Citizenship during an interval of fifteen days.

These new provisions did not offer an efficient solution to the flood of naturalisation demands, so that in November 2002 - just four months after its reinstatement - the government yet again suspended the restoration of nationality process for six months. In May 2003, upon the expiry of the new deadline, the law on citizenship was altered once more by a governmental ordinance approved by parliament with minor modifications in October 2003. The new ordinance reinstated the suspended provisions on the restoration of nationality as two additions to art.ro dealing with the reacquisition of nationality (classified as art. $\mathrm{IO}^{\mathrm{I}}$ and $\mathrm{IO}^{2}$ ), but introduced ample amendments to their implementation: Firstly, applicants to the restoration of nationality became subject to almost all of the conditions for naturalisation demanded of aliens; the only condition waived for former citizens was the obligation to relocate to Romania and reside there for a mandatory period. Secondly, the requests for nationality had to be handed in personally to the Commission of Citizenship in Bucharest and only 'in thoroughly justi- 
fied cases' by attorneys or third parties. Until 2003, the requests for reacquisition of Romanian nationality could be filed not only personally but also 'by third parties', either at the Ministry of Justice in Bucharest or at Romania's consulates abroad. According to media reports, this procedure led to the creation of clientelist networks in Moldova for the collection of dossiers and their transport in huge packages to Bucharest. In order to eliminate these practices, the new ordinance obliged applicants to travel personally to Bucharest, sometimes for undetermined periods of time necessitated by the new bureaucratic procedures, thus increasing the costs of naturalisation. Thirdly, the ordinance introduced a new form of re-naturalisation of former citizens and their descendants: a new article $10^{2}$ allowed persons eligible for the restoration of nationality to apply for naturalisation directly at the Ministry of Justice after four years of continuous residence in Romania. This provision was another indication that Romanian authorities intended to transform the restoration of nationality into a privileged form of naturalisation of former citizens relocating to Romania. Fourthly, in order to eliminate opportunistic reacquisitions of nationality, the new amendments stripped new citizens of some of the most immediate advantages of Romanian nationality: art. 37 stated that former citizens who reacquire nationality and effectively live in Romania 'cannot exercise their right to free movement of persons', i.e. they are forbidden to travel abroad with a Romanian passport during the first four years after their naturalisation. Exceptions to this rule were allowed only in emergency situations, such as periods of study abroad, family unification, medical treatment abroad, etc. This overt form of discrimination against a certain category of Romanian citizens because of the manner of their naturalisation was abolished in September 2007.

These substantial amendments to the citizenship law revealed the government's intention to discontinue the restitution of nationality to former citizens living in Moldova and the Ukraine, transforming it instead into a selective and privileged naturalisation of alien ethnic Romanians relocating to Romania, after a residence of four years. Thus, while former citizens living abroad were required to fulfil additional conditions that made their naturalisation very lengthy and difficult, former citizens working, studying or living in Romania were granted access to direct naturalisation after a residence period of four years, by means of a special procedure. In addition, by requiring applicants to possess 'knowledge of the Romanian language and elementary notions of Romanian culture and civilisation, ${ }^{8}$ the government made it more difficult for non-ethnic Romanian applicants to recover their lost nationality, fuelling suspicion that the new conditions were specifically meant as an obstacle to their re-naturalisation. 


\subsubsection{The restoration of nationality reloaded}

Predictably, the May 2003 amendments to the citizenship law led to an almost complete deadlock in the process of re-naturalisation, at a time when the number of applications was soaring. The restrictive policy of the government triggered incendiary reactions from the pro-Moldovan interest groups in Romania, who conducted media campaigns against the governmental policy and - with the help of naturalised Moldovans elected in the Romanian parliament - initiated bills for amending the citizenship law. The most contested provision was the applicants' obligation to travel to Bucharest and file their dossiers in person. Following street protests in Bucharest of Moldovan citizens applying for naturalisation, this condition was finally abrogated by parliament in June 2003 .

In March and April 2006, two open letters signed by 25 non-governmental organisations from Romania and Moldova urged the government to unblock the process of nationality restitution. The petitioners argued that the bureaucratic blockage was 'premeditated,' with the Ministry of Justice deliberately creating obstacles to the restoration of nationality. In their view, the restoration of nationality was a 'legitimate right' of the Moldovans and its denial by the Romanian government violated basic human rights and established principles of international law. The petitioners also denounced the restrictions on free movement imposed on new citizens, arguing that this provision discriminated among Romanian citizens according to their place of residence and the manner of their naturalisation, in direct violation of the Constitution which stated that all citizens are equal before the law.

In two consecutive responses, the Ministry of Justice pointed out that the restoration of nationality is not an automatic entitlement of former citizens but a right granted by the Romanian state under certain conditions. Acknowledging that the Commission for Citizenship was overwhelmed by the large number of applications, the Ministry pledged to consider potential solutions to the problem. ${ }^{9}$

In 2006, two parliamentary bills attempted to provide a legal solution to the issue. In order to speed up the restoration of nationality process, they proposed simplifying the procedure, shortening the processing time, allocating more magistrates to the task and making the Commission of Citizenship responsible for the resolution of demands within 'reasonable administrative deadlines. ${ }^{\text {,O }}$ The senate nevertheless rejected both bills on the grounds that they contradicted Romania's obligations under the EU treaty of accession, and that they would lead to potential conflicts with the Commission of the European Union. ${ }^{\text {II }}$

More recently, however, mounting public and political pressure has convinced the government to again modify its citizenship laws. In September 2007 , a new governmental ordinance facilitated the restoration 
of nationality by means of major procedural amendments. Firstly, the Commission of Citizenship now consists of five specially appointed juridical councillors on a full-time basis, who replace the regular part time judges. Applications for nationality can be sent by post as well; incomplete files are not automatically rejected, with later additions also being permitted. Secondly, in order to speed up the process of naturalisation, the decisions are now also taken by the Minister of Justice and not solely by the entire Council of Ministers. Rejections can be appealed by applicants in local courts, not only in Bucharest; new requests for nationality can also be filed one year after a rejection. The ordinance also obliges naturalised citizens to take the oath of allegiance no later than three months after the decision to naturalise instead of within one year as previously requested. It is expected that these amendments will speed up the process of naturalisation and will increase the number of Moldovan citizens acquiring Romanian nationality.

\subsection{Statistics on the restitution of nationality}

Since there are no general official statistics available, the number of former citizens and their descendants re-naturalised to Romanian nationality is highly contested. Official sources acknowledge a number of I02,000 Moldovan and Ukrainian citizens naturalised until 200I; no general figures have been released for the period since then. According to alternative unofficial estimates, the Romanian government granted nationality to at least 300,000 Moldovan citizens belonging to various ethnic groups between I99I and 2000 alone. ${ }^{\mathrm{I2}}$ The number of 'restitutions' of nationality to Moldovan and Ukrainian citizens dropped to insignificant levels in the period 2000 to 2003 . Although the process of

Table 6.1 Naturalisations in Romania, 16 June 2000-29 October 2008

\begin{tabular}{lcrr}
\hline Year & $\begin{array}{c}\text { Total number } \\
\text { naturalisations }\end{array}$ & Moldovan citizens & Ukrainian citizens \\
\hline 2008 & 4,961 & 3,605 & 165 \\
2007 & 1,150 & 615 & 51 \\
2006 & 740 & 487 & 3 \\
2005 & 1,789 & 1,592 & 13 \\
2004 & 751 & 258 & 6 \\
2003 & 281 & 8 & 0 \\
2002 & 318 & 1 & 3 \\
2001 & 348 & 1 & 1 \\
2000 & 357 & 1 & 0 \\
Total 2000-2008 & 10,695 & 6,568 & 242 \\
\hline
\end{tabular}

Source: Monitorul Oficial al României, Part I; calculated from official sources made available by Constantin Dolghier, available at http://cetatenie.info.tm 
restitution of nationality was resumed in 2004, the annual number of (re-)naturalisations remains relatively low.

Since there was neither a drop in the number of demands nor an increase in the number of rejections during this period, the low number of restitutions of nationality was clearly due to the considerable slowdown in the bureaucratic processing of applications. According to various unofficial estimates, the number of accumulated applications for restoration of nationality filed by Moldovan citizens is currently between 500,000 and 900,000. ${ }^{\mathrm{I3}}$ Among these, in the period $200 \mathrm{I}$ to 2007, Romanian authorities officially registered only 31,764 requests (by publishing them in the Official Monitory), among which 29,276 originated in the Republic of Moldova and 838 in Ukraine. Overall, between I6 June 2000 and 28 October 2008, the Romanian government awarded Io,695 naturalisations, of which 6,568 were awarded to Moldovan citizens and 242 to Ukrainian citizens. ${ }^{\text {I4 }}$

Although Moldovan citizens continue to dominate the number of persons acquiring Romanian nationality, their proportion within the total number of naturalisations is much lower than the share of Moldovans among all applicants.

As shown in Figure 6.I, this gap is due to the fact that since 2000 the procedure of restitution of Romanian nationality to Moldovan and Ukrainian applicants has been slower than that of the naturalisation of aliens.

Figure 6.1 Duration in months of the process of naturalisation in Romania, by original nationality of applicants accepted in 2005, 2006 and 2007

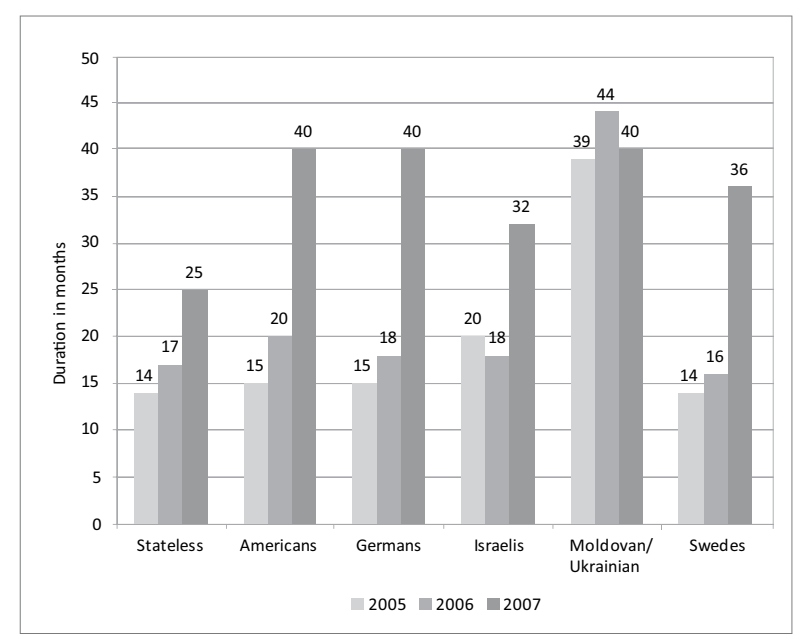

Source: Data compiled from official sources by Constantin Dolghier, available at http://cetatenie.info.tm 
On average, applicants from the Republic of Moldova and the Ukraine naturalised in 2005 (included in the graph under the label 'Moldovan/ Ukrainian') had to wait 39 months between the official registration of their requests and the decision regarding naturalisation; those naturalised in 2006 had to wait 44 months between the two stages. At the same time, other categories of aliens only waited, on average, between fourteen and eighteen months. Since the procedure for the naturalisation of aliens, according to the law, is in fact more complicated than that of the restitution of nationality, it becomes apparent that the length of the re-naturalisation process was not simply due to the record number of demands but also to a conscious political decision to halt the process by administrative means.

The amendments to the nationality law enacted in September 2007 made possible a massive increase in the number of naturalisations. As a consequence, the duration of the naturalisation process for all categories of applicants began to converge: while aliens had to wait longer (40 months at maximum), the waiting period for nationality restitution slightly decreased from 44 to 40 months (see Figure 6.I). Overall, between I6 June 2000 and I4 September 2007, the Romanian government awarded 5,062 naturalisations, of which 2,664 were restitutions of nationality to Moldovan citizens and 58 to Ukrainian citizens. ${ }^{\text {I5 }}$ Since the adoption of the new amendments to the nationality law on I4 September 2007, the Romanian government awarded a record number of 5,633 naturalisations (higher than the sum of 5,062 naturalisations granted in the previous seven years); of this number, 672 were granted in the last quarter of 2007 and 4,96I in 2008 (until October 2008). Out of this total number of new citizens, there were 1,826 naturalisations of aliens and 3,807 'restitutions' of nationality. Among the latter, 3I8 restitutions were registered between I4 September and 3I December 2007, 299 to Moldovan citizens and nineteen to Ukrainian citizens. A record number of 3,770 restitutions of nationality occurred during the period I January to 28 October 2008, among which were 3,605 to Moldovan citizens and $\mathrm{I}_{5}$ to Ukrainian citizens. These figures prove that, after the de facto suspension during the period 20002007 , the process of restitution of Romanian citizenship to former citizens from Moldova and the Ukraine has been resumed under the new 2007 provisions of the nationality law.

\section{5 (Re)constructing nationality in post-communist Romania: Comparative perspectives}

The collapse of the communist regimes led to the reorganisation of nationality policies in Central and Eastern Europe. One can distinguish 
two main clusters of nationality policies, in direct relation to patterns of nation-building and state-building in these regions: nationality policies in successor states in former multi-ethnic federal states such as Czechoslovakia, Yugoslavia and the USSR; and in post-communist nation-states such as Albania, Poland, Romania, Bulgaria and Hungary.

The dismantling of the former federal systems generated numerous legal, political and territorial conflicts, most notably in Yugoslavia and the USSR (the 'velvet divorce' between Slovakia and the Czech Republic was smoother, although it was not free of legal conflicts, see Liebich, Warner and Dragovic I995). In his analysis of 'citizenship struggle' in the successor states of the former USSR, Rogers Brubaker differentiated between a 'new state' model of legislation on nationality and a 'restored-state' model (I992: 275-276). The former was enacted in Soviet republics that lacked a statehood tradition. Without a history of distinctive citizenry, these republics, such as the Republic of Moldova, had to create their citizenship body by conferring rights on all of their residents, on an inclusive basis. The latter, 'restored-state' type, was applied in republics that relied on a pre-Soviet statehood tradition, such as the Baltic states. Motivated by the fear that their nation would 'die out', these states revived their pre-Second World War nationality laws in order to restore the citizenry that had existed prior to the Soviet conquest and to initially exclude from citizenship all residents who immigrated to these countries in the post-I945 period. To these, I would add a third, hybrid category, represented by 'new states' that have also assumed a 'restored' state-dimension, such as the Ukraine. The Ukrainian legislation granted citizenship to all inhabitants residing within the republic's territory, on a very inclusive basis. At the same time, it also granted access to Ukrainian citizenship to former citizens and their descendants born or permanently residing within any territories which formed a part of the historical states of the Ukrainian People's Republic, the Western Ukrainian People's Republic, the Ukrainian State, the Ukrainian Socialistic Soviet Republic, Trans-Carpathian Ukraine and Ukrainian Soviet Socialistic Republic (URSR), on the express condition that they renounce their foreign citizenship. ${ }^{\mathrm{I}}$

A different category of nationality policies can be found in post-communist nation-states. Although these states did not suffer territorial changes or a massive influx of population after i989, they have all revised their nationality laws in order to reflect the new political transformations. ${ }^{\text {I7 }}$ New nationality laws in these states encompassed an important national dimension, repressed under the regime of Soviet domination; after decades of political isolation from their kin-populations abroad, most of these states have resumed policies of 'positive discrimination' towards their co-ethnics. 
Romania's post-communist nationality policy belongs to the second cluster mentioned above; yet, due to the country's geo-political position and its territorial disputes with the Soviet Union during the Second World War, the Romanian policy combines elements characteristic of policies in East-Central European and former Soviet countries. The most important concept that dominated Romania's post-communist citizenship policy was that of the restoration of nationality in order to undo the effects of the territorial changes that took place during and after the Second World War, an issue declared taboo during the period of Soviet domination. Romania granted the right to re-naturalisation to all former citizens and their descendants, irrespective of their ethnic origin, their form of de-naturalisation and the period of their attachment to the Romanian state. In doing so, Romanian legislation went beyond regular laws on repatriation, of the kind post-communist Poland passed in relation to former citizens of Polish ethnic origin deported to the Soviet Union at the end of the Second World War. It also went beyond forms of privileged naturalisation of kin population abroad, as is the case with Hungary's policy towards former citizens of Hungarian ethnic origin relocating to the kin-state. To a certain extent, Romanian legislation resembles the policy of the restoration of citizenship to former citizens and their descendants implemented by the Ukraine, with the notable difference that, unlike the Ukraine, Romania allowed new citizens to hold dual citizenship and retain their domicile abroad. Most closely, Romanian citizenship legislation resembles the 'restored-state' policies of the Baltic states. This similarity is not surprising: Greater Romania's provinces of Bessarabia and Bukovina as well as the Baltic states were occupied by the Soviet Union in June I940 as a direct consequence of the I939 Ribbentrop-Molotov Pact. In the post-Soviet period, Romania and the Baltic states officially denounced the 'infamous pact' and tried to undo its legal consequences by applying the principle of restitution of pre-Soviet nationality. The major difference in the application of this principle was that in Romania its provisions were not meant to discriminate against 'internal foreigners' as in the Baltic states, but to include former citizens living abroad.

Due to the legacy of territorial conflicts and competing projects of nation-building and state-building in post-communist East-Central Europe, Romania's policy on the restoration of nationality generated interstate tensions, most evident in its relation to the Republic of Moldova. Given the complex and multifarious nature of this relationship, Romanian policymakers have been unable to put forward a coherent policy toward Moldova, oscillating between 'sentimentalism' and 'pragmatism'. On the one hand, Romanian politicians regard Moldova as Romania's former province, occupied as a result of the I939 RibbentropMolotov Pact, and reserve the country's right to unilaterally restore Ro- 
manian nationality to Moldovan citizens. On the other hand, Romania was the first country to recognise the independence of the new Republic of Moldova upon its proclamation in August i99I. Unlike the Federal Republic of Germany, in relation to the former GDR, or Greece, in relation to the Former Yugoslav Republic of Macedonia, Romania contested neither the statehood nor the name of the new republic. It has treated Moldova as an independent and sovereign state, thus implicitly recognising its legitimate right to establish its own version of national identity and citizenship legislation. The failure of the policy of special partnership inaugurated between the two countries in the early I990s and the forceful suspension of the process of restitution of nationality following pressure from the EU (200I-2007), widened the gap between these two policy lines.

What are the prospects of Romanian-Moldovan relations? Currently, both countries try to adapt their bilateral relations to the new realities created by Romania's EU membership. On the one hand, Romania has reiterated its historical rights to Bessarabia. In June I99I, the Romanian parliament officially condemned the I939 Ribbentrop-Molotov Pact as illegal, ab initio null and void of consequences for Romania; in September 2007, President Traian Băsescu announced his intention to officially condemn (yet again) the pact in order 'to give political force' to this declaration. ${ }^{\text {I8 }}$ Moreover, in September 2007 Romania relaunched its policy of restitution of nationality. Facing criticism from various EU agencies, ${ }^{\text {I9 }}$ Romanian authorities presented this policy as part of the EU's program of integration with neighbouring countries, arguing that it would enable the EU to boost its influence in the former Soviet space, as well as to import a qualified Moldovan workforce in order to reduce its labour shortages. On the other hand, Moldova's communist leadership, backed by Russia, took advantage of the securitisation of the EU border between Romania and Moldova and the imposition of travel visas to Moldovan citizens travelling to Romania in 2007 in order to discontinue socio-economic and cultural relations between the two countries. Moreover, a new Law on the Status of the Public Functionary, adopted in 2007, excludes all Moldovan citizens, who hold dual citizenship or have their domicile abroad, from public office; this effectively stripped a large part of the population of important political rights. Officially justified by the need to reduce the number of naturalisations abroad, to eliminate conflicts of interest with other states and to consolidate Moldova's statehood, this controversial Law primarily targets Romanian-Moldovan dual citizens with a view toward weakening political opposition to the ruling Communist party and to countering Romania's political influence in the republic. At a diplomatic level, Moldova has also tried to bypass Romania as a mediator in its relations with the EU (see the decision to prevent the opening 
of new Romanian consulates in Moldova and to instead use Hungary's embassy for granting of EU Schengen visas to Moldovan citizens). Although the effects of Romania's policy on the restitution of nationality and the response to it by the neighbouring states (mostly Moldova) should not be unduly exaggerated, it is likely that the interaction of citizenship policies in East Central Europe will continue to challenge inter-state relations in the region.

\section{Chronological list of citizenship related laws in Romania}

\begin{tabular}{|c|c|c|c|}
\hline Date & Document & Content & Source \\
\hline 1947 & $\begin{array}{l}\text { Law No. } 162 \text { for the } \\
\text { Modification of arts. 9, } 18 \text {, } \\
25,26,28,29,30,31 \text {, and } \\
34 \text { of the Law Concerning } \\
\text { the Acquisition and Loss of } \\
\text { Romanian Nationality of } 19 \\
\text { January } 1939\end{array}$ & $\begin{array}{l}\text { Restores citizenship to all } \\
\text { those who were domiciled } \\
\text { in Romania on } 26 \\
\text { September } 1920 \text { (the } \\
\text { ratification of the Treaty } \\
\text { with Austria), Jews de- } \\
\text { naturalised in the period } \\
\text { 1937-1944 and inhabitants } \\
\text { of Bessarabia who } \\
\text { immigrated to Romania } \\
\text { proper after the Soviet } \\
\text { occupation ( } 28 \text { June 1940) }\end{array}$ & $\begin{array}{l}\text { www.cdep.ro } \\
\text { (in Romanian) }\end{array}$ \\
\hline 1950 & $\begin{array}{l}\text { Decree No. } 145 \text { Concerning } \\
\text { the Abrogation of Law No. } \\
162 \text { of } 30 \text { May } 1947 \text { for the } \\
\text { Settlement of the } \\
\text { Citizenship of Certain } \\
\text { Categories of Inhabitants }\end{array}$ & $\begin{array}{l}\text { Abrogates Law No. } 162 \text {; } \\
\text { punishes false declarations } \\
\text { under that law with long- } \\
\text { term imprisonment }\end{array}$ & $\begin{array}{l}\text { www.cdep.ro } \\
\text { (in Romanian) }\end{array}$ \\
\hline 1952 & $\begin{array}{l}\text { Decree No. } 33 \text { Concerning } \\
\text { Citizenship in the Popular } \\
\text { Republic of Romania }\end{array}$ & $\begin{array}{l}\text { Abolishes previous laws on } \\
\text { state citizenship; redefines } \\
\text { conditions of access and } \\
\text { loss of Romanian } \\
\text { citizenship based } \\
\text { exclusively on the ius } \\
\text { sanguinis principle; serves } \\
\text { as a legal basis for } \\
\text { communist citizenship } \\
\text { doctrine }\end{array}$ & $\begin{array}{l}\text { www.cdep.ro } \\
\text { (in Romanian) }\end{array}$ \\
\hline 1954 & $\begin{array}{l}\text { Decree No. } 80 \text { for the } \\
\text { Reacquisition of } \\
\text { Citizenship by Certain } \\
\text { Categories of Persons }\end{array}$ & $\begin{array}{l}\text { Restores citizenship to all } \\
\text { those denaturalised under } \\
\text { previous special laws }\end{array}$ & $\begin{array}{l}\text { www.cdep.ro } \\
\text { (in Romanian) }\end{array}$ \\
\hline 1954 & $\begin{array}{l}\text { Decree No. } 296 \text { for the } \\
\text { Modification of art. } 1 \text { of the } \\
\text { Decree No. } 33 \text { of } 24 \\
\text { January } 1952 \text {, Concerning } \\
\text { Citizenship in the Popular } \\
\text { Republic of Romania }\end{array}$ & $\begin{array}{l}\text { Modifies art. } 1 \text { of the } 1952 \\
\text { Law; reconfirms Romanian } \\
\text { citizenship to all those who } \\
\text { held this status on } 28 \text { June } \\
1940 \text { and have resided in } \\
\text { Romania since that date; } \\
\text { excludes from Romanian }\end{array}$ & $\begin{array}{l}\text { www.cdep.ro } \\
\text { (in Romanian) }\end{array}$ \\
\hline
\end{tabular}




\begin{tabular}{|c|c|c|c|}
\hline Date & Document & Content & Source \\
\hline & & $\begin{array}{l}\text { citizenship the inhabitants } \\
\text { of Soviet-occupied } \\
\text { Bessarabia }\end{array}$ & \\
\hline 1956 & $\begin{array}{l}\text { Decree No. } 63 \text { on the } \\
\text { Citizenship of Certain } \\
\text { Categories of Persons }\end{array}$ & $\begin{array}{l}\text { Regulates the legal status } \\
\text { of certain categories of } \\
\text { persons }\end{array}$ & $\begin{array}{l}\text { www.cdep.ro } \\
\text { (in Romanian) }\end{array}$ \\
\hline 197 & $\begin{array}{l}\text { Law No. } 24 \text { Concerning } \\
\text { Romanian Citizenship }\end{array}$ & $\begin{array}{l}\text { Redefines conditions of } \\
\text { naturalisation, ascription } \\
\text { and reacquisition of } \\
\text { Romanian citizenship }\end{array}$ & $\begin{array}{l}\text { www.cdep.ro } \\
\text { (in Romanian) }\end{array}$ \\
\hline 1989 & $\begin{array}{l}\text { Decree-Law No. } 7 \\
\text { Concerning the } \\
\text { Repatriation of Romanian } \\
\text { Citizens and of Former } \\
\text { Romanian Citizens }\end{array}$ & $\begin{array}{l}\text { Guarantees the right to } \\
\text { repatriation of Romanian } \\
\text { citizens living abroad; } \\
\text { allows them duty-free } \\
\text { transfer of goods and } \\
\text { priority acquisition of } \\
\text { state-owned real estate }\end{array}$ & $\begin{array}{l}\text { www.cdep.ro } \\
\text { (in Romanian) }\end{array}$ \\
\hline 1990 & $\begin{array}{l}\text { Decree-Law No. } 137 \text { of } 11 \\
\text { May } 1990 \text { Concerning } \\
\text { certain Provisions } \\
\text { Pertaining to Romanian } \\
\text { Citizenship }\end{array}$ & $\begin{array}{l}\text { Allows reacquisition of } \\
\text { Romanian citizenship by } \\
\text { former citizens without } \\
\text { renunciation of foreign } \\
\text { citizenship and relocation } \\
\text { to Romania }\end{array}$ & $\begin{array}{l}\text { www.cdep.ro } \\
\text { (in Romanian) }\end{array}$ \\
\hline 1991 & $\begin{array}{l}\text { Law on Romanian } \\
\text { Citizenship }\end{array}$ & $\begin{array}{l}\text { Redefines conditions of } \\
\text { naturalisation, ascription } \\
\text { and reacquisition of } \\
\text { Romanian citizenship; } \\
\text { introduces the right of } \\
\text { restoration of citizenship } \\
\text { to former citizens of } \\
\text { interwar Greater Romania } \\
\text { according to a simple } \\
\text { procedure without } \\
\text { renunciation of foreign } \\
\text { citizenship and relocation } \\
\text { to Romania }\end{array}$ & $\begin{array}{l}\text { www.cdep.ro } \\
\text { (in Romanian); } \\
\text { www.legislationline.org } \\
\text { (in French) }\end{array}$ \\
\hline 1998 & $\begin{array}{l}\text { Law No. } 146 \text { for the } \\
\text { Abrogation of Decree-Law } \\
\text { No. } 7 / 1989\end{array}$ & $\begin{array}{l}\text { Abrogates facilities granted } \\
\text { upon the repatriation of } \\
\text { citizens living abroad }\end{array}$ & $\begin{array}{l}\text { www.cdep.ro } \\
\text { (in Romanian) }\end{array}$ \\
\hline 1999 & $\begin{array}{l}\text { Law No. } 192 \text { for the } \\
\text { Modification and } \\
\text { Additions to the Law on } \\
\text { Romanian Citizenship No. } \\
\text { 21/1991 }\end{array}$ & $\begin{array}{l}\text { Denies the state the right } \\
\text { to withdraw state } \\
\text { citizenship from those who } \\
\text { acquired it at birth; } \\
\text { abolishes repatriation as a } \\
\text { mode of reacquisition of } \\
\text { citizenship; transforms the } \\
\text { reacquisition of citizenship } \\
\text { into a simplified procedure } \\
\text { of naturalisation; increases } \\
\text { requirements for } \\
\text { naturalisation (continuous }\end{array}$ & $\begin{array}{l}\text { www.cdep.ro } \\
\text { (in Romanian) }\end{array}$ \\
\hline
\end{tabular}




\begin{tabular}{|c|c|c|c|}
\hline Date & Document & Content & Source \\
\hline & & $\begin{array}{l}\text { residential stage of seven } \\
\text { years, knowledge of the } \\
\text { country's language and } \\
\text { legislation) }\end{array}$ & \\
\hline 2001 & $\begin{array}{l}\text { GEO* No. } 167 \text { Concerning } \\
\text { the Suspension of Certain } \\
\text { Provisions Concerning the } \\
\text { Implementation of the } \\
\text { Law on Romanian Citizen- } \\
\text { ship No. } 21 / 1991\end{array}$ & $\begin{array}{l}\text { Suspends art. } 35 \text { on the } \\
\text { restoration of citizenship } \\
\text { for a period of six months }\end{array}$ & $\begin{array}{l}\text { www.cdep.ro } \\
\text { (in Romanian) }\end{array}$ \\
\hline 2002 & $\begin{array}{l}\text { Law No. } 225 \text { Concerning } \\
\text { the Approval of the GEO } \\
\text { no } 167 / 2001\end{array}$ & $\begin{array}{l}\text { Approves the suspension } \\
\text { of the right to restoration } \\
\text { of citizenship for six } \\
\text { months }\end{array}$ & $\begin{array}{l}\text { www.cdep.ro } \\
\text { (in Romanian) }\end{array}$ \\
\hline 2002 & $\begin{array}{l}\text { GEO No. } 68 \text { for the } \\
\text { Modification and } \\
\text { Additions to the Law on } \\
\text { Romanian Citizenship No. } \\
21 / 1991\end{array}$ & $\begin{array}{l}\text { Unifies the provisions on } \\
\text { the reacquisition of } \\
\text { citizenship with those on } \\
\text { the restoration of } \\
\text { citizenship }\end{array}$ & $\begin{array}{l}\text { www.cdep.ro } \\
\text { (in Romanian) }\end{array}$ \\
\hline 2002 & $\begin{array}{l}\text { Law No. } 542 \text { Concerning } \\
\text { the Approval of the GEO } \\
\text { No. } 68 \text { of } 13 \text { June } 2002\end{array}$ & $\begin{array}{l}\text { Approves the modification } \\
\text { with minor amendments }\end{array}$ & $\begin{array}{l}\text { www.cdep.ro } \\
\text { (in Romanian) }\end{array}$ \\
\hline 2002 & $\begin{array}{l}\text { GEO No. } 160 \text { Concerning } \\
\text { the Suspension of Certain } \\
\text { Provisions Concerning the } \\
\text { Implementation of the Law } \\
\text { on Romanian Citizenship } \\
\text { No. } 21 / 1991\end{array}$ & $\begin{array}{l}\text { Suspends art. } 35 \text { on the } \\
\text { restoration of citizenship } \\
\text { for a period of six months }\end{array}$ & $\begin{array}{l}\text { www.cdep.ro } \\
\text { (in Romanian) }\end{array}$ \\
\hline 2003 & $\begin{array}{l}\text { Law No. } 165 \text { Concerning } \\
\text { the Approval of the GEO } \\
\text { No. } 160\end{array}$ & $\begin{array}{l}\text { Approves the suspension } \\
\text { of the right to restoration } \\
\text { of citizenship for six } \\
\text { months }\end{array}$ & $\begin{array}{l}\text { www.cdep.ro } \\
\text { (in Romanian) }\end{array}$ \\
\hline 2003 & $\begin{array}{l}\text { GEO No. } 43 \text { for the } \\
\text { Modification and } \\
\text { Additions to the Law on } \\
\text { Romanian Citizenship No. } \\
21 / 1991\end{array}$ & $\begin{array}{l}\text { Introduces new conditions } \\
\text { for naturalisation of former } \\
\text { citizens; demands that } \\
\text { applicants submit their } \\
\text { requests personally in } \\
\text { Bucharest; introduces a } \\
\text { new form of re- } \\
\text { naturalisation of former } \\
\text { citizens living in Romania } \\
\text { after four years of } \\
\text { continuous residence; } \\
\text { denies former citizens re- } \\
\text { naturalised in Romania the } \\
\text { right to travel abroad for } \\
\text { four years }\end{array}$ & $\begin{array}{l}\text { www.cdep.ro } \\
\text { (in Romanian) }\end{array}$ \\
\hline 2003 & $\begin{array}{l}\text { Law No. } 405 \text { Concerning } \\
\text { the Approval of the GEO } \\
\text { No. } 43 / 2003\end{array}$ & $\begin{array}{l}\text { Approves the } \\
\text { modifications with minor } \\
\text { amendments }\end{array}$ & $\begin{array}{l}\text { www.cdep.ro } \\
\text { (in Romanian) }\end{array}$ \\
\hline 2007 & GEO No. 87 for the & Streamlines the procedure & www.cdep.ro \\
\hline
\end{tabular}




\begin{tabular}{lll}
\hline Date Document & Content & Source \\
\hline $\begin{array}{ll}\text { Modification of the Law on } \\
\text { Romanian Citizenship No. }\end{array}$ & $\begin{array}{l}\text { of naturalisation now Romanian) } \\
21 / 1991\end{array}$ & (in ted by the Ministry of \\
& Justice and not the Council \\
& of Ministers; reorganises \\
& the Commission of \\
& Citizenship under the \\
& leadership of the Ministry \\
& of Justice; enlarges the \\
& Commission to four \\
& members, but allows it to \\
& work with a quorum of at \\
& least three members \\
& \\
&
\end{tabular}

\section{Notes}

I This distinction also necessitates a terminological clarification: in Romania, the modern legal vocabulary of citizenship emulated the French legal terminology, employing naționalitate (nationality) in the sense of state citizenship. The semantic distinction between the terms 'citizenship' (meaning state membership) and 'nationality' (meaning 'ethnic origin') was only introduced in the official legal vocabulary after the Second World War, as part of the Soviet-style institutionalisation of ethnicity. On the one hand, due to its discriminatory use in the Second World War, the expression 'ethnic origin' (originea etnică) was purged from the communist political vocabulary. On the other hand, in order to continue to acknowledge the legal existence and legitimate collective rights of various ethnic groups living in the country side by side with the dominant ethnic group, the communist legislation employed the term 'nationality' to denote the ethnic origin of a person and not his or her state citizenship, as had previously been the case. To differentiate the new denotation of the term from its previous legal meaning (state citizenship), 'nationality' was employed in the communist political language mostly in plural, as 'co-inhabiting nationalities.' In the post-communist period, Romanian legislation employs the term natyionalitate alongside the expression 'origine etnică' (ethnic origin), and refers to ethnic groups mostly as minorităţi naționale (national minorities). The term 'citizenship' (cetățenie) is employed to refer to both the legal and participatory dimensions of this institution. This chapter uses the term 'nationality' to refer to state membership in line with the legal vocabulary employed in the current volume, irrespective of the previous or current understandings of the term 'naţionalitate' in Romanian.

2 All translations of legal texts are the author's, if not otherwise indicated.

3 See the parliamentary debates at www.cdep.ro.

4 Monitorul Oficial 75, 2I May I990.

5 'Voronin: 'În România sunt Io milioane de moldoveni', 24 February 2007, www.bbc.co.uk.

6 'Expunere de motive pentru aprobarea Ordonanţei de urgenţă a Guvernului nr. I60/ 2002', I, www.cdep.ro.

7 'Expunere de motive la Legea pentru aprobarea Ordonanţei de urgenţă a Guvernului nr. 160/2002,' www.cdep.ro.

8 Monitorul Oficial, Partea I, 399, 9 June 2003.

9 The petitions and the official answers are available on the site www.curaj.net. 
IO Ilie Ilaşcu, Session of the Senate, I9 March 2007, www.parlament.ro. A former Moldovan citizen imprisoned in Transnistria for his opposition to the secessionist leadership of the region during the civil war, Ilaşcu was later elected in the Moldovan and Romanian parliaments in absentia. Following international pressure, Ilaşcu was released from prison in $200 \mathrm{I}$ and migrated to Romania, where he agitates for dual citizenship for all Moldovans, in his capacity as a member of the Romanian parliament. On the case of Ilaşcu, see Iordachi (2004: 249-252)

II Petre Străchinariu, Session of the Chamber of Deputies, 28 June 2007, www.parlament.ro.

I2 Estimation by former Moldovan Prime Minister Mircea Druc, Evenimentul Zilei, 20 May 2000. See Iordachi (2004: 248).

I3 For this estimation, see http://en.wikipedia.org/wiki/Traian_Basescu.

I4 Data calculated after the Official Monitory of Romania, processed and made available online by Constantin Dolghier at www.cetatenie.info.tm.

I5 Data calculated after the Official Monitory of Romania, processed and made available online by Constantin Dolghier at www.cetatenie.info.tm.

I6 See art. 8 of the 200I Law on Citizenship of Ukraine, available at www.mfa.gov.ua.

I7 This claim is valid for Poland, as well. Although the I962 Polish Nationality Act has not been replaced by a new post-communist law, it was nevertheless amended in important points, while numerous procedural changes have also been implemented. See Górny \& Pudzianowska in this volume.

I8 'Traian Băsescu va denunţa Pactul Ribbentrop-Molotov', 2I December 2007, www.bbc.co.uk.

I9 On 25 September 2007, President Băsescu asked the government 'to simplify to the maximum' the naturalisation conditions for Moldovan citizens. His statement was criticised by Marianne Mikko, the President of the European Parliament Committee for the Cooperation between the EU and the Republic of Moldova, as lacking 'political wisdom'. See 'EP official: Basescu's statements about citizenship for Moldovans "not wise"', Nine O'Clock 4029, 28 September 2007, www.nineoclock.ro. In July 2007, Kalman Mizsei, the director of the EU representative office to Moldova, called on Romania to cancel its policy of nationality restitution for Moldovans as it contradicts the EU charter. See: 'Romania asked to cancel easy citizenship for Moldovans', New Europe: The European Weekly, I4 July 2007, www.neurope.eu.

\section{Bibliography}

Brubaker, R.W. (1992), 'Citizenship Struggles in Soviet Successor States', International Migration Review 26 (2): 269-29I.

Brubaker, R.W. (1996), Nationalism Reframed: Nationhood and the National Question in the New Europe. Cambridge: Cambridge University Press.

Cojocaru, G. (200I), Colapsul URSS şi dilema relaţiilor româno-române. Bucharest: Omega. Institutul Central de Statistică (I940), Anuarul Stat in I878 istic al României, 1939 şi 1940. Bucharest: Imprimeria Naţională.

Iordachi, C. (2002), Citizenship, Nation and State-Building: The Integration of Northern Dobrogea in Romania, 1878-1913. Pittsburgh: University of Pittsburgh Press.

Iordachi, C. (2004), 'Dual Citizenship and Policies toward Kin-Minorities in East-Central Europe: A Comparison between Hungary, Romania, and the Republic of Moldova', in Z. Kántor, B. Majtényi, O. Ieda, B. Vizi \& I. Halász, (eds.), The Hungarian Status Law Syndrome: A Nation Building and/or Minority Protection, 239-269. Sapporo: Slavic Research Centre, Hokkaido University. 
Iordachi, C. (2006), 'The Ottoman Empire: Syncretic Nationalism and Citizenship in the Balkans', in T. Baycroft \& M. Hewitson (eds.), What is a Nation? Europe, 1789-1914, I20-I5I. Oxford: Oxford University Press.

Liebich, A., D. Warner \& J. Dragovic (eds.) (I995), Citizenship, East and West. London: Kegan Paul International.

Marshall, T.H. (1950), Citizenship and Social Class. Cambridge: Cambridge University Press.

National Institute of Statistics (2006), Romanian Statistical Yearbook. Bucharest: National Institute of Statistics.

Shafir, M. (1985), Romania: Politics, Economics, and Society: Political Stagnation and Simulated Change. London: Pinter Publishers.

Verdery, K. (I99I), National Ideology under Socialism: Identity and Cultural Politics in Ceausescu's Romania. Berkeley: University of California Press. 



\title{
7 The politics of Bulgarian citizenship: National identity, democracy and other uses
}

\author{
Daniel Smilov and Elena Jileva
}

It is a well-known paradox that a polity cannot define its membership in a democratic way; there must be an already defined membership in order for a democratic procedure to take place. Therefore, even in genuinely democratic polities, the original membership rules are a complex mixture of normative egalitarian principles and historical contingency, which privileges certain groups. With the passage of time, the contingent privileges tend to acquire a self-perpetuating, normative status.

Modern Bulgarian citizenship laws are no exception to this general pattern. Various groups controlling the government and the parliamentary majority in the country have at one point or another attempted to entrench their privileged status in Bulgarian legislation. Such groups were most successful in times when democracy gave way to authoritarian regimes with fascist leanings and communist rule. What is surprising in the Bulgarian case, however, is the resilience of social pluralism, which has ultimately prevailed over such attempts. The overall result has been a certain normative incoherence of citizenship regulation in the country, which makes it capable of accommodating different historical narratives and normative visions. This inclusive incoherence, we argue, was and still is of crucial importance for the Bulgarian polity.

Bulgarian mediaeval states existed between the late seventh century and the Ottoman invasion in the fourteenth century - an event that left a substantial historical mark. Modern Bulgaria was established in 1878 I879 as a fairly independent principality in the former territories of the Ottoman Empire. Its subsequent turbulent history, which fits within its mere 130 years of existence with some difficulty, has not been conducive to the formation of a natural and self-explanatory sense of belonging to, and membership of, the Bulgarian polity. Ethnic Bulgarians (comprising today more than 80 per cent of the population), Turks, Roma, Greeks, Macedonians, Christians, Muslims and Jews - the main constituents of modern Bulgarian society - may differ in their interpretations of the past and their visions for the future of the country. Nevertheless, despite this lack of homogeneity, the Bulgarian polity has proven remarkably stable and, particularly over the last two decades, has made important strides towards the establishment of genuine liberal democracy. 
The main goal of this chapter is to trace the citizenship policies, which have played an important role in these developments. The first section outlines the history of Bulgarian citizenship laws in the period between the liberation from Ottoman rule and the end of communist rule. The second section discusses the developments after the fall of the Iron Curtain by focusing specifically on the I99I Constitution and the new citizenship laws. The third section provides an overview of the current political debates on citizenship in Bulgaria. The fourth section offers some statistical information about the current trends in the acquisition of Bulgarian citizenship. The chapter ends with some observations about the overall adequacy of the current citizenship regulation. As this introduction shows, Bulgarian regulation in this field is rather backward-looking, as it mainly addresses problems characteristic of the twentieth century. The danger is that by preserving this focus, it remains oblivious to the ever more pressing demands of a globalising world.

\subsection{History}

The history of the modern Bulgarian state begins with the liberation of the country in the Russo-Turkish war of I877-I878. In the spring of I879, the provisional Russian authorities in the mediaeval capital of Veliko Turnovo convoked a Constituent Assembly. It was given a mandate to adopt a constitution for the new Principality, which was practically independent but formally remained in a vassal (tributary) relationship with the Turkish Sultan. ${ }^{2}$ The decisions of this Constituent Assembly are very important from the point of view of citizenship policy in Bulgaria, and are thus worth examining in some detail (for the following, see Vladikin I994 and Balamezov I993).

Firstly, the delegates encountered the paradox outlined in the opening paragraph of this chapter: they faced the question of who had the right to participate in the Constituent Assembly - and whose interest it should represent. Of course, the Russian authorities had invited some of the Bulgarian nobility (notables), and had carried out impromptu elections in parts of the Bulgarian lands under their jurisdiction. However, in addition to these rather haphazardly gathered (though formally legitimate) representatives, there were numerous delegations from other lands inhabited by Bulgarians. These lands were to remain outside the territory of the Bulgarian Principality, according to the treaty concluded at the Berlin Congress of the Great Powers (I879). ${ }^{3}$

Before the formal opening of the Constituent Assembly, all of the delegates - both legitimate ones and others - met to discuss the question of the 'unity of the nation'. All of them agreed that the great powers 
had unjustly excluded certain Bulgarian territories from the Principality. ${ }^{4}$ The disagreement was about the proper course of action; some argued that the Constituent Assembly should be boycotted in protest against the Berlin Congress treaty. The adoption of a constitution, their argument went, would legitimise the partition of the Bulgarian lands. Others, strongly encouraged by the Russian authorities, insisted that a constitution should be adopted anyway in order to stabilise the new polity. Finally, common sense prevailed and, after numerous passionate patriotic speeches, the formally legitimised delegates began their work on the text of the Constitution. The discussions of the "national question', however, left an indelible mark on the ensuing proceedings; there was a common understanding that the Constitution should defend the interests of all Bulgarians as much as possible - both those living in the Principality and those left outside of it.

Secondly, another main issue, which became the focus of vigorous debate in the Constituent Assembly, was the scope of the (political) rights that were to be granted to citizens of the Principality. There were conservative voices in the Assembly who argued in favour of limited suffrage (based on education, wealth and property), or for special powers of the monarch to appoint members of parliament. These conservative voices were drowned out by a sea of egalitarian sentiments. The end result was full male suffrage in the elections for parliament, no powers for the monarch to appoint MPs, and a single-chamber legislature (without a senate of the type of the House of Lords, for instance). These institutional arrangements - which were decidedly untypical of the period - determined the egalitarian, Rousseauian bias of the Turnovo Constitution. Male citizens ${ }^{5}$ were entitled to an impressive set of political rights of participation.

Thus, the concrete citizenship arrangements, which the 1879 Constitution embodied, should be read through the double lens of nationalist and egalitarian-Rousseauian concerns and ideas. On the face of it, egalitarianism prevailed. Art. 54 stated that:

All persons born in Bulgaria who have not obtained any other citizenship as well as those born elsewhere of Bulgarian subjects are subjects of the Bulgarian Principality.

This emphasis on the principle of ius soli revealed the reluctance of the delegates to draw distinctions among the people living in Bulgaria: all were entitled to citizenship status, regardless of their ethnic origin and religion. Moreover, the Constitution prohibited drawing further distinctions among citizens: all males received the same scope of political rights (art. 60), there were express prohibitions of different estates 
(casts) of citizens (art. 57) and of any titles of nobility, orders or other signs of distinction (art. 58). ${ }^{6}$

The constitutional defence of national ideals was by no means neglected, however. The main concern of the drafters was to ensure that Bulgaria preserved legitimate claims over lands inhabited by Bulgarians. This was done, somewhat ingeniously, in the provisions on religion (arts. 37-42). It was here regulated that the dominant religion in the Principality would be Eastern Orthodox Christianity, and (more importantly) that the Principality 'constitute[d] an inseparable part of the Bulgarian Church District' and was 'subject [in religious matters] to the power of the Bulgarian Church, regardless of its seat'. The purpose of these articles was to constitutionalise the Bulgarian Exarchate - the autonomous Bulgarian Church recognised by the Ottoman Empire in I870 - whose seat was in Istanbul and whose jurisdiction extended well beyond the territory of the Principality; it covered both Eastern Rumelia and Macedonia, as well as some lands ceded to Serbia in I878. In this way, the articles regarding religion drew the informal boundaries of the Bulgarian political community, and in a highly symbolic way articulated the territorial claims of the new Bulgarian state.

It is important to stress this 'territorial' meaning of the regulations on religion; the entrenchment of Orthodox Christianity in this specific way was not designed to create religious discrimination against other faiths. The new Bulgarian state was by no means militantly religious. Art. 40 of the Constitution explicitly stated that all persons (citizens or not) residing (permanently or temporarily) in Bulgaria were entitled to religious freedom (as long as they did not violate the law). The real purpose of establishing Orthodox Christian faith was that it provided an opportunity for the Constituent Assembly to settle the "national question' in a way acceptable to all delegates. On the one hand, citizens of the new Principality were granted a broad spectrum of civil and political rights in a rather egalitarian fashion (for its time). On the other hand, ethnic Bulgarians living abroad were given the consolation that their lands were symbolically 'constitutionalised' through references to the Bulgarian Exarchate. These Bulgarians were granted the equivalent of a symbolic citizenship and a promise that the new Principality would take care of their interests as well. This promise actually determined the course of Bulgarian politics for the better part of the following century. Its influence is still evident in current citizenship law.

Along with the symbolic gains for ethnic Bulgarians, there were some more tangible privileges for them as well. The Constituent Assembly did not accept a strong ius sanguinis principle; no one really wanted all ethnic Bulgarians (or Bulgarians by blood) to automatically acquire citizenship rights in the Principality. This would create incentives for a mass exodus of Bulgarians from Eastern Rumelia, Macedo- 
nia, Eastern Thrace and other regions. Instead, the founding fathers of modern Bulgaria would maintain the compact Bulgarian population in adjacent lands as a way of legitimising future territorial expansion. Yet, these Bulgarians were granted some privileges - mostly in the form of less strict requirements for acquiring Bulgarian citizenship through naturalisation.

Based on the explanations given thus far, we will now provide a generalised description of Bulgarian citizenship regulations, since all subsequent laws adopted in the country took into account the principles elaborated in the Turnovo Constitution of I879. The first such law was adopted as early as 1880 (First Law on Bulgarian Nationality (podanstvo)). ${ }^{7}$ The second law was adopted by the State Council in I883. The Third Law on Bulgarian Nationality came into force in 1904. They were all heavily reliant on the principle of ius soli: all persons born in the territory of the Principality became Bulgarian citizens by right. Such was the case with the existing minorities of Turks, Greeks and others: 'Bulgarian subjects are all those individuals who at the time of the establishment of the Bulgarian Principality had residence in or were born on its territory' (1880 Law). ${ }^{8}$

By comparison, the principle of ius sanguinis had more limited applications. Persons born in foreign countries of parents who were Bulgarian subjects were granted citizenship by origin. Ethnic Bulgarians born or living abroad, however, did not automatically acquire citizenship, and this covered probably more than half of all Bulgarians living in the Ottoman Empire before the liberation of 1878 .

The principle of ius domicilii was also applied in two ways: firstly, as already mentioned, all former Ottoman subjects residing in the territory of the Principality at the time of its creation were granted citizenship; secondly, residence became a ground for acquiring citizenship through naturalisation. The regular residence requirement was three years based on a permit for permanent domicile. Those who did not have a permit for permanent domicile had to prove ten years of continuous residence to become eligible for naturalisation. The regulations foresaw the facilitated naturalisation of foreigners of Bulgarian extraction. They became entitled to citizenship one year after they obtained a grant for permanent domicile in the Principality. The same applied to men married to Bulgarian women and those who had performed a meritorious service to the country. (Needless to say, every alien woman who married a Bulgarian became ipso facto a Bulgarian.) Naturalisation was granted by the King's decree (ukaz) upon a proposal from the Minister of Justice.

Naturalised citizens enjoyed the civil and political rights of Bulgarian subjects with a few important exceptions: they were not eligible to membership in the National Assembly or any other elective public of- 
fice for fifteen years after naturalisation. This text of the law was actually in conflict with the Turnovo Constitution, which did not introduce such restrictions, ${ }^{9}$ but since there was no mechanism for constitutional review, such conflicts were resolved in favour of the law.

This was the model that lasted until I940 without any important changes of principle. In I885, the Bulgarian Principality was united with Eastern Rumelia, which almost doubled its territory and population. In I908, the Principality gained full formal independence and became a kingdom - the monarch received the original mediaeval Bulgarian title of 'tsar'. The defeats in the Balkan wars and the First World War paradoxically led to a certain enlargement of the territory of the kingdom; parts of Macedonia and Eastern Thrace were among the most important gains. The net result - territorially - was positive, although some lands of the Principality in Dobrudja were lost to Romania. But the real problem was the cost of the territorial gains. The numbers of dead and wounded were staggering, and the economy was in ruins and burdened by war reparations for decades to come. Most importantly, from our perspective, the problem of refugees arose. Significant numbers of people from Macedonia, Eastern and Western Thrace and other neighbouring territories moved to the motherland as a result of the war and of post-war policies of 'population exchange', which was really just an internationally regulated version of ethnic cleansing.

Immediately after the war, leading politicians attempted to abandon the territorial expansion paradigm ('unification of all Bulgarian lands', in the parlance of the time), which was at the root of so many political and social disasters. This proved virtually impossible, however. The populist-agrarian Prime Minister Alexander Stambolijski, who tried to mend fences with neighbouring countries and Serbia in particular, was considered a national traitor by many. Eventually he was brutally killed by Bulgarian-Macedonian nationalists, who insisted that the inclusion of Macedonian lands in Bulgaria should always be a top political priority. ${ }^{\mathrm{I}}$

Although the desire for territorial expansion remained a key factor of Bulgarian politics after the Balkan wars and the First World War, the symbolic geography of the Bulgarian political community dramatically changed. Firstly, the religious jurisdiction of the Bulgarian Exarchate over Macedonia and other lands was lost. Serbia (or rather the Kingdom of Serbs, Croats and Slovenes), Greece and other countries did not recognise this jurisdiction, and extended the jurisdiction of their own national churches over these lands. Secondly, the mass exodus of Bulgarians from Macedonia and Eastern Thrace led to important demographic changes in these regions. The end result was that the 
boundaries of the 'Bulgarian lands' were no longer so neatly defined as in the pre-war period.

The changes in the symbolic geography of Bulgarian lands led to the increased importance of the concept of 'Bulgarian origin' or 'Bulgarian extraction'. After the First World War, Bulgarian governments could no longer rely on the Exarchate and the Bulgarian schools to help preserve the Bulgarian national identity of those living in neighbouring countries. In fact, the Greek and Serbian governments both pursued a course of aggressive - and often physically repressive - replacement of the markers of Bulgarian identity. The Bulgarian government could not do much in this situation; in fact, all it could do was increase the privileges for ethnic Bulgarians within its domestic jurisdiction.

The Fourth Law on Bulgarian Nationality adopted in I940 was the primary example of this tendency. Formally, the law repeated some of the main provisions of previous legislation. ${ }^{\text {II }}$ However, there were many provisions in which the concept of ethnically defined 'Bulgarian origin' played a crucial role. Firstly, the law introduced a strongly ethnic definition of 'Bulgarian origin': 'all persons born of Bulgarian parents' (art. 4). Secondly, persons of Bulgarian origin were granted significant privileges vis-à-vis other groups. For instance, previous legislation allowed foreigners of non-Bulgarian extraction to be naturalised three years after obtaining a residence permit, ${ }^{\mathrm{I2}}$ while the I940 law raised the requirement to ten years (art. 9). At the same time, people of Bulgarian origin were entitled to naturalisation within a year (as in previous laws). Furthermore, and very tellingly, art. I5 of the law provided that Bulgarian subjects of non-Bulgarian origin who left the country would thereby lose their citizenship. Moreover, these individuals had to sell their property within three months of departure. These discriminatory provisions bear the mark of the time, and this mark was increasingly fascistic and paranoid. In his commentary on the law (prefaced by the then Minister of Justice Vasil Mitakov), Malinkov (I94I: 42) argues that these measures were necessary in view of the agreements with Turkey, Greece and Romania on population exchange. ${ }^{\text {I3 }}$ Another 'reason', cited by the author, was 'the strong Zionist propaganda, which resulted in a great number of Jews, who were Bulgarian subjects, resettling in Palestine.'

Thus, the I940 law shifted the emphasis of citizenship regulation from ius soli to ius sanguinis. Ethnic Bulgarians were given some significant privileges. Furthermore, the state became increasingly paranoid about its citizens of non-Bulgarian extraction. During the Second World War, Bulgaria was governed by a pro-German authoritarian regime headed by Tsar Boris III. Although this regime never openly endorsed the Nazi totalitarian ideology as a whole, in some of its policies it clearly came close to it. For instance, under German pressure, laws 
restricting the rights of Jews were implemented; the infamous Law on the Protection of the Nation (I940) was the primary piece of legislation modelled on the Nuremberg laws. Much of the Bulgarian legislation remained loosely enforced, however, and the population at large sympathised with the Jews. These public sentiments, along with the decisive action of the politician Dimiter Peshev and a few other members of the establishment and the Orthodox Church, ultimately led to the saving of 50,000 Bulgarian Jews from deportation to the death camps (see Todorov 200I). This triumph of citizen decency in repressive times was marred, however, by the deportation of II,O०० Jews from the territories occupied by the Bulgarian army in Greece, Macedonia and southeast Serbia to Treblinka and possibly other camps. ${ }^{\text {I4 }}$

Thus, the regime did succumb to the fascist political fashion of its time, and the I940 Law was a good example of this. Art. 2I, for instance, envisaged various grounds for a loss of Bulgarian citizenship, including 'acting against the security of the Bulgarian state'. It is important to note, that only Bulgarian subjects living abroad and Bulgarian subjects of non-Bulgarian origin could lose their citizenship in this way. The language in the provision for subjects of non-Bulgarian origin was particularly telling: they were to lose their citizenship 'if they ha[d] proven unworthy of it or were considered dangerous for state security and public order.' Needless to say, the vagueness of the provision was a guarantee for administrative abuses.

In September I944, the monarchical regime came to a crushing end through a communist takeover, which began the establishment of Soviet-sponsored communist rule in Bulgaria. This led to significant changes in Bulgarian nationality laws. The I947 Constitution of the People's Republic of Bulgaria did not have provisions pertaining to the acquisition, loss or restoration of nationality, but for the first time changed the legal status of Bulgarians by turning them from subjects to citizens - this was in line with the antimonarchical sentiments of the time. In I948, the Grand National Assembly adopted the Law on Bulgarian Citizenship, which replaced the I940 Law on Bulgarian Nationality. The reasons set out in the bill sent to the Assembly pointed out that there was a need to overcome an inadmissible differentiation of Bulgarian citizens into those of Bulgarian origin and those of non-Bulgarian origin who were treated less favourably. Therefore, the law reverted back to the pre-I940 main principles in this area. Art. I.I stated that a 'Bulgarian citizen by origin is any person whose parents are Bulgarian citizens'. The reference to 'Bulgarian parents' was eliminated, which turned the definition from an ethnic into a rather more civic one. Art. 2 introduced the principle of ius soli by stipulating that a: 
Bulgarian citizen by place of birth is every individual born or found inside the territory of the country, whose parents are unknown, or are of unknown citizenship or are without citizenship.

However, this was a more limited application of ius soli compared to the Law of I880, according to which practically every individual born in Bulgaria was considered a Bulgarian subject..$^{15}$ The restriction of the scope of the place-of-birth principle can be explained by contextual considerations: in 1948, Bulgaria was a country with a growing population that had absorbed significant waves of refugees over the previous two decades. There were practically no reasons for encouraging aliens to settle in Bulgaria. Paradoxically, however, this principle of limited ius soli became a permanent feature of subsequent legislation, even after the demographic context had completely changed.

Moreover, although the communist rulers attempted to abandon the fascist-inspired conceptions of 'Bulgarians by origin', they still preserved some of the most discriminatory practices embedded in the I940 Law. Thus, immediately after the communist takeover on 9 September 1944, many Bulgarians were deprived of Bulgarian citizenship for political reasons and their properties were confiscated (Aleksandrov I995: 44-45).

In 1968, a second Law on Bulgarian Citizenship was adopted. Under the 1968 Law all Bulgarians who refused to return behind the Iron Curtain were deprived of their citizenship. Similarly, anyone who in any way dared to express a negative opinion of the communist regime was also deprived of his or her citizenship. ${ }^{16}$ The ig68 Law, like the I940 Law, did not tolerate dual citizenship: a number of special bilateral international agreements were signed with a view toward eliminating or preventing dual citizenship (Valkanov I978: 33-48; Tzankov 2004: 48-51). ${ }^{\mathrm{I}}$ The 1968 Law did not explicitly require the renunciation of a previous citizenship by aliens who sought naturalisation, but it did deprive Bulgarians naturalised elsewhere of their Bulgarian citizenship.

This last clause was introduced at the time of the expulsion of the Bulgarian Turks (Liebich 2000: 105) - a shameful episode, which coincided with the end of communist rule in the country. Although crude analogies between fascist and communist rule are always misleading, it seems that in 1984 the Communist party leadership got infected with an ethnic paranoia that was very similar to that of their fascist predecessors. They decided to change the names of all ethnic Turks and Muslims into Bulgarian names (for more details, see Kalyonski \& Gruev 2008). The massive administrative operation was accompanied by intense propaganda, which promoted the idea that these minorities 
were actually ethnic Bulgarians forcefully assimilated by the Ottomans. Few ethnic Turks were convinced, which led to a protracted period of tension and repression, culminating in 1989 in the successful attempt of the Communist regime to expel more than 300,000 Turks to neighbouring Turkey. The regime argued that the process was a 'voluntary' resettlement; the public called it, with some irony, 'the Great Excursion'. Thus, the regime which started with a fierce rejection of the fascist laws and policies, ended up endorsing similar ones, albeit considerably less sinister (without death camps and 'a final solution', for instance). In the same year, communist rule finally collapsed, as a result of which between one-third and one-half of the 'excursion-goers' eventually returned home safely. ${ }^{18}$ On 20 December I990, the Grand National Assembly passed a law to have citizenship restored to the victims of the repressions against the Turks and Muslims, after which they could also reclaim any property confiscated during their absence (for more details, see the discussion in section 7.4). ${ }^{\text {19 }}$

\subsection{Current citizenship rules and practices}

The current Bulgarian legal regulations regarding citizenship are based on the provisions of the I99I Constitution. As we made clear in the previous section, the most repressive parts of the communist legislation were amended even before the adoption of the new basic law. However, the Constitution was meant to embody a complete vision of all questions relating to membership in the Bulgarian polity. Not surprisingly, much of this new philosophy resembles the approach of the Constituent Assembly in Veliko Turnovo in I879. Firstly, the Constitution grants citizenship to all persons born in the territory of Bulgaria, unless they acquire another citizenship by origin, or born to at least one parent who is a Bulgarian citizen (art. 25 (I)). Compared to the I880 Law, for instance, this is a more limited application of ius soli similar to the communist laws. Concessions to ethnic Bulgarians are also constitutionalised: 'A person of Bulgarian origin shall acquire Bulgarian citizenship through a facilitated procedure' (art. 25 (2)). In order to avoid some of the most repressive practices of previous regimes, the Constitution expressly prohibits depriving Bulgarian citizens by birth of their citizenship (art. 25 (3)) and the extradition or expatriation of citizens (art. 25 (4)). ${ }^{20}$

Furthermore, the Constitution practically guarantees the full scope of rights to all Bulgarian citizens without differentiating between citizens by birth or by naturalisation. There are only some minor, but symbolically important, exceptions, like the requirement of art. 93 (2), which states that candidates for the office of President of the Republic 
should be Bulgarian 'citizens by birth', ${ }^{2 \mathrm{I}}$ which, as a non-ethnic category, does not exclude representatives of minorities from running for this office. The inclusion of this provision was not a reflection of some grand ideology of Bulgarian nationhood, but was the result of a contextual, tactical political game among the major players in the Grand National Assembly, who wanted to block the candidacy for president of the then popular ex-communist leader Andrei Lukanov, who was born in the Soviet Union and originally had a Soviet passport.

As often happens with such contingent political calculations, this one also had serious unintended consequences for its drafters from the ex-communist Bulgarian Socialist Party (BSP). In 1996, Georgi Pirins$\mathrm{ki}$, the official BSP candidate for president was practically disqualified from the race by the Constitutional Court, which ruled that for the purposes of the presidential election citizenship by birth was to be established according to the law in force at the time of birth of the candidate. ${ }^{22}$ Thus, Pirinski was denied 'citizenship by birth' due to the vagaries of the communist citizenship laws in force at the time of his birth (Pirinski was born in New York, and according to the then valid law was not a citizen by birth). The dubious constitutional reasoning of the justices - which gave priority to the communist legislation over the Constitution - can be explained by the politicisation of the Court during that period; most of the judges just happened to be opponents of the BSP. This example vividly shows that citizenship policy is never solely a reflection of coherent ideologies and grand principles because key decisions can often be explained by contextual factors of temporary importance. Another example was the amendment to the Constitution that stipulated five years of residence in the country for presidential candidates. In the mind of the drafters, this requirement was designed to prevent Tsar Simeon II from running for the presidency in I99I. In fact, it did prevent him from doing so, but only ten years later (in 200I), when many of the drafters of this amendment would have been perhaps more supportive of his candidacy.

Leaving these unintended consequences aside, the Constitution had to solve one very serious problem indeed: the ongoing tension between the Bulgarian majority and the Turkish minority after the events of 1989. As mentioned above, the citizenship rights and property of Bulgarian Turks were restored, but many of them had already acquired Turkish citizenship and some had actually decided to resettle in Turkey permanently. ${ }^{23}$ The question about the status of these persons with double citizenship would require a major revision of citizenship policies, as both the 1940 and the communist regulations had expressly prohibited dual citizenship. The I99I Constitution altered this practice, mostly by remaining silent on the possibility of double citizenship. ${ }^{24}$ Thus, in order to remedy the former injustices against the Bulgarian 
Turks, Bulgaria became one of the few countries in Eastern Europe to recognise dual citizenship (Liebich 2000: I05).

Despite these concessions to the Turkish minority, the 1991 Constitution remains fundamentally sceptical about minority rights. It espouses an attitude that closely resembles the German constitutional doctrine of 'militant democracy', especially in its application to minorities in contemporary Turkish constitutionalism. ${ }^{25}$ The Constitution is specifically concerned with ethnic and religious politics and in a number of provisions it expressly prohibits the establishing political parties on an 'ethnic, racial or religious basis', (II(4)) or parties whose activities are directed against the integrity of the country, the unity of the nation, or the igniting of racial, national, ethnic, and religious hatred (44(2)).

These provisions threatened to bring the Bulgarian polity to a crisis immediately after the first parliamentary elections under the new Constitution in I99I. The reason was the controversy over the Movement for Rights and Freedoms (MRF), a political party organised mostly by members of the Turkish ethnic minority, which successfully ran in the in parliamentary election and formed a coalition government with the Union of Democratic Forces (UDF), the anti-communist opposition. BSP deputies attacked the constitutionality of the party before the Constitutional Court. ${ }^{26}$ In a well-reasoned decision, the Court effectively relaxed the prohibition of ethnic parties in art. II of the Constitution by arguing that only parties that are ethnically exclusive and threaten the constitutional order are to be banned. This decision legitimised the MRF, which gradually emerged as one of the major political parties in Bulgarian politics. The MRF is currently probably one of the few ethnic parties in Europe that officially belong to the European family of liberal parties. The MRF has been part of the ruling coalitions in Bulgaria since $200 \mathrm{I}$.

The rationale of the I99I Constitution was reflected in Bulgaria's citizenship legislation. The I968 Law went through a series of amendments. The most recent Law on Citizenship was enacted in I998. It took into consideration the new social developments of the transition period, as well as the prospect of EU membership. All of the remaining discriminatory positions included in the earlier Bulgarian citizenship laws, which affected those citizens who had left the country, were ultimately revoked by the 1998 Law. $^{27}$ The 1998 Law restored the citizenship of Bulgarians whose citizenship had been withdrawn by decrees during the period I944 to I947. ${ }^{28}$

\subsubsection{Acquisition of Bulgarian citizenship}

The present law, as already stated, accommodates multiple citizenship. Dual citizens are treated as Bulgarian citizens only when they enter 
Bulgarian territory and acquire the rights and duties of Bulgarian citizens. According to art. 3 in the current law:

Any Bulgarian citizen who is also a citizen of another state shall only be considered a Bulgarian citizen in the application of the Bulgarian legislation unless otherwise provided for by law.

There are very few disadvantages for people with dual citizenship, according to the Constitution: among the conditions for the election of deputies to the national parliament is the requirement that the "person must be a Bulgarian citizen who does not have another citizenship; the same is true for presidential candidates.

As Todorov points out, the I991 Constitution defines two notions: 'a person of Bulgarian origin' (a Bulgarian) and 'a Bulgarian citizen'. A Bulgarian is a person who by his or her origin is of Bulgarian 'blood'. Para. 2 (I) of the 1998 Law specifies that 'a person of Bulgarian origin is one whose ascendants (or at least one of these) are Bulgarian'. A Bulgarian is not necessarily a Bulgarian citizen. He or she could, for instance, be a Moldavian, a Macedonian or a Hungarian citizen. The notion 'Bulgarian' refers to an ethnic identity, not a legal status. The only privilege that the Constitution provides for ethnic Bulgarians is the ability to obtain Bulgarian citizenship through a facilitated naturalisation procedure. By contrast, the notion of the 'Bulgarian citizen' is legal and civic in its content. Bulgarian citizens, including those by birth, can be ethnic Bulgarians but also individuals from other ethnic groups such as Turks, Armenians, Chinese, etc. (Todorov i996: 7).

Therefore, the ethnic definition of 'Bulgarian' plays a role only in the rules for naturalisation. There are two methods for the acquisition of Bulgarian citizenship by naturalisation: a general regime and a preferential regime for certain categories of persons, including ethnic Bulgarians. The great majority of those who have acquired Bulgarian citizenship through naturalisation over the past few years have done so using the preferential regime (Tzankov 2005).

Art. I2 of the 1998 Law establishes the general regime for naturalisation. The requirements are that the applicant:

I. is of lawful age;

2. was granted permission for permanent residence ${ }^{29}$ in the Republic of Bulgaria not less than five years before application;

3. has not been sentenced by a Bulgarian court for an intentional crime of a general nature and has not been the subject of criminal proceedings for such a crime unless the person concerned has been rehabilitated;

4. has an income and occupation enabling him or her to support himself or herself in the Republic of Bulgaria; 
5. has a command of the Bulgarian language subject to verification in accordance with a procedure established by an order of the Minister of Education and Culture; and

6. was released from his or her previous citizenship or will be released from his or her citizenship at the moment of acquiring Bulgarian citizenship. ${ }^{30}$

It is clear from these provisions that the general regime for obtaining citizenship by naturalisation is quite restrictive. Applicants (if they do not fall into some special category) are normally required to have legally resided in the country for ten years (five years to obtain a permit, and another five to be eligible for citizenship). The waiting period for the permanent residence permit can be waived for those who have invested more than US\$ 500,000. Furthermore, the 1998 Law introduces for the first time the requirement of a clean criminal record, and, more importantly, knowledge of the Bulgarian language, ${ }^{3 \mathrm{I}}$ employment and income or income guarantees for an applicant of foreign origin. It is not surprising, then, that between 2000 and 2006 , there were only a total of 2,395 applications for Bulgarian citizenship through general naturalisation, of which only 865 were granted - all in all, statistically insignificant numbers (see Table I and Table 2 in section 7.4).

In contrast to the general regime, the 1998 Law is much less restrictive with regard to privileged groups. These can be divided into three categories. The first one is entitled to privileged naturalisation, which requires a minimum of three years residency after the acquisition of a permit for permanent residence in the territory of the Republic of Bulgaria. It includes persons married to Bulgarian citizens, persons having acquired permanent residence before the age of majority (art. 13) and refugees (art. I3a). Similar access is granted to stateless persons (art. I4).

The second category of persons who can benefit from the regime of privileged naturalisation includes those who have made special contributions and performed meritorious service to the Republic of Bulgaria. They are granted achievement-based nationality. Most often, this criterion is used to facilitate the acquisition of Bulgarian citizenship for athletes. $^{32}$

While refugees and foreign athletes must still satisfy a three-year residence requirement for facilitated naturalisation, this condition is dropped for the third category. It is, in fact, the most important group in terms of numbers and consists of persons of Bulgarian origin. According to art. I5 of the law, as amended in 200I, applicants of Bulgarian origin are exempted from all but two requirements: the minimum age and a clean criminal record. It is important to note that the exemption from language tests and residence requirements was adopted in 200I, which led to a significant increase in naturalisation proceedings, 
as discussed in section 7.4. The privileges for ethnic Bulgarian applicants also have financial implications; for instance, they pay a fee of only 5 BGN, whereas other foreigners pay I, 000 BGN..$^{33}$

Any person who is not a Bulgarian citizen may acquire Bulgarian citizenship through naturalisation provided that he or she is of Bulgarian origin. ${ }^{34}$ Establishment of Bulgarian origin is ethnic; the applicant has to show that at least one of his or her ancestors (ascendants - parents and grandparents) was an ethnic Bulgarian. The birth certificates of the parents and grandparents, their mother tongue, membership in Bulgarian institutions such as the Bulgarian Church, schools, former Bulgarian citizenship of the parents, etc., are relevant criteria for the establishment of the ethnic origin of the applicant through the ethnicity of his or her parents. It is important to note, however, that the law remains virtually silent about these more specific criteria of Bulgarian ethnicity, which leaves a significant degree of discretion to the administrative authorities in the resolution of individual cases..$^{35}$

An attempt to clarify the concrete conditions of proving 'Bulgarian origin' is made in the 2000 Law on Bulgarians Living outside the Republic of Bulgaria, which states that Bulgarian origin can be proven by documents issued by a Bulgarian or foreign state institution, an organisation of Bulgarians living outside the Republic of Bulgaria approved by the authorised state institution or by the Bulgarian Orthodox Church (art. 3). However, even with these clarifications, the problem of definitional indeterminacy and administrative discretion remains. ${ }^{36}$

\subsubsection{Loss of citizenship}

Following the Constitution's rationale to avoid the excesses of the communist regime, the 1998 Law declares that Bulgarian citizens by birth can lose their citizenship only if they express an explicit wish for this and acquire another citizenship. Generally, there are three ways to lose one's Bulgarian citizenship: release from Bulgarian citizenship, revocation of naturalisation, and deprivation of citizenship. According to art. 20:

any Bulgarian citizen who is permanently residing abroad may request to be released from Bulgarian citizenship, if he or she has acquired foreign citizenship or if there is information showing that a procedure for acquisition of foreign citizenship has been initiated.

Naturalisation can be withheld in a limited number of cases, for instance if the person has obtained it through the provision of false information or through the withholding of relevant information from the 
authorities (art. 22). Deprivation of citizenship of a naturalised person can take place if the person has committed grave crimes against Bulgaria (art. 24).

Revoked Bulgarian citizenship can be restored under certain conditions. These are dealt with both in the provisions in the 1998 Law and the amendments of 200I. The most important of these conditions is a residence requirement: three years of lawful permanent residence after the submission of the application for the restoration of one's citizenship (art. 26 (3)). ${ }^{37}$

\subsection{Current political debates}

The discussion thus far has demonstrated that, at the level of the Constitution, Bulgarian legislation provides for a fairly egalitarian framework, which could be interpreted as an acceptable basis for a civic community. However, this framework remains incomplete, and it allows for alternative interpretations through legislation; the main culprit in this regard is the provision for privileged naturalisation of Bulgarians by origin. The same is true of the provisions for multiple citizenship, which could also be interpreted as bestowing specific privileges on particular groups of citizens. Thus, ultimately, the Constitution leaves it to the political process to determine the precise make up of the Bulgarian political community, and the exact scope of the privileges for specific groups. In this section we therefore examine the dynamics of the political processes, which have a bearing on the questions discussed.

The most important recent development in this regard is the rise of populist politics in the country. Bulgarian populism is marked by a crisis in the representative system, and the 'mainstream parties' in particular, and the constant emergence of new players - such as the ex-Tsar Simeon's NDSV movement (National Movement Simeon the Second) ${ }^{38}$ in 200I, Boyko Borissov's GERB (Citizens for European Development of Bulgaria) in 2006 , and even something like a radical nationalist party - Ataka - in 2005. These populist players are largely indifferent to traditional left-wing or right-wing political ideologies. They use other means for the mobilisation of their people, which often include anticorruption campaigns and various milder or stronger versions of nationalism. The rise of populism in Bulgaria coincided with the transformation of the MRF - the Turkish minority party - into a mainstream player consistently taking part in the government of the country. ${ }^{39}$ Thus, the anti-elite, anti-establishment rhetoric of the newcomers also acquired some ethnic overtones; they started to ethnicise corruption and to portray the MRF as the most problematic element in the party system. However, evidence shows that the MRF, although prone to pa- 
tronage and clientelistic practices, is no more corrupt than the other parties.

In the face of populist attacks from these newcomers, the representatives of the 'mainstream parties', such as the BSP, had to revise their campaign strategies and react to the challenge. President of the Republic Georgi Parvanov - who was the former chairman of the BSP and a historian by training - played a primary role in the design of the new political course, which could be described as the 'mainstreaming' of some mild forms of nationalism in order to reduce the appeal of the populists. As the head of state, Parvanov started taking public positions on issues of 'historical importance', such as the significance of the struggles for the liberation of Macedonia in Bulgarian history, the 'misinterpretations' by domestic and foreign experts of specific events, such as the Batak massacre in 1876 , and so on. ${ }^{\circ}{ }^{\circ}$ Formal official rituals also underwent significant redevelopment in order to stress the historical continuity of the Bulgarian nation and the grandeur of the sacrifice made by its ancestors.

Of course, President Parvanov played an important role in the formation of citizenship policy as well, though in this area, the 'mainstreaming' of nationalism began even before the start of his mandate. Gradually, however, citizenship policy was included in the symbolic manifestations of mild nationalism, especially with regard to international relations with Macedonia.

Below we demonstrate how the rise of populism and the reactive 'mainstreaming' of mild nationalism affected three specific policy areas: the voting rights of Bulgarian Turks residing in Turkey, the naturalisation policies and policies that address demographic problems and the need for foreign labour.

\subsubsection{The voting rights of Bulgarian Turks living in Turkey}

As already discussed, in the I980s, the then communist regime of Bulgaria adopted a policy towards the Turkish minority in Bulgaria, according to which Bulgarians with Turkish origin were forced to adopt Slavic names. This led to a great wave of emigration back to Turkey in I989. After the one-party system collapsed in I989, many reclaimed their Bulgarian citizenship, but only some of them resettled in Bulgaria, while others who regained Bulgarian passports preferred to remain in Turkey (see also Kadirbeyoglu in this volume). Among this group, there are many children and retirees who nowadays spend their summers in Bulgaria. Some come back to pursue higher education or perform military service in Bulgaria, given the general fear among Turks of having to do one's military service in the Kurdish regions of Turkey. The two states have an agreement concerning the mutual recognition 
of one another's military service (which became a moot point after the professionalisation of the Bulgarian army). In general, the relationships between Bulgaria and Turkey have begun to flourish and have reached an unprecedented level of civility, especially when, in I997, the then newly elected Bulgarian President Peter Stoyanov delivered a speech to the Turkish National Assembly, asking for forgiveness for what had been done to the Turkish minority in his country (Petkova 2002: 52-54).

According to official migration statistics, Turkish migrants with dual Bulgarian and Turkish citizenship form a community of around 380,000 people. Under the 1998 citizenship law, these migrants have the right to regain their Bulgarian citizenship while keeping their Turkish citizenship. As dual citizens, they develop and share dual loyalty, rights and obligations (Özgür-Baklacioglu 2006: 322).

The rise of populism in Bulgaria meant that the voting rights of Bulgarian citizens of Turkish origin who are resident in Turkey came increasingly under attack. These rights are the same as those of other citizens; that is, they can participate in parliamentary, presidential, local and EP elections in Bulgaria. Debates about these voting rights arose first in the I990s. Thus, on the eve of parliamentary elections in December I994, the possibility of significant support for the MRF by Bulgarian Turkish voters in Turkey was strongly debated in the Bulgarian media. MRF supporters were estimated at 150,000 eligible voters. The main question was whether citizens with dual citizenship who were not resident in Bulgaria had the right to influence Bulgarian internal politics. However, this debate was not revived in the 1997 parliamentary elections when Bulgarians had much more serious crises to deal with, such as trying to survive after the economic crisis of 1996 (Ivanov 1997).

During all general elections held in the past fifteen years, the interested parties (specifically the MRF) have organised large numbers of Bulgarian Turks with voting rights who reside permanently in Turkey to vote either in polling stations in Turkey (in over 70 locations in 2005) or to be transported by bus to Bulgaria to cast their votes there..$^{4 \mathrm{I}}$ Bus transportation has been widely available during municipal elections in Bulgaria. In the June 200 I parliamentary election, the MRF received 38,840 of the 50,000 votes cast in Turkey. In this way, the votes of the dual citizens living in Turkey helped elect three MRF members to the Bulgarian Parliament (it needs to be noted, however, that dual citizens have neither a special representation quota nor specially designated MPs as their representatives). The local elections in 2003 showed similar results, when dual citizens contributed to MRF electoral victories in twelve municipalities as well as the election of 695 local mu- 
nicipality council members and advisors (Özgür-Baklacioglu 2006: 328).

Protests against the voting rights for dual citizens have been expressed by political parties, public opinion as well as some scholars (e.g. Boyadjiev 1996)..$^{42}$ In 2007, however, these protests escalated into a campaign by all of the opposition parties, in which individual members of the ruling majority also took part (including the BSP chairman of parliament who in a crucial vote on some of the debated residence requirements, sided with the opposition).

The conflict over the voting rights for dual citizens emerged in relation to the first European Parliament elections in May 2007. The question was whether the National Assembly should introduce specific residence requirements for voters in European Parliamentary elections, which would disqualify the Bulgarian Turks living in Turkey. The opposition parties proposed these requirements, which soon gained widespread public support. According to a study by the Alpha Research Agency, public opinion in Bulgaria was clear with some 78.7 per cent of all Bulgarians supporting residency requirements in these elections. Such a high rate of popular approval is comparatively rare in Bulgarian politics. The sole opponents of the new regulation were supporters of the MRF. ${ }^{43}$

In the ensuing heated parliamentary debates some members of the opposition even argued that MEPs elected with the help of Bulgarian voters in Turkey would in fact represent Turkey rather than Bulgaria. After four hours of debate over the controversial text, 80 opposition MPs walked out of the plenary hall. Ultimately, the ruling coalition allowed all citizens to be enfranchised regardless of where they resided. In the subsequent election, the MRF did exceptionally well and came in third with 20.26 per cent, just behind GERB (a centre-right populist party) with 2I.68 per cent and the BSP with 2I.4I per cent. The MRF received a total of 392,650 votes.

In the following local elections of 2007 , attempts to introduce the residency requirements succeeded initially, but were then dramatically watered down through various legal technicalities, which made it possible to claim residency only on the basis of a permanent address registered on one's identity card, which virtually all people have, even if they live abroad. Thus, the practice of 'electoral tourism' continued unabated.

It is important to note, however, that the MRF is gradually losing the public debate on residency requirements, and if they were to join the opposition, a reversal of policy is very probable. What is striking in the emerging dominant public opinion is the lack of a principled vision of citizenship. Some who support the denial of voting rights argue that this measure will eliminate possibilities for vote-buying and electoral 
fraud; others see it as a punishment for the 'corrupt' MRF; while still others try to argue that only taxpayers should have political rights; and last, but not least, are the Ataka supporters, who believe that ethnic Bulgarians should be privileged in terms of political rights. This cacophony of angry voices is the mark of populist mobilisation.

\subsubsection{Dual citizenship for persons with Bulgarian origin}

At first sight, the contemporary naturalisation policy of Bulgaria has been a success - numbers of applicants and naturalised citizens continue to rise. In a situation of negative demographic trends, ${ }^{44}$ this is undoubtedly good news. However, the problem is that this policy is not designed to help solve the demographic problem, or provide the necessary workforce, but mostly to win some symbolic battles over the past with neighbouring countries, as well as to mobilise domestic voters. The backward-looking nature of this policy means that its successes will hardly be sustainable.

The majority of applications for the acquisition of Bulgarian citizenship are based on Bulgarian origin. Between 200I and 2005 this amounted to 90 per cent of the total number of applications (Tzankov 2005). For the period 2000 to 2006 , the largest number of applications for citizenship were those based on origin and were filed by Bulgarians abroad, mainly from Macedonia, Moldova, Russia, Ukraine and Serbia. In total, there were 87,722 applications for citizenship based on origin. Of these, 32,702 came from Macedonia and 38,64I were filed by Moldovan citizens. During the same period, the number of citizens from Macedonia who were granted Bulgarian citizenship on the grounds of their Bulgarian origin by Vice-Presidential Decree was I0,850. The number for Moldova was 9,I87 (see Table I and Table 2 in section 7.4).

According to Stefan Nikolov from the State Agency for Bulgarians Abroad (SABA), 'since 200I, Bulgaria has been attractive because of its Euro-Atlantic prospects, its stability and the travel opportunities that Bulgarian passports offer'. Nikolov also noted that the number of applications has increased exponentially. In 200I, only 940 people acquired Bulgarian citizenship, but the number rose to 3,000 in 2002; 4,000 in 2003; 5,559 in 2004; 5,722 in 2005; and 6,5II in 2006 (see Table 2). One of the most prominent cases of Macedonians being granted Bulgarian citizenship was that of the former Prime Minister of Macedonia, Ljubcho Georgievski.

More than 20,000 people have received Bulgarian passports since 200I, when the number of applicants for Bulgarian citizenship was almost 5,500. That number rose to nearly 29,500 in 2004 . In 2005 alone, when 23,200 applications were submitted, more than 2,400 Ma- 
cedonians and a slightly greater number of Moldovans were granted Bulgarian citizenship. The total combined number of Russians, Israelis, Ukrainians and Serbs who received Bulgarian passports in 2005 was less than $700 .{ }^{45}$ Less than five months before Bulgaria joined the $\mathrm{EU}$, the number of applicants awaiting approval exceeded 50,000. In 2007 , that number rose to 60,000 persons waiting for Bulgarian citizenship. ${ }^{46}$

All this is due to the privileged and facilitated naturalisation procedure for members of Bulgarian minorities applying for Bulgarian citizenship in neighbouring countries. Once it is granted to them, they enjoy all the rights to which Bulgarians are entitled, without being obliged to give up their other nationality or live in Bulgaria.

But here lies the problem: it remains unclear what the actual contribution of these people to contemporary Bulgarian society is going to be. They are applying with the explicit expectation of the travel opportunities that a Bulgarian passport affords, without having to live in the country. The fear is that the ultimate result of this policy might be the further extension of the 'symbolic Bulgarian citizenship' without addressing the actual pressing social problems. There is also a European dimension to this issue: this type of external Union citizenship generates immigration rights and rights to political participation at the EU level, which may conflict with the developing EU immigration regime. This problem, however, has not even been registered in Bulgarian public debates.

As to the symbolic 'gains' that the policy offers, they come mostly in the form of settling historical scores with neighbouring countries. Macedonia is the primary target here, ${ }^{47}$ and thus it is no surprise that current Bulgarian naturalisation policy is most negatively received there, especially among the nostalgic pro-Yugoslav local political establishment. The concept of 'Bulgarian by origin' contradicts the 'official' interpretation of Macedonian identity because the concept assumes that there are ethnic Bulgarians living within Macedonian borders. The official reaction of the Macedonian government to the Bulgarian policy has been ambivalent, however, if we leave aside the ongoing anti-Bulgarian bias in the local media. Unlike the Ukraine, Macedonia has not chosen to penalise its citizens who hold dual citizenship.

Nevertheless, Macedonia has intensified its claims that Bulgaria is violating the rights of Macedonians in Bulgaria and, in particular, their rights to association and assembly. Symbolic politics here has indeed led Bulgaria to violate the European Convention on Human Rights (ECHR). In 2000, the Bulgarian Constitutional Court (BCC) banned the tiny nationalist Macedonian party OMO-Ilinden because it was seen as a threat to the integrity of the state and the unity of the nation. The BCC's decision ${ }^{48}$ strayed from its previous reasoned judgements 
concerning the MRF (see the discussion in section 7.2), and essentially ruled that certain speeches, letters and maps produced by the party were a substantial threat to the Bulgarian state. This paranoid reasoning was judged to be in violation of ECHR art. II (in conjunction with art. Io) by the European Court of Human Rights in 2006. ${ }^{49}$ Since then, Bulgarian authorities have denied registration to OMO on various formal and procedural grounds. These decisions have recently been criticised by the Committee of Ministers of the Council of Europe. ${ }^{50}$

It is difficult to say who has the upper hand in these friendly skirmishes in the symbolic warfare between Bulgaria and Macedonia. Naturalisation numbers and some famous 'casualties', such as the naturalised former PM of Macedonia, tilt the scales towards Bulgaria. But the OMO-Ilinden story and the general sympathy for the underdog seem to level the score. It is quite clear, however, that the target audience of the symbolic warfare is domestic; it is used for mobilisation purposes by particular actors, and at least in the Bulgarian case, it correlates to the rise of populism and the reactions to it. Not surprisingly, the major actors in this symbolic warfare in Sofia are, on the one hand, the leaders of the nationalistic-populist parties (Ataka, Internal Macedonian Revolutionary Organisation (VMRO), among others); on the other hand, it is the President of the Republic himself, who apart from being a key figure in the administration of naturalisation policies, regularly expresses the official Bulgarian position on the symbolic front.

In terms of more tangible international relations, Macedonia and Bulgaria, surprisingly, do not have any serious unresolved questions. Despite the apparent mutual animosities, Bulgaria has always staunchly supported Macedonia both in difficult times, such as during the bombardment of Kosovo by NATO, and now when Macedonia is on its way to becoming a NATO member. Patronising as this behaviour may appear to politicians in Skopje, it is still markedly different from the behaviour of Macedonia's other EU neighbour, Greece, which still refuses to recognise the official name of the country, and vetoed Macedonian NATO membership in April 2008.

\subsubsection{National dreams and the imperatives of a globalised world}

In this section, we further pursue the theme of an obsession with the past in the development of Bulgarian naturalisation policy, and raise the issue of its adequacy vis-à-vis more contemporary challenges. Many of the Bulgarian government's organisational efforts in this area can be understood as an attempt to symbolically restore the Bulgarian Exarchate through some modern surrogate, which would institutionalise links with the ethnic Bulgarians abroad. 
A primary recent example of these efforts is the aforementioned Law on Bulgarians Living outside the Republic of Bulgaria (2000). This law is based on a specific ethnic definition of Bulgarians abroad, which is less inclusive than the definition of 'Bulgarian by origin' (Özgür-Baklacioglu 2006: 335). 'Bulgarians by origin', to remind the reader, are those persons who have a Bulgarian parent (mother or father). 'A Bulgarian living outside the Republic of Bulgaria' is a person permanently residing abroad who has at least one parent of Bulgarian origin and has Bulgarian national consciousness. The law in question is designed to:

encourage the creation of favourable conditions for the free development of Bulgarians living outside [...] Bulgaria, according to the principles of international law and the legislation of the respective state with the aim of protecting their rights and lawful interests.

The Bulgarian state commits itself to support the organisation of Bulgarians outside Bulgaria whose activities are directed at the conservation and development of the Bulgarian language, as well as cultural and religious traditions. Furthermore, the law provides certain entitlements for Bulgarians living abroad; for instance, free elementary and secondary education in the state and municipal schools in the Republic of Bulgaria, according to current conditions and regulations for Bulgarian citizens. Significantly, with regard to the pursuit of higher education, the law grants Bulgarians living abroad the right to apply for public financial assistance (art. IO).

Apart from dealing with students, the law also regulates the state support for 'the preservation and demonstration of the Eastern Orthodox faith as the traditional religious affiliation of Bulgarians and as a factor in preserving the Bulgarian national identity'. Moreover, it makes special provisions for Bulgarians living abroad who wish to settle in Bulgaria. It creates favourable conditions for their return by offering them state-owned lands or municipal agricultural lands for use during the early years after settlement.

Although the law envisages the creation of a National Council for the Bulgarians Living Abroad, the state body responsible for relations with Bulgarians abroad is the State Agency for Bulgarians Abroad (SABA). This agency primarily establishes and maintains contact with and supports the activities of societies, associations, church communes, media and schools of the Bulgarian communities in dozens of countries. In addition, SABA is an important element in the processes of acquiring Bulgarian citizenship, in obtaining permission for long-term residence in Bulgaria and for certifying the Bulgarian origin of persons 
who have applied for Bulgarian citizenship. The SABA, in essence, serves as a functional substitute for the now defunct Exarchate.

The problem here is that because of the excessive focus on historical Bulgarian minorities in adjacent lands, ${ }^{5 \mathrm{I}}$ the state has virtually neglected the close to a million people who have left the country since I989, emigrating for economic reasons to Western Europe, North America and elsewhere. There is hardly any coherent policy concerning these people, who remain Bulgarian citizens in most cases. Many open questions concerning their situation - such as their health insurance contributions, for instance - are resolved ad hoc, if at all. The Council of Ministers discussed a special report on The Bulgarians Abroad and the State Policy towards Them on 20 December 2007 in an effort to respond to some of these problems..$^{2}$

However, as the report shows, the state is making efforts mainly to attract Bulgarians from historical minorities, while relatively few measures have been designed to motivate the Bulgarian emigrants living in Western Europe and North America to return. The report estimates that at present more than three million Bulgarians live abroad, of which one million are Bulgarian citizens. About 800,000 of these have emigrated to Western European or North American countries. Unfortunately, the report does not provide more detailed figures for the various regions. Nevertheless, it contains several interesting findings, such as the lack of a new migration of people to EU countries since accession. The policy measures envisaged by the report mainly involve preserving Bulgarian national identity abroad, and introducing educational and vocational advantages in the country for ethnic Bulgarians residing abroad with a view to curbing the worrying demographic trends; according to projections, the Bulgarian population will decrease from 7.7 million in 2004 to only 5.5 million by 2050 , if current trends continue.

While the interests of the historical Bulgarian communities are more or less addressed by the report and its recommendations, the problems of economic emigrants are largely neglected. Academic degrees and professional qualifications gained abroad still need to go through a complex procedure of domestic legalisation. EU accession partially resolved this problem for degrees and qualifications acquired in other EU countries, although, at the practical level, numerous problems persist. ${ }^{53}$ For North American emigrants, EU accession has not changed anything substantially. Moreover, Bulgarian employment and hiring practices in many areas (and especially in the public sector) remain highly clientelistic. The practice of widespread patronage in appointments is definitely a serious hurdle for any person motivated to return from a period of economic emigration. Significantly, the above-mentioned report fails to address any of these problems. 
At the end of his mandate, Prime Minister Ivan Kostov of the UDF proved to be an exception to the general trend of neglecting economic emigration by inviting 'prominent Bulgarians' living abroad (mainly in the EU and North America) to a grand seminar in Sofia. This initiative - episodic as it was - encouraged a number of young, well-educated Bulgarians to return to Bulgaria (ironically, most of them joined the Tsar's movement in 200I and became political opponents of Kostov). However, what is currently needed in this regard are not these kinds of episodic gatherings, but some major revisions in policies and institutional structures, which remain highly conservative and do not allow for 'external' competition. Restructuring institutions, ranging from the higher education system (which is highly inflexible to courses in foreign languages, guest professorships, etc.) to the administration and the business communities, would not only motivate Bulgarian emigrants who have left the country for economic reasons to return, but would also attract new highly skilled immigrants. Arguably, the latter are as important as the historical diaspora, since they could introduce newer skills and training, novel practices, etc.

Finally, an important flaw in the current state policy in terms of the imminent problems of labour shortages (recognised both by the aforementioned report and increasing insistent calls from the Bulgarian business community), is its implicit assumption that labour shortages can be addressed primarily by attracting ethnic Bulgarians, be they historical or contemporary emigrants. However, it is questionable whether the three million ethnic Bulgarians are willing to return to the motherland under the conditions Bulgaria can currently offer. Bulgaria may therefore have to look for alternative solutions to labour shortages such as non-ethnic immigration, which, in turn, would require dramatic immigration and citizenship policy revisions. This is a debate that has yet to take place, however.

\subsection{Current statistical trends}

As we have already mentioned, we can observe a marked increase both in the number of applications for Bulgarian citizenship and the number of those granted citizenship since 200I. Between 200I and 2005, the number of applications for citizenship increased by a factor of four, from 5,495 applicants in 2001 to 29,493 in 2004. There was a slight decrease in 2005 and 2006 , but the sizeable difference between applications filed and citizenships granted does not necessarily mean that those applications were denied. There are at present approximately 58,600 files still awaiting a decision, which might simply mean that there is an administrative backlog (Tchorbadjiyska 2007: IO०-IOI). 
d!ysuaz!!! วg fo uo!n! !วunuas 1of | suo!zbo! |ddio fo raquinN

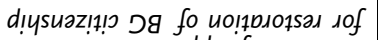
suo!luo!lddo fo aquinN
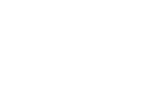


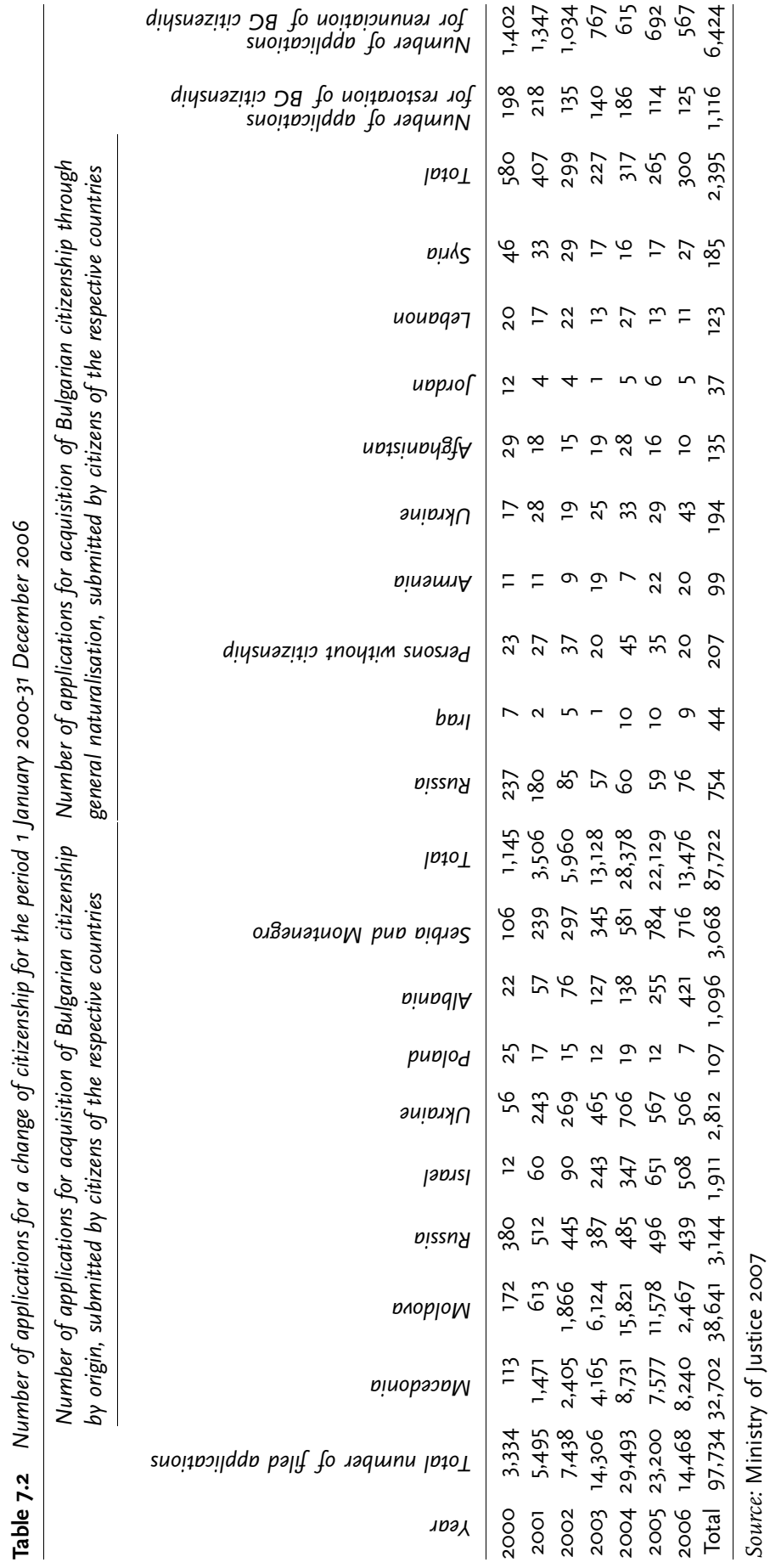


Table 7.I and Table 7.2 provide detailed data on the numbers of applications and the numbers of those granted citizenship status in Bulgaria between 2000 and 2006 . They differentiate between normal naturalisation procedures and the preferential treatment of ethnic Bulgarians.

According to Tchorbadjiyska (2007), one of the factors influencing the increase was a change in $200 \mathrm{I}$ in the laws regarding Bulgarian citizenship. Until 200I, applicants of Bulgarian ethnic origin needed to demonstrate proficiency in the Bulgarian language and, most importantly, had to either renounce their present nationality or commit themselves to doing so. As discussed, these two conditions were dropped after 200I. Thus, those Bulgarian minorities living abroad who might not have applied earlier because they did not want to lose their present nationality now have a possibility to acquire Bulgarian nationality while retaining their former citizenship. Apart from the change in legal conditions, the increase in citizenship applications is explained by changes in the visa regime. As most of the Bulgarian minorities abroad are citizens of countries that were either on the Bulgarian visa blacklist or were included in it upon entry to the EU, their travel options were seriously hampered. In this situation, the acquisition of Bulgarian citizenship, especially under simplified procedures, became an obvious solution.

\subsection{Conclusions}

The normative frame of Bulgarian citizenship discussed in this chapter is characterised by a degree of substantial incoherence. At the most basic level, the Bulgarian polity combines two different competing and sometimes conflicting principles. On the one hand, it commenced as, and remains, a predominantly Bulgarian project. On the other hand, there has been a genuine attempt to create an egalitarian political community, which does not differentiate between its members, be they of Bulgarian origin or not. This constitutive incoherence has resulted in a complex web of general equality norms, privileges and exceptions. Indeed, there were low points in the development of the Bulgarian polity, when the desire to entrench privileges led to discriminatory and repressive practices - especially in the authoritarian-totalitarian period of I940-1989. However, in times when democracy had a real chance, the incoherent normative framework proved sufficiently inclusive and thus stimulated a rich plurality of voices in Bulgarian public life. This inclusive incoherence characterises the contemporary regulation of citizenship as well. 
Normative incoherence has one significant drawback: it does not lend itself easily to constitutionalisation and judicial interpretation. Even Dworkin's super judge Hercules (Dworkin I986) would find it difficult to construct a theory that eliminates the tension between egalitarian and identity-based considerations in the Bulgarian case. In the absence of a judicially administrable citizenship rulebook, much has been left to the political process. It is an encouraging fact that at present this political process has provided for a robust representation of the main minorities in the country. However, as John Hart Ely (I980) predicted in another context, when you rely exclusively on the democratic process, there may be some tiny and insular minorities whose rights will be neglected. In Bulgaria, the associational rights of Macedonians have proven Ely right, and it is good that the country is already in an internationally regulated environment; under pressure from the Council of Europe and other organisations this problem is currently being resolved.

More worrying, however, are certain aspects of the internal dynamic of the political process related to the rise of populism. This phenomenon focuses domestic politics on issues such as anti-corruption, personal charisma and, most importantly, national identity and historical symbolism. This seems a common Central European development. It does not affect only the marginal radical nationalist parties. In the emerging political trend, Bulgarian actors stand together with the Kaczynski brothers in Poland, Victor Orban in Hungary, Fico and Mečiar in Slovakia, and so on. Populism threatens to turn the inclusive incoherence of the Bulgarian normative model into a cacophony of angry voices, in which some nasty overtones from authoritarian and totalitarian times are clearly discernible.

Overall, although the record of the Bulgarian polity in its modern history has been, at certain points, mixed, it still provides reasons for confidence. In the absence of thoroughly principled solutions to tensions and conflicts, the achievement of modus vivendi compromises has been the norm in this history. For students of coherent normative theories, this political modus vivendi response perhaps seems unsatisfactory. This is not such a great problem, however, because the very idea that civilised relationships among members of a pluralistic polity depend on the existence of a coherent theory embodied in a citizenship rulebook strikes us as utterly bizarre. 
Chronological list of citizenship-related legislation in Bulgaria

Date Document Content Source

1879 Turnovo Constitution

1880 First Law on Bulgarian Nationality

1883 Second Law on Bulgarian Nationality

1903 Third Law on Bulgarian Nationality

1940 Fourth Law on Bulgarian Nationality

1947 Constitution of the People's Republic of Bulgaria

1948 First Law on Bulgarian Citizenship

1968 Second Law on Bulgarian Citizenship

1991 Constitution of the Republic of Bulgaria
Defines Bulgarian subjects as those being born in Bulgaria who have no other citizenship and those born of Bulgarian subjects elsewhere Is based on the ius soli principle; envisages four modes of acquisition (by origin, adoption, marriage, naturalisation) and five modes of losing Bulgarian nationality (by renunciation, decision of the authorities, absence, adoption and marriage) Adds the ius domicilii to the ius soli principle (i.e. Bulgarian subjects are all Turkish subjects who were born on, or resided in, the territory of the Bulgarian Kingdom at the time of the liberation wars)

Maintains the main principles of the first two laws while the principle of ius sanguinis becomes more important

Stresses the ius sanguinis principle in addition to the ius soli principle

Changes the legal status of Bulgarians from subjects into citizens

Based on the ius sanguinis principle; declares that 'enemies' of the state and those who defected to the West can be deprived of Bulgarian citizenship

Deprives Bulgarian www.legislationline.org citizenship of all those who (as amended in 1989) refuse to return to Bulgaria; prohibits dual citizenship Defines as Bulgarian www.legislationonline.org citizens all those who have a parent with Bulgarian 


\begin{tabular}{|c|c|c|c|}
\hline Date & Document & Content & Source \\
\hline & & $\begin{array}{l}\text { citizenship and those born } \\
\text { in the Bulgarian territory } \\
\text { who are not entitled to any } \\
\text { other citizenship; foresees } \\
\text { a facilitated procedure of } \\
\text { acquiring citizenship for } \\
\text { those of Bulgarian descent }\end{array}$ & \\
\hline 1998 & $\begin{array}{l}\text { Law on Bulgarian } \\
\text { Citizenship }\end{array}$ & $\begin{array}{l}\text { Based on both ius soli and } \\
\text { ius sanguinis; establishes } \\
\text { four principles for the } \\
\text { acquisition of Bulgarian } \\
\text { citizenship (by origin, } \\
\text { place of birth, } \\
\text { naturalisation and } \\
\text { restoration); } \\
\text { accommodates multiple } \\
\text { citizenship }\end{array}$ & $\begin{array}{l}\text { www.bulgarianembassy. } \\
\text { org.uk }\end{array}$ \\
\hline 2001 & Amendments & $\begin{array}{l}\text { Facilitate the procedures } \\
\text { for acquisition of Bulgarian } \\
\text { citizenship for ethnic } \\
\text { Bulgarians; require } \\
\text { persons of non-Bulgarian } \\
\text { origin acquiring Bulgarian } \\
\text { citizenship by } \\
\text { naturalisation to be } \\
\text { released of their previous } \\
\text { citizenship }\end{array}$ & \\
\hline
\end{tabular}

\section{Notes}

I The authors thank Rossitza Guentcheva and Ruzha Smilova for their very helpful comments.

2 This had implications from the point of view of international law; formally, until 1908, Bulgarians were still considered subjects of the Turkish Sultan (Geshkoff 1927).

3 Such delegations mostly came from Eastern Rumelia - an artificially created, semiautonomous region in the Ottoman Empire - and Macedonia and Eastern Thrace (or the Vilayet of Adrianople), two other Ottoman regions which were to remain within the Empire without any special privileges for the compact localised masses of Bulgarians living there. Similar delegations came from other lands, such as Bessarabia in present-day Ukraine and Moldavia and Dobrudja in present-day Romania (see Vladikin I994: 97).

4 The delegates considered the Berlin treaty an illegitimate revision of the San Stefano Peace Treaty (March I878) between Russia and Turkey, which created Grand Bulgaria, including territories in what is today Macedonia, Turkey, Serbia and Greece. The date of this treaty -3 March - is currently the Bulgarian national holiday. San Stefano Bulgaria roughly coincided with the jurisdiction of the Bulgarian Exarchate, the Bulgarian Orthodox Church authorities in the Ottoman Empire. 
5 The Turnovo Constitution used subject (podanik) and citizen (grazhdanin) interchangeably. With the fall of the monarchy and the establishment of communist rule, the term subject was eliminated from legal documents and acquired negative connotations in official public discourse. However, it was not true that the subjects to the Bulgarian monarch had fewer rights than the citizens of the communist republic.

6 It is not only political rights that reflect the egalitarian bias of the Constitution. Art. 78 , for instance, granted the right to free public primary schooling to all subjects (both male and female) of the principality.

7 It envisaged four methods of obtaining Bulgarian nationality (by origin, adoption, marriage and naturalisation) and five methods for the loss of Bulgarian nationality (by renunciation, decision of the authorities, absence, adoption and marriage). The main principle embedded in the law again was the principle of ius soli. Art. I para. I stipulates: 'All individuals born on the territory of the Bulgarian Kingdom who have not obtained foreign nationality count as Bulgarian nationals.'

8 Art. 2 of the 1883 Law introduced a slightly more restrictive version - not all individuals, but only former Turkish subjects could make use of the principle stating that: 'Bulgarian subjects are all those Turkish subjects who at the time of war for the liberation of Bulgaria had residence or were born on the territory of the Bulgarian Kingdom'. This restriction, which was contrary to the general language of the Constitution (art. 54), was eventually eliminated from later versions.

9 Art. 65 just stated: 'Only Bulgarian subjects may occupy positions in the state, public and military service.'

Io This was the second assassination of a prime minister by Macedonian nationalists. In 1895 , Stefan Stambolov was slain in the centre of Sofia, partly for the same reasons.

II According to art. 7, a 'Bulgarian national is every person I) whose father or (if the father does not have a nationality or is of unknown nationality) mother is a Bulgarian subject, regardless of their places of birth; 2) legitimated by a Bulgarian subject, 3) born out of wedlock whose Bulgarian subject's origin is proved while he or she is a minor.' Ius soli was still present in art. 8: a 'Bulgarian subject by place of birth is every individual I) born in the Kingdom of unknown parents or parents without nationality and 2) born of foreigners, if he or she had permanent residence in Bulgaria and has not declared foreign nationality one year after coming of lawful age' (Valkanov i978).

I2 In order to obtain a residence permit, applicants had first to prove that they had lived in the kingdom for a year, and then to provide information about their origin (parents), religion, material standing and other details (art. 27).

I3 The treaty with Greece was ratified by Bulgaria on 4 October I920. In September I940, a similar treaty was signed with Romania.

I4 It is still being debated in Bulgarian scholarly literature whether the Bulgarian authorities were fully responsible for these deportations: some argue that the occupied territories were virtually under German command. Be that as it may, the Bulgarian authorities did nothing, or at least not enough, to prevent these deportations. Most importantly, Jews from the occupied territories were apparently not granted Bulgarian citizenship, while Greeks and Macedonians were.

I5 Those born in Bulgaria to an alien were entitled to Bulgarian citizenship if at the time of their majority they were domiciled in Bulgaria.

I6 Toni Nikolov, 'The Right of Bulgarian Citizenship and the European Norms', Demokratzija, I2 May 1998.

I7 Such agreements were concluded between the People's Republic of Bulgaria and the USSR in 1958, the People's Republic of Hungary in 1959, the Socialist Republic of Romania in 1959, and again with the USSR in 1966, the German Democratic 
Republic in I97I, the People's Republic of Poland in 1972 and the Czechoslovak Socialist Republic in 1975 (Zakon za bulgarskoto grazhdanstvo I968).

I8 From 3 June through 2I August I989 (when Turkey closed its borders), 3II, 862 ethnic Turks managed to leave the country. After the fall of Todor Zhivkov and the communist regime in November 1989 , some 125,000 returned to Bulgaria. By the end of I989, the refugees' back-and forth movements ceased and 245,000 refugees who had fled Bulgaria were granted Turkish citizenship (Özgür-Baklacioglu 2006: 32I).

I9 The reversal of policy against the Turkish minority started immediately after the fall of the communist regime in November 1989: there were communist leadership decisions calling for the repeal of the repressive legislation as early as December of that same year.

20 The last provision was amended in 2005 in compliance with international treaties concluded by Bulgaria regarding international criminal tribunals: 'No Bulgarian citizen may be surrendered to another State or to an international tribunal for the purposes of criminal prosecution, unless the opposite is provided for by international treaty that has been ratified, published and entered into force for the Republic of Bulgaria.'

2I 'Bulgarian by birth', according to the I99I Constitution, is not an ethnic category; it refers to those born within the country's borders or to Bulgarian citizen parents and includes thus ethnic Turks and other non-ethnic Bulgarians.

22 See Decision No. I2, 23 July i996.

23 There are no reliable data for the number of permanent settlers, but estimates show that it was about I00,000.

24 The Constitution mentioned the possibility of dual citizenship in its prohibition on dual citizens running for parliament and the presidency.

25 The term 'militant democracy', which was first coined by Karl Loewenstein in the I930s, refers to a constitutional legal doctrine according to which the democratic state should actively protect itself and its values against internal enemies and should prevent them from coming to power by using the democratic process. The doctrine requires instruments such as bans on extremist organisations and antisystem parties, loyalty requirements for civil servants, etc. The doctrine was first systematically implemented within the German Basic Law after the Second World War. For further information, see Sajo 2004.

26 Decision 4, 2I April 1992.

27 This process was ultimately finalised in 1998 because it was only then that the Union of Democratic Forces succeeded in the formation of a stable government. Until then, the country was run mainly by the ex-communist BSP, whose assessment of the communist period was rather ambivalent; in general, the party was unwilling to radically revise the policies of the communist regime.

28 Among those, for instance, were 43 former ambassadors of the Bulgarian Kingdom who had lost their Bulgarian citizenship by a decree issued by the erstwhile President Vassil Kolarov in 1947. They had refused to acknowledge the 'people's power' of the communist regime (Rossitza Milanova, 'The Citizenship of Those Bulgarians Whose Citizenship Was Denounced between 1944 and 1947 Is Restored', Democrazija, I2 May 1998).

29 There are different procedures for obtaining this permission. In most cases, the applicants have to show that they have legally resided in the country for the previous five years or that they have invested more than US\$500,000. Ethnic Bulgarians and foreigners born in Bulgaria are exempt from these conditions. Those who have performed meritorious service to the country are also exempted from the requirements. For more details, see the information at the site of the Ministry of Foreign Affairs: www.mfa.bg. 
30 This requirement was added in 2000.

3I Order No. 5 of 1999 of the Minister of Education and Science defines the procedure for the establishment of knowledge of Bulgarian language. The applicants either have to show documents proving that they have studied in Bulgarian schools or have valid certificates for the language proficiency, or they have to take a written exam before a special commission. They need to demonstrate that they have sufficient knowledge of the Bulgarian language to enable them to communicate at 'an elementary level' (art. 6(2)).

32 Until 2006, the proposal allowing foreign athletes to obtain Bulgarian citizenship was made by the Bulgarian vice prime minister responsible for sports. This provision was amended in 2006 when the government decided that the proposal should be made by the director of the State Agency for Youth and Sport (Telegraph, 8 June 2006).

33 Interview with Elitza Hristrova, State Agency for Bulgarians Abroad, 2 June 2007.

34 Alternatively, (2) he or she has been adopted by a Bulgarian citizen on terms of full adoption; (3) one of his or her parents is a Bulgarian citizen or has passed away as a Bulgarian citizen (art. I5).

35 While the 1998 Law envisions a preclusive deadline of three months for the facilitated naturalisation of foreigners with Bulgarian origin, the procedure usually takes two to three years due to the numerous inspections at various Bulgarian institutions. Such inspections are carried out by the Directorate for Migration at the Ministry of the Interior, the National Security Service, the State Agency for Bulgarians Abroad (SABA) and others (Interview, State Agency for Bulgarians Abroad, 2 June 2007). The problem of discretion in the administration of these checks remains quite acute, however.

36 The State Agency for Bulgarians Abroad (SABA) is also involved in the process of verifying Bulgarian origin: see the discussion in section 7.3.3 on this topic. Stefan Nikolov (SABA) said that officials are conducting 'thorough inspections' to prevent unlawful claims and abuses, since many of those waiting for their applications to be processed might have submitted 'documents with dubious validity' ('Thousands Seeking Bulgarian Citizenship Ahead of EU Entry', Southeast European Times, I4 August 2006, www.setimes.com).

37 Some usual provisos apply, such as the absence of a criminal record and the requirement of good, moral behaviour.

38 The NDSV could only be interpreted as a populist party in is first two years of its existence; it gradually transformed into a 'normal' party, albeit at the cost of its popularity.

39 The reasons for this development are numerous, but one is that MRF can rely on the relatively stable ethnic support of Bulgarian Turks. In circumstances of declining turnout, the stability of the electorate of the MRF increases its relative influence.

40 In a curious development, in 2007, the Bulgarian President involved himself in a public debate with a junior art historian, who was supported in her research by a young German scholar. The art historian had written a paper interpreting the "myth of the Batak massacre'. Apparently, she had traced the reconstruction of specific events in the public memory from the Bulgarian uprising against the Ottomans in I876, exploring the role that works of art played in this construction. The President interpreted the whole project as an attempt to deny that the massacre ever happened (an indisputable fact), and to misinterpret Bulgarian history. He even hosted an 'open history class' in the town of Batak, the main purpose of which was to discredit the art historian's project. Leaving aside the historical substance of the debate, it is highly unusual for a head of state to take on the role of a guardian of national history, especially when his opponents are academics. 
4I Some Bulgarian elections have coincided with major Muslim holidays, in order to make the 'electoral tourism' possible.

42 In 2006 , the radical nationalist party Ataka proposed amendments to the 1998 Law on Bulgarian Citizenship. These amendments were meant to eliminate dual citizenship. The party proposed that a Bulgarian citizen cannot be a citizen of another country, with the exception of citizens of Bulgarian ethnic origin and Bulgarian culture. These privileges would be confined to persons living permanently in neighbouring regions in Greece, Macedonia, Serbia and Romania, and also including Bessarabian Bulgarians. The Bulgarian Parliament rejected the proposal with nineteen votes 'for', 78 'against' and 26 abstentions (Telegraph, 8 June 2007).

43 Rumjana Bachvarova, 'The Reticence of Power', Capital, 23 February 2007, www.capital.bg.

44 The country is losing between 30,000-50,000 citizens per year, although the most recent statistics show that the decrease in population is slowing down.

45 Although there is a relatively large community of some 235,000 Bulgarians in the Ukraine, not many applications for Bulgarian citizenship are filed from this country, as according to Ukrainian law, they have to renounce their Ukrainian citizenship in the process. Serbians have been increasingly interested in obtaining Bulgarian citizenship since Bulgaria joined the EU. Since the beginning of 2007 , nearly I,200 Serbs (actually ethnic Bulgarians from Dimitrovgrad and Bosilegrad) have taken advantage of the right to obtain Bulgarian citizenship. According to the Bulgarian Ministry of Justice, another 3,400 had submitted applications and were awaiting decisions ('Serbians Are Increasingly Interested in Obtaining Bulgarian Citizenship', Sofia Echo, 6 August 2007, www.sofiaecho.com).

46 In contrast to Hungary, the privileges for 'external citizens' neither created heated public debates nor significant problems during EU accession negotiations. There are several reasons for this. Firstly, the Bulgarian diaspora in neighbouring countries is smaller than the Hungarian one, and much less organised. In most cases, the policy provides for individual exit strategies of Bulgarians abroad. Secondly, Bulgaria has complied with all of the formal requirements of the EU visa regulations, and has imposed visa restrictions on neighbouring countries in which Bulgarians live. Finally, the issue is not internally divisive, as is the case in Hungary; no major party, including the MRF, opposes the current policies.

47 As Özgür-Baklacioglu argues, the Law on Bulgarians Abroad established kin minority protection and turned dual citizenship into an engine of intensive nation-building. Dual citizenship status for the migrant community in Turkey remains a subject of political debate, while it does not create problems in cases involving Macedonian applications. In other words, the accommodation of Macedonians as Bulgarian citizens has a special historical importance in building the Bulgarian nation. In nationalist circles, it is perceived as the return of the Macedonians to their 'first' origin, i.e. the Bulgarian one. As understood from the application procedure, Macedonian applications are handled under the provision for applicants with Bulgarian origin. Macedonians do not need a permanent resident status and do not have to show a certificate proving knowledge of the Bulgarian language. Among the initial set of application documents is a declaration that verifies Bulgarian cultural consciousness (Özgür-Baklacioglu 2006: 336).

48 Decision I, 29 February 2000.

49 Case of the United Macedonian Organisation Ilinden and others v. Bulgaria, I9 January 2006.

50 See Svetoslav Terziev, 'Strassbourg Harasses Bulgaria about OMO', Sega, 27 March 2008, www.segabg.com. 
5I One of the main target groups of the SABA is the community of Bessarabian Bulgarians and Bulgarian minorities in Serbia, Moldova and Romania.

52 At the time of writing there is an ongoing debate organised by SABA on this document; see www.saba.government.bg.

53 For instance, the so-called VAK (Supreme Commission of Attestation) still has the right to examine, in substantive terms, degrees earned in the EU. It is true that the Commission, as a rule, does not usually apply this right. But still, according to the law it can deny the domestication of an EU degree on substantive grounds by a secret vote!

\section{Bibliography}

Aleksandrov, E. (1995), Pravo na zadrganichnite bulgari. Sofia: Agency for Bulgarians Abroad.

Balamezov, S. (1993), Konstitutsionno pravo: chast purva. Sofia: Sofi-R.

Boyadjiev, M. (I996), 'Dvojnoto grazhdanstvo i Bulgaria: zagubvane i pridobivane', Mezhdunarodni otnosheniya 2: 69-76.

Dworkin, R. (1986), Law's Empire. Cambridge, MA: Harvard University Press.

Ely, J. H. (I980), Democracy and Distrust. Cambridge, MA: Harvard University Press.

Geshkoff, T. (I927), 'An analysis of the Bulgarian Nationality Law', American Journal of International Law 2I (3): 534 - 537

Ivanov, A. (2007), Minority Nationalism in the Balkans: the Bulgarian Case. www.ime-bg.org.

Kalyonski, A. \& M. Gruev (2008), Vuzroditelnijat process [The Rebirth Process]. Sofia: Institute for the Study of Recent Past.

Liebich, A. (2000), 'Plural Citizenship in Post-Communist States', International Journal of Refugee Law I2 (I): 97-I07.

Malinkov, A. (I94I) Komentar na Zakona za bulgarskoto podanstvo. Sofia.

Özgür-Baklacioglu, N. (2006), 'Dual Citizenship, Extraterritorial Elections and National Policies: Turkish Dual Citizens in the Bulgarian-Turkish Political Sphere', in O. Ieda (ed.), Beyond Sovereignty: From Status Law to Transnational Citizenship?, 319-358. Sapporo: Slavic Research Center.

Petkova, L. (2002), 'The Ethnic Turks in Bulgaria: Social Integration and Impact on Bulgarian-Turkish Relations, I947-2000', The Global Review of Ethnopolitics I (4): 42-59.

Sajo, A. (ed.) (2004), Militant Democracy. Utrecht: Eleven International Publishing.

State Agency for Bulgarians Abroad (2007), Introduction. www.aba.government.bg.

Todorov, T. (I996), 'Grazhdanstvo po rozhdenie po chl. 93, al. 2 ot Konstitutzijata', Pravna misul (4): 7-I4.

Todorov, T. (200I), The Fragility of Goodness: Why Bulgarian Jews Survived the Holocaust. Princeton, NJ: Princeton University Press.

Tzankov, V. (2004), Bulgarsko grazhdanstvo. Sofia: Bulgarian Academy of Sciences.

Tzankov, V. (2005), Az, grazhdaninut na Republika Bulgaria i na Evropejskija suүuz. Sofia: Ministry of Justice.

Tchorbadjiyska, A. (2007), 'Bulgarian experiences with visa policy in the accession process: A story of visa lists, citizenship and limitation of citizenship rights', Regio, Minorities, Politics, Society 10: 87-107.

Valkanov, V. (1978), Bulgarskoto grazhdanstvo. Sofia: Bulgarian Academy of Sciences.

Vladikin, L. (I994), Istoriya na Turnovskata constitutsia. Sofia: Narodna kultura.

Zakon za bulgarskoto grazhdanstvo from 1968 (I982) In Dogovori za pravna pomosht, konventzii za urezhdane na dvojnoto grazhdanstvo i grugi aktove. Sofia: State Publishing House 'Science and Art'. 


\section{Part III}

\section{Post-partition states}





\title{
8 Czech citizenship legislation between past and future ${ }^{\mathrm{I}}$
}

\author{
Andrea Baršová
}

The main contours of the Czech (formerly Czechoslovak) citizenship laws were shaped by momentous historic events. Administrators, judges and lawyers smoothed over rough outlines made by political forces, adding to them exceptions, interpretations and remedies. Consequently, Czech citizenship legislation has always been complex. ${ }^{2}$ This chapter follows the main trends of its development and gives a brief account of Czech citizenship legislation and the politics and policies linked with it since I9I8. It focuses on responses to unprecedented social changes and challenges in the last two decades, which may be stimulating for the current debates on citizenship policies in the European and transnational context.

\subsection{History of Czechoslovak citizenship policies}

\subsubsection{Citizenship policies from 1918 to 1993}

Czechoslovak citizenship came into existence with the creation of Czechoslovakia on 28 October I9I8. It was linked to the municipal right of domicile that had been an important instrument regulating migration within the Habsburg monarchy. ${ }^{3}$ Former Austro-Hungarian nationals, who had a right of domicile in municipalities that became part of the Czechoslovak territory after the break-up of the Austro-Hungarian Empire, acquired Czechoslovak citizenship. The basic rule was modified by peace treaties ${ }^{4}$ and constitutional laws ${ }^{5}$ which regulated the issue of citizenship in order to protect ethno-national minorities and provided options to choose the citizenship of an ethnic kin state. The creation of Czechoslovakia led to the massive remigration of ethnic Czechs and Slovaks, in particular from Austria (Vaculík 2002: 38-39; Kristen I989: 83). Apart from specific provisions linked to the creation of the new state, provisions of old Austrian laws on citizenship remained in force in the Czech lands of Bohemia and Moravia. ${ }^{6}$ This was the case, for instance, with the ius sanguinis principle laid down in the I8II Austrian Civil Code.

The end of the Second World War ${ }^{7}$ and the restoration of Czechoslovakia led to the adoption of ad hoc laws that introduced the criterion of 
ethnicity into citizenship legislation. The new legislation was linked to post-war (both forced and voluntary) migration. Under the President's Constitutional Decree No. 33/I945 Coll. Concerning Czechoslovak Citizenship of Persons of German and Hungarian Ethnicity (one of the socalled 'Beneš decrees'), Czechoslovak nationals of German and Hungarian ethnic origin were deprived of Czechoslovak citizenship. ${ }^{8}$ On the other hand, Constitutional Act No. 74/1946 Coll. Concerning the Naturalisation of Compatriots Returning to the Homeland and its implementing regulations provided for facilitated naturalisation of ethnic Czechs, Slovaks and members of other Slavonic nations who settled or re-settled in Czechoslovakia. Naturalisation was often linked to changes of names to Czech or Slovak ones (Vaculík 2002: 40-49). In the postwar years, more than 200,000 Czechs, Slovaks and members of other Slavonic nations immigrated to Czechoslovakia while more than 2,820,000 inhabitants of German ethnicity were expelled.

After the communists seized power in Czechoslovakia in February I948, deprivation of citizenship was introduced as a supplementary penalty for certain political offences. A complex new citizenship legislation was adopted in I949. Act No. I94/I949 Coll. on Czechoslovak Citizenship modified by Act No. 72/1958 Coll., replaced the old legislation, but preserved many of its features, such as the ius sanguinis principle and the principle of a single citizenship. Both in the communist ideology and in legal theory, citizenship meant not only legal but also factual bonds between a citizen and the society. A legal textbook published in $1_{9} 63$ defines 'socialist citizenship' in the following way: 'Socialist citizenship is not only a legal bond between a citizen and the state, but it means also belonging to a community of working people, who participate in the building of socialist (communist) society and in the building and defence of the socialist state; it means belonging to the community connected by shared dreams and ideals' (Černý \& Červenka i963: i9).

The law also provided for depriving people of Czechoslovak citizenship. It was applied as penalty to those citizens who lived abroad and had engaged in activities 'which might endanger state interests', those who had left the territory of Czechoslovakia 'illegally', those who had not returned to Czechoslovakia when requested to do so by the Ministry of the Interior and those who lived abroad for more than five years without a 'valid passport permitting its holder to live abroad'. These legal provisions existed until I990.

The Prague Spring of i968, a movement towards the liberalisation of communist rule, was accompanied by the Slovak national movement. ${ }^{9}$ This movement demanded the introduction of a federal system within a multiethnic, but centralised, Czechoslovakia. As of I January I969, the unitary Czechoslovak state was transformed into a federal 
state, composed of the Czech and the Slovak Republics. ${ }^{\text {Io }}$ At the level of citizenship legislation, this change was reflected by the adoption of Federal Act No. I65/1968 Coll. on the Principles of Acquisition and Loss of Citizenship, which was followed by the Act of the Czech National Council No. 39/1969 Coll. on the Acquisition and Loss of Citizenship of the Czech Socialist Republic, adopted in April I969. . The new legislation introduced, in addition to the (federal) Czechoslovak citizenship, citizenship of the two (Czech and Slovak) Republics as the constituent entities of the Federation. ${ }^{\mathrm{I} 2}$ Under this legislation, Czechoslovak nationals automatically acquired the citizenship of either the Czech or Slovak Republic, based on their place of birth and some supplementary criteria.

The new legislation gave people a right to change the republic-level citizenship at their discretion but this right was rarely exercised. The reason was trivial: the republic-level citizenship had no practical consequences whatever. In fact, most citizens were not even aware of their republic-level citizenship. ${ }^{3}$ In addition, the freezing period of 'normalisation' in the I970s and I980s, which followed the suppression of the Prague Spring, pushed most people into private and family life as the only remaining space for meaningful activities, where the question of citizenship had no significance.

The fall of the communist regime in November I989 prompted new developments in all spheres, including citizenship legislation. The first task for the new democratic government was to remedy injustices caused by deprivations of citizenship under the communist rule. In response to communist abuses of power, a constitutional provision was introduced, to stipulate that, "no one shall be deprived of his or her citizenship against his or her will'. ${ }^{4}$ In I990, Act No. 88/1990 Coll. was adopted, which provided for the reacquisition of the Czechoslovak citizenship by emigrants who had lost it in the period of communist rule. The law, which was not free of certain restrictions and shortcomings, ${ }^{15}$ identified one strand of future development in the field of citizenship legislation that I will call restitution legislation.

\subsubsection{Break-up of Czechoslovakia and creation of the Czech citizenship}

The demise of the communist regime opened a space for the resurgence of nationalist feelings and politics. ${ }^{\text {I6 }}$ In Czechoslovakia, the rebirth of the Slovak nationalist movement led to a consensual break-up of the federal state. In the fall of I992, as the break-up of Czechoslovakia was increasingly becoming a realistic option (negotiated and carried through by the ruling political elite), ${ }^{\mathrm{I}}$ many Czechoslovaks started to think about their future in terms of citizenship. ${ }^{\text {I8 }}$ The dormant provisions of the existing citizenship legislation, which allowed for a simple 
switch between the Czech and the Slovak republic-level citizenships, started to be widely invoked. Until the end of 1992, some 65,000 Slovak republic-level citizens applied for the Czech republic-level citizenship.

On I January 1993, the Czech and the Slovak Republics were established as successor states to the former Czechoslovakia. In the Czech Republic, citizenship issues were regulated by the hastily drafted and adopted Act No. 40/1993 Coll. on the Acquisition and Loss of Citizenship of the Czech Republic. ${ }^{19}$ The primary aim of the law was to identify nationals of the new state and to prevent dual (Czech and Slovak) citizenship. $^{20}$

The provisions of the new legislation fell into two main categories. The first was a set of transitory provisions regulating initial determination of nationals of the new state, ${ }^{2 \mathrm{I}}$ complemented by provisions governing the option for Czech citizenship. The other category involved rules of permanent nature, regulating e.g. acquisition of the Czech citizenship by birth, naturalisation or loss of Czech citizenship.

Table 8.1 Conceptual scheme of Act No. 40/1993 Coll. on the Acquisition and Loss of Citizenship of the Czech Republic

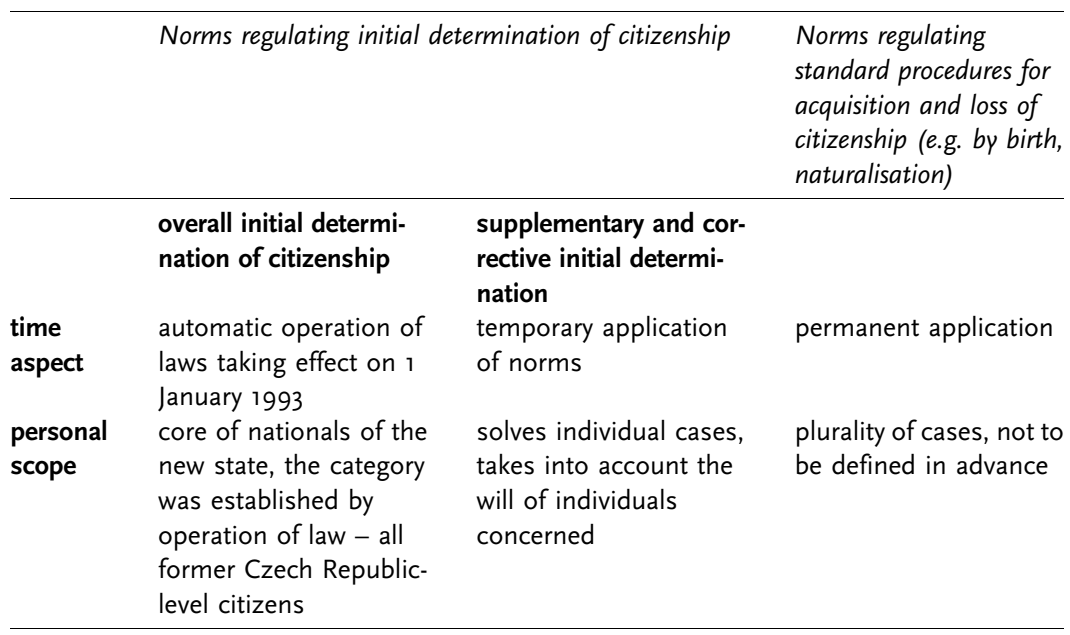

As regards the initial overall determination of citizenship, Act No. 40/ I993 Coll. stipulated that, 'natural persons, who were citizens of the Czech Republic as of 3I December I992, are citizens of the Czech Republic as of I January I993.' Leading Czech jurists explain the establishment of Czech citizenship in the following way. 'As a consequence of the disappearance of Czechoslovakia and the establishment of the Czech Republic as an independent entity under public international 
law, the Czech republic-level citizenship acquired as of I January 1993 an international dimension and turned into full-fledged state citizenship.' (Černý \& Valášek i996: 99). The same approach as regards overall (collective) initial determination was adopted by Slovak legislators. This prevented de iure statelessness in the wake of the break-up of Czechoslovakia. ${ }^{22}$

The primary rule was supplemented with a set of transitory provisions regulating the right of option and facilitating naturalisation for certain Slovak citizens. In the period from I January I993 to 30 June I994, 240,000 former Czechoslovak citizens acquired Czech citizenship under the option clauses.

The criteria for exercising this right of option, however, included not only two years of permanent residence in the territory of the Czech Republic, but also a clean criminal record. ${ }^{23}$ The application of the latter condition had a disproportionate impact on members of the Roma (Gypsy) minority. ${ }^{24}$ It was criticised by Czech human rights activists as well as by the international community. The criticism led to piecemeal adjustments and a softening of Act No. 40/1993 Coll. in relation to former Czechoslovak (now Slovak) nationals. ${ }^{25}$

In the decade following the establishment of the independent Czech Republic, public and political discourse on citizenship matters was dominated by one issue: the intentional and accidental consequences of the break-up of Czechoslovakia. In the shadow of this central theme, some problems related to the restitution of Czechoslovak (now Czech) citizenship for emigrants were also discussed. In the autumn of 1998 , with the change of government (from liberal-conservative to social-democratic), a more profound reform of citizenship legislation was put on the government agenda. This led to (a) significant alterations of the transitory provisions of the 1993 Citizenship Act, and (b) the adoption of Act No. 193/1999 Coll. on the Citizenship of Some of the Former Czechoslovak Citizens, which was another piece of restitution legislation.

(a) The former legislation mitigated the harsh consequences of the break-up of Czechoslovakia for some groups of former Czechoslovak nationals. A ruling of the Constitutional Court of the Czech Republic of 5 May $1997^{26}$ also fostered this development. The Court held that one does not lose Czech citizenship by one's declaration to opt for citizenship in the Slovak Republic. (These individuals became dual nationals.) ${ }^{27}$ Major amendments to the 1993 Citizenship Act were implemented by Act No. 194/1999 Coll. which not only transformed this ruling into a statutory provision, but also allowed all Czech citizens who were former nationals of Czechoslovakia to acquire Slovak citizenship without losing their Czech citizenship. (This is an exception to one of the declared principles of the Czech citizenship legislation, i.e. the prevention of dual citizenship.) 
The law also introduced a simplified procedure for acquisition of Czech citizenship by declaration for former Czechoslovak nationals who had been living continuously in the territory of the Czech Republic since the break-up of Czechoslovakia. This was a corrective provision. It provided for acquiring Czech citizenship by those who for various reasons (legal or personal) could not opt or apply for Czech citizenship before. The necessity of the remedy is demonstrated by this figure: 6,278 former Czechoslovak citizens acquired Czech citizenship in 1999 alone, by invoking the new provision. ${ }^{28}$

A subsequent amendment to Act No. 40/1993 Coll. adopted in 2003 (Act No. 357/2003 Coll.) introduced further remedial provisions. It gave former Czechoslovak nationals who were granted Slovak citizenship (i.e. were naturalised in Slovakia) in the period from I January I994 to I September I999 the right to (re-)acquire the lost Czech citizenship by declaration. The amendment also gave the right to acquire the Czech citizenship by declaration to certain groups of Slovak nationals who were minors at the time of the break-up of Czechoslovakia. ${ }^{29}$

(b) Act No. I93/1999 Coll. on the Citizenship of Some of the Former Czechoslovak Citizens, reintroduced and broadened the right of reacquisition of Czech citizenship by declaration. It applied to emigrants who had lost Czechoslovak citizenship under communist rule, but for legal or practical reasons had not been able to make use of the first restitution act of I990. Originally, the applicability of the law was limited to five years after its entry into force.

\subsection{Basic principles of acquisition and loss of Czech citizenship}

As stated above, the citizenship legislation has gone through a series of adjustments since I993. While the greater part of the fine-tuning was related to the situation of former Czechoslovak nationals, there have been other changes, such as acquisition of citizenship by children or naturalisation. Some changes reflected reforms of the administrative structures. This section describes the main principles of Czech citizenship legislation in force as of I January 2008. It does so only selectively in so far as they reflect topical political discussions or indicate new trends.

\subsubsection{Acquisition of citizenship}

There are four ways of acquiring Czech citizenship: a) acquisition of citizenship by former Czechoslovak citizens by option, declaration or facilitated naturalisation (as described above), b) acquisition of citizenship by birth, adoption and establishment of paternity, c) acquisition of 
citizenship by being found in the territory of the Czech Republic and d) acquisition of Czech citizenship by naturalisation.

Under the ius sanguinis principle, one acquires Czech citizenship at birth if at least one parent is a Czech citizen. The place of birth is not relevant. Ius soli applies if the parents are stateless and at least one of them is a permanent resident (i.e. a green-card holder). ${ }^{30} \mathrm{~A}$ natural person found in the territory of the Czech Republic is a Czech citizen unless it is proved that he or she acquired the citizenship of another state at birth.

The conditions for naturalisation are strict: ${ }^{3 \mathrm{I}}$ permanent residence for at least five years, clean criminal record, ${ }^{32}$ passing a Czech language test, renunciation of the previous citizenship, ${ }^{33}$ no infringement of immigration law, and fulfilment of certain statutory duties, such as paying taxes, health, social and retirement insurance. The permanent residence status is an eligibility criterion that may not be waived. Under the immigration legislation in force until April 2006 an immigrant could apply for permanent resident status (i.e. a green card) only after ten years of continuous legal residence in the Czech Republic and after eight years in cases of family reunion. Exemptions were made only for those related to Czech citizens or permanent residents and on humanitarian grounds. Thus, the waiting period for naturalisation for many immigrants was in fact fifteen years or more. ${ }^{34}$

There are statutory exemptions for certain categories (such as recognised refugees and stateless persons). For instance, refugees are eligible for naturalisation without having to renounce their original citizenship. (They acquire permanent resident status by virtue of being granted asylum.) Most of the requirements can be waived at the discretion of the Ministry of the Interior if certain conditions are met. For instance, the Ministry may waive the five-year duration of permanent residency (but not the permanent resident status as such) for applicants born in the Czech Republic, former Czech (or Czechoslovak) nationals, spouses of Czech nationals, children of Czech nationals, stateless persons or refugees.

There is a long list of discretionary exemptions from the requirement to renounce one's original citizenship. This list was extended by Act No. 357/2003 Coll. partly because of an initiative by the Human Rights Council (see below). Applicants may keep their previous citizenship (and become dual or multiple nationals) if they are permanent residents, have stayed legally in the territory for at least five years, have a genuine link to the Czech Republic and, in addition, satisfy one of the prescribed conditions. These are, for example, situations when the applicant's renunciation of the previous citizenship involves unreasonable fees or other demands not acceptable in a democratic state, when naturalisation is in the interest of the Czech Republic because of the ex- 
pected significant contribution to the Czech society in science, societal life, culture or sports or when the applicant is a former Czech (or Czechoslovak) national. ${ }^{35}$ There is also an exemption for applicants who have resided legally in the Czech Republic for at least twenty years and have held permanent resident status for five years or more.

The relatively simple language test is waived for all Slovak nationals and for any one else at the discretion of the authorities.

The Ministry also screens all applicants in order to assess the security risk that they pose to the state. Some authors consider passing the security test an additional condition for naturalisation (Valášek \& Kučera 2006: 85).

\subsubsection{Loss of citizenship}

Since the Czech Constitution prohibits deprivation of citizenship against one's own will, it may not be imposed as a penalty. In conformity with the principle of ius sanguinis even later generations of Czech descent born and living abroad cannot lose Czech citizenship by mere operation of law.

A Czech national can lose citizenship in two ways: by a declaration of renunciation and by acquisition of foreign citizenship at his or her request. A Czech citizen may lose his or her citizenship by a declaration of renunciation if he or she stays abroad and at the same time possesses the citizenship of a foreign state (cases of dual and multiple citizenship). ${ }^{36}$ A Czech citizen automatically loses Czech citizenship as a consequence of acquiring a foreign citizenship if the latter citizenship is acquired at his or her own request. (This does not apply if the acquisition of a foreign citizenship is automatic, for example by descent.) This mode of automatic loss of citizenship was introduced by the I993 Citizenship Act and did not exist before I January I993. ${ }^{37}$ This provision became controversial in practice. ${ }^{38}$ Its constitutionality was also challenged with reference to the ban on deprivation of citizenship against one's will but was eventually confirmed by the Constitutional Court. ${ }^{39}$

The 2003 amendment to the I993 Citizenship Act (Act No. 357/ 2003 Coll.) introduced an exemption from the loss of citizenship in relation to marriage. If a Czech national acquires the citizenship of his or her spouse during the marriage, he or she will not lose Czech citizenship. ${ }^{40}$

\subsubsection{Dual and multiple citizenship}

The Czech legislation is becoming generally more tolerant about dual (and multiple) citizenship. This trend is clearly visible in spite of the 
fact that the official citizenship policy followed the principle of prevention of dual citizenship until recently. In reality, there are numerous dual and multiple nationals who acquired the status legally. These are e.g. former Czech and Czechoslovak citizens who reacquired Czech citizenship by declaration under the restitution laws, people who became dual Czech and Slovak nationals due to the break-up of Czechoslovakia, applicants for naturalisation for whom the Ministry of the Interior waived the requirement for them to renounce their former citizenship (including cases of achievement-based naturalisation), naturalised refugees, and Czech spouses of foreign citizens. There are those who acquired dual citizenship by descent and emigrants who acquired foreign citizenship but never lost their Czech (or Czechoslovak) citizenship.

Moreover, there are many cases in the grey zone. For instance, if the Czech authorities are not informed of the acquisition of a foreign citizenship by a Czech citizen or by the foreign state concerned, which is often the case, they still treat the person as a Czech citizen (e.g. they will grant him or her a passport).

\subsubsection{International treaties}

The Czech Republic is party to certain bilateral and multilateral treaties concerning citizenship. The current trend is toward accession to multilateral treaties ${ }^{4 \mathrm{I}}$ as most bilateral treaties were terminated, primarily because they were not compatible with the provisions of the I997 European Convention on Nationality as regards the preservation of dual citizenship for children whose parents have different citizenship. These terminated bilateral agreements were with the former Soviet Union and some of its successor states as well as the German Democratic Republic, Hungary, Poland, Bulgaria, and Mongolia.

Politically, the most controversial of the bilateral agreements was the I928 Naturalisation Treaty between the United States and Czechoslovakia, which precluded dual citizenship of emigrants. ${ }^{42}$ The Treaty was valid until 20 August 1997. The application of the Treaty excluded many former Czechoslovak citizens from restitution of their property lost during the communist regime.

\subsubsection{Procedure}

The Ministry of the Interior is responsible for citizenship issues. The Ministry decides on naturalisations. It maintains a central register of persons who have acquired or lost Czech citizenship. A decision by the Ministry may be appealed. In this case, the Minister of the Interior decides. The Minister receives the opinion of a special consultative commission, but is not bound by it. ${ }^{43}$ Decisions on citizenship are open to 
judicial review. ${ }^{44}$ Fees are relatively high - Io,००० Czech crowns (approximately 400 euros) for granted naturalisation. The acquisition of citizenship by declaration is free of charge.

\subsection{Current political debates}

The gradual solution to the problem of the break-up of Czechoslovakia, which dominated the citizenship agenda in the first decade after 1993 created some space for fresh approaches to the fundamental issues of citizenship legislation. The shift of perspective was also due to a new phenomenon: increasing migration to the Czech Republic and evolving integration policies (Baršová 2005; Baršová \& Barša 2005: 23I-238).

An impetus for an overall revision of the citizenship legislation came from the government Council for Human Rights. ${ }^{45}$ Following an Analysis of Dual Citizenship Issues submitted to the government and the adoption of major amendments to the 1993 Citizenship Act in 2003, the government decided that the Ministry of the Interior should prepare a comprehensive analysis of the citizenship legislation based on broad public consultation and submit it to the government by 30 June 2005. The Ministry circulated a consultation paper in the autumn of 2004 and subsequently, in May 2005, a draft Analysis of the Legislation on the Acquisition and Loss of Citizenship. ${ }^{46}$

The Analysis discusses the fundamental principles of the new citizenship law. It suggests the following crucial moves towards liberalisation: a) full toleration of dual (multiple) citizenship on both the entry and exit sides and b) facilitated acquisition of citizenship by secondand third-generation migrants.

a. As regards the grounds for this profound reform, the Ministry refers to both the prevailing trends toward liberalisation abroad and practical aspects. There are countries which do not allow, in legislation or in practice, renunciation of one's citizenship. This is a source of undue administrative burden, according to the Ministry. ${ }^{47}$

b. The Ministry suggests that foreign nationals born in the territory of the Czech Republic should have the right to acquire Czech citizenship by declaration within two years after the age of majority if they are permanent residents and have a clean criminal record. The same should apply to those who have lived continuously in the Czech Republic since early childhood. Even if this proposal is not a very favourable solution in comparison with other options (such as the application of ius soli at birth), it is still a positive change in the national context. At present the Czech citizenship legislation does not have any provisions specifically addressing the issue of second and third generation immigrants. The proposed rule would at least 
eliminate the need to apply for membership in the community where the applicant was born and grew up.

On the other hand, the Ministry states that the strict conditions for naturalisation should be maintained or even be tightened. It proposes excluding from naturalisation applicants who are likely to become a public burden. The Analysis also contemplates some changes in language testing: the testing should be more professional. ${ }^{48}$

In July 2005, the government approved the Analysis. ${ }^{49}$ A year later, in June 2006, the Ministry of the Interior circulated the first framework draft of the new legislation. In addition to the changes mentioned above, the Ministry proposes to amend the Constitution so as to allow the withdrawal of citizenship in cases of false acquisition of citizenship (e.g. fraudulent use of documents). Another controversial proposal of the draft concerns an amendment to the Constitution introducing the clause that there is 'no legal right to be granted citizenship'. This proposal can be regarded as the Ministry's response to the criticism that it was making extensive use of discretion in naturalisation cases (see below).

The parliamentary elections held in June 2006 and the subsequent establishment of a right- wing centrist government slowed down the legislative process, but they have so far not brought about a major reorientation..$^{\circ}$ On I7 March 2008, the government discussed the new draft framework legislation submitted by the Minister of the Interior. ${ }^{5 I}$ The blueprint consisted of two pieces: the framework Constitutional Act on Citizenship of the Czech Republic and the framework Law on Citizenship of the Czech Republic..$^{22}$

The primary aim of the proposed constitutional act is to implement the two controversial changes discussed above. It also proposes to exempt from judicial review a denial of naturalisation if it is justified on the grounds of possible risks to the sovereignty, security or democratic foundations of the state.

Guided by the opinion of its Legislative Council, the government eventually rejected the proposed constitutional legislation. According to the opinion of the Council, it is neither necessary nor advisable to amend the constitution for the purposes of the intended reform. ${ }^{53}$

However, the government approved the framework citizenship law and decided that the Minister of the Interior should submit a full version of the bill for approval no later than 3I May 2009. The law should enter into force as of I January 2010.

The approved blueprint builds upon the analysis and suggests merging all legislation on citizenship into a single code. The transformation provisions of the existing citizenship law relating to the break-up of Czechoslovakia would be deleted. Broadly formulated provisions en- 
abling former Czechoslovak and Czech citizens, as well as their descendants, to acquire Czech citizenship by declaration, would replace the existing specific restitution legislation. Excluded are, however, those who lost Czechoslovak citizenship under the Beneš decrees and their descendants. Acquisition of citizenship by declaration is also suggested for second-generation migrants. The acquisition of citizenship by declaration is in both cases construed as a legal right with relatively simple qualifying conditions. This is in marked contrast with the proposed naturalisation rules.

Conditions for naturalisation are detailed and strict. They allow for a thorough screening of applicants and include, inter alia, a test of written Czech proficiency as well as knowledge and orientation tests, stricter requirements regarding one's criminal record, and compliance with an extensive range of public law obligations, obligations in relation to the municipality where the applicant lives, and even some civil law obligations.

Because of the rigorous naturalisation requirements, activists from various human rights organisations have criticised the proposal. Martin Rozumek of OPU (Organisation for Aid to Refugees) argues: 'The proposal requires that foreigners fulfil a number of conditions which most Czech citizens would find difficult to fulfil. ${ }^{54}$

The blueprint includes an unrestricted acceptance of dual (multiple) citizenship on both the entry and exit sides. However, there are indications that this liberal approach may change in the future, albeit only with regard to foreigners applying for naturalisation. In fact, the government urged the Minister of the Interior to reconsider this particular issue in further stages of legislative drafting. ${ }^{55}$ The liberalisation on the exit side (that is in relation to Czech citizens who acquire foreign nationality) remains unchallenged.

As one of the conditions for property restitution introduced in the early I990s was the Czechoslovak (Czech) citizenship of the applicant, legislators and the general public have consistently viewed citizenship legislation and its changes in this context. Notwithstanding the criticism of various international bodies, including the UN Human Rights Committee ${ }^{56}$ this restriction has been retained both by the legislature and by the Constitutional Court. ${ }^{57}$ The need to protect legal certainty, ownership rights, and the stability of the legal order were raised to defend the status quo. As a result, the link between restitution of citizenship and restitution of property often hampered the adoption of more inclusive citizenship legislation.

Lukewarm attitudes towards Czech emigrants among part of the local population also influenced the discussion on the possible extension of the legislation on reacquisition of Czech citizenship. Finally, the 2006 amendment to Act No. 193/1999 Coll. on the Citizenship of 
Some Former Czechoslovak Citizens merely abolished the deadline for making a declaration on the reacquisition of Czech citizenship. The senate, without support of the government, pushed the bill through parliament. $^{5}$

The link between the restitution or the retention of citizenship and the restitution of property also plays a key role in relation to the Beneš decrees, which deprived people of German and Hungarian ethnic origin of their Czechoslovak citizenship. The interpretation of these decrees still plays a role in some restitution cases and remains highly controversial. ${ }^{59}$ The prevailing public opinion on the restitution of German property is negative. Therefore, it is not surprising that the government does not contemplate any change in the citizenship legislation in this regard. The decrees thus remain a sensitive political issue not only in Slovakia and Hungary, but also in the Czech Republic.

Among the practical problems repeatedly brought to the attention of the government by non-governmental organisations and other actors, such as the Ombudsman, is the extensive discretion of the Ministry of the Interior in decisions on naturalisation and the way it is exercised. In practice, the Ministry's negative decisions do not often constitute grounds for rejection of an application, but refer vaguely to administrative discretion as such and to the fact that there is 'no legal right to be granted citizenship'. Until recently the courts conducting the judicial reviews have sustained the practice. ${ }^{60}$ It was only a few legal scholars who expressed doubts about whether 'granting citizenship is, indeed, an act of mercy, exercised by the state at its own good will' or is rather in the interest of society (Chlad 2004: 350; Molek \& Simíček 2005: I42-I44). A cautious shift in the jurisprudence regarding the use of discretion in naturalisation procedures was brought about by the Supreme Administrative Court (established in 2003). ${ }^{\text {I }}$ Most recently, the idea that discretionary naturalisation should be completed or replaced by granting a right to naturalisation once the specified conditions are met, is gaining some ground within the administration and the justice system. However, the Ministry of the Interior, a key player in the formulation of citizenship policies, still rejects the idea strongly. ${ }^{62}$

\subsection{Statistics $^{63}$}

If we exclude Slovak nationals, the numbers of persons naturalised annually in the Czech Republic have been surprisingly stable in the last decade, with a maximum of 2,000 persons and a minimum of 837 per annum, as shown in Table 8.2. 
Table 8.2 Naturalisations (excluding Slovak nationals) in the Czech Republic, 1993-2007

Year 199319941995199619971998199920002001200220032004200520062007 $\begin{array}{lllllllllllllllllllll}1,469 & 1,412 & 2,000 & 1,380 & 837 & 1,128 & 1,031 & 1,059 & 1,121 & 1,150 & 1,267 & 1,495 & 1,177 & 1,355 & 1,027\end{array}$

Source: Ministry of the Interior

The number of Slovak nationals granted Czech citizenship based on supplementary and corrective initial rules (see Table 8.I) is still significant (Act No. 40/1993 Coll., Sections I8a, I8b and I8c).

Table 8.3 Number of Slovak and other nationals acquiring Czech citizenship from 2001-2007

\begin{tabular}{lrrrrrrr}
\hline Year & 2001 & 2002 & 2003 & 2004 & 2005 & 2006 & 2007 \\
\hline Total & 6,321 & 4,532 & 3,410 & 5,020 & 2,626 & 2,346 & 1,877 \\
Declaration based on Act No. 139/1999 Coll. & 1,607 & 1,273 & 1,154 & 1,784 & 190 & 205 & 225 \\
Act No. 40/1993 Coll. - total & 4,714 & 3,259 & 2,256 & 3,236 & 2,436 & 2,141 & 1,652 \\
Slovakia - Act No. 40/1993 Coll. - total & 3,593 & 2,109 & 989 & 1741 & 1,259 & 786 & 625 \\
$\quad$ Slovakia - declaration section 18a* & 3,378 & 1,862 & 850 & 627 & 565 & 375 & 268 \\
Slovakia - declaration section 18b*** & - & - & 55 & 364 & 123 & 63 & 49 \\
Slovakia - declaration section 18c**** & - & - & 5 & 573 & 325 & 167 & 177 \\
$\quad$ Slovakia - naturalisation section 7 & 215 & 247 & 79 & 177 & 246 & 181 & 131 \\
Other naturalisations (section 7) - & 1,121 & 1,150 & 1,267 & 1,495 & 1,177 & 1,355 & 1,027 \\
Act No. 40/1993 Coll. & & & & & & &
\end{tabular}

Source: Czech Statistical Office

* Former Czechoslovak nationals who had lived continuously in the territory of the Czech Republic since the break-up of Czechoslovakia

*** Former Czechoslovak nationals who were naturalised in Slovakia in the period from 1 January 1994 to 1 September 1999

* Former Czechoslovak nationals born in Slovakia who were minors during the break-up of Czechoslovakia, but with at least one parent a Czech republic-level citizen

In 2007 , the total number of persons naturalised was I,I58. This number included 424 Ukrainian nationals, I3I Slovak nationals, I02 Russian nationals, 50 Polish nationals, 40 Vietnamese nationals, 39 Belarusian nationals, 36 Romanian nationals, 33 Moldovan nationals, 3I Greek nationals and 28 Armenian nationals. ${ }^{64}$

Table 8.4 Slovak nationals who acquired Czech citizenship by declaration (Section 18a of Act No. $40 / 1993$ Coll.)

\begin{tabular}{llllllllll}
\hline Year & 1999 & 2000 & 2001 & 2002 & 2003 & 2004 & 2005 & 2006 & 2007 \\
\hline & 6,278 & 5,377 & 3,378 & 1,862 & 850 & 627 & 565 & 375 & 268 \\
\hline
\end{tabular}

Source: Ministry of the Interior 
Table 8.4 shows that at the end of I990 there were still a number of former Czechoslovak citizens living in the Czech Republic whose status was not adequately regularised. The decreasing numbers indicate that the problem is diminishing.

Table 8.5 Former Czechoslovak nationals who (re-)acquired Czech citizenship by declaration under Act No. 193/1999 Coll.

\begin{tabular}{llllllllll}
\hline Year & 1999 & 2000 & 2001 & 2002 & 2003 & $2004 *$ & 2005 & 2006 & 2007 \\
\hline & 798 & 1,899 & 1,607 & 1,273 & 1,154 & 1,784 & 190 & 205 & 225 \\
\hline
\end{tabular}

Source: Ministry of the Interior

* The deadline for making the declaration expired on 2 September 2004. The Act No. $46 / 2006$ Coll. deleted the deadline and thus made the law operational again. It was published and entered into force on 27 February 2006.

Act No. 193/1999 Coll. concerns those who emigrated during the communist regime. As they live all over the world, the process requires time both for spreading the information on the right to reacquire the Czech citizenship and for the actual exercising of that right. The numbers show that the deletion of the deadline for making the declaration is warranted.

\subsection{Conclusions}

The consensual division of Czechoslovakia caused many problems regarding citizenship. The new legislation did not generate de iure stateless persons, as was sometimes mistakenly contended by its critics. Rather, the consequence of the restrictive and inadequate citizenship legislation was that some former Czechoslovak citizens ended up with the citizenship of a successor state in which they did not live and to which they were only formally attached. ${ }^{65}$ This revealed the need to clarify international rules concerning cases of state succession. ${ }^{66}$ It also raised a more puzzling question: Does the right to a citizenship imply a right to choose one's own citizenship?

By the application of remedial provisions introduced in the period 1993-2003, most of the problems related to the break-up of Czechoslovakia have been solved. Nonetheless, the original intention of the legislators to avoid dual Czech and Slovak citizenship has not been fully achieved. On the contrary, the precarious position of some groups of citizens shows that there are situations in which it is not justified to deny a person the right to dual citizenship. Cases of dual Czech and Slovak citizenship are numerous.

Conditions are unfavourable as regards naturalisation except for foreign nationals with strong family links to Czech citizens (spouses, chil- 
dren). They involve long waiting periods to fulfil the eligibility criteria as regards the residence requirement. Longer periods of absence are not tolerated and only formal continuous legal status counts. There is also a Czech language test (although kept at a reasonably easy level). As a rule, applicants have to relinquish their original citizenship and a number of additional criteria are tested. There are no specific provisions for automatic acquisition of the Czech citizenship by second- and third-generation immigrants (not even at the age of majority) or facilitated naturalisation for this category. Decisions denying naturalisation are open to judicial review but both in theory and practice administrative discretion is applied very broadly in naturalisation cases. On the other hand, the legal status of naturalised citizens is secure as a ban on the deprivation of citizenship is guaranteed under the Constitution.

At present, Czech citizenship legislation is at a crossroads. Issues related to the break-up of Czechoslovakia, which have dominated the political debates, are losing their topicality. New challenges are linked to increasing immigration. In particular, the restrictive nature of current as well as proposed naturalisation provisions, which reflects the surviving parochial character of Czech society, is in conflict with the declared need for effective integration policies. The proposed comprehensive citizenship reform should address the issue more adequately. It is also important that the considered liberal approach to former Czechoslovak and Czech citizens and their descendants is not in practice narrowed down to an ethnic preference. At a more general level, the proposed reform can be seen as a key element in the transformation of the Czech self-image from an ethnic to a civic nation.

Chronological list of citizenship-related legislation in Czechoslovakia/the Czech Republic

\begin{tabular}{lll}
\hline Date & Document & Content \\
\hline 1920 & $\begin{array}{l}\text { Act of } 29 \text { February 1920, } \\
\text { No. } 121 \text { Coll. of Acts of the }\end{array}$ & $\begin{array}{l}\text { Provides for a single } \\
\text { Czechoslovak Republic, }\end{array}$ \\
$\begin{array}{l}\text { introducing the } \\
\text { and prohibits dual } \\
\text { Constitutional Charter of }\end{array}$ & \\
the Czechoslovak Republic & \\
Constitutional Act of & Implements provisions of \\
9 April 1920, No. 236, & the peace treaties \\
Supplementing and & concerning the state \\
Amending Existing & succession in relation to \\
Provisions on the & citizenship; determines \\
Acquisition and Loss of & who are Czechoslovak \\
Citizenship and on & citizens; provides for the \\
Domicile in the & continuation of Austro- \\
Czechoslovak Republic & Hungarian citizenship \\
& legislation
\end{tabular}




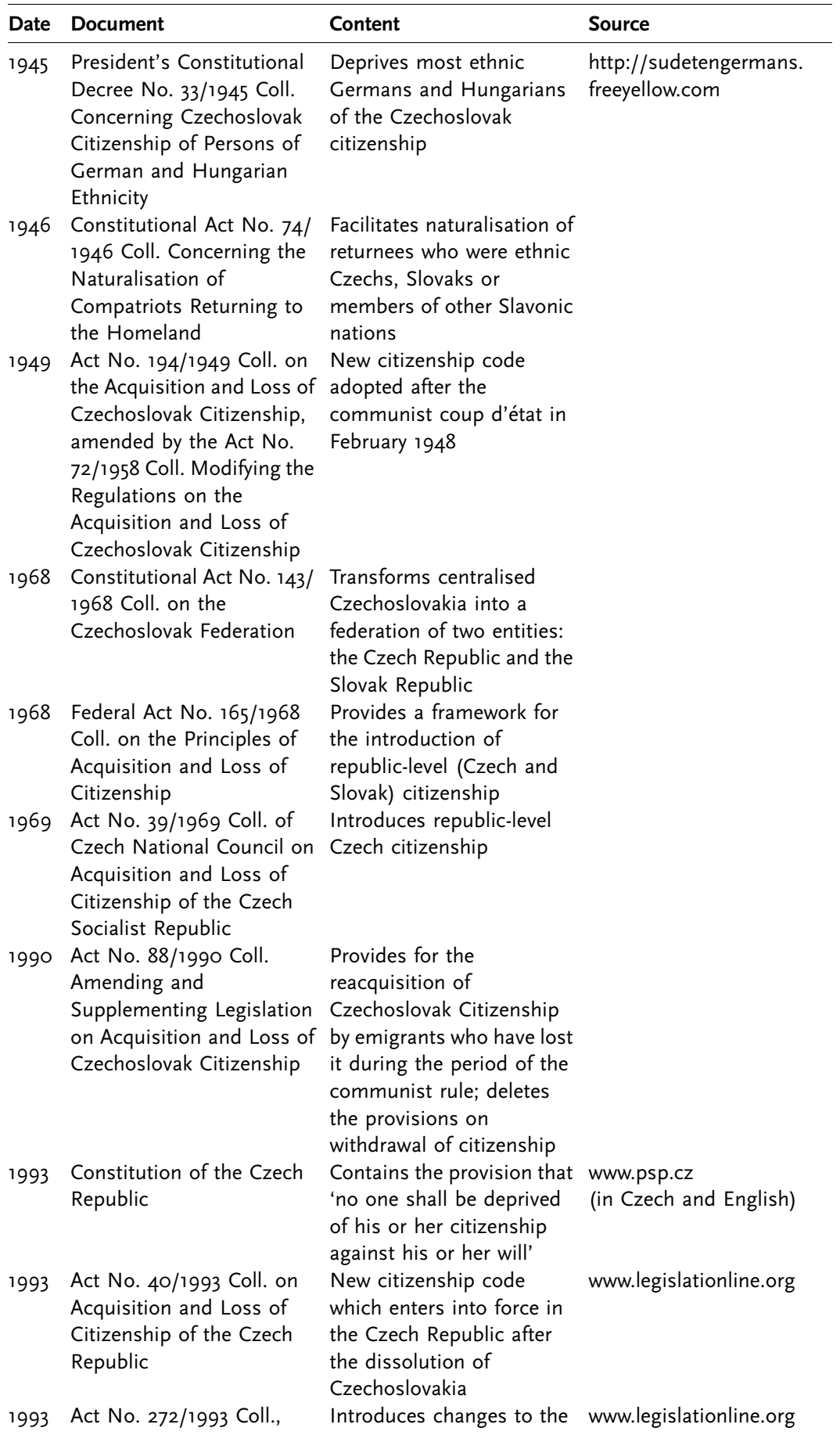




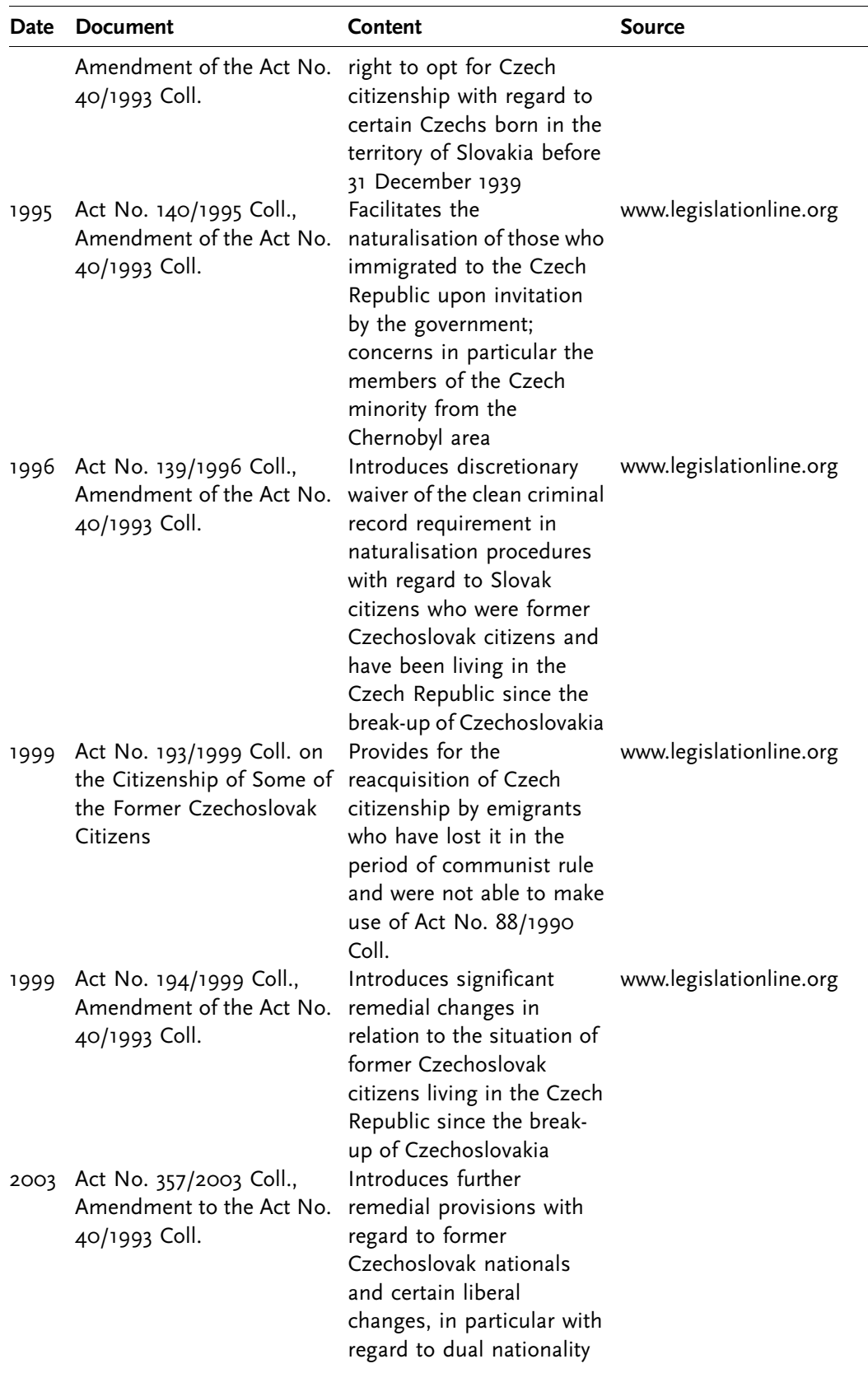




\begin{tabular}{lll}
\hline Date & Document & Content \\
\hline 2006 & Act No. 46/2006 Coll., & Removes the deadline for \\
Amendment to Act No. & making declarations on \\
193/1999 Coll. on the & reacquisition of Czech \\
Citizenship of Some of the & citizenship by some of the \\
Former Czechoslovak & former Czechoslovak \\
Citizens & citizens (emigrants)
\end{tabular}

\section{Notes}

I The author and editors would like to thank Tibor Papp from the Institute of Informatics and Statistics in Bratislava for providing the most recent information on the draft bill in section 8.3 and the data for 2006 and 2007 in section 8.4.

2 See the leading handbooks on Czech citizenship law Černý \& Valášek 1996 and Valášek \& Kučera 2006.

3 Domicile (domovské právo, Heimatrecht) refers to membership in a municipal community. In the Czech lands (Bohemia and Moravia) as parts of the Austro-Hungarian Empire, domicile was regulated by Act No. $105 / 1863$ Coll. [Collection] of Acts of the Empire, as amended by Act No. 222/1896 Coll.

4 E.g. Treaty of Versailles (I9I9), Treaty of Saint-Germain-en-Laye (I9I9) and Treaty of Trianon (1920).

5 Constitutional Act of 9 April I920, No. 236, Supplementing and Amending Existing Provisions on the Acquisition and Loss of Citizenship and on Domicile in the Czechoslovak Republic and Act of 29 February 1920, No. I2I Coll. of Acts of the Czechoslovak Republic, introducing the Constitutional Charter of the Czechoslovak Republic. The basic principles of the Czechoslovak citizenship were thus regulated by constitutional laws and treaty provisions. The system, however, failed to achieve the declared aim of protecting minorities and preventing statelessness.

6 In Slovakia, provisions of former Hungarian laws remained in force. See also Kusá in this volume.

7 In October 1938, Czechoslovakia lost parts of its territory inhabited mainly by a German population. In March 1939, after the secession of Slovakia, the rest of the Czech lands were turned into the Protectorate Bohemia and Moravia. The complex legal consequences in terms of citizenship are described by Verner (I947, Appendix II: 227-270).

8 The Presidential Decree exempted from withdrawal of citizenship those citizens of German and Hungarian ethnicity who had joined the fight for liberation or were persecuted by the Nazis. The legislation also established a possibility to apply for the restitution of Czechoslovak citizenship within six months after the entry of the Decree into force. Most of the Czechoslovak citizens concerned had actually acquired German or Hungarian citizenship in the period I938-1945.

9 See also Kusá in this volume.

Io Constitutional Act No. I43/1968 Coll. on the Czechoslovak Federation.

II The corresponding law regulating the same issue in the Slovak Republic was the Act of the Slovak National Council No. 206/1968 Coll.

I2 In this paper, the term republic-level citizenship is used to denote membership in the constitutive entities of the federal state. The term (state) citizenship is used exclusively to indicate membership of a sovereign state. In Czech language and legal terminology, the term state citizenship (státni občanstvi) is used for both legal statuses. 
I3 The republic-level citizenship was not recorded in any official documents, such as birth certificates, ID cards or passports. On the other hand, the ID and other documents recorded the ethnic origin (národnost), (e.g. Czech, Slovak, Hungarian), which was based, in principle, on one's own declaration.

I4 Constitutional Act No. 23/199I Coll. introducing the Charter of Fundamental Rights and Freedoms. The Act amended art. 5 of Constitutional Act No. 143/1968 Coll. on the Czechoslovak Federation. The Act came into force on 8 February I991. Later, it was transformed into art. I2(2) of the Czech Constitution. The provision offers stronger protection against deprivation of citizenship than art. I5(2) of the Universal Declaration of Human Rights, which only bans arbitrary deprivation of citizenship.

I5 Act No. 88/1990 Coll. provided for the reacquisition of Czechoslovak citizenship by former Czechoslovak citizens who had lost Czechoslovak citizenship in the period between I October 1949 and 3I December 1989. The reacquisition took effect in certain cases through a simple declaration. However, two issues are important. First, the law did not go back to before 1948 to cover former Czechoslovak citizens who were deprived of Czechoslovak citizenship by the post-war Presidential Decrees (Germans and Hungarians). Second, the law provided a relatively short period to exercise the right to request the reacquisition of citizenship. It expired on 3I December 1993 .

I6 See Kusá in this volume.

I7 The Constitutional Act No. 542/1992 Coll. on the Dissolution of Czechoslovakia on 3I December 1992 was adopted by the Federal Assembly on 25 November 1992.

I8 Since the establishment of Czechoslovakia in I9I8, there has been much intra-state migration. For instance, in the period I9I8-I938 many Czechs went to Slovakia as part of a new Czechoslovak administration. After 1945, there was continuous economic emigration from Slovakia to Bohemia and Moravia. One important element of the post-war internal movements of inhabitants was (both spontaneous and state-organised) resettlement of Slovak Roma in industrial towns and cities of Moravia and Bohemia.

I9 The drafting and the adoption of the law took place in exceptional circumstances. The whole process was finished within two months.

20 The possibility of dual (Czech and Slovak) citizenship was the most divisive issue between the ruling political elites - Slovak nationalists and Czech pragmatists. It was favoured by the former and denied by the latter. Since an agreement on state succession regarding citizenship had not been reached, two separate citizenship laws regulated the citizenship of the successor states.

2I For the concept of the initial determination (Erstabgrenzung), see the work by Krombach $(1967)$.

22 The same criterion, i.e. republic-level citizenship, was used in some countries of former Yugoslavia (Slovenia, Croatia), while the countries of the post-Soviet Eurasia applied a permanent residency criterion instead.

23 The right to opt for Czech citizenship was restricted by the requirement that the person had not been convicted in the last five years for an intentional criminal offence.

24 Most Roma migrated to Czech lands from Slovakia after i945. Consequently, many Czech Roma became Slovak citizens by the application of the general rules of initial determination.

25 The first significant change was introduced by Act No. 139/1996 Coll., which allowed for exceptions in naturalisation procedures from the clean criminal record requirement for former Czechoslovak citizens who had resided in the territory of the Czech Republic since the break-up of Czechoslovakia. See Linde 2006 for a 
comprehensive explanation of the causes that have led to the state's changes in attitude.

26 File No. IV US 34/97.

27 The ruling was confirmed by a subsequent ruling on I4 November 2000 (File No. I. US 337/99). The Court argued that exercising the right of option does not mean that a person acquired foreign, i.e. Slovak citizenship at his or her own request, which would lead to automatic loss of Czech citizenship. In practical terms, this ruling concerned mostly ethnic Czechs living in Slovakia.

28 See also below Table 8.4.

29 See below Table 8.3, sections i8b, I8c.

30 The situation of children born to a stateless parent without permanent residence is not regulated adequately.

3I I do not distinguish between eligibility and conditions for naturalisation. In Czech citizenship legislation, the conditions for naturalisation fall into two categories: a) conditions sine qua non, which cannot be waived, and b) conditions, which can be waived at the discretion of the authorities.

32 The applicant has not been convicted for an intentional crime in the last five years.

33 The applicant has to submit a certificate of the loss of his or her previous citizenship or a certificate that by the acquisition of Czech citizenship he or she will lose his or her previous citizenship.

34 Act No. 326/1999 Coll., as amended (Aliens Act). The amendment of the Aliens Act, Act No. I6I/2006, which entered into force on 27 April 2006, cut the waiting period for permanent resident status to five years (in order to implement EU Directive 2003/I09/EC Concerning the Status of Third-country Nationals who are Long-term Residents).

35 This does not apply to Slovak citizens.

36 In order to avoid statelessness, there is no provision allowing for the renunciation of Czech citizenship if the person concerned is not a citizen of another state.

37 We assume that the intention of the drafters of the law was to reduce the cases of Czech citizens living abroad transferring Czech citizenship over several generations.

38 It had particularly precarious consequences for Czech women who married citizens of some Islamic countries. The status of non-citizens put them at a disadvantage with regard to inheritance rights, for example whereas the potential loss of Czech citizenship in the case of naturalisation would deprive them of diplomatic protection. Another category adversely affected are citizens who applied for a foreign citizenship before the law entered into force but were granted a foreign citizenship after I January I993.

39 In the Court's opinion, there is a distinction between deprivation of citizenship, prohibited by the Constitution, and loss of citizenship. Those who apply for a foreign citizenship should be aware of the legal consequences attached to the act, which are provided for by law. Thus, the loss of citizenship based on the acquisition of foreign citizenship does not constitute deprivation of citizenship against one's will. See Ruling published under No. 6/1996 Coll. Concerning the Proposal to delete Section I7 of Act No. 40/1993 Coll. on the Acquisition and Loss of Citizenship of the Czech Republic.

40 This provision existed previously, but the wording was not clear and, in practice, it was incorrectly applied only to rare cases of automatic acquisition of citizenship through marriage.

4I The Czech Republic is party to the following multilateral treaties: I997 European Convention on Nationality (No. 76/2004 Collection of International Treaties, henceforth Coll. of I. T.), date of entry into force: I July 2004; I96I UN Convention on the Reduction of Statelessness (No. 43/2002 Coll. of I. T.), date of entry into 
force: I9 March 2002; I954 UN Convention Relating to the Status of Stateless Persons (No. I08/2004 Coll. of I. T), date of entry into force: I7 October 2004.

42 Published as Act No. I69/1929 Coll. The treaty established a rule that in the case of naturalisation, the citizenship of the state of origin is automatically lost.

43 In 2007, the Ministry issued 577 negative decisions regarding naturalisation. 3I9 unsuccessful applicants appealed. In 92 cases the Minister of the Interior overturned the negative decision (Ministry of the Interior 2008: I55).

44 Act No. 150/2002 Coll. on Judicial Reviews of Administrative Acts. For judicial review in naturalisation cases see section 8.3 of this chapter.

45 The Council for Human Rights is an advisory body to the government. See Resolution of the Government of the Czech Republic No. 493/2002 Related to the Communication by the Council for Human Rights on the Citizenship of the Czech Republic. The communication concerned certain urgent issues, such as the incompatibility of the remaining bilateral agreements with the requirements of the European Convention on Nationality. It also brought to the attention of the government certain problems of interpretation and practice in the field of citizenship law.

46 Ministry of the Interior, Document No. VS - 473/50/2-2004.

47 The fundamental incentives for the switch towards toleration of multiple citizenship thus seem to be those described by Hagedorn (2003). Obviously, citizens and immigrants campaign for dual citizenship for different reasons. Dual citizenship corresponds to the needs of both expatriates and immigrants and offers them a greater scope for individual choice.

48 At present, the state authorities processing applications for naturalisation carry out the testing. This does not guarantee uniform standards of testing.

49 Ministry of the Interior, Analýza úpravy nabývání a pozbývání státniho občanství. [Analysis of the regulation on acquisition and loss of state citizenship] Adopted on I3 July 2005 by Government Resolution No. 88I.

50 The governing coalition consists of the liberal-conservative Civic Democratic Party, Christian Democrats and the Greens. In its programme declaration, the new government stated that it would 'consider the possibility of simplifying the acquisition of dual nationality'. See the Programme Declaration of the government, available at www.vlada.cz.

5I Under the government's legislative rules, a framework law (věcný záměr zákona) normally precedes the full legislative draft if a law regulates new and complex issues. These blueprints represent a step in legislative drafting at government level. As such, they are not subject to consultation with, or decision by, the parliament. Consultations on the draft legislation within the administration and with other stakeholders took place from July to November 2007.

52 Ministry of the Interior, Návrh věcného záměru ústavniho zákona o státním občanství České republiky a návrh věcného záměru zákona o státním občanství České republiky, VSI283/50/2-2007 [The proposal of the framework for the Constitutional Act on Citizenship of the Czech Republic and the framework for the Act on Citizenship of the Czech Republic]. The government took its decision by Resolution of I7 March 2008, No. 254 .

53 See Stanovisko Legislativní rady vlády ze dne 7. února 2008 [Opinion of the Legislative Council adopted on 7 February 2008].

54 See Martin Rozumek, 'Připomínky Organizace pro pomoc uprchlíkům k návrhu věcného záměru nového zákona o nabývání a pozbývání státního občanství České republiky [Comments of the Organisation for Aid to Refugees concerning the framework proposal of the new Czech Citizenship Law]', I5 August 2007, www.migraceonline.cz. 
55 Government Resolution of I7 March 2008, No. 254, point II.

56 The Human Rights Committee expressed in its views in several cases, e.g. No. $516 /$ 1992 (Simunek et al.), 586/1994 (Joseph Adam), 857/1999 (Blazek et al.) and 747/ I997 (Dr. Karel Des Fours Walderode), that 'a requirement in the law for citizenship as a necessary condition for restitution of property previously confiscated by the authorities makes an arbitrary, and, consequently a discriminatory distinction between individuals who are equally victims of prior state confiscations, and constitutes a violation of article 26 of the Covenant [on Civil and Political Rights]'.

57 See Judgement of the Constitutional Court published under No. I85/1997 Coll. The European Court of Human Rights declared cases that concerned the restitution of property inadmissible. See European Court of Human Rights, Grand Chamber decisions of Io July 2002 as to the admissibility of application No. 38645/97, Polacek v. the Czech Republic and application No. 39794/98, Gratzinger v. the Czech Republic.

58 The Chamber of Deputies passed the bill on 23 November 2005. One hundred and two deputies voted for the bill and 49 against. The Act No. 46/2006 Coll. was published and entered into force on 27 February 2006.

59 Some of the judicial cases concern the citizenship of deceased persons, as the right to restitution by heirs depends on this issue. In certain cases, the Ministry of the Interior completed legal proceedings that had started in the late I940s, using the then valid citizenship legislation. (See e.g. Decision of the Supreme Administrative Court of 27 November 2003, ref. no. 6 A 90/2002-82 (www.nssoud.cz) and the Judgment of the Constitutional Court of 29 June 2005, IÚS 98/04 (www.concourt.cz).

6o See Molek \& Šimíček 2005.

6I Resolution by the Supreme Administrative Court of 23 March 2005, ref. no. 6A 25/ 2002-42 and Decision by the Supreme Administrative Court of 4 May 2006, ref. no. 2 As $3 \mathrm{I} / 2005-78$. (www.nssoud.cz). In the former case the Court decided that negative decisions on naturalisation can be reviewed by administrative courts. (The Ministry of the Interior as well as some courts were of the opinion that naturalisation cases, unlike other citizenship cases, can not be reviewed by courts because of the non existence of the legal entitlement to citizenship.) In the latter case the Court confirmed its opinion on the possibility of administrative review of naturalisation cases and rejected the whole theory of unlimited administrative discretion in these procedures.

62 In the discussion on the draft citizenship legislation in 2007-2008, the Ministry of Justice, the Supreme Administrative Court and the Minister of Human Rights and Minorities supported this idea.

63 As part of a new, more active approach to the issues of immigration and integration, the Czech Statistical Office started to gather and analyse data on naturalisation in a systematic manner. These statistics however only cover the period since 200I. They can be found at www.czso.cz.

64 See Czech Statistical Office, www.czso.cz.

65 In many cases, Slovak citizens living in the Czech Republic had even difficulties to acquire permanent resident status (Boučková \& Valášek 1999). In some of these cases, the situation developed into de facto statelessness.

66 The variety of solutions adopted in the numerous cases of state succession made it difficult to prove the presence of a concrete and detailed customary law on state succession and citizenship. It was only the 1997 European Convention on Nationality that introduced certain generally applicable rules on citizenship in cases of state succession. 


\section{Bibliography}

Barša, P. (2005), 'National Identities and Migration Policies', Tr@nsit online. www.iwm.at.

Baršová, A. (2003a), 'Dvojí občanství: lidské právo v post-nacionálním světě?’, Sociální studia 9: 5I-64.

Baršová, A. (2003b), 'Státní občanství', in Právní komparativní studie programu migrace, 3744. Prague: Poradna pro občanství \& OSF.

Baršová, A. (2004), Vícečetné státní občanství: teoretické a praktické pohledy. www.diskriminace.cz.

Baršová, A. (2005), 'Foreigners Integration Policies in the Czech Republic', in Social and Cultural Diversity in Central and Eastern Europe, 30-3I. Prague: MKC. www.mkc.cz.

Baršová, A. \& P. Barša (2005), Přistěhovalectví a liberální stát. Imigrační a integrační politiky v USA, západní Evropě a Česku. Brno: Masarykova univerzita, MPU.

Bauböck, R. (I994), Transnational Citizenship. Membership and Rights in International Migration. Aldershot: Edward Elgar.

Boučková, P. \& M. Valášek (I999), 'Slovenští občané v České republice a trvalý pobyt', Správní právo 2: 93-III.

Černý, J. \& M. Valášek (I996), České státní občanství. Prague: Linde.

Černý, J. \& V. Červenka (I963), Státní občanství ČSSR. Prague: Orbis.

Chan, J. M. M. (I99I), 'The Right to a Nationality as a Human Right', Human Rights Law Journal I2: I-I4.

Chlad, L. (2004), 'Státní občanství v kontextu Evropské integrace', Právnik I43 (4): 333382 .

Faist, T. (2004), 'Dual Citizenship as Overlapping Membership', in D. Joly (ed.), International Migration in the New Millennium, 210-23I. Aldershot: Ashgate.

Grawert, R. (I973), Staat und Staatsangehörigkeit. Verfassungsrechtliche Untersuchungen zur Entstehung des Staatsangehörigkeitsrechts. Berlin: Duncker \& Humboldt.

Hagedorn, H. (2003), 'Administrative Systems and Dual Nationality. The Information Gap', in D. A. Martin \& K. Hailbronner (eds.), Rights and Duties of Dual Nationals. Evolution and Prospects, I83-200. The Hague: Kluwer Law International.

Hansen, R. \& P. Weil (eds.) (2002), Dual Nationality, Social Rights and Federal Citizenship in the U.S. and Europe. The Reinvention of Citizenship. New York: Berghahn Books.

Kaspersen, L. B. (I997), War, State, Sovereignty and Citizenship. PhD Thesis. Department of Political Science, Aarhus University.

Kristen, V. (I989), 'Vznik Československé republiky a rakouští krajané', in Češi v cizině 4: $77-87$.

Krombach, D. (I967), Erstabgrenzungen im Staatsangehörigkeitsrecht im 19. Jahrhundert und am Anfang des 20. Jahrhunderts. Inaugural Dissertation. Rechts- und Staatswissenschafliche Fakultät der Rheinischen Friedrich-Wilhelms-Universität Bonn.

Linde, R. (2006), 'Statelessness and Roma Communities in the Czech Republic: Competing Theories of State Compliance', International Journal on Minority and Group Rights I3: $34 \mathrm{I}-365$.

Martin, D. A. \& K. Hailbronner (2003), Rights and Duties of Dual Nationals. Evolution and Prospects. The Hague: Kluwer Law International.

Ministry of the Interior (2008), Zpráva o situaci v oblasti migrace na území Ceské republiky $\checkmark$ roce 2007 . www.mvcr.cz.

Molek, P. \& V. Šimíček (2005), 'Udělování státního občanství - na cestě od milosti státu k soudně přezkoumatelnému správnímu uvážení', Právnik I44 (2): I37-I56.

Schmied, E. (I974), Das Staatsangehörigkeitsrecht der Tschechoslowakei. 2nd edn. Frankfurt/ Main: Alfted Metzner Verlag.

Vaculík, J. (2002), Češi v cizině - emigrace a návrat do vlasti. Brno: Masarykova univerzita. 
Valášek, M. \& V. Kučera (2006), Státní občanství. Komentár. Prague: Linde.

Verner, V. (I947), Státní občanství a domovské právo republiky Československé. Prague: Václav Tomsa.

Weis, P. (1979), Nationality and Statelessness in International Law. Alphen aan den Rijn, Germantown: Sijthoff and Noordhoff.

Wiessner, S. (1989), Die Funktion der Staatsangehörigkeit: eine historisch-rechtsvergleichende Analyse unter besonderer Berücksichtigung der Rechtsordnungen der USA, der UdSSR und der Bundesrepublik Deutschland. Tübingen: Attempto Verlag. 



\title{
9 The Slovak question and the Slovak answer: Citizenship during the quest for national self- determination and after ${ }^{\mathrm{I}}$
}

\author{
Dagmar Kusá
}

Citizenship is both a status and a praxis. As a status, it is defined by a collection of laws and regulations. In Slovakia, these have been shaped by both principles of ius soli and ius sanguinis, the latter gaining importance especially after the First and the Second World War. The praxis involves the civic and political participation by citizens as well as the policies of governments concerning the implementation of the law in relation to its citizens as well as to non-citizens. The latter depend strongly on the political situation of the times. The first two turbulent decades of the Czechoslovak Republic were marked by attempts to ethnically homogenise the 'Czechoslovak' nation, targeting primarily the German and Hungarian minorities (but also Roma and others) as unwanted elements, culminating in three years of 'homelessness' after the end of the Second World War. Only the communist government restored their civil and political rights. Yet it was unable to do away with the national sentiments of the Slovaks, striving to achieve national selfdetermination within or without Czechoslovakia. The Federation of I968 (and the Warsaw Pact tanks that preceded it) quieted the nationalist voices until 1989, when they echoed through the public squares with all the more vigour. The dissolution of Czechoslovakia, which followed in I993, made for a messy transition period in citizenship policy with the need to address both issues related to the end of the communist regime and its victims, as well as to the status of Czech nationals in Slovakia.

The last decade has also brought new challenges connected to the integration of Slovakia into the European Union and marked by general globalisation processes. Slovakia is figuring out its relationship towards an influx of newcomers from parts of the world with which it had no cultural contact in the past. International institutions shape these policies to a large degree, although the careful observation of Hungary's its closest neighbour and historic adversary - citizenship policies seems to have just as much impact on shaping the public debate and legal provisions taken in Slovakia. While we will be focusing in this chapter primarily on citizenship as a status, the political praxis of gov- 
ernments does need some attention to complete our understanding of what shaped citizenship policies at different times.

\subsection{History of Slovak citizenship}

\subsubsection{Citizenship policies since the first Czechoslovak Republic}

Czechoslovak citizenship was created with the first Czechoslovak Republic on 28 October I9I8. The collective identity to which it referred was cumbersome, to say the least, and was a result of the historical path of the Czech and Slovak nation-building processes as well as of the peculiar nature of the new state that had resulted from the dissolution of the Austro-Hungarian Empire and from the peace treaties following the First World War. The Wilsonian principle of self-determination influenced the understanding of the concept of citizenship and contributed to the growing role of ethnicity in its legal definition. Concepts of citizenship and ethnic nationality are often difficult to set apart neatly. They influence each other, and both depend heavily on political interpretations. The Czechoslovak Republic consisted of a multitude of ethnic groups and the leadership struggled with asserting the dominant position of the Czech and Slovak nations in their newly established Republic. National minorities, especially the three million Germans and close to a million Hungarians, formed 44 per cent of the total population. The Czechoslovak Government thus enforced an official Czechoslovak nationality ${ }^{2}$ (instead of separate Czech and Slovak nationalities).

The sovereign nation needed to be propped up by some 'objective' quantifiable measures of dominance. Population censuses helped to provide these measures and also allowed citizens to be distinguished from foreigners. ${ }^{3}$ The power of numbers as represented in the census was becoming apparent to national leaders prior to the foundation of Czechoslovakia. With the growing turbulence over what was then called the 'nationality question' within the Habsburg Empire the census was becoming more and more powerful as an expression of 'real' power, as a ticket to future control over territory and as one of the determinants of state formation and boundaries. In I9oo, for example, the German newspaper in Bohemia appealed to its readers: 'Dear fellow citizens! Please pay close attention to column I3 (Umgangssprache) in the census form. The future of our nation depends on this minor entry. I. What is the language used on a daily basis? It is the language most commonly used by an individual. Daily use means the communication in the family, among people that live together, in their employment, with an employer. Wherever this communication happens in the German language, no other language should be entered into column 
I3. Is the language used on a daily basis identical with the mother tongue? Absolutely not. Czech employees [...] use in their German employment the German language instead of their mother tongue. German is their language of everyday use.' (Zeman I994: 37). In a similar manner Czech, Slovak and Ruthenian leaders appealed to their respective constituencies to enter their mother tongue. Data were collected by census officials, often with the aid of the army and police and accompanied by threats, blackmail or violence.

The census remained important, especially in border disputes after I9I8. The northern part of the Czech Teschen-Silesia region as well as the southern part of the Slovak borderlands with Hungary were heavily disputed after the war and nationality was used as a tool for demarcation policies. Polish representatives based their arguments on census data from before I9I8, which showed a clear majority of ethnic Poles in those territories. As the populations here were ethnically mixed and their mother tongue was often Polish or Hungarian, the question in the I92I census carried out by the Czechoslovak Government was promptly changed to ask directly about nationality. A Silesian nationality was created (besides Polish and Czechoslovak). Respondents in this category were then automatically counted among Czechoslovak nationals. This resulted in a complete change of the population proportions. While the percentage of Poles fell to 25 per cent (from 139,000 to 69,000 ), the percentage of Czechoslovaks grew from 40 per cent to 65 per cent (from I23,000 to I77,000) (Paul I998: I63).

The fate of Teschen-Silesia was decided at the Paris Peace Conference. Polish representatives succeeded in their demand for a plebiscite. If this had been carried out, Czechoslovakia might have lost some of these economically strong territories. However, the international commission overseeing the plebiscite could not agree on the conditions, the Red Army was already invading Poland, and legal norms in Czechoslovakia were confusing due to the existing state of legal dualism where Czech lands inherited the legal system from Austria, and Slovakia that of Hungary. A plebiscite was to be carried out not only in Silesia, but also in the northern Slovak areas of Spiš and Orava, which would result in implementing two plebiscites regulated by differing sets of laws. The northern boundary was therefore finally decided upon the recommendation of the Allied Powers. Poland was compensated for much of Silesia with 25 settlements in Orava and Spiš (Klimko I980; Peroutka I99I).

Legal dualism was caused by differing practices in granting citizenship and domicile before I9ı 8 following the Austro-Hungarian Compromise of 1867 . While in Austria domicile, i.e. a legal title of residence in a municipality (Heimatrecht), was closely registered, it was not in the Hungarian part of the empire that included Slovakia. ${ }^{4}$ Even 
though domicile was granted to all those born and residing in a municipality, the gentry had a right to deny some people domicile even if they were born or had resided in the locality for a long time. Jurová (2002) maintains this was the fate of many Roma who moved from village to village. This was due to arts. 8-I5 of the municipal law (XXVII/ I886) that tied the acquiring of domicile of those who move and/or marry to fulfilling certain duties towards the municipality, thus giving the authorities opportunities for convenient interpretation. Furthermore, Act No. 222/1896 amended some provisions of the 1863 municipal law that specified conditions under which a Roma could be granted domicile.

The Roma and Hungarians were groups that succeeding Czechoslovak governments sought to minimise statistically after I9I8. The census of I92I shows a remarkable number of 'foreigners' without Czechoslovak citizenship that still have domicile on Slovak territory. The extent to which these groups were affected by citizenship policies has unfortunately not been extensively researched and quantitative data in this area are missing (Jurová 2002).

Czechoslovakia's citizenship regulations were further disturbed by the events of the Second World War. Slovakia experienced its first (debatably) independent statehood as a Nazi puppet state, while the Czech lands were occupied under the Third Reich's Protectorate. The end of the Second World War and the restoration of Czechoslovakia led to the adoption of ad hoc laws that introduced the criterion of ethnicity into citizenship legislation. The new legislation was linked to the post-war massive emigration and population exchange. Under the President's Constitutional Decree No. 33/1945 Coll. (Collection), Czechoslovak citizens of German and Hungarian ethnic origins were deprived of Czechoslovak citizenship. ${ }^{5}$ This also meant their exclusion from official institutions (Order 99/1945 of the Slovak National Council), as well as from reimbursement for war damages, and implied other practical consequences. ${ }^{6}$ Further decrees also disbanded German and Hungarian associations and organisations.

The transfers of ethnic Germans were agreed to by the Allied Powers at the Potsdam Conference in I945. They did, however, not approve of applying the same policy based on a principle of collective guilt to Hungarians. The alternative solution found by the Beneš Government was a 'voluntary exchange of populations' between Czechoslovakia and Hungary. This plan resulted in the removal of 89,660 ethnic Hungarians, who were moved into Hungary, in return for receiving 73,273 ethnic Slovaks (Vadkerty 2002: 32). Oral history projects document that the nature of the exchange was in many cases coercive. Another wave of transfers, labelled by the Czech historian Karel Kaplan as an 'internal colonisation' (Kaplan, I993: 9), was based on the Presidential De- 
cree No. 88/1945 on universal labour service. Ethnic Hungarians were recruited for 'voluntary agricultural work' into the then vacant Sudetenland. Age limits imposed by the Decree were also frequently ignored and property left behind was confiscated (in direct violation of the Decree) (Kusá 2005). These policies were accompanied by a programme of re-Slovakisation, passed by the Slovak National Council in June I946. This policy gave ethnic Hungarians an opportunity to 'reclaim' Slovak citizenship (based on the premise of previous coercive Magyarisation of Slovaks) within the time span of one year. Some 320,000 Hungarians were granted Slovak citizenship on this basis. However, as the census of I960 shows, many returned to claiming Hungarian ethnicity in the census as soon as the political situation tolerated it. ${ }^{8}$

This era has been dubbed as the 'homeless years' by Hungarian authors. Citizenship was eventually restored to the Germans and Hungarians remaining in Czechoslovakia in 1948 by the newly established communist government; most Hungarians who had been transferred to Sudetenland have returned. Many, however, never recovered lost properties. The Beneš Decrees and their legal and practical consequences remain a painful open wound in Czech and Slovak political memory to this day and have been repeatedly debated, especially in connection with possible compensation for those affected and their descendants. Representatives of German and Hungarian communities sometimes called for an annulment of the Beneš Decrees, but due to the complexity of the political situation of interwar and post-Second World War years and a lack of political will in the Czech and Slovak Republics, it is unlikely that such a measure will be adopted. Some conciliatory steps were taken by the Czech and Slovak governments in the past decade on the level of bilateral declarations (the Czech-German Declaration of 1997) or public speeches (e.g. Hrušovský 2003).

\subsubsection{Regulation of Czechoslovak citizenship in 1949-1968 and the 'Slovak Question'}

The rise of communist monopoly rule meant, ironically enough, the end of 'homelessness' for the Hungarians and Germans in Czechoslovakia. Citizenship laws were, however, misused for other political purposes, as one of the tools to keep the lid on the population, as a sort of preventive blackmail of those who might think of publicly voicing their disapproval of the communist regime.

The legal process of acquisition and loss of Czechoslovak citizenship in the period following the February putsch of 1948 was governed by the Act on the Acquisition and Loss of Czechoslovak Citizenship No. I94/1949, as amended by the Act No. 72/1958 Modifying the Regula- 
tions on the Acquisition and Loss of Czechoslovak Citizenship. ${ }^{9}$ Czechoslovak citizenship could be acquired in four ways: I) by birth: Czechoslovak citizenship was transferred to the child by his or her parent citizens regardless of whether the child was born in the territory of the Czechoslovak Republic or abroad. If the child was born in the territory of the Czechoslovak Republic, it was sufficient if one of the parents was a Czechoslovak citizen; ${ }^{\mathrm{IO}}$ 2) by marriage: A foreigner could acquire Czechoslovak citizenship on demand upon marrying a Czechoslovak citizen. This acquisition needed to be investigated and approved by a district National Committee within six months; 3) by grant: A foreigner could be granted Czechoslovak citizenship upon request after meeting two principal conditions: residing in the Czechoslovak territory for five consecutive years and abandoning his or her previous citizenship. There was no legal entitlement to be granted citizenship; 4) by reacquisition: This applied to the acquisition of citizenship by the 'homeless' persons of German and Hungarian nationality ex lege after taking a citizenship oath without the need to apply or to fulfil other conditions. ${ }^{\text {II }}$

The loss of Czechoslovak citizenship was possible by I) renunciation upon request, ${ }^{\mathrm{I2}}$ 2) revocation by the state due to hostile acts against the Republic, illegal emigration, or not returning to the homeland for the period of five years or upon request of the Ministry of the Interior, 3) marrying and acquiring citizenship in another country (with a possibility to request retention of Czechoslovak citizenship), 4) a court decision as a penalty for 'high treason, espionage, desertion of the Republic, military subversive activities, war treason, assassination of a state official, ${ }^{13}$ 5) naturalisation in the United States of America, and 6) as a consequence of agreements on dual citizenship. ${ }^{\mathrm{I}}{ }^{4}$

During this period of time, and especially during the détente period of the I96os, when literature and arts were flourishing after the denunciation of the Stalinist doctrine, Slovak leaders and intellectuals voiced their desire for self-determination of the Slovak nation in a federative arrangement. They did not wish to be Czechoslovak citizens, but Slovak citizens of Czechoslovakia. While the Czech elite focused on market liberalisation and democratisation of the regime, Slovaks called for 'first federalisation, then democratisation' - a slogan that reappeared repeatedly in public squares after 1989 in a much more malevolent form. This issue divided Czech and Slovak intellectuals during the entire duration of the communist regime, as the Czech cultural leaders failed to see the urgency of this issue for the Slovaks. The Soviet leadership, however, duly noted Slovak aspirations for federation. Thus when the tanks rolled into Prague and Bratislava on the 2I August I968 it brought with it different realities for the two nations. While the oppression following the Warsaw Pact invasion was equally suffocating in both parts of the country, it also brought the desired federation for the 
Slovaks. Dissent in Slovakia was therefore more muted compared to the Czech region. The Soviets poured investment into the Slovak industry in the post-I968 era further contributing thereby to different perceptions of the 'normalisation' period between the two nations. What was an era of darkness for most Czechs, was seen by many Slovaks as a repressed society, but with real industrialisation and federation at least on paper. While this reality itself may not have had an immediate impact on citizenship laws and practice, it certainly reverberated on the political scene after 1989, when the cultural divide between Czechs and Slovaks escalated into the 'Velvet Divorce'.

\subsubsection{Regulation of Czechoslovak citizenship in 1969-1992: Czechoslovak Socialist Federative Republic}

Until I968, when the Czechoslovak Federation was established, Czechoslovakia was a unitary state with a single Czechoslovak citizenship. The establishment of a federation also resulted in the creation of Czech and Slovak citizenships. Constitutional Law No. 143/1968 Coll. on the Czechoslovak Federation, which came into force on I January I969, is based on the principle of individual preference when determining the citizenship of the two constituent republics. ${ }^{15}$

The original text contains a provision according to which every citizen of one of the republics is also a citizen of Czechoslovakia (art. 5). Citizenship was regulated by the Constitutional Act of the National Council of the Czechoslovak Socialist Republic No. I65/ig68 Coll. on the Principles of Acquisition and Loss of Czech and Slovak Citizenship, followed by the Act No. 206/1968 Coll. of the Slovak National Council on Acquisition and Loss of Citizenship of the Slovak Socialist Republic.

Normally citizenship at the level of the two republics was determined by the place of birth or by the citizenship of the parents, if that could be identified. Czech or Slovak citizens could, however, choose a different citizenship until 31 December 1969. The Act precluded dual citizenship, one had to choose one or the other. The Slovak National Council passed Act No. 206/1968 Coll. to apply these rules in domestic legislation.

Between I969 and 1992 it was possible to acquire Slovak and Czech citizenship by birth, ${ }^{16}$ by choice (within one year after the establishment of the federation), by marriage, or by grant (after five consecutive years of residence for foreigners and two years for Czech citizens with permanent residence in Slovakia).

Loss of citizenship in the 'normalisation' era was similar to previous regulations. It could be renounced, lost due to acquiring Czech citizenship, or one could still be deprived of it on the basis of art. 7 of Act No. 
I94/I949 Coll., naturalisation in the US, or according to agreements on dual citizenship.

After the fall of communism, both Czech and Slovak national elites struggled to assert the position of their nations within Europe. National identity had to be reconstructed and to a large extent even re-invented. Both elites turned to their past to seek linkages and justification for steps towards self-determination. Czechs and Slovaks, however, sought friendship with very different animals from their past. Czechs built on Masaryk's democratic ideals from the first interwar republic, while Slovaks viewed this era suspiciously with a memory of Czech 'Pragocentrism $^{\text {,17 }}$ and of the refusal of the Czechoslovak Government to grant Slovakia the right to self-determination or autonomy in a federation. Instead, Slovaks referred to the legacy of the Slovak puppet state created by the Nazis. ${ }^{\text {I8 }}$ The discrepancy in perceptions of the post-I968 era added to the rift between the two nations. This 'failure to find a decent past' together, as Igor Lukes (I995) coined it, contributed to the choice of separate paths for the future by the political elites, whose sentiments were, however, not reciprocated by the majorities of populations on either side of the new border.

In the confused atmosphere of rampant nationalism that had antiCzech, anti-Hungarian, anti-Semitic, and even anti-Western traits in the years prior to the Velvet Divorce, Slovak representatives raised many issues that seemed to be frivolously escalating the conflict into what became popularly known as the 'hyphen war', i.e. the war about the spelling of 'Czechoslovakia'. Slovak delegates claimed that the term Czechoslovakia was discriminatory to the Slovaks, who are commonly mistaken for Czechs abroad. Claims were backed by invoking the myths of one thousand years of suffering by the Slovaks under the Hungarian yoke, only to be replaced by the Czech yoke in I9I8. The Federative Assembly finally settled on 'Czech and Slovak Federative Republic' as the name for the post-communist state.

The Slovak Prime Minister Vladimír Mečiar conducted a policy of blackmail, threatening the Czech leadership with the possibility of secession over each major political issue. The Czech Prime Minister Klaus eventually called his bluff and startled Mečiar by accepting the proposal for separation. The divorce was decided at the top political level without being ratified by popular participation, but also without strong protests by the Czech and Slovak public. Over half of the respondents in public opinion surveys voiced their desire to remain in the common state and/or to have an opportunity to decide its fate in a referendum (Nemcová I992). It was instead decided by political elites. On I January I993, the two nations started a new period in their history and had to determine their identities and related policies anew. Even before the dissolution, the citizenship laws had been growing in 
significance, and many Czechs and Slovaks were using their right to choose their republic-level citizenship.

In Slovakia, the nationalist craze played out directly in many legal provisions that concerned anybody 'other' than ethnic Slovaks. ${ }^{\text {I9 }}$ Such was the case with the 'Sign Law' (a law regulating public inscriptions such as topographical names of towns, villages, streets and store signs), the Act on the Official State Language, which was passed without any provisions for the use of languages of the national minorities (which were adopted only in 1997), the 'Territorial Arrangement' that redrew district boundaries to lessen the percentage of ethnic Hungarians in areas where they were concentrated, and other legislation. This policy has also affected the practice of allowing access to those seeking asylum, with possible hopes for eventually acquiring citizenship in the Slovak Republic. While the legislation regulating the asylum procedures was not markedly different from other countries, the political environment was palpably hostile. During the war in Bosnia and Herzegovina, Slovakia, just as many other countries, received an influx of refugees. The Migration Office of the Ministry of the Interior was at that time particularly untoward in granting anyone the status of a refugee. Many, if not most, displaced persons had to contend with a protective status of the United Nations High Commissioner for Refugees office in Slovakia, and most were turned back after a few months, not always into safe conditions.

After the accession of the Slovak Republic to the European Union in 2004 and its becoming a part of the Schengen territory in 2007, a number of EU regulations were transposed into Slovak Law. With the amendment of the Asylum Law in 2007 the Slovak Republic implemented the EU provision on minimal standards for the granting and loss of the refugee status and also implemented the Dublin Treaty, which sets criteria for determining which EU Member State is responsible for processing a particular asylum application. The Slovak Republic, unlike its neighbours, still lacks a coherent immigration and integration strategy, although a plan for establishing Immigration and Naturalisation Services is underway.

In 2007, the Slovak Government amended the Act on Citizenship, gearing up towards accession to the Schengen Treaty. According to the Minister of Interior, Robert Kaliňák, the new act is a response to 'the growing danger of organised crime and international terrorism. ${ }^{20}$ The new version of the citizenship act significantly tightens the naturalisation requirements. According to this law, a foreigner may acquire Slovak citizenship after eight years of permanent residence in the Slovak Republic (as opposed to the previous five).

The law also stipulates that foreigners applying for Slovak citizenship must pass a test where they must demonstrate a thorough knowl- 
edge of the Slovak language, the basic historical and geographical facts regarding the Slovak Republic and Slovak culture. Applicants are interviewed about their person and family, and must further demonstrate 'basic general knowledge', and pass a written test where they are asked to summarise a random newspaper article. These new requirements, which demand that applicants 'prove cultural acclimatisation,' are perhaps more a reflection of the nature of the government that came to power in 2006 (a coalition consisting of the populist SMER, or the People's Party - Movement for Democratic Slovakia, led by the notorious former prime minister Vladimír Mečiar, and the nationalist Slovak National Party) than of any purported requirements relating to accession to the Schengen Treaty.

\subsection{Current regulations of acquisition and loss of Slovak citizenship}

In the first years of the Slovak Republic, Slovak citizenship was either determined by law or could be individually chosen. Those who were citizens of the Slovak Republic before 3I December 1992 automatically became citizens of independent Slovakia, as stipulated in Act No. 40/ I993 Coll. on Citizenship of the Slovak Republic. Czech citizens could apply for Slovak citizenship until 3I December 1993 by way of a written request to the District Office in the territory of the Slovak Republic or to the Diplomatic Mission or Consular Office of the Slovak Republic abroad. This option was open to all citizens of the former Czech and Slovak Federative Republic. Those applying for Slovak citizenship had to provide proof that they were Czechoslovak citizens as of 3I December 1992 and state their place of birth and permanent residence (art. 7).

\subsubsection{Acquisition of citizenship}

Slovak citizenship can currently be acquired by birth, by adoption, or by grant. The laws regulating citizenship are comparatively generous towards individuals with Czech or Slovak roots, allowing for a plural citizenship and extending considerable citizenship rights to the Slovak expatriates living abroad.

Acquisition of citizenship by birth is firmly based on ius sanguinis except in those cases where a child would otherwise become stateless. In current legislation a child acquires Slovak citizenship only if at least one of the parents is a citizen of the Slovak Republic or if the child was born in the territory of the Slovak Republic to parents who are stateless or whose citizenship is not transmitted to the child iure sangui- 
nis. ${ }^{2 \mathrm{I}}$ If citizenship cannot be established, a child is considered to be a citizen of the Slovak Republic if he or she was born or was found in the territory of the Slovak Republic and his or her parents are not known. If one of a child's parents is a citizen of another country and the other is a citizen of the Slovak Republic, then the child is a citizen of the Slovak Republic even if it is later established that the child's parent who is a citizen of the Slovak Republic is not the child's natural parent. A child can also acquire citizenship when he or she is adopted by a Slovak citizen. In the case of a disagreement between the parents, Slovak citizenship can be determined by a court judgement on the basis of one parent's or a legal guardian's request.

Citizenship in the Slovak Republic can also be granted upon request to a foreigner. This requires consecutive permanent residence and physical stay in the Slovak territory for at least eight years immediately prior to submitting an application for citizenship. Slovak law also requires sufficient basic proficiency in the Slovak language. Applicants must also have a clean criminal record, which means that they must not have been prosecuted for an intentional crime during those five years before the application, must not be under an administrative expulsion order from the country of residence or subject to extradition proceedings. ${ }^{22}$

Facilitating factors in the application procedure are if an applicant is stateless or voluntarily renounces his or her previous citizenship. Furthermore, citizenship can be granted upon request to those who have entered into marriage with a Slovak citizen (after living in the Slovak Republic for a period of five consecutive years), or those who have made special contributions to the Slovak Republic through their achievements in the field of economy, science, culture or technology.

There are also special provisions for the restoration of citizenship to those who lost it according to previous legislation. A person whose former Czechoslovak citizenship has expired or who has lost the Czechoslovak citizenship due to a long absence or on the basis of citizenship law during the communist regime, may be granted citizenship of the Slovak Republic even if the abovementioned condition of five years consecutive permanent residence has not been met. Former Slovak citizens returning to live in Slovakia have to have permanent residence in the Slovak Republic for three years prior to filing an application for citizenship. ${ }^{23}$

\subsubsection{Loss of citizenship}

Slovak citizenship can be lost, only upon the holder's own request, by releasing the person from the state bond. Only those can be released 
who already possess another citizenship, or who will acquire another citizenship as soon as they are released from Slovak citizenship.

A Slovak citizen cannot be released if he or she is being prosecuted, is currently serving a sentence or is due to serve a sentence or has outstanding taxes or other debts to pay to the state. The District Office, Diplomatic Mission or a Consular Office of the Slovak Republic makes the final decision on the loss of citizenship. Citizenship is lost on the day of receipt of the document stating his or her release from the state bond of the Slovak Republic.

\subsubsection{Procedure}

Slovak citizenship acquired by naturalisation is awarded by the Ministry of the Interior of the Slovak Republic based on a written application. This application has to be filed in person at a District Office, Diplomatic Mission or Consular Office of the Slovak Republic. It must include personal data about the applicant and must be accompanied by a dossier of documents including a brief curriculum vitae, an identification card, a birth certificate, a personal status certificate, and a certificate of residence in the Slovak Republic. Former Czechoslovak citizens that qualify for restoration of citizenship have to provide a document stating the release from the state bond of the Czechoslovak Republic, the Czechoslovak Socialist Republic or the Slovak Socialist Republic (whichever applies). Former Slovak citizens applying for citizenship after two years of residence in Slovakia can submit a Slovak Status ID as a form of identification. The Ministry of the Interior can ask for other documents if required to render a decision.

The application is accompanied by a questionnaire on the basis of which the authorities evaluate the applicant's Slovak language skills. Verification has to be done in a way that takes the applicant's circumstances into account. The District Office has the right to request a statement from the police and will then forward the complete application with all documents and statements to the Ministry of the Interior for a final decision. When making its decision, the Ministry of the Interior has to take into account the public interest as well as statements of state institutions and of the police. It has nine months from receipt of an application to issue a decision. If statements of state institutions and of the police are required, the processing period is prolonged to one year.

Slovak citizenship is acquired by obtaining a Certificate of Acquisition of Slovak Citizenship at the District Office, Diplomatic Mission or Consular Office of the Slovak Republic and after taking the obligatory oath. The citizenship oath reads: 'I promise on my honour and conscience that I will be loyal to the Slovak Republic, I will respect the Slo- 
vak Constitution, laws and other legal rules and will duly fulfil all duties of a Slovak citizen. ${ }^{24}$

If the applicant doesn't pick up the Certificate of Acquisition within six months of receiving a written notification the Ministry will stop the procedure. If the Ministry rejects the application then the applicant can apply again after a minimum waiting period of one year.

\subsubsection{International treaties}

Slovakia is party to many international multilateral and bilateral treaties that impact on domestic citizenship regulations. International treaties take precedence over domestic law - if they differ from the provisions in the Act No. 40/1993 Coll. on Citizenship of the Slovak Republic, the legal regulations of international law outweigh domestic law (art. I7).

As in the case of the Czech Republic, the treaty with the United States that precluded naturalised American citizens of Czech and Slovak origin from holding dual citizenship (the I928 Naturalisation Treaty) expired in I997. This allowed many former citizens and their descendants to restore their Slovak citizenship and to file claims for restitution of property with the Slovak state.

Among the other important bilateral treaties was the Agreement on Slovak-Hungarian Neighbourly Relations from I995, which had implications for the practical implementation of certain cultural and educational rights of ethnic Hungarians in Slovakia. Many international provisions - including this one - were passed only because of extensive pressure from European institutions dangling the carrot of EU accession in front of the Slovak leadership. The Slovak-Hungarian Treaty was passed at the peak of the Mečiar Government era, to the bewilderment of his followers and perhaps of himself, after Slovakia had received demarches from the OSCE High Commissioner on National Minorities and other international institutions regarding its practices concerning national minorities and foreigners. The international community thus played a key role in shaping domestic policies in this transition period keeping the ugly dragon of nationalism and xenophobia on a somewhat shorter leash.

\subsubsection{Dual and multiple citizenship}

Slovak legislation tolerates dual citizenship. Regulations of dual and multiple citizenship on a European level are, however, developing slowly and with obstacles. The regime changes and successive creation of new states after I989 created a need to come up with common regulations regarding citizenship policies that resulted in the European 
Convention on Nationality (ETS No. I66), which entered into force on I March 2000. It was the first international document to establish core principles and rules applying to all aspects of citizenship to which the domestic law of the parties to the treaty should conform. The Convention was opened for signature to Member States of the Council of Europe as well as non-members on 6 November 1997. Slovakia signed and ratified the Convention, as did the Czech Republic.

Among other issues the Convention covers questions of multiple citizenship. Art. I4 directly stipulates the right to dual citizenship in the case of acquiring citizenship of another country by marriage. The force of the Convention is, however, softened by arts. I5 and 16 , which give the parties the right to determine whether their nationals who acquire or possess the nationality of another state retain or lose their citizenship; and the right of state parties to make the acquisition or retention of their citizenship conditional upon renunciation or loss of another citizenship (unless it is not possible or cannot reasonably be required). These articles are often used in practice to preclude multiple citizenship. There have been speculations as to whether Slovakia could use them in this way if the Hungarian Parliament passes the law on dual citizenship for ethnic Hungarians living abroad (see Kovács \& Tóth in this volume). This would not be possible without amendments to the current law, which stipulates that the loss of Slovak citizenship results only from a person's own request to be released from the state bond. The state cannot on its own initiative deprive any person of their Slovak citizenship. It is, however, possible that some ethnic Hungarians residing in Slovakia could be released from the state bond upon their own request after gaining Hungarian citizenship, thus becoming Hungarian foreign nationals living in Slovakia. This status would, however, bring more inconveniences than benefits to the applicants. It is far more likely that, if Hungary passed the dual citizenship law, most ethnic Hungarians in Slovakia would hold on to their Slovak citizenship.

As was already mentioned, Czech and Slovak nationals could choose their citizenship for a period of one year after the dissolution of the Czechoslovak Federative Republic. This situation was not without complications. It rendered tens of thousands of Roma living in the Czech Republic stateless due to improper documentation, permanent residence in Slovakia (many migrated from Slovakia to Czech lands before I989), lack of information about the procedure (and the need to apply), a criminal record or other reasons. ${ }^{25}$ Furthermore, from 1994 it became harder for Czech or Slovak citizens to live and work in the other part of the former common republic. In I999, after years of continuous pressure from European institutions and non-governmental organisations, and following a Czech Supreme Court decision of I997, which ruled that the Czech citizens who chose Slovak citizenship in 
I993 did not lose their Czech citizenship, the Czech citizenship laws were amended to allow for reacquisition of the Czech citizenship for certain groups of people within a stipulated period. Further revisions of the Czech law were passed in September 2005 to allow for dual citizenship for Czechs living in Slovakia, who had lost their Czech citizenship by acquiring the Slovak nationality between I January I994 and September 1999. ${ }^{26}$ Applications for dual citizenship can be submitted to the Consular Office of the Czech Embassy in Bratislava. The application process takes up to two months. Approximately five thousand people requested dual citizenship in $2005 .{ }^{27}$

\subsection{Current political debates and reform plans}

\subsubsection{The Hungarian Status Law and referendum on dual citizenship}

Slovak-Hungarian relations have been an inflammable issue on the Slovak political scene since the fall of communism. Much nationalist rage was directed against the former dominant nation, the Hungarian part of the dual monarchy. Policies of forceful Magyarisation in the late nineteenth and early twentieth century and the turbulent dissolution of the empire that left one third of the ethnic Hungarians outside the borders of the Hungarian state, provide historical memories that shaped mutual relations in a controversial fashion. The myth of a thousand years of suffering under the Hungarian yoke has long been nurtured by Slovak nationalists and after i989 it often served as a useful rallying point.

The question of Hungary's relationship with ethnic Hungarians living abroad, especially in the areas immediately bordering on Hungarian state territory, was therefore watched closely and suspiciously. The issue exploded in the Slovak media in 200I when Hungary passed the Status Law (the law on Hungarians living abroad) and again in 2004 when a referendum was held on allowing ethnic Hungarians to acquire dual citizenship. The content and impact of these Hungarian initiatives are described in detail in Mária M. Kovács's and Judit Tóth's chapter on Hungarian citizenship in this book, so I will focus here only on the repercussions in Slovakia.

\section{The Hungarian Status Law}

The question of ethnic Hungarians living abroad was not used for a nationalist agenda in Slovakia alone. It also polarised the political scene in Hungary and deepened the left-right divide. Viktor Orbán's FIDESZ played on national sentiments of Hungarians about co-ethnic minorities in neighbouring countries and produced a bill on benefits for eth- 
nic Hungarians living abroad, passed by the Hungarian Parliament in 200I.

The first version of the law, which entered into force on I January 2002, provided for financial stipends for students of Hungarian ethnic origin abroad. Members of Hungarian minorities could also apply for Hungarian identity cards (Status ID), with which they can access further benefits such as discounts in Hungary for public transportation and entrance fees for museums and cultural and educational events. The Status ID was handed out on the basis of a recommendation from local cultural organisations representing Hungarian minorities abroad by the newly established Office for Hungarians living abroad with its seat in Budapest. After the refusal of the Slovak and Romanian Governments to allow implementation of the Status Law in their states' territories and after criticism by the Venice Commission that was asked by the Council of Europe to examine the matter, ${ }^{28}$ the law was amended in summer 2003. Since then the education stipend is no longer addressed to individuals, but to institutions that offer education in the Hungarian language or on Hungarian culture. The financial aid is thus accessible not only to ethnic Hungarians but to anybody who wishes to study Hungarian culture and history.

The amended version was approved by a majority of the Hungarian Parliament, with the exception of the FIDESZ party, the originator of the law, and the FKGP, the Smallholders' Party, which had lost seats due to a large corruption scandal involving its president. It was also accepted by the Venice Commission and Romanian Government. Slovak representatives, however, remained opposed to it, and the political parties of the ruling coalition (apart from the Party of Hungarian Coalition SMK) contemplated passing an 'anti-law', which would prevent the implementation of the Status Law in the territory of the Slovak Republic. The lengthy, emotionally charged squabble between Slovak and Hungarian leaders was finally resolved in December 2003 by the Slovak-Hungarian Agreement on Support for the National Minorities in the Areas of Culture and Education. An article on the Slovak-Hungarian Agreement in the daily paper SME summarises its key points. ${ }^{29}$ The treaty identifies two specific cultural foundations that are permitted to distribute financial aid to cultural and educational institutions only (some university students qualify as an exception). It establishes a principle of reciprocity, and the distribution of funds will be subject to annual control by a Slovak-Hungarian commission of experts.

The crux of the tensions, however, was apparently not in the law itself. Old historical grievances were voiced in the circles of the law's critics, accusing the political representation of Hungary of 'soft irre- 
dentism, i.e. attempts to recreate the Hungary of the times of the Hungarian kingdom on a psychological level, and of lurking historic revisionism among the Hungarian minorities themselves.

František Mikloško, one of the most prominent Christian Democrats and the former Speaker of the National Council of the Slovak Republic, expressed views that can be attributed to Slovak representatives in general: 'I voiced my opinion even on TV, and my Hungarian Colleagues hold it against me. I would say that the Status Law psychologically creates the concept of a Great Hungary. The Slovak side made mistakes too, when the Law was debated we were sleeping and suddenly we were confronted with a done deed. There is one serious problem however: Hungary is passing a law that is implemented in the territory of the Slovak Republic. We don't mind if Hungarians have some advantages, but it seemed to be a precedent that would not be good, and the Venice Commission has also denounced it. ${ }^{30}$

The representatives of the Party of the Hungarian Coalition in Slovakia, which had seats in the Slovak coalition government, found themselves between the grindstones as it were of the two national leaderships. Both sides looked to them for resolution and they drew fire from Slovak nationalists for being 'irredentist Hungarians', as well as from Hungarian leaders in Hungary for being too passive. László Nagy, member of the SMK Presidium and chair of the Committee for Human Rights, Nationalities, and Status of Women of the NCSR, laments: 'One problem of the Law is that it became a part of the internal political game. We are not affected by it, but Dzurinda and others assume that the voter expects rejection of the Status Law by the Slovak political leaders, which may be an erroneous assumption. It has played a negative role in Slovak-Hungarian relations that got decidedly chilly in 2002. ${ }^{3 \mathrm{I}}$

The subject of the Hungarian Status Law is divisive among the Slovak-Hungarian population of the Slovak south as well. Although tensions between Slovaks and Hungarians in this ethnically mixed region are usually less than in the rest of the country, they have been palpable concerning topics related to the quasi-citizenship of the Status Law and the question of dual citizenship, which emerged shortly afterwards.

\section{The question of dual citizenship for ethnic Hungarians}

The question of dual citizenship for ethnic Hungarians living abroad emerged as a hot political issue in 2003 . The first requests to the Hungarian leadership came from the Hungarian minority in Vojvodina, later accompanied by similar demands from Hungarians in Romania. The World Federation of Hungarians prepared a petition for a referendum about dual citizenship. Its goal was to achieve Hungarian citizen- 
ship for all applicants who were already holders of a Status ID under the Hungarian Status Law.

This initiative was supported by the opposition political parties in Hungary - the Young Democrats (FIDESZ) and the Hungarian Democratic Forum (MDF), which managed to rally enough support to get the required number of signatures on the petition for a referendum that would decide whether to grant Hungarian citizenship to ethnic Hungarians from abroad. The referendum took place on 5 December 2004, but, since over 60 per cent of eligible voters decided to stay at home, the referendum results (in favour of dual citizenship by a small margin) were declared invalid..$^{22}$

Dual citizenship for ethnic Hungarians was justified mainly on the basis of empathy with ethnic kin. The press again debated attempts to repair the 'Trianon Injustice' that truncated the Hungarian nation after the First World War. On the other hand, the initiative was also designed to give practical advantages resulting from Hungarian nationality. This would be relevant especially for Hungarians living outside of the EU borders. The ruling parties MSZP and SZDSZ stood firmly against the referendum, appealing mostly against the costly consequences that implementation of the law would have. The situation was further complicated by the fact that Romanian and Ukrainian legislations preclude dual citizenship, thus ethnic Hungarians acquiring Hungarian citizenship would have to renounce their original citizenship, which could lead to an untenable situation for the Hungarian Government.

The Slovak leadership watched the development leading to the referendum with a heightened sense of insecurity and antagonism. According to diplomatic sources (report of Ministry of Foreign Affairs), Slovakia was prepared to protest in the EU if the referendum was successful, based on its inconsistency with the Agreement on Slovak-Hungarian Neighbourly Relations from I995, as well as with the principles of the EU of non-discrimination and democratic governance.

The SMK was once again caught in the middle. While the executive vice-president of the SMK, Miklós Duray, supported the idea of the referendum, the official SMK position, as represented by its chairman Béla Bugár, was to support policies that will help ethnic Hungarians to stay in the country where they were born. He warned that the initiative might antagonise Hungarians living in Hungary and members of Hungarian minorities. 'We find ourselves unwillingly amidst the Hungarian internal political struggle and are receiving one slap after another. We have not received such slaps even in our native country. We want to remain in our native country, pay taxes there, etc. ${ }^{33}$

The heated debate ended up in a Slovakian Court. The Slovak National Party (SNS) sued the Vice-Chairman of the SMK, Miklós Duray (one of the more radical leaders of the Hungarian minority in Slova- 
kia), for treason because of his speech in favour of the dual citizenship initiative in the Hungarian Parliament. ${ }^{34}$ The ethnically charged debates about the Status Law and the referendum on dual citizenship have probably also contributed to support for Slovak nationalist and populist platforms, which has grown over the past two years.

\subsubsection{Comparison of the Slovak Act on Expatriate Slovaks with the Hungarian Status Law}

The Hungarian Status Law is not a unique invention without parallel (as it sometimes appeared to be from the indignant reactions in the Slovak press). In 1997, the Slovak Republic passed Act No. 70/1997 on Expatriate Slovaks. Prior protection of Slovak nationals living abroad was guaranteed by a declaration of support in the Slovak Republic's constitution. The House of Expatriate Slovaks, founded by the Ministry of Culture of the Slovak Republic, has also been in existence since 1995, focusing on cultural cooperation and support of expatriate Slovak institutions. According to the Act No. 70/1997, it is sufficient to apply for the status of an expatriate Slovak or to be a direct descendant of a Slovak national. If the applicant cannot provide any documentation certifying his or her ethnic origin, a letter from an institution representing Slovaks abroad or two witnesses that have the status of expatriate Slovaks will do. Application is submitted to the Ministry of Foreign Affairs (MFA) of the Slovak Republic and the application process takes two months. If it is successful the MFA issues an Expatriate Slovak Certificate. Among the benefits that this status brings is the permission to reside 'for a long time' in the territory of the Slovak Republic and the opportunity of applying for permanent residence in Slovakia. It is likewise possible to apply for studies at any Slovak university or to apply for a job without having permanent residence in Slovakia or the employment authorisation required by other foreign nationals..$^{35}$

The Hungarian Status Law has inspired changes in the Slovak Status Law. In 2005 the National Council of the Slovak Republic passed an Amendment to the Act on Expatriate Slovaks ${ }^{36}$ (now properly labelled 'Slovaks living abroad') that established the Office for Slovaks Living Abroad, which is funded from the state budget and is responsible for carrying out the official state policy towards Slovakia's external citizens. The Office also issues Certificates of Ethnic Slovaks Living Abroad (Slovak Status IDs) that make the process of claiming benefits related to the status easier. Financial support is tied to the areas of culture, education and research, information, and media. Individuals and institutions can apply for funding in 'activities that further the development of Slovak identity, culture, language, or cultural heritage in these countries. ${ }^{37}$ 
Hopefully, the amended law will help to provide assistance to Slovaks living abroad at the place of their residence. Some representatives of the Slovak institutions abroad complain that the direct result of the Slovak Status Law is a brain drain of young people who leave to study and work in Slovakia rather than financial support for Slovak publications and cultural events in the areas where Slovaks living abroad are concentrated. ${ }^{3}$ The most remarkable difference between the Slovak and Hungarian Status Law in their current form is the territorial limitation of the latter, which restricts the implementation of the law to neighbouring countries with a large proportion of Hungarian minorities. The Slovak counterpart has no such stipulation. This is easily explained by the fact that most of the Slovaks living abroad reside in the United States (over I,200,000 Slovaks).

\subsection{Statistical trends (acquisition of Slovak citizenship since 1993)}

After the fall of communism, Slovakia experienced tumultuous shifts in population, largely in connection with the dissolution of the Czech and Slovak Federative Republic, but undoubtedly also as a result of its strategic position as a bridge between Western and Eastern Europe. There have been shifting migration trends, too. In the early I990s, the Slovak Republic was losing its citizens to the Czech Republic. This trend ceased after I994 when Slovakia started gaining population from abroad and increasingly so, from the East. Most migration is temporary and circular with migrants returning after short stays in Slovakia. The number of those who actually ask for Slovak citizenship changes with domestic and international events, circumstances and legislation. The following tables and graphs show the numbers of successful applicants who acquired Slovak citizenship.

Table 9.1 Number of persons who acquired citizenship of the Slovak Republic, 1993-2008

\begin{tabular}{|c|c|c|c|c|c|c|c|c|c|c|c|c|c|c|c|c|}
\hline & 1993 & 1994 & 1995 & 1996 & 1997 & 1998 & 1999 & 2000 & 2001 & 2002 & 2003 & 2004 & 2005 & 2006 & 2007 & 2008 \\
\hline $\begin{array}{l}\text { zech } \\
\text { itizens }\end{array}$ & 64,834 & 20,612 & 1,379 & 575 & 416 & 399 & 849 & & 175 & 805 & 942 & 2,262 & 2,439 & 120 & 155 & 91 \\
\hline Other & 1,550 & 1,393 & 910 & 768 & 1,519 & 535 & 417 & 623 & 1,362 & 3,539 & 3,100 & 1,508 & 539 & 930 & 1,235 & 555 \\
\hline otal & 66,384 & 22,005 & 2,289 & 1,343 & 1,935 & 934 & 1,266 & 4,526 & 1,537 & 4,344 & 4,042 & 3,770 & 2,978 & 1,050 & 1,390 & 646 \\
\hline
\end{tabular}

Source: Ministry of the Interior, Slovak Republic

As can be seen from Table 9.I, in 1993 and I994, the vast majority of those who acquired Slovak nationality were Czech nationals. Due to the possibility of choosing citizenship in I993, the proportion of Czech 
nationals among the successful applicants for citizenship was overwhelming. This proportion has gradually declined thereafter and was lowest in 1996 to 1998 , which is probably due to the political situation in Slovakia. The numbers of Czech applicants rose again especially after the amendments to the citizenship law in 1999, and have also been growing in the years up to 2005. Since then, the number of Czech applicants has dropped rapidly. One explanation for this drop might be that both the Czech Republic and Slovakia joined the European Union in 2004.

For others the trends in the acquisition of citizenship are quite different. Notable again is the decline in numbers in the years 1995 and I996, followed by an increase due to the influx of refugees fleeing from the countries of former Yugoslavia. There is a marked increase in the naturalisation of foreigners from outside former Czechoslovakia especially since the year 2000 , when more applicants from Asia and the Near East sought to settle in the Slovak Republic. The more detailed application procedure for citizenship specified in the Act on Citizenship No. 265/2005 Coll. and stricter conditions for naturalisation that were introduced in the Act No. 344/2007 may have contributed to the drops in the number of citizenship acquisitions in 2005 and 2008 , although these drops were not more dramatic than in some of the previous years.

Figure 9.I illustrates the diverse trends in the two populations who have acquired Slovak citizenship over the past decade. (The years 1993 and 1994 have been excluded here due to the high number of Czech applications for citizenship resulting from the dissolution of Czechoslovakia.) We can clearly see the impact of the Czech amendments to the citizenship law in 1999 in the resulting increase of Czech nationals applying for and receiving Slovak citizenship. The rapid increase in citizenship granted to other foreign nationals cannot be readily explained on the basis of legislative changes, but rather on the basis of new migration patterns. Compared to earlier times, many more foreigners looking both for asylum and for citizenship have settled in Slovakia.

Among those who seek Slovak citizenship are people fleeing from persecution, violence, civil war or other conditions threatening their lives and security in their home countries. More than 54,000 foreigners have applied for asylum in Slovakia since 1992. However, as of the end of 2008 , asylum status was granted to only 632 of them. This tendency makes Slovakia a country with one of the lowest rates of refugee recognition in Europe. The year 2004 recorded the highest number of applicants, increasingly coming from countries such as India, Russia (particularly Chechnya), Pakistan and China. Since 2004, there has been a steady decline in the number of applications for asylum, mirroring larger migration trends within Europe and changes in Slovak asylum policies as well as the 2007 entry of the Slovak Republic into the Schengen area. ${ }^{39}$ 
Figure 9.1 Czechs and other foreign nationals who acquired citizenship of the Slovak Republic, 1995-2008

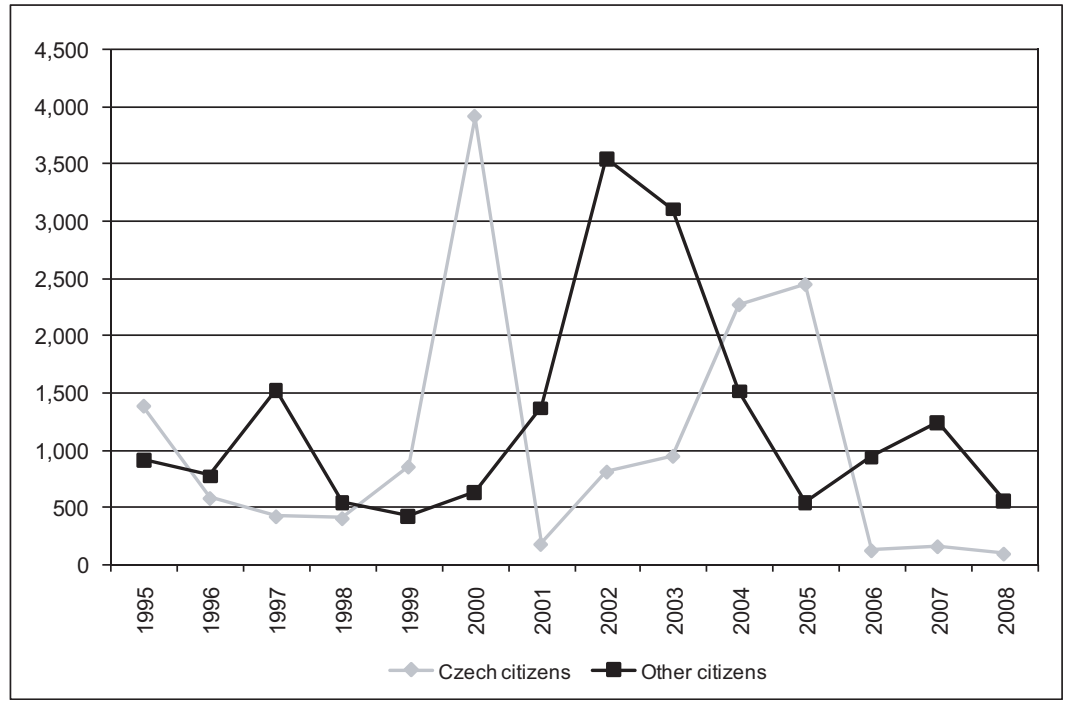

Source: Ministry of the Interior, Slovak Republic

Table 9.2 Refugees and asylum seekers in the Slovak Republic, 1995-2008

\begin{tabular}{|c|c|c|c|c|c|c|c|c|c|c|c|c|c|c|}
\hline & 1995 & 1996 & 1997 & 1998 & 1999 & 2000 & 2001 & 2002 & 2003 & 2004 & 2005 & 2006 & 2007 & 2008 \\
\hline $\begin{array}{l}\text { Asylum } \\
\text { applications }\end{array}$ & 359 & 415 & 645 & 506 & 1,320 & 1,556 & 8,151 & 9,734 & 10,358 & 11,395 & 3,549 & 2,849 & 2,642 & 909 \\
\hline $\begin{array}{l}\text { Persons granted } \\
\text { refugee status }\end{array}$ & 80 & 72 & 69 & 53 & 26 & 11 & 18 & 20 & 11 & 15 & 25 & 8 & 14 & 22 \\
\hline $\begin{array}{l}\text { Refugees granted } \\
\text { Slovak citizenship }\end{array}$ & o & 4 & 14 & 22 & 2 & o & 11 & 59 & 42 & 20 & 2 & 5 & 18 & 4 \\
\hline
\end{tabular}

Source: Ministry of the Interior, Slovak Republic

\subsection{Conclusions}

The evolution of policies relating to the definition, granting and withdrawal of citizenship in Central Europe was closely tied to turbulent events on the international and regional political scene. More than in the West, the ideals and practices of citizenship were marked by struggles for national self-determination, as well as power struggles between the small neighbouring states squeezed in between the warring superpowers during the Cold War period. 
Slovak national development had not run its course in the period before i948. The Slovaks had not achieved a truly independent statehood and were not content to be submerged in a centralised Czechoslovak state after the Second World War. The Slovak Question emerged as a dominant issue at several turning points in history. It impacted on citizenship policies within the common state of Czechs and Slovaks in I968, when the Slovaks received the gift of federation from the invading Soviet troops, and then again after i989, when it led to the Velvet Divorce between the two nations.

Citizenship practices as well as the understanding of what citizenship entails and should entail were murky due to frequent changes in policies prior to I989, due to their ad hoc nature and inconsistencies in the first years of the post-communist regime, as well as because of the tumultuous political scene in Slovakia and new challenges resulting from Slovak independence in I993.

Slovak citizenship policies were strongly shaped by international influences, especially by pressures from the European Union and binding treaties with the Council of Europe. On the other hand, they also reacted to the heated, historically and emotionally charged political debates on the status of Hungarians living abroad and the possibility of their acquiring dual citizenship in Hungary. Central European reality shows us how closely citizenship and identity are intertwined and how easily they are misused for political machinations that further the egoistic agendas of parties and leaders.

Citizenship policies are being gradually simplified and fitted to the new migratory trends that result from membership in the EU. Central European neighbours have not quite yet abandoned nationalist appeals and contentious policies that seek easy enemies to rally supporters. At the same time, they have to quickly figure out how to absorb inflows from parts of the world very different from theirs. All these developments occur in the context of an enlarging European Union with the common citizenship of the Union linking the nationality policies of its Member States to each other.

Chronological list of citizenship-related legislation in Czechoslovakia/the Slovak Republic

\begin{tabular}{llll}
\hline Date & Document & Content & Source \\
\hline 1945 & President's Constitutional & Deprives most ethnic & http://sudetengermans. \\
& Decree No. 33/1945 Coll. & Germans and Hungarians & freeyellow.com \\
& Concerning Czechoslovak & of Czechoslovak & \\
& Citizenship of Persons of & citizenship & \\
& German and Hungarian & & \\
& Ethnicity & &
\end{tabular}




\begin{tabular}{|c|c|c|c|}
\hline Date & Document & Content & Source \\
\hline 1948 & $\begin{array}{l}\text { Act No. } 245 / 1948 \text { on the } \\
\text { Citizenship of Persons of } \\
\text { Hungarian Ethnicity }\end{array}$ & $\begin{array}{l}\text { Returns Czechoslovak } \\
\text { citizenship to ethnic } \\
\text { Hungarians who were } \\
\text { Czechoslovak citizens on } 1 \\
\text { November } 1938 \text { and were } \\
\text { not subject to the 'voluntary } \\
\text { exchange of population' } \\
\text { between Slovakia and } \\
\text { Hungary in } 1946\end{array}$ & $\begin{array}{l}\text { www.centrum.usd.cas.cz } \\
\text { (in Slovak) }\end{array}$ \\
\hline 1949 & $\begin{array}{l}\text { Act No. 194/1949 on the } \\
\text { Acquisition and Loss of } \\
\text { Czechoslovak Citizenship, } \\
\text { amended by the Act No. } \\
72 / 1958 \text { Modifying the } \\
\text { Regulations on the } \\
\text { Acquisition and Loss of } \\
\text { Czechoslovak Citizenship }\end{array}$ & $\begin{array}{l}\text { Is adopted as the new } \\
\text { citizenship code after the } \\
\text { communist coup d'état in } \\
\text { February } 1948\end{array}$ & $\begin{array}{l}\text { www.portal.gov.cz } \\
\text { (in Czech) }\end{array}$ \\
\hline 1952 & $\begin{array}{l}\text { Act No. } 59 / 1952 \text { on } \\
\text { Contracting Marriage with } \\
\text { a Foreigner }\end{array}$ & $\begin{array}{l}\text { Stipulates a requirement to } \\
\text { obtain permission from } \\
\text { the Ministry of the Interior } \\
\text { to marry a person of non } \\
\text { Czechoslovak citizenship }\end{array}$ & www.lexdata.cz (in Czech) \\
\hline 1953 & $\begin{array}{l}\text { Act No. } 34 / 1953 \text { Coll. on } \\
\text { the Acquisition of } \\
\text { Czechoslovak Citizenship } \\
\text { by Particular Persons }\end{array}$ & $\begin{array}{l}\text { Returns Czechoslovak } \\
\text { citizenship to ethnic } \\
\text { Germans who were } \\
\text { deprived of it by the } \\
\text { Presidential Constitutional } \\
\text { Decree No. } 33 / 1945 \text { and } \\
\text { are permanent residents of } \\
\text { the Czechoslovak Republic }\end{array}$ & $\begin{array}{l}\text { www.centrum.usd.cas.cz } \\
\text { (in Czech) }\end{array}$ \\
\hline 1968 & $\begin{array}{l}\text { Constitutional Act No. 143/ } \\
1968 \text { Coll. on the } \\
\text { Czechoslovak Federation }\end{array}$ & $\begin{array}{l}\text { Transforms centralised } \\
\text { Czechoslovakia into a } \\
\text { federation of two entities: } \\
\text { the Czech Republic and the } \\
\text { Slovak Republic }\end{array}$ & \\
\hline 1968 & $\begin{array}{l}\text { Act No. 165/1968 Coll. on } \\
\text { Acquisition and Loss of } \\
\text { Czech and Slovak } \\
\text { Citizenship }\end{array}$ & $\begin{array}{l}\text { Provides a framework for } \\
\text { the introduction of } \\
\text { republic-level (Czech and } \\
\text { Slovak) citizenship }\end{array}$ & \\
\hline 1968 & $\begin{array}{l}\text { Act No. 206/1968 Coll. of } \\
\text { Slovak National Council on } \\
\text { Acquisition and Loss of } \\
\text { Citizenship of the Slovak } \\
\text { Socialist Republic }\end{array}$ & $\begin{array}{l}\text { Introduces republic-level } \\
\text { Slovak citizenship }\end{array}$ & \\
\hline 1990 & $\begin{array}{l}\text { Act No. 88/1990 Coll. } \\
\text { Amending Regulations on } \\
\text { Acquisition and Loss of } \\
\text { Czechoslovak Citizenship }\end{array}$ & $\begin{array}{l}\text { Sets regulations for re- } \\
\text { acquisition of Czech or } \\
\text { Slovak citizenship by } \\
\text { emigrants or others who } \\
\text { were deprived of Czech or } \\
\text { Slovak citizenship prior to } \\
1989\end{array}$ & www.zbierka.sk (in Slovak) \\
\hline
\end{tabular}




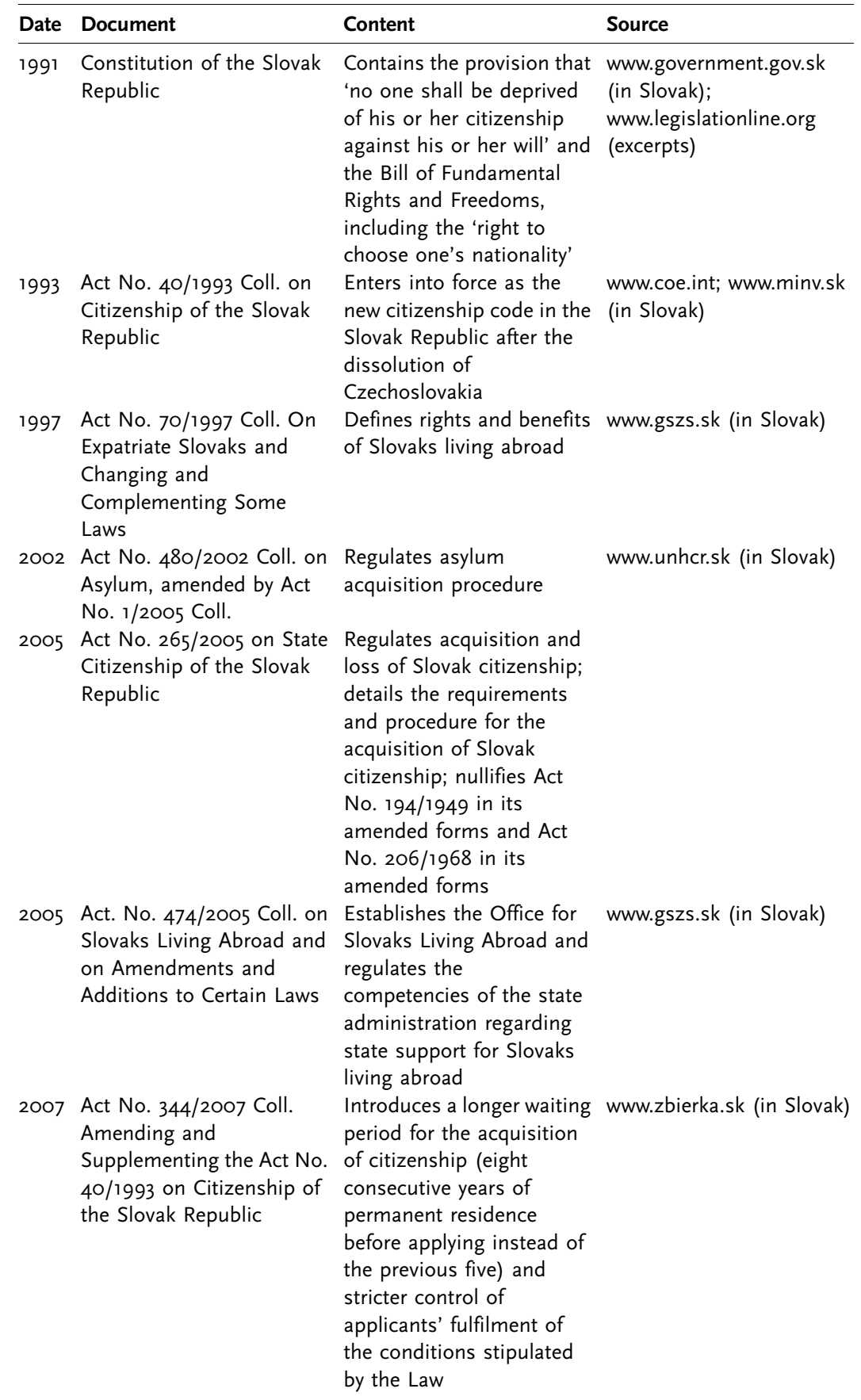




\begin{tabular}{llll}
\hline Date & Document & Content & Source \\
\hline 2007 Act No. 502/2007 Coll. on & Consolidates existing & www.zbierka.sk (in Slovak) \\
Citizenship of the Slovak & legislation on citizenship \\
Republic & (Act. No. 40/1993, Act No. \\
& $70 / 1997$ on Slovaks living \\
& abroad, Act No. 36/2005 \\
& on family, Act No. 265/ \\
& 2005 and Act No. 344/ \\
& \\
&
\end{tabular}

\section{Notes}

I The author and the editors thank Lucia Mokrá for her research contributions on legal and statistical developments.

2 Nationality in this context is not a synonym for citizenship, but refers to membership in an ethnic nation. The idea of a Czechoslovak nation did not take root - it was neither popular with Czech and Slovak political representatives nor with the general population and was eventually abandoned in favour of separate Czech and Slovak nationalities.

3 For a detailed history of census taking and practices, see Kertzer \& Arel 2002.

4 For a more detailed description of the development in the Czech part of Czechoslovakia see Baršová in this volume.

5 The Presidential Decree exempted from loss of citizenship those citizens of German and Hungarian ethnicity who had joined in the fight for liberation or were victims of Nazi persecution. The legislation also established a possibility to apply for the regranting of Czechoslovak citizenship (a policy called 'Re-Slovakisation in Slovakia') within six months after the Decree entered into force.

6 For decades, the topic of the transfers of ethnic Hungarians was taboo in Slovak literature. The few texts that were written were from the pen of Hungarian authors in Slovakia - Zoltán Fábry's The Accused Speaks Out (written in 1946) was published in the I96os, and in I982 Kálmán Janics's Czechoslovak Policy and the Hungarian Minority, $1945-1948$ was published in the US in a small edition of a few hundred copies. After I989, the topic was begrudgingly picked up. The most comprehensive analysis and documentation was published by Vadkerty (2002).

7 The voluntary part was secured by leaflets promising return of Czechoslovak citizenship in return for being recruited as agricultural labourers. Leaflets also reiterated that this was the very last chance for Hungarians to reacquire Czechoslovak citizenship.

8 The Czechoslovak census of I947 records 390,000 Hungarians in Slovakia, the I96I census records 518,782 (data from Kocsis \& Kocsis-Hodosi 1998).

9 See also Baršová in this volume for the same pieces of legislation from a Czech perspective.

Io Children born of mixed marriages, where one parent was a Czechoslovak citizen and the other was the citizen of the Soviet Union, Poland or Hungary, represented an exception. In those cases, citizenship was determined by an agreement of the parents at the time of inscription in the book of births. In cases where an agreement wasn't reached, the child acquired the citizenship of the parent in the state of birth. If the child was born in the territory of a third state, it acquired citizenship of the state on whose territory the child's parents had resided before they went abroad. 
II Act No. 34/1953 Coll. Concerning the Acquisition of Czechoslovak Citizenship by Particular Persons and Act No. 245/I948 on the Nationality of Hungarian Nationals.

I2 Stipulated by art. 6 of the Act on Czechoslovak Citizenship.

I3 This provision was defined by Act No. 86/1950 of the Penal Code. The penalty included the loss of citizenship rights, expulsion from the army, and forfeiture of property. Act No. 63/1965 abrogated this penalty and the next codification of the Czechoslovak Penal Law did not include this kind of penalty.

I4 Most socialist states had concluded bilateral agreements that excluded dual citizenship among them.

I5 See also Baršová in this volume.

I6 A child whose parents were Slovak citizens acquired Slovak citizenship. If one of them was Slovak and the other Czech, and the child was born in the Slovak territory, then the child acquired Slovak citizenship. If the child was born abroad, it acquired the mother's citizenship. Parents could also agree on the child's citizenship via a statement until six months after birth.

I7 'Pragocentrism' was a term used by the Slovak leaders to denote the tendency of the Czech representation to rule the country from a strong unitary centre, Prague. Slovak elites have had qualms with Pragocentrism ever since the creation of the first republic in I9I8.

I8 This claimed heritage is a controversial and complex one. Though perhaps only the Slovak National Party would fully claim the legacy of the Slovak Republic of the war period, together with the persona of its president, Jozef Tiso, responsible for sweeping anti-Semitic measures, all parties and most leaders do recognise at least its partial validity as the first form of official Slovak statehood.

I9 For a description of the developments in the Czech Republic see Baršová in this volume.

20 'Conditions for Gaining Slovak Citizenship Will Tighten', The Slovak Information Press Agency, 26 June 2007.

2I Art. 5 of Act No. 40/I993 Coll. on Citizenship of the Slovak Republic.

22 Art. 7 of Act No. 40/1993 Coll. on Citizenship of the Slovak Republic as amended by Act No. 344/2007 Coll.

23 Art. 7 of Act No. 40/1993 Coll. on Citizenship of the Slovak Republic as amended by Act No. 344/2007 Coll.

24 Art. 8a, sect. 9 of Act No. 40/1993.

25 See European Roma Rights Center report 'Personal Documents and the Threat to the Exercise of Fundamental Rights Among Roma in Former Yugoslavia', www.errc.org, retrieved in May 2006.

26 See also Baršová on Czech citizenship in the present volume.

27 Embassy of the Czech Republic in Slovakia, www.mzv.cz.

28 Among the main objections was the charge of ethnic discrimination concerning access to the benefits of the law. The Status Law is also territorially limited in implementation to certain neighbouring countries where the Hungarian minority is numerous and where the standard of living is not higher than within Hungary itself. Austria was therefore not included among the countries where the Status Law was to be implemented.

29 I. Stupňan, 'Schválili dohodu s Maďarskom' [Agreement with Hungary Approved], SME, I2 December 2003.

30 The interview with František Mikloško was conducted by the author in Bratislava on I3 June 2003.

3I The interview with László Nagy was conducted by the author in Bratislava on I8 June 2003 . 
32 Only 37.5 per cent of registered voters participated in the referendum. 5I.5 per cent of the voters were in favour of dual citizenship, 48.5 per cent against. 50 per cent of eligible voters have to participate for a referendum to be valid in Hungary (or an equivalent of over 25 per cent of all eligible voters must select the same answer on the referendum). Source: 'Neplatné maďarské referendum o dvojitom občianstve [Invalid Hungarian Referendum on Double Citizenship], BBC Slovak.com, 6 December 2004. www.bbc.co.uk.

33 Peter Stahl, 'Madari hlasujú o dvojitom občianstve' [Hungarians Vote on Double Citizenship], Hospodárske noviny [daily newspaper], 3 December 2004. http://hnonline.sk.

34 The SNS sued Miklós Duray many more times afterwards for treason, libel, damaging the name of the Republic, and more. Each charge was dismissed by the courts. SNS leader Jan Slota called the representatives of the Hungarian minority 'radioactive extremists' (Slota: 'Politici z SMK sú rádioaktívni extrémisti' [Politicians from the Party of Hungarian Coalition are Radioactive Extremists], 6 June 2005, www.sns.sk). Shortly before the parliamentary elections of June 2006 SNS popularity climbed to almost to per cent in public opinion polls. In the June 2006 elections, the populist left-leaning party SMER-SD came out on top with 29 per cent of the votes. SNS came in third with almost I2 per cent of the votes. The former leader of the government coalition SDKÚ received I8 per cent of the votes (Source: SITA [Slovak Press Agency], i8 June 2006).

35 Arts. 5 and 6 of the Act No. 70/1997 Coll. on Expatriate Slovaks and Changing and Complementing Some Laws.

36 Act No. 474/2005 Coll. on Slovaks Living Abroad and on Amendments and Additions to Certain Laws.

37 Art. 5 of the Act No. 474/2005 Coll. on Slovaks Living Abroad and on Amendments and Additions to Certain Laws.

38 Ondrej Štefanko, 'Slovenská republika a zahraniční (dolnozemskí) Slováci' [Slovak Republic and Foreign (Hungarian) Slovaks], Český a slovenský svet [Czech and Slovak World], www.svet.czsk.net, accessed in May 2006.

39 'Počet žiadatel'ov o azyl na Slovensku výrazne klesol' [Number of applicants for asylum has gone significantly down in Slovakia], Sme, I March 2009. www.sme.sk.

\section{Bibliography}

Drgonec, J. (I997), Základné práva a slobody podla Ústavy SR. Bratislava: MANZ.

Černý, J. \& V. Cervenka (I963), Státní občanství ČSSR. Prague: ORBIS.

Černý, J. \& M. Valašek (I996), České státní občanství. Prague: LINDE.

Fábry, Z. (1994), Obžalovaný prehovorí: Dokumenty $z$ dejín Măarov na Slovensku. Bratislava: Kalligram.

Hrušovský, P. (2003), Face of a Country; Address of the President of the National Council of the Slovak Republic Pavol Hrušovský on the Occasion of the 1oth Anniversary of the Slovak Republic, Ist January 2003. Bratislava: Vydavateľstvo Michala Vaška.

Janics, K. (I982), Czechoslovak Policy and the Hungarian Minority, 1945-1948. New York: Columbia University Press.

Jurová, A. (2002), 'Historický vývoj rómskych osád na Slovensku a problematika vlastníckych vzťahov k pôde ("nelegálne osady")', Človek a spoločnoš̌ 4. www.saske.sk.

Kaplan, K. (I993), 'Předmluva', in Š. Šutaj (ed.), Akcia Juh, Odsun Madarov zo Slovenska do Ciech v roku 1949. Prague: Sešity Ústavu pro soudobé dějiny.

Kertzer, D. \& D. Arel (eds.) (2002), Census and Identity; The Politics of Race, Ethnicity, and Language in National Censuses. Cambridge: Cambridge University Press. 
Klíma, K. (2002), Ústavní právo. Prague: FINIDR.

Klimko, J. (I980), Vývoj územia Slovenska a utváranie jeho hraníc. Bratislava: Obzor.

Kocsis, K. \& E. Kocsis-Hodosi (1998), Hungarian Minorities in Carpathian Basin. Budapest: Simon Publications.

Kusá, D. (2005), 'Historical Trauma in Ethnic Identity: the Years of Homelessness of the Hungarian Minority in Post-War Slovakia', in E. Breuning, J. Lewis \& G. Pritchard (eds.), Power and the People; A Social History of Central European Politics, 1945-56, I30I49. Manchester: Manchester University Press.

Lukes, I. (I995), 'Czechs and Slovaks: The Failure to Find a Decent Past', Cultural Survival Quarterly 2: 19-24.

Matoušek, S. \& S. Zdobinský (I984), Štátne občianstvo socialistických krajín. Bratislava: Obzor.

Nemcová, K. (1992), Continuity and Change in Slovakia. Bratislava: Slovak Archive of Social Data SASD.

Očovský, Š. (I992), 'Interpretácia štatistických údajov o národnostiach na Slovensku', in J. Plichtová (ed.), Minority v politike, Kultúrne a jazykové práva, 82-9I. Bratislava: Československý výbor Európskej kultúrnej nadácie.

Paul, E. L. (I998), 'Czech Teschen - Silesia and the Controversial Czechoslovak Census of I92I', The Polish Review 43 (2), I6I-I7I.

Peroutka, F. (I99I), Budování státu. Prague: Lidové noviny.

Plichtová, J. (ed.) (I992), Minority v politike, Kultúrne a jazpkové práva. Bratislava: Československý výbor Európskej kultúrnej nadácie.

Posluch, M. \& Ľ. Cibulka (2003), Štátne právo SR. Šamorín: Heuréka.

Sack, R. D. (I986), Human Territoriality: Its Theory and History. Cambridge: Cambridge University Press.

Svák, J. \& Ľ. Cibulka. (I999), Ústavné právo SR. Bratislava: APZ SR.

Svetoň, J. (I970), Vývoj obyvatelstva na Slovensku. Bratislava: Epocha.

Ther, P. \& A. Siljak (eds.) (200I), Redrawing Nations; Ethnic Cleansing in East-Central Europe, 1944-1948. Lanham, Maryland: Rowman and Littlefield Publishers, Inc.

Tichý, L., R. Arnold, P. Svoboda, R. Král \& J. Zemánek. (I999), Evropské právo. Prague: C. H. Beck.

Vadkerty, K. (2002), Maðarská otázka v Československu, 1945-1948; Dekréty prezidenta Beneša a ich dôsledky na deportácie a reslovakizáciu. Bratislava: Kalligram.

Zdobinský, S. \& S. Matoušek. (1985), Státní právo ČSSR. Prague: Panorama.

Zeman, Z. A. B. (1994), 'The Four Austrian Censuses and Their Political Consequences', in M. Cornwall (ed.), The Last Years of Austria-Hungary, 3I-39. Exeter: University of Exeter Press. 



\title{
10 From civic to ethnic community? The evolution of Slovenian citizenship
}

\author{
Felicita Medved
}

This chapter focuses on državljanstvo of the Republic of Slovenia, i.e. on citizenship or nationality as a legal bond between a person and a sovereign state. After tracing the history of citizenship in the territory of present day Slovenia, it gives a brief description of the evolution of the Slovenian citizenship legislation, both in terms of the initial determination of its citizenry at the inception of the state in June I99I and the rules governing the acquisition and loss of citizenship. In fifteen years of statehood the legal regime on citizenship has undergone several changes. The Constitutional Law on citizenship was supplemented and changed five times, with the first supplement already adopted in December I99I and the latest amendments made in November 2006. These developments have, on the one hand, implied an opening towards certain groups, either in response to international standards or for national interests. On the other hand, they have slowly supplanted the civic conception of citizenship that governed the initial determination of Slovenian citizenry in I99I with a concept of nation as a community of descent.

\subsection{History of citizenship policies}

\subsubsection{History of citizenship up to 1991}

Citizenship legislation in the territory of Slovenia first evolved within the framework of the Habsburg Empire. The I8II Austrian Civil Code, which established a link between unified citizenship status and civil rights and other regulations concerning citizenship, operated in the Slovenian lands until the collapse of the monarchy, except in Prekmurje, where Hungarian citizenship law was in force after I879. In close relation to citizenship, the right of domicile in municipalities (domovinska pravica, Heimatrecht), as a form of local citizenship, which gives rights to unconditional residence and poverty relief, was regulated on similar principles in both parts of the Austro-Hungarian monarchy in the second half of the nineteenth century (Radmelič I994: 207; Kač \& Krisch I999: 607-6I3). 
On I December I9I8 most of the Slovene lands, the Croat lands and Bosnia and Herzegovina joined Serbia and Montenegro to form the Kingdom of Serbs, Croats and Slovenes (SHS), later to be named the Kingdom of Yugoslavia. The Saint-Germain-en-Laye Peace Treaty, which came into force in July I920, and the Trianon Treaty, which came into force one year later, established that a person who had a right of domicile outside of Austria and Hungary from then on acquired the citizenship of one of the successor states. The Saint-Germain Treaty postulated, inter alia, that such persons could opt for the citizenship of that successor state in which they once had domicile or the successor state where the majority was of their 'race' or spoke their language. However, not everyone who had domicile (pertinenza) in the Slovenian Littoral and part of Carniola that thereafter belonged to Italy automatically acquired Italian citizenship. Those who were not born there or acquired domicile after 24 May I9I5 or once had domicile in this territory could opt for Italian nationality. On 25 November I920 the provincial government of Slovenia issued the executive regulations to the Treaty on the acquisition and loss of Yugoslav citizenship by option and request. ${ }^{\text {I }}$ The option was based on previous domicile or nationality, i.e. ethnicity. According to the Rapallo Treaty between the Kingdom of SHS and Italy of I2 November I920, Yugoslavia provided a one-year right of option for Italian citizenship for ethnic Italians in the from then on Yugoslav territory (Kos I994).

At the level of Yugoslav internal legislation, the I928 Citizenship Act $^{2}$ introduced a unified citizenship, primarily based on ius sanguinis a patre and the principle of a single citizenship. In the early I930s, provisions of Austrian and Hungarian regulations concerning the right to domicile were replaced by membership of a municipality.

In the Slovenian Littoral, Italian citizenship legislation was in force from 7 June I923 until mid-September I947. Italy did not apply any special regulations concerning citizenship in the occupied territory during the Second World War, whereas the German and Hungarian occupying forces granted citizenship to certain groups of people by regulation and law respectively, which were subsequently nullified (Radmelič I994: 222-223).

The post-war regulation of Yugoslav citizenship started on 28 August I945 before the final organisation of the second Yugoslavia was clear. ${ }^{3}$ The following persons became Yugoslav citizens: I) all those who, on the date of the enforcement of the Act, were citizens under the then valid I928 Act; 2) persons who had domicile in one of the municipalities in the territory, which according to international treaties became part of Yugoslavia; and 3) persons who belonged to one of the Yugoslav nations and resided in its territory without right to domicile, unless they decided to emigrate or to opt for their previous citizenship. An excep- 
tion to this regulation was added in I948, excluding from citizenry with a retroactive effect those persons of German ethnicity who were abroad and were Yugoslav citizens as of 6 April I94I, having domicile in one of the municipal communities and were, according to art. $35 \mathrm{a}$ disloyal 'to the national and state interests of the nations of Yugoslavia during and before the war.' ${ }^{4}$ Another Act adopted in 1945 (and nullified in 1962) concerned officers of the former Yugoslav army who did not wish to return to Yugoslavia and members of various military formations who served occupying forces and escaped abroad. They lost citizenship ex lege, followed by the sequestration of their property. ${ }^{5}$

According to the Paris Treaty with Italy which came into force in September I947 persons who had permanent residence on Io June I940 in the territory that became Yugoslavia lost Italian citizenship. As obliged by the Treaty, Yugoslavia adopted a special Act on the citizenship of these persons in December $1947 .^{6}$ The Italian-speaking population had a one-year option for Italian citizenship and Yugoslavia could demand emigration of these persons within one year of the date of the option. In 1947, an option for Yugoslav citizenship was also given to those whose citizenship issue was not solved by the Treaty, i.e. to some I00,000 emigrants from the Littoral to Yugoslavia or other countries before June I940, who ethnically belonged to one of the Yugoslav nations. The Paris Treaty also established the Free Territory of Trieste, a project that lasted seven years until it was divided up between Italy and Yugoslavia by the 1954 London Memorandum of Understanding. The latter did not regulate citizenship directly, but gave guarantees for the unhindered return of persons who had formerly held domicile rights in the territories under Yugoslav or Italian administration, which the Yugoslav law interprets as a qualified option. ${ }^{7}$ Remaining unsolved questions were settled by the 1975 Osimo agreements, which confirmed that both states regulate citizenship and provided the possibility of migration for members of minorities (Kos 1994). ${ }^{8}$

Yugoslav citizenship was unified and excluded other citizenship. Acquisition of citizenship remained based on ius sanguinis. A victorious revolutionary communist and national spirit of the immediate post-war period was expressed in legal provisions concerning naturalisation for members of Yugoslav nations and those foreign citizens who actively cooperated in the national liberation struggle, on the one hand, and exclusion and deprivation of citizenship for certain ethnic groups or military formations who really or supposedly worked against Yugoslav interests, on the other. The 1964 reform, following the new constitution, abolished loss of citizenship on grounds of absence (as in previous Austrian and Yugoslav legal arrangements), relaxed naturalisation of expatriates (emigrants) and abolished the oath of loyalty upon admission. An odd characteristic of Yugoslav legislation was that in the areas 
which did not pose a threat to the regime, such as the equality of spouses, introduced in I945, gender equality and the position of minors the legislator was already progressive during the period when international standards were only in the making. Yugoslavia was also party to certain multilateral treaties concerning citizenship such as the Convention Relating to the Status of Stateless Persons of I954, the International Convention on the Nationality of Married Women of I957, the Covenant on Civil and Political Rights of i966, the International Convention on the Elimination of all Forms of Racial Discrimination of I966, the Convention on the Elimination of All Forms of Discrimination against Women of 1979 and the Convention on the Rights of the Child of i989. 9

To better understand the problems related to succession in the field of citizenship it is important to emphasise that Yugoslavia was a federal state with a so-called mixed system of citizenship. Jurisdiction to adopt citizenship legislation existed at two levels simultaneously, at the level of the federal state and at the level of the constituent federal units, i.e. republics. From the point of view of international public and private law, the primary citizenship was Yugoslav (Kos I996a). Internally, however, all Yugoslav citizens also had republic-level citizenship. ${ }^{\text {Io }}$ Changing the place of residence to another republic or abroad did not affect the republic-level citizenship. Access to another republic-level citizenship was relatively easy though. At first it was conditional on three years of residence, but already in I946 one year of residence sufficed. In the ig6os a simple declaration was enough for a change of republic-level citizenship, reflecting a high level of centralised decision making. ${ }^{\text {II }}$ The I974 Constitution, however, brought decentralisation of power. According to the 1976 Citizenship Act of the Socialist Republic of Slovenia, ${ }^{\text {I2 }}$ citizens of other republics received citizenship of Slovenia upon application if they had permanent residence in Slovenia. Residents from other republics, however, had the same rights as Slovenian citizens, except for those reserved only for citizens of the republic, such as voting rights.

\subsubsection{Succession and initial determination of citizens of the new state}

Since the developments of the late ig80s and early i990s showed that it would not be possible to reach a consensual agreement on some other organisational form for Yugoslavia or on succession, the Republic of Slovenia unilaterally declared its independence on 25 June I99I. Slovenia had no historical heritage of independent statehood or concept of political membership beyond republic-level citizenship within the former federation to fall back on. In that respect, Slovenia differs from some states which came into being following the break-up of former 
federations, such as the USSR. Notably Estonia and Latvia restored their citizenship laws of half a century earlier, emphasising state continuity broken by 'lost' or 'occupied' sovereignty (see Jaerve and Krūma in this volume). Some other new states adopted a 'zero-option' policy, granting their citizenship to all people actually residing in the republic either at the time of independence or at the moment the new citizenship law was passed. This policy was more acceptable in those states where the proportion of the 'titular' ethnic population was very high (Medved I996; Ziemele 200I; Mole 200I).

At the international level, citizenship in the context of state succession is addressed by binding and non-binding international instruments, such as the I96r UN Convention on the Reduction of Statelessness and the 1978 Vienna Convention on Succession of States in Respect of Treaties, containing large principles but lacking comprehensive regulations. ${ }^{\mathrm{I}}$ The primary concern of the international coverage of law on citizenship in cases of succession remains focused on reduction of dual citizenship and the avoidance of statelessness and deals less with the initial determination of citizens, which is not a concern of the established (old) states. Although there has been substantial development in human rights law, laws concerning the acquisition or loss of citizenship continue to be primarily considered a sovereign prerogative of the state. ${ }^{\mathrm{I} 4}$

In this context, Slovenia regulated citizenship issues through the Citizenship Act adopted within the scope of the legislation relating to Slovenia's gaining of independence. The constitution was adopted six months later, on 23 December I99I, and does not regulate citizenship, but leaves it to the law. Since then, the citizenship law has gone through several changes. The first supplement had already been adopted in December I991, followed by further changes in 1992, I994, $2002^{15}$ and most recently in $2006 .{ }^{16}$ Conceptually, the I99I Act contains two main categories. The first category includes provisions of a transitional nature, which refer to the initial collective and automatic determination of the citizens of the new state, complemented by provisions governing the option for Slovenian citizenship. ${ }^{\text {I7 }}$ The second category regulates the acquisition and loss of citizenship of a standard (permanent) nature.

As regards the initial overall determination of citizenship, the basic principle is the continuity of previous citizenship upon state succession. Art. 39 stipulates that any person, who held citizenship of Slovenia and of Yugoslavia according to existing valid regulations, was considered ex lege to be a citizen of Slovenia on the day when the Act came into force. This provision established the continuity with the previous legal order, meaning that all laws and regulations which due to various legal orders were in force in the territory of Slovenia in the past, in- 
cluding international agreements, are applied within the framework of this provision. The period in which a person was born determines which regulations apply for ascertaining citizenship.

The primary rule of the initial determination of citizens was complemented with the optional acquisition of Slovenian citizenship for citizens of other former Yugoslavian republics who had permanent residence in Slovenia on the day of the Plebiscite for the Independence and Autonomy of Slovenia on 23 December I990, and who actually lived in Slovenia. These two cumulative conditions determined what was considered the genuine link with Slovenia: the permanent residence connected with social, economic and certain political rights and the actual living there expressing the criterion of integration, which in practice meant that the person had to reside in Slovenia, not only have a formal residence there (Mesojedec-Pervinšek I999: 656-659; Medved 2005: 467). In dimensions of time 'actual living' was established by the Supreme Court to be at least the period between 23 December I990 and the date of issuance of a final decision on citizenship. As for the content of this notion, which is not legally defined, administrative court practice did not interpret it to mean continuous physical presence but also considered living activities in a certain territory, such as where a person earns a living, resides and fulfils obligations to the state to qualify as such (Polič i993).

The December I99I supplement on art. 40 specified a further restriction, stating that the person's application is to be turned down if that person has committed a criminal offence directed against the Republic of Slovenia since Slovenian independence or if the petitioner is considered to form a threat to public order, the security and defence of the state. ${ }^{\mathrm{I} 8}$

The legal period for the submission of the application was six months and expired on 25 December I99I. More than I74,000 persons, or 8.7 per cent of the total population, of which around 30 per cent were born in Slovenia, applied for citizenship on the basis of art. 40 and I7I,I25 became Slovenian citizens.

The registration of the former republican citizenship was not carried out very thoroughly and some persons who firmly believed themselves to be Slovenian citizens were not considered as such and could not prove their former republican citizenship in order to acquire Slovenian citizenship. To address this problem two corrections were made in I994, concerning the recognition and declaration of Slovenian citizenship. Art. 39a stipulates that a person is considered a Slovenian citizen if he or she was registered as a permanent resident on 23 December I990 and has permanently and actually lived in Slovenia since that date. However, this only applies if the person in question would have acquired the citizenship of Slovenia according to the previous legal or- 
der. On the other hand, according to the new art. 4I, persons younger than 23 and older than eighteen years who were born in Slovenia can declare themselves Slovenian citizens if one of their parents was a citizen of Slovenia at the time of their birth, but the parents later agreed on adopting the citizenship of another republic.

Registered permanent residency posed a problem for those immigrants who were not registered, but had a long-time factual residence in Slovenia. They could not apply for Slovenian citizenship since they were not legally considered residents. ${ }^{\text {I9 }}$ The problem of permanent residency also arose for those who were registered, but did not apply for or did not acquire Slovenian citizenship. Becoming aliens, they had to apply for residency status irrespective of how long they had been resident. The Aliens Act ${ }^{20}$ did not contain any special provisions for this group of people. ${ }^{2 \mathrm{I}}$ It only provided that with respect to the said persons provisions of the Law should start to apply two months after the expiry of the time within which they could apply for Slovenian citizenship or on the date of issuance of a final decision on citizenship. On 26 February I992, when the Aliens Act started to apply to these persons, administrative authorities transferred those who did not apply for residency status from the permanent population register to the foreigners record without any decision or notification addressed to those concerned to inform them of their new legal position. ${ }^{22}$ This secret 'erasure' became known to the public only much later and the exact numbers of those affected remain unknown. The state admits that 18,305 persons had been deprived of their legal residence. In spite of several appeals by the Ombudsman for human rights, ${ }^{23}$ non-governmental organisations and some individuals, it was only in I999 that the Constitutional Court found that the Aliens Act had failed to regulate the transition of the legal status of this group of people to the status of foreigners. ${ }^{24}$ The Constitutional Court decided that the error should be corrected by the legislator within six months which resulted in the Settling of the Status of Citizens of Other SFRY Successor States in the Republic of Slovenia Act. ${ }^{25}$ However, in 2003, the Constitutional Court also found this regulation unconstitutional and ordered the Ministry of the Interior to immediately issue decisions to retroactively return the status of permanent residence to those who already had had their status changed. Moreover, it asked the legislator to pass a new law within six months, clarifying the criteria for those who, in the period between 1992 and 2003 , left Slovenia for shorter or longer periods. ${ }^{26}$ The polarisation of the political scene as well as public opinion led to various interpretations of the Constitutional Court decision. This resulted in a number of initiatives for referenda, supported by right-wing parties, as well as in the preparation of two separate acts. After the adoption of the socalled 'technical law' in October 2003, opposition parties succeeded in 
calling a referendum on 4 April 2004. The voter turnout was less than a third of the I.6 million electorate, and the Act was rejected by almost 95 per cent. This development succeeded in thwarting the adoption of any law to comply with the decisions of the Constitutional Court. ${ }^{27}$ The current right-centre government is now trying to prepare a special Constitutional Law.

In the meantime, in order to settle the position of some of the people who could not or did not wish to apply for Slovenian citizenship in I99I, or whose applications were rejected and who subsequently became aliens or were even 'erased', the Citizenship Act was amended in 2002. The new 'transitional and final provisions' facilitated acquisition of Slovenian citizenship for citizens of other republics of the former Yugoslavia who were registered as permanent residents on 23 December 1990 and who have been living in Slovenia continuously from that day. Duration of residence, personal, family, economic, social and other ties with Slovenia, as well as the consequences a denial of citizenship might have caused, were also taken into consideration. The deadline for a free application expired on 29 November 2003 , with 1,676 persons being naturalised under this provision.

Apart from the two main categories - initial determination of citizenship and optional naturalisation - the Citizenship Act contained a third category of transitional provisions that were of compensatory or restitutional nature. These provided for reacquisition of citizenship, which was, according to art. 4I, made possible for those who were deprived of Yugoslav citizenship and Slovenian citizenship on the basis of the I945/ 46 federal law on the deprivation of citizenship or on the grounds of absence. ${ }^{28}$ They and their children could acquire Slovenian citizenship if they filed an application within one year of the enforcement of the Act. Since most of these people were living abroad, the application period was prolonged to two years in 1992. At the same time, a new art. I3a in the section concerning exceptional naturalisation stipulated that, notwithstanding the conditions for regular naturalisation, an adult may obtain Slovenian citizenship if he or she is of Slovenian descent through at least one parent and if his or her citizenship in the Republic of Slovenia has ceased due to release, renunciation or deprivation or because the person had not acquired Slovenian citizenship due to historical circumstances. The article also granted the government the right to give a preliminary opinion on the applications. Due to this extensive discretion and, inter alia, the violation of the principle of equality before the law, arts. 4I and iza were nullified in $1993 .{ }^{29}$ 


\subsection{Basic principles of acquisition and loss of Slovenian citizenship}

The characteristics of current legislation are the principle of ius sanguinis and only limited application of ius soli, the prevention of statelessness, gender equality in acquisition of citizenship, equality of parents in deciding the citizenship of their minor children, equality of children born in wedlock with children born out of wedlock, will of the person concerned in the process of acquisition and loss of citizenship and protection of personal data. Further principles are the relative tolerance of multiple citizenship and the validity of Slovenian citizenship in these cases, meaning that a dual or multiple citizen is treated as a citizen of the Republic of Slovenia, while in the territory of Slovenia, unless otherwise stated by an international agreement. Foreign citizens may acquire Slovenian citizenship by naturalisation on the basis of residence or of family ties or because of special interests of the state. ${ }^{30} \mathrm{Fa}$ cilitated naturalisation is provided for immigrant children born and raised in Slovenia and for Slovene emigrants and their descendants. Discretionary power is provided for in all cases of naturalisation, however, it may only be exercised if the reasons, including the proof thereof, are recorded in the written decision..$^{3 \mathrm{I}}$

\subsubsection{Acquisition of citizenship}

Slovenian citizenship is acquired by descent, by birth in the territory of Slovenia, by naturalisation (through application) and in compliance with international agreement (which is applicable only in cases where borders have changed).

Under the ius sanguinis principle there are two modes of acquiring Slovenian citizenship: ex lege and by registration. The registration has a constitutive character and retroactive effect (ex tunc).

At birth, a natural person obtains Slovenian citizenship ex lege: i) when both parents are Slovenian citizens, ii) when the child is born in Slovenia and at least one parent is a Slovenian citizen (in the latter case the acquisition of the citizenship ex lege is combined with the territorial principle) ${ }^{32}$ and iii) when the child is born abroad and one of the parents is a Slovenian citizen while the other parent is unknown, of nondetermined citizenship or stateless.

Children born abroad with one parent of Slovenian citizenship at the time of the child's birth can acquire Slovenian citizenship by registration. Registration can be initiated within eighteen years after birth by the Slovenian parent without the consent of the other parent or if a minor is a ward of his or her guardian, who must be a Slovenian citizen. ${ }^{33}$ As of 1994, children over fourteen years of age have to give their 
consent. Those over the age of eighteen can acquire Slovenian citizenship based on a personal declaration for registration. The age limit for this procedure was extended from 23 to 36 years of age in 2002 . The November 2006 Act amending the Citizenship of the Republic of Slovenia Act, further clarifies the procedure and adds the condition that those who register their Slovenian citizenship should not previously have lost it due to release, renunciation or deprivation after they reached majority.

Acquisition of citizenship by adoption follows the principle of citizenship by descent when at least one of the adoptive parents is a Slovenian citizen. An adoptee foreigner older than fourteen years has to give his or her consent.

Ius soli applies for a foundling or a newborn infant in the territory of Slovenia with no known parentage or if the parents are of unknown citizenship or stateless. If it is discovered prior to the child reaching the age of eighteen that the parents are foreign citizens, then Slovenian citizenship shall cease at the parents' request.

Those who acquire Slovenian citizenship under above described principles are regarded as citizens of the Republic of Slovenia by birth.

Foreign citizens may acquire Slovenian citizenship by regular, facilitated and exceptional naturalisation.

The conditions that must be fulfilled for regular naturalisation are very strict. The applicant has to submit a release from current citizenship or a proof that such a release will be granted if he or she acquires Slovenian citizenship unless the applicant is stateless or can submit evidence that his or her citizenship is cancelled by naturalisation by the law of his or her state of origin or that such a release was not decided upon by this state in a reasonable period of two years. ${ }^{34}$ In cases where applicants cannot present proof of expatriation, e.g. because the voluntary acquisition of a foreign citizenship is considered an act of disloyalty, the declaration by an applicant that he or she will renounce his or her current citizenship if granted Slovenian citizenship suffices. However, the applicant usually has to present proof of expatriation before he or she can be naturalised. This may lead to temporary statelessness which can become permanent if after release from the previous citizenship an applicant is no longer eligible for naturalisation, e.g. due to loss of means of subsistence or a prison penalty. Since the authorities have to check if other conditions are still fulfilled after the prescribed period within which an applicant must present proof of release, the 2006 amendments specify that only those conditions that can be verified administratively will suffice. The condition of a release from current citizenship is waived for citizens of those EU Member States where reciprocity exists. 
A second condition is that the applicant must have lived in Slovenia for ten years, of which the five years prior to the application must be without interruption, and, as added in 2002, the person should have the status of foreigner. This imprecisely defined status is clarified in the 2006 amendments as describing those people who have either a temporary or permanent residence permit, which in practice prolongs the waiting period for naturalisation. In addition, the applicant should not have had his or her residence in Slovenia curtailed.

Further requirements are that the person does not constitute a threat to public order or the security and defence of Slovenia, has fulfilled his or her tax obligations and has a guaranteed permanent source of income. ${ }^{35}$ In fact, the latest amendments state that the applicant is required to have such means of subsistence as will guarantee material and social security to the applicant and persons he or she has an obligation to support i.e. a basic minimum income for each person. Moreover, the law demands a clean criminal record, meaning, inter alia, that the applicant should not have served a prison sentence of more than three months or have been sentenced to a conditional prison term of more than one year. ${ }^{36}$ The applicant will also be obliged to take an oath of respect for the free democratic constitutional order of Slovenia, which replaces the requirement to sign a declaration of consent to the legal order of the Republic of Slovenia introduced in 2002. Finally, there is the required knowledge of the Slovene language, which has changed substantially. In the early i990s, it sufficed that the person could communicate. In I994, an obligatory examination was instituted. Many people failed the examination even though they had been educated in Slovenia. Currently, an obligatory examination at an elementary level is required unless the applicant went to school or acquired education at a higher or at a university level in Slovenia or is over 60 years of age and has actually lived in the country for fifteen years or, as was added in 2006, has acquired an elementary or secondary education in the Slovenian language in a neighbouring country where there are autochthonous Slovene minorities. Exceptions are made for illiterates and for health reasons.

Facilitated naturalisation reflects specific interests of the state and more recently, the will of the state to better comply with the standards of the I997 European Convention on Nationality. This mode of naturalisation affects particular groups of persons: Slovenian emigrants and their descendants, foreigners married to Slovenian citizens, minors and since 2002 persons with refugee status, stateless persons and those born in Slovenia and living there since their birth. To these groups of persons, the 2006 amendments added foreigners who have concluded their university education in Slovenia. Exemptions from certain requirements are provided for these groups of applicants, in particular regard- 
ing the release from current citizenship and the required duration of residency with a foreign status in Slovenia. For example, an individual of Slovenian descent or a foreign spouse of a Slovenian citizen can become a Slovenian citizen after one year of uninterrupted residence. However, the 2006 amendments show that these two groups of persons are not treated equally. While the generational criterion (up to the third generation for direct descent) for descendants of Slovenian emigrants was extended up to the fourth generation, the period of marriage before a foreign spouse of a Slovenian citizen is eligible to apply for naturalisation was prolonged from two to three years in order to dissuade marriages of convenience. For those who have lost Slovenian citizenship in accordance with the present Act or prior Acts valid in the territory of Slovenia, the residence requirement is limited to six months. Acknowledged refugees and stateless persons may be naturalised after five years of actual and uninterrupted residence in the country. For persons born in Slovenia who have lived there since birth (mainly citizens of successor states of the SFRY), personal, family, economic, social and other connections with Slovenia as well as the consequences a denial of naturalisation may cause are taken into consideration. Foreigners who have concluded their university education in Slovenia will be eligible to apply for naturalisation after seven years of residence. For all these cases, release from current citizenship is not necessarily required.

A minor acquires Slovenian citizenship upon the request of one or both naturalised parents if the child has lived with that parent in Slovenia for at least one year prior to the application. If the child is born in Slovenia, Slovenian citizenship can be acquired before the age of one year. Citizenship may also be granted to a child having no parents or whose parents have lost their parental rights or functional capacity and who has lived in Slovenia since birth on the grounds of a petition by the guardian who is a Slovenian citizen and who lives with the child. The Ministry for Family and Social Affairs has to confirm that the acquisition of citizenship is for the benefit of the child. In all of the above cases the consent of the child above the age of fourteen is also necessary. ${ }^{37}$ In the case of adoption, where there is no such relation between the adoptive parent and adoptee as between parents and children, a child not older than eight years, living permanently in Slovenia, can acquire citizenship upon the request of the adoptive parents.

In cases of exceptional naturalisation, the interests of the state for example in the field of culture, economy, science, sport, and human rights are decisive and must be confirmed by the government. A person qualifying for exceptional naturalisation may remain a double or multiple citizen, but has to actually live in Slovenia without interruption for at least one year with a foreigner's status before applying for citizenship. The latter condition does not have to be fulfilled when his or 
her naturalisation benefits the state for national reasons, i.e. when the person is of Slovene ethnicity. The 2006 amendments clarify the conditions for exceptional naturalisation of persons of Slovene descent, including persons belonging to Slovene minorities in neighbouring countries. Neither residence in Slovenia nor other conditions such as material and social security or fulfilled tax obligations in a foreign country are required in these cases.

\subsubsection{Loss of citizenship}

A Slovenian citizen cannot lose his or her citizenship by mere operation of law. There are five ways to lose one's Slovenian citizenship: release, renunciation, deprivation and loss of citizenship through international agreements, with the latter only being applied to cases involving changes to state borders. Citizenship can also be lost by the nullification of naturalisation.

Release is the regular way of losing citizenship by application. It is the right of any Slovenian citizen who fulfils the stipulated conditions, such as actual residence abroad and proof that he or she will be granted a foreign citizenship. Release has to be approved by a public authority, but discretionary power is limited to specific reasons such as national security and national interests, reciprocity or other reasons derived from relations with a foreign country.

Renunciation is a qualified option for dual citizens, meaning that such a person has the right to renounce Slovenian citizenship. It is accorded to individuals up to 25 years of age, born in a foreign country, residing there and holding a foreign citizenship. Other conditions have not been foreseen. The Ministry of the Interior has no discretionary power and may issue a decree stating that Slovenian citizenship of such a person ceased on the day that such a statement of renunciation was filed. Minors, up to the age of eighteen years, enjoy a substantially higher degree of protection regarding the release from and renunciation of citizenship, compared to the acquisition of citizenship. The consent of both parents is required, regardless of their citizenship. In a case of dispute, the Ministry for Family and Social Affairs decides in the best interests of the child. Furthermore, children older than fourteen years must give their personal consent.

Deprivation of citizenship is the only type of citizenship loss that the state may initiate. A Slovenian citizen, actually residing in a foreign country and in possession of a foreign citizenship may be deprived of citizenship if it is ascertained that this person's activities are contrary to the international and other interests of the Republic of Slovenia. Proof of the existing conditions must be given in the decree on the depriva- 
tion of citizenship, which may be issued by exception in the absence of the party concerned.

Cancellation of a decree on naturalisation may occur if it is discovered that naturalisation was granted based on false declarations or deliberate concealment of essential facts or circumstances on the side of the individual in question. It may also be nullified if the person acquired citizenship on the grounds of a foreign state's guarantee that the person's foreign citizenship will cease to exist if the person acquires the Slovenian citizenship and evidence of the loss of the previous citizenship has not been submitted within the prescribed period. Nullification is not possible if such a person would become stateless.

\subsubsection{Dual and multiple citizenship}

In general, Slovenian legislation is relatively tolerant of plural citizenship on both entry and exit sides. The ius sanguinis and gender equality principles contribute to dual citizenship for citizens by birth, both in Slovenia and abroad, since ius sanguinis transmission of Slovenian citizenship is not limited to the first or second generation or by any other requirements. Multiple citizenship is even possible for adopted persons. Acquisition of the citizenship of another country does not mean that the Slovenian citizenship is automatically forfeit, neither is release from current citizenship required for certain groups that qualify for facilitated and exceptional naturalisation, nor in cases of regular naturalisation where expatriation would have harsh consequences.

The number of dual and multiple citizens is unknown. In June I99I, there were I5,000 registered dual citizens residing abroad (Končina I992). After independence the number of dual and multiple citizens substantially increased, both in the country and abroad. In 2005, it was estimated that around 60,000 Slovenes permanently residing abroad had Slovenian citizenship. Slovenia grants substantial political rights to citizens abroad, including franchise in local, parliamentary and presidential elections. The number of dual citizens in Slovenia is much larger and is mainly the consequence of specific historical circumstances in which the new state was created and was partially dependent on the citizenship legislation of other countries, notably Italy.

The transitional provisions regulating the option for Slovenian citizenship did not touch upon dual citizenship and it is estimated that almost all people from other republics of the former Yugoslavia are dual citizens. In I99I, it was also objectively impossible to make this type of naturalisation conditional on a release from current citizenship. The outcome of the Yugoslav crisis was unknown and the possibility of a bilateral or multilateral regulation of citizenship did not bear fruit. The break-up of Yugoslavia did not lead to de iure statelessness, since all 
successor states applied the principle of continuity of former republiclevel citizenship (Kos I996b; Mesojedec-Pervinšek I999: 655). Nevertheless, the interest in Slovenian citizenship was much higher than expected in I99I when the authorities estimated that approximately 80,000 persons would apply for Slovenian citizenship (Mesojedec-Pervinšek I997: 32-34). The reasons for such a response are various and have so far not been well researched. Public discussions emphasise utilitarian motives, in particular the possibility to purchase socially owned housing which was only open to Slovenian citizens. Suspicions that holders of dual citizenship may be disloyal and that they pose a potential threat to state security led to a change in the political and public mood and to legislative attacks on this status, mainly supported by the Slovene National Party and the Peoples' Party in the period from I993 to I996. While the liberal democratic government also proposed the abolishment of dual citizenship in I993, some other proposals openly called for the retroactive nullification of all decrees under art. 40. In I995, there was even an official initiative for a referendum on the issue, which was only stopped by the Constitutional Court ${ }^{38}$ (Cerar I995; Dujić I996; Medved 2005: 470-474).

\subsubsection{Jurisdiction and procedures}

Up to the end of 2006, the Ministry of the Interior had jurisdiction over naturalisation and loss of citizenship. Following the concept of territorial de-concentration of state administration, the 2006 amendments to the Citizenship Act transfer this competence from the Ministry of the Interior to local administrative units. Only cases of exceptional naturalisation remain under the jurisdiction of the Ministry of the Interior. Moreover, the Ministry still has a 'controlling' role in the obligatory revision procedure for decisions on naturalisation and loss of citizenship as well as documents related to the release from prior citizenship. In this procedure the Ministry can either confirm decisions made at the local level or make a new decision. A period of nine months is envisaged for the transfer of decision making.

Legislative competence lies with the government, which specifies the requirements for regular naturalisation regarding, inter alia, residence, income and threat to public order, security and defence of the state, and defines the criteria for the naturalisation on the grounds of national interest and for the refusal of release from citizenship. A decision by the Ministry may be appealed and is open to judicial review (see Polič I997a, I997b). Fees are relatively low (30,000-35,000 SIT, i.e. I25-I50 euros).

Local administrative units have the authority to establish and register citizenship. ${ }^{39}$ Record keeping of citizenship is done in compliance with 
the Births, Deaths and Marriages Registry Act at the register of births. ${ }^{40}$ The Ministry of the Interior keeps the central citizenship register. Since this register does not constitute a separate database but is part of the permanent population register, the 2006 amendments provide that the Ministry of the Interior and local administrative units shall keep a register of persons who acquired citizenship by naturalisation and those who lost Slovenian citizenship. This register shall be computerised and connected to the registers of foreigners and of births, deaths and marriages. Personal data from this register may be used by the employees of internal affairs when performing their duties defined by law and can be forwarded to other users only if these are authorised by law or upon the consent or request of the individual to whom they relate. The Ministry of the Interior can forward personal data of an individual to other states under the condition of reciprocity only if such data are used for clearly defined purposes (such as settling citizenship issues or realisation of penal proceedings) and that in that state personal data protection applies also to foreigners. Slovenian citizenship can be proven by attestation or any other public document of citizenship issued by an agency with the authority for administering the official register in which the citizenship of the person is entered, or by the administrative unit where the person permanently resides. According to the latest change, any administrative unit can issue attestations of citizenship.

\subsection{Current political debates}

Until recently, the citizenship agenda was dominated by the heritage of the dissolution of Yugoslavia. Subsequently, the citizenship legislation went through a series of adjustments related to the admission of citizens of other successor states of the former Yugoslavia. As has already been pointed out above, the issue of plural citizenship prevailed in the mid-I990s. After unsuccessful legislative attempts to abolish dual citizenship there is an acceptance of plural citizenship for this group of people as a reflection of the historical experience. Since the late I990s, the political scene has been dominated by the issue of the 'erased'. Until now, there have only been partial solutions to resolve the problems of this group of people, either by regulating their status as foreigners or enabling them to naturalise. Moreover, despite the more recent criticism by the Commissioner for Human Rights at the Council of Europe and by the Commission against Racism and Intolerance (ECRI) of the Council of Europe, it is not expected that further attempts, including the current government's attempt to introduce a special Constitutional Law, which requires a two-thirds parliamentary majority, will bear any 
fruit before the next parliamentary elections. Current political debates have thus shifted the focus to societal integration of naturalised 'foreigners' and political participation and representation for these 'new minorities'. This debate is further enhanced by the realities of more recent immigration and reforms necessary as a result of joining the European Union in May 2004.

In the pre-accession period the eurocompatibility was influenced more by international trends, such as the I997 European Convention on Nationality of which Slovenia is not a party, than by indirect pressure from the EU. This applies in particular to the amendments in 2002, refining and relaxing access to citizenship for recognised refugees, stateless persons and second- and third-generation immigrants. On the other hand, conditions for naturalisation have been maintained and tightened. Since 2002 , applicants must have the status of foreigner, as explained above. This status is an eligibility criterion that may be waived only in some exceptional cases of naturalisation. Further changes concern the question of loyalty. In 2002, the declaration of agreement with the legal order of Slovenia was introduced, which in 2006 was supplanted by an oath of loyalty. In July 2005, the government also further specified national interest as a reason for exceptional cases of naturalisation, in other words, criteria for cultural i.e. ethnicaffinity based naturalisation of Slovenes living abroad. The Governmental Office for Slovenes around the world may offer an opinion on the applicant, which has led to criticism and protests from members of the Slovene diaspora.

In line with this protest, the political discussion focused on legislation regulating relations between Slovenia and Slovenians abroad, in particular concerning the legal position of autochthonous minorities living in neighbouring countries and emigrants and their descendants with or without Slovenian citizenship. In April 2006, the National Assembly passed the Republic of Slovenia and Slovenians Abroad Act. ${ }^{\text {I }}$ The Act is based on art. 5 of the Constitution, the I996 Resolution on the Position of Autochthonous Slovene Minorities in Neighbouring Countries and the Related Tasks of State and Other Institutions in the Republic of Slovenia ${ }^{42}$ and the 2002 Resolution on Relations with Slovenes Abroad. ${ }^{43}$ The objectives of this legislation are to arrange relations of the 'homeland' with Slovene diasporas in order to strengthen national identity and consciousness and promote mutual ties in the fields of culture, care for the Slovene language, education and science, sports, economy and regional cooperation. It introduces a new status of a Slovene without Slovenian citizenship, regulates its acquisition and loss and provides certain advantages to its beneficiaries. Acquisition of this status would primarily depend on descent, activity in Slovenian organisations abroad and active ties with the 'homeland'. The Governmental 
Office for Slovenes around the world will be responsible for issuing this status. When in Slovenia, the holders of this status will enjoy preferential enrolment at institutions of higher education, equal access to research projects and public cultural goods, such as libraries or archives, as well as equal property rights. They will also enjoy priority in employment over other third-country nationals. Until now, no one has applied for, let alone acquired, this 'quasi-citizenship' status. The Act also supports the return of Slovenian expatriates and their children and also provides for repatriation, meaning immigration of Slovenes, organised and financed by Slovenia in cases when there is, according to the assessment of the Ministry for Foreign Affairs, a severe crisis, political or otherwise, in the states where they reside, and if their repatriation contributes to the development of the 'homeland'. The Council for Slovenians Abroad and the Council for Slovenians in Neighbouring Countries will function as permanent advisory bodies. The councils are headed by the Prime Minister, who appoints their members, composed of representatives of state bodies, institutions, political organisations and civil society organisations from Slovenia and abroad. ${ }^{44}$

There are certain parallels between the Slovenians Abroad Act and the famous and controversial 200I Hungarian Status Law, the 1997 Law on Expatriate Slovaks and the I999-200I failed Polish move to install a similar law (see Liebich, Kovács \& Tóth, Kusá and Górny \& Pudzianowska in this volume). However, the Slovenian Government claims that the Slovenian law cannot be equated with the Hungarian Status Law since it does not interfere with the competences of other EU Member States or the free movement of workers, nor does it establish Identity Cards valid in the territory of any other EU Member State.

The most recent political discussion concerned the future development of citizenship legislation. A working group was set up to analyse current citizenship legislation and its implementation and prepare changes to the Citizenship Act. Due to the complexity of current citizenship legislation there was a tentative suggestion for an overall revision, but this was hardly to be expected. In fact, when in July 2006 the Act amending the Citizenship of the Republic of Slovenia Act was proposed, the government claimed that it would not change the aims and principles of the existing legislation, but it focused instead on requirements for naturalisation and some practical aspects, such as clarifications of imprecisely defined provisions, and on harmonisation with other legislation, specifically concerning immigration and record keeping.

Nevertheless, the Act was not adopted in a short parliamentary procedure as initially proposed by the centre-right government but caused extensive discussion, particularly regarding the 89-word long oath of loyalty, suggested by the Ministry of Justice. While the Liberal-Demo- 
crats proposed that the text of the oath be simplified, the Social Democrats, another opposition party, argued that the text confuses the concepts of 'state' and 'homeland' as the latter is not a legal concept and that taking an oath of loyalty 'to my new homeland' shames a civilised and modern society and is reminiscent of nineteenth century patriotism. Moreover, the Liberal Democrats opposed the transfer of the jurisdiction over naturalisation and loss of citizenship from the Ministry of the Interior to local administrative units, which in the government's view is the main novelty of the amended Act. They argued that such an arrangement could lead to arbitrary decisions in spite of the revision procedure by the Ministry. While none of the political parties opposed relaxed naturalisation for ethnic Slovenes, the Liberal Democrats criticised that conditions, such as residence in Slovenia or material and social security, are waived in these cases.

The Act amending the Citizenship of the Republic of Slovenia Act was passed by the National Assembly on 24 November 2006. Since the National Council did not veto the adopted Act in the prescribed seven-day period, the Act came into force at the end of the year 2006 .

\subsection{Statistics}

At the end of 2008 , there were 208,484 naturalised citizens or approximately one-tenth of the total population of Slovenia. Roughly 8I per cent of all naturalised persons acquired citizenship according to the optional provisions in the immediate post-independence period, with the corrective provision of 2002 contributing to less than I per cent. The great majority (98.7 per cent) of naturalised citizens originated in other successor states of the Social Federal Republic of Yugoslavia, of these 46 per cent from Bosnia and Herzegovina, meanwhile only I.3 per cent from other countries. When considering naturalisation by standard provisions the share of the latter rises to II per cent. These were mainly citizens from Western European countries and overseas OECD-states. For example, 2,I59 were citizens of EU States or Switzerland, among them I,024 of Italy and 510 of Germany. These are followed by previous citizens of the Russian Federation (28I) and of Ukraine (237).

A quarter of all those naturalised according to standard provisions acquired Slovenian citizenship by fulfilling all conditions. Almost 58 per cent of those were naturalised according to facilitated procedure. Exceptional naturalisations present a rather large I7 per cent share.

Over 80 per cent of facilitated naturalisations refer to extension of citizenship to family members, i.e. to spouses and minor children. Ethnic-affinity based naturalisations are also significant. 
Table 10.1 Admission to Slovenian citizenship based on supplementary and corrective initial determination rules (art. 40, 1991, art. 19, 2002) and on standard provisions for naturalisation by country of origin, 25 June 1991-31 December 2008

\begin{tabular}{|c|c|c|c|c|c|c|}
\hline \multirow[t]{2}{*}{ Country of origin } & \multicolumn{2}{|c|}{ Art. 40, 1991} & \multicolumn{2}{|c|}{ Art. 19, 2002} & \multicolumn{2}{|c|}{ Standard provisions } \\
\hline & Total & $\%$ & Total & $\%$ & Total & $\%$ \\
\hline Bosnia \& Herzegovina & 78,918 & 46.12 & 825 & 46.93 & 16,714 & 46.96 \\
\hline Croatia & 58,531 & 34.20 & 319 & 18.15 & 7,194 & 20.21 \\
\hline Serbia \& Montenegro & 28,537 & 16.68 & 540 & 30.72 & 6,041 & 16.97 \\
\hline Macedonia & 5,150 & 3.00 & 51 & 2.90 & 1,617 & 4.54 \\
\hline Other countries & & & 23 & 1.30 & 4,029 & 11.32 \\
\hline Total & 171,136 & 100 & 1,758 & 100 & 35,595 & 100 \\
\hline
\end{tabular}

Source: Ministry of the Interior ${ }^{45}$

Table 10.2 Regular and facilitated naturalisations by groups of persons in Slovenia, 1991-2008

\begin{tabular}{|c|c|c|c|c|c|c|c|}
\hline \multirow{2}{*}{$\begin{array}{l}\text { Regular } \\
\text { naturali- } \\
\text { sation }\end{array}$} & \multicolumn{7}{|c|}{ Facilitated naturalisation } \\
\hline & Minors Spouses & $\begin{array}{l}\text { Slovenes Born in } \\
\text { by descent Slovenia* }\end{array}$ & $\begin{array}{l}\text { Recognised } \\
\text { refugees* }\end{array}$ & $\begin{array}{l}\text { Reacqui- } \\
\text { sition* }\end{array}$ & $\begin{array}{l}\text { Stateless } \\
\text { person* }\end{array}$ & $\begin{array}{l}\text { Educated } \\
\text { in Slovenia*** }\end{array}$ & Total \\
\hline 9,547 & 8,108 & 1,789 & 25 & 21 & 5 & 8 & 21,870 \\
\hline
\end{tabular}

*From 2002

***From 2006

Source: Ministry of the Interior

Table 10.3 Regular and facilitated naturalisations in Slovenia per year, 1991-2008

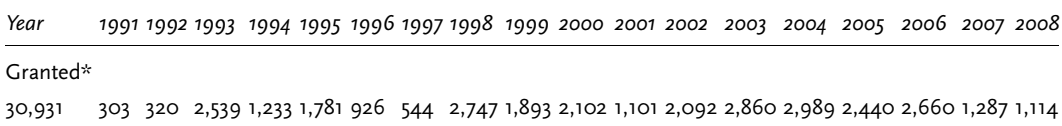

*Including art. 19, 2002

Source: Ministry of the Interior

The numbers naturalised annually reflect changes in legislation with a low of 303 persons in I991 and a high of 2,989 in 2004. The increasing trend after $200 \mathrm{I}$ can mainly be attributed to the corrective measure added in 2002 to incorporate those whose status was not adequately regulated in I99I. The decreasing number in 2005 indicates that this problem is diminishing.

Table 10.4 Reasons for granting exceptional naturalisations in Slovenia

\begin{tabular}{|c|c|c|c|c|c|c|c|c|c|c|c|}
\hline $\begin{array}{l}\text { National } \\
\text { interest }\end{array}$ & $\begin{array}{l}\text { Born in } \\
\text { Slovenia }\end{array}$ & Culture & $\begin{array}{l}\text { Health } \\
\text { sector }\end{array}$ & Sport & $\begin{array}{c}\text { Education/ } \\
\text { science }\end{array}$ & Economy & $\begin{array}{c}I T \\
\text { sector }\end{array}$ & $\begin{array}{l}\text { Interest of } \\
\text { the state }\end{array}$ & Religion & Defence & $\begin{array}{c}\text { Tourism/ } \\
\text { traffic }\end{array}$ \\
\hline 4,884 & 605 & 180 & 157 & 108 & 107 & 99 & 63 & 6 & 13 & 2 & 3 \\
\hline
\end{tabular}

Source: Ministry of the Interior 
Ethnic affinity is the dominant ground of national interest for exceptional naturalisations, with birth in Slovenia representing the second largest interest. All other state interests play only a secondary role, comprising a modest $\mathrm{I} 2$ per cent share.

Table 10.5 Exceptional naturalisations in Slovenia per year, 1991-2008

\begin{tabular}{llllllllllllllllllllll}
\hline Year & 1991 & 1992 & 1993 & 1994 & 1995 & 1996 & 1997 & 1998 & 1999 & 2000 & 2001 & 2002 & 2003 & 2004 & 2005 & 2006 & 2007 & 2008 \\
\hline Granted & & & & 15 & 159 & 218 & 391 & 150 & 628 & 571 & 444 & 274 & 245 & 716 & 446 & 344 & 244 & 464 & 210 & 631 \\
6,227 & 47 & 45 & 159 \\
Not granted & & & & 19 & 68 & 36 & 88 & 66 & 14 & 88 & 35 & 27 & 32 & 130 & 57 & 16 & 506 & n/a & n/a & n/a \\
1,185 & 3 & 19 &
\end{tabular}

Note: $\mathrm{n} / \mathrm{a}=$ not available

Source: Ministry of the Interior

Since the peak in 2002, there has been a decreasing trend of exceptional naturalisations per year. On the one hand, this is the effect of the 2002 supplements to the Citizenship Act whereby second- and third-generation immigrants can be granted citizenship according to a facilitated procedure. On the other hand, a strikingly high number of refusals for naturalisation in 2005, mainly ethnic Slovenes living abroad, can be attributed to the government's redefinition of national interest in citizenship acquisition. This is expected to drop again in the coming years due to the changes in 2006 concerning the naturalisation of ethnic Slovenes. Nevertheless, a substantial rise in citizenship acquisition was recorded in the election year 2008 .

Table 10.6 Release from Slovenian citizenship per year, 1991-2008

\begin{tabular}{lllllllllllllllllllllll}
\hline Year & 1991 & 1992 & 1993 & 1994 & 1995 & 1996 & 1997 & 1998 & 1999 & 2000 & 2001 & 2002 & 2003 & 2004 & 2005 & 2006 & 2007 & 2008 \\
\hline Granted & 12 & 263 & 432 & 365 & 307 & 888 & 423 & 311 & 249 & 352 & 227 & 350 & 304 & 217 & 103 & 90 & 28 & 39 \\
4,960 & 12 & 10
\end{tabular}

Source: Ministry of the Interior

The development of release from citizenship is relatively modest, showing an increase until I996 and since then a steady decrease to a low figure of 28 and 39 in 2007 and 2008, respectively; I03 persons altogether were not released from Slovenian citizenship until the end of 2005 .

\subsection{Conclusions}

As a new state, Slovenia went through a process of initial determination of its citizenry. The question of the initial 'body' of citizens and 
simultaneously of legal integration of the majority of 'non-ethnic' Slovenes was resolved early in the process of independence and international recognition, and without great controversy. Several factors contributed to this development. Firstly, although the establishment of Slovenia as a nation-state can be considered as a product of the so-called eastern type of ethno-cultural nationalism, asserting the right to selfdetermination and self-governance of the Slovenian 'nation', the initial policy of citizenship rather supported democratic statehood over 'nationhood'. Citizenship was defined in territorial terms, close to 'zerooption' policies, in order to ensure an even jurisdiction over the territory and people within the boundaries of the new state. By adopting such an approach Slovenia could exercise 'effective governance', which supported its claim for international recognition, in combination with other elements of external conditionality attached to international recognition, notably democracy and respect for minorities. This meant that although some political groups had favoured, at this juncture, a more restrictive definition of citizenry and consequently of polity based primarily on 'ethnic' criteria, the timing would have worked against it. What mattered was the very fact of instituting an autonomous citizenship, a highly visible claim to external sovereignty. Secondly, such an approach afforded all those affected by state succession the possibility of participating in the establishment of Slovenia, reflecting confidence in a harmonious relationship between 'titular' nation and 'other' citizens. The promise given to permanent residents from other former Yugoslav republics that they would receive the Slovenian citizenship, if they so wished, was seen as fulfilled. ${ }^{46}$ In order to satisfy émigré communities, which largely supported the independence process and to remedy injustices caused by deprivation of citizenship under the previous regime, they were granted preferential treatment regarding naturalisation.

What might initially have appeared as a progressive principle of membership based on a civic conception, which could serve as a reference point for the evolving statehood and an opportunity for defining national identity by embracing the multiethnic reality, took an ambiguous turn after independence was achieved. There were attempts to abolish dual citizenship for people from other Yugoslavian successor states and only reluctantly was it eventually tolerated. Furthermore, some of those who did not apply for or were not granted Slovenian citizenship were deprived of their legal residence. At the same time, however, citizenship policy and supplementary or changed provisions on naturalisation functioned as instruments for regulating the status of immigrants and citizens of other Yugoslavian successor states whose status had not adequately been regulated in I99I. In this process, the 
judiciary, in particular the Constitutional Court, played an important role.

At the same time, Slovenia responded to international standards in the field by introducing facilitated naturalisation for certain categories of persons such as second- and third-generation immigrants or recognised refugees. Nevertheless, state interests in naturalisation prevail over those of the individual. The concept of a nation as a community of descent means that the principle of ius sanguinis prevails in defining those entitled to citizenship at birth, that ethnic criteria play a major role in naturalisation procedures and that Slovenia is attempting to establish a special connection with Slovenes residing abroad. It also supports a notion of imagined community by, for example, explicit requirement of proficiency in the Slovenian language for naturalisation. Furthermore, even naturalised citizens are often seen as foreigners in most areas of public life. Current debates point to a need for a stronger public sense of citizenship in the democratic polity, but do not suggest any substantial change of the basic philosophy guiding citizenship policy nor - after the recent amendments - a comprehensive legislative reform.

\subsection{Epilogue}

In April 2007, less than half a year after the most recent amendments, the National Council of the Republic of Slovenia proposed a bill amending the Citizenship Act of Slovenia. The National Council is the 40-member 'upper chamber' of the parliament, representing social, economic, professional and local/territorial interests. It is designed to neutralise the influence of political parties that are involved in legislative processes, primarily through the National Assembly. The bill was initiated by Marjan Maučec, the representative of local interests in the National Council and a member of the Slovenian People's Party (SLS). He proposed that persons who were over 25 years of age in I99I should have an opportunity to register as Slovenian citizens by personal declaration until the age of 45 , instead of 36 , which was the result of a 2002 amendment. Moreover there was a proposal to further relax the conditions for the exceptional naturalisation of persons of Slovenian descent, although the 2006 amendments had already facilitated naturalisation for this particular group. The 2007 proposal foresaw that ancestors of persons who applied for this type of naturalisation did not have to originate from the current territory of the Republic of Slovenia. In the discussion held at the National Assembly's Committee of Interior Affairs, Public Administration and Justice, it became clear that members of the Slovenian diaspora in Argentina, Australia, Brazil and 
Canada had initiated the proposed amendments. They had been 'promised' by some Slovenian politicians that these amendments would be accepted. Nevertheless, the proposal was rejected by the Committee, with the Minister of the Interior arguing that the age prescribed for registration was already very high compared to some other states and that the exceptional naturalisation of persons who had at least one parent who held Slovenian citizenship should remain limited to those whose parents were citizens by descent and not by naturalisation. The Liberal Democrats (LDS) expressed concern that this argument might imply a differentiation between citizenship acquired by descent and citizenship acquired by naturalisation.

Chronological list of citizenship-related legislation in Yugoslavia/Slovenia

\begin{tabular}{|c|c|c|c|}
\hline Date & Document & Content & Source \\
\hline $1811 / 1867$ & $\begin{array}{l}\text { Austrian Civil Code (arts. } \\
28-32 \text { ) }\end{array}$ & $\begin{array}{l}\text { Regulates the citizenship } \\
\text { status of citizens living in } \\
\text { Slovenian territories } \\
\text { placed under Austrian } \\
\text { rule within the Austro- } \\
\text { Hungarian Empire }\end{array}$ & \\
\hline 1879 & $\begin{array}{l}\text { Law on Hungarian } \\
\text { Citizenship (art. 'L') }\end{array}$ & $\begin{array}{l}\text { Regulates the citizenship } \\
\text { status of citizens living in } \\
\text { Prekmurje placed under } \\
\text { Hungarian rule within } \\
\text { the Austro-Hungarian } \\
\text { Empire }\end{array}$ & \\
\hline $1920 / 1921$ & $\begin{array}{l}\text { Executive regulations to } \\
\text { the Saint-Germain-en- } \\
\text { Laye Peace Treaty (No. } \\
\text { 147/1920; No. 122/1921) }\end{array}$ & $\begin{array}{l}\text { Regulates the acquisition } \\
\text { and loss of Yugoslav } \\
\text { citizenship by option and } \\
\text { request }\end{array}$ & \\
\hline 1920 & Treaty of Rapallo & $\begin{array}{l}\text { Provides a one-year right } \\
\text { of option for Italian } \\
\text { citizenship for ethnic } \\
\text { Italians residing in the } \\
\text { former Italian territory } \\
\text { that became part of } \\
\text { Yugoslavia }\end{array}$ & \\
\hline 1923 & $\begin{array}{l}\text { Italian citizenship } \\
\text { legislation }\end{array}$ & $\begin{array}{l}\text { Regulates citizenship in } \\
\text { the Littoral according to } \\
\text { the operative Italian } \\
\text { citizenship legislation } \\
\text { from } 7 \text { June } 1923 \text { until } \\
\text { mid-September } 1947\end{array}$ & \\
\hline 1928 & $\begin{array}{l}\text { Citizenship Act of the } \\
\text { Kingdom of Serbs, Croats } \\
\text { and Slovenes }\end{array}$ & $\begin{array}{l}\text { Introduces a unified } \\
\text { citizenship throughout } \\
\text { the Kingdom }\end{array}$ & \\
\hline
\end{tabular}

(No. 254/1928) 


\begin{tabular}{|c|c|c|c|}
\hline Date & Document & Content & Source \\
\hline 1941 & $\begin{array}{l}\text { German and Hungarian } \\
\text { citizenship legislation }\end{array}$ & $\begin{array}{l}\text { Regulates the citizenship } \\
\text { of certain groups of people } \\
\text { in the German and } \\
\text { Hungarian occupied } \\
\text { territory during the } \\
\text { Second World War }\end{array}$ & \\
\hline $\begin{array}{l}1945 / \\
1946\end{array}$ & $\begin{array}{l}\text { Citizenship Act of the } \\
\text { Democratic Federative } \\
\text { Yugoslavia (DFY) } \\
\text { (No. 64/1945; No. 54/ } \\
\text { 1946) }\end{array}$ & $\begin{array}{l}\text { Defines the initial } \\
\text { citizenry of the newly } \\
\text { formed Yugoslavia; } \\
\text { establishes Yugoslav } \\
\text { federal citizenship and } \\
\text { republic-level citizenship of } \\
\text { the six constituent } \\
\text { republics; is confirmed and } \\
\text { amended after the } \\
\text { adoption of the } 1946 \\
\text { Constitution of the Federal } \\
\text { People's Republic of } \\
\text { Yugoslavia (FPRY) }\end{array}$ & $\begin{array}{l}\text { www.sluzbenilist.co.rs } \\
\text { (in Serbo-Croatian) } \\
\text { f } \\
\text { I }\end{array}$ \\
\hline $\begin{array}{l}1945 / \\
1946\end{array}$ & $\begin{array}{l}\text { Law on the Deprivation } \\
\text { of Citizenship for } \\
\text { Officers and Non- } \\
\text { Commissioned Officers } \\
\text { of the Former Yugoslav } \\
\text { Army Who Do Not Want } \\
\text { to Return to the } \\
\text { Homeland, and for the } \\
\text { Members of the Military } \\
\text { Who Have Served for the } \\
\text { Enemy and Have } \\
\text { Defected Abroad (No. } \\
64 / 1945 ; \text { No. } 86 / 1946)\end{array}$ & $\begin{array}{l}\text { Deprives Yugoslav } \\
\text { citizenship of those } \\
\text { military personnel of the } \\
\text { former army of the } \\
\text { Kingdom of Yugoslavia } \\
\text { who did not want to return } \\
\text { to the 'new' Yugoslavia, } \\
\text { those serving in military } \\
\text { formations loyal to the } \\
\text { occupying forces and } \\
\text { those who left Yugoslavia } \\
\text { at the end of the Second } \\
\text { World War; is revoked in } \\
\text { 1962 (No. 22/1962) }\end{array}$ & $\begin{array}{l}\text { www.sluzbenilist.co.rs } \\
\text { (in Serbo-Croatian) }\end{array}$ \\
\hline 1947 & $\begin{array}{l}\text { Law on Citizenship of } \\
\text { Persons in the Territory } \\
\text { Annexed by Yugoslavia } \\
\text { according to the Peace } \\
\text { Treaty with Italy } \\
\text { (No. 104/1947) }\end{array}$ & $\begin{array}{l}\text { Determines that people } \\
\text { residing in territories } \\
\text { annexed by Yugoslavia on } \\
\text { 10 June 1940 lose their } \\
\text { Italian citizenship and } \\
\text { acquire Yugoslav } \\
\text { citizenship; provides a } \\
\text { one-year period for ethnic } \\
\text { Italians to opt for Italian } \\
\text { citizenship and a } \\
\text { possibility for the Slav } \\
\text { population from the } \\
\text { contested borderland } \\
\text { region between } \\
\text { Yugoslavia and Italy to } \\
\text { opt for Yugoslav } \\
\text { citizenship }\end{array}$ & $\begin{array}{l}\text { www.sluzbenilist.co.rs } \\
\text { (in Serbo-Croatian) }\end{array}$ \\
\hline
\end{tabular}




\begin{tabular}{|c|c|c|c|}
\hline Date & Document & Content & Source \\
\hline $1948 / 1997$ & $\begin{array}{l}\text { Amendment and } \\
\text { Revision of the Law on } \\
\text { Citizenship (No. 105/ } \\
\text { 1948); Constitutional } \\
\text { Court Decision: } \\
\text { U-I-23/97 }\end{array}$ & $\begin{array}{l}\text { Excludes from the } \\
\text { Yugoslav citizenry, with } \\
\text { retroactive effect, all } \\
\text { citizens of German } \\
\text { ethnicity residing abroad } \\
\text { on the basis of their } \\
\text { 'disloyal conduct toward } \\
\text { the national and state } \\
\text { interests of the peoples } \\
\text { of FPRY' during and } \\
\text { before the war; is } \\
\text { confirmed as } \\
\text { constitutional in } 1997 \\
\text { when applied to } \\
\text { procedures concerning } \\
\text { the ascertainment of } \\
\text { citizenship }\end{array}$ & $\begin{array}{l}\text { www.sluzbenilist.co.rs } \\
\text { (in Serbo-Croatian); } \\
\text { http://odlocitve.us-rs.si } \\
\text { (in Slovenian and } \\
\text { English) }\end{array}$ \\
\hline 1950 & $\begin{array}{l}\text { Citizenship Act of the } \\
\text { People's Republic of } \\
\text { Slovenia (No. 20/1950) }\end{array}$ & $\begin{array}{l}\text { Defines ius sanguinis as } \\
\text { the basic principle for } \\
\text { acquisition of Slovenian } \\
\text { citizenship; specifies } \\
\text { conditions for a newborn } \\
\text { child to acquire } \\
\text { Slovenian citizenship if } \\
\text { the parents hold different } \\
\text { republic-level } \\
\text { citizenships, depending } \\
\text { on their residency }\end{array}$ & \\
\hline 1964 & $\begin{array}{l}\text { Law on Yugoslav } \\
\text { Citizenship } \\
\text { (No. 38/1964; No. } 42 / \\
\text { 1964) }\end{array}$ & $\begin{array}{l}\text { Enacted after the } 1963 \\
\text { Yugoslav Constitution; } \\
\text { regulates the relationship } \\
\text { between the federal and } \\
\text { republic-level } \\
\text { citizenships; provides for } \\
\text { a united Yugoslav } \\
\text { citizenship; regulates } \\
\text { that only a federal citizen } \\
\text { can have republican } \\
\text { citizenship and that } \\
\text { republican citizenship is } \\
\text { lost with the loss of } \\
\text { federal citizenship }\end{array}$ & $\begin{array}{l}\text { www.sluzbenilist.co.rs } \\
\text { (in Serbo-Croatian) }\end{array}$ \\
\hline 1965 & $\begin{array}{l}\text { Citizenship Act of the } \\
\text { Socialist Republic of } \\
\text { Slovenia (No. 11/1965) }\end{array}$ & $\begin{array}{l}\text { Confirms ius sanguinis } \\
\text { as the main criterion for } \\
\text { automatic acquisition of } \\
\text { Slovenian citizenship; } \\
\text { unlike the } 1950 \text { Law, } \\
\text { stipulates that both } \\
\text { parents have to agree on } \\
\text { the child's citizenship if } \\
\text { they hold different }\end{array}$ & \\
\hline
\end{tabular}




\begin{tabular}{|c|c|c|c|}
\hline Date & Document & Content & Source \\
\hline & & $\begin{array}{l}\text { republic-level } \\
\text { citizenships; determines } \\
\text { that any SFRY citizen has } \\
\text { a right to choose his or } \\
\text { her republic-level } \\
\text { citizenship and is thus } \\
\text { free to choose the } \\
\text { citizenship of any } \\
\text { republic without being } \\
\text { born or residing there; } \\
\text { abolishes the loss of } \\
\text { citizenship on grounds of } \\
\text { absence; relaxes the } \\
\text { naturalisation of } \\
\text { expatriates (emigrants); } \\
\text { abolishes the oath of } \\
\text { loyalty upon admission }\end{array}$ & \\
\hline 1976 & $\begin{array}{l}\text { Citizenship Act of the } \\
\text { Socialist Republic of } \\
\text { Slovenia (No. 23/1976) }\end{array}$ & $\begin{array}{l}\text { Confirms ius sanguinis } \\
\text { as the main criterion for } \\
\text { automatically acquiring } \\
\text { Slovenian citizenship; } \\
\text { specifies conditions of } \\
\text { citizenship acquisition in } \\
\text { cases in which the } \\
\text { parents do not agree or } \\
\text { do not sign a statement } \\
\text { in the first two months } \\
\text { following the birth of } \\
\text { their child; regulates } \\
\text { acquisition of citizenship } \\
\text { for citizens of other } \\
\text { republics who have } \\
\text { permanent residence in } \\
\text { Slovenia }\end{array}$ & \\
\hline 1976 & $\begin{array}{l}\text { Law on Citizenship of the } \\
\text { Socialist Federal } \\
\text { Republic of Yugoslavia } \\
\text { (No. } 58 / 1976 \text { ) }\end{array}$ & $\begin{array}{l}\text { Is adopted after the } 1974 \\
\text { Yugoslav Constitution; } \\
\text { repeats the provisions } \\
\text { from the } 1964 \text { Act on the } \\
\text { relationship between the } \\
\text { various federal and } \\
\text { republic-level } \\
\text { citizenships; adds an } \\
\text { article on how to resolve } \\
\text { possible disputes caused } \\
\text { by the republican laws on } \\
\text { citizenship }\end{array}$ & $\begin{array}{l}\text { www.sluzbenilist.co.rs } \\
\text { (in Serbo-Croatian) }\end{array}$ \\
\hline
\end{tabular}




\begin{tabular}{|c|c|c|c|}
\hline Date & Document & Content & Source \\
\hline 1991 & $\begin{array}{l}\text { Citizenship of the } \\
\text { Republic of Slovenia Act } \\
\text { (No. 1/1991-I) }\end{array}$ & $\begin{array}{l}\text { Constitutes the initial } \\
\text { body of citizens and } \\
\text { basic principles of } \\
\text { acquisition and loss of } \\
\text { citizenship; provides for } \\
\text { optional naturalisation of } \\
\text { residents from other } \\
\text { republics of SFRY (art. } \\
40 \text { ) and reacquisition of } \\
\text { citizenship for those who } \\
\text { were deprived of it on the } \\
\text { basis of prior federal law } \\
\text { (art. } 41 \text { ) in the } \\
\text { transitional period }\end{array}$ & $\begin{array}{l}\text { http://e-uprava.gov.si } \\
\text { (in Slovenian); } \\
\text { www.legislationline.org; } \\
\text { www.coe.int }\end{array}$ \\
\hline 1991 & $\begin{array}{l}\text { Act Amending the } \\
\text { Citizenship of the } \\
\text { Republic of Slovenia Act } \\
\text { (No. 30/1991-I) }\end{array}$ & $\begin{array}{l}\text { Supplements art. } 40 \text { and } \\
\text { stipulates that the } \\
\text { person's application for } \\
\text { citizenship is to be } \\
\text { turned down if that } \\
\text { person is considered to } \\
\text { form a threat to public } \\
\text { order, security or defence } \\
\text { of the state or has } \\
\text { committed a criminal } \\
\text { offence directed against } \\
\text { the Republic of Slovenia }\end{array}$ & $\begin{array}{l}\text { www2.gov.si } \\
\text { (in Slovenian and } \\
\text { English); } \\
\text { www.legislationline.org; } \\
\text { www.coe.int }\end{array}$ \\
\hline 1991 & $\begin{array}{l}\text { Constitution of the } \\
\text { Republic of Slovenia (No. } \\
33 / 91-\text {; No. } 331 / 1991-I ; \\
\text { No. 42/1997; No. 66/ } \\
\text { 2000; No. 24/2003; No. } \\
69 / 2004 \text {; No. 69/2004; } \\
\text { No. 69/2004; No. 68/ } \\
2006 \text { ) }\end{array}$ & $\begin{array}{l}\text { Postulates in art. } 12 \text { that } \\
\text { citizenship shall be } \\
\text { regulated by law and in } \\
\text { art. } 5 \text { (2) that Slovenes } \\
\text { not holding Slovene } \\
\text { citizenship may enjoy } \\
\text { special rights and } \\
\text { privileges in Slovenia, the } \\
\text { nature and extent of } \\
\text { which shall be regulated } \\
\text { by law }\end{array}$ & $\begin{array}{l}\text { www.dz-rs.si } \\
\text { (in Slovenian) }\end{array}$ \\
\hline 1992 & $\begin{array}{l}\text { Act Amending the } \\
\text { Citizenship of the } \\
\text { Republic of Slovenia Act } \\
\text { (No. 38/1992) }\end{array}$ & $\begin{array}{l}\text { Regulates naturalisation } \\
\text { for persons of Slovenian } \\
\text { descent through at least } \\
\text { one parent if they lost } \\
\text { their Slovenian } \\
\text { citizenship due to release, } \\
\text { renunciation or } \\
\text { deprivation or if they have } \\
\text { not acquired Slovenian } \\
\text { citizenship due to } \\
\text { historical circumstances } \\
\text { (art. } 13 . a \text { ) }\end{array}$ & $\begin{array}{l}\text { www.2.gov.si } \\
\text { (in Slovenian); } \\
\text { www.coe.int }\end{array}$ \\
\hline
\end{tabular}




\begin{tabular}{|c|c|c|c|}
\hline Date & Document & Content & Source \\
\hline 1992 & $\begin{array}{l}\text { Constitutional Court } \\
\text { Decision repealing } \\
\text { Articles } 41 \text { and } 13 . \text { a of the } \\
\text { Citizenship of Slovenia } \\
\text { Act } \\
\text { (No. 61/1992; } \\
\text { Constitutional Court } \\
\text { Decision U-I-69/92-30) }\end{array}$ & & $\begin{array}{l}\text { http://odlocitve.us-rs.si } \\
\text { (in Slovenian) }\end{array}$ \\
\hline 1992 & $\begin{array}{l}\text { Constitutional Court } \\
\text { Decision repealing } \\
\text { Article } 28 \text { of the } \\
\text { Citizenship of Slovenia } \\
\text { Act (No. 61/1992; } \\
\text { Constitutional Court } \\
\text { Decision } \\
\text { U-I-98/91-21) }\end{array}$ & $\begin{array}{l}\text { Provides that the reasons } \\
\text { for a discretionary } \\
\text { decision must be stated } \\
\text { in such a way that it is } \\
\text { evident whether the } \\
\text { administrative authority } \\
\text { in exercising its } \\
\text { discretionary power of } \\
\text { decision has acted } \\
\text { 'within the limits of } \\
\text { authorisation and in } \\
\text { accordance with the } \\
\text { intention of granting } \\
\text { such an authorisation' }\end{array}$ & $\begin{array}{l}\text { http://odlocitve.us-rs.si } \\
\text { (in Slovenian) }\end{array}$ \\
\hline 1994 & $\begin{array}{l}\text { Act amending the } \\
\text { Citizenship of the } \\
\text { Republic of Slovenia Act } \\
\text { (No. 13/1994) }\end{array}$ & $\begin{array}{l}\text { Provides for the } \\
\text { recognition and } \\
\text { declaration of citizenship } \\
\text { for residents from other } \\
\text { former Yugoslav } \\
\text { republics; extends the } \\
\text { age limit for citizenship } \\
\text { by registration; tightens } \\
\text { the naturalisation } \\
\text { criteria, specifically as to } \\
\text { language proficiency; } \\
\text { introduces consent of } \\
\text { minors older than } \\
\text { fourteen }\end{array}$ & $\begin{array}{l}\text { www2.gov.si } \\
\text { (in Slovenian); } \\
\text { www.unhcr.org }\end{array}$ \\
\hline 1994 & $\begin{array}{l}\text { Decree on Criteria for } \\
\text { Establishing the } \\
\text { Compliance with } \\
\text { Specified Conditions for } \\
\text { Acquiring the Citizenship } \\
\text { of the Republic of } \\
\text { Slovenia (No. 47/1994) }\end{array}$ & & \\
\hline
\end{tabular}




\begin{tabular}{|c|c|c|c|}
\hline Date & Document & Content & Source \\
\hline 1996 & $\begin{array}{l}\text { Resolution on the } \\
\text { Position of } \\
\text { Autochthonous Slovene } \\
\text { Minorities in } \\
\text { Neighbouring Countries } \\
\text { and the Related Tasks of } \\
\text { State and Other } \\
\text { Institutions in the } \\
\text { Republic of Slovenia (No. } \\
35 / 1996 \text { ) }\end{array}$ & $\begin{array}{l}\text { Envisages various forms } \\
\text { of aid for these } \\
\text { minorities, taking into } \\
\text { account their specific } \\
\text { needs and interests and } \\
\text { providing them with } \\
\text { concrete aid in the } \\
\text { cultural, language, } \\
\text { informative, economic } \\
\text { and financial areas }\end{array}$ & $\begin{array}{l}\text { www.uszs.gov.si } \\
\text { (in Slovenian) }\end{array}$ \\
\hline 1999 & $\begin{array}{l}\text { The Settling of the Status } \\
\text { of Citizens of Other SFRY } \\
\text { Successor States in the } \\
\text { Republic of Slovenia Act } \\
\text { (No. 61/1999; No. 54/ } \\
\text { 2000; Constitutional } \\
\text { Court Decision U-I-295/ } \\
99-13 \text {, No. 64/2001) }\end{array}$ & $\begin{array}{l}\text { Regulates the acquisition } \\
\text { of permanent residence } \\
\text { for citizens of other SFRY } \\
\text { successor states } \\
\text { registered as permanent } \\
\text { residents in the territory } \\
\text { of Slovenia on } 23 \\
\text { December } 1990 \text { or } \\
\text { residing in Slovenia since } \\
25 \text { June } 1991\end{array}$ & $\begin{array}{l}\text { www.uradni-list.si } \\
\text { (in Slovenian); } \\
\text { www.legislationline.org }\end{array}$ \\
\hline 2002 & $\begin{array}{l}\text { Act amending the } \\
\text { Citizenship of the } \\
\text { Republic of Slovenia Act } \\
\text { (No. 96/2002) }\end{array}$ & $\begin{array}{l}\text { Extends the age limit for } \\
\text { acquiring citizenship by } \\
\text { registration; adds stricter } \\
\text { criteria for regular } \\
\text { naturalisation, such as } \\
\text { the status of foreigner; } \\
\text { relaxes naturalisation for } \\
\text { refugees, stateless } \\
\text { persons and second- and } \\
\text { third-generation } \\
\text { immigrants }\end{array}$ & $\begin{array}{l}\text { www.uradni-list.si } \\
\text { (in Slovenian) }\end{array}$ \\
\hline 2002 & $\begin{array}{l}\text { Resolution on the } \\
\text { Relations with Slovenes } \\
\text { Abroad (No. 7/2002) }\end{array}$ & $\begin{array}{l}\text { Envisages cooperation } \\
\text { with Slovenes abroad in } \\
\text { fields of culture, } \\
\text { language, information, } \\
\text { economy, science and } \\
\text { foreign policy; declares } \\
\text { interest in repatriation, a } \\
\text { status of Slovenes } \\
\text { without citizenship and } \\
\text { citizenship and voting } \\
\text { rights for citizens abroad }\end{array}$ & $\begin{array}{l}\text { www.uradni-list.si } \\
\text { (in Slovenian) }\end{array}$ \\
\hline 2002 & $\begin{array}{l}\text { Constitutional Court } \\
\text { Decision: U-I-246/O2-28 } \\
\text { (No. 36/2003) }\end{array}$ & $\begin{array}{l}\text { Finds the Settling of the } \\
\text { Status of Citizens of } \\
\text { Other SFRY Successor } \\
\text { States in the Republic of } \\
\text { Slovenia Act } \\
\text { unconstitutional }\end{array}$ & $\begin{array}{l}\text { http://odlocitve.us-rs.si } \\
\text { (in Slovenian) }\end{array}$ \\
\hline
\end{tabular}




\begin{tabular}{|c|c|c|c|}
\hline Date & Document & Content & Source \\
\hline 2006 & $\begin{array}{l}\text { Relations between the } \\
\text { Republic of Slovenia and } \\
\text { Slovenians abroad Act } \\
\text { (No. 43/2006) }\end{array}$ & $\begin{array}{l}\text { Introduces the status of } \\
\text { Slovenes without } \\
\text { Slovenian citizenship }\end{array}$ & $\begin{array}{l}\text { www.uradni-list.si } \\
\text { (in Slovenian) }\end{array}$ \\
\hline 2006 & $\begin{array}{l}\text { Act amending the } \\
\text { Citizenship of the } \\
\text { Republic of Slovenia Act } \\
\text { (No. 127/2006) }\end{array}$ & $\begin{array}{l}\text { Introduces stricter } \\
\text { requirements for regular } \\
\text { naturalisation (material } \\
\text { and social security, clean } \\
\text { criminal record, oath of } \\
\text { loyalty) and } \\
\text { naturalisation of spouses } \\
\text { of Slovenian nationals; } \\
\text { redefines groups of } \\
\text { persons eligible for } \\
\text { facilitated and } \\
\text { exceptional } \\
\text { naturalisation }\end{array}$ & $\begin{array}{l}\text { www.dz-rs.si } \\
\text { (in Slovenian) }\end{array}$ \\
\hline
\end{tabular}

\section{Notes}

I Official Gazette of the Provincial Government for Slovenia, I47/I920 and I22/I92I.

2 Official Gazette of the Kingdom of Serbs, Croats and Slovenes (SHS), 254/1928.

3 Official Gazette of the Democratic Republic of Yugoslavia (DRY), 64/1945; Official Gazette of the Federal People's Republic of Yugoslavia (FPRY), 54/1946, 90/1946, 88/1948 and $105 / 1948$.

4 Official Gazette of the FPRY, I05/1948. In 1997, the Constitutional Court of the Republic of Slovenia found that the use of this provision is not unconstitutional in procedures concerning the ascertainment of citizenship. Constitutional Court Decision, U-I-23/93 of 20 March 1997.

5 Official Gazette of the DRY, 64/1945; Official Gazette of the FPRY, 86/1946 and 22/ I962.

6 Official Gazette of the FPRY, 104/1947.

7 The Memorandum includes a special statute that guarantees for both sides the rights of minorities. It is the first international document that regulates the protection of the Slovene ethnic minority ('Yugoslav ethnic group') in Italy - for the Trieste region.

8 See also Slovenia, Italy, White Book on Diplomatic Relations published in 1996 by the Ministry of Foreign Affairs of the Republic of Slovenia.

9 Official Gazette of the FPRY, 9-96/I959, 7-II5/58; Official Gazette of the Socialist Federal Republic of Yugoslavia (SFRY), 7-35/I97I, 3I-448/1967, II-48/198I and I5-65/1990. Slovenia is a party to these instruments by succession.

IO In this chapter, the term 'republic-level citizenship' is used to denote the membership in constituting entities of the federal state. The term 'citizenship' is used to indicate membership of a sovereign state. In the Slovenian language and legal terminology, državljanstvo is used for both legal concepts.

II Official Gazette of the SFRY, 38/64.

I2 Official Gazette of the Socialist Republic of Slovenia, 23/1976. 
I3 Moreover, most of these instruments such as the European Convention on Nationality, which was opened for signature on 6 November 1997 and entered into force on I March 2000, and the relevant provisions of the 1999 draft articles on the Nationality of Natural Persons in Relation to the Succession of States, were drafted after the changes that had reshaped the European political landscape at the end of the twentieth century. The former contains a chapter on state succession which focuses on principles and general rules but does not provide for specific rules which states should respect in cases of state succession.

I4 In this regard, it must also be noted that the European Union does not consider nationality matters to be in its sphere of competence.

I5 Official Gazette of the Republic of Slovenia, I/I99I-I. Amendments and Supplements to this Act were published in the Official Gazette of the Republic of Slovenia, 30/I99I-I, 38/1992, 13/1994 and 96/2002. The officially revised text was published in the Official Gazette of the Republic of Slovenia, 7/2003. www.mnz.gov.si.

I6 The Act amending the Citizenship of the Republic of Slovenia Act was adopted by the National Assembly on 24 November 2006. Official Gazette of the Republic of Slovenia, $127 / 2006$.

I7 For these concepts also, see Baršová in this volume.

I8 In I999 the Constitutional Court repealed the paragraph related to the public order risk. Constitutional Court Decision, U-I-89/99 of io June I999.

I9 That immigrants from other republics did not register their permanent residence was partly due to the fact that they did not know of this possibility or simply did not care; partly it can be attributed to the concept of migration registration and registration of permanent residency in the former state. Slovenia was the sole republic of the SFRY which registered in- and out-migration.

20 Official Gazette of the Republic of Slovenia, I/I99I-I, 44/I997 and 50/I998 - Constitutional Court Decisions.

2I Under the then valid Aliens Act they could obtain a one-year temporary residence permit and after three years of uninterrupted residence a permit for permanent residence. Later this condition was prolonged from three to eight years. Cf. the controversial I993 Estonian law on aliens, which declared that anybody living in Estonia without Estonian citizenship, which had no legal status in Estonian law in 1992/1993, would have to apply for residency status. The Council of Europe experts criticised that the status of those already resident in Estonia was equated with that of non-citizens not currently resident there (see Day \& Shaw 2003; also see Jaerve in this volume).

22 Only upon the request of applicants themselves did administrative authorities issue a certificate of removal from the register.

23 The Ombudsman in his first yearly report of 1995 refers to the so-called 'aliens sur place' (zatečeni tujci) using a label which resembles the term 'refugees sur place'.

24 Constitutional Court Decision, U-I-284/94 of 4 February 1999.

25 Official Gazette of the Republic of Slovenia, 6I/1999 and 64/200I.

26 Constitutional Court Decision, U-I-246/02-28 of 3 April 2003.

27 The Ministry of the Interior, however, issued decisions on residency from 26 February 1992 to those 'erased', who already had permanent residence permits. 4,IO7 such decisions were issued until mid-January 2005 , while 8,470 were still in the procedure.

28 I,278 Slovenes were deprived of citizenship based on collective decisions by federal authorities, of which the individuals were never notified, and 67 due to absence.

29 Constitutional Court Decision, U-I-69/92-30 of ro December I992. 
30 Decree on Criteria for Establishing the Compliance with Specified Conditions for Acquiring the Citizenship of the Republic of Slovenia through Naturalisation, Official Gazette of the Republic of Slovenia, 47/1994.

3 I Constitutional Court Decision, U-I-98/9I of Io December 1992.

32 Under the principle of equality of children born in wedlock and children born out of wedlock a child of a foreign mother is a Slovenian citizen if the fatherhood of a Slovenian citizen is acknowledged, declared or otherwise established. The legal effect of fatherhood is retroactive and as such affects the citizenship of the child.

33 The registration is not necessary if the child would otherwise become stateless or if the child moves to Slovenia, together with the Slovenian parent, before he or she is eighteen years old.

34 Before I994 an applicant did not have to submit this evidence.

35 The condition of a guaranteed residence was dropped in 2002 .

36 Before the 2006 amendments the requirements did not include conditional prison sentences. Moreover, the accepted period of imprisonment was decreased from a maximum of one year to three months.

37 See also Constitutional Court Decision, U-I-I24/94-8 of 9 February I995. http://odlocitve.us-rs.si.

38 Constitutional Court Decision on the request for holding a referendum on Article 40 of the Citizenship Act of the Republic of Slovenia, U-I-266/95-8 of 20 November I995, Official Gazette of the Republic of Slovenia, No. 69/1995.

39 Until I995 this function was performed by municipalities and then transferred to local administrative units by the Act on the Takeover of State Functions Performed until 3I December 1994 by Municipal Bodies, Official Gazette of the Republic of Slovenia, 29/1995, 44/1996 - Constitutional Court Decision.

40 Official Gazette of the Republic of Slovenia, 37/2003 and 39/2006. The officially consolidated text was published in the Official Gazette of the Republic of Slovenia, 59/2006.

4I Official Gazette of the Republic of Slovenia, 44/2006.

42 Official Gazette of the Republic of Slovenia, 35/1996.

43 Official Gazette of the Republic of Slovenia, 7/2002.

44 The Council for Slovenians in Neighbouring Countries is composed of six representatives of the Slovenian minority in Austria, four from Italy and two from Hungary and Croatia. The Council for Slovenians Abroad consists of four representatives of Slovenians living in European states, three from South America and North America respectively, two from Australia and one from Slovenians residing in other countries around the world.

45 The Statistical Office of the Republic of Slovenia does not gather and analyse data on naturalisation. Tables in this section draw on data provided by the Ministry of the Interior.

46 This promise was given by all of the political parties and in the Letter of Good Intent (Official Gazette of the Republic Slovenia, 40/1990) adopted by the Slovenian Assembly prior to the plebiscite on the autonomy and independence on which all permanent residents could vote. Furthermore, the Constitutional Act Implementing the Basic Constitutional Charter on the Independence and Sovereignty of the Republic of Slovenia (Official Gazette of the Republic Slovenia, I/I99I-I) in art. I3 specially provided that citizens of other republics having permanent residence registered in Slovenia on the day of the plebiscite and who actually lived there should have equal rights and duties as Slovenian citizens during the transitional period with regards to the acquisition of Slovenian citizenship. Questions concerning the correct interpretation of this document, however, have arisen specifically concerning the implementation of the Aliens Act. 


\section{Bibliography}

Cerar, M. (I995), 'Zakonodajni referendum o odvzemu državljanstva', Pravna praksa I4 (I9-20): 8-II.

Day, S. \& J. Shaw (2003), 'The boundaries of suffrage and external conditionality: Estonia as an applicant member of the EU', European Public Law 9: 2II-236.

Dujić, S. (I996), 'Zakonodajni referendum o odvzemu državljanstva', Pravna praksa I5 (2): 22-27.

Kač, M. \& M. Krisch (I999), 'Pregled predpisov o državljanstvu ı9ı8-ı99ı', in Slovensko javno pravo na prehodu v novo tisočletje, Dnevi javnega prava Portorož 1999, 607-631. Ljubljana: Inštitut za javno upravo.

Končina, N. (I992), 'Dvojno državljanstvo', Pravna praksa II (25): II-I2.

Kos, B. (I994), 'Mednarodni sporazumi z Italijo in državljanstvo', Pravna praksa I3 (I6): 2-3.

Kos, B. (I996a), 'Primerjava zakonov o državljanstvu držav, ki so nastale na ozemlju nekdanje SFRJ', Pravna praksa I5 (22-23): XIII.

Kos, B. (I996b), 'Zakoni o državljanstvu v novih državah na območju bivše SFRJ: postopki, prehodne in končne določbe', Pravna praksa I5 (7): I.

Medved, F. (I996), 'Slovenias bevisbyrde', Nordisk Östforum 2: 9I-IO4.

Medved, F. (200I), 'Interaction Between Citizenship and Integration', $2^{\text {nd }}$ European Conference on Nationality: Challenges to national and international law on citizenship at the beginning of the new millennium', 23-39. Strasbourg: Council of Europe, Proceedings. www.coe.int.

Medved, F. (2005), 'Politična integracija: državljanstvo, politična participacija in reprezentacija', in M. Komac \& M. Medvešek (eds.), Percepcije slovenske integracijske politike, 453-558. Ljubljana: Institute for Ethnic Studies.

Mesojedec-Pervinšek, A. (I997), Predpisi o državljanih in tujcih z uvodnimi pojasnili. Ljubljana: ČZ Uradni list Republike Slovenije.

Mesojedec-Pervinšek, A. (I999), 'Učinek mednarodnega prava v notranjem pravu Republike Slovenije na podočju državljanstva', in Slovensko javno pravo na prehodu v novo tisočletje, Dnevi javnega prava Portorož 1999, 647-66I. Ljubljana: Inštitut za javno upravo.

Mole, N. (200I), 'Multiple nationality and the European Convention on Human Rights', $2^{\text {nd }}$ European Conference on Nationality: Challenges to national and international law on nationality at the beginning of the new millennium', I29-147. Strasbourg: Council of Europe, Proceedings. www.coe.int.

Polič, V. (I993), 'Kdo “tukaj dejansko živi”?’, Pravna Praksa I2 (22): I6-I7.

Polič, V. (I997a), 'Državljanstvo RS. Tri odločitve VS RS, v katerih je bilo obravnavano: nevarnost za javni red države; ničnostni razlog; ugotovitev državljanstva RS', Pravna praksa I6 (I7-I8): I5-I7.

Polič, V. (I997b), Statusna stanja človeka in državljana v Republiki Sloveniji. I. del (part one). Ljubljana: Center Marketing Int.

Radmelič, B. (I994), 'Pridobitev državljanstva na ozemlju Slovenije od obdobja AvstroOgrske do konca druge svetovne vojne', Javna uprava 30 (2): 207-227.

Rakočević, S. (2002), “'Izbrisani” prebivalci Slovenije, urejanje pravnega statusa državljanov drugih držav naslednic nekdanje SFRJ v Republiki Sloveniji, Pravna praksa 2I (32): 8-9.

Ziemele, I. (200I), 'General aspects of nationality and human rights in relation to state succession', $2^{\text {nd }}$ European Conference on Nationality: Challenges to national and international law on nationality at the beginning of the new millennium', I49-I7I. Strasbourg: Council of Europe, Proceedings. www.coe.int. 


\title{
11 Croatian citizenship: From ethnic engineering to inclusiveness
}

\author{
Francesco Ragazzi and Igor $\check{S}_{t i k s}{ }^{\mathrm{I}}$
}

The politics of citizenship in post-Yugoslav Croatia are deeply marked by the political climate in which they emerged. The law on Croatian citizenship was enacted on the day (8 October I99I) that the country's declaration of independence from the Socialist Federal Republic of Yugoslavia (SFRY) was enacted. The first decade of Croatia's independence was burdened by the I99I-I995 war against Belgrade and military involvement in the war in neighbouring Bosnia-Herzegovina, and dominated by Franjo Tudjman's overtly nationalist party $\mathrm{HDZ}^{2}$, which was in power between I99I and I999.

The new citizenship legislation cannot, therefore, be analysed separately from the process of Yugoslavia's disintegration. Almost all of Yugoslavia's successor states - with some variation according to their specific context and at a different pace - used their founding documents, constitutions and citizenship laws as effective tools to accelerate nation-building and to 'ethnically engineer' their populations to the advantage of the majority ethnic group. Croatia was no exception to this rule. ${ }^{3}$ In many ways, citizenship laws in Croatia were one of many instruments used to create what could be defined as a transnational nationalism'4, a nationalism that, by taking Croatian ethnicity as its core, aimed not only to homogenise the national population through the exclusion of non-Croats, but also to include all ethnic Croats in a single national group, regardless of their place or country of residence. The citizenship laws proved a vital tool in the attempt to achieve this goal. This attempt at both deterritorialised inclusion and targeted exclusion was limited only by general international standards and norms related to citizenship laws that the Croatian government of the I990s was obliged to respect. ${ }^{5}$

With the death of Franjo Tudjman in 1999 and the subsequent electoral defeat of the HDZ, the beginning of 2000 marked a sharp contrast with the practices of the previous decade. Owing in part to democratic changes within Croatian politics and Croatia's bid for EU membership, the implementation of the citizenship laws began to demonstrate more inclusiveness towards ethnic non-Croats, although the law on citizenship itself remained unchanged. It is through an examination of these political conflicts and debates and their historical 
context that we can best present the normative framework that regulates citizenship in Croatia today.

\subsection{The history of citizenship policy in Croatia since 1945}

\subsubsection{Citizenship in federal Yugoslavia (1945-1991)}

The citizenship laws in the Croatian lands (Croatia, Slavonia and Dalmatia) that preceded the formation of the 'first' Yugoslavia in I918, date back to the second half of the nineteenth century. The I879 Law on Hungarian Citizenship (art. L) was applied in Croatia and Slavonia, whereas the laws on Austrian citizenship (arts. 28-32) based on the I8II (ı867) Austrian Civil Code were applied in Dalmatia. In I9ı8, following the founding of the Kingdom of Serbs, Croats and Slovenes (renamed the Kingdom of Yugoslavia in I929), the citizenship issues that arose due to the break up of the Austro-Hungarian Empire and the subsequent creation of new states, were largely settled by the post-First World War peace treaties signed by the new Kingdom with neighbouring countries. ${ }^{6}$ Yugoslavia only enacted its own law on citizenship in I928, a law that established a single Yugoslav citizenship.

On 28 August I945, the recently liberated 'new' Yugoslavia, a state that resurrected itself as a federation on the political map of Europe after the collapse of the Kingdom of Yugoslavia in April I94I, enacted the Law on Citizenship of Democratic Federal Yugoslavia.7 Art. 35 of this law provided that everyone who had been a Yugoslav citizen on 28 August I945 under the I928 Citizenship Act of the Kingdom of Yugoslavia would become a citizen in Democratic Federal Yugoslavia. Yugoslav citizenship was primarily based on the principle of descent (ius sanguinis; see Medvedović I998: 27-29; Jovanović I977: 22; Tepic \& Basic I969: xxxvi). Since it was often impossible to prove former Yugoslav citizenship due to the widespread destruction caused by the war, art. 25 declared that anyone belonging to one of the 'peoples' of Yugoslavia (that is, to one of the South-Slavic ethnic groups), those born and raised in the territory of Yugoslavia and the permanent residents of the Federal People's Republic of Yugoslavia (FPRY) would be considered citizens of the FPRY. Enacted in I948 was an unusually named law on deprivation of citizenship (which additionally entailed the confiscation of goods): the Law on the Deprivation of Citizenship for Officers and Non-Commissioned Officers of the Former Yugoslav Army Who Do Not Want to Return to the Homeland, and for the Members of Military Forces Who Have Served the Enemy and Have Defected Abroad (this law was invalidated in I962). ${ }^{8}$ Furthermore, in the same year the law on citizenship was revised in order to exclude from Yugoslav citizenship all citizens of German ethnicity residing abroad on the 
basis of their 'disloyal conduct toward the national and state interests of the peoples of FPRY.'?

A special act related to Yugoslav citizenship - the Law on Citizenship of Persons Residing on the Territory Annexed to Yugoslavia According to the Peace Treaty with Italy $^{10}$ - was adopted in I947 following the Paris Peace Treaty between Yugoslavia and Italy. According to this Law, anyone who, as of Io June I940, had been a resident of the territories annexed by Yugoslavia would lose his or her Italian citizenship and acquired Yugoslav citizenship. Ethnic Italians had a one-year period to opt for Italian citizenship - in effect, to opt for whether they wanted to live in Yugoslavia or Italy. In addition, an equivalent offer of Yugoslav citizenship was made to the Slavic population from the contested borderland region between Yugoslavia and Italy. The citizenship of these groups was later defined by the Memorandum of Understanding between the Government of Italy, the United Kingdom and Yugoslavia, ${ }^{\text {II }}$ which divided the Free Territory of Trieste (I947-I954) between Italy and Yugoslavia. Subsequently, their status was regulated by the I975 Osimo Treaty between Italy and Yugoslavia (Medvedović I998: 32; Jovanović I977: 27-3I; see also Medved in this volume).

Together with the law on Yugoslav federal citizenship, the republiclevel citizenships of the constitutive republics were established. ${ }^{\text {I2 }}$ Yugoslav citizens were allowed to have only one republic-level citizenship. This measure had very important practical and political consequences. According to the Voting Registers Act of Io August I946, only citizens of a particular republic had the right to vote in that republic. Citizens from other Yugoslav republics who happened to reside on the territory of that republic were not allowed to vote there. Republican People's Assemblies were supposed to be elected only by citizens of these republics, although some republics, such as Croatia, would later allow both its citizens and residents to participate in elections of delegates for the Croatian Parliament (see Hondius I968: I84). It is important to note that only republic-level registries of citizens existed in Yugoslavia between I945 and 199.. ${ }^{\text {I3 }}$ During the era of socialist Yugoslavia, three laws on Yugoslav citizenship were enacted (in I945/1946, I964 and I976), following important constitutional changes in I945 and I946, ${ }^{196} 3^{14}$ and I974. They defined the relationship between federal-level and republic-level citizenship. Art. I, para. 2 of the I945/46 Law on Yugoslav citizenship stated that: 'Every citizen of a people's republic is simultaneously a citizen of FPRY and every citizen of FPRY is principally a citizen of a people's republic.' The I964 Law provided for a united Yugoslav citizenship (art. I), made republic-level citizenship conditional upon federal citizenship, and declared that the republic-level citizenship would be lost with the loss of federal citizenship (art. 2, para. 2). ${ }^{\text {I5 }}$ The I976 Law on Yugoslav citizenship contained a similar provision 
and added an article (22) on how to resolve disputes caused by the republics' laws on citizenship. ${ }^{16}$ These norms regulated the citizenship status of a child either according to the citizenship laws in force in the republic of which the child's parents were citizens or, if the parents did not have the same citizenship, according to the citizenship laws of the republic where the child was born. The norms also offered an option for parents of different citizenships to agree on the citizenship of their child. If the parents could not agree, the child was granted a possibility of naturalising in the republic of his or her birth. Not surprisingly for the confederated structure that Yugoslavia progressively became after the late I960s, these adopted norms show some similarities to the norms of international law in cases of legal collisions among sovereign states (Jovanovic I977: 53).

The republic-level laws on citizenship were fashioned to harmonise with the federal law on citizenship, but in fact they varied from one republic to the other. They were adopted in three waves: in 1950, in 1965 and in the period between I975 and 1979. In I950, the Citizenship of the People's Republic of Croatia ${ }^{17}$ provided that the basic principle for acquisition of Croatian republican citizenship was ius sanguinis. However, if parents of a newborn child had different republican citizenships, the child could acquire Croatian citizenship if both parents agreed. If they did not agree and they had residence in Croatia, the child would automatically acquire Croatian citizenship. If the parents did not have residence in Croatia but the father had Croatian citizenship, the child would become a Croatian citizen as well.

The 1965 Law on Citizenship of the Socialist Republic of Croatia brought some changes. ${ }^{18}$ Croatian citizenship was automatically granted if a child was born in Croatia and both parents had Croatian citizenship. In all other cases, parents had to agree on the child's citizenship. Nevertheless, the law offered a possibility to any SFRY citizen to opt for Croatian citizenship without being born or residing there and regardless of his or her ethnicity (UNHCR 1997: 16).

In the 1977 Law on Citizenship of the Socialist Republic of Croatia ${ }^{\mathrm{I} 9}$ we can observe some new changes related to the acquisition of Croatian citizenship. Ius sanguinis principle remained the automatic criterion for acquiring Croatian citizenship; if both parents were Croatian citizens, the child would automatically become a Croatian citizen. However, if only one parent was a Croatian citizen, the parents had to agree. In cases in which the parents did not agree or did not sign a statement within two months following the birth of their child, Croatian citizenship was automatically accorded to the child if the parents had permanent residence in Croatia. If the parents did not have permanent residence in Croatia, the child would acquire Croatian citizenship if his or her birth was registered in Croatia's register of births. ${ }^{20}$ 
As shown above, citizenship in the socialist Yugoslavia was bifurcated into a federal citizenship, on the one hand, and a republic-level citizenship, on the other hand. According to art. 249 of the last (I974) SFRY Constitution, citizens possessed a 'single citizenship of SFRY' and every citizen of a republic was 'simultaneously' a citizen of SFRY. The third line of the article offered an important right to all federal citizens: 'a citizen of a republic on the territory of another republic has the same rights and obligations as the citizens of that republic.'

Yugoslav citizens were thus, in principle, able to choose their republican citizenship depending on their residency or employment. Nevertheless, since the republican citizenship was of no practical relevance, citizens usually did not change their republican citizenship status if they moved to another republic, and often they did not even register changes of residence. Internal Yugoslav migration established strong personal and family ties across republican borders, whilst economically motivated migrations and the resettlement of federal administration personnel resulted in a considerable number of individuals living outside of their republic of origin. This in turn affected the balance between ethnic groups in Yugoslav republics to a certain degree. From the moment of Yugoslavia's dissolution, federal citizenship ceased to exist and the previously irrelevant republic-level citizenship became the main criterion for the initial determination of citizenship in the successor states. The 'internal' Yugoslav migrants, residing in a republic whose citizenship they did not possess and to whose ethnic majority they did not belong, were the first to suffer the consequences of the new citizenship regimes.

\subsubsection{Croatian citizenship since 1991}

The Croatian declaration of independence of 25 June I99I - which entered into force on 8 October I99I after a three-month moratorium brokered by the international community - was based on the referendum on Croatian independence of I9 May I99I. Croatian citizens were essentially asked to vote - which they did in huge numbers - in favour of recognising

the Republic of Croatia as a sovereign and independent state that guarantees the Serbs and members of other nationalities in Croatia cultural autonomy and all rights of a citizen. ${ }^{2 \mathrm{I}}$

However, Croatian Serbs generally boycotted the referendum and even held their own to express their desire to remain part of Yugoslavia.

Six months previously, in December I990, the new Croatian constitution had proclaimed 'the Republic of Croatia as the national state of the Croatian people and the state of members of other nations and 
minorities who are its citizens.' The new Constitution, adopted after the first democratic elections in Croatia, replaced the I974 Constitution of the Socialist Republic of Croatia, which had defined Croatia 'as a national state of the Croatian people, state of the Serbian people in Croatia [emphasis added] and state of nationalities living on its territory' (art. I). Although the referendum question, together with the Constitution itself, mentioned the rights of ethnic minorities and their equal status in new Croatia, the constitutional definition of Croatia as primarily an ethnically Croatian state had a direct impact on the new citizenship law (which entered into force simultaneously on 8 October I99I). ${ }^{22}$ The law was conceived on the basis of two major principles: legal continuity with citizenship of the Socialist Republic of Croatia and Croatian ethnicity (see Omejec i998: 99).

All holders of the former Croatian republican citizenship became citizens of the new state ex lege (art. 30, para. I). All other residents became aliens overnight, irrespective of how long they had resided in Croatia. Their naturalisation as Croatians was regulated by art. 8 of the Law on Croatian Citizenship. According to this article, in order to be naturalised a resident must have at least five years of registered residence in Croatia, provided that the following conditions were met: that he or she had renounced a foreign citizenship or will submit proof that he or she will be released from a previous citizenship if admitted to Croatian citizenship; that he or she is proficient in the Croatian language and Latin script; that it can be concluded from the applicant's conduct that he or she is attached to the legal system and customs of the Republic of Croatia; and finally, that he or she accepts the Croatian culture [emphases added]. ${ }^{23}$

The law put those with less than five years of registered residence and those who were unable to prove that they had been released from foreign citizenship (i.e. previous republican citizenship) ${ }^{24}$ in a particularly difficult position. In a context in which Croatia was at war with the Yugoslav Federation (which initially consisted of the Republics of Serbia, Montenegro, Macedonia and Bosnia-Herzegovina and then progressively shrank to just Serbia and Montenegro) it was virtually impossible to satisfy this condition. Only aliens born in the territory, spouses, emigrants and those whose citizenship was of interest to Croatia did not have to prove release from their previous citizenship under the naturalisation procedure. However, the first two categories have to fulfil more requirements than the latter two. Moreover, all applicants for naturalisation have to prove that they accept the Croatian legal system, customs and culture (see section II.2.I.3 for further details). Between I99I and I993 decisions on applications, which are made by the Ministry of Internal Affairs, were discretionary, since the Ministry was not obliged to state its reasons for refusing a request. In 
I993 the Constitutional Court ordered the Ministry in charge to begin explaining its decisions. ${ }^{25}$

The ethnocentric features of the I99I Citizenship Law were confirmed again in the transitional provisions, determining the initial citizenry of Croatia and including a special mode of acquiring citizenship for ethnic Croats who were registered but did not possess Croatian republic-level citizenship. They could acquire Croatian citizenship by declaration, i.e. by issuing a written statement to the police that they considered themselves Croatian citizens. Once the police had checked whether the individual in question had fulfilled the above requirements, he or she was then entered into the citizenship registry (see art. 30, para. 2). ${ }^{26}$ In 1993, the Croatian Constitutional Court rejected the petition filed by the Social Democratic Union demanding the removal of the entire art. 30 on the basis of the latter's discrimination against non-Croats in the same position. The Court stated that the Croatian Citizenship Law respected international law on statelessness and that it did not threaten to 'leave a person without citizenship', since all SFRY citizens had to have a republic-level citizenship. Furthermore, the Court stated that the Law itself did not explicitly revoke anyone's citizenship (UNCHR I997: I7).

Not only does the law lay down a specific procedure of acquiring Croatian nationality for residents of Croatian ethnicity in the article determining the initial citizenry of Croatia, it also offers facilitated naturalisation to emigrants and their descendents, who accept the Croatian legal system, customs and culture (art. I2). Moreover, it paves the way for ethnic Croats without previous or current residence in Croatia to obtain Croatian nationality by declaration (art. I6). There is in fact a large population of Croats living abroad. Non-resident Croats can be classified in two categories. The first category is composed of the descendents of emigrants who left Croatian territory. This comprises the I880-I9I4 migration, mainly to the Americas. About 600,000 Croats were believed to be living in North America by I9I4 (Holjevac I968: 23). This flow continued in the Ig20s and I930s. However, it also comprises the post-Second World War emigration of about 300,000 people (Bilandžić ı985: 9) who fled Communist Yugoslavia, as well as an estimated number of I,I00,000 'gastarbeiter' and their descendents ${ }^{27}$ who remained in their mainly European countries of destination (Baskin I986: 27). The second 'diaspora' category is composed of Croats from Bosnia and Herzegovina, who represent about 16 per cent of the total population of that country. Despite the fact that they were one of the 'constitutive peoples' of the Republic of Bosnia and Herzegovina, they were considered potential Croatian citizens in 'diaspora'. Indeed, art. I6 facilitated the naturalisation of ethnic Croats living in the "near abroad' (former Yugoslav republics), especially for those in Bosnia-Her- 
zegovina, while art. II facilitated the naturalisation of the Croatian ethnic emigrants and their descendents, even if they did not satisfy the conditions stated in art. 8 regarding proficiency in the Croatian language.

Since legal continuity with previous citizenship of the Socialist Republic of Croatia was the determining factor for the establishment of the initial citizenry of the newly independent state, the Republican Registrar's Office was supposed to issue certificates on Croatian citizenship. Problems occurred, however, when an individual was registered but his or her republican citizenship was not Croatian (for instance, the father's republican citizenship was sometimes used to determine the republican citizenship of a child), or if no republican citizenship was officially recorded. In the former cases, the persons were considered aliens and had to apply for naturalisation, whereas the latter were sent to police agencies to have their citizenship determined or were allowed to register as Croatian citizens - according to art. 30, para. 2 - if they were able to prove Croat ethnic origins (UNHCR I997). If they were not able to provide the necessary proof (or were simply of a different ethnicity), they were considered aliens by law. But how could someone actually prove his or her Croat ethnic origins? Any official document released by SFRY or republican authorities in which a person declared himself to be ethnically Croat usually sufficed, but sometimes more unusual documents, such as Catholic Church certificates (among South Slavs born south of Slovenia being a Roman Catholic has been considered the strongest proof of someone's 'Croatness') were also accepted by state authorities. ${ }^{28}$

The citizenship status of Croatia's Serb minority in the Krajina region was particularly problematic. ${ }^{29}$ Given the fact that in I99I the Croatian Serb militia, with the help of the Yugoslav federal army, took control of almost one-third of Croatia's territory (mostly in the Krajina region but also in Central and Eastern Slavonia), the citizenship status of the ethnic Serb population living in these regions remained unresolved for almost a decade. Croatian Serb refugees, who fled or were forced to leave Krajina during and after the Croatian military takeover in 1995 and found themselves in Serbia or Bosnia-Herzegovina (in the Serb entity), were in a particularly difficult situation. They were all legally Croatian citizens but did not possess a certificate of Croatian citizenship (domovnica) and, therefore, could not claim all their rights as Croatian citizen. Up until the political changes in 2000 , the Croatian authorities imposed numerous obstacles to prevent ethnic Serb refugees from acquiring valid documents (certificates on citizenship, passports, etc.) testifying to their nationality - the goal being to make their return to Croatia and the restitution of their goods impossible (see report on Croatia in Imeri 2006: I29-I3I). 
With the death of Croatia's President Franjo Tudjman and the subsequent defeat of his party (HDZ) in the 2000 parliamentary elections, Croatia declared its willingness to quickly satisfy all the conditions necessary for EU membership. As a consequence, the situation regarding citizenship policy has significantly improved. Although there have as yet been no changes in the text of its citizenship law, the administrative implementation reveals a greater degree of inclusiveness towards ethnic non-Croats - without, however, withdrawing privileges offered to ethnic Croats outside the country. Today, Croatian Serb refugees face no significant obstacles in acquiring proof of Croatian citizenship, although some issues related to the citizenship policies of the I990s remain unresolved. ${ }^{30}$ The EU stated that the return of these refugees to Croatia and the full restitution and reparation of their material goods was an important political condition for Croatia's membership talks.

\subsection{Acquisition and loss of Croatian citizenship: Current legal provisions}

\subsubsection{Acquisition of Croatian citizenship}

The I991 Law on Croatian Citizenship as amended in I992 offers four modes of acquiring Croatian citizenship:

I. acquisition by descent;

2. acquisition by birth on the territory of the Republic of Croatia;

3. acquisition through naturalisation;

4. acquisition through international treaties.

The last of these is not explicitly discussed in the citizenship regulations, since the treaties themselves regulate the modalities for acquiring Croatian citizenship. The only treaty of interest here is the agreement on dual citizenship signed by Croatia and Bosnia-Herzegovina on 29 March 2007 but not yet ratified (see section II.2.3 below).

\subsubsection{Acquisition by descent}

As regulated in art. 4 and art. 5, the principle of descent - ius sanguinis, the dominant principle for the acquisition of Croatian citizenship - applies when (I) both parents are Croatian citizens at the time of a child's birth, irrespective of the place of birth; (2) one parent is a Croatian citizen and the child is born in the Republic of Croatia; (3) one parent is a Croatian citizen and the other parent is stateless or of unknown citizenship and the child is born abroad; (4) one parent is a Croatian citizen and the other parent is a foreign citizen or of unknown citizenship and the child is born abroad, provided that the child, before turning eighteen, either (a) has been registered as a resi- 
dent in the territory of the Republic of Croatia or (b) has been registered with Croatian authorities, abroad or in Croatia; (5) one parent is a Croatian citizen and the other parent is a foreign citizen or of unknown citizenship and the child is born abroad, even if the child does not comply with the above mentioned conditions, if he or she would otherwise be left stateless; finally (6) a stateless child, or a child of foreign citizenship, has access to Croatian citizenship if he or she is adopted by Croatian citizens. There is no provision in the law specifying the number of generations that can benefit from the acquisition of citizenship by descent. Moreover, those born abroad who do not satisfy the above conditions can acquire citizenship through two other provisions: art. II (concerning emigrants) and art. I6 (concerning ethnic Croats who do not reside in the Republic of Croatia).

\subsubsection{Acquisition by birth on the territory}

As is common practice in all European states, art. 7 adds a residual dimension of ius soli in order to prevent statelessness: a child who was born or found on the territory of the Republic of Croatia acquires Croatian citizenship if both of his or her parents are unknown or of unknown citizenship or if they are stateless persons. However, the child loses his or her Croatian citizenship if by the time he or she is fourteen both of his or her parents are recognised as foreign citizens.

\subsubsection{Acquisition by naturalisation}

Naturalisation has been pointedly used to grant Croatian citizenship to former citizens of SFRY who did not fulfil the criteria of art. 30 para. I. and para. 2 that regulate the initial determination of the Croatian citizenry (see section II.I.2 for further details). Following the description of Omejec (1998), Croatian citizenship legislation foresees two modes of acquiring Croatian citizenship through naturalisation: 'regular' and 'facilitated' naturalisation. It also considers the case of minors, and the case of individuals who can be 'reintegrated' into the Croatian citizenry.

\section{Regular naturalisation}

In order to obtain Croatian citizenship, an alien is required to fulfil the following requirements contained in art. 8. The foreign national must:

I. be at least eighteen years old when submitting his or her request;

2. have renounced any foreign citizenship, or submit proof that he or she will be released from other citizenships;

3. have had registered residence in the territory of the Republic of Croatia for at least five years;

4. be familiar with the Croatian language and the Latin alphabet. 
5. Moreover, it must be concluded from his or her behaviour that he or she respects the legal order, the customs and the culture of the Republic of Croatia. This particular provision (art. 8.I.5) of the law has been often used in the past by the Ministry of Interior (the Ministry in charge of determining the validity of naturalisation applications) to deny Croatian citizenship to ethnic non-Croats with longterm residence in Croatia.

\section{Facilitated naturalisation}

The procedure of facilitated naturalisation is used when, in spite of the fact that some of the conditions listed above are not fulfilled, there is an intention to admit an alien into the Croatian citizenry. There are several grounds on which an alien can be naturalised in this way:

I. Art. 9 allows for granting citizenship to aliens who were born in the Republic of Croatia, have had five years of residence prior to their application and for whom it can be concluded from their behaviour that they have respected the legal order, the customs and the culture of the Republic of Croatia. Hence, this specific group of applicants does not have to fulfil conditions I, 2 and 4 of the regular naturalisation procedure. ${ }^{3 \mathrm{I}}$

2. Art. Io allows for the spouse of a Croatian citizen with permanent residency in the Republic of Croatia to obtain Croatian citizenship, provided that it can be concluded from his or her behaviour that he or she respects the legal order, the customs and the culture of the Republic of Croatia.

3. Emigrants, their descendants and their spouses are similarly granted citizenship following art. II, even if they do "not meet the prerequisites from art. 8, paragraph I, points I-4'. An emigrant is defined as a 'person who has emigrated from Croatia with the intention to live permanently abroad'. There is no specification in the law as to the number of generations entitled to apply through art. II. This opens a possibility to all emigrants and their descendents to acquire Croatian citizenship. Candidates have to show documents proving the emigration from the territory of the Republic of Croatia, and the connection to the original emigrant (through birth and marriage certificates).

4. According to art. I2, any foreign citizen, as well as his or her spouse, can be granted Croatian citizenship by the competent ministry if this is deemed to be in the interest of the Republic of Croatia (upon condition, as always, that it can be concluded from his or her behaviour that he or she respects the legal order, the customs and the culture of the Republic of Croatia). 


\section{Naturalisation of minors}

The Law on Croatian Citizenship does not allow minors to acquire Croatian citizenship independently of their parents. According to art. I3, there are three possibilities for a child to acquire Croatian citizenship through naturalisation: (I) if both parents acquire citizenship by naturalisation; (2) if only one parent acquires citizenship by naturalisation and the child lives in the Republic of Croatia; or (3) if only one parent acquires citizenship by naturalisation and the other is a stateless person or a person of unknown citizenship and the child is living abroad. Finally, according to art. I4, a child adopted by a Croatian citizen with parental effect can be naturalised according to the facilitated procedure even if he or she does not meet the prerequisites defined in art. 8.I.I-4.

\section{Reacquisition of Croatian citizenship}

On top of the legal dispositions for the naturalisation of aliens, there are provisions for reacquisition of citizenship by former Croatian citizens who have lost it. There are two main possibilities for 'reintegrating' people into the Croatian citizenry. According to art. I5, Croatian citizenship can be granted again to an individual who had to renounce his or her Croatian citizenship for another citizenship in order to 'conduct a profession or a business', even if he or she does not meet the prerequisites of art. 8.I.I-4. Another case concerns individuals who have lost their citizenship as minors. According to art. 23, children of Croatian citizens whose citizenship has been revoked (art. 20) or renounced by their parents while they were minors (art. 22) can regain citizenship if they reside for one year in the territory of the Republic of Croatia and issue a written statement stating that they consider themselves Croatian citizens.

\section{Acquisition by declaration}

Art. I6, quite problematically, grants citizenship to any 'member of the Croatian people who does not have a place of residence in the Republic of Croatia [...] if he or she meets the prerequisites of art. 8.I.5 of this Law and if he or she issues a written statement that he or she considers himself or herself to be a Croatian citizen.' ${ }^{32}$

\subsubsection{Loss of Croatian citizenship}

According to art. I7, there are three principal ways in which Croatian citizenship can be terminated: (I) release, ${ }^{33}$ (2) renunciation or (3) through international treaties. The last of these, as is the case for the 
acquisition of citizenship, is not explicitly discussed in citizenship regulations for the above-mentioned reasons.

\subsubsection{Release}

Release from citizenship by the state authorities, is regulated by art. I 8 and art. I9. Release from citizenship cannot be obtained by a Croatian citizen who at the moment of the request is charged and prosecuted ex officio, or as long as he or she has not served his or her sentence. In addition, the citizen must be at least eighteen years old, must have fulfilled his military service obligations, must have paid taxes and must have fulfilled any obligations to his or her spouse, parents and children. Moreover, proof of a foreign citizenship or evidence that the foreign citizenship will be granted must also be submitted. The price of this procedure is, however, unusually high for an ordinary Croatian citizen. It is currently fixed at 3,600 kunas, i.e. approximately 500 euros, which is just below the average monthly wage in Croatia. ${ }^{34}$

\subsubsection{Renunciation}

According to Omejec (1998: 122), the purpose of the right to renounce Croatian citizenship is to not restrict the freedom of choice of those in possession of dual citizenship. Croatian citizens have the right to renounce citizenship if they are over eighteen, have a foreign citizenship and reside abroad. The children of these citizens, if they are minors, are considered in the same way as their parents, although they can reclaim their lost citizenship, as explained above.

\subsubsection{Lapse or withdrawal of citizenship}

The Croatian citizenship regulations do not specify cases in which citizenship is lost against the will of the person affected. Contrary to most countries, there are no provisions concerning, for example, treason or service in a foreign army.

\subsubsection{Dual citizenship}

The question of dual citizenship is rather ambiguously treated. Two articles are in fact in partial contradiction. On the one hand, art. 2 explicitly states that Croatian citizens may have another citizenship, even if it is not recognised by the Republic of Croatia: 'the citizen of the Republic of Croatia who has foreign citizenship is, before the state authorities of the Republic of Croatia, to be considered a Croatian citizen exclusively'. On the other hand, art. 8 specifies that a foreign national who intends to acquire Croatian citizenship has to renounce his or her current citizenship (art. 8.I.2). In practice, members of the Croatian 'diaspora' in the US, Canada, Australia, Germany and other countries 
have been able to obtain Croatian citizenship quite easily and maintain their other citizenship. The same is true for citizens of Bosnia and Herzegovina. ${ }^{35}$

\subsection{Current political debates and planned changes}

Since its adoption in I99I, the Croatian Law on Citizenship has been heavily criticised, particularly by NGOs and international human rights agencies, as well as by some non-nationalist political parties, for its ethnic overtones, open discrimination against ethnic non-Croats and Croatia's policy of granting its citizenship to ethnic Croats abroad, particularly to those living in the 'near abroad' in Bosnia-Herzegovina. In spite of these occasional calls for changes to the text of the law, the I99I Law, although amended, is still in force. Nevertheless, with the acceleration of Croatia's membership negotiations with the EU, changes to the law itself were announced by government officials in relation to Croatia's adoption of the European Convention on Nationality.

The Croatian Parliament (Hrvatski Sabor) was supposed to adopt the European Convention on Nationality in 2006. Art. 5 of the Convention explicitly forbids discrimination on ethnic, religious or racial grounds, and since the Council of Europe had already required Croatia to change its law on citizenship, it was made clear by the Croatian authorities that the law - especially the controversial points regarding unequal treatment of individuals of non-Croat ethnicity regarding the residency requirement - would be rewritten. If the Convention had been adopted, it would have been more difficult for ethnic Croats permanently residing outside Croatia to obtain citizenship without satisfying the usual requirements of current residence in Croatia. Some other provisions that discriminate against non-ethnic Croatian residents should likewise have been removed. However, the ruling conservative party (HDZ, Croatian Democratic Union) blocked the adoption of the Convention in the Sabor - even though the adoption of the Convention had actually been proposed by a government dominated by the HDZ fearing it would automatically and detrimentally influence relations between Croatia and the Croat ethnic diaspora, in particular Bosnia-Herzegovina's Croats. Interestingly, at almost the same time in 2006, Italy adopted a law granting Italian citizenship to a number of descendants of Italian ethnic origin who live in the Slovene and Croatian territories that were annexed by Italy in the inter-war period or during the Second World War. This move provoked a fierce reaction from both Slovenia and Croatia. Some senior Croatian politicians (many from the HDZ) complained that Italy had deliberately created citizens with a 'double loyalty', clearly forgetting that granting Croatian citizenship to ethnic 
Croats from Bosnia-Herzegovina - one of three constituent peoples in that country - resulted in precisely the same kind of 'double loyalty'. ${ }^{36}$

It is certain that the HDZ had in mind a controversial Croatian electoral law that creates a special electoral constituency for the Croatian diaspora. The vast majority of votes in this constituency come from the Bosnian Croats, who vote predominantly for the HDZ and other nationalist parties. The outcome of recent parliamentary elections in Croatia (November 2007) clearly reveal all of the particularities of the current situation in Croatia. The HDZ eventually won the elections by a tiny margin thanks, in large part, to the votes from the diaspora constituency, ${ }^{37}$ the majority of which came from Bosnia-Herzegovina. This electoral unit had been boycotted by the largest opposition party, the Social-Democratic Party and other non-nationalist and left-leaning parties, which continue to demand changes in the electoral law. One can thus witness parallel attempts to, on the one hand, preserve the ethnocentric character of the state - most obviously by maintaining strong ties to and influence on Croatian ethnic population in Croatia's 'near abroad' - and, on the other, to demonstrate a high degree of political inclusion of ethnic minorities in conformity with the democratic norms of the EU. After the 2007 parliamentary elections, and in harmony with this new euro-compatible face of Croatia, one of the highest positions in the government was offered to a member of the largest ethnic Serb party in Croatia for the first time since I99I.

\subsection{Statistical developments}

It is very difficult to obtain comprehensive statistical data related to citizenship matters in independent Croatia. After several enquiries directed at the Croatian Ministry of Interior, the authors received the following response in June 2008:

In the period between 2002 and 2007, 53,095 requests for acquisition of Croatian citizenship were favourably resolved, and II,32I requests were denied. During the same period, the requests for acquisition of Croatian citizenship submitted by 7,057 persons were suspended or rejected.

We would like to underline that we are communicating the above-cited data with reservations, and that we cannot be held responsible for their accuracy. We do not have the technical facilities necessary to generate exact statistical data. In the abovementioned period, there were no unified parameters for the statistical treatment of data related to the acquisition of Croatian citizenship. As for the period between I991 and 200I, we are un- 
able to communicate the required data. During this period, no statistical data was produced in relation to the resolved requests for acquisition of Croatian citizenship, because there was no adequate informational system for this database.

It is difficult to assess the reliability of this statement. On the one hand, the first years of independence in the Republic of Croatia were marked by war and considerable administrative reorganisation. This gives credence to the Ministry's claims. On the other hand, the highly politicised question of Croatian citizenship, as well as the 'ethnic engineering' aspect of the citizenship policies are obviously something that the Croatian government does not want to see quantified. The authors find the statement that between I99I and 200I (ten years!) there was 'no adequate informational system for this database' surprising. The fact that another author (Omejec 1998) was able to obtain some data for that period and that these data were quoted in an UNHCR report (I997), confirms that some statistical data must be available.

In the period from October 8, I99I, to June 30, I995, the Ministry of Internal Affairs of RC [Republic of Croatia] resolved 557,379 requests for determination of Croatian citizenship according to art. 30 para. I LCC [Law on Croatian Citizenship]. According to the analysis, these cases mostly involved citizens of the former SFRY with a residence in SRC [Socialist Republic of Croatia] who were not registered in the citizens' registry of SRC or were registered after February 29, I978 yet did not have a citizenship recorded in the 'republican citizenship' section, and their citizenship was disputable. There is no data regarding how many of the 557,379 requests submitted on the grounds of art. 30 para. I LCC were denied. In the same period (October, 8, I99I - June, 3, I995) the MIA of RC resolved 394,910 requests for subsequent registration on the grounds of art. 30 para. 2 LCC. These cases mostly involved ethnically Croatian individuals who were not citizens of SRC, but who had a residence on its territory and submitted a statement that they considered themselves to be Croatian. Therefore, in the period from October 8 , I99I, to June 30, I995, 952,33I procedures for determination of Croatian citizenship were executed on the basis of art. 30 LCC (Omejec I998: II6). ${ }^{38}$ 


\subsection{Conclusions}

The Croatian case confirms that the dominant paradigm of ethnic citizenship has not been radically challenged in the Balkans, except in those countries (Bosnia-Herzegovina, Kosovo and, to a large extent, Macedonia) that are under direct international supervision and where the UN and the EU have strong civilian, police and military missions. Since 2000 , however, we have generally witnessed a greater degree of inclusiveness and less discrimination on ethnic grounds, as well as an increased sensitivity to the political aspirations of ethnic minorities (most clearly in the EU candidate countries, Macedonia and Croatia). Nonetheless, in countries such as Slovenia, Croatia and Serbia, where the EU is not in a position to directly control lawmakers or the behaviour of the state apparatus, the pressure coming from Brussels is mostly concentrated not on eventual changes in citizenship legislation, but rather on the administrative practice and political life of the countries in question.

In order to satisfy the political conditions for EU membership, Croatia is demonstrating - even in the behaviour of its leading conservative politicians - more political inclusiveness towards the Serb minority and, in general, is acting as a democratic state that does not discriminate on an ethnic basis (as was the case during the I990s). Nevertheless, it continues to do everything it can to preserve the strong ties it has established with its diaspora (again, primarily in Bosnia-Herzegovina) and here Croatian citizenship granted to ethnic Croats abroad plays a crucial role. The diaspora voting machine, based mainly in the Croatpopulated Western Herzegovina, has been repeatedly used by the main Croatian right-wing party (HDZ) at the time of elections as a political chip in Croatian internal politics. Nevertheless, we can conclude that, beyond electoral campaigns, Croatia's bid for EU membership relegates the question of Croatian ethnic diaspora from the political sphere to the spheres of educational, cultural and social ties.

Since Croatia seems to be on a fast track to joining the EU, it is important to point out that Croatia's membership will automatically create more than 500,000 EU citizens permanently residing in a non-EU country. The Croatian policy of granting citizenship to ethnic Croats in Bosnia-Herzegovina will thus indirectly affect all other EU Member States as well.

To sum up, the case of Croatia demonstrates how sticks and carrots employed by the EU could alter relations between a nationalising state and its internal minorities as well as between a kin state and its ethnic diaspora in the 'near abroad'. At the same time, it shows how the latter relations can be preserved - even if they remain politically dormant within the institutional framework of the EU. We thus witness parallel 
attempts to integrate a country into the supranational institutions of the EU, democratise its political life and clearly show political and social inclusiveness towards ethnic minorities, but also to maintain a transnational ethnic community by using ethno-centric citizenship laws.

\section{Chronological list of citizenship-related legislation in Yugoslavia/Croatia}

\begin{tabular}{|c|c|c|c|}
\hline Date & Document & Content & Source \\
\hline $\begin{array}{l}1811 / \\
1867\end{array}$ & $\begin{array}{l}\text { Austrian Civil Code (arts. } \\
28-32 \text { ) }\end{array}$ & $\begin{array}{l}\text { Regulates the citizenship } \\
\text { status of citizens living in } \\
\text { Dalmatia placed under the } \\
\text { Austrian rule within the } \\
\text { Austro-Hungarian Empire }\end{array}$ & \\
\hline 1879 & $\begin{array}{l}\text { Law on Hungarian } \\
\text { Citizenship (Article 'L') }\end{array}$ & $\begin{array}{l}\text { Regulates the citizenship } \\
\text { status of citizens living in } \\
\text { Croatia and Slavonia } \\
\text { placed under Hungarian } \\
\text { rule within the Austro- } \\
\text { Hungarian Empire }\end{array}$ & \\
\hline 1928 & $\begin{array}{l}\text { Law on Citizenship of the } \\
\text { Kingdom of Yugoslavia }\end{array}$ & $\begin{array}{l}\text { Establishes a single } \\
\text { Yugoslav citizenship } \\
\text { throughout the Kingdom }\end{array}$ & \\
\hline $\begin{array}{l}1945 / \\
1946\end{array}$ & $\begin{array}{l}\text { Law on Citizenship of the } \\
\text { Democratic Federal } \\
\text { Yugoslavia (No. 64/1945; } \\
\text { No. 54/1946) }\end{array}$ & $\begin{array}{l}\text { Defines the initial citizenry } \\
\text { of the newly formed Yugo- } \\
\text { slavia; establishes Yugo- } \\
\text { slav federal citizenship } \\
\text { and republic-level citizen- } \\
\text { ship of the six constituent } \\
\text { republics; is confirmed } \\
\text { and amended after the } \\
\text { adoption of the } 1946 \text { Con- } \\
\text { stitution of the Federal } \\
\text { People's Republic of Yugo- } \\
\text { slavia (54/1946) }\end{array}$ & $\begin{array}{l}\text { www.sluzbenilist.co.rs } \\
\text { (in Serbo-Croatian) }\end{array}$ \\
\hline $\begin{array}{l}1945 / \\
1946\end{array}$ & $\begin{array}{l}\text { Law on Deprivation of } \\
\text { Citizenship for Officers } \\
\text { and Non-Commissioned } \\
\text { Officers of the Former } \\
\text { Yugoslav Army Who do not } \\
\text { Want to Return to the } \\
\text { Homeland, and for the } \\
\text { Members of Military } \\
\text { Forces Who Have Served } \\
\text { for the Enemy and Have } \\
\text { Defected Abroad } \\
\text { (No. 64/1945; No. } 86 / \\
\text { 1946) }\end{array}$ & $\begin{array}{l}\text { Deprives Yugoslav } \\
\text { citizenship of those } \\
\text { military personnel of the } \\
\text { former army of the } \\
\text { Kingdom of Yugoslavia } \\
\text { who did not want to return } \\
\text { to the 'new' Yugoslavia and } \\
\text { those serving in military } \\
\text { formations loyal to the } \\
\text { occupying forces who left } \\
\text { Yugoslavia at the end of } \\
\text { the Second World War; is } \\
\text { revoked in } 1962 \text { (No. 22/ } \\
\text { 1962) }\end{array}$ & $\begin{array}{l}\text { www.sluzbenilist.co.rs } \\
\text { (in Serbo-Croatian) }\end{array}$ \\
\hline
\end{tabular}




\begin{tabular}{|c|c|c|c|}
\hline Date & Document & Content & Source \\
\hline 1947 & $\begin{array}{l}\text { Law on Citizenship of } \\
\text { Persons Residing in the } \\
\text { Territory Annexed by } \\
\text { Yugoslavia according to } \\
\text { the Peace Treaty with Italy } \\
\text { (No. 104/1947) }\end{array}$ & $\begin{array}{l}\text { Determines that persons } \\
\text { residing in territories } \\
\text { annexed by Yugoslavia on } \\
10 \text { June } 1940 \text { are to lose } \\
\text { their Italian citizenship } \\
\text { and acquire Yugoslav } \\
\text { citizenship; provides a } \\
\text { one-year period for ethnic } \\
\text { Italians to opt for Italian } \\
\text { citizenship and a } \\
\text { possibility for the Slav } \\
\text { population from the } \\
\text { contested borderland } \\
\text { region between Yugoslavia } \\
\text { and Italy to opt for } \\
\text { Yugoslav citizenship }\end{array}$ & $\begin{array}{l}\text { www.sluzbenilist.co.rs } \\
\text { (in Serbo-Croatian) }\end{array}$ \\
\hline 1948 & $\begin{array}{l}\text { Amendment and Revision } \\
\text { of the Law on Citizenship } \\
\text { (No. 105/1948) }\end{array}$ & $\begin{array}{l}\text { Excludes from the } \\
\text { Yugoslav citizenry all } \\
\text { citizens of German } \\
\text { ethnicity residing abroad } \\
\text { on the basis of their } \\
\text { 'disloyal conduct toward } \\
\text { the national and state } \\
\text { interests of the peoples of } \\
\text { FPRY' }\end{array}$ & $\begin{array}{l}\text { www.sluzbenilist.co.rs } \\
\text { (in Serbo-Croatian) }\end{array}$ \\
\hline 1950 & $\begin{array}{l}\text { Citizenship of the People's } \\
\text { Republic of Croatia } \\
\text { (No. 23/1950) }\end{array}$ & $\begin{array}{l}\text { Defines ius sanguinis as } \\
\text { the basic principle for } \\
\text { acquisition of Croatian } \\
\text { citizenship; specifies } \\
\text { conditions for a newborn } \\
\text { child to acquire Croatian } \\
\text { citizenship if the parents } \\
\text { hold different republic- } \\
\text { level citizenships, } \\
\text { depending on their } \\
\text { residency }\end{array}$ & \\
\hline 1964 & $\begin{array}{l}\text { Law on Yugoslav } \\
\text { Citizenship } \\
\text { (No. } 38 / 1964 ; \\
\text { No. } 42 / 1964 \text { ) }\end{array}$ & $\begin{array}{l}\text { Enacted after the } 1963 \\
\text { Yugoslav Constitution; } \\
\text { regulates the relationship } \\
\text { between the federal and } \\
\text { republic-level citizenships; } \\
\text { provides for a united } \\
\text { Yugoslav citizenship; } \\
\text { regulates that only a } \\
\text { federal citizen can hold } \\
\text { republican citizenship, and } \\
\text { that the republican } \\
\text { citizenship is lost with the } \\
\text { loss of the federal } \\
\text { citizenship }\end{array}$ & $\begin{array}{l}\text { www.sluzbenilist.co.rs } \\
\text { (in Serbo-Croatian) }\end{array}$ \\
\hline
\end{tabular}




\begin{tabular}{|c|c|c|c|}
\hline Date & Document & Content & Source \\
\hline 1965 & $\begin{array}{l}\text { Law on Citizenship of the } \\
\text { Socialist Republic of } \\
\text { Croatia } \\
\text { (No. } 13 / 1965 \text { ) }\end{array}$ & $\begin{array}{l}\text { Confirms ius sanguinis as } \\
\text { the main criterion for } \\
\text { automatically acquiring } \\
\text { Croatian citizenship; unlike } \\
\text { the } 1950 \text { Law, stipulates } \\
\text { that both parents have to } \\
\text { agree on the child's } \\
\text { citizenship if they hold } \\
\text { different republic-level } \\
\text { citizenships; guarantees } \\
\text { that any SFRY citizen has a } \\
\text { right to choose his or her } \\
\text { republic-level citizenship } \\
\text { and is thus free to choose } \\
\text { citizenship of any republic } \\
\text { without being born or } \\
\text { residing there }\end{array}$ & \\
\hline 1976 & $\begin{array}{l}\text { Law on Citizenship of the } \\
\text { Socialist Federal Republic } \\
\text { of Yugoslavia } \\
\text { (No. } 58 / 1976 \text { ) }\end{array}$ & $\begin{array}{l}\text { Is adopted after the } 1974 \\
\text { Yugoslav constitution; } \\
\text { repeats the provisions } \\
\text { from the } 1964 \text { Law on the } \\
\text { relationship among the } \\
\text { federal and republic-level } \\
\text { citizenships; adds an } \\
\text { article on how to resolve } \\
\text { possible disputes caused } \\
\text { by the republican laws on } \\
\text { citizenship }\end{array}$ & $\begin{array}{l}\text { www.sluzbenilist.co.rs } \\
\text { (in Serbo-Croatian) }\end{array}$ \\
\hline 1977 & $\begin{array}{l}\text { Law on Citizenship of the } \\
\text { Socialist Republic of } \\
\text { Croatia (No. 32/1977) }\end{array}$ & $\begin{array}{l}\text { Confirms ius sanguinis as } \\
\text { the main criterion for } \\
\text { automatically acquiring } \\
\text { Croatian citizenship; } \\
\text { specifies conditions of } \\
\text { citizenship acquisition in } \\
\text { the case in which the } \\
\text { parents do not agree or do } \\
\text { not sign a statement } \\
\text { during two months } \\
\text { following the birth of their } \\
\text { child }\end{array}$ & \\
\hline 1991 & $\begin{array}{l}\text { Law on Croatian } \\
\text { Citizenship } \\
\text { (No. 53/1991) }\end{array}$ & $\begin{array}{l}\text { Defines the citizenship of } \\
\text { the Republic of Croatia; } \\
\text { determines the initial body } \\
\text { of citizens according to the } \\
\text { principles of legal } \\
\text { continuity and Croatian } \\
\text { ethnicity; defines all } \\
\text { modes of acquiring and } \\
\text { losing nationality after } \\
\text { independence }\end{array}$ & $\begin{array}{l}\text { www.nn.hr (in Croatian); } \\
\text { www.legislationline.org } \\
\text { (as amended in 1992) }\end{array}$ \\
\hline
\end{tabular}




\begin{tabular}{|c|c|c|c|}
\hline Date & Document & Content & Source \\
\hline 1992 & $\begin{array}{l}\text { Law on Modifications and } \\
\text { Amendments of the Law } \\
\text { on Croatian Citizenship } \\
\text { (No. 28/1992) }\end{array}$ & $\begin{array}{l}\text { Corrects the text of the } \\
1991 \text { Law; amends } \\
\text { inconsistencies and legally } \\
\text { problematic provisions; } \\
\text { specifies the } \\
\text { administrative procedures }\end{array}$ & www.nn.hr (in Croatian) \\
\hline 1993 & $\begin{array}{l}\text { Decree of the } \\
\text { Constitutional Court of the } \\
\text { Republic of Croatia U-I- } \\
206 / 1992 \text {, U-I-207/1992, } \\
\text { U-I-209/1992, U-I-222/ } \\
1992 \text { of } 8 \text { December } 1993 \\
\text { (No. 113/93) }\end{array}$ & $\begin{array}{l}\text { Orders the Ministry of } \\
\text { Interior to justify its } \\
\text { decisions in case of the } \\
\text { refusal of requests made } \\
\text { through the regular } \\
\text { naturalisation procedure } \\
\text { (art. 8) }\end{array}$ & www.nn.hr (in Croatian) \\
\hline
\end{tabular}

\section{Notes}

I The authors thank Iris Goldner for her useful comments.

2 Hrvatska Demokratska Zajednica - Croatian Democratic Union.

3 For a detailed analysis of the citizenship legislation and practices in other former Yugoslav states since I99I, see Štiks 2006. For a study of Slovenia's citizenship legislation, see also Medved in this volume.

4 For more on Croatia's particular brand of 'transnational nationalism', see Ragazzi 2009; for the notion of transnational nationalism, see Basch, Glick-Schiller \& Szanton Blanc 1995 and Kastoryano 2006.

5 International law itself does not question the right of sovereign states to enact their own nationality policy. However, international law, declarations and treaties do seek to impose certain rules and thereby influence the behaviour of states when it comes to citizenship and nationality legislation and administrative practice. Art. I5 of the I948 Universal Declaration of Human Rights states that 'everyone has the right to a nationality' and that 'no one shall be arbitrarily deprived of his nationality nor denied the right to change his nationality.' The European Commission for Democracy through Law (also known as the Venice Commission), the Council of Europe's advisory body for constitutional issues, adopted The Declaration on Consequences of State Succession for the Nationality of Natural Persons in September 1996. It states that, besides respecting the principle that every person has a right to a nationality and the general prevention of statelessness, states should 'respect, as far as possible, the will of the person concerned.' It also repeats that 'in all cases of State succession, the successor State shall grant its nationality to all nationals of the predecessor State residing permanently on the transferred territory.' In a similar fashion, art. I8 of the I997 European Convention on Nationality, prepared by the Council of Europe, declares that, in the case of succession, states should take into account 'the genuine and effective link of the person concerned with the State' and 'the habitual residence of the person concerned at the time of State succession.'

6 The most important treaties for citizenship issues in the Croatian lands were the Peace Treaty of St.-Germain-en-Laye with the Republic of Austria, signed on Io September I9I9, and the Trianon Peace Treaty with Hungary, signed on 4 June I920. 
7 Official Gazette of Democratic Federal Yugoslavia 64/1945. The law was confirmed and amended on 5 July I946 (see Official Gazette of the Federal People's Republic of Yugoslavia (FPRY) 54/I946). The law was further amended and revised in I947 (see Official Gazette of the FPRY I04/1947) and twice in 1948 (see Official Gazette of the FPRY 88 and I05/1948).

8 Official Gazette of the FPRY 86/1948 and 22/1962.

9 Official Gazette of the FPRY I05/1948.

Io Official Gazette of the FPRY I04/1947.

II Official Gazette of the FPRY Supplement No. 6/1954.

I2 This was not the case in two other socialist multinational federations. Republic-level citizenship was established in Czechoslovakia only in 1969 and the first Soviet republic that enacted its own citizenship law was Lithuania in November 1989.

I3 The fact that only republic-level registers existed at the moment of Yugoslavia's break-up would prove to be very important, because all Yugoslav republics would adopt a policy of legal continuity between previous republic-level citizenship and citizenship of the new state. Only those granted Yugoslav citizenship at a Yugoslav embassy who were residing abroad were not included in the republic-level registers. Once they established their residence in Yugoslavia, they were also entered into the register of the republic in which they resided.

I4 In the $1_{9} 6_{3}$ Constitution, the FPRY was renamed the Socialist Federal Republic of Yugoslavia (SFRY).

I5 Official Gazette of the Socialist Federal Republic of Yugoslavia (SFRY) 38/1964 (corrected version in $42 / 1964)$.

i6 Official Gazette of the SFRY 58/1976.

I7 Official Gazette of the People's Republic of Croatia 23/1950.

I8 Official Gazette of the Socialist Republic of Croatia $13 / 1965$.

I9 Official Gazette of the Socialist Republic of Croatia 32/1977.

20 Obviously, between 1965 and 1977 the automatic acquisition of republic-level citizenship was not a rule if only one parent had Croatian citizenship, even if a child was born in Croatia (on changes in the Croatian law on republic-level citizenship and administrative practices between 1950 and I991, see the report on Croatia in UNHCR I997).

2I Official Gazette of the Republic of Croatia 2I/I99I.

22 Official Gazette of the Republic of Croatia 53/9I; modifications and amendments in Official Gazette of the Republic of Croatia 28/92. These amendments were mainly corrections of inconsistencies in the law, or legal clarifications of its provisions, which were written and adopted hastily in the context of Croatia's declaration of independence from SFRY and its open conflict with Belgrade. Some changes were obviously made after complaints were received from the ground about the implementation of the law. An important amendment was that the renunciation of foreign citizenship required for naturalisation was eased (see note 24).

23 These 'conditions' were imposed on ethnic non-Croats coming from other Yugoslav republics. They also provided a basis for the Ministry in charge to refuse Croatian citizenship to certain individuals, non-Croats from other republics, but also to some Croatian Serbs (see II.2.I.3 for further details).

24 The 1992 amendments, however, facilitated access to Croatian citizenship for those who, for various reasons, are unable to obtain release from their previous citizenship. Following these amendments, applicants have to state that they will renounce their previous citizenship, if granted Croatian citizenship.

25 Official Gazette of the Republic of Croatia II3/1993.

26 The 1991 Law additionally required ten years of residence for this group, which was not in accordance with art. 8 and art. I6 and was therefore corrected in the 
amendments adopted only seven months later on 8 May 1992. Applicants merely had to prove that they were registered as residents (see Official Gazette of the Republic of Croatia 28/1992).

27 Guestworkers, or 'workers temporarily employed abroad', according to the official Yugoslav terminology.

28 If a person did not declare himself or herself an ethnic Croat in official documents such as a birth certificate or a marriage certificate, or if a person had declared ethnicity as Yugoslav and/or was born in a so-called 'mixed marriage', the state authorities (the Ministry of the Interior) established a person's membership of the Croatian people by using Catholic Church certificates (if available) and even passed judgement on the 'Croatness' of a person's family name. This was certainly a somewhat delicate matter since a large percentage of 'Croatian' family names are shared by Serbs and other South Slavic groups (see also the report on Croatia in Imeri 2006: 127).

29 A significant number of the Croatian Serbs continued to live in territory controlled by the Croatian authorities. They managed to regulate their status either smoothly (i.e. as holders of the former Croatian republican citizenship they were automatically registered into the new registries of citizens), or in some cases, with considerable difficulties. Numerous reports testify to cases of violations of their right to Croatian citizenship in the I990s. See, for instance, reports on the issue published in Dika, Helton and Omejec 1998 and also the report on Croatia in Imeri 2006.

30 For more details on the present situation and descriptions of some concrete cases, see the report on Croatia published in Imeri (2006: 97-I23). The report points out that, for instance, the status of persons of non-Croat ethnic origin who were permanent residents of Croatia before the 1991 Law on citizenship still awaits regulation.

3I This article was modified by art. 4 of the Law on Modifications and Amendments of the Law on Croatian Citizenship (Official Gazette of the Republic of Croatia 28/1992), deleting the five years of permanent residence requirement demanded in the first version of the law. As the law stood in I99I, those born in the country who could apply for facilitated naturalisation had to fulfil a longer residence requirement than those applying for regular naturalisation. To obtain permanent residence one first has to prove five years of temporary residence, according to the new Law on Aliens. In practice this would have thus meant that a person born in the country had to prove ten years of residence in the country, whereas those applying for regular naturalisation only had to prove five. However, the modification does not imply that those born in the country do not have to fulfil any residence requirement; they now have to prove five years of registered residence just as those applying for regular naturalisation. It is important here not to confuse this modification with another important modification of residence requirements introduced by art. 13 of the same amendments, which deleted the ten years residence required in art. 30 para. 2 of the I99I Law defining a specific procedure of acquiring Croatian nationality by declaration for ethnic Croats (see note 26). The authors would like to thank Iris Goldner for this clarification.

32 It also adds that 'the statement from paragraph I of this Article shall be given before the competent authority or before the diplomatic or consular office of the Republic of Croatia abroad'.

33 'Revocation' in the text of the law.

34 For more information on the procedure, see: www.mup.hr. The average net salary in 2007 was 4,84I kuna per month (see Central Bureau of Statistics, Statistical information 2008. www.dzs.hr). 
35 Art. 4 of the Law on Citizenship of Bosnia-Herzegovina allows Bosnian citizens to hold a citizenship of another country provided there is a bilateral agreement. The question of the dual (Croatian and Bosnian) citizenship of many citizens of BosniaHerzegovina was regulated by the agreement on dual citizenship signed by Croatia and Bosnia-Herzegovina on 29 March 2007. The ratification is still pending.

36 See 'Talijani u RH i Hrvati u BiH nemaju ista prava?!' [Italians in Croatia and Croats in Bosnia-Herzegovina Do Not Have Equal Rights?!], www.tportal.hr, ı March 2006.

37 Art. 45 of the 1990 Constitution granted Croats abroad the right to vote. This provision was enacted for the first time during the 1995 elections, during which the ruling party, the HDZ, decided that the seats attributed to the 'diaspora' should represent Io per cent of the representatives, namely twelve seats. After many debates, this was changed in 1999 and the seats were apportioned according to voter turnout. This secured only six seats for the 'diaspora' vote in the 2000 and 2007 elections.

38 The UNHCR report quotes the same data, but adds that 'a total of 4I2,I37 requests were submitted to the Ministry of Internal Affairs between 8 October I99I and 3I December 1995 under article 30 paragraph 2.' This slightly changed the total number of processed requests through art. 30, paras. I and 2, available in Omejec (1998) and fixed it at 969,553 at the end of 1995 (UNHCR 1997: I6). Indeed, Jasna Omejec is quoted as a co-author of the national report on Croatia published in UNHCR. Although published in 1998 , her own article was obviously written before the UNHCR report published in I997.

\section{Bibliography}

Basch, L. G., N. Glick-Schiller \& C. Szanton Blanc (1995), Nations Unbound: Transnational Projects, Postcolonial Predicaments, and Deterritorialized Nation States. Amsterdam: Gordon and Breach.

Baskin, M. A. (1986), Political Innovation and Policy Implementation in Yugoslavia: The Case of Worker Migration Abroad. Ph.D. dissertation. University of Michigan, Ann Arbor.

Bilandžić, D. (1985), Historija Socijalističke Federativne Republike Jugoslavije: Glavni Procesi 1918-1985 [History of the SFRY: Main Processes I9I8-I985]. Zagreb: Školska knjiga.

Dika, M., A.C. Helton \& J. Omejec (eds.) (1998), 'The Citizenship Status of Citizens of the Former SFR Yugoslavia after its Dissolution', Croatian Critical Law Review 3 (I-2): I-259.

Holjevac, V. (I968), Hrvati Izvan Domovine [Croats outside of the Homeland]. Zagreb: Matica Hrvatska.

Hondius, F.W. (1968), The Yugoslav Community of Nations. The Hague: Mouton.

Imeri, Sh. (ed.) (2006), Rule of Law in the Countries of the Former SFR Yugoslavia and Albania: Between Theory and Practice. Gostivar: Association for Democratic Initiatives.

Jovanović, S.Đ. (1977), Državljanstvo Socijalističke Federative Republike Jugoslavije [Citizenship of the Socialist Federal Republic of Yugoslavia]. Belgrade: Službeni List SFRJ.

Kastoryano, R. (2006), 'Vers un nationalisme transnational. Redéfinir la nation, le nationalisme et le territoire', Revue française de science politique 4 (56): 533-555.

Medvedović, D. (1998), 'Federal and Republican Citizenship in the Former SFR Yugoslavia at the Time of its Dissolution', Croatian Critical Law Review 3 (I-2): 2I-56.

Omejec, J. (I998), 'Initial Citizenry of the Republic of Croatia at the Time of the Dissolution of Legal Ties with the SFRY, and Acquisition and Termination of Croatian Citizenship', Croatian Critical Law Review 3 (I-2): 99-I28. 
Ragazzi, F. (2009), "The Croatian "Diaspora Politics" of the I990s: Nationalism Unbound?' in U. Brunnbauer (ed.), Transnational Societies, Transterritorial Politics. Migrations from the (Post) Yugoslav Area. New York: Palgrave (forthcoming).

Štiks, I. (2006), 'Nationality and Citizenship in the Former Yugoslavia: From Disintegration to the European Integration', South East European and Black Sea Studies, 6 (4): $483-500$.

Tepić, Đ. \& I. Bašić (eds.) (I969), Zbirka propisa o državljanstvu [The Collection of the Citizenship Regulations]. Zagreb: Narodne novine.

UNHCR, Regional Bureau for Europe (1997), Citizenship and Prevention of Statelessness Linked to the Disintegration of the Socialist Federal Republic of Yugoslavia. European Series 3 (I; June 1997). Geneva: UNHCR. 



\section{Part IV}

Mediterranean post-imperial states 



\title{
12 Malta's citizenship law: Evolution and current regime'
}

\author{
Eugene Buttigieg
}

\begin{abstract}
Malta's legal regime on citizenship is relatively young as it came into being on the day of Malta's acquisition of independence from British rule in I964. Throughout these years, however, particularly over the past two decades, it has undergone extensive alterations marking changes in the governing principles. This chapter first traces the evolution of the citizenship laws during these years, noting the important policy changes, their possible causes and implications. It then explores the different modes of acquisition and loss of citizenship under the current regime. Finally, statistical data is produced to highlight the extent to which persons seeking to acquire or reacquire Maltese citizenship by registration or naturalisation benefited from these legislative changes, apart from the non-quantifiable number of persons who through these legislative changes acquired or reacquired citizenship automatically.
\end{abstract}

\subsection{Historical background}

Malta was a British colony from I800 until 2I September I964 when it acquired independence from British rule. All persons born in Malta during this period were automatically British subjects according to British law. It was thus only on Independence Day, 2I September I964, that Malta acquired its first provisions conferring and regulating Maltese citizenship. The Constitution of Malta, that entered into force on Independence Day, contained provisions conferring Maltese citizenship that were typical of independence constitutions drafted by the British for their colonies. The Constitution contained a section, chapter III, on citizenship, that conferred Maltese citizenship automatically on all persons who were born in Malta and were citizens of the United Kingdom and Colonies before 21 September I964, provided that one of the parents was also born in Malta; thus a combined application of the ius soli and ius sanguinis principles. This was necessary to avoid imposing Maltese citizenship on children born in Malta to British military personnel families and British nationals stationed in Malta, while Malta was a British colony. Persons born abroad also acquired Maltese citi- 
zenship on 2I September I964 provided the father and a paternal grandparent were both born in Malta.

On the other hand, persons born on or after the date of independence acquired Maltese citizenship by mere birth in Malta irrespective of whether or not any of their parents were born in Malta; in other words on the strength of the ius soli principle only. In practice, this meant that children born of foreign parents in Malta acquired Maltese citizenship by birth even if they were not of Maltese descent.

Chapter III of the Constitution also established that a Maltese citizen should have no other citizenship. Adults in possession of another citizenship had to renounce it by 21 September i967. If a minor who was a Maltese citizen possessed any other citizenship, upon reaching his or her eighteenth birthday, he or she would have had to renounce any other citizenship within a year if he or she wished to retain Maltese citizenship. Moreover, Maltese adults who acquired the citizenship of any other country would have automatically forfeited Maltese citizenship while foreigners who acquired Maltese citizenship by registration or naturalisation would have had to renounce any other citizenship held by them within six months from registration or three months from naturalisation.

Not unlike the general policy worldwide at the time, in the case of children born abroad, the question whether the child would acquire Maltese citizenship or not depended on whether it was the father or the mother who possessed Maltese citizenship at the time of birth. If the father was Maltese (by birth in Malta, by registration, or by naturalisation) though not the mother, the child would acquire Maltese citizenship but if the father was non-Maltese even though the mother was Maltese the child would not acquire Maltese citizenship. Thus, a Maltese mother could not transmit her citizenship to her child born outside Malta unless she was unmarried. Likewise, consistent with the international trend at the time, while the foreign wife of a Maltese citizen was entitled to become a citizen of Malta by registration, a foreign husband of a Maltese citizen was not.

The first law that complemented the Constitution on citizenship matters was the Maltese Citizenship Act (chapter I88 of the Laws of Malta) that was enacted the following year in I965. This regulated in particular the acquisition of Maltese citizenship by registration and naturalisation. The law was prejudiced in favour of Commonwealth citizens as the latter could acquire Maltese citizenship by registration after five years of residence in Malta, while other foreigners required six years of residence in Malta to acquire Maltese citizenship by naturalisation. The next development in this field was the enactment of the Immigration Act (chapter 2I7 of the Laws of Malta) in 1970 that laid down rules providing for the control of immigration into Malta. 


\subsubsection{The 1989 amendments}

Although throughout the years various amendments were made to all these laws, necessitated inter alia by Malta's transformation into a republic on I3 December 1974, the first major reform in the citizenship laws took place in August 1989 when chapter III of the Constitution, the Maltese Citizenship Act and the Immigration Act (via Acts XXIII, XXIV and XXV of 1989 respectively) were radically amended to indicate a clear change of policy regarding citizenship by (i) making an exception to the prohibition against dual citizenship for emigrants born in Malta and who had spent at least six years abroad ${ }^{2}$ - this had significant implications as, especially in the I950s and I960s, well over I00,000 Maltese citizens (more than one fourth of the current population) had emigrated to countries such as the United Kingdom, Australia, Canada and the United States to seek employment and thereby obtained a second citizenship (ii) shifting to a rule based more on ius sanguinis than on ius soli (iii) allowing Maltese mothers to transmit their citizenship to their children born abroad (iv) granting the same rights to foreign husbands of citizens of Malta as foreign wives of citizens of Malta by allowing them to be registered as citizens of Malta and (v) reintroducing acquisition of citizenship by adoption.

This change in policy was due to the influence of changing international trends favouring ius sanguinis over ius soli and a greater international acceptance of dual and multiple citizenship as well as the increasing recognition at the international level of the need to safeguard gender equality in the citizenship laws. Malta has always participated actively in international fora and endorsed international instruments in this field and has moulded its policy accordingly. Moreover, the government had been elected in 1987 on the strength of an electoral mandate that included the promise to allow expatriates to regain their lost citizenship retrospectively by acquiring dual citizenship and that citizenship laws would guarantee gender equality. A number of overseas associations representing expatriates also exerted pressure for this concession to expatriates to be extended to further generations.

As a result of these amendments, Maltese emigrants were now allowed to hold dual citizenship. Art. 27(3) of the Constitution was amended to enable Maltese emigrants born in Malta to hold dual citizenship, provided of course that the country of which they were citizens recognised the concept of dual citizenship. This applied retrospectively. A Maltese citizen born in Malta who, as the law stood at the time, had automatically lost his Maltese citizenship upon emigrating and acquiring the citizenship of the country to which he had emigrated, would now be deemed never to have lost his Maltese citizenship, provided he had spent at least six years in that country. Thus, his 
dual citizenship would be backdated to the date when he acquired the foreign citizenship. This also affected children born of a Maltese emigrant father who had lost his Maltese nationality because he had acquired another nationality. Since the dual nationality would be backdated so that the father is deemed never to have lost his Maltese citizenship, children who were born of fathers who had 'lost' their Maltese citizenship at the time of their birth and who were therefore deemed not to be Maltese citizens, also acquired Maltese citizenship with this amendment, effective from their date of birth, once their fathers were reinstated in their previous status as citizens of Malta.

It should be noted that under the current legislation, only Maltese persons habitually resident in Malta have voting rights in national general elections and voting does not take place abroad in Malta's embassies or consulates. So this extension of citizenship to expatriates does not signify any right to participate in the process of democratic selfdetermination of the country.

As stated above, under the Constitution, anyone born in Malta automatically became a citizen of Malta by mere birth in the country. However, with the 1989 amendments to the Constitution this has changed, as these amendments limit such acquisition by adding the ius sanguinis to the ius soli criterion in establishing that, as from the coming into force of these amendments on I August I989, a person born in Malta will acquire Maltese citizenship only if at least one of the parents is a citizen of Malta or was born in Malta and emigrated and enjoys freedom of movement in Malta in terms of art. 44 of the Constitution.

The amendments also removed gender inequality in two respects: (i) in relation to Maltese mothers of children born abroad and (ii) with respect to foreign men married to Maltese women.

Prior to I989 Maltese citizenship was transmitted to the children only if the father was a Maltese citizen. However, with these amendments it now suffices that either of the parents is a Maltese citizen (by birth in Malta, by registration, or by naturalisation). The Maltese mother just as the Maltese father may now transmit citizenship to her children born abroad.

Before the 1989 amendments to the Constitution, while a foreign woman married to a citizen of Malta or to someone who became a citizen of Malta was entitled to acquire Maltese citizenship by registration, a foreign husband of a female Maltese citizen was not. This was therefore discriminatory against foreign husbands as compared to foreign wives. The amendments extended this right to foreign husbands of Maltese citizens so that they are now on a par with foreign wives of Maltese citizens. Moreover, this right now extends even to the widow or widower of a person who was a citizen of Malta at the time of death 
or would have been on 21 September I964 had he or she lived till that day.

Another significant change in policy is related to the acquisition of citizenship by adoption. Until I976 it was possible under Maltese law to acquire Maltese citizenship through adoption, i.e. a person lawfully adopted by a citizen of Malta would acquire Maltese citizenship by that adoption. This was no longer possible following a legislative amendment on I January I977. In I989, the amendments to the Constitution reintroduced this facility for the acquisition of citizenship through adoption, subject to the proviso that the child adopted must be under ten years of age on the date of adoption.

In I989, the distinction made in the Maltese Citizenship Act between Commonwealth citizens and other foreigners for the acquisition of Maltese citizenship by residence in Malta, a remnant of British influence, was abolished, so now any person may be naturalised as a citizen of Malta if he or she has resided in Malta for at least five years. The I989 amendments to the Maltese Citizenship Act also extended naturalisation to any person who, being descended from a person born in Malta, is a citizen of a country other than the one in which he or she resides and whose access to the country of which he or she is a citizen is restricted.

\subsubsection{The 2000 amendments}

In 2000, further changes were made to the citizenship laws (via Acts III and IV of 2000) building on and fine-tuning the I989 amendments, in particular by now completing the shift in policy towards dual and multiple citizenship. ${ }^{3}$ One major legislative change was designed to dissuade marriages of convenience whereby foreigners were marrying Maltese citizens simply to acquire the benefits of Maltese citizenship since, according to the prevailing law, marriage with a Maltese citizen immediately entitled the foreign spouse to apply for Maltese citizenship.

The detailed provisions on citizenship in chapter III of the Constitution were transferred to the Maltese Citizenship Act that thereby became the main law regulating citizenship while the Constitution now only contains the general principles on citizenship in art. 22.

Dual citizenship that was hitherto permitted only exceptionally in the case of Maltese emigrants has now become the rule, following the amendments of 2000, as Maltese citizens are now allowed to hold dual or even multiple citizenship. ${ }^{4}$ Thus, as from the entry into force of the amendments on Io February 2000, Maltese citizens who acquire another citizenship do not lose their Maltese citizenship. Moreover, since minors holding another citizenship only lost their Maltese citizenship 
if they did not renounce the foreign citizenship by their nineteenth birthday, all citizens of Malta having another citizenship who were minors on that date or had not reached their nineteenth birthday by that date were able to retain both citizenships after their nineteenth birthday. Likewise, foreigners who acquire Maltese citizenship by naturalisation or registration are no longer required to renounce their other citizenships.

Not only was there this complete shift in policy in favour of multiple citizenship but these provisions were made applicable retrospectively to persons born in Malta or abroad and who had Maltese citizenship by birth or descent but had lost this citizenship when they acquired another citizenship, provided they had resided outside Malta for an aggregate period of at least six years. In such cases, they would be deemed never to have lost their Maltese citizenship; with this provision they regained their lost citizenship automatically. ${ }^{5}$ On the other hand, those who had lost their Maltese citizenship because they had acquired another citizenship before this date but had not resided abroad for such an aggregate period of time or their Maltese citizenship had been acquired by registration or naturalisation not by birth or descent may regain Maltese citizenship only by registration (and so not automatically). ${ }^{6}$ Irrespective of where they are currently residing they may submit an application to be registered as citizens of Malta.

Building on the reform of 1989 that had extended citizenship to children born to Maltese mothers abroad, the law was further changed to entitle such children born between 21 September 1964 (date of independence) and I August I989 (date of coming into force of the I989 amendments) to be registered as Maltese citizens, irrespective of whether or not they reside or resided in Malta while allowing them to retain their other citizenship.

As stated above, with a view to discouraging marriages of convenience, the law was amended to provide that foreigners married to Maltese citizens may apply for Maltese citizenship on the strength of their marriage only if they have been married for at least five years and no longer immediately following the marriage. ${ }^{7}$

Another legislative change related to the position of foundlings. Until 2000, a new-born infant found abandoned in Malta was deemed to have been born in Malta but could not acquire Maltese citizenship as long as the identity and nationality of the parents remained unknown. As stated above, since 1989 it has become an essential pre-requisite for Maltese citizenship that at least one of the parents is a citizen of Malta. So this meant the child would be stateless. But in 2000 the Maltese Citizenship Act was amended to the effect that, notwithstanding that the nationality of the parents was unknown, such a child would be deemed 
to be a citizen of Malta until his or her right to any other citizenship is established. $^{8}$

Malta's accession to the European Union in 2004 did not necessitate nor lead to any changes in the country's laws and policies on citizenship.

\subsection{Current modes of acquisition and loss of citizenship}

\subsubsection{Modes of acquisition of citizenship}

Acquisition by ius soli and/or ius sanguinis ${ }^{9}$

Every person born in Malta before the date of independence (2I September I964), who until then was a citizen of the United Kingdom and Colonies and either of whose parents was born in Malta, automatically acquired Maltese citizenship on the date of independence. Moreover, even a person born outside Malta before the date of independence automatically acquired Maltese citizenship on the date of independence if he or she was a citizen of the United Kingdom and Colonies until the date of independence and his or her father and a paternal grandparent were both born in Malta.

On the other hand, for those who were born in Malta on or after the date of independence but before I August I989, the mere fact of being born in Malta was enough to entitle that person to automatically acquire Maltese citizenship at birth. The only exception is in the case of someone born in Malta during this period where both parents are nonMaltese with the father enjoying diplomatic immunity. Those born outside Malta during this period acquired citizenship at birth only if at the time of birth the father ${ }^{\mathrm{IO}}$ was a citizen of Malta whether by birth in Malta, by registration or by naturalisation.

However, following the 1989 amendments, for persons born on or after I August 1989, birth in Malta no longer sufficed to entitle the person to acquire Maltese citizenship at birth: one of the parents must also have been a citizen of Malta at the time of his or her birth. For those born outside Malta on or after I August I989 citizenship is also acquired automatically at birth if, at the date of birth, one of the parents was a citizen of Malta whether by birth in Malta, by registration or by naturalisation. Thus, the essential requirement now is descent, not birth on Maltese territory.

An exception to this rule is made in the case of newborn infants found abandoned anywhere in Malta who would as a result be stateless. Such infants are deemed to have been born in Malta and are considered citizens of Malta, even though the identity and citizenship of the parents are unknown, until such time as their right to any other citizenship is established. 
A person who became a citizen of Malta on 21 September I964 or at birth but subsequently lost this citizenship, having acquired or retained the citizenship of another country, reacquired citizenship automatically and retrospectively following the entry into force of the amendments of 2000 on Io February 2000, that removed the prohibition of dual and multiple citizenship for Maltese citizens, if he or she resided outside Malta for an aggregate period of at least six years. By virtue of these amendments they are deemed retrospectively to never have lost their Maltese citizenship. ${ }^{\text {II }}$

\section{Acquisition by adoption ${ }^{12}$}

Since I August I989, Maltese citizenship may also be acquired automatically by adoption when a person is lawfully adopted (under Maltese law) on or after this date with one of the adopting parents being a citizen of Malta at the time of adoption, provided that the person adopted is under ten years of age on the date of adoption.

For persons whose adoptions took place prior to this date but after 3I December 1976, adoption did not automatically lead to acquisition of Maltese citizenship even if the adopters were citizens of Malta. This was because during this period adoptions were considered by law as without effect as far as Maltese citizenship is concerned. Persons adopted during these years would have to apply to be naturalised as citizens of Malta, a mode of acquisition that is discussed below. Although the granting of citizenship in these cases is subject to the discretion of the minister responsible for matters related to Maltese citizenship (hereinafter 'the minister'), it has, since I987, been generally granted on humanitarian grounds as a matter of policy.

Adoptions that took place before I January I977 did lead to automatic acquisition of Maltese citizenship by the adopted person on adoption but, in the case of a joint adoption, as in the case of any other birth outside Malta at the time, it had to be shown that at least the male adopter was a citizen of Malta. It would not have sufficed if only the female adopter were a citizen of Malta.

\section{Spousal transfer of citizenship ${ }^{13}$}

A non-Maltese person married to a citizen of Malta may, after five years of marriage, acquire Maltese citizenship by applying to be registered as a citizen of Malta, provided the spouses are still married and living together (if the Maltese spouse is still alive) at the time the application for citizenship is made. However, if the couple were to separate de iure or de facto after five years of marriage the foreign spouse may still apply for Maltese citizenship provided the spouses had lived together during those five years of marriage. Moreover, if the Maltese spouse dies before the fifth year of marriage, the foreign spouse may still apply for 
Maltese citizenship following the lapse of the fifth year from the date of marriage, provided that up to the time of death the spouses were living together.

Citizenship may also be acquired, if, although at the time of marriage both spouses were non-Maltese, subsequently one of the spouses acquires Maltese citizenship through some other mode of acquisition. The other spouse would now be entitled, subject to the conditions mentioned above, to apply to be registered as a citizen of Malta on the strength of the marriage.

A foreign spouse is entitled to apply to be registered as a citizen of Malta even where the marriage took place before the date of independence so that at the time of marriage neither of the spouses was a citizen of Malta, if on independence the other spouse either (i) became, or would have become were it not for his or her death, a citizen of Malta on the date of independence or (ii) became a citizen of Malta after independence.

\section{Acquisition by registration ${ }^{14}$}

Apart from the special case of spousal transfer of citizenship, there are other instances where a person may acquire Maltese citizenship by registration.

Former citizens who, having lost their citizenship before 2000 because of the possession or acquisition of another citizenship as prescribed by the law prevailing at the time, fail to qualify for automatic reacquisition of this citizenship either because they had not spent the requisite six years abroad or because they were formerly citizens of Malta by registration or naturalisation and not by birth, may nevertheless apply to be registered as citizens of Malta.

Furthermore, an emigrant who was formerly a citizen of Malta by birth or descent but ceased to be a citizen of Malta after emigrating may also reacquire citizenship by registration if he or she returns to Malta and takes up permanent residence.

Likewise, persons born outside Malta before I August I989 who are not citizens of Malta because their mother rather than their father was a citizen of Malta by birth, registration or naturalisation, may also acquire Maltese citizenship by registration.

Citizenship is acquired by registration only if the applicant takes an oath of allegiance to the country and in some instances, such as in the case of the spousal transfer of citizenship, provided the granting of citizenship to the applicant is not contrary to the public interest. With this mode of acquisition, citizenship takes effect from the date of registration and not retrospectively. 


\section{Acquisition by naturalisation ${ }^{15}$}

Any person, including stateless persons, may apply to acquire Maltese citizenship by naturalisation if he or she has resided in Malta during the year immediately preceding the date of application and for a further aggregate period of at least four years over the past seven years immediately preceding the date of application, provided he or she has an adequate knowledge of the Maltese or English language, is of good character and is deemed to be a suitable citizen of Malta.

In practice, however, unless the applicant is of Maltese descent, as described below, the Department for Citizenship and Expatriate Affairs follows a strict policy of granting naturalisation only where the applicant has resided in Malta for quite a number of years and has children born in Malta. Every case is dealt with on its own merits and the Minister enjoys a non-reviewable discretion as explained below; but while in the past residence alone would not have been a ground for naturalisation, today the general policy is to consider favourably requests for naturalisation by residents who have been residing in Malta for a substantial number of years and have formed a family here. Income and property are not determining factors. Nor is any exception made to this long-term residence rule for labour migrants.

However, no residence conditions apply where the applicant was born abroad of a father that was likewise born abroad but the paternal grandfather and great-grandparent were both born in Malta. In such cases the person born abroad may apply for naturalisation merely on the strength of his or her Maltese descent. It should be noted, though, that the policy is that applications under this category would normally be accepted only if the applicant resides in Malta.

Likewise, no residence conditions apply where the applicant had been a citizen of Malta by birth before he or she emigrated from Malta and ceased to be a citizen of Malta or if he or she had emigrated before the date of independence and failed to obtain Maltese citizenship on independence merely because he or she had ceased to be a citizen of the United Kingdom and Colonies on the date of independence. There have been few applications under this category as most persons that fall under this category already enjoy dual citizenship.

Again, no residence conditions apply to persons who prove descent from a person born in Malta and who are citizens of a country other than the country of their residence and who are denied access to the country of which they are citizens. They may apply to acquire Maltese citizenship by naturalisation merely on the strength of their Maltese descent. However, there have been few instances of naturalisation under this category because not many persons would qualify under it, as it requires the applicant to produce all the birth and marriage certificates starting from his or her own birth up to the ancestor who was 
born in Malta. If the link is broken or cannot be proven by documentary evidence or if the birth certificate of the ancestor born in Malta cannot be traced, the application for citizenship would not be successful. Persons in this category are usually persons of Maltese descent residing in North African countries who may generally encounter great difficulties to trace the documents in these countries that would prove this descent.

Special rules apply for those who are and have always been stateless but were born in Malta of parents who are not citizens of Malta. In such cases the person is entitled to naturalisation as a citizen of Malta only if he or she has been ordinarily resident in Malta for a period of five years up to the date of his or her application and has not been convicted in any country of an offence against the security of the state or sentenced to a punishment depriving personal liberty for a term of not less than five years.

If the stateless person was not born in Malta but either of his or her parents was a citizen of Malta at the date of his or her birth, he or she is entitled to naturalisation as citizen of Malta only if he or she has been ordinarily resident in Malta for a period of three years up to the date of his or her application and has not been convicted in any country of an offence against the security of the state. So once again, where Maltese descent can be shown, the conditions for naturalisation are less stringent than where only the connection by birth on Maltese territory can be proved.

As in the case of citizenship by registration, where citizenship is acquired by naturalisation, it takes effect from the date upon which the applicant was naturalised. ${ }^{\mathrm{I}}{ }^{6}$ All applications are made to the Minister and there is no right of appeal against the decision of the Minister on any such application nor is such a decision subject to review in any court. ${ }^{17}$ However, in the Cabinet Citizenship Guidelines that were issued in 1987 , it is stated that all applications for citizenship by the following persons are given favourable consideration:

a. former citizens of Malta;

b. children born abroad of returned migrants;

c. foreign citizens born in Malta to a parent who is a citizen of Malta;

d. children born to parents who were non-Maltese but who later acquired Maltese citizenship; and

e. those born abroad but of Maltese descent.

It is stated that, on the other hand, applications from those who do not fall under any one of these categories will only be given favourable consideration if there are humanitarian grounds. ${ }^{18}$

Since the drawing up of these guidelines in 1987 , significant changes have been made to the Maltese Citizenship Act in 1989 and 
2000, as shown above. Hence those falling into categories (a) and (b) have practically all been re-instated as Maltese citizens or are now Maltese citizens automatically in view of the dual citizenship amendments to the law. Moreover, following these amendments, persons falling under category (c) may re-acquire Maltese citizenship simply by registration.

Though refugees in Malta are granted some rights they have no right to Maltese citizenship nor are there any provisions in the law that facilitate the granting of citizenship to refugees. ${ }^{\text {I9 }}$

Since, as stated above, the law prescribes that one of the conditions for naturalisation is that there should be evidence of the applicant's good character and suitability for citizenship, apart from being supported by documents attesting to the applicant's place of residence, birth and Maltese descent, the application in question must also be sponsored by persons that are deemed trustworthy (such as lawyers, notaries, magistrates, judges, members of parliament, police officers, medical practitioners, parish priests, etc.) who, having had occasion to assess the applicant in the course of exercising their profession or vocation, are thereby able to vouch for his or her integrity. As in the case of citizenship by registration, the applicant is required to take an oath of allegiance to the country before he or she may be naturalised.

\subsubsection{Modes of loss of citizenship}

Acquisition or retention of another citizenship no longer leads to the denial or forfeiture of Maltese citizenship as dual and multiple citizenship is now fully acknowledged by Maltese law. ${ }^{20}$ This also means that in the case of mixed marriages, the children can acquire the citizenship of both parents. The only ways in which citizenship may be lost are detailed below.

\section{Renunciation of citizenship ${ }^{21}$}

Any citizen of Malta who is also a national of another country may renounce citizenship by making a declaration to this effect and upon registration of this declaration he or she would cease to be a citizen of Malta. It is a condition for renunciation that the Maltese citizen should also be a national of another country so that acceptance of the renunciation would not lead to the person becoming stateless. Such renunciation may be refused if it is made during any war in which Malta is engaged or if in the opinion of the Minister it would otherwise be contrary to public policy. 
Deprivation of citizenship acquired by registration or naturalisation ${ }^{22}$ A citizen of Malta who acquired his or her citizenship by registration or naturalisation may be deprived of this citizenship by order of the Minister if the Minister is satisfied that:

a. the registration or naturalisation was obtained by means of fraud, false representation or the concealment of any material fact; or

b. the citizen has shown himself or herself by act or speech to be disloyal or disaffected towards the President or the government of Malta; or

c. the citizen has, during any war in which Malta was engaged, unlawfully traded or communicated with an enemy or been engaged in or associated with any business that was to his or her knowledge carried on in such a manner as to assist an enemy in that war; or

d. the citizen has within seven years after becoming naturalised or being registered as a citizen of Malta, been sentenced in any country to a punishment depriving personal liberty for a term of not less than twelve months; or

e. the citizen has been ordinarily resident in foreign countries for a continuous period of seven years and during this time has neither been at any time in the service of Malta or of an international organisation of which the government of Malta was a member nor given notice in writing to the Minister of his or her intention to retain citizenship of Malta.

However, in all of these cases a person shall be deprived of his or her citizenship only if the Minister is satisfied that it is not conducive to the public good that the person should retain his or her citizenship and in the case referred to in (d) above only if it appears to the Minister that that person would not thereupon become stateless.

Before the Minister issues an order depriving a person of his or her citizenship, the person concerned must be given notice in writing informing him or her of the ground on which the order will be issued and of his or her right to an inquiry. If the person requests an inquiry the Minister will have to refer the case to a committee of inquiry appointed by the Minister but presided over by a person with judicial experience.

\subsection{Statistical developments}

These legislative amendments, particularly the shift to dual and multiple nationality, and the 2007 amendments described below (see section I2.4) are reflected in the statistical developments in the period I9902008. Statistics from the Department for Citizenship \& Expatriate Af- 
Table 12.1 Acquisition of Maltese nationality by registration for 1998-2008 according to the grounds for registration

\begin{tabular}{|c|c|c|c|c|c|c|c|c|c|c|c|}
\hline Acquisition by registration & 1998 & 1999 & 2000 & 2001 & 2002 & 2003 & 2004 & 2005 & 2006 & 2007 & 2008 \\
\hline $\begin{array}{l}\text { By virtue of marriage via } \\
\text { art. } 4 \text { or art. } 6\end{array}$ & 107 & 75 & 162 & 682 & 354 & 240 & 267 & 197 & 197 & 228 & 160 \\
\hline $\begin{array}{l}\text { Resettling permanently in } \\
\text { Malta after having } \\
\text { emigrated and ceased to } \\
\text { be citizens of Malta via art. } \\
\text { 4(4) }\end{array}$ & 4 & 4 & - & - & - & - & - & - & - & - & - \\
\hline $\begin{array}{l}\text { Being children born abroad } \\
\text { to female citizens of Malta } \\
\text { via art. 5(2) (a) }\end{array}$ & - & - & 173 & 241 & 221 & 192 & 210 & 268 & 180 & 179 & 184 \\
\hline $\begin{array}{l}\text { Being former citizens of } \\
\text { Malta via art. } 8\end{array}$ & - & - & 177 & 139 & 109 & 64 & 37 & 25 & 29 & 21 & 25 \\
\hline $\begin{array}{l}\text { Minor children of Maltese } \\
\text { descent }\end{array}$ & - & - & - & - & - & - & - & - & - & 5 & 62 \\
\hline $\begin{array}{l}\text { Persons of Maltese des- } \\
\text { cent }\end{array}$ & - & - & - & - & - & - & - & - & - & 27 & 163 \\
\hline Total & 111 & 79 & 512 & 1,062 & 684 & 496 & 514 & 490 & 406 & 460 & 594 \\
\hline
\end{tabular}

Source: Department for Citizenship \& Expatriate Affairs

Figure 12.1 Number of naturalisations and registrations in Malta, 1990-2008

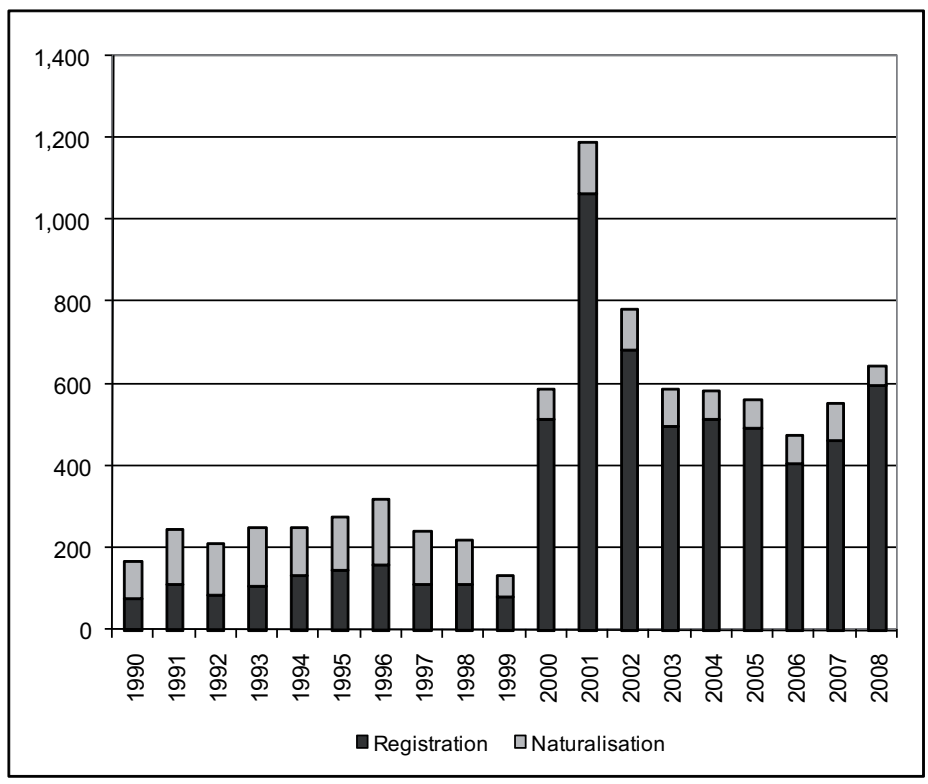

Source: Department for Citizenship \& Expatriate Affairs 
fairs for the years 1990-2008 show that the number of citizenships acquired by registration rose sharply from the year 2000 onwards (see Figure I2.I, which also shows that the change in policy regarding dual and multiple citizenship in 2000 had a greater effect on registrations than naturalisations). From an annual average of III in the I990 the number of registrations shot up to $5 \mathrm{I} 2$ in 2000 and I,062 in $200 \mathrm{I}$ and has remained in the region of 500 a year ever since.

The figure of $\mathrm{I}, 062$ in $200 \mathrm{I}$ remains the highest figure ever recorded for citizenship registrations in Malta. This increase is attributed by the National Statistics Office (NSO) in the Demographic Review 2001 to the removal of the prohibition against dual and multiple nationality by the legislative amendments that entered into force in February 2000. The figure remained high in 2002 when 684 registrations were recorded. ${ }^{23}$ This might be attributed to the fact that until 2002 Australian law prohibited dual and multiple nationality ${ }^{24}$ and this prevented the many Maltese emigrants residing in Australia from taking advantage of the changes in the Maltese legislation in 2000 and registering for Maltese citizenship. When Australia changed its law on 4 April 2002 and removed the prohibition, this resulted in a surge of registrations in 2002 by persons who were now able to retain both Maltese and Australian citizenship. ${ }^{25}$ In 2003 and 2004, the number of registrations decreased to 496 and 5I4, respectively, ${ }^{26}$ and remained at this level up to 2007 . The 2007 amendments, described in section 12.4. below, have again served to trigger an increase in citizenship registrations, though not to the level of the 2000 amendments since they affect more remote generations, raising the number of registrations to 594 in 2008 .

Table I2.I gives a breakdown of the figures for acquisition by registration for 1998-2008 according to the grounds for registration and shows that it was mostly (i) foreign spouses; (ii) children born abroad to female citizens of Malta; and (iii) former citizens of Malta who had lost their citizenship because of the possession or acquisition of another citizenship that took advantage of the change in policy regarding dual and multiple citizenship to acquire citizenship by registration. The last two grounds, 'minor children of Maltese descent' and 'persons of Maltese descent' are the new grounds introduced by the 2007 amendments.

\subsection{Recent reforms}

In 2007 important amendments to the Maltese Citizenship Act were passed by the House of Representatives (Act X of 2007) bringing three significant changes to Malta's citizenship law. 
First, in response to repeated requests by the Maltese diaspora, dual citizenship has been extended to second and subsequent generations of Maltese born outside Malta and living abroad. The I989 amendments to the Act had introduced dual citizenship for those who had been Maltese citizens by birth in Malta but who had emigrated and given up their Maltese citizenship, in order to enable them to reacquire Maltese citizenship. The 2000 amendments went a step further by extending dual citizenship to those who had been Maltese citizens by descent (i.e. because at least one of their parents was born in Malta) rather than by birth in Malta and who had subsequently lost this citizenship upon acquisition of citizenship in another country. This made it possible for children of Maltese emigrants born abroad to acquire or retain Maltese citizenship provided one of their parents had been born in Malta. However, this still excluded the offspring of these children, i.e. second and subsequent generations, from citizenship, because in their case, neither parent, though Maltese, had been born in Malta. The 2007 amendments extend dual citizenship to these generations, as the ius soli requirement was moved even further up the line of ancestry; provided that somewhere along the applicant's direct line of Maltese ancestry there is an ascendant who was born in Malta of a parent likewise born in Malta, applicants would be entitled to Maltese citizenship even though neither of their parents had been born in Malta.

Following the entry into force of the 2007 amendments on I August 2007 (LN I78 of 2007), art. 5 of the Citizenship Act now provides that those born outside Malta on or after the date of independence are entitled to apply for registration as citizens of Malta if they prove (through documentary evidence such as birth, marriage and death certificates) that they are the direct descendants of a Maltese ascendant born in Malta of a parent likewise born in Malta. However, if the applicant has parents, grandparents and other ancestors who are still alive and are also direct descendants themselves in this sense, they would also have to apply for Maltese citizenship under the new provision, as otherwise the Maltese citizenship link would have been broken down the line. If any of these ascendants entitled to Maltese citizenship died before I August 2007 or if a parent dies within three years from this date without applying for citizenship, he or she would still be deemed to have acquired citizenship for the purposes of this provision and so the line of Maltese citizenship throughout the generations would not be considered broken (i.e. a three-year grace period).

It has been reported that since the I989 amendments, the Citizenship Department has confirmed the right to dual citizenship for I2,250 applicants, a number that is expected to increase following this 2007 amendment, though not to the same extent, as obviously second-gen- 
eration and subsequent-generation Maltese are not as attached to Malta as first-generation Maltese. ${ }^{27}$

The second amendment, which came into force on 6 July 2007, makes an exception to the rule that a spouse of a citizen of Malta may acquire citizenship only five years after the marriage. A new provision in art. Io provides that the Prime Minister may, by means of a notice published in the Government Gazette, authorise the Minister to grant a certificate of naturalisation to the spouse of any citizen of Malta without any residence requirements when either the spouse or the said citizen has rendered 'exceptional services' to Malta or humanity.

A third amendment that entered into force on I August 2007 rectified an anomaly in the Act. Hitherto, those who were born outside Malta before the date of independence were deemed to have automatically acquired Maltese citizenship on the date of independence only if they were citizens of the United Kingdom and Colonies up to that date and their father and a paternal grandparent were both born in Malta. Conversely, those with a non-Maltese father whose mother and a maternal grandparent had both been born in Malta could acquire citizenship only by satisfying a five-year residency requirement. The amendments now redress this anomaly by introducing new provisions in art. 3 that remove this residency requirement and entitle such persons irrespective of any residency period to be registered as Maltese citizens because of their mother's and a maternal grandparent's birth in Malta. Moreover, the first amendment concerning dual citizenship for second and subsequent generations described above also benefits those born abroad before the date of independence who prove that they are descendants in the direct line of an ascendant born in Malta with a parent likewise born in Malta.

Apart from these legislative amendments, a policy decision has recently been taken that benefits a small category of foreigners who, while themselves not qualifying for Maltese citizenship in terms of the Maltese Citizenship Act, have children who are Maltese citizens because they were born in Malta before 1989, when the law as it stood then conferred citizenship on them, notwithstanding that they were not of Maltese descent. Maltese citizenship has been extended on the basis of a policy decision to these parents if they have been residing in Malta for fifteen years. ${ }^{28}$

\subsection{Conclusions}

The main motive for the acknowledgement of dual and multiple citizenship was to do justice to the thousands of Maltese citizens who had lost their citizenship when, due to economic circumstances, they had 
been forced to emigrate to seek work overseas and thereby acquired foreign citizenship. By extending citizenship to the third generation, the link to the diaspora has been extended beyond former Maltese citizens. Not only have Maltese diaspora regained their legal ties to their or their ancestors' homeland but, following Malta's accession to the European Union, they may now also partake of the benefits of European citizenship. Throughout the years, through its participation in international fora debating nationality issues Malta has regularly reviewed and revised its nationality policies in line with evolving concepts so that gender inequalities and other forms of discrimination prevailing in the law have now been mostly redressed bringing the legal regime in line with international trends.

However, although Malta has signed, though not yet ratified, the European Convention on Nationality, the Maltese Citizenship Act has yet to fully embrace the principle of non-discrimination between its nationals incorporated in art. 5(2) of the Convention as the provisions on deprivation of citizenship in art. I4(2) of the Act discriminate against persons who acquired citizenship by registration or naturalisation. Maybe this is one reason why Malta has yet to ratify the Convention that it signed on 29 October 2003 , though it should be noted that art. 5 (2) of the Convention does not have a mandatory effect but only constitutes a 'declaration of intent' by the signatories. ${ }^{29}$ This discriminatory issue has not been the subject of any public debate or controversy in Malta.

Following accession to the European Union, although accession itself did not necessitate changes in Maltese citizenship laws as the laws were already in consonance with internationally accepted norms, the fact that Maltese citizenship now automatically confers European citizenship rights on holders of Maltese citizenship means that Maltese authorities must now consider the wider implications of any policy changes relating to the acquisition and loss of citizenship, particularly in relation to its immigration policy.

Chronological list of citizenship-related legislation in Malta

\begin{tabular}{|c|c|c|c|}
\hline Date & Document & Content & Source \\
\hline 1964 & $\begin{array}{l}\text { Constitution of Malta } \\
\text { (chapter III) }\end{array}$ & $\begin{array}{l}\text { Contains provisions } \\
\text { conferring and regulating } \\
\text { Maltese citizenship based } \\
\text { on a combination of the } \\
\text { ius soli and ius sanguinis } \\
\text { principles and prohibiting } \\
\text { dual or multiple } \\
\text { citizenship }\end{array}$ & http://docs.justice.gov.mt \\
\hline
\end{tabular}




Date Document Content Source

1965 Maltese Citizenship Act, Introduces more detailed http://docs.justice.gov.mt chapter 188 of the Laws of provisions and regulates in Malta particular the acquisition of Maltese citizenship by registration and naturalisation

1974 Act LVIII amending the Maltese Citizenship Act and the Constitution of Malta

1975 Act XXXI amending the Maltese Citizenship Act

1977 Act IX amending the Maltese Citizenship Act

1989 Act XXIII amending the Constitution of Malta and Act XXIV amending the Maltese Citizenship Act

2000 Act III amending the Constitution of Malta and Act IV amending the Maltese Citizenship Act
Amendments necessitated http://docs.justice.gov.mt by Malta's transformation into a republic

Slightly amends provisions http://docs.justice.gov.mt on naturalisation

Prohibits acquisition of http://docs.justice.gov.mt citizenship by adoption Introduces an exception to http://docs.justice.gov.mt the prohibition against dual citizenship for expatriates; shifts to a rule based more on ius sanguinis than on ius soli by providing that mere birth in Malta would no longer suffice to confer citizenship at birth but must be accompanied by Maltese descent of at least one of the parents; amends some of the provisions that were resulting in gender inequality; reintroduces acquisition of citizenship by adoption; removes the distinction between Commonwealth citizens and other foreigners for naturalisation purposes; extends the grounds for naturalisation

Allows dual and multiple citizenship; introduces restrictions in the provisions on spousal transfer of citizenship to discourage marriages of convenience; transfers the detailed provisions on citizenship in chapter III of the Constitution to the Maltese Citizenship Act http://docs.justice.gov.mt 


Date Document Content $\quad$ Source

2007 Act $X$ amending the Maltese Citizenship Act

\author{
that thereby becomes the \\ main law regulating \\ citizenship while the \\ Constitution now only \\ contains the general \\ principles on citizenship; \\ makes further \\ amendments to redress \\ gender inequality; \\ introduces provisions to \\ improve the position of \\ foundlings \\ Introduces the right to http://docs.justice.gov.mt \\ dual or multiple \\ citizenship for second- and \\ subsequent- generation \\ Maltese born outside \\ Malta and living abroad; \\ introduces an exception to \\ the five-year rule for \\ spouses of Maltese \\ citizens who render \\ 'exceptional services' to \\ Malta or humanity; \\ extends citizenship by \\ registration to persons \\ born abroad before 1964 of \\ a non-Maltese father if \\ their mother and a \\ maternal grandparent were \\ both born in Malta
}

\section{Source}


9 Ibid., arts. 3-5, I7.

Io Except in the case of illegitimate children where the national status of the mother becomes relevant - ibid. art I7.

II Ibid., art. 9.

I2 Ibid., art. I7.

I3 Ibid., arts. 4 and 6.

I4 Ibid., arts. 8 and 9 .

I5 Ibid., art. Io.

I6 Ibid., art. I2.

I7 Ibid., art. I9.

I8 These guidelines currently appear on the website of the relevant ministry, the Ministry for Justice and Home Affairs, www.mjha.gov.mt.

I9 However, recently a government minister (Minister for the Family and Social Solidarity, Dolores Cristina, as reported in The Times of I8 June 2005 on p. I9) announced that the government is considering a change in policy in this regard in favour of granting citizenship to refugees who have been living in Malta for ten years so as to enable them to integrate better into society. So far, however, there has been no official change in policy on these lines.

20 Maltese Citizenship Act, art. 7 and art. 22(2) of the Constitution.

2I Maltese Citizenship Act, art. I3.

22 Ibid., art. I4.

23 Demographic Review 2002, National Statistical Office (NSO) 2003.

24 Art. I7 of Australia's law on citizenship did not allow dual citizenship so that citizens of Australia would lose citizenship if they acquired another citizenship voluntarily through registration.

25 Ministry for Justice and Home Affairs, Annual Report 200I-2002.

26 Demographic Review 2003, NSO 2004.

27 Home Affairs Minister Borg, House of Representatives, sitting of I3 February 2007 and press conference of I5 May 2007. However, for the second and subsequent generation Maltese living in a non-EU country, such as Australia, the US and Canada, and the much smaller communities still living in Egypt and Tunisia, there is the added attraction that Maltese citizenship brings with it the right to travel, study, live and work in any EU country.

28 Home Affairs Minister Borg, House of Representatives, sitting of I3 February 2007.

29 Explanatory Report to the European Convention on Nationality, point 45. 



\title{
13 Nationality and citizenship in Cyprus since 1945: Communal citizenship, gendered nationality and the adventures of a post-colonial subject in a divided country
}

\author{
Nicos Trimikliniotis
}

Mapping out the complex historical, structural, politico-legal and cultural setting that has generated a specific mode of nationality in the context of Cyprus is no easy task. In fact, we cannot speak of a nationality policy as such; such a policy has never been formally declared or publicly discussed, save for times in which the media hysterically criticised the granting of nationality. ${ }^{\mathrm{I}}$ It is, however, possible to deduce a policy from the practices since independence (Trimikliniotis 2005).

In an area of $9,25 \mathrm{I} \mathrm{km},{ }^{2}$ the total population of Cyprus is around 754,800, of whom 666,800 are Greek-Cypriots (living in the Cyprus Republic-controlled area). Upon independence in 1960, TurkishCypriots constituted i 8 per cent of the population, whilst the smaller 'religious groups', as referred to in the Constitution, consisting of Armenians, Latins, Maronites and 'others' (such as Roma), constituted 3.2 per cent of the population. It is the third largest island in the Mediterranean; its geographical position, in the far eastern part of the Mediterranean Sea, historically adjoining Europe, Asia and Africa has been both a blessing and a curse. Invaders and occupiers for centuries sought to subordinate it for strategic reasons, followed by British colonial rule.

It became an independent Republic in 1960. In the post-colonial years, there was inter-communal strife and constant foreign intervention of one kind or another, until I974 when a coup by the Greek junta and EOKA $\mathrm{B}^{2}$ was used as a pretext for an invasion by the Turkish army and the subsequent division of the island (Hitchens 1997; Attalides 1979). Turkey still occupies 34 per cent of the territory, whilst 200,000 remain displaced and 80,000 Turkish-Cypriots remain in the northern, occupied territories. Attempts to resolve the Cyprus problem have not been successful. Following the overwhelming rejection of the UN plan to resolve the problem by the Greek-Cypriots and the overwhelming endorsement on the 24 April 2004 by the Turkish-Cypriots, Cyprus has entered the EU with the Cyprus problem in a state of limbo. Cypriot policymakers still hope that the policy of accession to the 
EU will eventually act as a catalyst in the effort to find a settlement, but in the immediate aftermath of the referenda the two sides were divided about how to proceed (Hannay 2005; Palley 2005). ${ }^{3}$ The election of Demetris Christofias as President of the Republic of Cyprus in February 2008 has given new impetus to solving the Cyprus problem. Direct negotiations between Christofias and Talat, the two community leaders, began in September 2008.

To evaluate the question of nationality and citizenship, one is forced to view the ever-present 'Cyprus problem' in the historical and politicosocial context of the island and the wider troubled region of the near Middle East. While the 'Cyprus problem' persists and the de facto divide continues, the politics of 'citizenship' has not been 'frozen' in time. Citizenship has played a central role in political discourse, both during and following the referendum on the UN plan in April 2004. The particular construction of the Cyprus Republic was such that the struggle for legitimacy was elevated to the primary struggle for control of the state. In this conflict the two communal leaderships - the Greek-Cypriots and the Turkish-Cypriots - sought to materialise their 'national aspirations': For Greek-Cypriots the aim for Enosis (union with Greece) and for the Turkish-Cypriots the goal of Taksim (partition) would continue post-independence. The very concept of citizenship was not only ethnically/communally defined by the Constitution, but it was also a sharply divisive issue between the Greeks and Turks, acquiring strong ethnic and nationalistic overtones (see Tornaritis 1982; Chrysostomides 2000; Trimikliniotis 2000).

\subsection{History of nationality policy since 1945}

13.1.1 The national subject under the colonial spell: 'Modernising' the millet system, divide and rule and the rise of irredentist nationalism

Following the opening of the Suez Canal in 1864 , the UK persuaded the Ottomans to cede Cyprus to the UK. ${ }^{4}$ The British colonialists took over from the Ottoman rulers by order of Council on 7 October 1878. They immediately embarked on a programme of 'modernisation' from above and from outside by introducing an administrative system superseding Ottoman law with English law. Britain formally annexed Cyprus in I9I4, following Turkey's support for Germany in the First World War; in I923, under the Treaty of Lausanne, Turkey formally relinquished all its claims to Cyprus and it became a Crown Colony in I925.

In the historical setting prior to the modern era, 'identity' was not based on 'ethnicity': The notion of 'citizenship' did not exist under Ottoman rule outside the millet system. This implied that the Ottomans 
basically recognised the religious leaders of the flock and were co-operating with them in the administration (Katsiaounis 1996; Kyrris I980). ${ }^{6}$ With the annexation of Cyprus by Britain, Cypriots became 'natives of the colony', but the essential characteristics of the Ottoman millet system, a system that was based on communal organisation and leadership along the lines of faith, were the bases upon which the faith-groups would be 'modernised' as ethnic communities. Hence, the Muslim community and Christian-orthodox community millets were gradually 'modernised' by the British administrator. There was a transformation of the quasi-medieval community elites into 'ethno-communal' elites: on the one hand, the traditional religious leader of the Christian Orthodox flock, the archbishop, became the leader of the Greek community and, on the other, the old Ottoman administrators, who represented the fusion of the political and religious order of the sultanate-caliphate at local level, were transformed into the new political leadership of the Turkish community. The Cypriot 'natives of the colony' were thus gradually ethnocised. Nevertheless, the leaders of the autocephalous Greek-orthodox Church retained their 'ethnarchic role' (i.e. political leadership of the flock), despite the serious challenge from the mass secular movement AKEL (the Progressive Party for the Working People) from the I940s onwards (Katsiaounis 2007). Moreover, the old Ottoman administrators were eventually transformed into the Kemalist elite, following the rise of Mustafa Kemal to power in the Turkish Republic (which succeeded the Ottoman empire). ${ }^{7}$

\subsubsection{Moments of (in)dependence: Ethno-communal citizenship and the nationalising of legally divided subjects (1959-1963)}

The establishment of the Cyprus Republic marks an important development in the history of Cyprus, as the island became an independent republic for the first time since antiquity, albeit in a limited way (see Attalides I979; Faustmann 1999). The anti-colonial struggle had started in the I930s. ${ }^{8}$ The four-year armed campaign by the Greek-Cypriot EOKA (I955-59) for Enosis and the Turkish-Cypriot response for Taksim brought about a regime of 'supervised' independence by three foreign 'guarantor' nations (UK, Turkey and Greece). The Cyprus Constitution, adopted under the Zurich-London Accord of 1959, contains a rigorous bi-communalism, whereby the two 'communities', Greek-Cypriots, who made up 78 per cent of the population, and Turkish-Cypriots, who accounted for $\mathrm{I} 8$ per cent of the population, share power in a consociational system. Citizenship is strictly ethno-communally divided. There are also three other minority groups who have the constitutionally recognised status of 'religious groups': the Maronites, the Armenians and the Latins. In addition, there is a small Roma commu- 
nity, registered mostly as part of the Turkish-Cypriot community, but never recognised as a minority group (Trimikliniotis \& Demetriou 2009).

\subsubsection{The 'national' rift: Collision and division between Greek-Cypriots and Turkish-Cypriots (1963-1974)}

In I963, following a Greek-Cypriot proposal for amendment of the Constitution, the Turkish-Cypriot political leadership 'withdrew' from the government. Since then, the administration of the Republic has been carried out by the Greek-Cypriots. Inter-communal strife ensued until ig67. In 1964, the Supreme Court ruled that the functioning of the government must continue on the basis of the 'law of necessity', or, better yet, the 'doctrine of necessity', in spite of the constitutional deficiencies created by the Turkish-Cypriot withdrawal from the administration. ${ }^{9}$ The short life of the consociation did not manage to generate a strong enough inter-communal or trans-communal citizenship. This brief period of peaceful inter-communal political co-existence was tentative; we cannot therefore speak of a 'nationality policy' as such, above and beyond the politics of the Cyprus conflict and the separate national aspirations of Greek and Turkish Cypriots, who continued to work towards Enosis and Taksim respectively, even after independence. Although de iure the Republic continued to exist as a single international entity, in practice there were two de facto regimes in the enclaves, each group controlled, one for the Greek-Cypriots and one for the Turkish Cypriots - a situation aptly called 'the first partition' by one scholar (Droussiotis 2005). The fierce fighting between 1963 and I967 was followed by efforts to reconciliation until I974, but these efforts failed.

\subsubsection{The de facto partition: 1974-2003 following the invasion and occupation}

Since 1974 the northern part of Cyprus, some 35 per cent of its territory, has been under Turkish occupation and outside the control of the Cyprus government. Some roo Greek-Cypriots inhabit the northern territory, whilst only a few hundred Turkish-Cypriots continue to live in the government-controlled south (ECRI 200I, 2006; Kyle 1997) However, since the end of May 2003 the regime in the occupied territories has allowed Turkish-Cypriots to visit the Republic-controlled south on the condition that they return before midnight and the Greek-Cypriots to visit the north, on the condition of passport inspection and with restrictions on their stay.

During this 30-year period the de facto partition meant that in effect there were two separate 'stories' about nationality: the story of the 
Greek-Cypriots, who lived in the reduced territory of the internationally recognised Republic of Cyprus, and that of the Turkish-Cypriots, who lived under an unrecognised regime, the 'Turkish Republic of Northern Cyprus', which relied heavily on Turkey to maintain it. Turkish-Cypriots are entitled to citizenship/nationality of the Cyprus Republic and tens of thousands obtained a passport. However, the vast majority did not have access to the authorities and was not allowed to cross over to the 'other side' by the occupying regime; up to April 2003 there were few opportunities for ordinary Greek-Cypriots and Turkish-Cypriots to meet; while Greek-Cypriots did not have access to the occupied territories, Turkish-Cypriots were not allowed by the regime in the north to enter the area controlled by the Republic.

The period between 1974 and 2003 was characterised by the attempts of the break-away regime to consolidate partitionism in Cyprus (Dodd I993). In spite of the efforts to reach an agreement on a solution based on the 'High Level Agreements' of 1977 and 1979 ' Turkish side continued its route towards separatism. The 'Turkish Republic of Northern Cyprus' (TRNC), a regime recognised only by Turkey, was declared.

The constitution of the TRNC provides for an ethno-religious-based nationality and citizenship to a large extent reproducing the provisions of the Cyprus Republic (Dodd I993). However, TRNC nationals cannot make use of the nationality of an unrecognised state. Hence, many Turkish-Cypriots sought passports from Turkey (see Kadirbeyoglu in this volume) and the Republic of Cyprus - particularly after accession to the EU. In the late I99os, the TRNC leadership attempted to criminalise the access to the passport of the Republic of Cyprus, but such efforts were subsequently abandoned as the numbers of Turkish-Cypriots seeking passports grew and there was a reversal of this policy once the Annan Plan (version I) was first introduced in late 2002. In fact, many Turkish-Cypriot politicians now criticised the authorities of the Republic of Cyprus for failing to respond quickly enough to ensure the swift and full provisions of access to citizenship, passports and the public goods that are available to the nationals of the Republic of Cyprus.

During the post-I974 period the Republic of Cyprus attempted to reinforce its legitimacy claiming that Turkish-Cypriot citizens enjoy full and equal rights under the Republic's Constitution, such as general civil liberties and the rights provided by the European Court of Human Rights (ECHR) as well as other human rights, save for those provisions, that have resulted from (a) the 'abandoning' of the governmental posts in 1963-1964 and (b) the consequences of the Turkish invasion. The 'doctrine of necessity' would apply to allow for the effective functioning of the state, whilst the relevant provisions of the Constitution would be temporarily suspended, pending a political settlement (for 
more on this, see Chrysostomides 2000; Loizou 200I). However, Turkish-Cypriot citizens of the Republic had been denied their electoral rights since 1964 , a matter that was found to be in violation of the European Convention on Human Rights, ${ }^{\text {II }}$ save for the European Parliament elections in 2004. A new law was passed to at least partially remedy the situation before the parliamentary elections in May 2006.

All of the Republic of Cyprus governments have maintained that Turkish-Cypriots are entitled to full citizenship rights and the nationality of the Republic. The children of Cypriots who now reside in the occupied territories or abroad and were born after 1974 are entitled to nationality (as with Greek-Cypriots and 'others'). The bureaucratic elements involved are due to the non-recognition of any documentation such as e.g. birth certificates from the TRNC. ${ }^{\text {I2 }}$ The policy regarding the treatment of Turkish-Cypriots, who are Cyprus Republic nationals, is rather contradictory. This reflects the complexity of the Cyprus conflict and the constant conflict for legitimacy and recognition. Inevitably, 'the discourse of recognition' (Constantinou \& Papadakis 2002) spilledover into nationality politics, making a mess of the official policy of 'rapprochement'. Ultimately, the consequences of the situation resulted in failing to properly treat ordinary Turkish-Cypriots as 'strategic allies', in the context of independence from the Turkish-Cypriots' nationalistic leadership, who are perceived as 'mere pawns of Ankara'.

Even today, the Republic of Cyprus seems to be failing to address certain basic matters: Since Turkish is an official language of the Republic, allowing Turkish-Cypriots to communicate with government officials in their own language and making the laws, regulations and forms available in Turkish is a matter that could have been resolved, without much difficulty, and would protect the Republic from claims of discrimination and unconstitutionality (Trimikliniotis \& Demetriou 2008). Moreover, the enjoyment of all rights, including the right to property (of those Turkish-Cypriots who fled their homes in I9 $_{3}$, I967 and I974), could have been handled with greater sensitivity and care, so that the Turkish-Cypriots, who are Cypriot citizens, would feel more welcome. At the same, time one has to appreciate the context, particularly the massive displacement of I0०,००० Greek-Cypriots from the north, many of whom are housed in Turkish-Cypriot properties.

\subsubsection{New issues for nationality/citizenship policies}

In the I990s and early 2000, a number of key issues opening up the issue of citizenship and nationality and requiring a declared and consistent policy emerged.

First, the arrival of migrant workers, who today make up i5 per cent of the total working population of the island, is a significant factor al- 
tering the ethnic make up of the population. Although the initial design was that they be 'temporary', they seem to be a permanent feature of Cypriot society (Matsis \& Charalambous I993; Trimikliniotis 1999; Trimikliniotis \& Pantelides 2003; Trimikliniotis \& Demetriou 2007).

Second, the arrival of Turkish-Cypriot Roma from the poorer (occupied) north in the south between 1999 and 2002 created a panic that they were being 'flooded' with 'gypsies'. In spite of the fact that we are dealing with a group of Cypriots, who moved to the south, the reaction of the authorities, the media and the public at large displayed a hostile attitude as if they were undesirable 'alien citizens'. Studies indicate that there is wide-spread resentment by the local Greek-Cypriot residents to the Turkish-speaking Roma coming to their neighbourhood in Limassol and 'causing trouble'. There is evidence of discrimination against Roma in the Republic (Spyrou 2003; Trimikliniotis 2003; Trimikliniotis \& Demetriou 2009), as they are generally viewed with suspicion by Greek-Cypriots, but also by Turkish-Cypriots. The arrival of large numbers in the south was greeted with fear and suspicion, ${ }^{13}$ particularly when the then Minister of Justice and Public Order alleged that they may well be 'Turkish spies', ${ }^{\text {I4 }}$ whilst the Minister of the Interior assured Greek-Cypriots that the authorities 'shall take care to move them to an area that is far away from any place where any people live', in response to the racially motivated fears of local Greek-Cypriot residents. ${ }^{15}$ The socio-economic position of this generally destitute group renders them particularly vulnerable and dependent on welfare; the rights that derive from their citizenship status were thus mediated by the way various state authorities approached them (e.g. their lifestyle and harassment means that many do not have the necessary documents for claiming nationality such as birth certificates, identity cards, etc.). Hence the failure to take into account the socio-economic conditions of the Roma may result in the denial of the right to obtain a passport, as was found in cases investigated by the Cyprus Ombudsman. ${ }^{16}$

Third, the opening of the 'borders' which allowed many thousands of Turkish-Cypriots to visit the south were generally greeted by both Turkish-Cypriots and Roma residing in the south with relief and optimism. ${ }^{17}$ However, there was a tense atmosphere generated in the run up and aftermath of the referendum on the Annan plan to reunite the island on the 24 April 2004, the rejection of which by the GreekCypriots has given rise to nationalist sentiments in the south (see Hadjidemetriou 2006). The political atmosphere has drastically changed since the presidential election in February 2008 and the beginning of new negotiations to resolve the problem.

The fourth issue concerns the children of settlers who are married with Turkish-Cypriots. This is a highly controversial issue as it brings out the conflict over the nature of the Cyprus problem: the Turkish pol- 
icy of colonising the north seems to be a major obstacle to a solution. There is a misguided conflation of the internationally condemned policy by an aggressor country, with the fact that we are also dealing with some basic rights and humanitarian issues relating to the rights of children and individuals who marry, found families and continue with their lives. The granting of nationality rights to children and spouses of Turkish-Cypriots is a major political issue which has increasingly taken up the headlines and is discussed in the last section of this chapter. Moreover, the condemnation of a war crime (colonisation) must not be conflated and confused with issues regarding the conditions of sojourn and living conditions of poor undocumented workers, who are primarily present to be exploited as cheap foreign labour.

Finally, the issue of gender has become an important issue as regards citizenship. The position of women in the processes of nationbuilding and nationalism raises the crucial question of a gendered Cypriot nationality, in what one scholar referred to as the one remaining bastion of male superiority in the present territorially divided state' (Anthias I989: 150). This last 'bastion' was formally abolished with an amendment of the citizenship law in 1999 (No. 65/99), which introduced entitlement to citizenship for descendants of a Cypriot mother and a non-Cypriot father. The apparent reluctance of Cypriot policymakers to amend the citizenship law, allegedly due to the concern about upsetting the state of affairs as it existed prior to I974, cannot stand closer examination. After all, there have been seven amendments to the citizenship law prior to the amendment No. 65/99. It is apparent that the issue of gender equality had not been a particularly high political priority. Besides, in the patriarchal order of things, the role of Cypriot women as 'symbolic reproducers of the nation', particularly in the context of 'national liberation', as transmitters of 'the cultural stuff', required that potential association and reproduction of women with men outside the ethnic group be strictly controlled (Anthias I989: 151).

\subsubsection{The rise of trans-communal subjectivity: Challenging the ethno- communal boundaries}

On 23 April 2003 there was a sudden decision by the authorities of the unrecognised TRNC, to partially lift the ban on freedom of movement. This has taken most by surprise (Demetriou 2007), as the TRNC was abandoning the long-term vigorous opposition to Greek-Cypriot and Turkish-Cypriot contacts. The Turkish-Cypriot leadership allowed the possibility for a course of action the peace and rapprochement movement had been advocating for years; yet the move was certainly a surprise. The issue of 'passport control' between the check points became an issue of tension between Greek-Cypriot politicians and media and 
their Turkish-Cypriot counterparts. However, this bureaucratic measure which attempts to force on people the issue of 'recognition' has become part of the 'struggle for legitimacy and recognition' between the two political regimes, even though it is up to states and international organisations to recognise them.

Cross-boundary contacts and interaction opened up new possibilities for nationality policy, as the barbed-wire at last became penetrable. The fluidity of the situation allows greater scope for citizens' initiatives aiming at reunification (see Demetriou 2006, 2007) and has opened up the debate on reconciliation in Cyprus (Kadir 2007; Sitas, Latif \& Loizou 2007; Trimikliniotis 2007). The current measures cannot be a substitute for a settlement; it is an awkward state of limbo, whereby the 'nationals' are divided along ethnic lines, even though all Turkish-Cypriots are entitled to citizenship in the Republic of Cyprus and many thousands have actually acquired citizenship and passports. The contact since 2003 has created a pattern whereby a consistent number of persons cross over for work, leisure or other activities, estimated at about 20 per cent of the population. ${ }^{\mathrm{I}}$ The Third ECRI Report on Cyprus notes that a large number of Turkish-Cypriots has been issued with Cyprus passports $(35,000)$, identity cards $(60,000)$ and birth certificates $(75,000)$, all of which are relevant figures as far as Cypriot citizenship is concerned (ECRI 2006: para. 78). Interestingly, according to the Demographic Survey Report (PIO 2006: I2), the population of Cyprus is estimated at 854,300 at the end of 2005 (compared to 837,300 at the end of the previous year), of whom 766,400 live in the territories under the control of the Republic. Turkish-Cypriots are said to be 87,000 persons, Greek-Cypriots 656,000 and foreign citizens IIo,000. The same report estimates, on the basis of data from Turkish Cypriot sources, that about 58,000 Turkish Cypriots have emigrated since I974. The number of 'illegal settlers from Turkey' is said to be 'most probably in the range of I50-I6o thousand, which is estimated on information of significant ${ }^{\mathrm{I} 9}$ arrivals of Turks in the occupied area' (PIO 2006: II). The study by Hatay (2005) shows significantly lower figures for settlers and higher numbers for Turkish-Cypriots. The population issue remains a hotly contested issue, not only between the two communities, but also within the Turkish-Cypriot community (see Hatay 2008; Faiz 2008).

\subsection{Modes of acquisition and loss of citizenship}

Following the annexation of Cyprus by the UK, ${ }^{20}$ all Ottoman citizens who were born in or normally resided in Cyprus became British subjects. $^{2 \mathrm{I}}$ From that day on the basic law regarding the granting of na- 
tionality in Cyprus was the British Nationality and Status of Aliens Act of I9I4 and later the I948 British Nationality Act. Post-independence art. I9 8 of the Constitution of the Cyprus Republic, and Annex D of the Treaty of Establishment, which was annexed to the Constitution, regulated the initial determination of the citizenry and the granting of citizenship/nationality. Annex D was implemented with independence, as required by art. I95, which provides for the general principle of international law that all residents of the former colonial territory would automatically become citizens of the Republic (Tornaritis I982: 35; Loizou 200I: 44I). ${ }^{22}$ Art. I98.I(b) provided that:

any person born in Cyprus, on or after the date of the Constitution coming into force, shall become a citizen of the Republic if on that date his father has become a citizen of the Republic or would but for his death have become such a citizen under the provisions of Annex D of the Treaty of Establishment.

This was the case until the enactment of the main Law on Citizenship in I967. ${ }^{23}$ In 2002, a new Law on the Population Data Archives No. I4I(I)/2002 unified all provisions regarding the archiving of births and deaths, registration of residents, registration of constituent voters and the registration of citizens. It also introduced special provisions for the issuing of passports and travel documents and refugee identity cards to refugees. The new Law has so far been amended four times; however, none of these changes affected the acquisition and loss of citizenship. ${ }^{24}$ Together with Annex D this law currently regulates the acquisition and loss of Cypriot citizenship.

Cypriot policy-makers have followed the 'mixed' principle that combines ius soli and ius sanguinis (Tornaritis I982: 38-39). However, ius sanguinis is far more important in the regulations than ius soli, as Cypriot descent is the primary criterion for acquisition of citizenship as will be shown further down. Citizenship can be acquired automatically, via registration and naturalisation, but at the core of citizenship policy remains the notion that all persons of Cypriot descent are entitled to apply.

\subsubsection{Acquisition by descent}

A person born in Cyprus or abroad on or after I6 August i960 automatically acquires Cypriot citizenship provided that at the time of his or her birth either of the parents was a citizen of the Republic or, in the case that the parent(s) were deceased at the time of his or her birth, either of them was entitled to acquire citizenship had he or she not been deceased. In cases of permanent residents abroad, this provision 
is not applicable unless the child's birth is registered in the prescribed manner. ${ }^{25}$ Moreover, there are two exceptions to this general rule:

Firstly, the current law provides that children born to parents, one of whom unlawfully entered or resides in the Republic, do not automatically become citizens of Cyprus even if the other parent holds or would have been entitled to Cypriot citizenship. They can become citizens only following a decision of the Council of Ministers. ${ }^{26}$ This amendment was apparently directed against Turkish nationals who settled in the north at a time when it was deemed politically 'necessary' or 'expedient' by policymakers. However, it is obviously discriminatory against persons who have Turkish-Cypriot descent from one parent and is contrary to the Constitution and international obligations of the Republic.

Whether children of Turkish nationals should be granted Cypriot citizenship is a hot political issue and there are conflicting accounts of what categories of persons are affected. Media reports and right-wing politicians seem to concur that the issue at stake is the granting of citizenship to children who have one Cypriot parent and another who is a settler. However, ministry officials claim that persons falling under this category are invariably granted nationality, albeit in a manner that does not cause strong reactions. ${ }^{27}$ In any case, making a child's nationality conditional on the status of 'legality' or 'illegality' of the parents, or even worse of one of the two parents, not only violates the rights of children, as provided for in the UN Convention for the Rights of the Child, but also constitutes discrimination against the children who are victimised by the political situation and whom the Republic has an obligation to protect and respect. Due to the lack of transparency, it is not possible to assess the implementation of this law. The Third ECRI Report on Cyprus (2006: 8) notes that the Cyprus Ombudsman is currently investigating 'the conformity of this procedure with national and international standards'. Moreover, it notes that 'citizenship has been granted by this procedure to children whose Cypriot parent was a Turkish Cypriot and whose other parent was a citizen of Turkey'; however, it also states that 'decisions to grant nationality have resulted in intolerant and xenophobic attitudes in public debate'.

Secondly, sect. I09(3) of law I4I(I)/2002 expressly prescribes that the above provisions for acquisition of citizenship do not come into force in cases where a person is born in Cyprus or abroad between i6 August I960 and II June 1999, if his or her claim is based solely on his or her mother's citizenship, or the fact that she was entitled to citizenship of the Republic. However, the law stipulates that the person (or if the person is a minor, his or her father or mother) may submit an application to the minister to be registered as a citizen of Cyprus. The Equality Body of Cyprus examined a complaint claiming discrimination on the grounds of sex/gender and nationality (and indirectly 
ethnic or racial origin) for descendants of women of Cypriot origin born between I6 August I960 and II June 1999. ${ }^{28}$ The Equality Body (the Ombudsman in its capacity as the Equality and Anti-discrimination Body) considered that the said provision was indeed discriminatory; however, in a rather obscure decision, it refused to take any further action, due to the 'transitory nature of the provision, to counter the situation and the expectations that had formed up to 1999 on the basis of the regimen of acquiring citizenship. ${ }^{29}$ In any case, they are entitled to obtain nationality via registration.

Another mode of acquisition (sect. Io9(3)) is provided for persons born on or after 16 August 1960 and who are of Cypriot origin, i.e. descendants of a person who:

a. became a British citizen on the basis of the Cyprus (Annexation) Order-in-Council between I9I4 and I943; or

b. was born in Cyprus between 5 November I9I4 and I6 August I960 during which time his or her parents were ordinarily resident in Cyprus.

These persons are entitled to be registered as citizens provided that they are adults and of sound mind, ${ }^{30}$ apply to the minister ${ }^{3 \mathrm{I}}$ via the designated means and provide an official confirmation of loyalty to the Republic, according to the format provided in the Second Table annexed to the law. ${ }^{32}$

\subsubsection{Acquisition via registration}

The following persons are entitled to be registered as Cypriot citizens upon application to the relevant Minister:

I. Citizens of the United Kingdom and Colonies or a country of the Commonwealth, ${ }^{33}$ who are of Cypriot descent, ${ }^{34}$ provided that they:

- ordinarily reside in Cyprus and/or resided for a continuous period of twelve months in Cyprus or a shorter period that the minister may accept under special circumstances of any specific case, immediately before the date of the submission of their application, or are serving in the civil or public service;

- are of good character;

- intend to remain in the Republic, or depending on the circumstances, continue serving in the civil or public service (sub-sect. IIO(I)); and

- sign an official confirmation of loyalty to the Republic.

2. Spouses or widowers/widows of persons who were citizens of the Republic, or spouses of persons who, had they not been deceased, would have become or would have the right to become citizens of the Republic, provided that they: 
- ordinarily reside in Cyprus and/or resided there for a period not less than three years, ${ }^{35}$

- are of good character;

- intend to remain in the Republic, or depending on the circumstances, continue serving in the civil or public service of the Republic or the educational service of the Republic or the Police Force of the Republic even after registration as citizens of the Republic (subsect. IIO(2)); and

- sign an official confirmation of loyalty to the Republic.

3. Underage children of any citizen. In this case the application for citizenship has to be submitted by the parent or the guardian of the child.

A person who has renounced his or her citizenship of the Republic or has been deprived of it may not be registered as citizen of the Republic according to sect. IIO, but may still be registered with the approval of the minister (subsect. IIo(4)). Persons who have been registered under this section become citizens of the Republic from the date of their registration (subsect. IIO(5)).

This provision places Cypriot descent at the core of the right to acquire citizenship; spouses and under-age children who are resident in Cyprus can apply but their application is treated as dependent on the person of Cypriot origin. Moreover, there is an issue of how the rights of spouses and dependents are implemented. In fact, the practice of the immigration authorities to deport migrants who have been living in Cyprus for several years continued in spite of criticism from legal circles, human rights NGOs, from the Ombudsman and from the Commissioner for Legislation. ${ }^{36}$ Within a time span of only a few weeks, the Court cancelled deportation orders on numerous instances. ${ }^{37}$

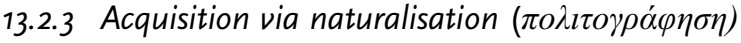

A non-Cypriot who resides lawfully in the Republic may acquire citizenship via discretionary naturalisation if he or she fulfils all of the following conditions formulated in Table 3 annexed to the law (subsect. III):

a. he or she has lawfully resided in the Republic of Cyprus for the entire duration of twelve months immediately preceding the date of application;

b. over and above the twelve months referred to above, an additional continuous period of seven years in the period immediately prior to this, the applicant must have ordinarily resided in the Republic, or have been serving in the civil or public service of the Republic, or a 
bit of both, for periods amounting in total to no less than four years;

c. he or she is of good character; and

d. he or she intends to reside in the Republic.

The law also provides for acquisition of citizenship via naturalisation for students, visitors, self-employed persons, athletes and coaches, domestic workers, nurses and employees who reside in Cyprus with the sole aim of working there as well as spouses, children or other dependent persons. The prerequisites are that they must have ordinarily resided in the Republic for at least seven years and one year in the period immediately prior to the application their stay must be 'continuous.'. ${ }^{8}$ There are also exceptional situations where citizenship may be granted. ${ }^{39}$

One must bear in mind that all of the above are based on the discretion of the Council of Ministers and the Minister of the Interior. Moreover, given that there has been a policy that migrant worker permits cannot be extended beyond four years, the chance of acquiring citizenship for these groups is rather slim, unless they are married to a Cypriot or are granted leave to stay on other exceptional grounds. Cypriot authorities are very reluctant to grant citizenship to migrants. The Cyprus government failed to transpose Directive 203/I09/EC by 23 January 2006 . The law was passed in February 2007; following criticism by NGOs and strong trade union opposition, the restrictive criteria originally foreseen for granting long-term migrants this special status, which included proficiency in Greek language, history and civilisation, were eventually dropped by the parliament.

The naturalisation procedure has been criticised in the Second ECRI Report on Cyprus as the conditions apparently 'leave a wide margin of discretion to the Naturalisation Department as concerns decisions to grant citizenship'; moreover the same Report claims that 'there have been complaints that these decisions are sometimes discriminatory' (ECRI 200I: 9). The same practice was criticised by the Third ECRI Report (2006: 8), which also notes that 'decisions are still excessively discretional and restrictive' but that 'this is reflected not only in the use made of public order considerations, but also in the application of residency and language requirements'.

The 'Cyprus problem' is often quoted as a 'national priority' and is invoked by Greek-Cypriot authorities as the reason for their reluctance to open up citizenship rules so as not to alter the demography, particularly in the context of the Turkish policy of settlement in the occupied northern territories. However, this does not withstand close scrutinity as numerous amendments were made to facilitate various population policies that benefit what is perceived as 'the Greek-Cypriot interest'. 
Several decisions by the Ombudsman have criticised a number of practices of the Population Data Archives regarding the process of granting citizenship. In particular, criticism is directed at the restrictive approach of the Director of the Population Data Archives as regards the acquisition of citizenship via registration and naturalisation; particularly critical are the decisions regarding the rejection of applications for citizenship based on marriage with Cypriots. ${ }^{40}$ Moreover, the decisions also highlight considerable delays in the processing of the applications, prejudice based on the religion of the applicant and the exercising of administrative discretion in the interpretation of the regulation that excludes those who have entered the country illegally from acquiring citizenship. ${ }^{4 \mathrm{I}}$

Overall, the implementation of the rules on naturalisation and with the wide margin of discretion provided for by the legislation, is an issue of concern regarding the fairness of these policies. There is little encouragement and information for persons entitled to be naturalised and there are bureaucratic obstructions that make the application for naturalisation unattractive and cumbersome. One can explain this policy as a mixture of the colonial legacy and the keenness of the authorities to hold on to their 'sovereignty' concerning entry, sojourn, residence and citizenship, particularly as the protracted Cyprus conflict is often invoked as a pretext. The consequence is a restrictive regime that requires reform if it is to observe international law standards on the subject.

\subsubsection{Renunciation and deprivation of citizenship}

Any adult citizen of sound mind who is also a citizen of another state may renounce his or her citizenship by submitting a confirmation of renunciation, and the minister will take the appropriate action for the registration of such confirmation (sect. II2).

Deprivation of citizenship is possible, only for citizens who acquired citizenship via registration or naturalisation, via an Order of the Council of Ministers (sect. II3) under the following circumstances:

a. When it is established that the registration or certification of citizenship was obtained by deceit, false pretences or concealment of a material fact (subsect. II3(2)).

b. If the Council of Ministers (subsect. II3(3)) is satisfied that:

- through deeds or words this person has demonstrated a lack of loyalty to the laws of the Republic; ${ }^{42}$ or

- in a war fought by the Republic this person was illegally involved in an exchange with the enemy, has contacted the enemy or was in any way involved in any operation in which he knowingly assisted the enemy; or 
- within five years from naturalisation, he or she is convicted in any country of a crime carrying a sentence of one year or more.

c. If the Council of Ministers (subsect. II3(4)) is satisfied that the naturalised citizen has ordinarily resided in foreign countries for a continuous period of seven years.

The Council of Ministers cannot deprive a person of citizenship unless it is satisfied that it is not in the public interest that the said person remains a citizen of the Republic (sub-sect. II3(5)).

It is apparent that the above is contrary to art. 5 of the I997 European Convention on Nationality, which Cyprus is yet to sign. In fact, the Second and Third ECRI Reports on Cyprus recommend that Cyprus signs and ratifies this Convention. In any case, there is a complaint before the Equality and Anti-discrimination Body arguing that the above provision is contrary to the general prohibition of discrimination as laid down in art. I of Protocol I2 to the European Convention on Human Rights, which has been ratified by the Republic of Cyprus.

It is apparent that the decisive element in the granting of citizenship is Cypriot descent which is combined with birth to form the various categories of rights provided. First, we can identify the following categories of persons of Cypriot descent:

I. Greek-Cypriots (and the three religious groups) born in the area controlled by the Republic of Cyprus: this category is not really an issue as citizenship is granted automatically.

2. In principle, the same ought to apply to Turkish-Cypriots born in Cyprus and to children who have at least one Cypriot parent. Turkish-Cypriots born in the occupied territories are automatically entitled to citizenship provided that they submit documents of their parents or grandparents issued by the Republic of Cyprus or the colonial authorities (TRNC documents are not recognised). However, in practice, art. Io9 of the Law referred to above may result in a more discretionary regime for persons, one of whose parents is a Turkish national, even if they reside in the area under control of the Republic.

3. Persons of Cypriot origin born abroad, who have one Cypriot parent, are entitled to citizenship.

4. Persons of Cypriot origin born abroad between I6 August 1960 and II June 1999 and whose entitlement to Cypriot citizenship is solely based on their mother being Cypriot (or being entitled to Cypriot citizenship) are not entitled to citizenship. They may, however, apply to acquire citizenship via registration.

5. Children born in Cyprus to non-Cypriot migrants who legally entered and reside in Cyprus and have acquired or would have been 
entitled to acquire Cypriot citizenship via naturalisation are entitled to citizenship.

'Collateral' policies have been developed to use tax incentives and national service 'discount' for men (six months if under 26 and three months if over 26 instead of the 25 months of normal national service) to attract Greek-Cypriots from abroad to live in Cyprus.

Second, those who are not of Cypriot origin can only acquire citizenship via naturalisation or registration. Therefore,

I. Non-Cypriots who legally entered and reside in Cyprus are not entitled to acquire Cypriot citizenship. But they can acquire citizenship by discretionary naturalisation, providing that they fulfil the required qualifications.

2. Children born in Cyprus to migrants who do not hold Cypriot citizenship or have a right to acquire it are not entitled to citizenship.

\subsection{Current debates: The challenges of gender equality, migration, Europeanisation and reunification}

\subsubsection{Europeanisation}

There is little doubt that the language of 'Europe' has become dominant in Cyprus as there is an orientation of political discourse and rhetoric towards Europe as a reference point. ${ }^{43}$ The question is whether the process of Europeanisation has touched upon citizenship and nationality. One issue is European citizenship itself, which affects the divided Cypriot citizenship. A number of key issues relate to the right to the free movement of workers in the EU; for instance, the fact that Cyprus has not yet regulated same-sex marriages and extra-marital relationships has resulted in various forms of discrimination against lesbian, gay, bisexual and transsexual Union citizens, thus constituting effective obstacles to free movement. Another problem is the regulation of the 'Green line' that divides the country (see Trimikliniotis 2008).

European Citizenship has different aspects relevant to the potential for transformation of the citizenship/nationality issue in Cyprus. First it may provide an all encompassing identity that has the potential to overcome the ethnic divide between Greek-Cypriots and Turkish-Cypriots. It is argued that 'shared cultural experience' between Greek-Cypriots and Turkish-Cypriots - many times suppressed by nationalists in the past 'in order to focus on ethnic differences' - could become a new focus as there are common aspects of identity that can unite the two communities. According to this optimistic view, EU membership may emphasise the shared culture and help in finding a solution to the Cyprus problem (Botswain I996: 94). Moreover, EU Citizenship may 
have a positive impact on human rights as the EU is expected to act as a guarantor of rights, such as the freedom of movement, settlement and ownership of land as provided in the Treaty of Rome and in line with the 'acquis communautaire'. 'Citizenship' would underpin rights (communal/individual) thus assisting in creating a better climate of trust and security through the European Court of Justice, the European Court of Human Rights, the Council of Europe and the EU in general. ${ }^{44}$ The European Conventions of the Council of Europe and other international instruments for 'minority rights' (Thornberry 1994), although technically outside the acquis, could arguably be a useful mechanism from which Turkish-Cypriots stand to gain; 45 however, Turkish-Cypriots are not a 'minority' but a 'community' in a consociation regime.

Moreover, matters are, in practice, far more complicated. Since the rejection of the UN plan in April 2004, the Europeanisation issues have not acted as a constructive force: the issue of EU accession has become yet another point of contestation between Greek-Cypriots and Turkish-Cypriots and the question of what kind of future 'European solution' there will be for the Cyprus problem, is becoming a dominant question. Inevitably, the questions of citizenship have been more or less put on hold as they are subordinate to the solution of the Cyprus problem. It is, however, highly likely to return in the near future as it remains one of the key issues in the Cyprus problem.

\subsubsection{Reunification, partition and settlers: Nationality turns into a hot political issue}

This is perhaps the greater challenge in the adventures of nationality in Cyprus. We have already referred to some of the issues as regards the period 1974-2004 and the challenges of migration. However, the central question arises out of the latest efforts to resolve the Cyprus problem, which resulted in the UN plan known as 'the Annan Plan'.

The issue of who is entitled to nationality is a hot political issue. In the northern territories the policy of Turkey is to 'replace' Turkish-Cypriot émigrés with Turkish settlers from the mainland or to distort the demographic balance of the Cyprus population by giving TRNC nationality to a large number of settlers. ${ }^{46}$ In the area under the control of the Republic of Cyprus it is estimated that there are between I5,000 to 20,000 Pontian Greeks from the former Soviet Union, a few of whom were granted nationality, after residing for a period of seven years in Cyprus. ${ }^{47}$ The demographic study conducted by the Ministry of the Interior in 2000 found that there were I0,000-I2,000 Greek Pontians residing in Cyprus at the time. However, there have been changes since; 
in any case, Pontian organisations claim to represent 40,000-45, 000 Greek-Pontians residing in Cyprus.

The UN proposal for resolution contains specific provisions over the number of settlers who would be granted nationality. This has proven to be a particularly sore point for the Greek-Cypriots, who eventually rejected the plan. In fact, it is widely believed that one of the reasons the Greek-Cypriots voted 'NO' to the plan was the fear over the 'large numbers' of settlers who would eventually be allowed to remain. ${ }^{48}$ Nevertheless, these provisions were seen by Greek-Cypriots as problematic in that they were alleged to allow for a 'perpetual inflow of settlers', in spite of the 5 per cent cap for any future migration from Turkey and Greece. ${ }^{49}$

In the 'main articles' of the Foundation Agreement of the Annan plan (art. 3) there is reference to 'a single Cypriot citizenship' regulated under federal law as well as the 'internal constituent state citizenship status' to be enjoyed by 'all Cypriot citizens'; moreover, the plan lays out a set of complicated rules about preserving the 'identity' (see appendix I). The acquisition of citizenship is regulated by an agreed constitutional law which essentially deals with the issue of settlers from Turkey. Moreover the plan envisages a federal law on 'aliens and immigration' (Foundation Agreement, Attachment 5, Law I) as well as a federal law for international protection and the implementation of the Geneva Convention Relating to the Status of Refugees and the I967 Protocol on the Status of Refugees (Foundation Agreement, Attachment 5, Law 2) which, in the event of a settlement, would replace the current laws on immigration and refugees.

The plan was rejected by the Greek-Cypriots, but remains relevant to current and possible future negotiations as the most comprehensive plan ever to be negotiated, and is therefore a valuable source of ideas on the formation of a bizonal, bicommunal federation (see Trimikliniotis 2009). In the absence of a solution, prior to the referendum and soon after, a number of public debates erupted that centred on the question of nationality policy. The question of moving towards an effective right to nationality by providing passports for the Republic of Cyprus has been relevant particularly since accession. For the Greek-Cypriot post-referendum political arena, an issue that became a hot political issue was the question of granting the right of nationality to children of Turkish-Cypriots who married Turkish settlers. Right-wing media attacked the cabinet decision to grant nationality rights to 703 persons one of whose parents was a Turkish settler. ${ }^{50}$ The government was forced to go on the defensive with the Minister of the Interior claiming that 'the legislation does not allow the granting of nationality, either to settlers or an alien from another country, who has entered the Republic illegally. ${ }^{51}$ The media as well as some members of the coali- 
tion partners ${ }^{52}$ stated that because 'invasion, colonisation and changing the demographic character of a country' is a 'war crime', granting nationality to the offspring of colonisers is never justified. In fact, there are allegations that there is an unofficial moratorium on the subject to freeze the applications of children of settlers married to Cypriots; a practice that has been criticised by human rights organisations. ${ }^{53}$

The current situation in Cyprus leaves the nationality policy regarding this category of persons in a state of limbo. In practice, pending a resolution of the problem, the Cyprus problem will always predominate and colour the nationality policy. The greatest challenge for Cypriot policymakers is to adopt a nationality and citizenship policy that enhances the possibility for reunification and thus does not consolidate and indirectly officially endorse partition.

\subsection{Statistical developments since 1985: The 'politics of numbers' and the 'numbers game'}

Table I3.I shows that the anomaly of the Cyprus problem has had a massive impact on the numbers of citizenship acquisitions. The largest figure involves Turkish-Cypriots. Most of these acquired citizenship after 23 April 2003 when the checkpoints were opened - although Turkish-Cypriots had a right to Cypriot citizenship before that date, they could not make use of this right due to the war and the de facto partition since I974. Between I995 and 3 March 2009, IoI,778 Turkish-Cypriots have acquired birth certificates of the Republic of Cyprus; 83,372 have acquired identity cards and 54,595 passports. Moreover, the numbers of applications for citizenship more than doubled since Cy-

Table 13.1 Acquisitions of Cypriot citizenship by modes, 1985-3 March 2009

\begin{tabular}{llr}
\hline & Mode of acquisition & Number \\
\hline 1 & Naturalisation & 5,395 \\
2 & Spousal transfer of citizenship & 12,824 \\
3 & Transfer to children whose parents obtained citizenship & 5,160 \\
4 & Registrations of persons of Cypriot descent & 2,250 \\
5 & Persons who acquired citizenship on grounds of origin, e.g. expatriate & 23,932 \\
& Cypriots & \\
6 & Turkish-Cypriots who acquired passports of the Republic of Cyprus \\
& since 1995 & \\
7 & Turkish-Cypriots who acquired identity cards of the Republic of Cyprus \\
& since 1995 & 83,372 \\
8 & Turkish-Cypriots who acquired birth certificates of the Republic of \\
& Cyprus since 1995 & 101,778 \\
\hline
\end{tabular}

Sources: Personal Communication of the Civil Registry Migration Department and the Population Data Archives, 3 March 2009 
prus acceded to the EU and there is a backlog of some hundreds of applications pending.

The second largest group of people granted Cypriot citizenship were Cypriot by descent or by origin $(2,250$ for category 4 and 23,932 for category 5). This figure reflects the favourable conditions for return migration to Cyprus, which has enjoyed a steady improvement of the living standards and relative stability despite the conflict and the continuing division. Moreover, it illustrates the importance of the ties with Cyprus and the ethnic connections amongst the Cypriot diasporic communities abroad. Finally, it may reflect the relative success of various population policies aimed at encouraging expatriates to return to $\mathrm{Cy}$ prus. However, it is difficult to verify how far these incentives influenced the decision to migrate to Cyprus. It has to be noted that this category includes an unknown number of Turkish-Cypriots.

The third largest category comprises of those who acquire citizenship by marriage, a total of 12,824 persons. Research shows that the large majority of these are foreign women married to Cypriot men (ratio 7:I) and that there is a preference for certain nationalities (FuliasSouroulla 2008).

The next largest group are naturalised persons (category I). The number of naturalisations is rather small considering that that there are 138,000 non-Cypriots residing in Cyprus, ${ }^{54}$ which includes however over 70,000 EU citizens. ${ }^{55}$ The number of non-Cypriot naturalised migrants is even smaller since an unknown share of those naturalised are persons of Cypriot origin born in the Commonwealth prior to I960 and who could only acquire Cypriot citizenship by naturalisation as well as those who renounced or were deprived of Cypriot citizenship to acquire another citizenship (e.g. German). In any case, about half of those who acquire citizenship by naturalisation are Greek Pontians residing in Cyprus: it is estimated that about 400 Greek Pontians were granted Cypriot citizenship in 2004 and about 500 in $2005 .{ }^{56}$

\subsection{Conclusions}

The mechanics of acquisition, renunciation and deprivation of citizenship in the Republic of Cyprus revolves around Cypriot descent: persons of Cypriot origin are basically entitled to citizenship, whilst persons of non-Cypriot descent may be allowed to apply if they have resided in Cyprus for seven years to acquire citizenship via registration and naturalisation mechanisms. The reference of one of the very few Cypriot legal scholars dealing with the subject, Criton Tornaritis (I982: 39), that Cyprus has adopted a 'mixed principle combining ius soli and ius sanguinis' is not very helpful as Cypriot descent forms the core. 
Although, we cannot locate a declared policy on citizenship/nationality as such in the Republic of Cyprus, what we do find instead is a practice that derives from the long-standing Cyprus conflict as well as international developments such as accession to the EU, economic development and migration, and to some extent changing attitudes, particularly as regards the question of gender. Other factors are also of relevance, such as population control, economic and welfare issues, social policy, etc. As for the unrecognised Turkish Republic of Northern Cyprus, the issue of citizenship is totally subsumed in its own 'struggle for recognition' and it is a mirror image of the country it broke away from and yet can never escape from, the Republic of Cyprus.

In the context of Cyprus, nationality policy is inevitably subordinated to the unique historical conjunctures that perpetuate the island's protracted ethno-national conflict. In fact, the question of nationality goes to the heart of the existence of the country's very own 'nation-state dialectic' (see Trimikliniotis 2000, 2005): the challenge for a citizenship that manages to transcend the ethno-national conflict and the ethnocommunal divide is perhaps the greatest challenge of all for this country's European aspirations for a re-united and peaceful future. The negotiations between the two community leaders resumed in September 2008 and have raised hopes for a resolution of the dispute in a manner that will reunite the island on the basis of a bi-zoned, bi-communal federation with a single sovereignty, territory and nationality. This solution would radically transform the nationality issues as we have known them.

Chronological list of citizenship-related legislation in the Republic of Cyprus

\begin{tabular}{|c|c|c|c|}
\hline Date & Document & Content & Source \\
\hline 1960 & $\begin{array}{l}\text { Constitution of the } \\
\text { Republic of Cyprus }\end{array}$ & $\begin{array}{l}\text { Regulates initial } \\
\text { determination of Cypriot } \\
\text { citizenry after } \\
\text { independence (Annex D); } \\
\text { regulates acquisition of } \\
\text { citizenship (art. 198) }\end{array}$ & $\begin{array}{l}\text { www.kypros.org; } \\
\text { www.legislationline.org }\end{array}$ \\
\hline 1967 & $\begin{array}{l}\text { Citizenship Law No. 43/ } \\
1967\end{array}$ & $\begin{array}{l}\text { Regulates acquisition and } \\
\text { deprivation of citizenship; } \\
\text { defines person's descent } \\
\text { on his or her father's side } \\
\text { as basic criterion for } \\
\text { citizenship acquisition }\end{array}$ & $\begin{array}{l}\text { www.legislationline.org; } \\
\text { www.coe.int }\end{array}$ \\
\hline 1972 & $\begin{array}{l}\text { Citizenship (Amendment) } \\
\text { Law No. } 1 / 1972\end{array}$ & $\begin{array}{l}\text { Extends the minister's } \\
\text { discretion regarding } \\
\text { deprivation or renunciation } \\
\text { of citizenship, if the }\end{array}$ & www.coe.int \\
\hline
\end{tabular}




\begin{tabular}{|c|c|c|c|}
\hline Date & Document & Content & Source \\
\hline 1983 & $\begin{array}{l}\text { Citizenship (Amendment) } \\
\text { Law No. } 74 / 1983\end{array}$ & $\begin{array}{l}\text { minister is of the opinion } \\
\text { that the aim of such a } \\
\text { declaration is to avoid } \\
\text { military service or criminal } \\
\text { prosecution } \\
\text { Extends entitlement to } \\
\text { citizenship to persons born } \\
\text { in Cyprus prior to } \\
\text { independence and whose } \\
\text { father was of Cypriot } \\
\text { descent; deleted subsect. } 4 \\
\text { (d), which entitles 'persons } \\
\text { born in Cyprus, who are not } \\
\text { entitled by birth to acquire } \\
\text { any other citizenship', to } \\
\text { Cypriot citizenship }\end{array}$ & www.coe.int \\
\hline 1996 & $\begin{array}{l}\text { Citizenship (Amendment) } \\
\text { Law No. } 19(\mathrm{I}) / 1996\end{array}$ & $\begin{array}{l}\text { Extends the right to } \\
\text { citizenship via registration } \\
\text { to persons whose father } \\
\text { was a British subject on the } \\
\text { basis of the Annexation of } \\
\text { Cyprus Orders of Council } \\
\text { 1914-1943 or was born in } \\
\text { Cyprus between 1914-1960 }\end{array}$ & \\
\hline 1996 & $\begin{array}{l}\text { Citizenship (Amendment) } \\
\text { Law No. } 58(\mathrm{I}) / 1996\end{array}$ & $\begin{array}{l}\text { Regulates the } \\
\text { naturalisation procedure } \\
\text { for persons of non-Cypriot } \\
\text { descent residing and } \\
\text { working in Cyprus } \\
\text { (conditions included: nine } \\
\text { years of residence out of } \\
\text { the previous thirteen years, } \\
\text { plus twelve months of } \\
\text { continuous residence } \\
\text { immediately prior to } \\
\text { application) }\end{array}$ & \\
\hline 1996 & $\begin{array}{l}\text { Citizenship (Amendment) } \\
\text { Law No. } 70(\mathrm{I}) / 1996\end{array}$ & $\begin{array}{l}\text { Introduces facilitated } \\
\text { naturalisation for reasons } \\
\text { of public interest } \\
\text { irrespective of residence } \\
\text { rules }\end{array}$ & \\
\hline 1997 & $\begin{array}{l}\text { Citizenship (Amendment) } \\
\text { Law No. } 50(\mathrm{I}) / 1997\end{array}$ & $\begin{array}{l}\text { Extends the right to apply } \\
\text { for naturalisation to } \\
\text { spouses, children or other } \\
\text { dependent persons }\end{array}$ & \\
\hline 1998 & $\begin{array}{l}\text { Citizenship (Amendment) } \\
\text { Law No. } 102(\mathrm{I}) / 1998\end{array}$ & $\begin{array}{l}\text { Deletes a section in the } \\
\text { Second Table of the main } \\
\text { law which empowered the } \\
\text { Council of Ministers to use } \\
\text { discretion for extending }\end{array}$ & \\
\hline
\end{tabular}




\begin{tabular}{|c|c|c|c|}
\hline Date & Document & Content & Source \\
\hline & & $\begin{array}{l}\text { citizenship to persons of } \\
\text { Cypriot descent }\end{array}$ & \\
\hline 1998 & $\begin{array}{l}\text { Citizenship (Amendment) } \\
\text { Law No. } 105(I) / 1998\end{array}$ & $\begin{array}{l}\text { Empowers the minister to } \\
\text { grant citizenship to } \\
\text { spouses or widows / } \\
\text { widowers married to a } \\
\text { Cypriot for at least two } \\
\text { years }\end{array}$ & \\
\hline 1999 & $\begin{array}{l}\text { Citizenship (Amendment) } \\
\text { Law No. } 65(I) / 1999\end{array}$ & $\begin{array}{l}\text { Extends the right to } \\
\text { citizenship to any person of } \\
\text { Cypriot descent (i.e. } \\
\text { regardless of whether the } \\
\text { father or the mother is } \\
\text { Cypriot); makes automatic } \\
\text { acquisition of citizenship } \\
\text { conditional on lawful entry } \\
\text { and stay in the Republic } \\
\text { (effectively this covers } \\
\text { children one of whose } \\
\text { parents is a Turkish settler) }\end{array}$ & \\
\hline 1999 & $\begin{array}{l}\text { Citizenship (Amendment) } \\
\text { Law No. 128(I)/1999 }\end{array}$ & $\begin{array}{l}\text { Deletes the subsection } \\
\text { empowering the Minister of } \\
\text { the Interior to register the } \\
\text { wives or widows of Cypriots } \\
\text { as citizens provided that he } \\
\text { or she is satisfied that they } \\
\text { meet the required } \\
\text { conditions }\end{array}$ & \\
\hline 2001 & $\begin{array}{l}\text { Citizenship (Amendment) } \\
\text { Law No. } 168(1) / 2001\end{array}$ & $\begin{array}{l}\text { Extends the period of } \\
\text { marriage before spouses or } \\
\text { widows/widowers can } \\
\text { acquire citizenship by } \\
\text { registration to at least three } \\
\text { years }\end{array}$ & \\
\hline 2002 & $\begin{array}{l}\text { Population Data Archives } \\
\text { Law No. } 141(\mathrm{I}) / 2002\end{array}$ & $\begin{array}{l}\text { Unifies the Citizenship Law } \\
\text { with various other } \\
\text { population issues, such as } \\
\text { archives, elections, } \\
\text { registration, identity cards, } \\
\text { passports and deaths, into } \\
\text { one law called Population } \\
\text { Data Archives Law No. } 141 \\
\text { (I) } / 2002\end{array}$ & \\
\hline 2004 & $\begin{array}{l}\text { Annan Plan: Foundation } \\
\text { Agreement }\end{array}$ & $\begin{array}{l}\text { Comprehensively } \\
\text { restructures population } \\
\text { issues including citizenship }\end{array}$ & www.cyprus-un-plan.org \\
\hline
\end{tabular}




\section{Notes}

I This occurred when the government decided to grant citizenship to children of Turkish-Cypriots married to settlers in 2004 and 2005.

2 This was an illegal terrorist organisation launched allegedly to campaign for Enosis, i.e. union with Greece; it carried out bombings, murders of civilians and tried several times to assassinate President Makarios (Droussiotis I994).

3 These are two contrasting approaches regarding the refenda on 24 July 2004 and they have implications on how to proceed if a solution is to be found.

4 In return for protection from the expansionist aims of Russia and an annual payment to Turkey of the sum of $£$ 12,000.

5 The 'modernisation' began before the British arrived in Cyprus; however, it was intensified with the arrival of the British colonists at the end of the nineteenth and the beginning of the twentieth century (see Katsiounis 1996).

6 Such were the privileges granted to the Cypriot Greek Orthodox Church of Cyprus that the archbishop of Cyprus had direct recognition from the Sultan, as Ethnarchic leader, the millet bashi.

7 The beginning of the twentieth century saw a conflict between the 'traditionalists' and the 'modernists' in the Turkish-Cypriot community; a battle that was decisively won by the modernists (Anagnostopoulou 2004).

8 In the I940s, the Left had risen and competed with the church for leadership of the anti-colonial movement (Katsiaounis 2000). By the mid I950s the church reestablished its authority with EOKA. EOKA (Ethniki Organosis Kyprion Agoniston National Organisation of Cypriot Fighters) was the Greek-Cypriot nationalist organisation which started a guerrilla campaign against British colonial rule aimed at selfdetermination and union with Greece (Enosis). The political leadership of EOKA was the church.

9 The case was Attorney General of the Republic v Mustafa Ibrahim and Others (I964), Cyprus Law Reports I95 (see also Nedjati I970; Loizou 200I).

Io These agreements set the basis for a bi-communal and bi-zonal federal Republic following the invasion.

II See Aziz v. Republic of Cyprus, ECHR, Application No. 69949/or. The full text of the judgement is available on the website of the European Court of Human Rights: www.echr.coe.int.

I2 Hence the requirements to produce documents relating to birth of their Cypriot parents prior to 1974 .

I3 M. Hadjicosta, 'Fears over gypsy influx', The Cyprus Weekly, I3-I9 April 200I. www.domresearchcenter.com.

I4 J. Matthews, 'More gypsies crossing from north as Koshis warns about spies', The $C_{Y}$ prus Mail, 3 April 200I. www.domresearchcenter.com.

I5 Apparently, the Minister of the Interior at the time, Mr. C. Christodoulou, now Governor of the Central Bank, said that he would not reveal the options discussed, because, 'in this country, when it comes to illegal immigrants or gypsies (moving into an area), everyone reacts'. See 'Our reaction to gypsies raises some awkward questions', The Cyprus Mail, Io April 200I. www.domresearchcenter.com.

I6 A Turkish-Cypriot woman filed a complaint because her application to be registered in the Republic's Citizens Record was rejected, on the basis that the birth of her mother had not been recorded in the Republic's archives. The complainant's mother had been born to Roma parents who failed to register her birth. It was also noted that the complainant was inconvenienced for several months due to ill advice by government officers as to the procedure with regard to her registration. In addition, she complained about the rejection of her application to enrol her child in school 
because the child did not have a birth certificate from the Republic. Following the Commissioner's report on the matter, her child was finally enrolled in school.

I7 They thought that they could no longer be singled out, targeted and harassed and there was a general feeling of optimism and rapprochement (Trimikliniotis 2003).

I8 Research by the college of Tourism in April 2004 is indicative.

I9 The term 'significant' is not explained in the Demographic Report of 2005.

20 The Cyprus (Annexation) Order-in-Council 19I4, No. I629 Statutory Rules and Orders Rev. (1948), vol. V, pp. 577-578. The order can also be found in Cyprus, (1920), Handbook No. 65 in the series, London: HMSO.

2I The Cyprus (Annexation) Order-in-Council I9I7, No. I374 S.R \& O. and The Cyprus (Annexation) Order-in-Council I9I4, No.I629 S.R \& O. Rev. (I948), vol. V, pp. 578582.

22 The provisions of Annex D are quite detailed governing different categories of persons and set out the basic structure of citizenship acquisition that was to follow also in the subsequent legislation on the subject (Tornaritis I982: 33-4I).

23 Law No. 43/67, as amended by Laws No. I/72, 74/83, I9(I)/96, 58(I)/96, 70(I)/96, $50(\mathrm{I}) / 97, \mathrm{I02}(\mathrm{I}) / 98$, I05(I)/98, 65(I)/99, I28(I)/99, I68(I)/200I.

24 With laws No. 65(I)/2003, 76(I)/2003, 62(I)/2004 and I3(I)/2006.

25 Sects. IO9(I) and (2) of Law No. I4I(I)/2002 provide for the procedure and the appropriate forms. In cases where the applicant is under age, the application can be made by a parent.

26 Art. Io9 Population Data Archives Law No. I4I(I)/2002. This clause was first introduced by Law 65(I)/I999 that came into force on II June I999.

27 This information was provided by the officer of the Population Data Archives of the Ministry of the Interior, Christiana Ketteni, on I5 December 2006. She stated that the standard practice of the Council of Ministers is to approve ten to fifteen applications each time there is a meeting of the Council of Ministers. Moreover, she claimed that the people affected by the Council of Ministers' discretion are 'persons who have a Cypriot grandparent', but it remained unclear how this category could fall under art. Io9.

28 It was alleged that discrimination is ongoing as the specific provision has resulted in the perpetual and future discrimination of this category of persons and their descendants since the principle of anti-discrimination is not only momentarily applied, but it is also forward looking. It is likely that this provision is in violation of the laws against discrimination and, in particular, Law No.I42(I)/2004, which transposes the anti-discrimination acquis and more importantly Protocol I2. See File No. 62/2005 of the Ombudsman's Report.

29 See File No. 62/2005 of the Ombudsman's Report.

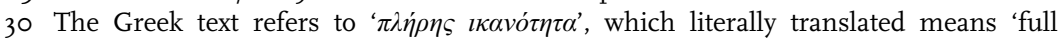
ability', but it must be construed as meaning of 'sound mind', which was the old British formulation.

3I The relevant minister is the Minister of the Interior.

32 A number of Tables are annexed to the Law. The First Table specifies the fees for issuance of passports; the Second Table includes the format of making a formal oath of allegiance to the Republic of Cyprus; the Third Table describes the conditions for naturalisation.

33 For subsect. IIo, 'a country of the Commonwealth' includes every country excluding the Republic of Cyprus, on the date of entering into force of the Law, which is a member of the British Commonwealth and includes the Republic of Ireland and any other country that has been declared by an Order of the Council of Ministers as a Commonwealth Country for the purposes of this section. 
34 For the purposes of subsect. IIo, a person of Cypriot descent is defined as any person born in Cyprus and whose parents ordinarily resided in Cyprus at the time of his or her birth and includes every person that descends from these persons.

35 There are also specific provisions allowing the minister to take measures after less than three years, but it is restricted to a minimum of two years. Also, for the purposes of this subsection 'ordinary residence' requires at least six months stay in Cyprus but in any case the total residence in Cyprus during the preceding three years prior to submission of the application must not be less than two years.

36 L. Leonidou, 'Authorities in the dock over treatment of immigrants', The Cyprus Mail, I5 January 2006.

37 Some indicative cases are the following: Lali Jashiashvili \& Costas Hadjithoma v. The Ministry of the Interior and the Immigration Officer and Nebojsa Micovic v. The Republic of Cyprus through the Chief Immigration Officer, where the Supreme Court cancelled the deportation order against nationals living with their families and working in Cyprus since 1998. Another case involved the deportation order issued against the Pakistani national Mahmoud Adil when his asylum application was rejected. The deportation order was cancelled by the Court on I3 January 2006 based on the argument that the immigration authorities should have taken into account the fact that the appellant was married to a Polish (and therefore EU) citizen.

38 Introduced by amendment 58(I)/1996.

39 Introduced by amendment 70(I)/1996.

40 See relevant Ombudsman Reports, Files No. 2599/2005, 1958/2005, 2059/2005, 2368/2005, 2599/2005, 2780/2005.

4I See Ombudsman Report, File No. 727/2006.

42 The Greek term used is vонцорооби́v

43 One scholar termed this as 'the Europeanisation of political thinking' (Theophylactou I995: I2I), whilst another scholar interpreted this as the embracing of a 'Euro-centric ideology' by the Greek-Cypriot political elite (Argyrou 1996: 43).

44 It is sometimes assumed that possible 'weaknesses' in the settlement would gradually be somehow eliminated by the operation of the acquis and via access to the European Court of Justice and the European Court of Human Rights.

45 Minority rights for 'old' ethnic minorities have a significantly long tradition of protection under various treaties and authorities, even from the last century, though these were very restricted and at the whim of the great powers (Hannum I996: 5074). However, art. 8 of the European Convention on Human Rights guarantees the right to private and family life (which has been interpreted as to include ethnic identity) and art. 9 guarantees 'the right to freedom of thought, conscience and religion'. More specifically, art. 27 of the Covenant on Civil and Political Rights refers to the rights of 'ethnic, religious or cultural minorities' to 'enjoy their own culture, to profess and practice their own religion, or use their own language', but these are set to be extended in other areas of freedom (Hannum 1996: 62-63). However, the European 'regime' on ethnic minority groups' protection, is problematic, as there is a distinct lack of enforcement mechanisms. These rights are heavily dependent upon the nation-states for implementation; in any case the mechanisms for implementation are very weak if not irrelevant (Hannum I996).

46 The veteran Turkish-Cypriot leader has often been quoted saying: 'A Turk leaves, another Turk comes'.

47 It appears that in the days of the collapse of the USSR, Greek-Cypriot policy-makers toyed with the idea of bringing to Cyprus Greek-Pontians rather than other migrants, due to their ethnic origin, in part to unofficially and quietly 'redress' the Turkish settler policy. Officially this was never admitted by right-wingers, and nationalists 
regularly referred to the Pontians as the alternative to 'an Afro-Asian' new minority (see Trimikliniotis 1999).

48 Obviously there was scare mongering and exaggeration by the Greek-Cypriot 'No campaign' about the figures and misinformation about the actual provisions. Palley (2005) has a chapter devoted to the subject and puts forward the case for the GreekCypriot side and the reasons for the Greek-Cypriot rejection as regards this issue.

49 The provisions were depicted by Greek-Cypriot anti-Annan critics as rewarding the policy of colonisation. However, this is a highly complex issue which requires a detailed analysis and a resolution that bears in mind the principles of justice and international law, as well as the humanitarian, the individual rights and the personal dimensions of the problem.

50 See G. Psyllides, 'Citizenship for settler children: Christou hits back', Cyprus Mail, I July 2004 .

5I Minister Andreas Christou quoted in Politis, 7 June 2004. Also see the explanations of the legal regulations in section 2.I of this chapter.

52 See Cyprus Mail, I July 2004. Palley (2005) deals with the legal and political issues of the settlers. Also see Hannay (2005).

53 In a press release dated 2 July 2004, the human rights NGO 'KISA' (Action for Equality, Support and Anti-racism) expressed concern over the intolerant and racist attitudes developing around the issue of granting nationality to these children.

54 Data provided by the Civil Registry Migration Department and the Population Data Archives on 3 March 2009. I would like to thank Andros Ktorides for his help in obtaining the data and for his lucid analysis. Of course, the argumentation and conclusions are mine.

55 This figure was provided by the Civil Registry Migration Department and the Population Data Archives (3 March 2009). However, different numbers are produced by the Ministry of Labour and Social Insurance: according to their data only 49,639 EU citizens were residing in Cyprus in July 2008 (see Total Aliens and Europeans Data 2008, www.mlsi.gov.cy).

56 This figure was provided by Christiana Ketteni, an official of the Population Data Archives, Ministry of the Interior who was asked to comment on the categories, figures and the underlying policies (I5 December 2006).

\section{Bibliography}

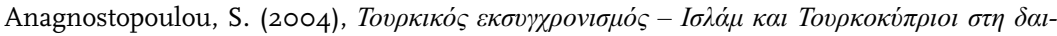

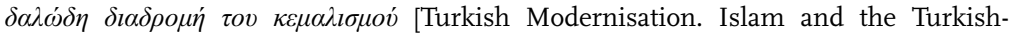
Cypriots on their Dedalus-like Route to Kemalism]. Athens: Vivliorama.

Anthias, F. (1989), 'Women and nationalism in Cyprus', in N. Yuval-Davis \& F. Anthias (eds.), Woman, Nation-State, I50-167. London: Macmillan.

Argyrou, V. (1996), Tradition and Modernity: The Symbolic Class Struggle of the Cypriot Wedding. Cambridge: Cambridge University Press.

Attalides, M. (I979), Cyprus Nationalism and International Politics. Edinburgh: Q Press.

Botswain, T. (I996), 'Perceptions of Cyprus as European', in J. Charalambous, M. Sarafis \& E. Timini (eds.), Cyprus and the European Union. A Challenge, 93-II9. London: University of North London.

Chrysostomides, K. (2000), The Republic of Cyprus. A Study in International Law. London: Martinus Nijhoff Publishers.

Constantinou, M.C. \& Y. Papadakis (200I), 'The Cypriot State(s) in situ: cross ethnic contact and the discourse of recognition', in T. Dier (ed.), The European Union and the $C \gamma$ - 
prus Conflict. Modern Conflict, Post-Modern Union, 73-97. Manchester: Manchester University Press.

Demetriou, O. (2006), 'Freedom Square: The unspoken reunification of a divided city', HAGAR Studies in Culture, Polity and Identities 7 (I): 55-77.

Demetriou, O. (2007), 'To cross or not to cross? Subjectivization and the absent state in Cyprus', Journal of the Royal Anthropological Institute (N.S.) I3: 987-1006.

Dodd, C.H. (I993), 'From Federated State to Republic 1975-84', in C. H. Dodd (ed.), The Political Social and Economic Development of Northern Cyprus, I03-I35. Cambridgeshire: The Eothen Press.

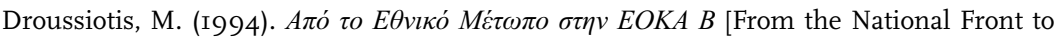
EOKA B]. Nicosia: Alfadi.

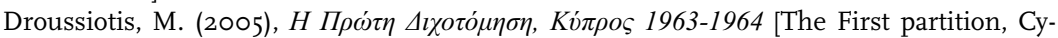
prus I963-I964]. Nicosia: Alfadi.

ECRI (200I), Second Report on Cyprus. European Commission against Racism and Intolerance. Strasbourg: Council of Europe.

ECRI (2006), Third Report on Cyprus. European Commission against Racism and Intolerance. Strasbourg: Council of Europe.

Faiz, M. (2008), 'The Population Issue in North Cyprus', The Cyprus Review 20 (2): I75I87.

Faustmann, H. (1999), Divide and Quit? British Colonial Policy in Cyprus 1878-1960. Including a special Survey of the Transitional Period: February 1959-August 1960. Mannheim: Mateo.

Fulias-Souroulla, M. (2008), 'Marriage and Migration: Greek Cypriot Representations and Attitudes towards Inter-societal Marriage', The Cyprus Review 20 (2): II7-I43.

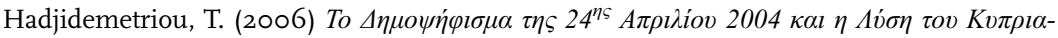
кov [The Referendum of 24 April 2004 and the Solution to the Cyprus Problem]. Athens: Papazisis.

Hannay, D. (2005), Cyprus: The Search for a Solution. London: I. B. Tauris.

Hannum, H. (1996), Autonomy, Sovereignty and Self-determination. The Accommodation of Conflicting Rights. Philadelphia: University of Pennsylvania Press.

Hatay, M. (2006), Beyond Numbers. An Inquiry into the Political Integration of the Turkish 'Settlers' in Northern Cyprus. PRIO Report 4/2005. Oslo: International Peace Research Institute (PRIO).

Hatay, M. (2008), "The Problem of Pigeons: Xenophobia and a Rhetoric of the "Local" in North Cyprus', The Cyprus Review 20 (2): I45-I7I.

Hitchens, C. (I997), Hostage to History. Cyprus From the Ottomans to Kissinger. 2nd edition. London: Verso.

Kadir, D. (2007), 'Truth and Reconciliation on Cyprus will be Possible, when...', The Cyprus Review ig (I): 163-I69.

Katsiaounis, R. (1996), Labour, Society and Politics in Cyprus during the Second Half of the Nineteenth Century. Nicosia: Cyprus Research Centre.

Katsiaounis, R. (2007), 'Cyprus I93I-I959: The Politics of the Anti-colonial Movement',

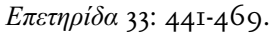

Kyle, K. (I997), Cyprus: In Search for Peace. Minority Rights Group International Report. London: Minority Rights Group.

Kyrris, C. (I980), Peaceful Coexistence. Nicosia: Public Information Office.

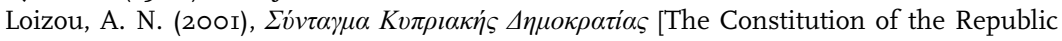
of Cyprus]. Nicosia: Kaila Printing.

Matsis, S. \& A. Charalambous (I993), 'The Demand and Supply Dimensions of the Labour Market: The Issue of Foreign Labour', in E.I. Demetriades, N.F. Khoury \& S. Matsis (I996), Labour Utilization and Income Distribution in Cyprus, 23-54. Nicosia: Department of Statistics and Research, Ministry of Finance. 
Nedjati, Z. (I970), Cyprus Administrative Law. Nicosia.

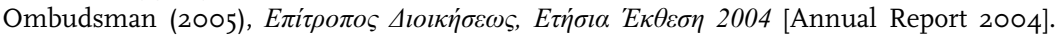
Nicosia: Cyprus Republic Printing Office.

Palley, C. (2005), An International Relations Debacle. The UN Secretary-General's Mission of Good Offices in Cyprus 1999-2004. Oxford: HART Publishing.

PIO (2006), Demographic Survey Report of 2005. Statistics Department. Nicosia: Republic of Cyprus.

Sitas, A., D. Latif \& N. Loizou (2007), Prospects of Reconciliation, Coexistence and Forgiveness in Cyprus. A Research Report. PRIO Report 4/2007. Oslo: International Peace Research Institute (PRIO). www.prio.no.

Spyrou, S. (2003), Educational Needs of Turkish-speaking Children in Limassol. Report for UNOPS. Nicosia.

Theophylactou, D.A. (I995), Security, Identity and Nation Building. Cyprus and the European Union in Comparative Perspective. Avebury: Ashgate.

Thornberry, P. (I994), 'International and European Standards on Minority Rights', in H. Miall (ed.), Minority Rights in Europe. The Scope for a Transnational Regime, I3-29. London: Pinter.

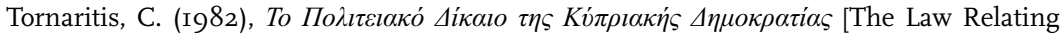
to the Government of the Republic of Cyprus]. Nicosia: Cyprus Research Centre.

Trimikliniotis, N. (I999), 'New Migration and Racism in Cyprus: The Racialisation of Migrant Workers', in F. Anthias \& G. Lazaridis (eds.), Into the Margins: Migration and Exclusion in Southern Europe, I39-I79. Aldershot: Ashgate.

Trimikliniotis, N. (2000), The Role of State Processes in the Production and Resolution of 'Ethnic' and 'National' Conflict: the Case of Cyprus. PhD thesis. University of Greenwich.

Trimikliniotis, N. (2003), Discriminated Voices. Cyprus Report. www.multietn.uu.se.

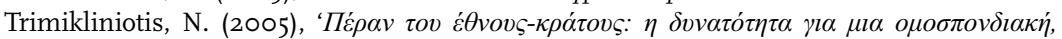

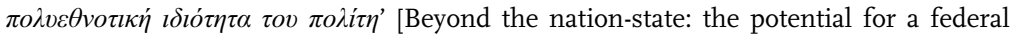

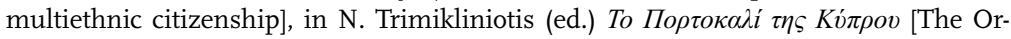
ange Colour of Cyprus], I67-244. Athens: Nisos.

Trimikliniotis, N. (2006), 'A Communist's Post-modern Power Dilemma: One Step Back, Two Steps Forward, "Soft No" and Hard Choices', The Cyprus Review I8 (I): 37-86.

Trimikliniotis, N. (2007), 'Reconciliation and Social Action in Cyprus: Citizens' Inertia and the Protracted State of Limbo', The Cyprus Review i9 (1): I23-160.

Trimikliniotis, N. (2008), Cyprus Report 2007 of Network on the Free Movement of Workers within the European Union. Odysseus Academic Network coordinated by the Institute for European Studies Brussels.

Trimikliniotis, N. (2009), 'Annan V: Rethinking the Viability of the Constitutional Arrangement and its Future Importance', in H. Faustmann \& A. Varnava (eds.), The Failure to Reunify Cyprus: The Annan Plan, the Referendums of 2004 and the Aftermath. London: Tauris (forthcoming).

Trimikliniotis, N. \& C. Demetriou (2007), 'Cyprus', in A. Triandafyllidou \& R. Gropas (eds.), European Immigration: A sourcebook, 45-58. Aldershot: Ashgate.

Trimikliniotis, N. \& C. Demetriou (2008), 'Evaluating the Anti-discrimination Law in the Republic of Cyprus: A Critical Reflection', The Cyprus Review 20 (2): 79-II6.

Trimikliniotis, N. \& C. Demetriou (2009), "The Cypriot Roma and the Failure of Education: Anti-Discrimination and Multiculturalism as a Post-accession Challenge", in N. Coureas \& A. Varnava (eds.), The Minorities of Cyprus: Development Patterns and the Identity of the Internal Exclusion. Cambridge: Cambridge Scholars Publishing (forthcoming).

Trimikliniotis, N. \& P. Pantelides (2003), 'Mapping Discrimination in Cyprus: Ethnic Discrimination in the Labour Market', The Cyprus Review I5 (I): I2I-I48. 


\title{
14 Changing conceptions of citizenship in Turkey
}

\author{
Zeynep Kadirbeyoglu
}

International migration and globalisation are factors which affect citizenship practices throughout the world. Increasing tolerance of multiple citizenship is, amongst other things, one of the results of these trends. This chapter analyses the Citizenship Law in Turkey and argues that the most important changes in the law were made to accommodate the needs and wishes of the emigrants who - even up to the third generation - maintain vibrant ties with their home countries. The chapter starts with the history of citizenship in Turkey. The following section outlines the amendments to the current law that regulates the acquisition and loss of citizenship. Subsequently, the main forms of acquisition and loss of citizenship in Turkey are mapped out. A final section looks at the statistics of people acquiring and losing citizenship in Turkey.

\subsection{History of Turkish citizenship law}

\subsubsection{From the Ottoman Empire to the founding of the Republic}

An analysis of the history of Turkish citizenship should begin with the last period of the Ottoman Empire. Whereas, prior to the I869 Ottoman Citizenship Law (Tabiyet-i Osmaniye Kanunu), the subjects of the Ottoman Empire were divided along religious lines, the new law recognised all residents of the Ottoman territories as nationals of the Empire. It was based on the ius sanguinis principle, but allowed for non-Ottoman children born in the Ottoman territories to apply for citizenship in the Empire when they reached adulthood (İçduygu, Çolak \& Soyarık i999).

The first constitution of the Republic of Turkey (1924) granted Turkish nationality to all residents of the Republic irrespective of race or religion. The nationality law of the Republic was accepted in 1928 and, like its Ottoman predecessor, it was based on ius sanguinis but was complemented by a territorial understanding (İçduygu et al. I999: I93). Aybay (2001: 45) argues that behind this decision was the desire to extend Turkish nationality to as many people as possible. ${ }^{2}$ 
İçduygu et al. (I999: 195), for example, argue that the notion of nationality was not defined solely in terms of ethnic background since the new Turkish nationality was 'open to non-Turkish Muslim groups [...] so long as they were willing to assimilate culturally and linguistically into the Turkish culture.' However, the analysis of groups that were given the right to settle in Turkey reveals that in practice the ability to enjoy full citizenship rights was related to ethnicity and religion (Kirişçi 2000: I).

Specifically, in accordance with the Law on Settlement adopted in I934, ${ }^{3}$ Turkey provided refugee and immigrant status to groups such as Muslim Bosnians, Albanians, Circassians, Tatars, etc., but declined to accept the settlement of groups such as Christian Orthodox Gagauz Turks and Shi'a Azeris. This policy effectively pre-screened those applying for citizenship and helped Sunnis settle in Turkey, in spite of official statements that only those of Turkish descent and culture would be so favoured (Kirişçi 2000). ${ }^{4}$

At the beginning of the twentieth century, Anatolia (Asia Minor) was a heterogeneous piece of land and was home to Rum (an Orthodox Christian Greek speaking group), Armenian, Kurdish, Jewish, Circassian, Laz and some other ethnic or religious groups. The spread of nationalism from Western Europe, its birthplace, to the Ottoman lands led to conflicts and to the disappearance of heterogeneity by way of the forced migration of Armenians during the First World War and the population exchange with Greece in 1923. During the War of Independence there was a clear reference to the multicultural nature of Anatolia. However, after the Sheikh Said uprising of 1925,5 there was no longer any reference made to the 'peoples of Turkey' and thus all citizens of Turkey were expected to adopt Turkish identity (Ergil 2000: I25). This was a fabricated umbrella identity and was instituted through education and cultural policies but carried the name of one of the ethnic groups (the Turks). The group which was not willing to identify with this were the Kurds. Their struggle for autonomy, and sometimes secession, led to a battle between the PKK (Kurdistan Workers Party) and the army. At the height of this armed conflict, the President at the time, Suleyman Demirel, began a discussion on constitutional citizenship, which was intended to create a new common identity (İçduygu et al. I999: 192). However, these discussions were shortlived and did not lead to any policy changes.

\subsubsection{The impact of Turkish emigration to Western Europe}

The current law that regulates the acquisition and loss of Turkish citizenship was put into effect in $1964{ }^{6}$ This period also marks the beginning of the migration of guest-workers to Western Europe. As of 2005, 
3.I million Turkish citizens were living in Europe. Together with another 530,000 Turkish citizens living in other parts of the world, Turkey's emigrant population numbers an approximate 3.6 million (TCCSGB 2005).

In order to understand the economic significance of these emigrants for Turkey, we should first examine the initial goals of the process of labour force exportation to Western European countries. According to Sayarı (1986) the main goals included fighting the rising unemployment within Turkey and bolstering foreign exchange reserves in order to cover trade deficits. A secondary goal was to increase the skill level of workers who would, then, through remittances, be able to increase the level of investment in small and medium-sized companies in the emigrants' home towns in Turkey (Sayar1 I986). The remittances were very important for Turkey. During the I980s, 24 per cent of Turkey's imports were covered by the cash remittances and foreign exchange deposits of Turkish workers abroad (Kumcu I989).

Germany was the main destination for guest-workers from Turkey. Turkish workers in Germany were encouraged to maintain their ties to Turkey and not to undergo 'Germanisation'7 so that a constant flow of remittances could be guaranteed (Hunn 200I). Migrants were encouraged to remit their savings by means of special interest rates given to foreign currency saving accounts in Turkey and by certain privileges that were extended to emigrants who wished to import goods to Turkey (Sayar1 I986). Lately, in addition to remittances, direct investments by the second generation of Turkish emigrants, especially in the textiles industry, are increasing in importance (Faist 1998: 213). In addition to the economic investment, it is expected that Turkey will enjoy political benefits thanks to the migrants living in Western Europe. The lobbying potential of migrants living in European countries has been seen as an asset by governments in Turkey. ${ }^{8}$

The realisation that Turkish workers are not temporary guests in their host countries has led to significant amendments to the citizenship law in Turkey. The motives of politicians and bureaucrats have been shaped by the demands of emigrants who faced problems related to military service, property ownership, and lack of political rights in their countries of immigration. A fairly organised and quasi-official process was used to communicate the needs of citizens living abroad to the Turkish officials.

The first amendment to the law took place in I98I and legalised dual citizenship as long as the person acquiring a second nationality informed the government (Keyman \& İçduygu 2003); otherwise, public authorities could withdraw his or her Turkish citizenship. Furthermore, the amendment initiated gender equality in the transfer of citi- 
zenship to children; as a result women can also transfer their citizenship to their children through ius sanguinis.

The change in article 23/III of the Citizenship Law made it possible to release individuals from Turkish nationality if they wished to acquire another country's citizenship. ${ }^{9}$ In subsequent years, many individuals who acquired a new citizenship reacquired their Turkish citizenship immediately after renouncing it. This was supported and encouraged by Turkish authorities and embassies. This method of circumventing German Citizenship Law - which prohibits dual citizenship - was legally possible only until 2000 . The pre-2000 law maintained only that the person naturalising in Germany should not have another nationality. Yet, the new law made it possible for German officials to withdraw German citizenship from those who had taken up another citizenship following their naturalisation in Germany - hence those who had become dual citizens 'illegally'. ${ }^{\circ}$ Based on this clause, the German Government declared that 48,000 people of Turkish origin who had naturalised in Germany since 2000 had lost their German nationality because they had become 'illegal dual citizens'. ${ }^{\text {II }}$ These people were to have their German nationality withdrawn but could stay in Germany as permanent residents and reapply for naturalisation there provided they were willing to renounce their Turkish nationality. ${ }^{\text {I2 }}$

This did not have a significant impact on the public debate in Turkey but was strongly opposed by Turkish associations in Germany. These associations blamed the Turkish Government for not responding even though they had encouraged these 48 , 000 people to reacquire Turkish nationality. Even though the spokesperson for the German Ministry of the Interior claimed that they had compiled a list of those who were 'illegal' dual citizens from the records collected at borders and in government offices, there were claims that the Turkish authorities had submitted the list because of threats that their EU application process would not be supported. ${ }^{\mathrm{I}}$ There is evidence that the German regional authorities have been contacting those they suspect of holding two passports by mail and asking them whether they had acquired a second nationality. The results of these inquiries and bureaucratic confusion are yet to be seen.

The I98I change was debated in a secret session by the National Security Council because it was initiated by the Ulusu Government, which was established following the military coup. ${ }^{\mathrm{I}}$ The amendment also facilitated the processes for stripping individuals of their citizenship. ${ }^{15}$ The clause added to the law stated that those who are outside the borders of Turkey and who have been charged with endangering the internal or external security of the country will have their Turkish citizenship withdrawn unless they return within three months during regular periods and one month under emergency rule. ${ }^{\mathrm{I}}{ }^{6}$ 
Following this coup, 227 people had their Turkish citizenship withdrawn by means of this clause. However, in February I992, the Parliament removed this clause after hearing arguments that the clause had permitted a violation of human rights. ${ }^{17}$ Those who wished were allowed to reacquire their citizenship and to have their property reinstated or receive compensation for the value of confiscated property. ${ }^{18}$

Parliamentary debates on issues of citizenship and/or problems of Turkish citizens living abroad have not been restricted to amendments of the laws pertaining to citizenship. The events in Solingen, where five Turkish emigrants died as a result of an arson attack on their house, were debated in the Turkish Parliament on 8 June I993. During these debates, the ANAP (centre right party) group spokesperson emphasised the importance of having the right to vote in Germany. He claimed that there are individuals who, despite having lived in Germany for the last 30 years, are still denied the right to vote. According to this argument, the right to vote is the key to finding a long-term solution to the problems faced by Turkish persons residing in Germany. He claimed that under the current circumstances dual citizenship rights were of greater importance and the Turkish Government ought to propose that Germany put this issue on its agenda. ${ }^{\text {I9 }}$

The SHP (centre-left party) group spokesperson claimed that in addition to the security aspects surrounding the Solingen events, political and legal issues should also be debated. He stated that obtaining equal rights in the political, economic and social spheres by obtaining German citizenship would not automatically prevent these attacks, but that extreme right parties would be more cautious about taking an anti-immigration stance as immigrants would form part of the electorate. His argument was that as long as Germany banned dual citizenship, the goal of the Turkish State should be to encourage emigrants to naturalise in Germany while maintaining their rights in Turkey. ${ }^{20}$

Following this logic, the amendment to the Turkish Citizenship Law in 1995 instituted the so-called 'pink card' or the privileged non-citizen status. ${ }^{2 \mathrm{I}}$ In the statement giving reasons for this amendment, the government stressed the fact that it was a result, among other factors, of the actions of countries that refused to accept multiple citizenship.

The proposal for this amendment was drafted by Rona Aybay (a prominent law professor specialising on citizenship issues) after he had attended meetings in Germany at the invitation of the Türkische Gemeinde in Deutschland (TGD). ${ }^{22}$ Once accepted in I995, the amendment created a privileged non-citizen status. This status permits holders of a pink card ${ }^{23}$ to reside, to acquire property, to be eligible for inheritance, to operate businesses and to work in Turkey like any citizen of Turkey. Pink card holders were only denied the right to vote in local and national elections. ${ }^{24}$ Aybay states that the head of the TGD, 
Hakkı Keskin, a very old friend of his, invited him to find a solution to citizenship-related problems faced by Turkish people living in Germany. ${ }^{25} \mathrm{He}$ makes it quite clear that the main issue was how to devise a mechanism that would allow people living in Germany to acquire German citizenship without losing their rights in Turkey. ${ }^{26}$ This was the motivation behind the creation of the special non-citizen status. ${ }^{27}$

During the parliamentary debates when this amendment was discussed, the spokesperson of the ANAP group argued that this law was what all factions of Turkish emigrants in Germany had been demanding for years. He claimed that these emigrants wanted to have political rights in Germany and that this amendment would ease their difficulties in acquiring German citizenship. He also mentioned that Turkish emigrants would become a key electoral group in Germany, with some influence in the tight electoral competition between the two major parties. ${ }^{28}$ Another MP emphasised the benefits of this amendment by referring to the possibility of Turkish people becoming elected representatives in Germany and, therefore, politically strengthening the position of Turkey. ${ }^{29}$

Some MPs raised their concern about whether this amendment would enable the 'Armenians, Jews, Rum, etc. ${ }^{30}$ (who had renounced their Turkish citizenship in order to acquire another citizenship) to come back to Turkey and reclaim property that had been confiscated when they changed their citizenship. This is telling in that it demonstrates that the tolerance for dual citizenship and special rights for those who had renounced their citizenship was intended to apply exclusively to Turkish emigrants who had left the country under specific conditions; the amendment was never intended to include the minorities who left Turkey before I98I, and explicitly stated that the privileged non-citizen status would apply only to those who had acquired Turkish citizenship by birth and who had relinquished it by being granted permission by the Council of Ministers. ${ }^{3 \mathrm{I}}$ This way of renouncing Turkish citizenship was made possible only after the amendments to the citizenship law in I98I.

Despite good intentions, the special non-citizen status was criticised by groups who were dissatisfied with its implementation. The TGD organised a summit in July 2000 and produced a declaration pertaining to the problems and expectations of the Turkish citizens living in Germany. The declaration stated that there were many problems in the practical use of the pink card in Turkey as the bureaucracy was not informed about it. Therefore, people who had renounced their Turkish citizenship were facing problems in their interactions with the bureaucracy in Turkey.

During the same summit there was a call for Turkey to stop releasing its citizens and to make it impossible for Turkish citizens to re- 
nounce their citizenship through new legislation. This would enable Turkish citizens to enjoy dual citizenship through an exception in the new German Law which states that in cases where the country of origin does not permit its citizens to relinquish their original citizenship, Germany might allow dual citizenship. This instance shows how the demands of immigrant organisations have changed depending on the situation in Germany.

\subsubsection{Policies towards historic Turkish groups abroad}

Emigrants were not the only group who influenced the amendments to the citizenship law in Turkey. The disintegration of the USSR and the increasing numbers of arranged marriages in Turkey alerted authorities and the amendment in 2003 requires spouses to wait for three years before spousal transfer of nationality is possible. ${ }^{32}$ The second amendment that same year made it possible for citizens of Northern Cyprus to easily acquire Turkish citizenship (see Trimikliniotis in this volume). ${ }^{33}$ In 2003, a total of 2,403 Cypriots acquired Turkish citizenship. ${ }^{34}$ The latest amendment was passed in 2004 and concerned a minor issue relating to the pink card.

As can be seen from the amendments that were outlined above, apart from the one attempting to prevent arranged marriages, there is no debate about immigrants in Turkey. The focus has been on emigrants from Turkey who live in Western Europe. Politicians in Turkey feel little need to respond to immigrant issues because these are not yet politicised, which is a common feature of countries that have only recently begun receiving economic immigrants.

Prior to the I980s, immigrants accepted to Turkey have been predominantly from among peoples considered to be 'of Turkish descent and culture' and they were settled using the Law on Settlement. ${ }^{35}$ The Law on Settlement allowed for two types of migration to Turkey: those who were settled by the state and those who settled themselves (Doğanay no date). According to Doğanay this law was considered insufficient during the last two decades and it was amended to accommodate those forced to migrate to Turkey from Bulgaria in 1989 (see Smilov \& Jileva in this volume). Many of the Bulgarian Turks who arrived with the first wave of migration in 1989 were granted Turkish nationality. When these migrants could reacquire their Bulgarian nationality and passports in 2000 (hence become dual citizens), Turkish politicians encouraged them to vote in the elections in Bulgaria in order to strengthen the political party representing ethnic Turks and play a positive role in establishing cooperation between two countries on the way to EU membership. Some Bulgarian Turks, who had not been able to naturalise in Turkey, were sent back to Bulgaria towards the end of the 
I9905. ${ }^{36}$ Special laws were enacted in order to regulate the settlement of other groups known to have ethnic Turkish origin such as Afghan immigrants and Ahiska Turks who migrated from Russia. ${ }^{37}$

There are not many organised immigrant groups in Turkey able to place significant pressure on the government. Two of the few immigrant groups that made it to the media, for instance, were the Network of Foreign Spouses and Muslim immigrants such as Bulgarian Turks. The Network of Foreign Spouses referred to ideals of fairness and demanded more rights for individuals who are foreigners in Turkey. ${ }^{38}$ The pragmatic nature of the debates on citizenship and the reactive policy style hinders the politicisation of, and reciprocation of tolerance towards, immigrants in Turkey. ${ }^{39}$ In other words, if values that underlie the promotion of dual citizenship for Turkish emigrants were brought into the public sphere, they could lead to demands of reciprocity for immigrants in Turkey.

\subsection{Modes of acquisition and loss of Turkish citizenship}

The law currently regulating the acquisition and loss of Turkish citizenship was put into effect in $1964^{40}$ and was amended as described in the previous section. There are three broad principles through which Turkish citizenship can be acquired or lost: change of status can be brought about ex lege, by a decision of the authorities and through option.

\subsubsection{Ex lege acquisition of citizenship}

The acquisition of citizenship for children of Turkish mothers or fathers is automatic whether the child is born in Turkey or abroad. This rule is clearly based on ius sanguinis. Children of non-Turkish citizens born in Turkey become Turkish citizens automatically if they cannot acquire the citizenship of their parents (the ius soli exception). Marriage to Turkish citizens does not automatically transfer citizenship. There is a waiting period of three years after which the spouse can acquire Turkish citizenship by option. However, those who lose their original citizenship due to marriage automatically become Turkish citizens. Turkish citizenship is extended to children of women who marry a Turkish citizen, if the child's father is dead, unknown or stateless or if the mother has custody over the child. 


\subsubsection{Acquisition of nationality through the decision of authorities}

There are three types of acquisition within this category. The first is the regular mechanism through which naturalisation takes place and is regulated by art. 6 of the Law. The conditions for application are the following. The person should:

a. be an adult (eighteen years or older);

b. have five years of residence in Turkey;

c. have decided to settle in Turkey;

d. have good moral conduct;

e. not have a threatening illness;

f. speak sufficient Turkish;

g. have a job or revenue to support himself or herself and dependents.

The second mechanism, exceptional acquisition, can apply to the following categories of persons without enforcing requirements b) and c): the adult children of those who have lost Turkish citizenship, those who are married to a Turkish citizen and their adult children, those who are of Turkish descent, their spouse and their adult children, those who are residents of Turkey with the intention of marrying a Turkish citizen and those who have or will serve Turkey as industrialists, scientists or artists (achievement-based acquisition of nationality).

The third path, which is reacquisition, applies to all those who have renounced their Turkish citizenship in the past for various reasons. In all three types of acquisition the procedure for naturalisation is lengthy and goes through the Ministry of Internal Affairs and the Prime Minister. The decision to grant citizenship is given by the Council of Ministers.

\subsubsection{Acquisition through option}

Children who lost their Turkish citizenship when their parents renounced their citizenship can choose to reacquire their citizenship upon reaching adulthood. As mentioned above, foreign spouses also can acquire their partner's Turkish nationality by option three years after the marriage. There is no residency requirement for the naturalisation of spouses as long as they remain married.

\subsubsection{Loss of citizenship ex lege}

This is valid only for women who wish, upon marriage, to automatically receive the foreign citizenship of their husbands. Although Turkish nationality law calls this a loss by law, it is in fact an optional loss 
since it occurs only if there is a declaration by the individual to the relevant authorities.

\subsubsection{Loss through a decision of the authorities}

The first method through which Turkish citizenship can be lost is to renounce it (i.e. to ask for a permission to exit). This path of loss is mostly used by citizens who wish to naturalise in countries that do not accept dual citizenship. The release from citizenship may be granted by the Ministry of the Interior by declaration if certain conditions are satisfied. The procedures do not permit renunciation if it results in statelessness.

The second method is the nullification of Turkish citizenship for people who have acquired it in the last five years and who have submitted false information in their application. The third method is the withdrawal of Turkish citizenship from individuals because of specific actions, such as working against the interests of Turkey in a foreign country despite warnings, acquiring another citizenship without informing the Turkish authorities, working for a foreign state which is at war with Turkey, not responding to a call to military service for three months and residing abroad for more than seven years and not showing any interest in maintaining ties with Turkey.

\subsection{Loss through option}

This mode of loss applies to children who acquired Turkish citizenship when their mothers naturalised in Turkey. They can renounce their Turkish citizenship within a year of reaching adulthood as long as this does not result in statelessness. Furthermore, women who acquired Turkish citizenship upon marriage can renounce it upon divorce.

\subsection{Statistics}

In this section, I will undertake a preliminary analysis of the statistics on the acquisition and loss of citizenship. The statistics on acquisitions through the law are shown in Table I4.I. The data for the years I997I999 are missing yet it is possible to conclude that following the disintegration of the Soviet Bloc there has been a steady rise in the number of women who acquired Turkish citizenship through spousal transfer. Consequently, the change in 2003 of the law on spousal transfer of citizenship led to a sharp decline in numbers in the following year. 
Table 14.1 Automatic acquisition of Turkish citizenship, 1990-2008

\begin{tabular}{llllll}
\hline Year & $\begin{array}{l}\text { Through } \\
\text { mother or } \\
\text { father }\end{array}$ & $\begin{array}{l}\text { Through } \\
\text { adoption }\end{array}$ & $\begin{array}{l}\text { Through } \\
\text { ius soli }\end{array}$ & $\begin{array}{l}\text { Through } \\
\text { marriage }\end{array}$ & Total \\
\hline 1990 & 187 & - & & & \\
1991 & 118 & - & 7 & 491 & 683 \\
1992 & 339 & - & 7 & 1,067 & 1,192 \\
1993 & 344 & - & 9 & 1,057 & 1,403 \\
1994 & 434 & - & 25 & 1,380 & 1,733 \\
1995 & 290 & - & 25 & 1,590 & 2,049 \\
1996 & 104 & - & 3 & 1,148 & 1,463 \\
2000 & 259 & 1 & 41 & 933 & 1,040 \\
2001 & 230 & n/a & 57 & 5,384 & 5,685 \\
2002 & 231 & n/a & 52 & 7,630 & 7,917 \\
2003 & 659 & n/a & n/a & 8,416 & 8,699 \\
2004 & 885 & n/a & n/a & 6,912 & 7,571 \\
2005 & 598 & n/a & n/a & 1,261 & 1,413 \\
2006 & 507 & n/a & n/a & 1,798 & 1,859 \\
2007 & 422 & n/a & n/a & 2,721 & 2,305 \\
2008 & 342 & n/a & n/a & 3,820 & 3,143 \\
\hline
\end{tabular}

Note: $\mathrm{n} / \mathrm{a}=$ not available

Source: General Directorate of Population and Citizenship, Ankara

The statistics on acquisition through the decision of authorities are shown in Table I4.2 below.

Table 14.2 Acquisition of Turkish citizenship through a decision of the authorities, 1990-2008

\begin{tabular}{lcccr}
\hline Year & Regular Acquisition & Exceptional acquisition & Reacquisition & Total \\
\hline 1990 & 119 & 785 & $\mathrm{n} / \mathrm{a}$ & 904 \\
1991 & 1,172 & 475 & $\mathrm{n} / \mathrm{a}$ & 1,647 \\
1992 & 888 & 452 & $\mathrm{n} / \mathrm{a}$ & 1,340 \\
1993 & 634 & 439 & $\mathrm{n} / \mathrm{a}$ & 1,073 \\
1994 & 949 & 467 & $\mathrm{n} / \mathrm{a}$ & 1,416 \\
1995 & 1,229 & 710 & $\mathrm{n} / \mathrm{a}$ & 1,939 \\
1996 & 955 & 3,927 & $\mathrm{n} / \mathrm{a}$ & 4,882 \\
2000 & 633 & 736 & 13,004 & 14,373 \\
2001 & 1,161 & 3,917 & 28,317 & 33,395 \\
2002 & 745 & 14,564 & 8,330 & 23,639 \\
2003 & 1,236 & 12,938 & 3,040 & 17,214 \\
2004 & 1,276 & 6,434 & 1,999 & 9,709 \\
2005 & 816 & 4,650 & 864 & 6,330 \\
2006 & 987 & 2,161 & 2,006 & 5,154 \\
2007 & 718 & 1,358 & 979 & 3,055 \\
2008 & 824 & 2,383 & 1,348 & 4,555 \\
\hline
\end{tabular}

Note: $\mathrm{n} / \mathrm{a}=$ not available

Source: General Directorate of Population and Citizenship, Ankara 
The statistics provided by the General Directorate of Population and Citizenship reveal that in the category of regular acquisition by a decision of the authorities, 6o per cent were Greek heimatloss ${ }^{4 \mathrm{I}}$ in I99I whereas 9 per cent were Iranian citizens. Between 2000 and 2003, approximately 50 per cent of this same category were Bulgarians. Between I990 and I993, the majority of those who acquired Turkish citizenship on exceptional grounds had previously held Iraqi citizenship (3I per cent for I990, 32 for I991, 23 for I992 and 34 per cent for I993). The largest group within this category were Bulgarians (they constituted 82 per cent of the total exceptional acquisition in 2002 and 84 per cent in 2003).

Table I4.3 shows the statistics on the numbers of withdrawals of Turkish citizenship (the third method explained in section 2.5 above). It should be noted that within the group of people who lost their Turkish nationality between 2000 and 2005 there is no case of loss resulting from failure to reside in the country during the preceding seven years. The majority of people whose citizenship was withdrawn were those who did not return to the country to fulfil their military service despite being called up by the authorities - for instance, out of I,920 people who lost their Turkish citizenship in 2000, I,868 were in this category. This figure is 2,689 out of 2,735 in $2001,2,193$ out of 2,316 in $2002,5,077$ out of 5,489 in 2003 , I,975 out of 2,367 and I78 out of 464 in 2005 .

The number of Turkish citizens whose nationality was withdrawn because they did not inform the Turkish authorities that they were acquiring another citizenship increased between 2000 and 2005. The numbers are 42 for 2000, 24 for 200I, 8I for 2002, 272 for 2003,246 for 2004 and 242 for 2005 . The application of this rule is random at best since there are many people in this situation who have maintained their Turkish citizenship for many years. The increase in the numbers

Table 14.3 Loss of Turkish citizenship by a decision of the authorities, 2000-2008

\begin{tabular}{lc}
\hline Year & Withdrawal of citizenship \\
\hline 2000 & 1,920 \\
2001 & 2,735 \\
2002 & 2,316 \\
2003 & 5,489 \\
2004 & 2,367 \\
2005 & 464 \\
2006 & $n / a$ \\
2007 & $n / a$ \\
2008 & $n / a$ \\
\hline
\end{tabular}

Note: $\mathrm{n} / \mathrm{a}=$ not available

The General Directorate of Population and Citizenship reported there was no record for this category for the years 2006-2008.

Source: General Directorate of Population and Citizenship, Ankara 
in this category cannot really be explained with the available data or information. The only possibility is the sensitisation of the authorities as a result of events that led to the withdrawal of the Turkish citizenship of a member of parliament who had sworn allegiance to the US by becoming a citizen there prior to the elections in Turkey.

Statistics on loss of citizenship are also published for those who have subsequently reacquired their Turkish citizenship (see Table I4.4 below). Up until 2002, individuals who renounced their Turkish citizenship could easily reacquire their original citizenship following naturalisation in Germany. However, the realisation that a new law can lead to nullification of their German citizenship if it is discovered that they have reacquired their original citizenship has led to a sharp drop in the number of individuals who have reacquired Turkish citizenship thereafter.

Table 14.4 Previous loss of citizenship by those who have reacquired Turkish citizenship according to three main categories, 2000-2004

\begin{tabular}{lrrrrr}
\hline Reason for Loss & \multicolumn{1}{c}{2000} & \multicolumn{1}{c}{2001} & 2002 & 2003 & 2004 \\
\hline Permission to exit & 12,635 & 27,576 & 8,027 & 2,874 & 1,828 \\
Inappropriate conduct & 29 & 71 & 58 & 85 & 121 \\
Loss by option & 340 & 670 & 245 & 81 & 50 \\
Total & 13,004 & 28,317 & 8,330 & 3,040 & 1,999 \\
\hline
\end{tabular}

Note: The General Directorate of Population and Citizenship reported no data for the years 2005-2008

Source: General Directorate of Population and Citizenship, Ankara

\subsection{Conclusions}

The findings suggest that maintaining vibrant economic links with citizens living abroad (especially those living in Germany) has been a constant concern for Turkish governments despite the severe neglect for the social problems faced by these groups. The research results show that there are a number of organisations and actors, especially within Germany, that pressure the policymakers in Turkey to accommodate their need to integrate into their host country without having to relinquish their rights to land ownership and inheritance in Turkey. The main amendments to the Law on Citizenship in Turkey were made as a result of the realisation that the guest-workers were in fact permanent residents in their host countries. The most interesting finding is the interaction between the Turkish and German governments and the attempts of the former to formulate legislation based on the developments in Germany. 
Turkish governments have demonstrated a willingness to address the practical problems faced by the Turkish people living abroad. In many cases the intentions were sincere even though official actions to solve the problems were either slow or non-existent. However, this inability did not stem from apathy towards the real problems or the aim of strategically using the issue for political gain. It was rather the result of a general lack of political incentives, as those living abroad who still possess the right to vote in Turkey cannot practically do so unless they return to Turkey during elections. ${ }^{42}$

As outlined in the sections above, there is a very pragmatic debate concerning citizenship in Turkey. The principles of citizenship acquisition and loss are seldom discussed and immigrants have not been a real concern of policymakers, either because they are not mobilised or because the issue is not politicised. Foreigners, like Bulgarian Turks or those coming from Central Asia, are not considered part of these immigrant groups since, in most cases, they acquired Turkish citizenship based on their cultural, linguistic and religious backgrounds.

There are many cases of immigrants who find ways to work in Turkey and leave the country every three months (this applies to many Bulgarian Turks who do not have citizenship). Many foreigners who do not need a visa to enter Turkey are employed in Turkey illegally. Even some Western European citizens who reside in Turkey without a work permit resort to this method. Very few of these immigrant groups have organised and begun trying to pressure the Turkish state. Brücke, a German-Turkish bridging organisation, and the Association of Foreign Wives are exceptions. Hence, if in the next five to ten years immigration issues become more important and appear in the public sphere we might begin to see more pressure applied to Turkey. ${ }^{43}$

\subsection{Epilogue}

The history of Turkish Citizenship Law, which was recounted above, shows that there have been numerous changes to the law since ig64. Most of these changes regarded two issues: they either addressed the interests of emigrants from Turkey or adapted the Turkish regulations to international standards. As a consequence of these amendments, the law has been transformed into a patchwork full of inconsistencies, which is one of the reasons why the Turkish government decided to propose a new Nationality Law. Moreover, this new law aims to harmonise the Turkish regulations with those of the European Convention on Nationality (Tiryakioglu 2006).

Hence, the new law mainly attempts to reduce inconsistencies. Moreover, there are also three substantive changes to the acquisition 
and loss of citizenship. The most important change concerns the withdrawal of citizenship from males who have not served in the military and those citizens who have acquired another country's citizenship without informing the authorities. The law, as it currently stands, stipulates that these two types of actions are punishable by the withdrawal of Turkish citizenship. The new law eliminates this possibility and restores the citizenship of those who have lost their citizenship as a result of these clauses. The second major change, which will be implemented by 20I0, will abolish preferential treatment of those applicants for naturalisation who are of Turkish origin by applying a five-year residency requirement for all applicants. The third substantive change is the three-year residency requirement for those who wish to reacquire their Turkish citizenship following loss through renunciation or withdrawal as a result of inappropriate conduct. The new law on citizenship was accepted in the parliament on 29 May 2009 (No. 5901/2009 on Turkish Citizenship).

Finally, the Turkish government recently adopted a new law that facilitates voting by Turkish citizens abroad. Even though Turkish citizens residing abroad were able vote in Turkey's general elections, there was no practical method for doing so other than the setting up of ballot boxes at the borders for emigrants who travelled to and from Turkey. This situation changed with Law No. 5749 (adopted on I3 March 2008), which clarifies the methods through which Turkish citizens living abroad can vote in general elections, presidential elections, and referenda in Turkey. There are now four different ways to vote: by regular mail, at the borders (during a 75-day period prior to the election date as practised during previous elections), at the consulates abroad (over a period of 45 days prior to the election date), and electronically (over a period of 30 days prior to the election date). The Constitutional Court cancelled the possibility of voting through mail ballots because it violates the secrecy of voting.

Chronological list of citizenship-related legislation in Turkey

\begin{tabular}{lll}
\hline Date & Document & Content \\
\hline 1869 & $\begin{array}{l}\text { Ottoman Nationality } \\
\text { Regulation }\end{array}$ & $\begin{array}{l}\text { Recognises all residents of } \\
\text { the Ottoman territories as } \\
\text { nationals of the Empire }\end{array}$ \\
1924 Constitution of the & $\begin{array}{l}\text { Grants Turkish nationality to } \\
\text { all residents of the Republic } \\
\text { Republic of Turkey }\end{array}$ & $\begin{array}{l}\text { irrespective of race or } \\
\text { religion } \\
\text { Based on ius sanguinis but } \\
\text { complemented by a } \\
\text { Law No. 1312/1928: } \\
\text { Turkish Citizenship Act }\end{array}$ \\
&
\end{tabular}




\begin{tabular}{|c|c|c|c|}
\hline Date & Document & Content & Source \\
\hline 1934 & $\begin{array}{l}\text { Law No. } 2510 / 1934 \text { on } \\
\text { Settlement }\end{array}$ & $\begin{array}{l}\text { Provides refugee and } \\
\text { immigrant status to groups } \\
\text { such as Muslim Bosnians, } \\
\text { Albanians, Circassians, } \\
\text { Tatars, etc. }\end{array}$ & www.ifc.org \\
\hline 1961 & $\begin{array}{l}\text { Constitution of the } \\
\text { Republic of Turkey }\end{array}$ & $\begin{array}{l}\text { Renewed following the } \\
\text { coup; states that children } \\
\text { born to Turkish mothers or } \\
\text { fathers are Turkish and that } \\
\text { it is not possible to revoke } \\
\text { the citizenship of } \\
\text { individuals unless they have } \\
\text { been disloyal to the country; } \\
\text { determines that children } \\
\text { born to Turkish mothers } \\
\text { and foreign fathers acquire } \\
\text { citizenship based on the } \\
\text { citizenship law }\end{array}$ & $\begin{array}{l}\text { www.legislationline.org; } \\
\text { www.hri.org }\end{array}$ \\
\hline 1964 & $\begin{array}{l}\text { Law No. 403/1964: } \\
\text { Turkish Citizenship Act }\end{array}$ & $\begin{array}{l}\text { Based on the principles } \\
\text { outlined in art. } 54 \text { of the } \\
1961 \text { Constitution }\end{array}$ & www.coe.int \\
\hline 1981 & $\begin{array}{l}\text { Law No. } 2383 / 1981 \\
\text { amending Law No. } 403 / \\
1964\end{array}$ & $\begin{array}{l}\text { Legalises dual citizenship } \\
\text { provided that the person } \\
\text { acquiring a second } \\
\text { nationality informs the } \\
\text { government }\end{array}$ & www.legislationline.org \\
\hline 1982 & $\begin{array}{l}\text { Constitution of the } \\
\text { Republic of Turkey (as } \\
\text { amended in 1987, 1995, } \\
2001 \text { ) }\end{array}$ & $\begin{array}{l}\text { Keeps the same principles } \\
\text { regarding citizenship as the } \\
1961 \text { Constitution }\end{array}$ & $\begin{array}{l}\text { www.tbmm.gov.tr } \\
\text { (in Turkish) }\end{array}$ \\
\hline 1989 & $\begin{array}{l}\text { Law No. } 3540 / 1989 \\
\text { amending Law No. } 403 / \\
1964\end{array}$ & $\begin{array}{l}\text { Amends two articles of the } \\
\text { law regulating the process } \\
\text { of acquisition of Turkish } \\
\text { citizenship, specifically } \\
\text { regarding the procedure for } \\
\text { conditional naturalisation; } \\
\text { determines that persons } \\
\text { who fail to fulfil a } \\
\text { requirement within two } \\
\text { years following } \\
\text { naturalisation are likely to } \\
\text { lose their citizenship }\end{array}$ & \\
\hline 1992 & $\begin{array}{l}\text { Law No. } 3808 / 1992 \\
\text { amending Law No. 2383/ } \\
1981\end{array}$ & $\begin{array}{l}\text { Removes the clause stating } \\
\text { that those who are outside } \\
\text { the borders of Turkey and } \\
\text { who have been charged with } \\
\text { endangering the internal or } \\
\text { external security of the } \\
\text { country will be stripped of } \\
\text { Turkish citizenship unless } \\
\text { they return within three }\end{array}$ & \\
\hline
\end{tabular}




\begin{tabular}{|c|c|c|c|}
\hline Date & Document & Content & Source \\
\hline \multirow[b]{2}{*}{1995} & & $\begin{array}{l}\text { months during regular } \\
\text { periods and one month } \\
\text { under emergency rule }\end{array}$ & \multirow{35}{*}{ www.legislationline.org } \\
\hline & $\begin{array}{l}\text { Law No. 4112/1995 } \\
\text { amending Law No. 403/ } \\
1964\end{array}$ & $\begin{array}{l}\text { Institutes the privileged } \\
\text { non-citizen status (also } \\
\text { known as the 'Pink Card') }\end{array}$ & \\
\hline \multirow[t]{6}{*}{1999} & Law No. 4465/1999 & $\begin{array}{l}\text { Ratifies an agreement } \\
\text { between the Turkish }\end{array}$ & \\
\hline & & Republic and the Republic & \\
\hline & & of Northern Cyprus on & \\
\hline & & facilitating the & \\
\hline & & naturalisation of Cypriots in & \\
\hline & & Turkey & \\
\hline \multirow[t]{3}{*}{2003} & Law No. 4866/2003 & Introduces a waiting period & \\
\hline & amending Law No. 403/ & of three years for acquisition & \\
\hline & 1964 & of citizenship by spouses & \\
\hline \multirow[t]{4}{*}{2003} & Law No. $4862 / 2003$ & Introduces facilitated & \\
\hline & amending Law No. 403/ & acquisition of Turkish & \\
\hline & 1964 & citizenship for citizens of & \\
\hline & & Northern Cyprus & \\
\hline \multirow[t]{7}{*}{2004} & Law No. 5203/2004 & Clarifies the rights linked to & \\
\hline & amending Law No. 403/ & the privileged non-citizen & \\
\hline & 1964 & status; states that holders & \\
\hline & & retain social insurance & \\
\hline & & rights but lose voting rights, & \\
\hline & & the right to be elected and & \\
\hline & & $\begin{array}{l}\text { the right to be employed in } \\
\text { the civil service }\end{array}$ & \\
\hline \multirow[t]{5}{*}{2008} & Law No. 5749 amending & Allows Turkish citizens & \\
\hline & Law No. $298 / 1961$ on & living abroad to vote by mail & \\
\hline & Elections and Voter & (repealed by the & \\
\hline & Registration & Constitutional Court), & \\
\hline & & $\begin{array}{l}\text { electronically, at the border } \\
\text { or at consulates }\end{array}$ & \\
\hline \multirow[t]{8}{*}{2009} & Law No. 5901 Turkish & Eliminates the possibility to & \\
\hline & Citizenship Law & withdraw citizenship from & \\
\hline & & males who have not served & \\
\hline & & in the military and those & \\
\hline & & citizens who acquired & \\
\hline & & another country's & \\
\hline & & citizenship without & \\
\hline & & informing the authorities & \\
\hline
\end{tabular}

\section{Notes}

I The author wishes to thank Esra Derle, Selçuk Uğuz and Özlem Atikcan for their help in facilitating access to resources. 
2 It should not be forgotten that this was taking place in the context of sharp declines in the size of the population of Anatolia as a result of the First World War.

3 Law No. 2510/1934 on Settlement.

4 Sunni Islam, which is considered to be the mainstream, differs from Shi'a Islam.

5 The Sheikh Said uprising was one of the first important rebellions against the state. The Sheikh gathered support on the basis of tribal and religious allegiance, and hence the insurgency was not exclusively one of Kurdish nationalism (Robins I993: 660).

6 Law No. 403/1964 on Turkish Citizenship.

7 Turkish authorities were counselling emigrants not to lose their socio-cultural identity and to maintain ties with Turkey. Germanisation, according to this perspective, would distance emigrants from Turkey.

8 Parliamentary Minutes, 7 June I995, Period I9, Legislative Year 4, Volume 88, 89I09.

9 Law No. 2383/198I on Turkish Citizenship.

Io German Citizenship Law, art. 25. The only exceptions to the strict ban on dual citizenship are those who have a second passport from a European Union country and those who have applied for permission.

II Y. Özdemir, 'Ankara-Berlin Kıskacında: Çifte Vatandaşlık Gerçeği' [Caught between Ankara and Berlin: the Truth about Dual Citizenship], Evrensel [daily newspaper], 26 January 2005. This move came at a critical juncture in German politics whereby expelling these citizens impacted on the number of voters. According to one estimate, approximately 20,000 out of 600,000 German-Turkish voters were disenfranchised in the general elections of 2005 (Deutsche Welle, I7 September 2005, www.dw-world.de).

I2 Radikal [daily newspaper], II February 2005.

I3 Y. Özdemir, 'Ankara-Berlin Kıskacında: Çifte Vatandaşlık Gerçeği’ [Caught between Ankara and Berlin: the Truth about Dual Citizenship], Evrensel [daily newspaper], 26 January 2005 .

I4 After the military coup Bülend Ulusu was given the responsibility of forming a technocratic government (www.tbmm.gov.tr). Until the Advisory Council was formed the National Security Council (NSC) sanctioned all decisions of the government. The members of the NSC were the four generals and one admiral who staged the coup. The minutes of the I3 February I98I meeting of the National Security Council $\left(38^{\text {th }}\right.$ Meeting, Volume I, I98I) indicate that the members of the Council voted in favour of debating all amendments related to Turkish Citizenship Law in a secret session. The debate lasted for approximately two hours.

I5 Cumhuripet, I5 February I98I.

I6 Law No. 2383/198I amending Law No. 403/1964 on Turkish Citizenship.

I7 Law No. 3808/1992 amending Law No. 2383/198I. In between these two amendments there is Law No. 3540/1989, which amended two articles of the law regulating the process of acquisition of Turkish citizenship.

I8 Parliamentary Minutes, 27 May I992, Period I9, Legislative Year I, Volume I2, 53-55.

I9 Parliamentary Minutes, 8 June I993, Period I9, Legislative Year 2, Volume 36, I89I92.

20 Ibid., 203-206.

2I Law No. 4II2/1995 amending Law No. 403/1964 on Turkish Citizenship.

22 The Turkish Immigrants Union (later to become Almanya Türk Toplumu - TGD) was established in 1985 . It is an umbrella association with around 200 members, including the German Turkish Academics Association Union, German Turkish Students Association Union and various occupational organisations. TGD promotes the interests of the Turkish population of Germany vis-à-vis both the German and 
the Turkish governments, attempts to influence public opinion, and to secure rights through legislative changes (www.tgd.de).

23 The pink card is the document given to the people who have the special non-citizen status.

24 Law No. 4II2/I995 amending Law No. 403/1964 on Turkish Citizenship.

25 Interview with Rona Aybay, 20 August 2002.

26 People who have acquired Turkish citizenship by means other than birth do not have the right to a pink card.

27 Parliamentary Minutes, 8 June I993, Period I9, Legislative Year 2, Volume 36, 203206.

28 Parliamentary Minutes, 7 June I995, Period I9, Legislative Year 4, Volume 88, 8990.

29 Ibid., 96.

30 Speaker of the RP (Refah Partisi - religious right wing party) group (Parliamentary Minutes, 7 June I995, Period I9, Legislative Year 4, Volume 88, I03). Many other MPs voiced their concern on this issue as well.

3I Art. 29 of Law No. 4II2/1995 amending Law No. 403/1964 on Turkish Citizenship. This provision is against the principle of non-discrimination between citizens by birth and by naturalisation incorporated in the 1997 European Convention on Nationality. Turkey has not signed this Convention.

32 Law No. 4866/2003 amending Law No. 403/1964 on Turkish Citizenship.

33 Law No. 4862/2003 amending Law No. 403/1964 on Turkish Citizenship. The citizens of the Turkish Republic of Northern Cyprus (TRNC) have always enjoyed preferential treatment in Turkey. Law No. 4465/1999 further strengthened this by attempting to provide TRNC citizens with all the social and economic rights of Turkish citizens except voting rights. Since TRNC is not a recognised state (except by Turkey) TRNC citizens could travel abroad only with a Turkish passport (except for the UK and USA which recognised the TRNC passport as an identity card and issued visas for TRNC citizens on a blank page and not the passport itself). TRNC citizens could obtain a Turkish passport without becoming a citizen of Turkey. They also had the right to be dual citizens and Law No. 4465/1999 states that there shall be a fasttrack process for the citizenship applications of those TRNC citizens who want to acquire the citizenship of the Republic of Turkey. Dual citizenship has also existed for those Turkish citizens who settled in the TRNC. Those with five years residence are granted TRNC citizenship provided that they fulfil certain conditions (Law No. 25/I993 TRNC Nationality Law). Yet the TRNC Council of Ministers can also grant TRNC citizenship on a discretionary basis. The TRNC government was accused of such discretionary behaviour prior to the 2003 elections in order to influence the election results (Hylland 2003).

34 Data used in this paper related to citizenship in Turkey were provided by the General Directorate of Population and Citizenship, Ankara.

35 Law No. 2510/1934 on Settlement. The Council of Ministers was in charge of determining which groups were considered to be of Turkish descent. Groups such as Pomacks, Roma and Albanians have also been settled in Turkey by being assigned this status (Şahin no date).

36 'Sofya'da bir Kurultay', Milliyet [daily newspaper], I6 July 2000; 'Soydaşa Green Card', Milliyet, 4 March I997; 'Menderes: "Çifte Vatandaşlık Kolaylaştırılsın”, Milliyet, 24 February 1997.

37 Law No. 264I/1982 and Law No. 3835/1992 respectively.

38 The majority of the women in this association were Germans and they did not want to naturalise in Turkey because they would lose their German citizenship.

39 For a classification of policy styles, see Richardson (I982). 
40 Law No. 403/1964 on Turkish Citizenship.

4I The term Greek Heimatloss is used to refer to those Greek citizens of Western Thrace (of Turkish origin) who were expelled from Greek citizenship.

42 Voting during general elections in Turkey has been a widely debated issue. Legally it is possible for Turkish people living abroad to vote during elections from the country where they reside. However, due to practical problems, such as setting up ballot boxes in other countries and the insecurity of mail ballots, this has never been practised. Fuat Boztepe, who is the head of the department in charge of workers abroad at the Ministry of Labour, stated that the greatest problem occurs in countries where there are a significant number of workers and the host country does not allow ballot boxes to be put in public spaces. Given the number of people who could vote, setting up ballot boxes only in the consulates and embassies does not provide a solution (interview with Fuat Boztepe, Head of the Department of External Relations and Services for Workers Abroad at the Turkish Ministry of Labour and Social Security, I4 May 2003).

43 Ahmet İçduygu, Bilkent University, Department of Political Science, confirmed this possibility (interview: 15 May 2003).

\section{Bibliography}

Aybay, R. (200I), Vatandaşlık Hukuku [Citizenship Law]. İstanbul: Aybay Yayınları.

Doğanay, F. (no date), Türkiye'ye Göçmen Olarak Gelenlerin Yerleşimi [The Settlement of Migrants to Turkey]. www.balgoc.org.tr.

Ergil, D. (2000), 'The Kurdish Question in Turkey', Journal of Democracy II (3): I22-I35.

Faist, T. (I998), 'Transnational Social Spaces out of International Migration: Evolution, Significance and Future Prospects', Archives Européennes de Sociologie 39 (2): 213-247.

Hunn, K. (200I), “'Alamanya, Alamanya, Türk gibi İsçi Bulamanya... Alamanya Alamanya, Türkten Aptal Bulamanya" Labour Migration from Turkey to the Federal Republic of Germany in the Years of Official Labour Recruitment (I96I-I973)', German-Turkish Summer Institute Working Paper 4.

Hylland, A. (2003), Northern Cyprus Parliamentary Elections. www.humanrights.uio.no.

İçduygu, A., Y. Çolak \& N. Soyarık (1999), 'What is the Matter with Citizenship? A Turkish Debate', Middle Eastern Studies 35 (4): I87-208.

Keyman, E. F. \& A. İçduygu (2003), 'Globalization, Migration and Citizenship: The Case of Turkey', in E. Kofman \& G. Youngs (eds.), Globalization: Theory and Practice, I93206. London: Continuum.

Kiriş̧̧i, K. (2000), 'Disaggregating Turkish Citizenship and Immigration Practices,' Middle Eastern Studies 36 (3): I-22.

Kumcu, M. E. (1989), 'The Savings Behavior of Migrant Workers: Turkish Workers in W. Germany,' Journal of Development Economics 30: 273-286.

Richardson, J. J. (ed.) (1982), Policy Styles in Western Europe. Boston: Allen and Unwin.

Robins, P. (I993), 'The Overlord State: Turkish Policy and the Kurdish Issue', International Affairs 69 (4): 657-676.

Şahin, Z. (no date), Türkiłe'Ye Yönelik Dış Göçteki Değişim Ve Süreklilik [The change and continuity in the migration towards Turkey]. www.stradigma.com.

Sayar1, S. (1986), 'Migration Policies of Sending Countries: Perspectives on the Turkish Experience', Annals of the American Academy of Political and Social Science 485: 87-97.

TCCSGB (TC Çalışma ve Sosyal Güvenlik Bakanlığı) (2005), Bulletin 5 (2).

Tiryakioglu, B. (2006) 'Multiple Citizenship and its Consequences in Turkish Law', Ankara Law Review 3(I): I-I6. 


\title{
'A call to kinship'? Citizenship and migration in the new Member States and the accession countries of the EU
}

\author{
Wiebke Sievers
}

When the black British poet John Agard (2000) warns his readers to 'remember the ship in citizenship', he is implying that citizenship is not a fixed institution but something that should be adaptable to changes in the population. Agard explicitly refers to black immigration to Britain. In fact, his poem entitled 'Remember the Ship' was first published in 1998, 50 years after the SS Empire Windrush arrived at Tilbury, an event that has come to epitomise the beginning of black immigration to Britain. Commemorating this event, Agard demands: 'citizenship shall be / a call / to kinship / that knows / no boundary / of skin' (Agard 2000: 259). Of course, the poem implies a wider understanding of citizenship than what has been discussed in the present volume, including specific questions that address equal participation in the community. Nevertheless, if we only look at citizenship regulations, it is obvious that these have changed dramatically in recent years and that immigration has played a major role in these changes, albeit not always in the way Agard envisages. Thus, Britain has used citizenship regulations in order to reduce the immigration of blacks, in particular, from its former colonies when it introduced a new nationality law in I98I (see Dummett 2006: 568-570). Moreover, the NATAC study has shown that many recent changes in citizenship laws of the fifteen pre2004 EU Member States were in response to immigration, even if there is no single clear trend. While some countries, including Austria, Denmark, France, Greece, the Netherlands and the UK raised their requirements for naturalisation, others, such as Belgium and Portugal, have liberalised access to their nationalities for immigrants and their descendants (see Bauböck, Ersbøll, Groenendijk \& Waldrauch 2006: 23-25).

This is probably the most striking difference between the citizenship regulations in the fifteen 'old' Member States and those in the twelve new EU Member States and the two accession countries discussed in this book. Most of these are only just now starting to become countries of immigration. Yet, migration was also a very important issue concerning their citizenship regulations over the past two decades, albeit 
in different ways. These specific links between citizenship and migration shall be discussed in more detail in this summary. The first section will analyse policies of initial citizenship determination, which have often implied discrimination against long-term resident populations and their descendants, in particular those in Estonia and Latvia but also those in the former Yugoslavia. Subsequently, I will look at the legal regulations that specifically target emigrants, and the interactions between these and the citizenship regulations in the emigrants' current countries of residence. Finally, I will focus on various naturalisation regulations and their implications for the new immigrants who began to settle in these countries in the I990s.

\section{$1 \quad$ Excluding long-term residents and their descendants: Initial determination of citizenship in Estonia, Latvia, Slovenia and Croatia}

All of the newly formed states have to figure out how to determine who their citizens are. The majority of new states solve this puzzle by declaring those born or residing in their territory their citizens (see Brubaker 1992: 277). However, in order to prevent both the imposition of citizenship onto citizens of other states born or living in their countries and creating stateless persons abroad, emerging states usually distinguish between those who automatically become their citizens on the day of their establishment and those who can apply for citizenship within a certain period of time after that date. In Cyprus, for example, residence in the country was the decisive element in this process. Only those who had a special connection to the country ${ }^{\mathrm{I}}$ and had ordinarily resided on the island of Cyprus for any period of time in the five years before the day of independence automatically became citizens on that day, whereas those of Cypriot origin who were not residing in the country could apply for citizenship. In Malta, by contrast, birth in the country was considered more important. Only those citizens of the United Kingdom and the colonies who were born in Malta and one of whose parents was also born there, as well as those born outside Malta whose father and one of whose paternal grandparents were born in Malta, automatically became citizens of Malta. Those born in Malta of parents who were not born there had to apply for citizenship. In addition, both Cyprus and Malta made provisions for those who were naturalised under former regulations and women married to citizens of their countries (see Trimikliniotis and Buttigieg in this volume).

While Cyprus' and Malta's initial determinations of who their citizens are do not seem to have created too many problems, the situation was quite different in the post-communist states that were established 
or re-established in the I990s. The regulations that determined the initial citizenry in these countries, which resulted from partitioning or secession, turned former internal migrants into international migrants. Their legal statuses became unclear in countries like the Czech Republic, Slovakia and Slovenia, difficult in Croatia and extremely problematic in Estonia and Latvia.

The Czech Republic, Slovakia and the former Yugoslav republics decided to base their criteria for citizenship on the existing republic-level citizenship introduced in Yugoslavia just after the Second World War, and in Czechoslovakia in response to the Slovak national movement of the late ig6os. These existing regulations stipulated that all citizens of Yugoslavia and Czechoslovakia automatically were citizens of their respective states and of one of the federal republics within this entity. Although it was very easy to change the republic-level citizenship in both states, internal migrants usually did not bother because there was (almost) no benefit from such a change. As a consequence, 65,000 Slovaks applied for Czech republic-level citizenship in I992 when Slovakian threats to break away became a realistic possibility. Despite this run on applications, many Czechs and Slovaks ended up with the citizenship of the state in which they were not residing and, in some cases, where they had not even been granted permanent residence. Moreover, although each state gave the citizens of the respective other state the option to apply for its citizenship, there is some indication that it was particularly difficult for many Roma who had moved from the Slovak to the Czech part of Czechoslovakia after the Second World War to fulfil some of the requirements. It took about a decade and several legislative corrections to sort out these and similar problems (see Baršová and Kusá in this volume).

The situation was comparable in Slovenia, where citizens of the other Yugoslav republics, registered as residents in Slovenia on the day of the referendum for independence (23 December I990), were granted the option to apply for Slovenian citizenship within six months after independence, i.e. by 25 December I99I. A total of I7I,I25 persons (or about 8 per cent of the total population at the time) were granted Slovenian citizenship under this regulation. Despite the fact that this was a more inclusive approach to the initial determination of citizenry than in the other Yugoslav successor states, it nevertheless excluded those long-term residents who had never bothered to register their residence in Slovenia, which was not rare since Slovenia was the only one of the Yugoslav republics that recorded in- and out-migration and there was no immediate benefit to registering. Moreover, those who had registered their residence in Slovenia but did not apply for, nor acquire, Slovenian citizenship became aliens and had to apply for residency status even if they had resided in the country for years. If, 
for various reasons - including the lack of information, the difficulty of obtaining documentation in the period of Yugoslavia's break-up, confusing procedures, etc. - they had not applied for residency by the day when the Aliens Act became law (23 February 1992), they were automatically transferred from the register of residents to the aliens record without even being notified of this change in their status, which later became known as erasure. This erasure meant that they lost all of their civil, social and political rights that had been granted to them under the Yugoslav legal framework, such as the rights to work, healthcare and social benefits. The government admitted that it had deprived more than 18,000 persons of their residency status. However, this figure probably excludes those affected who left Slovenia before the matter became publicly known. Despite pressure from several NGOs and the ombudsman for human rights, who pointed out this problem in his first report in 1995, it was only in I999 that the Constitutional Court ordered the legislature to eradicate this mistake. For various reasons, the legislature has yet to follow up on this directive. However, 7,000 of those affected by this act have since been granted Slovenian citizenship under the 1999 Act Settling the Status of Citizens from other Yugoslav Successor States before it was declared unconstitutional in 2003. The same constitutional court decision ordered the Slovenian state to reissue permanent residence permits to those deleted from the population register whose status had yet to be determined at the time. Finally, this group was granted the right to apply for facilitated naturalisation by 23 November of the same year. Another I, 767 persons acquired Slovenian citizenship under this provision (see Medved in this volume; Štiks 2006: 490-49I).

Like Slovenia, Croatia decided to follow the principle of legal continuity. Hence, all citizens of the Yugoslav republic of Croatia automatically became citizens of the new state when it became independent on 8 October 1991. Unlike Slovenia, however, Croatia did not grant citizens of other Yugoslav republics/successor states residing in Croatian territory the right to opt for Croatian citizenship. As a consequence, these residents, who had sometimes been living in Croatia for years or were even born there, automatically became aliens on the day of independence, thereby losing all citizenship rights they had held under the Yugoslav legal framework. This most likely affected a much larger group of persons than the erasure in Slovenia, which had similar implications, but the exact figures of those excluded from Croatian citizenship by this action remain unknown. Only a specific group among these was granted privileged access to Croatian citizenship in the transitional provisions regulating the initial determination of who was Croatian: namely, just resident ethnic Croats. They could acquire citizenship by issuing a written statement to the police that they consid- 
ered themselves Croatian citizens. All other residents who had become foreigners and who wanted to acquire the citizenship of their state of residence had to apply for naturalisation. The naturalisation procedure, in line with the general spirit of the I99I Law, required abiding by Croatia's legal system, customs and culture. This gave the Ministry of Interior wide discretion in rejecting applications, which, according to several reports, seems to have resulted in discrimination against all non-ethnic Croats but in particular against Serbs. Administrative practice has become less discriminatory since Franjo Tudjman's death and subsequent political changes. However, the Croatian government has yet to adopt a new and less discriminatory law (see Ragazzi \& Štiks in this volume; Human Rights Watch 1995).

The initial determination of citizenship was most problematic in Estonia and Latvia because both states had created a large number of stateless persons in the process. Originally founded in 1920 , the three Baltic states of Latvia, Estonia and Lithuania were first occupied by the Soviet Union in 1940 and, after a short period of German occupation, they became part of the Soviet Empire in I944. During the period of Soviet annexation, which was also a period characterised by rapid industrialisation, especially in Latvia and Estonia, a large number of Russian workers moved to these two countries. When the Baltic states regained their independence in I990, these internal migrants 'secure in their Soviet citizenship' became 'international migrants of contested legitimacy and uncertain membership' (see Brubaker 1992: 269).

In principle, these three Baltic states followed the notion of state continuity, which means that they reinstalled the 1940 institutions and laws, including their respective citizenship legislation. However, Lithuania had already enacted a new nationality law in I989, using the authority in nationality matters granted by the Soviet authorities during the final days of the Soviet Union. This law was the outcome of negotiations between Lithuanian nationalist forces, which intended to reinstall the pre-I940 citizenship laws, and the Soviet government, which opposed the exclusion of Russians and Poles who lived in Lithuanian territory. Departing from the pre-I940 citizenship laws, it only regarded those pre-1940 nationals and permanent residents and their children and grandchildren who resided in Lithuania and did not hold another citizenship as citizens. Hence, emigrants and expatriates were excluded, a decision that Lithuania has been at pains to change ever since, as will be shown in the following section. At the same time, all of those persons who had held permanent resident status in Lithuania for at least two years prior to the adoption of the law and who had a legal source of income in the country, could declare their intention to become nationals within two years following enactment of the law. This meant that Lithuania gave immigrants who had arrived during 
the Soviet period the possibility of acquiring Lithuanian nationality. About 90 per cent of all non-Lithuanians seized this opportunity despite the fact that they had to renounce their USSR citizenship in the process, which at that time was not an easy option (see Krūma in this volume; Budryte 2005: I49ff).

Unlike Lithuania, Latvia and Estonia decided to reestablish their preI940 citizenry in I99I and I992, respectively, by restoring the nationality laws that were in force prior to their annexation. According to these regulations, all of those who were Estonian nationals prior to 16 June I940 and Latvian nationals on I7 June I940 and their descendants had a right to Estonian and Latvian nationalities, respectively, regardless of whether they resided in the country or not. By contrast, those who arrived after these dates and had lived in these countries ever since, had to go through the normal naturalisation procedures regardless of the amount of time they had spent in their country of residence. As a consequence, about one-third of the populations residing in these two countries, again, mostly Russian immigrants who arrived as workers during the time of Soviet occupation, became aliens or, even worse, stateless, since the state of their nationality, the Soviet Union, had ceased to exist. This also meant that they had no right to participate in referenda on their constitutions, nor could they vote or run in the first elections, plus they were prohibited from seeking a number of public positions, all of which enhanced their exclusion (see Krūma and Järve in this volume).

The differing approaches towards the Russian long-term residents in these three countries have often been explained by the fact that the numbers were much higher in Latvia and Estonia than in Lithuania. It is true that the share of the titular ethnic group declined from 90 to 6I per cent in Estonia and from 77 to 52 per cent in Latvia between 1939 and 1989 (these are self-ascriptions gathered in the censuses). Based on these figures, both countries argued that a strict stance on nationality was necessary in order to guarantee the survival of their ethnic nations and cultures. However, a large percentage of the non-titular ethnic groups in Latvia automatically acquired citizenship in I99I since they were (descendants of) persons who were citizens or permanent residents in I940 (see Aasland \& Fløtten 200I: I025). This explains why the percentage of aliens and stateless was lower in Latvia than in Estonia in 1993 ( 28 vs. 32 per cent).

This ratio changed drastically in subsequent years, as the naturalisation policies were very different in the two countries, with the requirements being far stricter in Latvia than in Estonia. The Estonian law adopted in 1992 required two years of permanent residence prior to application (as of 30 March 1990) and one year after an application had been filed, as well as a language exam. More than 87,000 persons were 
naturalised under these conditions between 1992 and 1995, when a new Citizenship Act came into law. The 1995 Act increased the required period of permanent residence to five years prior to, and one year after, application, introduced a test of applicants' knowledge of the Estonian Constitution and the Citizenship Act and upgraded the language exam. As a consequence, the naturalisation figures dropped sharply, decreasing from more than 22,000 who were granted citizenship in 1996 (under the 1992 Law) to 8,000 naturalised in 1997 (under the I995 Law). Despite international criticism, especially while it prepared for its accession to the EU, and several attempts to encourage naturalisation, the naturalisation figures have remained low and have only slightly increased since Estonia's EU accession in 2004. Nevertheless, the share of stateless persons decreased from 32 to 9 per cent between 1992 and 2008 , albeit not all of this was due to their being naturalised. While a similar share of the stateless left the country, a smaller share acquired Russian citizenship but remained in Estonia. However, the numbers of stateless persons applying for Russian citizenship has increased dramatically since the Estonian government decided to relocate a Soviet war memorial in April 2007, an event which not only initiated riots by mostly Russian-speaking youths but also considerably increased Estonians' mistrust of all Russian speakers. Moreover, there is some danger that older cohorts will continue to remain stateless, since the language exam prevents them from naturalising (see Järve in this volume).

In Latvia, the naturalisation requirements were far stricter from the outset. The law, which was restored in I99I and in force until I994, imposed sixteen years of residence among other requirements. Thus, it is not surprising that not a single person was naturalised under these conditions. The first proposals for a new Citizenship Act remained very strict. They foresaw first applications for citizenship for the year 2000 , limiting the numbers to o.I per cent of the previous year's total number of Latvian nationals. In practice, this would have meant that under these regulations about $\mathrm{I}, 000$ stateless persons could have become naturalised in 2000 , a ridiculously small number considering that Latvia had 673,398 stateless persons and foreigners in 1993. While the parliament adopted this proposal, the president never signed it. This was due to international pressure, mainly from the Council of Europe, which threatened not to admit Latvia if the law was adopted. It took another year before a new Citizenship Law was enacted in 1994. Although this law was more liberal with regard to the naturalisation requirements than the first proposal (five years of permanent residence and a language exam, among other requirements), it retained the socalled window system which limited the number of persons allowed to 
naturalise per year. This system was adopted since the legislators expected a run on Latvian citizenship.

However, the expected run on Latvian citizenship never materialised. In fact, the number of applications was so low and the pressure from abroad so high that the law was amended again in I995. These amendments did not affect the naturalisation requirements but addressed the problem of the large number of stateless persons residing in Latvia from two different angles. Firstly, they added a new category to those regarded as Latvian nationals: those who were permanently residing in Latvia, were duly registered and had completed their educations in a school where Latvian is at least one of the languages of instruction. This category has been interpreted to include some former USSR nationals. Secondly, they introduced a special non-citizen status for former USSR citizens who had become stateless, which guaranteed the holders of this status almost all of the same rights that nationals have except for electoral rights at the national level. After these amendments were enacted, the numbers of applications for naturalisation further decreased (from 4,543 in I995 to 2,627 in I996), with the disinterest in Latvian citizenship being attributed to the fact that persons were happy with the rights they had thus far been granted. ${ }^{2}$ It is only after the window system was abolished in 1998 that the numbers of applications for Latvian citizenship increased significantly. Nevertheless, the number of non-citizens and foreign nationals remains high in Latvia, constituting 20 per cent of the total population in 2008 - the same as in 2005 (compared to 28 per cent in I993). Moreover, only about half of the former non-citizens and foreigners have thus far acquired Latvian citizenship, while the rest have either become citizen of another country or have left the country (see Krūma in this volume).

\section{Reaching out to emigrants and expatriates: Restitution laws, dual nationality and status laws}

Apart from the decision made by Estonia and Latvia to deny a large group of residents the right to opt for their citizenships, the most debated citizenship issues in the countries under discussion in this volume were most probably Romania's decision to restore citizenship to those living in the former territories of Greater Romania and Hungary's decision to grant kin minorities in the former Hungarian territories a quasi-citizenship status. This was mainly because these laws were perceived as infringing upon the territorial sovereignty of neighbouring states, which unleashed an international debate. However, Romania and Hungary were not the only two countries that reached out to former citizens and ethnic kin beyond their borders. Most of the 
countries under discussion in this book introduced similar policies, albeit mainly addressing emigrants and their descendants, whose countries of residence are distant, large and powerful enough not to feel immediately threatened by these regulations. In the following sections, I will focus on these regulations, which roughly fall into three categories: post-communist restitution laws, special regulations that allowed expatriates to reacquire or maintain their original citizenship and quasicitizenship regulations that have granted a number of social rights to ethnic kin residing in other countries.

\subsection{Restitution laws}

Restitution laws have, in principle, been meant to right communist (or older) wrongs. Many post-communist countries adopted such laws but they often only had symbolic value, which should nevertheless not be underestimated. Czechoslovakia first adopted such legislation in I990 and the Czech Republic renewed it in I999 (since the first regulation expired in I993). Although the introductory phrases of this law imply that it aims to 'assuage the legacy of certain wrongs that occurred in the period I948 to I989', the law applies, in practice, to all those who lost Czechoslovak citizenship in the communist period. Moreover, although Czech law prohibits dual nationality (expressly exempting only Slovaks from this rule), the restitution law did not require applicants to renounce any other nationality. Nevertheless, the number of those who applied for Czech citizenship under this law has remained relatively low probably because the law was only introduced after the date for the application for restitution of property expired (the right to property restitution was limited to Czechoslovak citizens). Another example of this restitution law, which mainly had symbolic relevance, is the Polish right to repatriation, which was first introduced in the I990 and then reformulated in a separate Repatriation Act adopted in 2000. This Act is addressed to ethnic Poles who were residing 'in the East [...] due to deportations, exile and other ethnically motivated forms of persecution'. Again, this law applies to all ethnic Poles residing in the defined areas since they did not have to provide proof of deportation or persecution - which would probably also have been difficult. Nevertheless, it only attracts a small number of repatriates (see Liebich in this volume).

Unlike the Czech and Polish laws, the Bulgarian restitution law adopted in I990 not only had symbolic value but also had a real impact. This law served to restore citizenship to the more than 300,000 members of the Turkish minority who were deprived of this status and forced to resettle in Turkey in the final stages of the communist regime after years of ethnic repression. A large number of these refugees had, 
in the meantime, been granted Turkish citizenship and some of them had also actually remained in Turkey. But the law restoring their Bulgarian citizenship did not demand the renunciation of other citizenships nor did it require resettlement to Bulgaria. However, the resentment against the former communist regime in Bulgaria, which found expression in the restitution law, has since been supplanted by ethnic nationalism. As a consequence, the openness of the citizenship law, in particular to those residing in Turkey, has come under criticism. The debate was sparked off by the fact that all Bulgarian nationals, regardless of their place of residence, have the right to vote. Mobilised by the MRF, the Bulgarian party historically associated with the Turkish minority, Bulgarians residing in Turkey have made extensive use of this right. This situation was first criticised as undemocratic during the parliamentary elections of 1994. Protests escalated prior to the European parliamentary elections in 2007, in advance of which the radical nationalist party Ataka suggested changing the citizenship laws so that only ethnic Bulgarians could hold dual nationality. While this suggestion was not accepted in Bulgaria, it is a normal practice in many countries as will be shown below (see Smilov \& Jileva in this volume).

Restitution assumed a wider meaning in Romania, Latvia and Estonia. Romania's restitution policies started on a note that was similar to Polish and Czech laws. A decree adopted in Romania as early as 1989 not only guaranteed repatriation to all Romanian citizens residing abroad but also granted former Romanian citizens residing abroad the right to reacquire Romanian citizenship by repatriating without requiring them to renounce their other nationality. This implicit toleration of dual nationality was a novelty in Romanian law at the time. A second decree issued in I990 further extended the group of former citizens who were allowed to reacquire Romanian nationality by also waiving the residency requirement. However, it was only with the adoption of the new citizenship law in I99I that restitution acquired something more than mere symbolic significance in Romania. This law explicitly included a third group of former Romanian citizens now granted the right to reacquire citizenship, namely those who resided in the territories of Bessarabia and Northern Bukovina, which belonged to Romania before they were occupied by the Soviet Union in I940-I94I and annexed in 1944. Like the Baltic states, the Romanian government argued that this annexation had been illegal. While this particular law did not address migrants, it encouraged migration between Moldova, Romania and other EU countries. Moreover, several EU agencies warned that this policy of citizenship restitution could become a way of circumventing EU immigration controls when Romania acceded to the EU in 2007. This was one of the reasons why the Romanian government brought the naturalisation process to a halt and introduced more 
requirements for the reacquisition of citizenship for this particular group of people. While at least Io०,००० largely Moldovan citizens reacquired their citizenship in the first decade after the introduction of the law, this number dropped to fewer than 3,000 reacquisitions between $200 \mathrm{I}$ and 2007. Since the nationality law was amended in September 2007 the number of nationality restitutions has increased. More than 3,807 restitutions were granted within a year. However, between 500,000 and 900,000 applications by Moldovans alone are said to be awaiting a decision (see Iordachi in this volume).

A similarly broad understanding of restitution was applied in Estonia and Latvia; it restored nationality to all pre-I940 citizens and their descendants even if they had emigrated after that date. Moreover, while both countries in principle prohibit dual nationality, their regulations are often unclear and sometimes even openly tolerate dual nationality where emigrants are concerned. Thus, the Estonian regulations state that Estonians can be deprived of their nationality if they acquire the nationality of another state; this provision, nevertheless, does not apply to those who acquired Estonian nationality by birth. It therefore remains unclear whether 1940 nationals by birth and their descendants are still considered nationals even if they hold another nationality. Moreover, the state has been quite tolerant of dual nationality in cases of resumption by those who lost Estonian nationality as minors (see Järve in this volume). The restored nationality law in Latvia, by contrast, still explicitly demanded the renunciation of other nationalities for emigrants and their descendants. Only one group was excluded from this requirement in the transitional regulations of the restored law: refugees and those who were deported between 1940 and 1990 could register as citizens until I July I995. The new nationality law adopted in 1994 extended this exemption from the general prohibition of dual nationality to all I940 nationals and their descendants. Under this law, only those who had acquired a new nationality after Latvia's independence were required to renounce that nationality. In 2007, the Constitutional Court officially confirmed Latvia's unofficial policy of prohibiting dual nationality only in cases of naturalisation. Since then, there have been several discussions about also extending dual nationality to those who have recently left the country (see Krūma in this volume).

\subsection{Other special regulations allowing emigrants to acquire citizenship}

A second group of countries openly reached out to emigrants and expatriates by adopting special regulations in order to renew or maintain ties with these particular groups. As mentioned above, this holds true for Lithuania. Lithuania was the only one of the three Baltic states that 
had expressly excluded expatriates from its initial citizenry in 1989 by making permanent residence in the country a requirement for the acquisition of nationality for 1940 nationals and their descendants. Moreover, the law did not provide for dual nationality, primarily because the Lithuanian nationalist forces did not want Lithuanian citizens to keep their USSR citizenship. Both of these rules were amended in the course of the I990s in response to pressure from expatriate communities and criticism from the Council of Europe. However, Russian speakers were also interested in dual citizenship. These opposing forces might explain the special development of the Lithuanian citizenship regulations in the course of the I990s. The first new citizenship law adopted after independence lifted the residence requirement for I940 nationals as well as their children and grandchildren. Regarding the prohibition of dual nationality, early exceptions had already been introduced when the I989 Law was amended in I99I. In 1993, those who had been deported from Lithuania or had left during the occupation were allowed to recover their nationality without having to renounce another one. In 1994, the Constitutional Court declared that I940 nationals and their descendants were the only group exempted from losing Lithuanian nationality when acquiring another nationality. Based on this ruling, the nationality law was again amended in 1995. Since then, all 1940 nationals and their children have been considered nationals unless they had returned to their ethnic homeland (according to this rule an ethnic Pole who had relocated to Poland after I940 would not be allowed to keep both citizenships). Further pressure from expatriate groups led to an extension of this regulation to grandchildren and great-grandchildren of 1940 nationals in the new citizenship law that was enacted in 2003. ${ }^{3}$ However, all of these special regulations on dual citizenship for expatriates were declared unconstitutional by the Constitutional Court in 2006. The Court argued that the Constitution allowed dual nationality only in exceptional cases. How this relates to its earlier judgement regarding 1940 nationals and their descendants remains unclear (Krūma in this volume; Budryte 2005: 152ff.).

Other countries used similar methods in order to renew or maintain links to expatriate communities in the I980s and I990s. In I989, Malta allowed emigrants born in Malta and who had spent at least six years abroad to hold dual nationality. ${ }^{4}$ A large number of Maltese citizens had left Malta for the UK, Australia, Canada and the US in the I950s and I96os. Following the previous regulations, they automatically lost their Maltese citizenship when acquiring the citizenship of their new country of residence. The 1989 amendments applied retroactively, i.e. Maltese emigrants who had lost their Maltese citizenship when they acquired the citizenship of their country of residence were now deemed to have never lost it. In 2007, Malta extended the right to dual nation- 
ality to second and subsequent generations residing abroad. Unlike Lithuania, Malta proceeded to make dual citizenship the rule in 2000. This means that foreigners applying for Maltese citizenship no longer have to renounce their other nationalities (see Buttigieg in this volume).

Of course, it takes two states for these regulations to have any impact. If the emigrants' state of residence prohibits dual nationality, a change of law in the country of origin will not be enough of an incentive for former citizens to reacquire their citizenship. The Maltese changes are a good case in point: while in the I990s only about 200 persons annually reacquired their Maltese nationality by registration, this number increased to more than I,000 in 2002 when Australia began allowing dual nationality. How many former Maltese citizens automatically reacquired their Maltese citizenship because of this legal change in their country of residence is unknown (see Buttigieg in this volume).

However, there is no automatic guarantee that the legal regulations of other states are respected, as has been made evident in the Turkish case. Turkey introduced toleration of dual citizenship in 198I with a view to maintaining links with Turkish workers who have moved to Western Europe, particularly Germany, since the ig6os. Moreover, the Turkish state encouraged former Turkish nationals to reacquire their Turkish nationality after having renounced it in order to acquire German and Austrian nationality, for example, although these two states prohibited dual nationality acquired through naturalisation. While this was known in the countries of residence, the German state had no legal basis that would have allowed it to stop this practice, mainly because the German constitution did not permit withdrawing German nationality from German citizens residing in the country; this was in response to the Third Reich's massive denaturalisation of German Jews. This changed in 2000 when Germany introduced a new nationality law, which also granted the German state the right to withdraw German nationality from those who had acquired another nationality without the authorities' consent. More than 40,000 German-Turkish dual nationals lost their German nationality as a result of this new regulation (see Kadirbeyoglu in this volume).

\subsection{Quasi-citizenship regulations for expatriates}

Several countries in our sample adopted laws that provided co-ethnics with a form of quasi-citizenship by granting them a set of rights usually reserved to citizens, including privileged access to education and employment. The most important and most debated of these was the introduction of the so-called Status Law in Hungary in 200I. Granting 
quasi-citizenship to ethnic Hungarians residing in neighbouring countries, this law was met with heavy criticism (until 2003 when the most debated provisions were deleted), particularly in Slovakia, despite the fact that Slovakia had already introduced a similar law in I997. So had Bulgaria in 2000, Slovenia in 2006 and Poland in 2007 (see Kovács \& Tóth, Kusá, Medved, Górny \& Pudzianowska and Smilov \& Jileva in this volume).

While all of these countries introduced a form of quasi-citizenship in order to establish and maintain links with co-ethnics abroad holding the citizenship of their country of residence, Turkey introduced a similar regulation in order to encourage citizens residing abroad to acquire the nationality of their respective country of residence. When several Turkish emigrants were killed in xenophobic arson attacks in Mölln in I992 and Solingen in I993, the Turkish government decided to encourage its nationals abroad to acquire the nationality of their country of residence, arguing that a large Turkish electorate would at least prevent parties from openly mobilising against immigrants. The main reason for Turkish nationals not acquiring German nationality was the fact that they had to renounce their Turkish nationality and thus the right to property and inheritance in Turkey. That is why the Turkish government introduced a quasi-citizenship status in 1995, which has become known as the 'pink card' (reflecting the colour of the document given to such status holders). This status grants former Turkish nationals all the rights of citizens except the right to vote. While the numbers of Turkish citizens granted German citizenship has increased significantly since the introduction of the pink card, the number of applications for the pink card has remained low. This implies that other factors were responsible for the increase in naturalisations (see Kadirbeyoglu in this volume; Caglar 2004; the statistics compiled by Harald Waldrauch for the NATAC project as published on www.imiscoe.org).

All of the states discussed here have reached out to their expatriates and kin minorities in the last two decades. As the following section will show, this attitude contrasts strongly with the lack of attention paid to immigrants as potential future citizens.

\section{Excluding recent immigrants: Naturalisation requirements}

As mentioned above, the countries discussed in this book have only recently begun to attract immigration. As a consequence, these new immigrants have not really become an issue in their respective citizenship regulations. Granted, all of them have regulations for the acquisition of citizenship by naturalisation, the requirements of which are in principle similar to those in the fifteen pre-2004 EU Member States. All of 
the countries under discussion here require a specific period of residence in the country, ranging from five (in nine countries) to ten years (in Lithuania and Slovenia). However, unlike many of the 'old' Member States, six of the new Member States do not count all of the years from the date of entry but rather count from the date when the respective person was granted a residency permit, which certainly increases the required period of residency significantly. Moreover, all of these countries demand a clean criminal record, thirteen out of the fourteen countries require command of the national language, ten demand proof of some kind of legal income, seven demand that the applicants swear an oath of loyalty and three conduct a test on the country's constitution (also see Dumbravă 2007: 462 for the new Member States; Waldrauch 2006: I34-I59 for the fifteen pre-2004 Member States).

Only rarely are there any clear indications that specific changes in the citizenship laws are motivated by recent immigration. One example is Romania's tightening of its naturalisation requirements in 1999 and 2003. In I999, the Romanian government not only increased the residence requirement from five to seven years, but also introduced tests on an applicant's knowledge of the Romanian language, elementary norms of Romanian culture and civilisation. In 2003, the residence requirement was further increased to eight years (but reduced to five years for foreign spouses of Romanian nationals). Moreover, the law now also demands knowledge of the national anthem and a declaration of loyalty. This marked increase in requirements, particularly in the cultural domain, is not unlike recent developments in West European countries such as Denmark, Germany, the Netherlands and the UK.

Malta, Cyprus and Poland have the lowest number of legal requirements. For example, Poland - the only post-communist country which has not introduced a new citizenship law since the fall of the Iron Curtain - officially demands only five years of permanent residence, which in practice comes to at least ten years of residence in the country. However, this does not mean that these are the most open countries but rather that their authorities exercise broad discretion in deciding who can become a citizen. Again, Poland is an interesting case in point: applications for naturalisation in Poland have to include additional information on the parents' nationality, sources of income, the applicants' most recent job, knowledge of the Polish language and services rendered to Poland (or Polish diaspora organisations, etc.). However, the citizenship law does not contain any requirements that explain why these documents are necessary to make a decision on an applicant. Nor are there clear rules for their evaluation. Practice indicates that not only Poland but also Cyprus and Malta select future citizens based on their ancestry (see Buttigieg, Trimikliniotis and Górny \& Pudzianowska in this volume). 
Moreover, even in those countries where the requirements are very similar to those in the pre-2004 EU Member States, the focus is rarely on new immigration, which becomes obvious when we look at regulations that address specific groups. Apart from the three countries mentioned above where descent is important in practice although not mentioned in the law, five countries offer facilitated naturalisation to co-ethnics by reducing the residence requirement from ten years to one in the case of Slovenia (see Medved in this volume), from eight years to at least one year for ethnic Hungarian descendants of former citizens (see Kovács \& Tóth in this volume) and from five years to no residence requirement at all in Bulgaria, Croatia and Turkey (see Iordachi, Ragazzi \& Štiks and Kadirbeyoglu in this volume). Hence, eight of the fourteen countries apply ethnic preferences in one way or another. There are only two other groups of foreigners who enjoy preferential treatment in a large number of these countries: those regarded as being of interest to the country because of their special merits and the spouses of nationals.

However, in their most recent amendments, and in order to prevent marriages of convenience, Slovenia and Malta have already raised the number of years that spouses are required to reside in the country before they can naturalise (see Medved and Buttigieg in this volume). Special regulations for other groups of immigrants are rare: Bulgaria, the Czech Republic, Slovenia and Hungary have reduced residence requirements for refugees (see Smilov \& Jileva, Baršová, Medved and Kovács $\&$ Tóth in this volume), while Croatia, Slovenia, Lithuania and Hungary have special regulations for foreigners born in their countries, but these usually address very specific groups, such as residents from other former Yugoslav republics in Slovenia and Croatia (see Ragazzi \& Štiks, Medved, Krūma and Kovács \& Tóth in this volume). In the Czech Republic, all foreigners born within its borders are treated somewhat more favourably than other foreigners, as they do not necessarily need to meet the five-year residency requirement to qualify for naturalisation. The Czech Republic is also the only country that has made an attempt to introduce special regulations for second-generation foreigners born in the Czech Republic of immigrant parents, but the legislative process was hampered by the parliamentary elections of 2006 . A new draft bill containing regulations for this particular group is expected to be presented in 2009 (see Baršová in this volume and Dumbravǎ 2007: 459). 


\section{Conclusions}

This chapter's discussion of migration and citizenship legislations in the new Member States, Croatia and Turkey has shown that the trends in these fourteen countries are comparable. Returning to Agard's earlier quotation we might be able to summarise that the main trend has been 'a call to kinship', although this call has not been addressed to immigrants but to kin minorities and former citizens in neighbouring states and to emigrants and expatriate communities in more distant countries. Furthermore, long-term residents were often subject to severe discrimination in the process of the establishment and re-establishment of states after the end of the communist period. Since immigration is a comparatively recent phenomenon in all of the countries under discussion, these new immigrants have not really become an issue with regard to citizenship regulations. In that respect, the citizenship legislations in the twelve new Member States, Croatia and Turkey differ markedly from those in the pre-2004 EU Member States, where most of the recent changes in citizenship laws were motivated by immigration.

However, as Dumbravǎ (2007) rightly points out, we should not fall into the trap of describing these differences in terms of restrictive Eastern European laws and liberal Western European laws (for a different opinion on this matter, see Howard 2009). Firstly, several of the pre2004 Member States also have regulations that facilitate citizenship acquisition for expatriates and co-ethnics, including Germany, Greece, Italy, Ireland, Spain and Portugal. Both the Western European and the above-described Eastern European regulations can, in principle, be used to enter any other Member State, since citizenship in one EU Member State automatically implies EU citizenship. There is, for example, some indication that Argentine citizens acquire Italian citizenship to be able to live and work in Spain. Hence, European concerns about national citizenship regimes are not only raised by Eastern European policies but also by analoguous Western European regulations.

Secondly, as pointed out above, citizenship in Western Europe has moved in opposite directions in recent years, with some formerly liberal countries, such as Denmark or the Netherlands, dramatically raising their naturalisation requirements (see Bauböck, Ersbøll, Groenendijk \& Waldrauch 2006: 23-25). Thirdly, there are specific trends that are similar in all of these countries. For instance, dual citizenship has become more accepted throughout the European Union. However, the reasons for the growing tolerance of dual nationality differ; in Western Europe this is mostly linked to facilitating naturalisation for immigrants, while in the twelve new Member States and two accession countries under discussion tolerance of dual citizenship is mainly re- 
served for co-ethnics and emigrants residing abroad. As a consequence, there has been a tendency to regard only the former as liberal, although the latter reforms also liberalise access to citizenship and may lead to a general acceptance of dual citizenship in the long run, as the case of Malta shows.

\section{Notes}

I British subjects, according to the Cyprus (Annexation) Orders, and persons born in Cyprus on or after 5 November I9I4, as well as descendants in the male line of both of these groups (see annex D to the Treaty concerning the Establishment of the Republic of Cyprus, sect. 2, para. 2, available at www.fco.gov.uk).

2 The most important reasons for the lack of interest in naturalisation were that people did not know Latvian, that they wanted to avoid military service and that it was easier for non-citizens than for Latvians to receive a Russian visa. The third point has since been further simplified; in 2008, Russia decided to grant visa-free travel to former USSR citizens who reside in Estonia and Latvia and have not acquired another citizenship (see Krūma in this volume).

3 Grandchildren of I940 nationals also had a right to nationality under the previous law but were required to renounce other nationalities when they wanted to exert that right.

4 Before that date only minors were allowed to have more than one nationality until their nineteenth birthdays.

\section{Bibliography}

Aasland, A. \& T. Fløtten (200I), 'Ethnicity and Social Exclusion in Estonia and Latvia', Europe-Asia Studies 53 (7): I023-1049.

Agard, J. (2000), 'Remember the Ship', in J. Procter (ed.), Writing Black Britain 19481998. An interdisciplinary anthology, 258-259. Manchester: Manchester University Press.

Bauböck, R., E. Ersbøll, K. Groenendijk \& H. Waldrauch (2006), 'Introduction', in R. Bauböck, E. Ersbøll, K. Groenendijk \& H. Waldrauch (eds.), Acquisition and Loss of Nationality: Policies and Trends in 15 European Countries. Vol. 1: Comparative Analyses, I5-34. Amsterdam: Amsterdam University Press.

Brubaker, W. R. (I992), 'Citizenship Struggles in the Soviet Successor States', International Migration Review 26 (2): 269-29I.

Budryte, D. (2005), Taming Nationalism? Political Community Building in the Post-Soviet Baltic States. Aldershot: Ashgate.

Caglar, A. (2004), “Citizenship Light”: Transnational Ties, Multiple Rules of Membership, and the "Pink Card"', in J. Friedmann \& S. Randeria (eds.), Worlds on the Move: Globalisation, Migration and Cultural Security, 273-291.Taurus: London.

Dumbravǎ, C. (2007), 'Citizenship regulations in Eastern Europe. Acquisition of citizenship at birth and through regular naturalization in sixteen postcommunist countries', CEU Political Science Journal 2 (4): 450-472.

Dummett, A. (2006), 'United Kingdom', in R. Bauböck, E. Ersbøll, K. Groenendijk \& H. Waldrauch (eds.), Acquisition and Loss of Nationality. Policies and Trends in 15 European States. Vol. 2: Country Analyses, 55I-585. Amsterdam: Amsterdam University Press. 
Howard, M. (2009), The Politics of Citizenship in Europe. Cambridge: Cambridge University Press (forthcoming).

Human Rights Watch (1995), Civil and Political Rights in Croatia. www.hrw.org.

Štiks, I. (2006), 'Nationality and Citizenship in the Former Yugoslavia: From Disintegration to European Integration', in Southeast European and Black Sea Studies 6 (4): 483500 .

Waldrauch, H. (2006), 'Acquisition of nationality', in R. Bauböck, E. Ersbøll, K. Groenendijk \& H. Waldrauch (eds.), Acquisition and Loss of Nationality. Policies and Trends in 15 European Countries. Vol. 1: Comparative Analyses, I2I-I82. Amsterdam: Amsterdam University Press. 



\section{List of contributors}

Andrea Baršová, Government Office, Human Rights Department, Prague

barsova@seznam.cz

Rainer Bauböck, Department of Political and Social Sciences, European University Institute, Florence rainer.baubock@eui.eu

Eugene Buttigieg, Department of European and Comparative Law, Faculty of Laws, University of Malta eugene.buttigieg@um.edu.mt

Agata Górny, Centre of Migration Research, University of Warsaw agata@gorny.edu.pl

Constantin Iordachi, Department of History, Central European University, Budapest iordachinc@ceu.hu

Priit Järve, Independent researcher, Vilnius, Lithuania jaerve@yahoo.com

Elena Jileva, Centre for Political and Constitutional Studies, Madrid ejileva@cepc.es

Zeynep Kadirbeyoglu, Political Science Department, Bogazici University, Istanbul zeynep.kadirbeyoglu@mail.mcgill.ca

Mária Kovács, Nationalism Studies Program, Central European University, Budapest kovacsma@ceu.hu 
Kristīne Krūma, Riga Graduate School of Law

Kristine.Kruma@rgsl.edu.lv

Dagmar Kusá, International Center for Conciliation, Boston and EUROCLIO, The Hague dagmarkusa@gmail.com

Andre Liebich, Graduate Institute of International and Development Studies, Geneva andre.liebich@graduateinstitute.ch

Felicita Medved, Independent researcher, Brezovica pri Ljubljani felicita.medved@siol.net

Bernhard Perchinig, Institute for Urban and Regional Research, Austrian Academy of Sciences, Vienna bernhard.perchinig@oeaw.ac.at

Dorota Pudzianowska, Faculty of Law, Warsaw University d.pudzianowska@uw.edu.pl

Francesco Ragazzi, School of Oriental and African Studies, London francesco.ragazzi@sciences-po.org

Wiebke Sievers, Commission for Migration and Integration Research, Austrian Academy of Sciences, Vienna wiebke.sievers@oeaw.ac.at

Daniel Smilov, University of Sofia and Centre for Liberal Strategies, Sofia daniel@cls-sofia.org

Igor Štiks, Institut d'Etudes Politiques de Paris, Paris and Northwestern University, Chicago/Evanston igorstiks@yahoo.com

Judit Tóth, Faculty of Law, Department of Constitutional Law, University of Szeged skula@juris.u-szeged.hu

Nicos Trimikliniotis, Centre for the Study of Migration, Inter-ethnic \& Labour Relations, University of Nicosia, Cyprus nicostrim@logosnet.cy.net 
Other IMISCOE titles

\section{IMISCOE Research}

Rinus Penninx, Maria Berger, Karen Kraal, Eds.

The Dynamics of International Migration and Settlement in Europe:

A State of the Art

2006 (ISBN 9789053568668 )

(originally appearing in IMISCOE Joint Studies)

Leo Lucassen, David Feldman, Jochen Oltmer, Eds.

Paths of Integration: Migrants in Western Europe (1880-2004)

2006 (ISBN 9789053568835 )

Rainer Bauböck, Eva Ersbøll, Kees Groenendijk, Harald Waldrauch, Eds. Acquisition and Loss of Nationality: Policies and Trends in 15 European Countries, Volume 1: Comparative Analyses 2006 (ISBN 978905356920 7)

Rainer Bauböck, Eva Ersbøll, Kees Groenendijk, Harald Waldrauch, Eds. Acquisition and Loss of Nationality: Policies and Trends in 15 European Countries, Volume 2: Country Analyses 2006 (ISBN 978905356 92I 4)

Rainer Bauböck, Bernhard Perchinig, Wiebke Sievers, Eds.

Citizenship Policies in the New Europe

2007 (ISBN 978905356922 I)

Veit Bader

Secularism or Democracy? Associational Governance of Religious Diversity 2007 (ISBN 978905356999 3)

Holger Kolb \& Henrik Egbert, Eds.

Migrants and Markets: Perspectives from Economics and the Other

Social Sciences

2008 (ISBN 978905356684 8)

Ralph Grillo, Ed.

The Family in Question: Immigrant and Ethnic Minorities in

Multicultural Europe

2008 (ISBN 9789053568699 9) 
Corrado Bonifazi, Marek Okólski, Jeannette Schoorl, Patrick Simon, Eds. International Migration in Europe: New Trends and New Methods of Analysis 2008 (ISBN 978905356894 I)

Maurice Crul, Liesbeth Heering, Eds.

The Position of the Turkish and Moroccan Second Generation in Amsterdam and Rotterdam: The TIES Study in the Netherlands 2008 (ISBN 978908964 06I I)

Marlou Schrover, Joanne van der Leun, Leo Lucassen, Chris Quispel, Eds. Illegal Migration and Gender in a Global and Historical Perspective 2008 (ISBN 978908964047 5)

Gianluca P. Parolin

Citizenship in the Arab World: Kin, Religion and Nation-State 2009 (ISBN 978908964045 I)

\section{IMISCOE Reports}

Rainer Bauböck, Ed.

Migration and Citizenship: Legal Status, Rights and Political Participation 2006 (ISBN 978905356888 o)

Michael Jandl, Ed.

Innovative Concepts for Alternative Migration Policies:

Ten Innovative Approaches to the Challenges of Migration in the 21st Century 2007 (ISBN 978905356990 o)

Jeroen Doomernik, Michael Jandl, Eds.

Modes of Migration Regulation and Control in Europe

2008 (ISBN 978905356689 3)

Michael Jandl, Christina Hollomey, Sandra Gendera, Anna Stepien, Veronika Bilger

Migration and Irregular Work in Austria. A Case Study of the Structure and Dynamics of Irregular Foreign Employment in Europe at the Beginning of the 21st Century 2008 (ISBN 9789089640536 )

Heinz Fassmann, Ursula Reeger, Wiebke Sievers, Eds. Statistics and Reality: Concepts and Measurements of Migration in Europe 2009 (ISBN 9789089640529 ) 


\section{IMISCOE Dissertations}

Panos Arion Hatziprokopiou

Globalisation, Migration and Socio-Economic Change in Contemporary Greece: Processes of Social Incorporation of Balkan Immigrants in Thessaloniki

2006 (ISBN 9789053568736 )

Floris Vermeulen

The Immigrant Organising Process: Turkish Organisations in Amsterdam and Berlin and Surinamese Organisations in Amsterdam, 1960-2000 2006 (ISBN 978905356875 o)

Anastasia Christou

Narratives of Place, Culture and Identity: Second-Generation

Greek-Americans Return 'Home'

2006 (ISBN 978905356878 I)

Katja Rušinović

Dynamic Entrepreneurship: First and Second-Generation Immigrant

Entrepreneurs in Dutch Cities

2006 (ISBN 9789053569726 )

Ilse van Liempt

Navigating Borders: Inside Perspectives on the Process of Human Smuggling into the Netherlands

2007 (ISBN 9789053569306 )

Myriam Cherti

Paradoxes of Social Capital: A Multi-Generational Study of Moroccans in London

2008 (ISBN 978905356032 7)

Marc Helbling

Practising Citizenship and Heterogeneous Nationhood: Naturalisations in Swiss Municipalities

2008 (ISBN 978908964034 5)

Inge Van Nieuwenhuyze

Getting by in Europe's Urban Labour Markets: Senegambian Migrants'

Strategies for Survival, Documentation and Mobility

2009 (ISBN 9789089640505 ) 


\author{
Nayla Moukarbel \\ Sri Lankan Housemaids in Lebanon: A Case of 'Symbolic Violence' and \\ 'Every Day Forms of Resistance' \\ 2009 (ISBN 978908964 O5I 2) \\ Jérôme Jamin \\ L'imaginaire du complot: Discours d'extrême droite en France et \\ aux Etats-Unis \\ 2009 (ISBN 978908964048 2) \\ John Davies \\ 'My Name Is Not Natasha': How Albanian Women in France Use \\ Trafficking to Overcome Social Exclusion (1998-2001) \\ 2009 (ISBN 978905356707 4)
}

